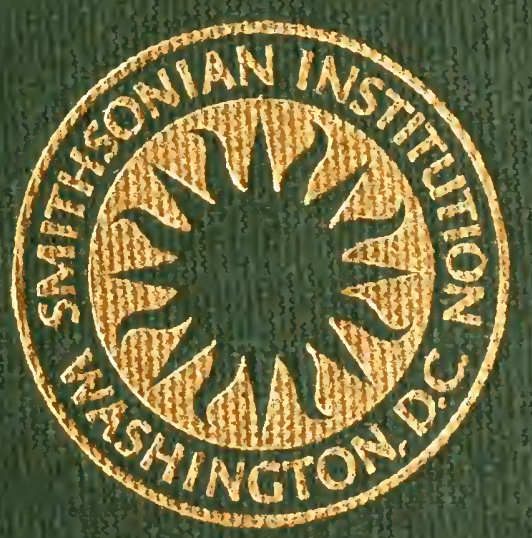





S M I T H SON I A N

I N S T I T U T I O N

M U S E U M

O F

NATURA L

H I S T O R Y 



\section{A Revision of the}

\section{Scenopinidae (Diptera) of the World}

L. P. KELSEY

University of Delaware

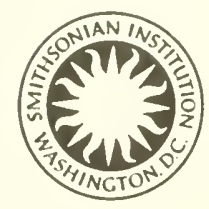

SMITHSONIAN I NSTITU'TION PRESS

$$
\begin{gathered}
\text { CITY OF WASHINGTON } \\
1969
\end{gathered}
$$




\section{Publications of the United States National Museum}

The scientific publications of the United States National Museum include two series, Proceedings of the United States National Museum and United States National Museum Bulletin.

In these series are published original articles and monographs dealing with the collections and work of the Museum and setting forth newly acquired facts in the fields of anthropology, biology, geology, history, and technology. Copies of each publication are distributed to libraries and scientific organizations and to specialists and others interested in the various subjects.

The Proceedings, begun in 1878 , are intended for the publication, in separate form, of shorter papers. These are gathered in volumes, octavo in size, with the publication date of each paper recorded in the table of contents of the volume.

In the Bulletin series, the first of which was issued in 1875, appear longer, separate publications consisting of monographs (occasionally in several parts) and volumes in which are collected works on related subjects. Bulletins are either octavo or quarto in size, depending on the needs of the presentation. Since 1902, papers relating to the botanical collections of the Museum have been published in the Bulletin series under the heading Contributions from the United States National Herbarium.

This work forms number 277 of the Bulletin series.

Frank A. Taylor Director, United States National Museum 


\section{Contents}

Introduction . . . . . . . . . . . . . . . . . . . . . . . 1

Acknowledgments . . . . . . . . . . . . . . . . 2

Methods. . . . . . . . . . . . . . . . . . 4

Biological notes . . . . . . . . . . . . . . . . . . . . 5

Classifieation. . . . . . . . . . . . . . . . . . . 6

S'ystematic Arrangement. . . . . . . . . . . . . . . . . . . . . . 7

Key to Genera of Seenopinidae. . . . . . . . . . . . . . . . . . 13

Genus Scenopinus Latreille . . . . . . . . . . . . . . . . . . . 14

Fenestralis group . . . . . . . . . . . . . . . . . . 16

Albieinctus group . . . . . . . . . . . . . . . . . . . 45

Brevicornis group . . . . . . . . . . . . . . . . . . . 93

Velutinus group . . . . . . . . . . . . . . . . . . 110

Genus Caenoneura Kröber . . . . . . . . . . . . . . . . . . . . 162

Genus Pseudomphrale Kröber . . . . . . . . . . . . . . . . . . . 164

Genus Brevitrichia D. E. Hardy . . . . . . . . . . . . . . . . . . . 165

Genus Metatrichia Coquillett. . . . . . . . . . . . . . . . . . . 214

Genus Pseudatrichia Osten Sacken . . . . . . . . . . . . . 221

Genus Belosta D. E. Hardy . . . . . . . . . . . . . . . . . . . . 274

Genus Propebrevitrichia, new genus . . . . . . . . . . . . . . 281

Genus Heteromphrale Kröber . . . . . . . . . . . . . . . . . . . . . 286

Genus Prepseudatrichia, new genus . . . . . . . . . . . . . . . . . 286

Genus Seguyella, new genus . . . . . . . . . . . . . . . . . . 294

Genus Neopseudatrichia, new genus . . . . . . . . . . . . . . . . . 299

Genus Scenopinula Paramonov . . . . . . . . . . . . . . . . 304

Genus Reikiella Paramonov . . . . . . . . . . . . . . . . . . . 304

Genus Stenomphrale Kröber . . . . . . . . . . . . . . . . . . 318

Genus Paratrichia, new genus . . . . . . . . . . . . . . . 320

Literature Cited . . . . . . . . . . . . . . . . . 323

Index . . . . . . . . . . . . . . . . . . . . 329 



\section{A Revision of the Scenopinidae (Diptera) of the World}

\section{Introduction}

Since Kröber's (1937) last revision of the Scenopinidae, no attempt has been made to classify this family on a worldwide scale. More recent papers by Paramonov (1955) on Australian Scenopinidae and D. E. Hardy (1944a) on North Ameriean species have treated with local faunas and have made valuable contributions to our knowledge. Kröber (1913, 1914a, and 1925) included many illustrations of the head and wings of previously described and new speeies. D. E. Hardy (1944a, 1944b, and 1960) is the first author to illustrate extensively the external genital structures as well. No attempt has been made, up to the present, to make detailed comparative studies of both external and internal structures of the male and female genitalia; only a single illustration of the internal structure of the male was found, that of Scenopinus fenestralis by Engel (1932).

The use of the genital structures has led to extensive revision of the family, the erection of a number of new genera, and the synonymizing of several which had no apparent justification. The use of the internal genital structure has been invaluable in separating species whose visible external features are so close that they could not otherwise be separated.

The type and allotype of every available described species has been figured and any discrepancies in the original descriptions have been noted. Where types have been lost, topotypes agreeing with published figures have been illustrated.

In the present classification, the family includes 16 genera, four subgenera, and 214 species. The genus Lagarinus Enderlein (1913), included by Kröber (1914a), was placed in synonymy with the genus Chiromyza in the family Stratiomyidae by G.H.Hardy (1921) and Bezzi (1922). Of the 13 genera listed by Kröber (1937) only six remain. Two new genera were erected by D. E. Hardy (1944a) and two by Paramonor (1955), while an additional five genera and four subgenera have been erected by me. 'The following genera have been removed from Kröber's list: Cerocatus Rondani (1848) belongs in the Therevidae as indicated by Rondani's plates, and thus will not be treated in this paper. Omphrale Meigen (1800) has recently been suppressed by the Inter- 
national Commission on Zoological Nomenclature (ICZN, 1963b) and the species described in this genus revert to Scenopinus. Lepidomphrale Kröber (1913), with the single species niveus Becker, is returned to Scenopinus where it agrees in all respects with other members of the Albincinctus group. Archiscenopinus Enderlein (1914), with the single species niger DeGeer, is in all ways, except for the widely separated eyes of the male, similar to other members of the genus Scenopinus in the Fenestralis group. Paromphrale Kröber (1937) containing the species glabrifrons and antennatus show no genitalic characters that would separate them from other members of the genus Scenopinus and other members of the Fenestralis group. Omphralosoma Kröber (1937) cannot stand because squamosa and albifasciatus agree more closely with the Albicinctus and Velutinus groups respectively, than with each other, and the presence of scales on the body hardly warrants their separation. Lucidomphrale Kröber (1937), with the single species lucidus, agrees with the members of the Albicinctus group except for the long aedeagal parameres of the male.

\section{Acknowledgments}

This study has taken several years to accomplish and would have been impossible without the cooperation and helpful suggestions of many colleagues. I wish particularly to thank Dr. Willis W. Wirth and Curtis Sabrosky of the U.S Department of Agriculture, Washington, D. C., for their enthusiastic encouragement of this study and for their many helpful suggestions in the preparation of this manuscript; Dr. George M. Worrilow, Dean, School of Agriculture, University of Delaware, and Dr. Morris Cover, Director, Delaware Agricultural Experiment Station, for their assistance in obtaining grants from the General Faculty Research Funds and General Research FundsAgricultural Experiment Station, which made possible an opportunity to visit museums in England, France and Belgium, to study the type specimens not available on loan; Dr. Dale F. Bray, Chairman, Department of Entomology and Applied Ecology, University of Delaware, for his encouragement and support of this study, Publication No. 366 of the Department of Entomology and Applied Ecology.

I also wish to express my appreciation to the following persons and institutions for the unselfish loan of material, including types with permission to dissect genitalia, which helped to make this study possible. The abbreviations listed below are used in parentheses throughout this text.

AMB Allan M. Barnes collection, State of California Department of Public Health, Berkeley, Calif. (A. M. Barnes).

AMNH American Museum of Natural History, New York, N. Y. (J. G. Rozen). 
AMS Australian Museum, Sydney, Australia (1). K. MeAlpine).

ANS

B.MNH

CAS

C1)A

CNC

C.MP

CSC

CSIRO

CSU

$\mathrm{CU}$

CUC

DEI

DZSA

IEE

INHS

IOC

I RSNB

$\mathrm{KSU}$

MCSNG

MCSNM

$\mathrm{MCZ}$

$M N H$

MNHN

MRAC

I'TJ

$\mathrm{MZU}$

$\mathrm{N} M \mathrm{BB}$

N.IP

$\mathrm{NMV}$

OSU

PAS

PDA

PIIT

PU

SEE

SMIIJ

Academy of Natural seiences, Philadelphia, Pa. (H. J. (irant, Jr.).

British Inseum (Natural History), London, Englaud (J. P. Doncaster, Keeper, 11. Olelroyd, and J. C. Deeming).

California Aeaclemy of heiences, Golden Cate Museum, San Franeiseo, Calif. (I'. H. Arnaurl, Jr.).

State of California, Department of Agriculture, Saleramento, Calif. (M. S. Wasbaner).

Canadian National Collection, Canada Department of Agriculture, Ottawa, Canada (J. G. Chilleott).

Carnegie Museum, Pittsburgh, Pa. (G. Wallace).

Curtis Sabrosky collection, U.S. National Museum, Washington, 1).C.

(C. Sabrosky).
Commonwealth seientific and Industrial Research Organization, Canberra, A.C.T., Australia (K. H. L. Key, Curator, and D. II. Colless).

Colorado State University, Fort Collins, Colo. (F. A. Lawson).

Cornell University, Ithaca, N.Y. (H. Dietrich).

Cairo University, Cairo, Egypt (M. Hafez).

Deutsches Entomologisehes Institut, East Berlin, D.D. R. (W. Hennig and G. Petersen).

Departmento de Zoologia, Secretaria da Agricultura, São Paulo, Brazil (M. Carrera and N. Papavero).

Instituto Español de Entomologia, Madrid, Spain (E. M. Agacino).

Illinois Natural History Survey, Urbana, Ill. (L. K. Gloyd).

Instituto Oswaldo Cruz, Rio de Janeiro, Brazil (H. S. Lopes).

Institut Royal des Sciences Naturelles de Belgique, Brussels, Belgium (J. Verbeke).

Kansas State University, Manhattan, Kans. (N. Marston).

Museo Civico di Storia Naturale, Genova, Italy (D. Guiglia).

Museo Civico di Storia Naturale, Milan, Italy (C. Conci).

Museum of Comparative Zoology, Cambridge, Mass. (P. J. Darlington, Jr.).

Musei Nationalis Hungarici, Budapest, Hungary.

Muséum National d'llistoire Naturelle, Paris, Franee (A. S. Balachowsky, Director and L. Matile).

Musée Royal de l'Afrique Centrale, Tervuren, Belgium (P. Basilewsky).

Maurice T. James colleetion, Washington State University, Pullman, Wash. (M. T. James).

Musée Zoologique de l'Université, Strasbourg, France (F. (ionin).

Naturhistorisches Museum, Basel, Switzerland (F. Keiser).

Natal Museum, Pietermaritzburg, South Africa (B. R. Stuckenberg).

Naturhistorisches Museum, Vienna, Austria (M. Beier).

Oregon state University, Corvallis, Oreg. (J. D. Lattin).

Polish Acatemy of Sciences, Warsaw, Poland (A. I)raber-Monko).

Pennsylunia Department of Agrieulture, Harrisburg, Pa. (F. B. Negley).

I. I1. Timberlake collection, University of California, Riverside, Calif. (P. II. Timberlake).

Purdue University, Iafayette, Ind. (L. Chandler).

Société Entomologique d'Egypte, Cairo, Egypt (A. Alfieri).

Seience Museum, The Institute of Jamaica, Kingston, Jamaica (T. II, Farr). 
SMNH Staatliches Museum für Naturkunde, Hamburg, Germany.

SMNS Staatliches Museum für Naturkunde, Stuttgart, Germany (E. Lindner).

TAES Texas Agrieultural Experiment Station, College Station, Tex. (H. P. Burke).

UAriz University of Arizona, Tueson, Ariz. (F. G. Werner).

U CalB University of California, Berkeley, Calif. (P. D. Hurd, Jr. and J. A. Powell).

UCalD University of California, Davis, Calif. (A. T. MeClay).

UGa University of Georgia, Athens, Ga. (H. O. Lund).

UKan University of Kansas, Snow Museum, Lawrence, Kans. (G. W. Byers).

UNebr University of Nebraska, Lincoln, Nebr. (W. T. Atyeo).

UQue University of Queensland, Brisbane, Australia (F. A. Perkins and T. E. Woodward).

USFS United States Forest Service; Berkeley, Calif. (C. B. Eaton); Moseow, Ida. (M. M. Furniss); Albuquerque, N. Mex. (C. L. Massey); Missoula, Mont. (R. E. Denton).

USNM United States National Museum, Smithsonian Institution, Washington, D.C. (J. F. Gates Clarke, Curator).

UZM Universitetets Zoologiske Museum, Kobenhavn, Denmark (S. L. Tuxen).

VMM Victoria Museum, Melbourne, Australia (C. W. Brazenor).

WSU Washington State University, Pullman, Wash. (M. T. James).

ZMH Zoologisches Museum der Humboldt Universität, East Berlin, D.D.R. (F. Peus and H. Schumann).

ZMUA Zoölogiseh Museum der Universiteit van Amsterdam, Amsterdam, Holland (W. N. Ellis).

ZMUH Zoological Museum of the University, Helsinki, Finland (W. Hackman).

ZSBS Zoologische Sammlung des Bayerischen Staates, Munich, Germany (W. Forster).

\section{Methods}

All figures were drawn using a binocular microscope provided with an ocular grid. Scale marks on all original figures represent one-half millimeter; the shorter of the two applies to the wing and lateral and frontal aspects of the head; the longer applies to the genitalia.

The genitalia were removed from the specimens after the abdomen was softened with water plus liquid detergent, boiled in $\mathrm{KOH}$, and drawn under water. Two or three views of each male genitalia were made: lateral, ventral (physically dorsal), and posterior where this would show added characters that would aid in identification; see figure 1 .

For the females, dorsal, ventral and lateral views of the sth and 9 th segments and roof of the bursa or other internal structures have been illustrated where necessary; see figure 1 .

All dissected parts have been stored in glycerin in microvials attached to the specimen. 


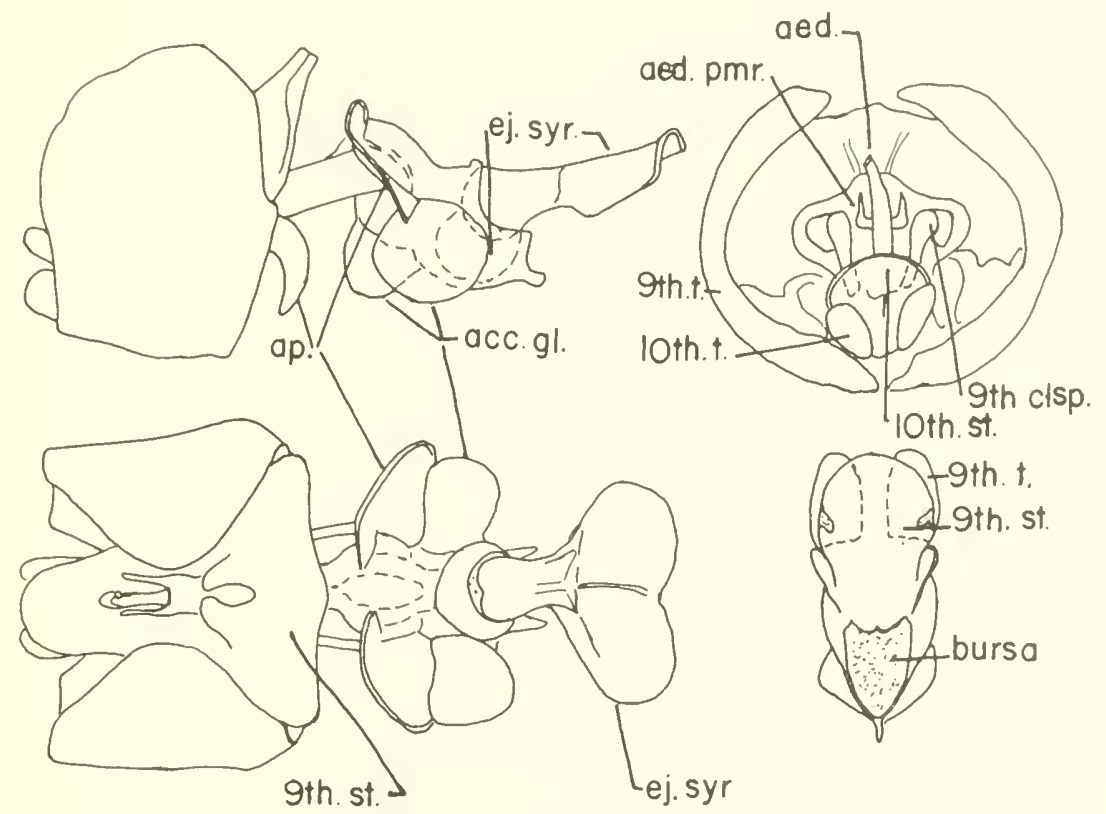

Figure 1.-Genitalic structures used in identification: aed., aedeagus; aed. pmr., aedeagal paramere; acc. gl., accessory gland; ap., apodeme; bursa, bursal cavity of female; ej. syr., ejaculatory syringe; 9th clsp., 9th segment clasper; 9th st., 9th sternum; 10th st., 10th sternum; 9 th t., 9th tergum; 10th t., 10th tergum.

Lateral and frontal aspects of the head and an enlarged view of the antenna were drawn for each sex, and a typical wing figure was made wherever possible.

\section{Biological Notes}

Very little is known of the biology of this interesting family. A few of the well known, widely distributed species, such as Scenopinus fenestralis and S. glabrifrons, have well documented life histories and have been associated with their hosts. From the meager records that are arailable, it is clear that the larvae of the Scenopinidae are all predacious on other insects. A number of species are predacious on the larrate of dermestids and have been commonly collected at the windows of storehouses, feed mills, and museums. Members of the gemus Pseudatrichia have been reared from the nests of wood rats, where they were feeding on the larvae of fleas and lice. Several species have been taken as larvae or pupae from the nests of birds and reared ont. Members of the genus Belosta from the western United States have been associated with bark-infesting beetles attacking pines and hardwood, and one species has been taken from a termite nest. The 
members of the genus Prepseudatrichia from Africa have all been reared from larvae collected in the wood of Acacia and Sterculia attacked by buprestid larvae.

Information concerning the habitat of the larvae or the hosts on which they feed has been recorded for less than ten percent of the known species of Scenopinidae. From the meager records at hand, howerer, some important clues to possible areas of concentration are indicated. Among the more obvious localities are: where dermestids occur, such as grain storages, warehouses and museums; birds' nests, particularly those occupied for relatively long periods of time; the nests or dens of animals; scar wood or under bark attacked by wood boring larvae; and the nests of termites.

The larvae are elongate, light bodied, hard, smooth, and wormlike with an elongate, pointed, strongly sclerotized, yellow head. When these larvae are found they should be maintained with the host culture, which should be held for a month or two after the emergence of the host adult, as the Scenopinid adults do not emerge until the next generation of the host has begun development. The pupae of the Scenopinidae appear very spiny, particularly along the abdominal segments.

The scarcity of specimens in most collections appears to be the result of failure to collect in the right place at the proper time. Most of the specimens observed have been obtained by sweeping foliage or flowers which strictly limits the chances of contact. The adult period appears to be relatively short in most cases and occurs at a regular time each year. There is good evidence that in areas with uniform plant or animal associations, large numbers of adults are present at the same time. In one instance, in California, over 150 specimens of a single species were taken on a two-day period along a distance of more than 100 miles. Other extensive series have also been seen that were taken in a short period by field crop inspectors sweeping the same crop over an extensive area. In other instances, members of the same species have been taken at the same locality in successive years on about the same date. The use of some permanent type of trap such as a Malaise trap would probably result in better sampling than that accomplished by most collectors with hand nets.

\section{Classification}

Provisional keys have been made up for those genera of Scenopinidae containing more than two species with the exception of Caenoneura and Pseudomphrale. I believe that the species listed in this paper comprise only a small part of the ultimate known fauna of Scenopinidae. For this reason, the simple characteristics of wing, halter and antennal color have been used as the primary basis for separation to species. 
The taxonomist is, therefore, cautioned to rheck carefully the figures and deseriptions of specimens which run through the keys. Unless the specimen comes from near the type area, it should be checked critically to see that it fits all the characteristics, as most species have only a limited distribution. For positive identification, the internal structures both of male and female should be checked against the figures.

In the following classification, the species have been grouped into genera on the basis of all arailable characters with particular emphasis on the genital characteristics which have not previously been used for identification of members of this family.

All males of this family examined to date have an internal ejaculatory syringe surrounded by accessory organs and apodemal structures to support the muscles of the ejaculatory syringe and aedengal ext ensors.

The females of Scenopinus are difficult to separate except by internal genitalic structures or the conformation of the eighth sternum; the shape of the bursal cavity is extremly helpful in identification.

In no case except $S$. niger has a male been examined where the eye was not divided into an upper portion with larger facets and a lower portion with smaller facets. In almost all cases, the lower portion of the eye appears darker than the upper part. All females have eyes with uniform facets in their make-up.

\section{Systematic Arrangement}

\section{Genus Scenopinus Latreille}

FENESTRALIS group

1. albicomus, new species $\sigma^{7}$

2. antennatus (Kröber) 1914b, 1. 74. (Omphrale) or

3. aquelonius, new species?

4. breviterminus, new species or o

5. cavifrons (Kröber) 1937, 1). 231. (Omphrale) 9

6. eflatouni, new species ?

7. fenestralis (Limnaens) 1758, p. 597. (. Musca) or o

8. glabrifrons Meigen $1824 \mathrm{p} .114 . \mathrm{O}^{7}$ ?

9. griseus (Kröber) 1913, p. 191. (Omphrale) $\sigma^{7}$

10. japonieus (Śćguy) 1920, p. 318. (Omphrale) ?

11. lesinensis Strobl $1902, \mathrm{p}, 474$. ?

12. mierogaster (Ségny) 1948, p. 15.). (Omphrale) o $\sigma^{7}$ ?

13. nidoreaupulus, new species ?

14. niger (DeGerer) 1776, p. 18. (Nemotelus) ơ 우

1.5. opaculus Loew 18.3, p. 145. 우

16. physadius (Séguy) 1930, 1) 111. (Omphrale) or $q$
'Tunisia

Algeria

British Columbia, Canadia

Calif., U.s.

Cantad:

Egypt

Worldwide

Europe; N. Africa; N. Americar:

Australia

I Iungary

Japan

Alustria

Chilla

Colo., It.s

Europe

samarkand (U.S.S. R.)

Moroceo 
17. saini, new speeies $0^{7}$

18. schroederi (Kröber) 1913, p. 201. (Omphrale) ?

19. sinensis (Kröber) 1928a, p. 1. (Omphrale) ?

20. undulafrons, new species ?

21. varipes Loew 1873, p. $148 . \sigma^{7}$

22. vitripennis Meigen 1824, p. 115. ?

\section{ALBICINCTUS group}

23. aethiopicus (Lindner) 195.5, p. 20. (Omphrale) ?

24. albicinctus (Rossi) 1790, p. 69. (1/ usca) or 9

25. angustifrons (Kröber) 1913, p. 197. (Omphrale)

26. anthrax, new speeies or?

27. balteatus Lamb 1922 , p. 363 . $\sigma^{7}$ 우

25. biroi Kertész, 1899, p. 173. ơ

29. bolgarti, new species or?

30. bouvieri (Séguy) 1920, p. 317. (Omphrale) $q$

31. brunneus (Kröber) 1913, p. 192. (Omphrale) $q$

32. bulbapennis, new species $\sigma^{7}$ ㅇ

33. canarius, new species $0^{7}$

34. curtipilosus, new species ?

35. darwini, new speeies $ᄋ$

36. evansi, new species $?$

37. flavipes (Kröber) 1939, p. 398. (Omphrale) ㅇ

38. fragosifrons, new species or o

39. gramieri, new species 우

40. inqualinus Séguy 1931, p. 113. 우

41. katbergi, new species $?$

42. keiseri, new species $ᄋ$

43. limpidipennis Loew 1874, p. 416. o 우

44. lucidus Becker, 1902, p. 39. 우 우

45. madagascariensis Enderlein 1934, p. 429. ㅇ

46. minutus, new species or 9

47. monodi (Séguy) 1933, p. 75. (Omphrale) or 우

48. niveus Becker, 1907, p. 61 . व'

49. norrisi, new species ?

50. oldenbergi (Kröber) 1913, p. 190. (Omphrale) 우

51. opacus deMeijere 1924 , p. 14 . $0^{7}$ ?

52. palmulapalpus, new species 우

53. papuanus (Kröber) 1912, p. 25. (Omphrale) or o

54. patrizi (Séguy) 1932, p. 499. (Omphrale)

55. perkinsi G. H. Hardy 1942, p. 202. 우 우

56. phaidimos, new species $\sigma^{x}$ 우

57. spurrelli, new species $ᄋ$

58. squamosus Villeneuve 1913, p. 111.
Egypt

Costa Rica

China

British Columbia, Canada

Russia

Europe

E. Africa

S. Europe

S. Africa

Magadasear; Hozambique

Seychelles

Australia; New

Guinea

W. Australia

Fr. Congo; ? Paris

E. Africa

Spain

Canary Islands

Egypt

N. Australia

N. Rhodesia

Kenya

W. Australia

Cameroun

Mozambique

S. Africa

Madagascar

N. Persia

Hawaii; Belg. Congo; Egypt; Canary

Islands

Madagascar

Australia

Soudan

Tunisia

Australia

Germany; ? Africa

Sumatra

S. Africa

Hawaii; Formosa;

New Guinea; Ceylon

Libya

Australia

Turkey

Australia

Algeria 
BREVICORNIS group

59. brevicornis Locw 1s73, p. 146. of ?

60. fraternus (Kröber) 1924, p. S1. (Omphrale) o o

61. fryeri, new spceies ?

62. halteralis Frey 1936, p. 33. o

63. lincinus, new species o

64. longiventris (Kröber) 1913, p. 206. (Omphrale) ₹

65. minusculus (Séguy) 1934, p. 74. (Omphrale) or $q$

66. nitidifrons (Krö̈ber) 1913, p. 194. (Omphralc) @

67. nitidulus Loew 1873, p. 149. o 우

65. parallelus, new species $0^{7}$

69. pilosus (Séguy) 1930, p. 111. (Omphrale) or

70. reduncus, new speeies ?

71. Larsalis (Kröber) 1913, p. 196. (Omphrale) or ?

72. Lurneri, new species or

73. unifascialus (Kröber), 1913, p. 195. (Omphrale) $\sigma^{7}$ 우

\section{VELUTINUS group}

74. adecnticius, D. E. Hardy 1960, 1). 329. o7 $q$

75. alalacteus, new species of $q$

76. albifasciatus (D. E. Hardy) 1944a, p. 41. (Omphralasoma) or 9

7 . barberi, new speeies or $q$

75. beameri (D. E. Hardy) 1944a, p. 43. (Omphrale) $\sigma^{2}+$

79. beameri var. fuscus (D. E. Hardy) 1944a, p. 43. (Omphrale) or $\sigma^{7}$

so. bryanti, new species o

81. buscki, new species or 9

82. butleri, new species or

83. chico, new species or

S4. rochisei, new species or ?

8.j. cooki, new species ot

86. crelatus, new species or क

87. (urlicornis (Köröber) 1913, p. 202. (Omphrale) q

s.8. clectus Adams 1904, 1). 44.). $0^{7}$

89. femoralus Macquart 183.5, ]. 7.

90. fijianus (Kröber) 1939, p. 399. (Omphroıle)

91. flandersi, new speeies or

92. gossypius, new species or

93. hagai, new species of ?

94. houdeni, new species ?

9.5. knilerti (D. E. Hardy) 1944r, ]. 46. (Omphrale) $\sigma^{x}+$

96. magdalenai, new species or

97. magnicornis (Kiröber) 1913, p. 202. (Omphralc) \&
Turkestan; Egypt

Egrpt

Serchelles

Canary Islands

Madagascar

Ceylon

Madagascar

E. Africa

Iran; Crete; Egypt

Rio de Oro

Morocco

Madagascar

Eritrea

S. Africa

Greece
Hawaii

Ida., Nev, U.s.

Calif., Ariz., N. Mex, U.S.

Ariz., U.心.

Calif., Nev., U.S.

Calif., U.S.

Ariz., U.s.

Panama; Jramaica

Ariz., U.'s'.

Calif., Ariz., Ner., U.'.

Ariz., Calif., U.S

Ariz., U.s.

Ila., Nev, U.s.

Brazil

Ariz., Callif., U.S.:

Baja Calif., Mexien

Brazil

Fiji Islamelo

Callif., U.s.

southern IT.

Ariz., U.S.

Ariz., I.s.

Texals, Ariz., Calif.,

N.M., U.s.

Mexico

Costal Rical; Peru;

Brazil 
98. mirabilis Adams 1904, p. 445. o 우

99. nubilipes Say 1829, p. $170 . \sigma^{7}$ ㅇ

100. pecki, new speeies or 우

101. pygmaeus Loew 1857 , p. $90 . \sigma^{7}$ ?

102. rossi, new species or $q$

103. schulzi Enderlein 1934, p. 429. or क

104. seftoni, new species or $\sigma^{7}$

105. serratus, new species $\sigma^{7}$

106. valgus (D. E. Hardy) 1944a, p. 50. (Omphrale) $0^{7}+$

107. vanduzeei, new species $\sigma^{7} \uparrow$

108. velutinus (Kröber) 1913, p. 203. (Omphrale) or 우

109. weemsi, new species $\sigma^{7} \uparrow$

110. werneri, new speeies $\sigma^{7}$

111. whillakeri (James) 1955, p. 47. (Omphrale) or $q$
Western U.S.;

Canada

Eastern U.S.

Alberta, Canada; Wyo., U.S.

Central America; West Indies;

Surinam

Mexico

Brazil, S. America

Mexico

Ariz., U.S.

Calif., Wash., U.S.

Mexico

Costa Rica; Mexico; Jamaica

Fla., U.S.

Ariz., U.S.

Wash., U.S.

\section{Genus Caenoneura Kröber}

112. robusta Kröber (1924), p. $75 \cdot \sigma^{7}$

Egypt

113. nigra, new species 우

Spain

\section{Genus Pseudomphrale Kröber}

114. clausa (Loew) 1873, p. 150. (Scenopinus) $\sigma^{7}$

115. crenata (Becker) 1913, p. 550. (Omphrale) q

1.6. dubiosa (Becker) 1913, p. 551. (Omphrale) ơ

117. longirostris (Becker) 1913, p. 549. (Omphrale)

118. ralaestinensis Kröber 1937, p. 229. જౌ
Iran

Iran

Iran

Iran

Palestine

\section{Genus Brevitrichia Hardy}

119. addacifors, new species $\sigma^{\pi}$ 우

120. arnaudi, n.w species of $q$

121. aspinosa, nev species ?

122. beameri, new species or $0^{7}$

123. boharti, new species or $0^{7}$

124. castanea, new specles वृ

125. coquillelti, new specie or 우

126. davisi, new species $0^{7} \zeta$

127. drcksoni, new species

128. downeyi, new species or 9

129. flocki, new species 웅

130. griffini, new species $\sigma^{7}$ 우

131. griseola (Coquillett) 1900, p. 501. (Pseudatrichia) $\sigma^{7}$ ?

132. halli, new species or 우

133. helenae (James) 1938, p. 22. (Pseudatrichia) $\sigma^{7}$

134. hodgdeni, new species or $ᄋ$

135. insulana (Cole) 1923, p. 462. (Pseudatrichia) or 우
Calif., U.S.

Baja Calif., Mexico

Ariz., U.S.

N. Mex., U.S.

Calif., U.S.

Ida., U.S.

Calif., U.S.

Utah, U.S.

Calif., U.S.

Calif., U.S.

Ariz., U.S.

Calif., U.S.

N. Mex., Tex., U.S.

Calif., U.S.

Colo., U.S.

Calif., U.S.

Baja Calif., Mexico 
136. kerni, new weeies 우

137. melanderi, ney species ?

138. minuta, new species ơ $\%$

139. oculvvirida, new species $\sigma^{7}$

140. ordwayi, new speries $\sigma^{7}$ 우

141. pruinosa, new species o

142. schlingeri, new speces ơ

143. scitulaesca, new speces $q$

144. timberlakei, new specics of $?$

145. yucatani, new species co
Calif., U.S.

N. Mex., U.S.

Ariz., Calif., U.S.

Baja Calif., Mexico

Ariz., U.S.

Baja Calif., Mexico

Calif., U.S.

Texas, U.S.

Calif., U.S.

Mexico; Guatemala

\section{Genus Metatrichia Coquillett}

146. bulbosa (Osten Sacken) 1877, p. 275. (Scenopinus) $\sigma^{x} \varsubsetneqq$

147. lophrysoma (Speiser) 1920, p. 216. (Pscudomphrale) ?

148. robusla Kröber 1913, p. 180. ¿q

149. stevensoni (Bezzi) 1925, P. 96. (Pondomphrale) or

150. watcrhousei (Paramonov) 1955, 1).640. (Pseudomphrale) or
U.S.; Mexico

ล. Afriea, Congo

Paraguay; Brazil ; Argentina

Rhodesia; Kenya:

S. W. Africa

Australia

\section{Genus Pseudatriclia Osten Sacken}

151. albocincta Van Duzee, 1926, 1) 164.

152. atombomba, new species or o

153. bakeri, new species ?

154. barnesi, new speeies or $q$

15.). biacristerna, new species ?

156. bryanti, new species ?

157. bupennis, new species $0^{7}$

15s. cajoni, new speeies or?

159. cloudcrofti, new species ?

160. cockerelli, new species or $q$

161. concava, new speeies ?

162. convexa, new speeies ?

163. eaithales, new species ?

164. evergreeni, new species

16.. garrelti, new species ?

166. gracilipennis, new species o

167. houdeni, urw species o

168. jamesi, new speeies o

169. lecchi, new spreiess ?

170. longiventris, new species on

171. longurio (Loew) 1866, p. 42. (1trichia)

172. melanderi, new species or $q$

173. morlani, new species or

174. nordeni, new species ?

175. parva I). I. IIardy, 1944: 1. 30. q

176. parvipennis, new" species o

$31:-1680-69-2$
Calif., U.S.

N. Mex., U.s.

Calif., U.s.

Calif., U.S.

N. Mex., U.s.

Ariz., U.S.

Calif., U.S.

Calif., U.S.

N. Mex., U.S.

Colo., U.S.

Calif., U.s.

Colo., U.s.

Colo., U.s.

Colo., U.s.

British Columbia,

Camada

Calif., U.S.

Ariz., U.S.

Colo., U.s.

Calif., U.S.

Costa Rica

Mexico

Callif., U.s.

N. Mex., U.S.

Calif., U.s.

Aliz., U.S.

Calif., U.s. 
177. peromysci, new species or 우

Calif., U.S.

178. punctulata D. E. Hardy, 1944b, p. 104. $\sigma^{\text {x }}$ ㅇ

Brazil

179. sabroskyi, new species ?

Oreg., U.S.

180. saccharcupa, new species 우

Calif., U.S.

181. toupeta, new species $\sigma^{7}$

Colo., U.S.

182. truncata, new species $\sigma^{7}$

Mexico

183. unicolor Coquillett 1900, p. 500. $\sigma^{7}$ ?

N. Mex., U.S.

\section{Genus Belosta D. E. Hardy}

184. albipilosa D. E. Hardy, 1944a, p. 38. 중

Calif., Idaho, U.S.

185. pilosa (Coquillett) 1903, p. 102. (Pseudatrichia) or?

186. telfordi, new species 우

187. termitophaga, new species $q$

188. viticolapennis, new species $\sigma^{7}$

Ariz., Calif., Colo., U.S.

Ariz., U.S.

Ariz., U.S.

Ariz., U.S.

\section{Genus Propebrevitrichia, new genus}

189. stuckenbergi, new species $\sigma^{7}$

S. Africa

190. turneri, new species or $\sigma^{7}$

S. Africa

\section{Genus Hetreromphrale Kröber}

191. cyanops (Edwards) 1932, p. 259. (Pseudom- Uruguay phrale) $\sigma^{\top}$

192. chilensis (Kröber) 1928b, p.31. (Pseudatrichia) ๆ Chile

\section{Genus Prejpseudatrichia, new genus}

193. mateui, new species 우우

194. stenogaster (Séguy) 1931, p. 114. (Scenopinus) 우

195. violacea, new species $q$
Sahara

Mozambique

Chad

\section{Genus Seguyella, new genus}

196. chinchona, new species $q$

197. galactica (Séguy) 1938, p. 334. (Omphrale) or

198. turneri, new species oㅇ
India

Kenya

S. Africa

\section{Genus Neopseudatrichia, new genus}

199. canei, new species $\sigma^{7}$

200. kewi, new species or

201. mariaensis (G. H. Hardy) 1933, p. 419. (Pseuda- Tasmania trichia) or $q$

\section{Genus Scenopinula Paramonov}

202. pallidipennis Paramonov 1955, p. 651. ㅇ
S. Australia

Australian Capital

Territory, Australia

New South Wales, Australia 


\section{Genus Riekiella Paramonov}

203. bicornis Paramonov 1955, p. 6.53.

204. collessi, new species or क

20.5. complexa, new species or

206. dycei, new speeies $q$

207. longiventris, new speeies

208. quadrifida, new speeies or ?

209. taylori, new speeies or

210. uncata, new species or ?
Queensland, Australia

New South Wales.

$$
\text { Australia }
$$

Australian Capital

Territory, Australia New South Wales,

Australia

W. Australia

Queensland, Australia

Vietoria, Australia

New South Wales,

Australii

\section{Genus Stenomphrale Kröber}

211. flaroscutellata (Körber) 1929, p. 80. (Pseudom- Egypt phrale) or?

212. teutankhameni (Kröber) 1924, 1) 72. (Pseudom- Egypt phrale) 중

\section{Genus Paratrichia, new genus}

213. lobosa, new speeies o

214. westralica (Paramonov) 1955, p. 641. (Pseudomphrale) $0^{7}$
Australian Capital

Territory, Australia W. Australia

\section{Key to the Genera of Scenopinidae}

1. Cell R5 open to the tip of the wing. . . . . . . . . . . . . . . 2 Cell R5 closed and petiolate . . . . . . . . . . . . . . . . . . 7

2. Vein $\mathrm{MI}+2$ fading before edge of wing . . . . . . . . . . . 3 Vein $\lambda I 1+2$ reaching edge of wing . . . . . . . . . . . . . . . . . 4

3. Vein $\mathrm{R} 4$ branching before the middle of cell R5

Scenopinula Paramonov (p. 304)

Vein R4 branching near or beyond the middle of eell $R 5$, vein $\mathrm{M} 1+2$ eurving toward vein R5. . . . . . Riekiella Paramonov (in part) (p. 304)

4. Vein $\mathrm{M} 4+\mathrm{Cu}$ normal, reaching edge of wing . . . . . . . . . . . . 5 Vein $\mathrm{M} 4+\mathrm{Cu}$ fading just beyond the $\mathrm{m}$ erossvein

Seguyella, new genus (p. 294)

5. Head longer than high, thorax depressed, long slim flies resembling Pseudatrichia. . . . . . . . . Prepseudatrichia, new genus (p. 286) Head higher than long, body not depressed, abdomen broad

Scenopinus Latreille, 6 (p. 14)

6. Large robust flies, with long slender antennae, vein $R 4$ branehing from $R 5$ before middle of eell R5; male 9 th tergum 4-lobed

Fenestralis group (p. 16)

Medium sized flies, variable antennae, vein $\mathrm{R} 4$ branehing from near center of cell R5; male 9th tergum 2-lobed, open ventrally

Albieinctus group (p. 45)

Medium sized flies, pear-shaped antennae, vein $R 4$ branching from near eenter of cell R5; male 9 th tergum with basal portion extending ventrally, 
open distally; female 8th sternum longer than tergum, 9th tergum usually with short spines . . . . . . . . . Brevicornis group (p. 93)

Medium to small flies, short antennae, vein $\mathrm{R} 4$ branching beyond the middle of cell R5; male 9th tergum 2-lobed closed below

Velutinus group (p. 110)

7. Vein $\mathrm{R} 5+\mathrm{M} 1+2$ ending at tip of wing . . . . . . . . . . . . . 8

Vein $\mathrm{R} 5+\mathrm{M} 1+2$ bending sharply to end in leading edge

Caenoneura Kröber (p. 162)

8. Long slender black flies . . . . . . . . . . . . . . . . . . . . 9

Brown, tan or gray flies . . . . . . . . . . . . . . . . . . 11

9. Head longer than high, body glabrous . . . . . . . . . . . . . . 10

Head higher than long, mouthparts atrophied, hairy

Belosta Hardy (p. 274)

10. Ninth tergum of male about as long as high and as long as the 10th tergum.

Female 9 th tergum and sternum subequal, tip of cell R5 blunt

Pseudatrichia Osten Sacken (p. 221)

Ninth tergum much taller than long, 10th tergum longer than 9 th. Female 10 th tergum with thick spines, tip of cell R5 sharp

Neopseudatrichia, new genus (p. 299)

11. Large robust bodied flies . . . . . . . . . . . . . . . . . . . 12

Smaller flies . . . . . . . . . . . . . . . . . . . . . 13

12. Very large flies with broad blunt abdomens in both sexes, frontal area swollen so that antennae project from middle of head; hairs often flat, scale-like

Metatrichia Coquillett (p. 214)

Smaller flies, with blunt abdomens, frons not swollen, male genitalia with flange-like lobes on inside of 9 th tergum . . Paratrichia, new genus (p. 320)

13. Small flies with pollinose seales on thorax . . . . . . . . . . . . . . 14

Small flies, black, shining . . . . . . . . . . . . . . . . 17

14. Wing with vein R4 branching from cell R5 near the base . . . . . . 15

Wing with vein $\mathrm{R} 4$ branching from the cell R5 near the middle . . . 16

15. Males with two long aedeagal spines, females with 8 th sternum excavated on distal margin, 9 th tergum often with row of stiff spines on posterior margin

Brevitrichia Hardy (p. 165)

Males with short aedeagal parameres, females with long pointed 8 th sternum, 9th tergum with stiff spines. . . . . Heteromphrale Kröber (p. 286)

16. Males with 9 th tergum as two flaps covering genitalia, females with spines on 9th tergum . . . . . . Propebrevitrichia, new genus (p. 281)

Males with 9 th tergum as four long lobes, females without spines on 9 th tergum . . . . . . . Riekiella Paramonov (in part) (p. 304)

17. Antennae pointed, vein $\mathrm{R} 4$ branching from distal third of cell R5

Stenomphrale Kröber (p. 318)

Antennae blunt, vein $\mathrm{R} 4$ branching from before the middle of cell R5

Pseudomphrale Kröber (p. 164)

\section{Genus Scenopinus Latreille}

Omphrale Meigen, 1800, p. 29 (rejected name).

Scenopinus Latreille, 1802, p. 463.

Atrichia Schrank, 1803, p. 54.

Cona Schellenberg, 1803, p. 66.

Hypseleura Meigen, 1803, p. 273.

Scenopoeus Agassiz, 1846, p. 333. 
Astoma Lioy, 1S64, p. 762.

Scacnopius Dalla Torre, 1878, p. 161.

Lepidomphrale Kröber, 1913, p. 182.

Archiscenopinus Enderlein, 1914, p. 25.

Lucidomphrale Kíröber, 1937, p. 222.

Omphralosoma Kröber, 1937, p. 222.

Paromphrale Kröber, 1937, p. 222.

Type-species, Musca fenestralis Linnaeus (monobasic). 'This genus is the largest, and by far the most cosmopolitan, genus, having representatives in all geographic regions. Because of its size (111 species) it has been subdivided into four infrageneric groups each with rather distinct continental distribution: Fenestralis, Albicinctus, Brevicornis, and Velutinus.

Fenestralis group.-The members of this group are characterized by a head that is higher than long, generally with long slender antennae, $\mathrm{R} 4$ branching from $\mathrm{R} 5$ at or before the middle of the cell; generally robust and of large size. The males have in common a four-lobed ninth tergum and a three-pronged genital apparatus consisting of a median aedeagus and two lateral aedeagal parameres. The females of this group have a large membranous bursal area; see figures.

Geographically this group is Palearctic with an extension down the west coast of the North American continent. Scenopinus fenestralis and $S$. glabrifrons have become world-wide in distribution as a result of transport in trade goods. S. niger, contrary to previous reports, is strictly limited to the European continent.

Albicinctus group.--The members of this group are characterized by having the head higher than long, the antennae only twice as long as wide, the vein $\mathrm{R} 4$ branching from $\mathrm{R} 5$ near to or beyond the middle of the cell and their size generally smaller than that of members of the Fenestralis group. The males are characterized by a bilobed ninth tergum which does not overlap or close on the ventral side (dorsal on the specimen) leaving the genitalia exposed. The aedeagus is rariable, with the parameres often longer than the aedeagus proper. The bursa of the female is generally as in the Fenestralis group but somewhat wider than long.

The members of this group are found in the Ethiopian, circumMediterranean area of the Palaearctic, the Oriental and Australian regions including Hawaii.

Brevicornis Group. - The members of this group have the head higher than long, the antenme generally pear-shaped. The wing has R4 branching from R5 at or near the middle of the cell. M1 tends to run parallel to $\mathrm{R} 5$ so that they are widely separated at the wing margin. 'The male terminalia, though open ventrally, have the proximal portion of the ninth tergum extending ventrally to partially cover the 
venter. In the female, the eighth sternum extends posteriorly beyond the margin of the tergum and the ninth tergum has randomly placed coarse hairs; the bursal cavity is longer than wide.

The species placed in this group have been removed from the preceding group, in some cases on a tentative basis, particularly where only the male is known. Other species presently included in the Albicinctus group may belong here but until their females are found their exact placement is questionable.

The members of this group are found in the circum-Mediterranean part of the Palaearctic and in the Ethiopian region.

VELUTINUS GROUP.-The members of this group are small to medium-sized flies with the abdomen broad and rounded. The head as in the other members of the genus is higher than long, the antennae are generally short, oval, rarely being over twice as long as wide. Vein $\mathrm{R} 4$ generally branching from R5 well beyond the middle of the cell. Male ninth tergum bilobed, generally extending ventrally to enclose the genitalia from view in the pinned specimen. The aedeagus is generally well developed and is flanked by two aedeagal parameres of variable length, generally but not always shorter than the aedeagus. The bursal cavity of the female is small and triangular.

This group is generally limited to the Nearctic and Neotropical regions with an extension into the Pacific Island area.

\section{FENESTRALIS group}

\section{Provisional Keys to Species of the Fenestralis Group}

\section{NEARCTIC SPECIES}

1. Antennae long and narrow . . . . . . . . . . . . . . . 2

Antennae short, pear-shaped . . . . . . . . . . . . . . 4

2. Wings hyaline, halter knob white to brown . . . . . . . . . . . . . . 3 Wings smoky gray, halter knob yellow-brown. . . . 오 S. schroederi Kröber

3. Frons shining, halter knob white, legs orange-brown

$\sigma^{7} \subsetneq$ S. glabrifrons Meigen

Frons rugose, halter knob brown to white, legs red-brown $\sigma^{7} \uparrow \mathrm{S}$. fenestralis (Linnaeus)

4. R4 branching before the middle of eell R5 . . . . . . . . . . . . . . 5 R4 branching at the middle of eell R5 . . . . . . S. aquelonis, new species

5. R4 branching from before the middle of cell R5 . $\mathrm{R} 4$ branehing from the basal quarter of eell R5

$\sigma^{7}+$ S. breviterminus, new speeies

6. Cell R5 narrowing gradually . . . . . . . S. undulafrons, new species Cell R5 narrowing abruptly at tip. . . . . S. nidorcaupulus, new speeies

PALAEARC'TIC SPECIES (MALES)

1. Wing hyaline . . . . . . . . . . . . . . . . . . . 2

Wing brown or milky white . . . . . . . . . . . . . . . . 4

2. Frons shining, halter knob white. . . . . . . . . . . . . . 3 
Frons rugose, halter knob variable, white to brown

S. fenestralis (Linuaeus)

3. Vein R4 branching well before middle of eell R5. . S. glabrifrons Meigen Vein R4 branching near middle of eell R5. . . . . . S. saini, new species

4. Wing brown or tinged brown . . . . . . . . . . . . . . . . 5 Wing milky or grayish . . . . . . . . . . . . . . . . . . . . .7

i) Halter knob brown or black-brown . . . . . . . . . . . . . . . . .6 Hialter knob white, abdomen with 6 white dorsal stripes. S. griseus Kröber

6. Ilalter knob black-brown, eyes widely separated, uniform facets, abdomen normal length . . . . . . . . . . . . . . . S. niger DeGeer IIalter knob brown, eyes nearly touching, divided into upper and lower facets, abdomen short and broad. . . . . . . . . . S. microgaster Séguy

¡. Halter knob white . . . . . . . . . . . . . . . . . 8 Halter knob brown on top white below. . . . . . . S. opaculus Loew

8. Third antennal segment long and narrow . . . . . . . . . . . . . . . 9 Third antennal segment short, swollen at base. . . S. antennatus (Köröber)

9. Abdomen with three stripes, first broad, second and third narrow

S. albicomus, new species Abdomen with three broad white stripes.

S. physadius (Séguy)

\section{PALAEARCTIC SPECIES (FEMALES)}

1. Wing hyaline . . . . . . . . . . . . . . . . . . . 2

Wing brownish or milky white . . . . . . . . . . . . . . 4 4

2. Frons shining, halter knob white or brown . . . . . . . . . . . . . . . 3 Frons rugose, halter knob variable brown to white. S. fenestralis (Linneaus)

3. Ilalter knob white. . . . . . . . . . . . . . S. glabrifrons Meigen granular.

Halter knob brown . . . . . . . . . . . . . . . . . . . . . .

4. Wing smoky white . . . . . . . . . . . . . . . . . . . . . .

Wing brownish . . . . . . . . . . . . . . . . . 6

5. Halter knob white. . . . . . . . . . S. physadius (Séguy)

Ilalter knob light tan. . . . . . . . . . . S. opaculus Loew

6. Halter knob red-brown, brown or black-brown; antenna variable . . . .7

IIalter knob light tan; antenna elongate, red-brown. S. efflatouni, new species

7. Halter knob brown or black-brown; antenna variable. . . . . . . . 8

IIalter knol, red-brown above, cream below; third antennal segment black, granular. . . . . . . . . . . S. lesinensis Strobl

8. Halter knob brown .. . . . . . . . . . . . . . . . . . .9

IIalter knob black-brown . . . . . . . . . . . . . . . . . 10

9. Antenna short, oval; vein R4 branching from near midclle of cell R5, abclomen short . . . . . . . . . . . . . S. microgaster (Séguy)

Antenna long, narrow; vin R4 branching from basal thirel of eell R5, abdomen normal. . . . . . . . . . . . . S. sinensis (Kröber)

10. Cell R5 open at end of wing, marginal length nearly equal to length of $\mathrm{r}-\mathrm{m}$ cross vein. . . . . . . . . . . . . . S. japonicus (Séguy)

Cell R5 elosed at end of wing, marginal length only half the length of $\mathrm{r}-\mathrm{m}$ eross vein. . . . . . . . . . . . . . S. niger (Deficer)

\section{Scenopinus albicomus, new species}

FigURE 2

MALE. - A moderately large black-brown fly typical of the group. Head black-brown; eyes black, tinged with red, the upper two-thirds 


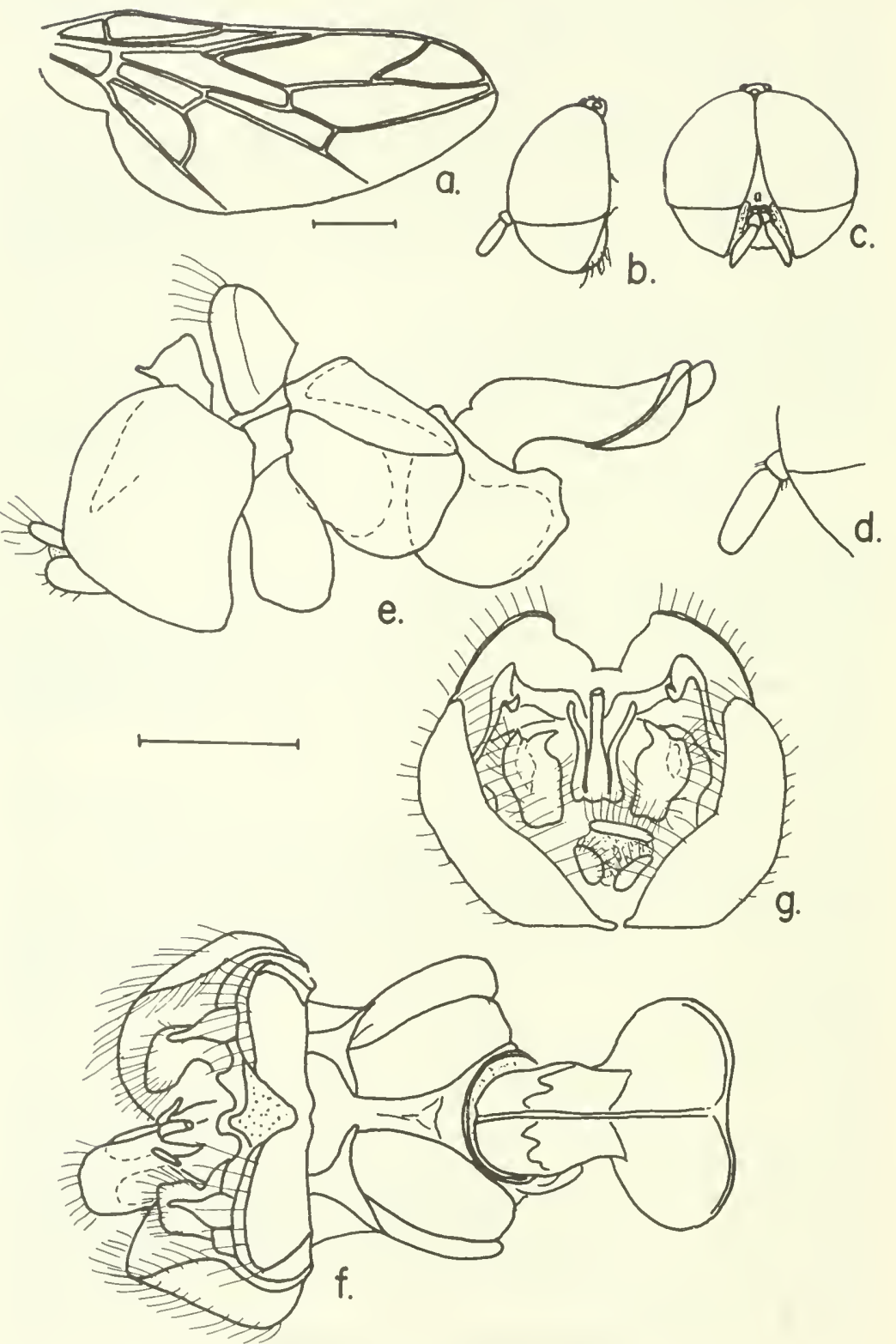

Figure 2.-Scenopinus albicomus, new species, male: $a$, wing; $b, c$, head, lateral and frontal aspects; $d$, enlarged detail of antenna; $e-g$, lateral, ventral, and posterior aspects of terminalia. 
with large facets and the lower third with fine facets; frons small, triangular, shining, with a shallow groove on the midline above the antennas; ocellar tubercle not prominent, ocelli yellow to orangeyellow. Antennae with first segment brown, short; second segment twice as large and light brown; third segment brown, long and narrow, over twice as long as first and second segments combined. Mouthparts well developed.

Thorax dorsum black-brown covered with short silvery hairs; posterior rim of humeral callus orange; supra-alar callus yellow. Wing smoky white, reins tan; stem of halter tan, knob white. Legs, femora and tibiae of all legs brown, tarsi yellow.

Abdomen first segment white to lateral margins, brown below scutellum; second segment brown; third segment with a wide band; fourth and fifth segments with narrower white bands with brown between; genital segment brown with aedeagus projecting visibly; see figure for details.

Female.-Unknown.

Length: Male body $4 \mathrm{~mm}$., wing $3 \mathrm{~mm}$.

Type-locality: Tunis (Tunisia); 2 August 1929 (C. Dumont). Holotype: Male (MNHN).

\section{Scenopinus antennatus (Kröber)}

FiguRE 3

Omphrale antennata Kröber, 1914b, p. 74.

Paromphrale antennata (Kröber).-Kröber, 1937, p. 214.

Male. - This species is known only from the type. A moderate sized fly of a red-brown color; eyes divided, with larger upper and

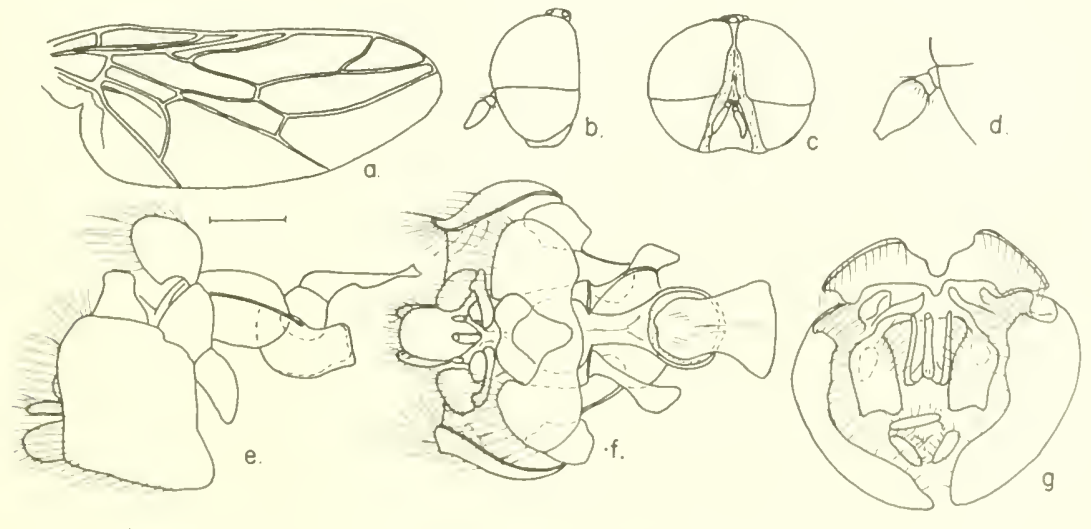

Figure 3.-Scenopinus antennatus (Kröber), male: $a$, wing; $b, c$, head, lateral and frontal aspects; $d$, enlarged detail of antenna; $e-g$, lateral, ventral and posterior aspects of terminalia. 
smaller lower facets; frons granular with a median depression above the antennae. The third antennal segment is broader at the base and shorter than normal for the group.

Thorax red-brown, covered with a thin pile of short hairs. Wings milky with light brown veins. Halter stem brown, knob cream. The legs are light brown with the basal portion of the tarsi yellow darkening distally.

Abdomen red-brown with three white bands. Genital segments as figured.

Female.-Unknown.

Length: Male body $4 \mathrm{~mm}$., wing $2.8 \mathrm{~mm}$.

Type-locality: Biskra, Algeria; May 1891 (Handrich).

Type: (NMV).

\section{Scenopinus aquelonius, new species}

Figure 4

Female.-A large fly with the typical $S$. fenestralis appearance except for the antennae which are shortened and pear-shaped.

Head black, eyes red-brown, postocular flange broad and subshining, frons wide, subshining, with a median groove, a shallow depression in the lower half. Back of the head concave; mouthparts brown, well developed; a shiny band of integument between the silvery pilosity lining the oral cavity and the lower eye margin. The ocellar tubercle red-brown, set off slightly from the frons; ocelli tan. The first antennal segment short, black; the second red-brown and twice as long as the first; the third segment dark red-brown, pear-shaped, twice as long as broad.

Thorax black; thinly covered with short silvery hairs, a patch of silvery pile above the red-brown humeral callus; supra-alar callus orange. Wings smoky brown, veins red-brown; halter stem brown, knob red-brown. Legs: femora and tibiae red-brown, tarsi brown.

Abdomen broad, dark red-brown; see figure for distinguishing characters of 8th sternum and bursa.

MaLe.-Unknown.

Length: Female body $5 \mathrm{~mm}$., wing $3.5 \mathrm{~mm}$.

Type-locality: Trinity Valley, B.C., Canada; 8 August 1928 (R. T. Turner).

Holotype: Female (CNC) 8632.

Paratype: Female, same locality, July 1937 (K. Graham) (CNC). 

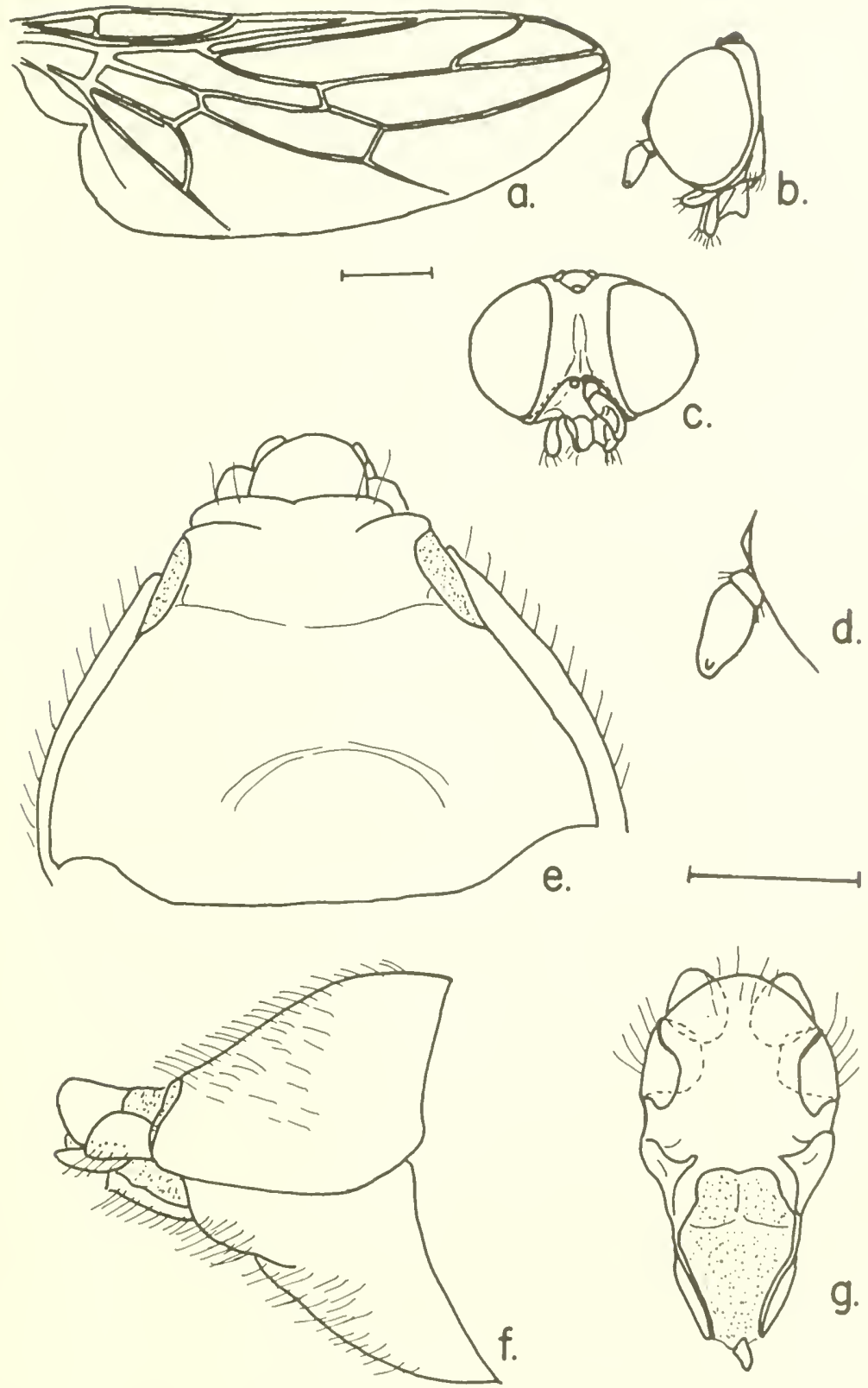

Figure 4.-Scenopinus aquelonius, new species, female: $a$, wing; $b$, $c$, lateral and anterior aspects of head; $d$, enlarged detail of antenna; $e$, 8th sternum; $f$, lateral aspects of 8 th and 9 th segments; $g$, detail of 9 th sternum and bursa. 


\section{Scenopinus breviterminus, new species}

FIgURE 5

MaLe.-A large robust fly similar to $S$. fenestralis except for head and genital structures.

Head black-brown; eyes red-brown, darker below; frons elongate, separating the eyes above by at least the width of the median ocellus, pitted and with three indistinct shallow grooves on lower frons; ocellar tubercle black, distinct; ocelli clear in specimen. First antennal segment small, brown, shining; second segment orange, larger than the first; third segment red-brown, darker at tip, not twice as long as wide.

Thorax dorsum black-brown, rugose, thinly covered with silvery hairs; humeral callus red-brown, light yellow behind, supra-alar callus red-brown; pleural region red-brown. Wings smoky hyaline, reins brown; halter stem brown, knob red-brown. Legs all segments light red-brown.

Abdomen red-brown, segments 3-5 banded with white on posterior margin. Terminalia red-brown; see figure for details. Internal structure lost through feeding by dermestids. The ninth tergum lobes are shorter than in typical fenestralis.

Female.-A large black fly resembling fenestralis except for the antennae which are shorter.

Head black, eyes black; postocular flange flat, dull. Frons with a median groove from the antennae to median ocellus, slightly swollen above the antennae, granular, except smooth bands along eye margins.

Thorax black, rugose, subshining, humeral and supra-alar calli orangebrown; halter stem brown, knob oxblood red, polished. Wing hyaline, tinged brownish, veins brown. Foreleg with coxa red-brown, trochanter orange, femur red-brown, tibia orange-brown, tarsus straw colored; middle leg with trochanter orange-brown, femur dark redbrown, tibia lighter and tarsus straw colored; hind leg with all segments dark red-brown except tarsus straw colored.

Abdomen dark red-brown; see figure for details of eighth sternum and bursa.

Length: Male body 4.5-5.0 mm., wing $3.5 \mathrm{~mm}$.; female body 5.7 mm., wing $3.7 \mathrm{~mm}$.

Type-locality: Kerr Ranch, New Mexico; 23 April 1910 (J. D. Mitchell), on Yucca.

Holotype: Male (USNM) 67453.

Allotype: Female, Carson Pass, California, in fungus (Mont. A. Cazier) (USNM). 

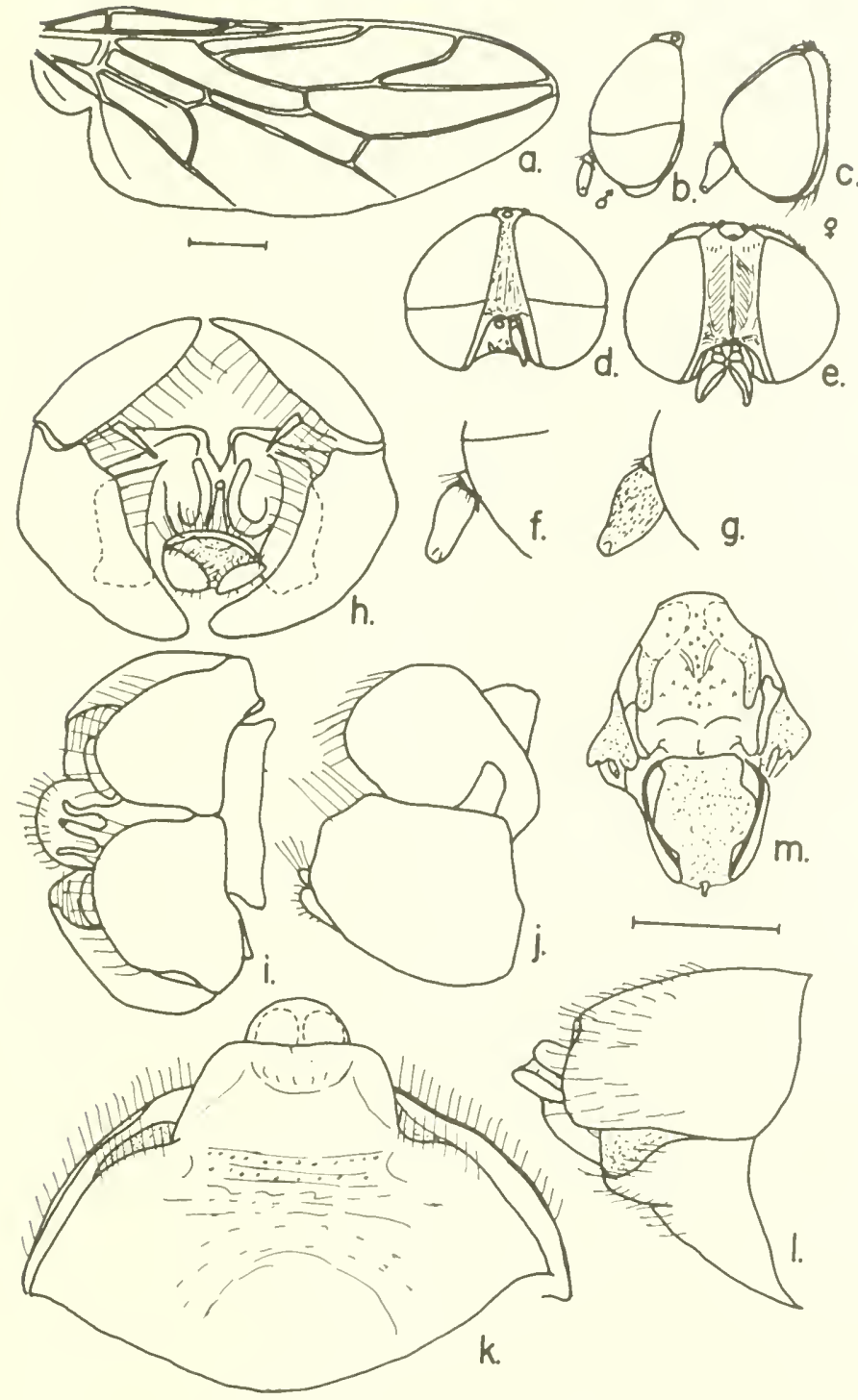

c.

.

\section{.}

Figure 5.-Scenopinus breviterminus, new species, male, female: $a$, wing; $b, d$, lateral and frontal aspects of male head; $c, e$, lateral and frontal aspects of female head; $f, g$, enlarged details of male and female antennae; $h-j$, posterior, ventral and lateral aspects of male terminalia (internal structures destroyed); $k$, ventral aspect of female 8th sternum; $l$, lateral aspect of female 8th and 9th segments; $m$, female 9 th sternum and bursa. 


\section{Scenopinus cavifrons (Kröber)}

Figure 6 (after Kröber)

Omphrale cavifrons Kröber, 1937, p. 231.

The type of this species has been destroyed.

Length: Female body $4.1 \mathrm{~mm}$., wing $3.7 \mathrm{~mm}$.

Type-locality: Joinville, Algonquin, Canada?

Holotype: (SMNH).

A long series has been seen in the collection of the Illinois Natural History survey with the label "Algonquin" (Northern Illinois) which may actually have been the source of Kiröber's specimen. These specimens all agreed with fenestralis (L.). However, since the type cannot be checked, I have let the name stand.
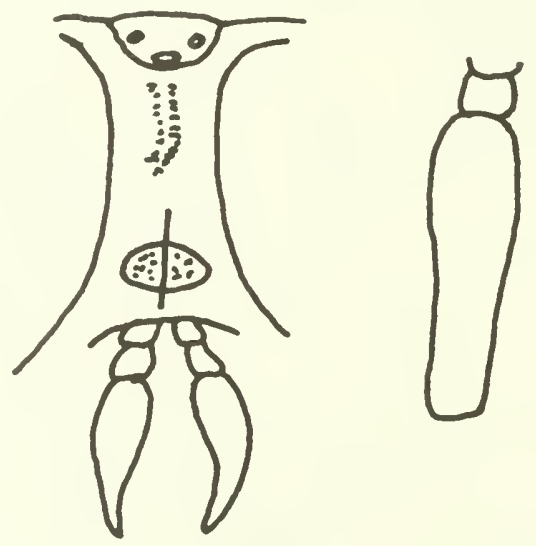

Figure 6.-Scenopinus cavifrons (Kröber), female:

Details of frons and antenna (after Kröber).

\section{Scenopinus efflatouni, new species}

Figure 7

Female.-A moderately large robust fly typical of the group. Head red-brown; eyes red-brown; postocular ridge moderately broad; frons subshining with small pits for fine hairs, swollen on either side of a median groove extending from the upper half to the median ocellus, flat below; the ocellar tubercle slightly swollen, ocelli orange-brown. First two antennal segments orange-brown; third segment three times as long as the first two combined, red-brown. Mouthparts well developed.

Thorax red-brown, with short recumbent white hairs, the posterior margin of the humeral callus orange-brown; scutellum red-brown with short erect white hair. Wings subhyaline, with brown cast, veins 

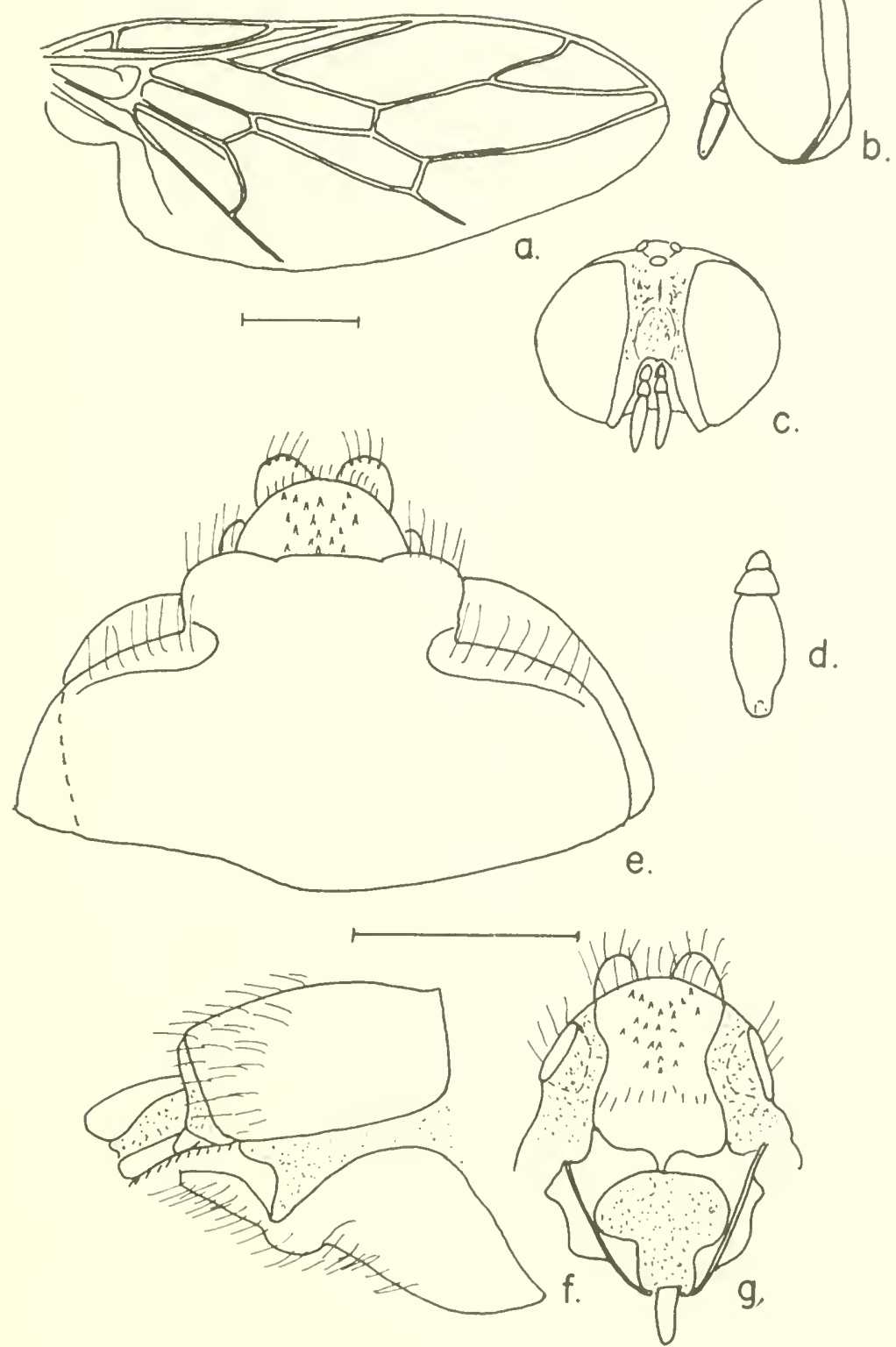

Figure 7.-Scenopinus efflatouni, new species, female: $a$, wing; $b$, $c$, lateral and frontal aspects of head; $d$, detail of antenna; $e$, ventral aspect of 8 th sternum; $f$, lateral aspect of 8th and 9th segments; $g$, 9th sternum and bursa. 
brown; halter stem yellow, knob light tan. Legs with femora and tibiae brown, tarsi straw yellow, darkening distally.

Abdomen red-brown, with short recumbent hairs, middle segments with membranous posterior margins; see figure for details of eighth sternum and bursa.

MaLE.-Unknown.

Length: Female body 4.0-4.5 mm., wing 3.0-3.4 mm.

Type-locality: Abu Rowash, Egypt; 5 November 1924 (Efflatoun).

Holotype: Female (SEE).

Paratype: Female, Cairo; 4 July 1918 (Efflatoun) (SEE).

\section{Scenopinus fenestralis (Linnaeus)}

Figure 8

Musca fenestralis Linnaeus, 1758, p. 597.

Musca saltitans Scopoli, 1763, p. 350.

Musca spoliata Scopoli, 1763, p. 350.

Musca senillis Fabricius, 1794, p. 331.

Atrichia fasciata Schrank, 1803, p. 103.

Scenopinus pallipes Say, 1823, p. 100.

Scenopinus sulcicollis Meigen, 1824, p. 114.

Scenopinus domesticus Meigen, 1824, p. 116.

Scenopinus rufitarsis Meigen, 1838, p. 165.

Scenopinus scutellatus Macquart, 1843, pp. 6-8, pl. 1.

Scenopinus furcinervis Zetterstedt, 1844, p. 897.

Musca "tarda" Linnaeus.-Haliday, 1851, p. 138.'

Scenopinus graminicola Zetterstedt, 1859, p. 6045.

Scenopin us fuscinervis Schiner, 1862, p. 159.

Scenopinus scutellatus var. nigroscutellatus Frey, 1945, p. 36.

Scenopinus perkinsi Paramonov (not Hardy), 1955, p. 651.

The type of this species has long been lost but it is a well established and easily identified species which is distributed over all of the zoogeographic regions of the world. It is characterized by the rugose frons in both sexes; antennae long, slender and dark brown; and legs yellow-brown. The halteres vary from white to dark brown. The male terminalia has a notch at the tip of the dorsal lobe that shows considerable variation; see figure $8 \mathrm{~m}$. Specimens with these different

\footnotetext{
${ }^{1}$ In 1851, Haliday published a paper in the Stettiner entomologische Zeitung, vol. 12 , p. 138, dealing with the Linnaean collection in London. The reference to "tarda" is to a manuscript name in the Linnaeus collection which Haliday says is a synonym of fenestralis.
}

Figure 8.-Scenopinus fenestralis (Linnaeus), male, female: $a$, wing; $b, d$, lateral and frontal aspects of male head; $c, e$, lateral and frontal aspects of female head; $f$, enlarged detail of antenna; $g-i$, ventral, lateral and posterior aspects of male terminalia; $j$, ventral aspect of female 8th sternum; $k$, lateral aspect of female 8th and 9th segments; $l$, female 9th sternum and bursa; $m$, various emarginations on ventral margin of male 9 th tergum. 


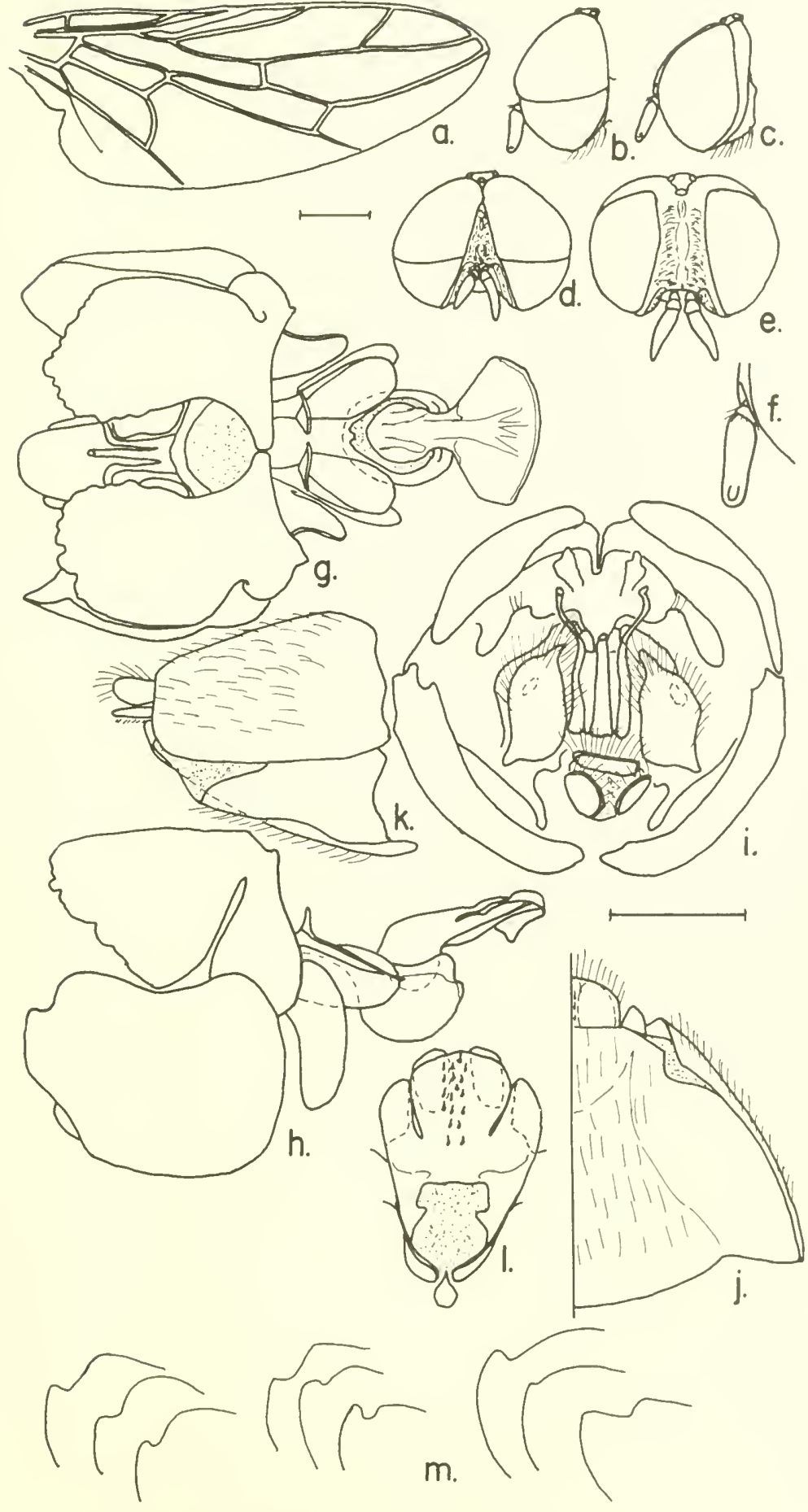


patterns are widely distributed in North America and Europe and are believed to be conspecific.

Length: Male body 4.0-4.5 mm., wing $3 \mathrm{~mm}$.; female body $4.5-5.5 \mathrm{~mm}$., wing $3.5-3.7 \mathrm{~mm}$.

Type-locality: Europe.

Distribution: Worldwide.

\section{Scenopinus glabrifrons Meigen}

Figure 9

Scenopinus glabrifrons Meigen, 1824, p. 114.

Scenopinus halterata Meigen, 1824, p. 113.

Scenopinus orbita Meigen, 1824, p. 114.

Scenopinus laevifrons Loew, 1857, p. 88.

Omphrale glabrifrons var. surcoufi Séguy, 1920, p. 318.

Scenopinus civiculus G. H. Hardy, 1933, p. 418.

Paromphrale glabrifrons (Meigen).-Krober, 1937, p. 214.

These are large flies similar to Scenopinus fenestralis but are easily separated on the basis of the shining frontal areas of both the male and female. Antennae elongate orange-brown at the base and darker at the tip. Halteres are white (similar appearing flies with dark halteres are Scenopinus vitripennis Meigen). Male ninth tergum with smooth margins; female eighth sternum and bursa with minor characters. Paramonov (1955, p. 649) places glabrifrons in synonomy with civiculus.

Length: Male body 4.0-4.5 mm., wing $3 \mathrm{~mm}$.; female body 4.5-5.5 mm., wing 3.5-3.7 mm.

Type-locality: Europe-type-specimen lost.

Distribution: Worldwide.

\section{Scenopinus griseus (Kröber)}

FIGURE 10

Omphrale grisea Kröber, 1913. p. 191.

MALE.-This small fly differs noticeably from most members of this group, being considerably smaller and having very short swollen antennae. It does, however, have the four-lobed condition of the male genitalia placing it in this group. The abdomen has most of the dorsal surface of segments $2-7$ white. The wings have a brownish cast and the halter knobs are white.

Female.-Unknown.

Length: Male body $2.5-2.7 \mathrm{~mm}$., wing $1.8 \mathrm{~mm}$.

Type-locality: Gyón, Hungary.

Holotype: (MNH) destroyed.

Topotype: Male, Gyón (Kértész) (ZMUH).

Other specimen examined: Gyón (NMV). 

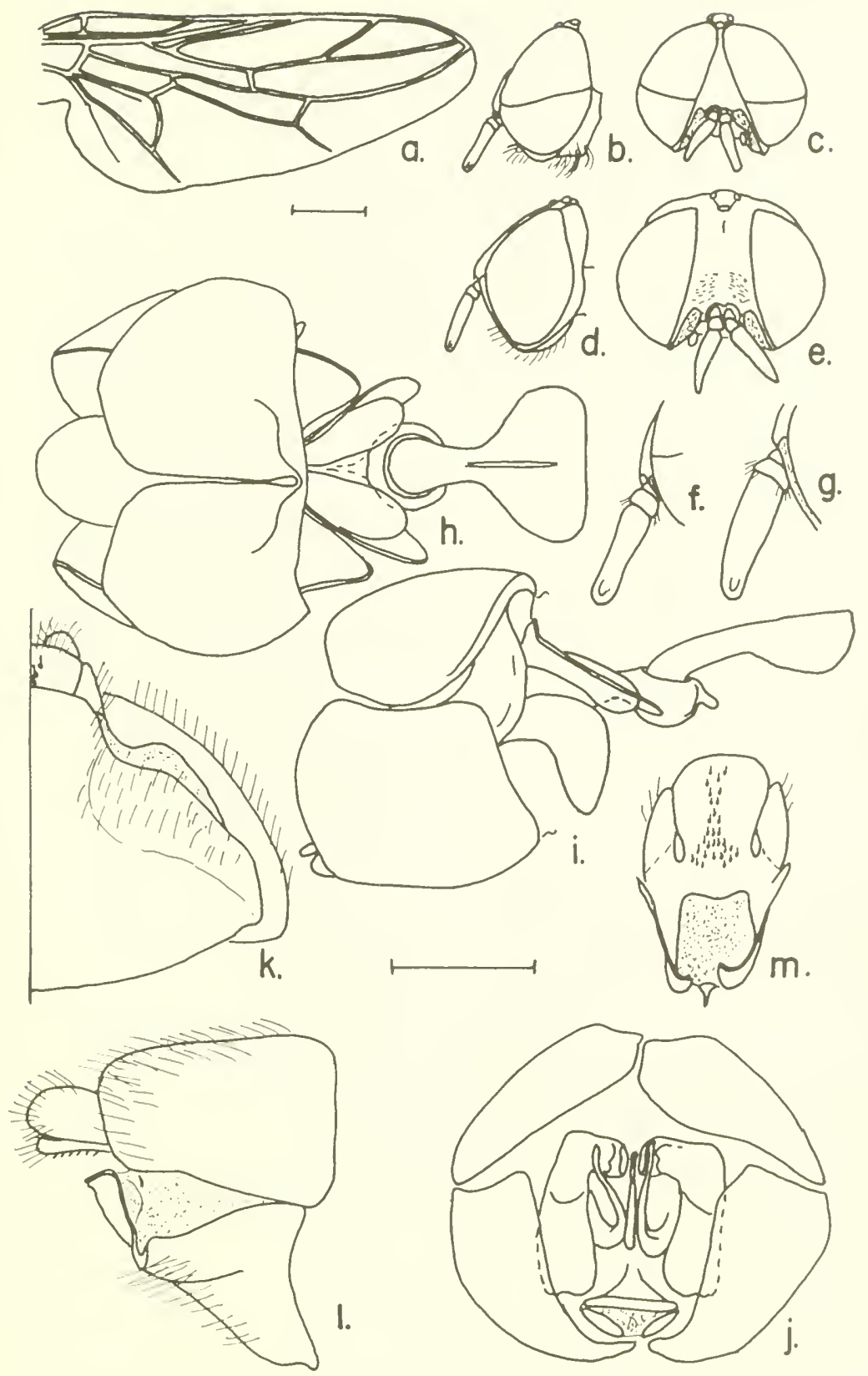

Figure 9.-Scenopinus glabrifrons Meigen, male, female: $a$, wing; $b, c$, lateral and frontal aspects of male head; $d, e$, lateral and frontal aspects of female head; $f, g$, enlarged details of male and female antennae; $h-j$, ventral, lateral and posterior aspects of male terminalia; $k$, ventral aspect of female 8 th sternum; $l$, lateral aspect of female 8 th and 9 th segments; $m$, female 9 th sternum and bursa. 

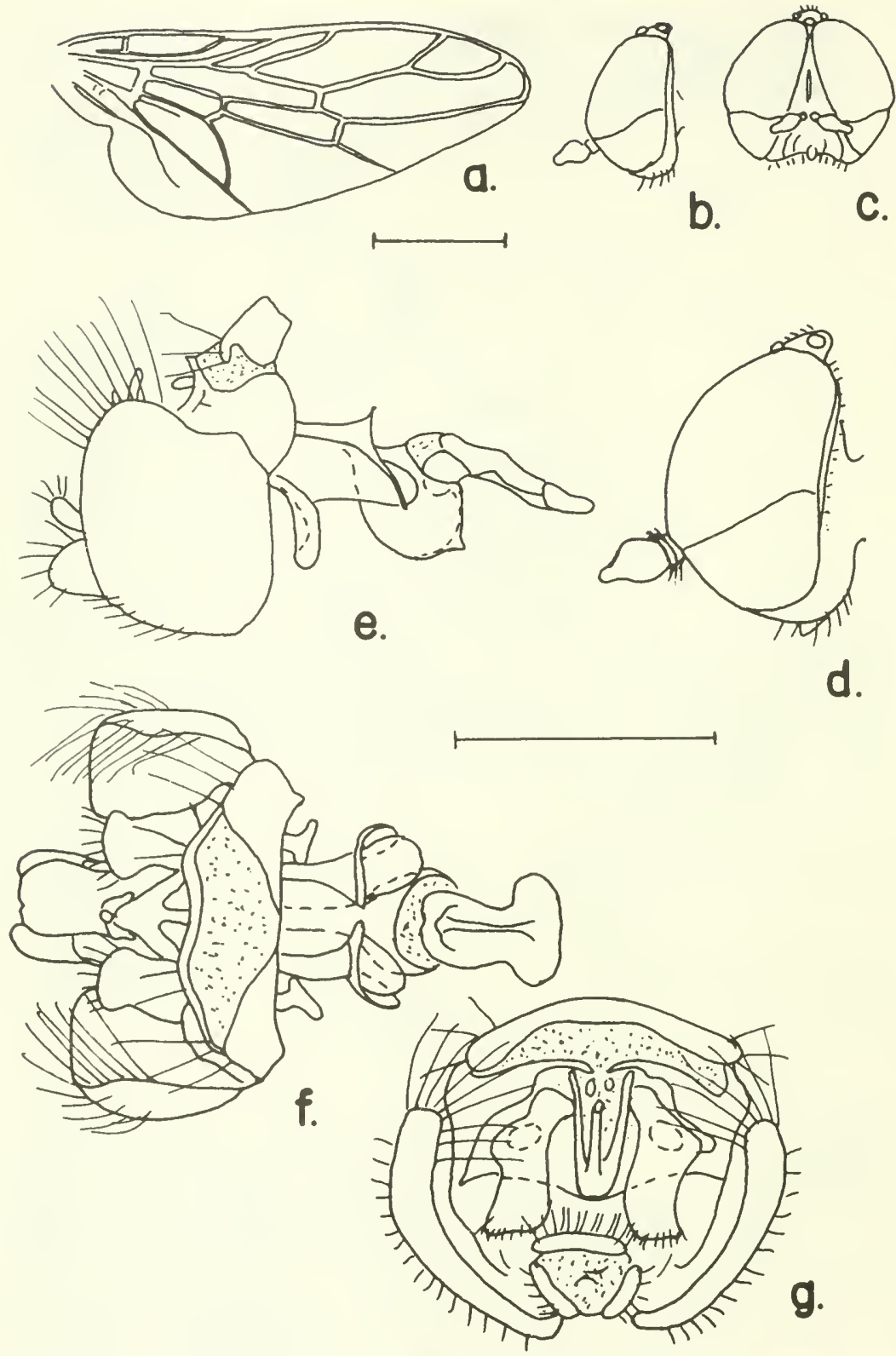

d.

Figure 10.-Scenopinus griseus (Kröber), male: $a$, wing; $b, c$, lateral and frontal aspects of head; $d$, enlarged detail of head; $e-g$, lateral, ventral and posterior aspects of terminalia. 


\section{Scenopinus japonicus (Séguy)}

FIGURE 11

Omphrale japonicus Séguy, 1920, p. 318.

Female.-This is a medium sized black fly; the head of the type was crushed and the antennae which Séguy describes as being blackish brown are missing. Frons rugose with pit above the antennae and shining band extending up to ocellar triangle. Wing and terminalia as figured.

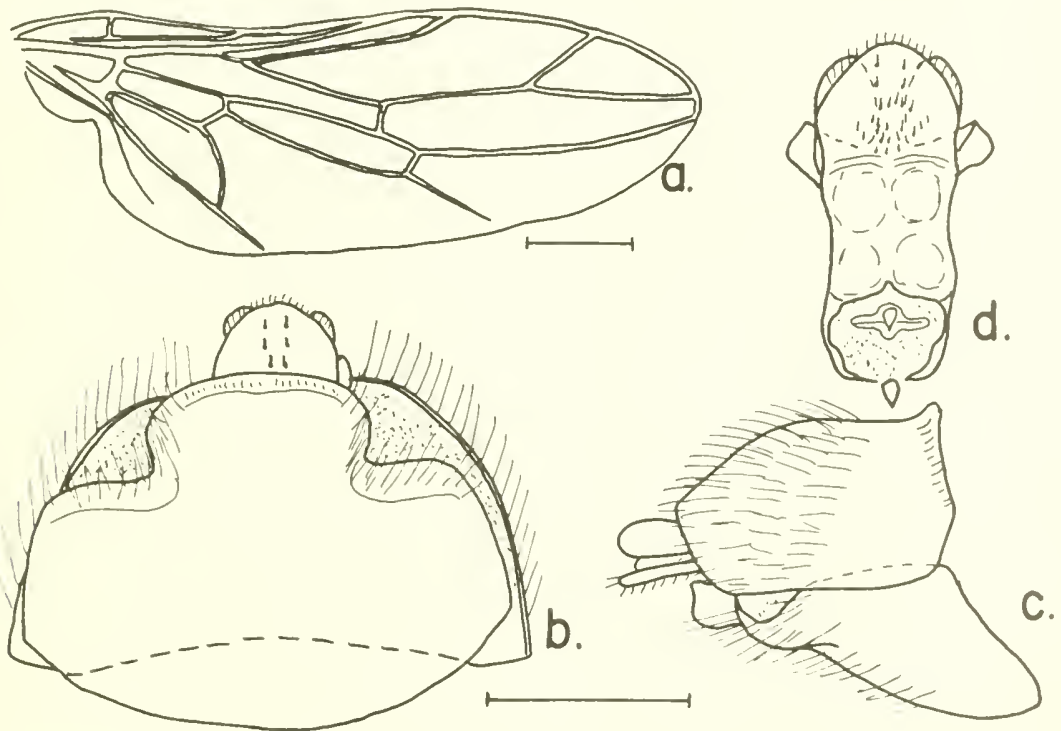

Figure 11.-Scenopinus japonicus (Séguy), female: $a$, wing; $b$, ventral aspect of 8 th sternum; $c$, lateral aspect of 8 th and 9 th segments; $d, 9$ th sternum and bursa.

MaLe.-Unknown.

Length: Female body $3.8 \mathrm{~mm}$., wing $2.5 \mathrm{~mm}$.

Type-locality: environs of Tokyo, Mt. Nikko, Japan; 1901 (J. Harmand).

Type: (MNHN).

\section{Scenopinus lesinensis Strobl}

Figure 12

Scenopinus lesinensis Strobl, 1904, pp. 533-34.

The type and allotype of this species are presumed to be lost. The specimens illustrated are presumed to be the species but are larger than the specimens of Strobl. 

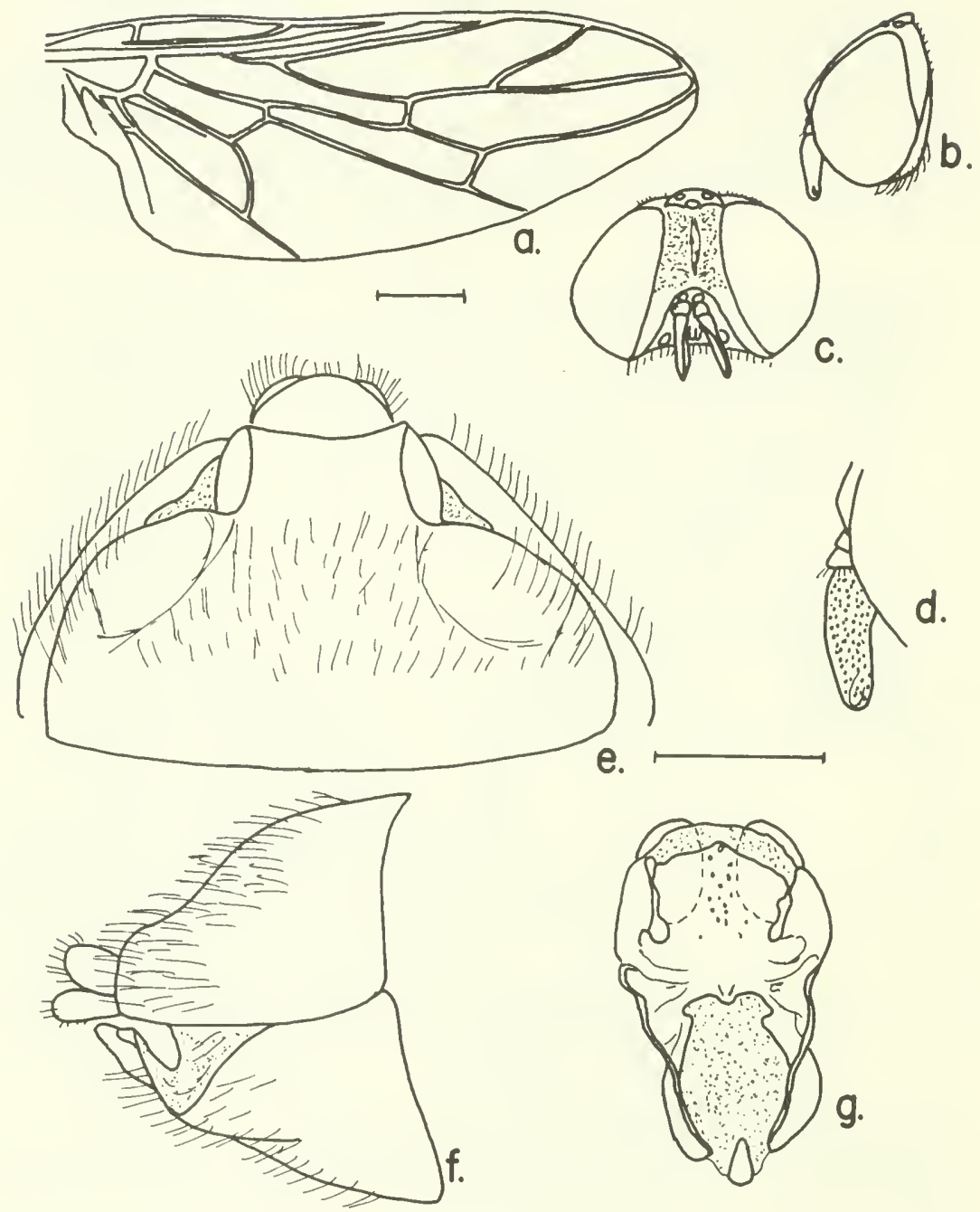

Figure 12.-Scenopinus lesinensis Strobl, female: $a$, wing; $b$, $c$, lateral and frontal aspects of head; $d$, enlarged detail of antenna; $e$, ventral aspect of 8 th sternum; $f$, lateral aspect of 8 th and 9 th segments; $g$, 9th sternum and bursa.

Female.-Head black. Eyes black-brown with a reddish cast, postocular ridge moderate; frons rugose with median groove; subshining, with a few sparse hairs; mouthparts dark brown, well developed; lower facial area subshining. Antennae elongate, first segment black, short; second red-brown; third elongate, granular, black. Ocellar triangle not prominent, ocelli orange. 
Thorax black with short sparse hairs directed posteriorly, humeral and supra-alar calli orange; posterior margin of seutellum orange. Wings brown, reins dark brown; halter stem brown, knob red-brown above, crean below. Legs orange-brown, except tips of tarsi brown, hind legs darker.

Abdomen dark red-brown, hairy; see figure for details of 8th sternum and bursa.

Length: Female $5.5 \mathrm{~mm}$., wing $4.2 \mathrm{~mm}$.

Type-locality: Verbosca and Brusji in Lesina, Yugoslavia, July.

Type: Lost.

Specimen figured, one of 4 females reared from larvae, Kitzbuhel, Austria; end of May 1952 (NMV).

\section{Scenopinus microgaster (Séguy)}

FIgURe 13

Omphrale microgaster Séguy, 1948, p. 155.

This species from South China is eharacterized by the very short abdomen of both male and female.

Male.-Frons rugose with a median depression above a narrow transverse ridge above the antennae. Antennae short and pear-shaped. Wings smoky brown, reins brown; three narrow white bands across the abdomen.

Fevale.-Frons with a slightly elevated central ridge with incurving lower side pieces along upper two thirds, a slight dimple in the median groove above a central depression. For details of the eighth sternum and bursa see figure.

Length: Male body $3.25 \mathrm{~mm}$., wing $2.75 \mathrm{~mm}$.; female body $4 \mathrm{~mm}$. Type-locality: Kouy (Kouri) Tcheou, China; 1921 (Cavalerie). Type and allotype: (MNHN).

\section{Scenopinus nidorcaupulus, new speeies}

Figure 14

This is a large species much like $S$. fenestralis except for the antennae which are short and broad.

Female.-Head black, eyes black-brown; postocular ridge moderately wide and polished; front roughened except shining at eye margins, shallow median groove above the antennae with a slight swelling on either side; mouthparts dark brown, hairy; palpi less than half as long as the oral opening, flattened, paddlelike. Ocellar tubercle black, not prominent, median ocellus depressed into the front. Antennal segments black-brown, second shorter than first, segment 3 twice as long as 1 and 2 combined, wide at base with a rounded tip. 

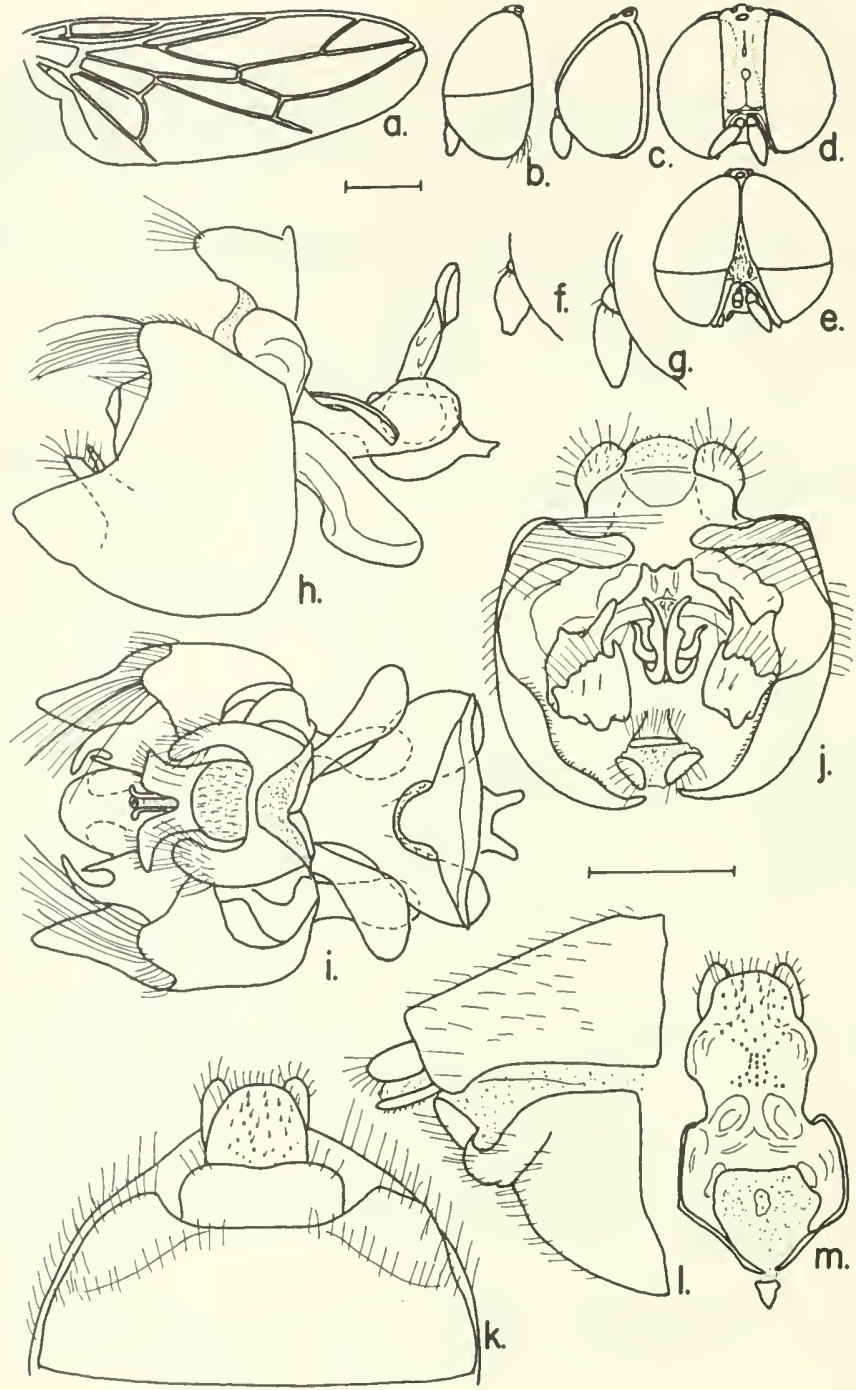

Figure 13.-Scenopinus microgaster (Séguy), male, female: $a$, wing; $b, e$, lateral and frontal aspects of male head; $c, d$, lateral and frontal aspects of female head; $f, g$, enlarged details of male and female antennae; $h-j$, lateral, ventral and posterior aspects of male terminalia; $k$, ventral aspect of female 8th sternum; $l$, lateral aspect of female 8th and 9th segments; $m$, female 9 th sternum and bursa.

Thorax dorsum black, transversely striated; humeral and supraalar calli red-brown. Wings a dusky brown, veins brown; stem of halter dark brown, knob shining, red-brown. Legs with femora dark red-brown, tibiae brown and tarsi yellow-brown. 


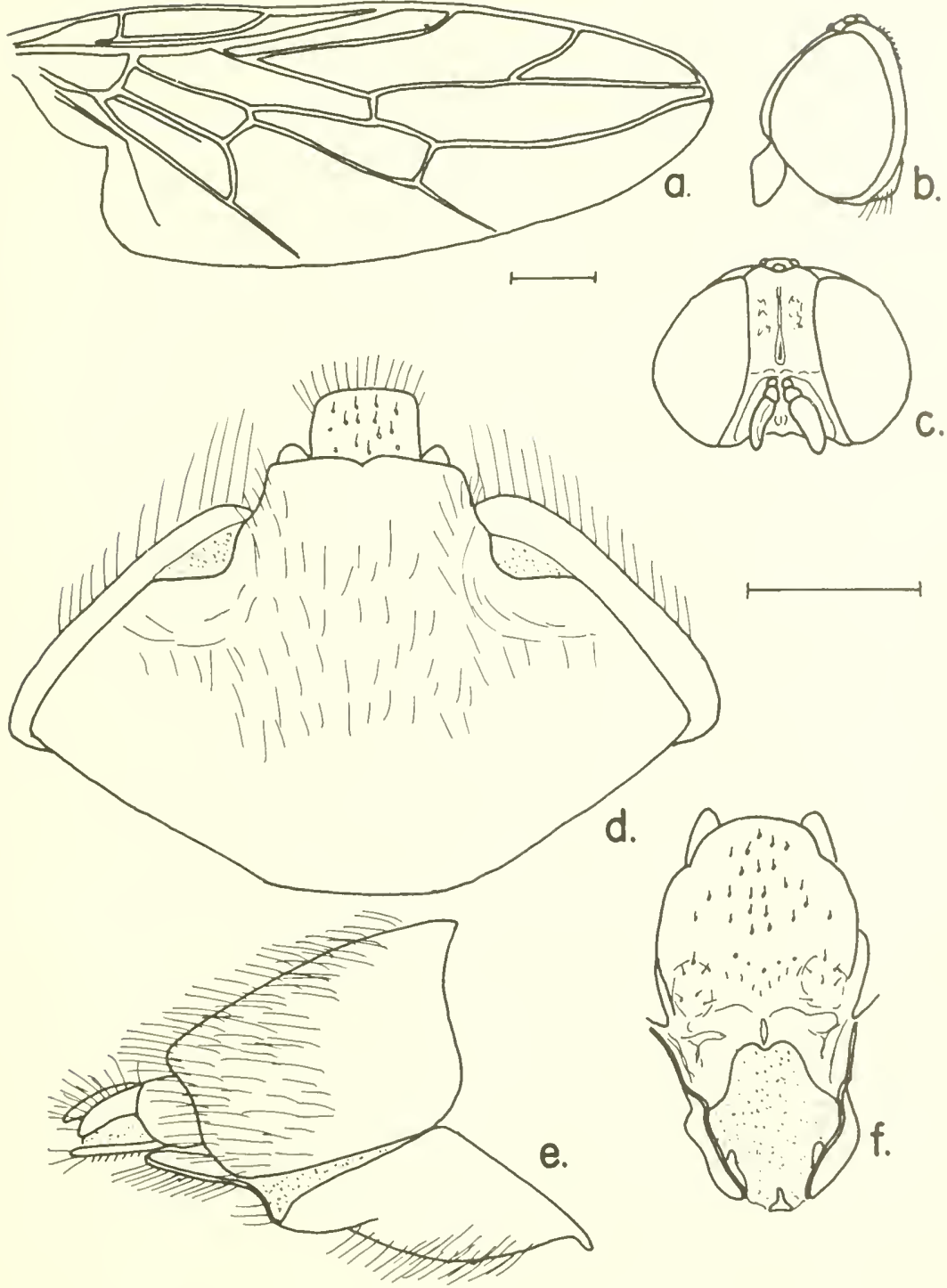

FigURE 14.-Scenopinus nidorcaupulus, new species, female: $a$, wing; $b$, $c$, lateral and frontal aspects of head; $d$, ventral aspect of 8 th sternum; $e$, lateral aspect of 8 th and 9 th segments; $f, 9$ th sternum and bursa.

Abdomen dark red-brown to red-brown; see figure for details of eighth stermum and bursa.

MaLe.-Unknown.

Length: Female body $6+\mathrm{mm}$., wing $4.2 \mathrm{~mm}$. 
Type-locality: Steamboat Springs, Colorado; 1 August 1943, 6800 ft. (Bryant).

Holotype: Female (CAS) 8926.

\section{Scenopinus niger (De Geer)}

Figure 15

Nemotelus niger De Geer, 1776, p. 188.

Musca fenestralis Fabricius, 1781, p. 444.

Musca rugosa Fabricius, 1794, p. 330.

Nemotelus tarsata Panzer, 1809, p. 20.

Scenopinus atra Fallén, 1817, p 2.

Scenopinus nigripes Meigen, 1824, p. 117.

Scenopinus fasciata Walker, 1851, p. 85

This well-known European species is distinctive in that the male is one of the very few where the frons broadly separates the eyes and the eyes are not divided into upper coarse facets and lower fine facets. This species appears to be limited to continental Europe and is not found on the Pacific Islands where other dark-winged species occur.

Length: Male body $4.45 \mathrm{~mm}$., wing $4 \mathrm{~mm}$.; female body $5.2 \mathrm{~mm}$., wing $4.7 \mathrm{~mm}$.

Type-locality: Europe.

Type: Lost?

Specimens present in most European collections.

\section{Scenopinus opaculus Loew}

Figure 16

Scenopinus opaculus Loew, 1873, p. 145.

This species from the trans-Caspian region looks like a small edition of S.fenestralis with dark legs. The male genitalia, however, are quite distinctly different. The abdomen of the female was lost so the details of the eighth sternum and bursa could not be illustrated.

Length: Male body $1.25 \mathrm{~mm}$., wing $1.25 \mathrm{~mm}$.; female body $1.5-2$ mm., wing $1.25-1.75 \mathrm{~mm}$.

Type-locality: Samarkand.

Type: (ZMH).

16. Scenopinus physadius (Séguy)

Figure 17

Omphrale physadius Séguy, 1930, p. 111.

This species from Morocco resembles $S$. glabrifrons in many ways. The frons of the male is shining but does not protrude as much as glabrifrons; the female frons is slightly granular and is covered with 


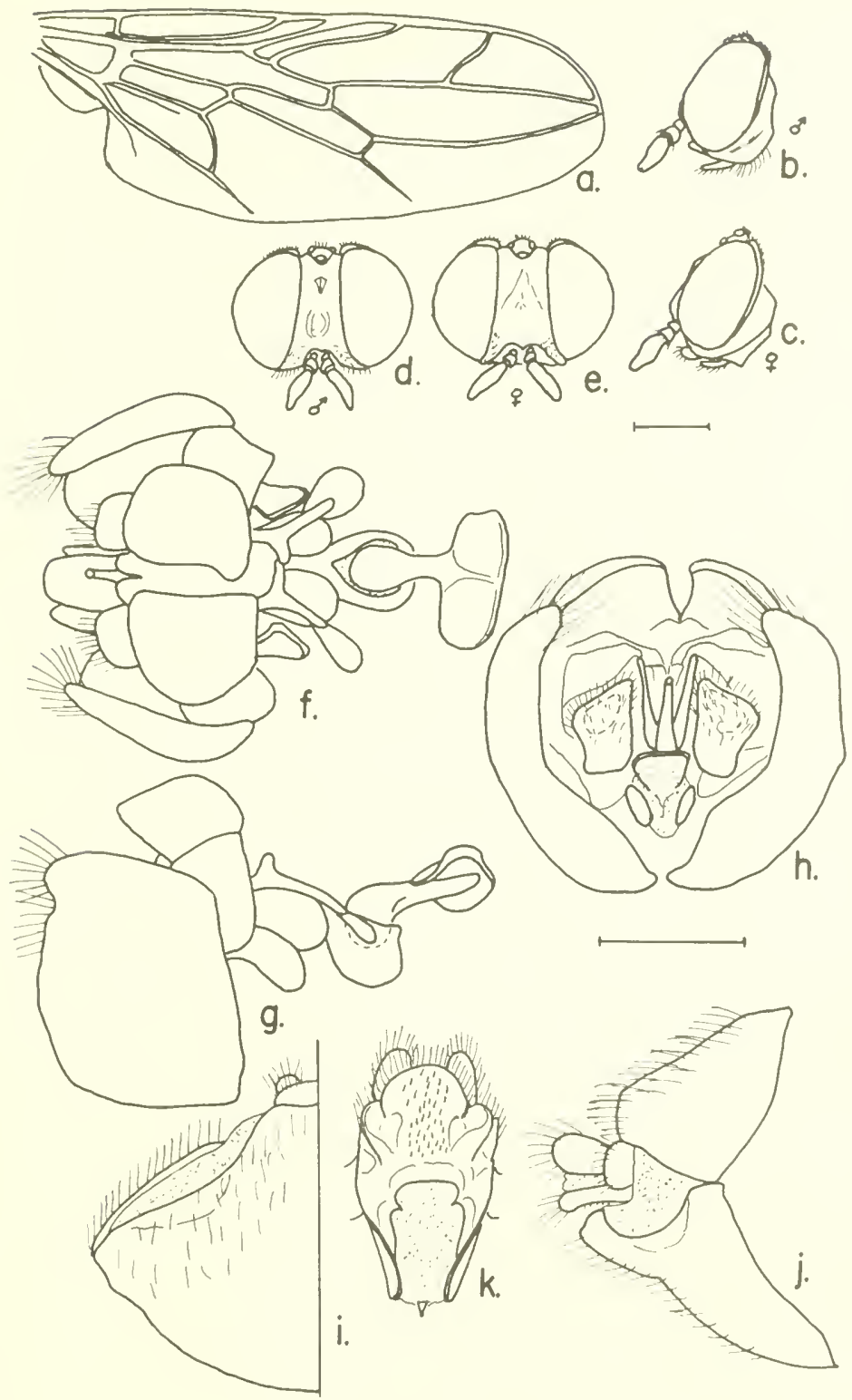

Figure 15.- Scenopinus niger (De Gecr), malc, femalc: $a$ wing; $b$, $d$, lateral and frontal aspects of male head; $c, e$, lateral and frontal aspects of femalc head; $f-h$, ventral, lateral and posterior aspects of male terminalia; $i$, ventral aspect of female 8 th sternum; $j$, lateral aspect of female 8 th and 9 th segments; $k$, female 9th sternum and bursa. 

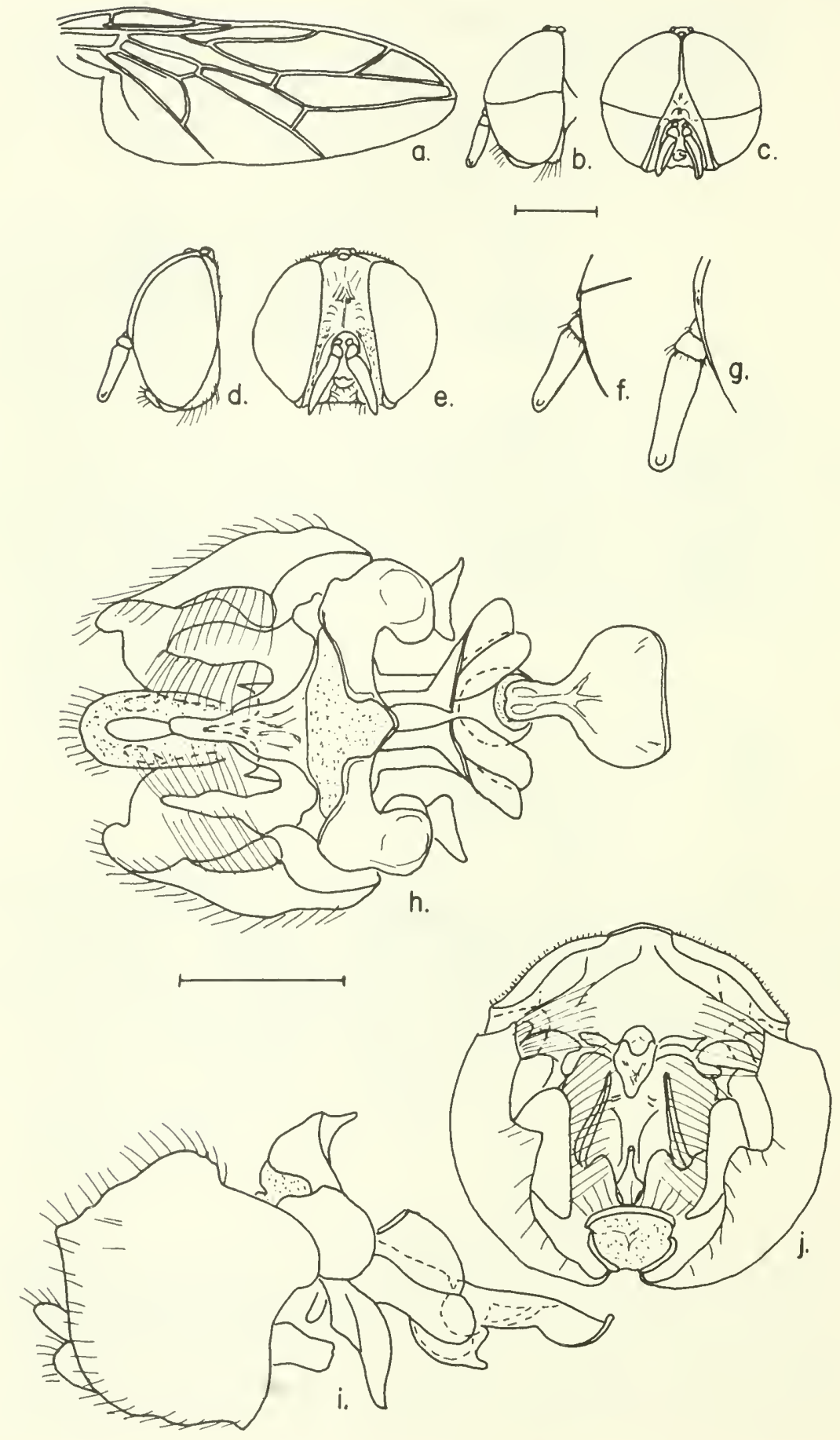

e. 
short hairs. The wings are a smoky white with yellow reins and the halteres of both sexes are white. The terminalia of both sexes are distinctive; see figure for details.

Length: Male body $4.5 \mathrm{~mm}$., wing $3 \mathrm{~mm}$.; female body $5.5 \mathrm{~mm}$., wing $3.5 \mathrm{~mm}$.

Type-locality: Bou Denib, Morocco (de Lepiney).

Type: (MNHN).

17. Scenopinus saini, new species

Figure 18

MaLE.-This moderately large dark-colored fly is closely related to $S$. fenestralis. Head black-brown, eye facets brown above and blackbrown below; frons subshining, slightly smaller above the antennae; ocellar tubercle prominent with a few anteriorly directed hairs, ocelli clear; back of head concave; postocular ridge lacking. Antennae elongate with subequal black-brown first and red-brown second segments, third segment red-brown, slender, about four times as long as 1 and 2 combined.

Thorax dorsum black, shining, with a thin pile of whitish hairs; humeral and supra-alar calli red-brown; pleural areas red-brown, with thin pile of hair. Legs red-brown throughout. Wings hyaline, veins straw colored; halter stem red-brown, knob white.

Abdomen red-brown with broad white membranous borders on segments 4-6; terminalia red-brown; see figure for details.

Female.-Unknown.

Length: Male body $3.7 \mathrm{~mm}$., wing $3 \mathrm{~mm}$.

Type-locality: W. El Lega, S. Sinai, Egypt; June-August 1942 (Hafez).

Holotype: Male (CUC).

\section{Scenopinus schroederi (Kröber)}

Figure 19

Omphrale schroederi Kröber, 1913, p. 201.

This large Central American species from Costa Rica is placed in the Fenestralis group on the basis of the long third antennal segment, vein $\mathrm{R} 4$ branching from before the middle of cell R5 and the open bursal cavity.

Male.-Unknown.

Figure 16.-Scenopinus opaculus Loew, male, female: $a$, wing; $b$, c, lateral and frontal aspects of male head; $d, e$, lateral and frontal aspects of female head; $f, g$, enlarged detail of male and female antennae; $h-j$, ventral, lateral and posterior aspects of male terminalia. 


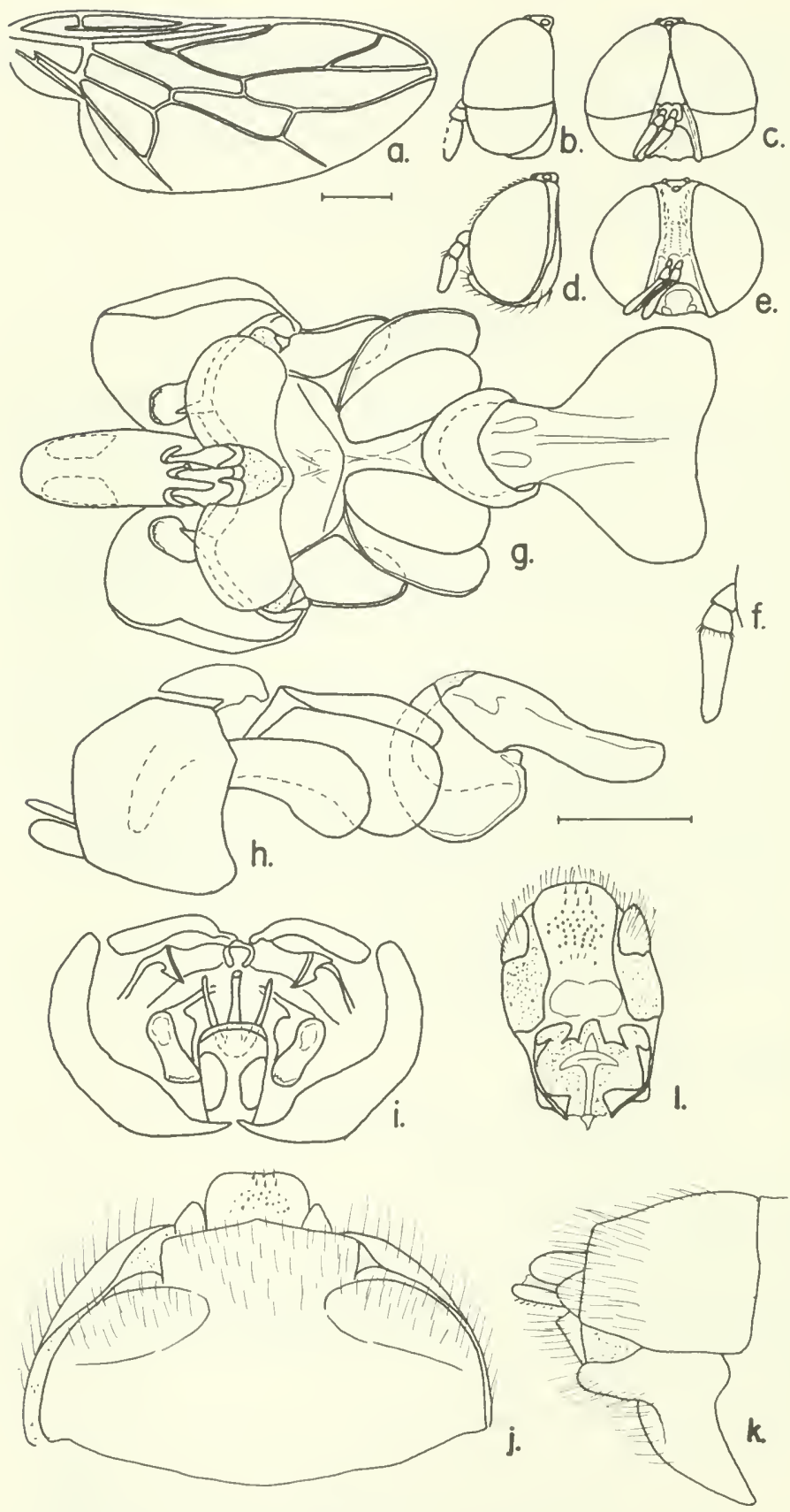


Length: Female body $5 \mathrm{~mm}$., wing $4 \mathrm{~mm}$.

Type-locality: Costa Rica.

Type: Stettiner Museum. (Now housed in [PAS] Warsaw.)

\section{Scenopinus sinensis (Kröber)}

Figure 20 (after Kröber)

Omphrale sinensis Kröber, 192Sa, p. 1.

This species was known only from the type female which was destroyed during World War II.

Male.-Unknown.

Length: Female body $4.1 \mathrm{~mm}$.

Type-locality: Canton, China (Helms).

Type: (SMNH) destroyed.

\section{Scenopinus undulafrons, new speeies}

FIGURE 21

This is another of the $S$. fenestralis type flies found along the west coast of continental North America and is distinguished by its shorter antennae and by its genital structures.

Female.-Head black; eyes red-brown; the froms broad, slightly swollen, subshining, with a definite longitudinal depression just above the antennae, a slight median depression on the upper half; ocellar tubercle slightly elevated, the median ocellus depressed; ocelli redbrown to clear; postocular flange broad and elevated. Mouthparts well developed, pale tan with numerous red hairs; palpi short, red-brown, lighter at tip. Antenna with first segment dark brown, seeond redbrown, third red-brown, less than twice as long as broad, see figure.

Thorax dorsum black, rugose, with short hairs; humeral callus orange-brown, supra-alar callus red-brown. Wings smoky brown, veins brown. Halter stem red-brown, knob red-brown. Legs with front coxa through the tibia red-brown; the first tarsal segment straw yellow, darkening distally.

Abdomen and terminalia red-brown; see figure for details of eighth sternum and bursa.

MaLE.-Unknown.

Length: Female body $5.2 \mathrm{~mm}$., wing $3.5 \mathrm{~mm}$.

Type-locality: Terrace, B.C., Canada (Mrs. M. E. Hippisley).

Figure 17.-Scenopinus physadius (Séguy), male, female: $a$, wing; $b, c$, lateral and frontal aspects of male head; $d, e$, lateral and frontal aspects of female head; $f$, enlarged detail of antenna; $g-i$, ventral, lateral and posterior aspects of male terminalia; $j$, ventral aspect of female 8th sternum; $k$, lateral aspect of female 8 th and 9 th sternum; $l$, female 9 th sternum and bursa. 


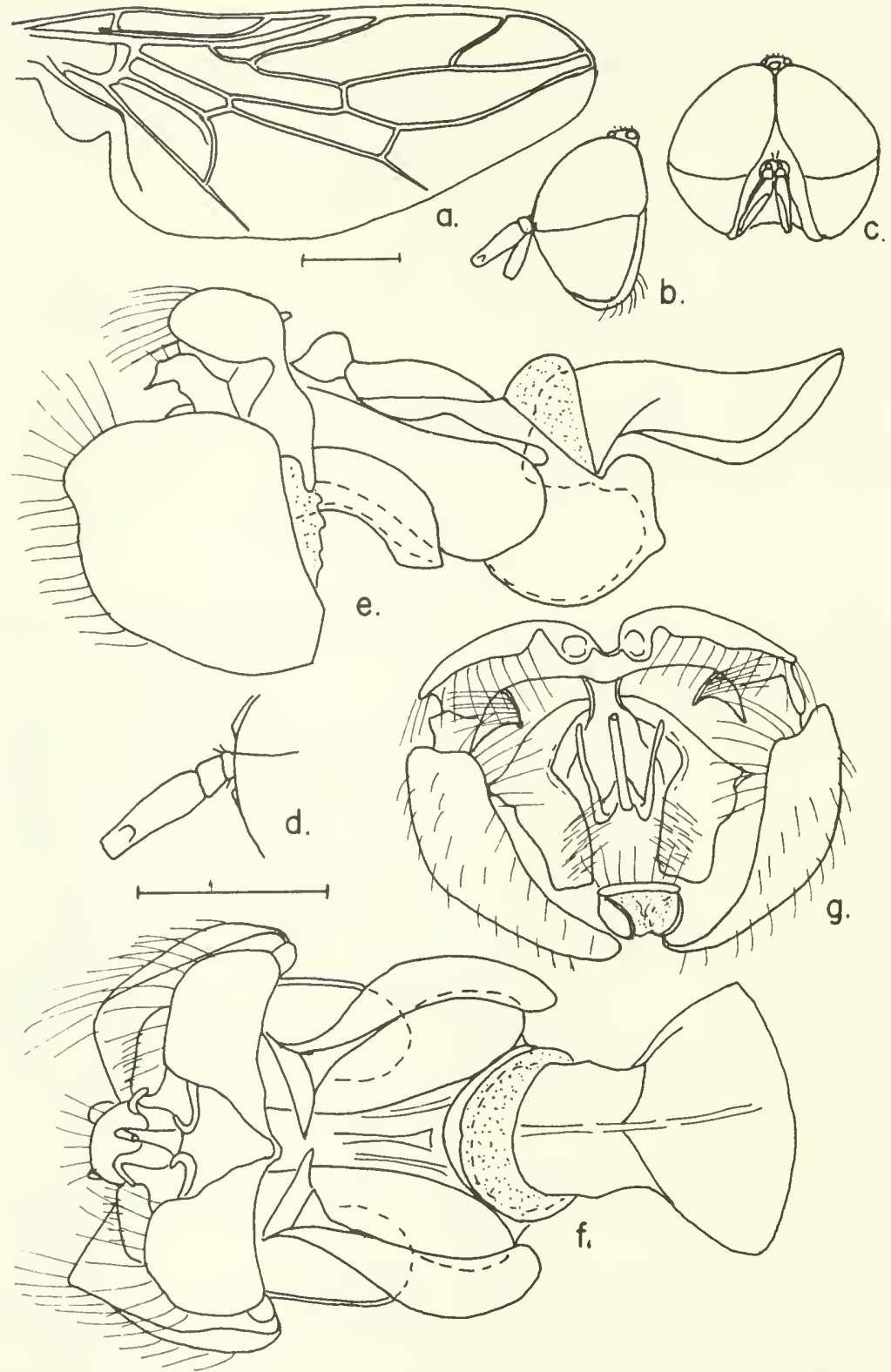

FigURE 18. - Scenopinus saini, new species, male: $a$, wing; $b$, lateral aspect of head; $c$, frontal aspect of head; $d$, enlarged detail of antenna; $e$, lateral aspect of terminalia; $f$, ventral aspect of terminalia; $g$, posterior aspect of terminalia. 


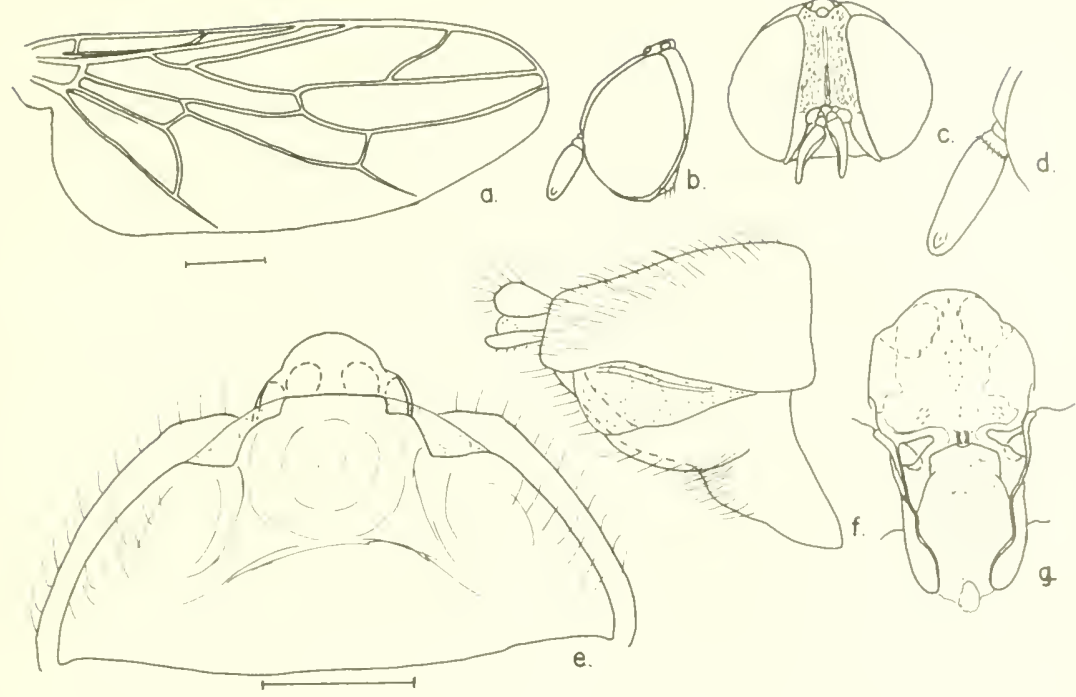

Figure 19.-Scenopinus schroederi (Kröber), female: $a$, wing; $b, c$, lateral and frontal aspects of head; $d$, enlarged detail of antenna; $e$, ventral aspect of 8 th sternum; $f$, lateral aspect of 8th and 9th segments; $g$, 9th sternum and bursa.
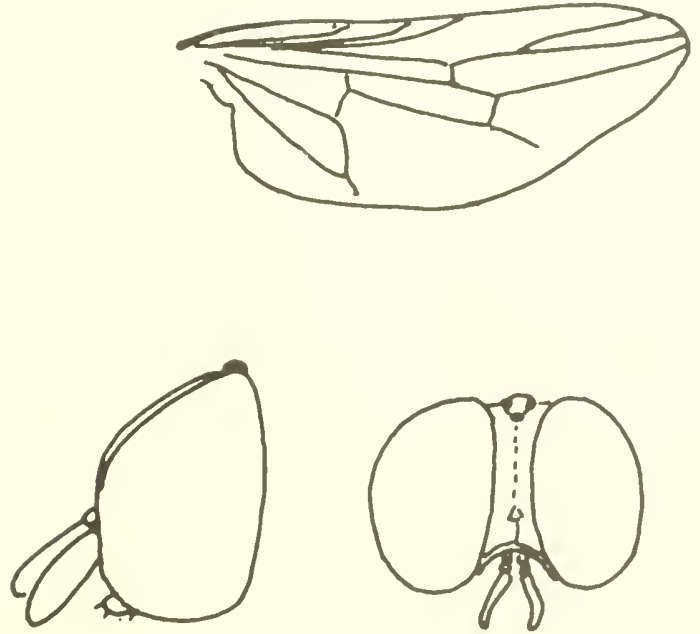

Figure 20.-Scenopinus sinensis (Kröber), female: Wing, and lateral and frontal aspects of head (after Kröber).

Holotype: Female (USNM) 67454.

Paratype: \& Oliver, B.C., Canada; 12 June 1958 (H. and A. Howden) (CNC). 

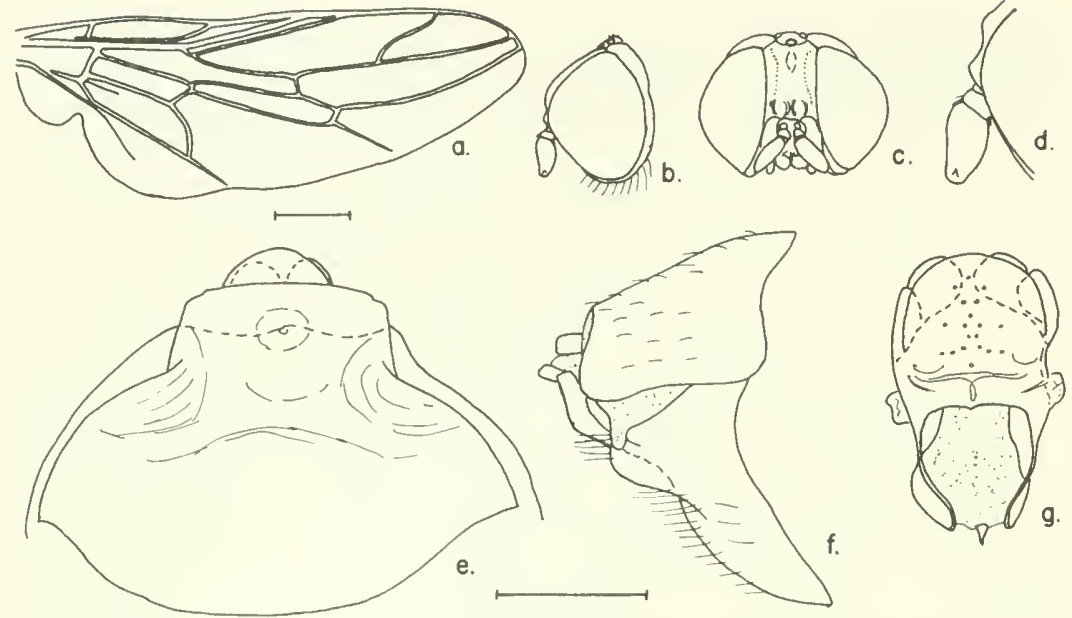

Figure 21.-Scenopinus undulafrons, new species, female: $a$, wing; $b, c$, lateral and fronta 1 aspects of head; $d$, enlarged detail of antenna; $e$, ventral aspect of 8 th sternum; $f$, lateral aspect of 8 th and 9th segments; $g$, 9th sternum and bursa.

\section{Scenopinus varipes Loew}

Scenopinus varipes Loew, 1873, p. 148.

This species appears to be lost to science; at least all my efforts to find its whereabouts have been fruitless.

Length: Male body $1 \mathrm{~mm}$., wing $1 \mathrm{~mm}$.

Type-locality: Balfrusch (Babul), Iran; Christoph Coll.

Type: Location unknown.

\section{Scenopinus vitripennis Meigen}

\section{Figure 22}

Scenopinus vitripennis Meigen, 1824, p. 115.-Trojan, 1956, p. 1-10.

This species has been synonymized with $S$. glabrifrons by a number of the earlier workers. On the basis of the wing venation, however, Trojan (1956) showed that vitripennis is a valid species. It is most easily identified as a brown haltered glabrifrons-like species. The formation of the eighth sternum and bursa further confirm 'Trojan's evidence that this is a different species; see figure.

The only known male of this species is presumed lost.

Specimens identifiable to this species have been found in a number of European collections and come from Eastern Europe.

Length: Female body 4.5-5.5 mm., wing 3.5-3.7 mm.

Type-locality: Austria (Megerle).

Type-specimen: lost. 

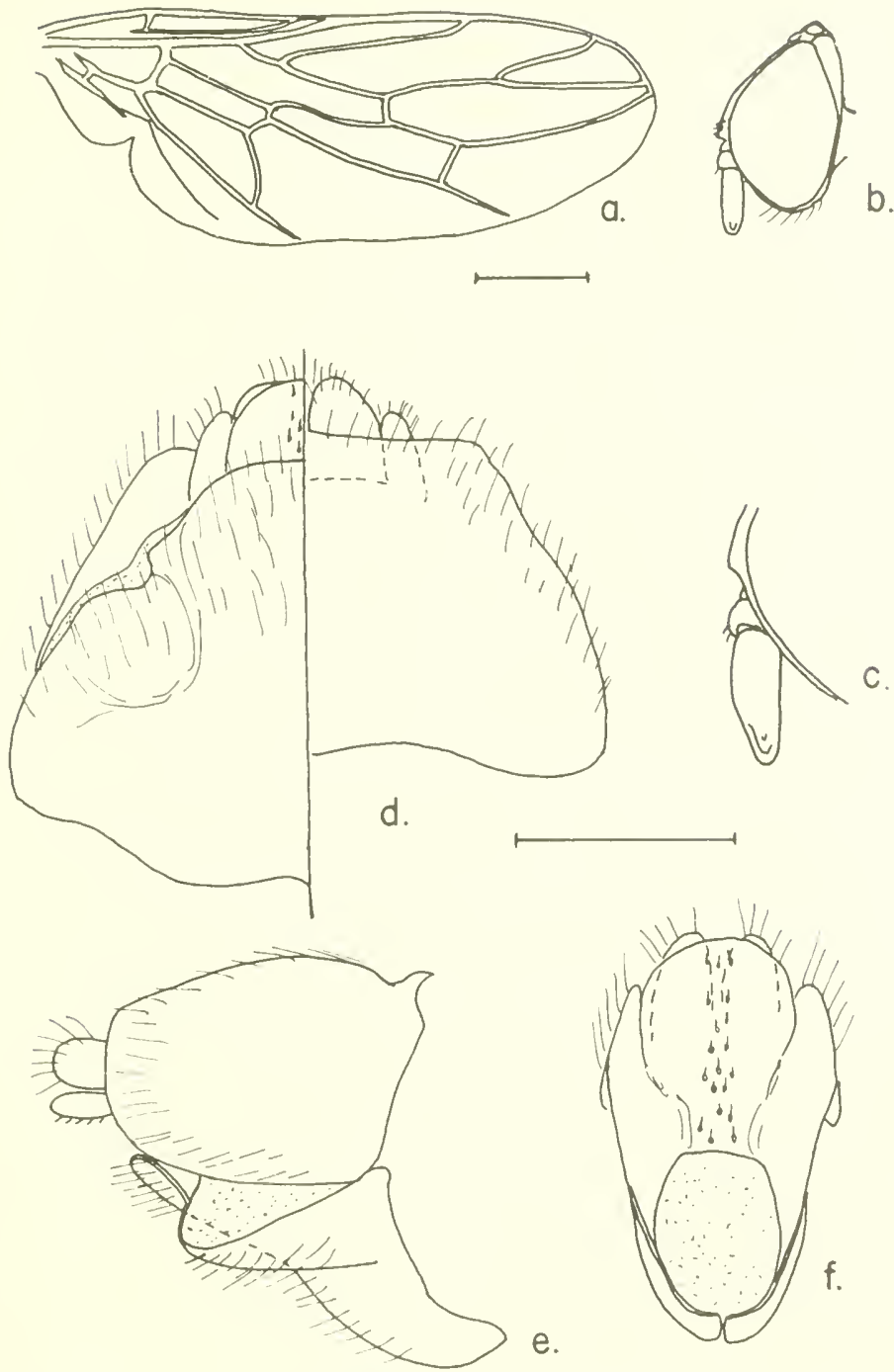

e.

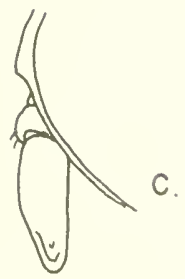

FigURE 22.-Scenopinus vitripennis Meigen, female: $a$, wing; $b$, lateral aspect of head; $c$, enlarged detail of antenna; $d$, left, ventral aspect of 8 th sternum; right, dorsal aspect of 8 th and 9 th segments; $e$, lateral aspect of 8 th and 9 th segments; $f$, ventral aspect of 9 th sternum and bursa.

\section{ALBICINCTUS group}

Key to Speeies of the Albicinctus group PALAEARCTIC SPECIES (MALES)

1. Wing white or smoky brown . . . . . . . . . . . . . . . 2

Wing hyaline, not definitely white or brown . . . . . . . . . . . 3 
2. Wing white, halter knob white . . . . . . . . . S. niveus Becker Wing smoky brown, halter knob brown . . . S. bulbapennis, new species

3. Halter knob cream . . . . . . . . . . . . . . . . . . . . . . 4

Halter knob white . . . . . . . . . . . . . . . . 5

4. Wing with whitish east, antenna brown . . . . . S. albicinctus (Rossi) Wing with brownish microtrichia, antenna black-brown

S. canarius, new species

5. Antenna red-brown or black-brown . . . . . . . . . . . . 6 Antenna black . . . . . . . . . . . . . S. limpidipennis Loew

6. Antenna red-brown. Abdomen with three white bands, the first broad, terminalia with two long aedeagal spines .' . . . . . . . S. lucidus Becker Antenna black-brown, three narrow white stripes on abdomen, terminalia with aedeagus short . . . . . . . . . . S. phaidimos, new species

\section{PALAEARCTIC SPECIES (FEMALES)}

1. Wing brown or with brown patches. . . . . . . . . . . . . . 2

Wing hyaline . . . . . . . . . . . . . . . . . 4

2. Wing brown, body without scale-like hairs . . . . . . . . . . . . 3

Wing hyaline with brown patches in center of cells, body clothed with flat scale-like hairs . . . . . . . . . . . S. squamosus Villeneuve

3. Halter knob white, antenna brown . . . . . . . . . . S. patrizi (Séguy) Halter knob brown, antenna black-brown . . . S. bulbapennis, new species

4. Halter knob white . . . . . . . . . . . . . . . . . 6 Halter knob cream or tan . . . . . . . . . . . . . . . . . . 5

5. Halter knob cream, antenna black, body without noticeable hair

Halter knob tan, antenna brown, body with short hair

S. albicinctus (Rossi)

S. curtipilosus, new species

6. Antenna red-brown or black, $\mathrm{M} 1+2$ ending after the tip of the wing . . . 7 Antenna black-brown, M1 +2 ending before the tip of the wing

S. phaidimos, new species

7. Antenna with basal segments orange or red-brown, third segment brown or red-brown . . . . . . . . . . . S. lucidus Becker Antenna with third segment black . . . . . . S. limpidipennis Loew

\section{E'THIOPIAN SPECIES (MALES)}

1. Wing hyaline, halter knob white, antenna black-brown or brown . . . . 2 Wing milky white, halter knob white, antenna orange-brown

S. monodi Séguy

2. Halter knob white, abdomen with one white band 3 Halter with base of knob red-brown, remainder white, no white stripes on the abdomen

S. anthrax, new species

3. Antenna black-brown; abdomen with one white band, aedeagal parameres slender . . . . . . . . . . . . . . . . S. balteatus Lamb

Antenna brown darkening distally, abdomen with one narrow white band, aedeagal parameres antler-like . . . . . . S. inquilinus Séguy

\section{ETHIOPIAN SPECIES (FEMALES)}

1. Wing hyaline. . . . . . . . . . . . . . . . 2

Wing milky or brown . . . . . . . . . . . . . . . . . 8

2. Halter knob white or cream . . . . . . . . . . . . . 3

Halter knob tan, brown or black-brown . . . . . . . . . . 5 
3. Halter knob cream . . . . . . . . . . . . . . . . . . . . 4

Halter knob white . . . . . . . . . . . . . . . . . . . 7

4. Halter cream above, white below, antenna brown. . S. keiseri, new species Ilalter knob cream, antenna black . . . . . . . S. bouvieri (Séguy)

5. Halter knob brown or black-brown .

Halter knob tan dorsally, whiter ventrally, antenna orange at base darkening at tip.

S. brunneus (Kröber)

6. Halter knob brown, antenna brown darkening distally

Halter knob black-brown above, white below, antenna black-brown

S. inquilinus (Séguy)

S. angustifrons (Kröber)

7. Antenna red-brown, frons flat, wide, shining . . S. gromieri, new species Antenna black-brown, frons narrow, rugose . . . . S. balteatus Lamb

8. Wing brown.

Wing milky, halter white . . . . . . . . . . . S. monodi Séguy

9. Halter knob red-brown to black . . . . . . . . . . . . . . 10

Halter knob yellow-brown . . . . . . . . S. flavipes (Kïröber)

10. Halter red-brown or base of knob red-brown remainder white . . 11

Halter knob brown or black . . . . . . . . . . . . . . . 14

11. Halter knob red-brown . . . . . . . . . . . . . . . 12

Halter knob with basc red-brown, remainder white

S. anthrax, new species

12. Halter knob red-brown shining antenna orange, darkening at tip, palpus broad and paddle-like. . . . . . . S. palmulapalpus, new species Halter knob red-brown, antenna red-brown, palpus normal . . . . . . 13

13. Frons widening dorsally, cell R5 narrowing at tip . . S. evansi, new species Frons widening ventrally, cell R5 nearly uniformly wide throughout

S. katbergi, new species

14. Halter knob brown, antenna dark, mouthparts normal . . . . . . . 15

Halter knob black-brown, antenna yellow, mouthparts atrophied

S aethiopicus (Lindner)

15. Halter knob brown above cream below, antenna orange basally darkening distally, cell R5 parallel sided. . . . . S. madagascariensis Enderlcin Halter knob brown, antenna black, cell R5 broad, vein $M 1+2$ ending in tip of wing . . . . . . . . . . . . . S. oldenbergi (Kröber)

\section{ORIENTAL AND PACIFIC SPECIES}

1. Males .

Females . . . . . . . . . . . . . . . . . . . .

2. Wing brown, halter knob red-brown or black, antenna black or cream . . . 3

Wing hyaline, halter knob white, antenna ycllow-brown, terminalia with two long acdeagal spines. . . . . . . . . . . . S. lucidus Beeker

3. Ilalter knob with base red-brown, remainder white, no white bands on the abdomen, antenna black . . . . . . . . . . S. papuanus (Kröber) IIalter knob black, antenua cream, abdomen with white bands

S. opacus deMcijere

4. Wing brown, halter knob brown or with red-brown . .5 Wing hyaline, halter knob white.

S. lucidus Becker

5. Halter knob with base red-brown, remainder white, antenna black

S. papuanus (líröber)

Halter knob brown, antenna cream

S. opacus de.Meijere 


\section{AUSTRALIAN SPECIES (MALES)}

1. Wing white . . . . . . . . . . . . . . . . . 2

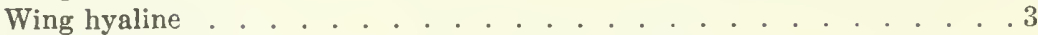

2. Halter knob red-brown, antenna brown, frons rugose

S. bolgarti, new species Halter knob red-brown with a cream band separating the upper and lower halves, frons triangular, pebbly . . . . . . S. fragosifrons, new species

3. Halter knob red-brown or brown, antenna brown or black-brown . . . . 4 Halter knob black, antenna brown . . . . . . S. perkinsi G. H. Hardy

4. Halter knob brown, antenna brown, normal sized fly . . . . S. biroi Kertész Halter knob red-brown, antenna black-brown, very small fly

S. minutus, new species

\section{AUSTRALIAN SPECIES (FEMALES)}

1. Wing smoky brown or white . . . . . . . . . . . . . . . . 2

Wing hyaline ........ . . . . . . . . . . . . 5

2. Wing smoky brown . . . . . . . . . . . . . . . . 3

Wing white. . . . . . . . . . . . . . . . . . . 4

3. Halter knob white, antenna red-brown, veins $R 5$ and $M 1+2$ separated at the wing tip . . . . . . . . . . . . S. spurrelli, new species

Halter hnob red-brown, antenna black-brown, wing with veins $\mathrm{R} 5$ and $\mathrm{M} 1+2$ meeting at the wing tip. . . . . . . . . S. darwini, new species

4. Halter knob red-brown with a cream band dividing the upper and lower halves, antenna red-brown, frons pebbly, swollen

S. fragosifrons, new species Halter knob as above, antenna brown, frons rugose but not swollen

S. bolgarti, new species

5. Halter knob brown or red-brown . . . . . . . . . . . . . . . . 6 Halter knob black . . . . . . . . . . . S. perkinsi G. H. Hardy

6. Halter knob brown, antenna orange-brown or brown Halter knob red-brown, antenna black-brown, a very small fly

S. minutus, new species

7. Antenna orange-brown darkening to brown at tip. . S. norrisi new species Antenna brown

S. biroi Kertész

\section{Scenopinus aethiopicus (Lindner)}

Figure 23

Omphrale aethiopicus Lindner, 1955, p. 20.

Female.-This appears to be a good species distinct from other described African species. There are several characters that Lindner overlooked; both specimens referred to in his description are females; the type specimen had atrophied mouthparts as illustrated, while the paratype had well developed mouthparts. Front with an elongate depression above the antennae reaching over one-third the distance to the ocellar triangle. Halter rounded at apex. The eighth sternum appears to be characteristic but could not be illustrated in detail along with the bursa as I was not granted permission to dissect.

MALE.-Unknown.

Length: Female body 3-4 mm. 
Type-locality: Kisangara, Kenya; 31 December 1951 or 1 January 1952 (D. O. Afrika Exp.).

Type: (SMNS).
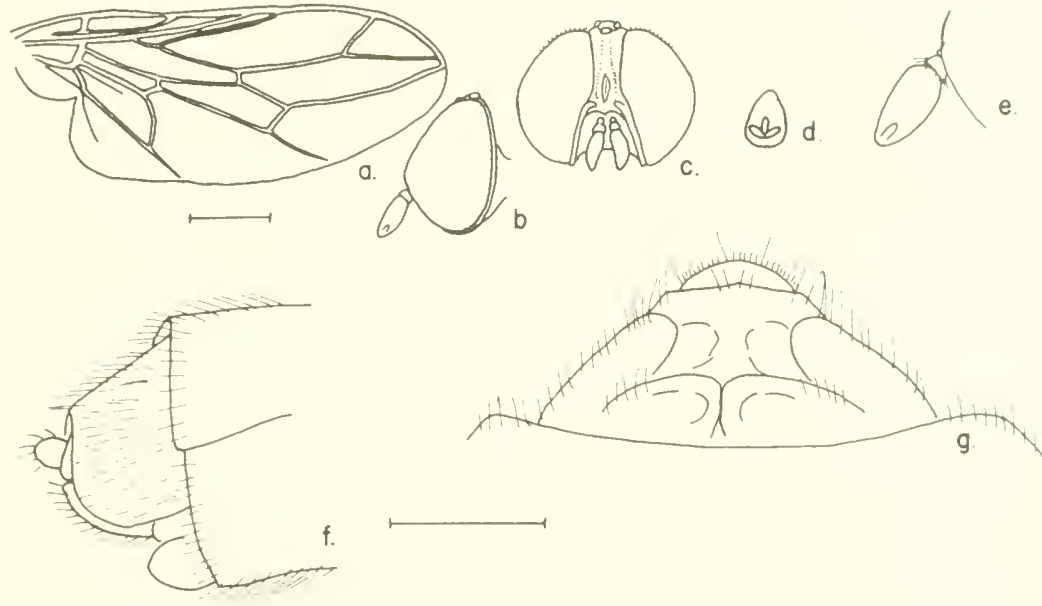

Figure 23.-Scenopinus aethiopicus (Lindner), female: $a$, wing; $b$, $c$, lateral and frontal aspect of head; $d$, sketch of atrophied mouthparts; $e$, enlarged detail of antenna; $f$, lateral aspect of undissected 8 th and 9 th segments; $g$, ventral aspect of undissected 8 th sternum.

\section{Scenopinus albicinctus (Rossi)}

FigURE 24

Musca albicincta Rossi, 1794, vol. 2, p. 69.

Scenopinus zelleri Loew, 1845, p. 314; 1857, p. 89; 1873, p. 151.

Scenopinus albicinctus (Rossi).-Bezzi, 1898, p. 36.

Omphrale albicincta (Rossi).-Kröber, 1913, p. 184.

This species is easily identified by its general light coloration. Front white, dorsum of thorax and lower pleural areas dark with a wide band of yellow extending from humeral area to posterior margin of scutellum. Basal portion of the ninth tergum of male dark with distal end white. Abdomen with a white band below scutellum; second segment broad, remaining segments narrower and banded white behind.

Length: Male body 3-4.5 mm., wing $3 \mathrm{~mm}$.; female body $3.5-$ $4 \mathrm{~mm}$., wing $3 \mathrm{~mm}$.

Type-locality: Italy.

Type: presumably lost.

Specimens examined: $2 \sigma^{x} \sigma^{x}, 1$, Djerba, Tunis (R. C. Shannon) in (USNM); 1 o $^{7}$, Macedonia, Greece, September 1933 (R. C. Shannon) in (USNM). 

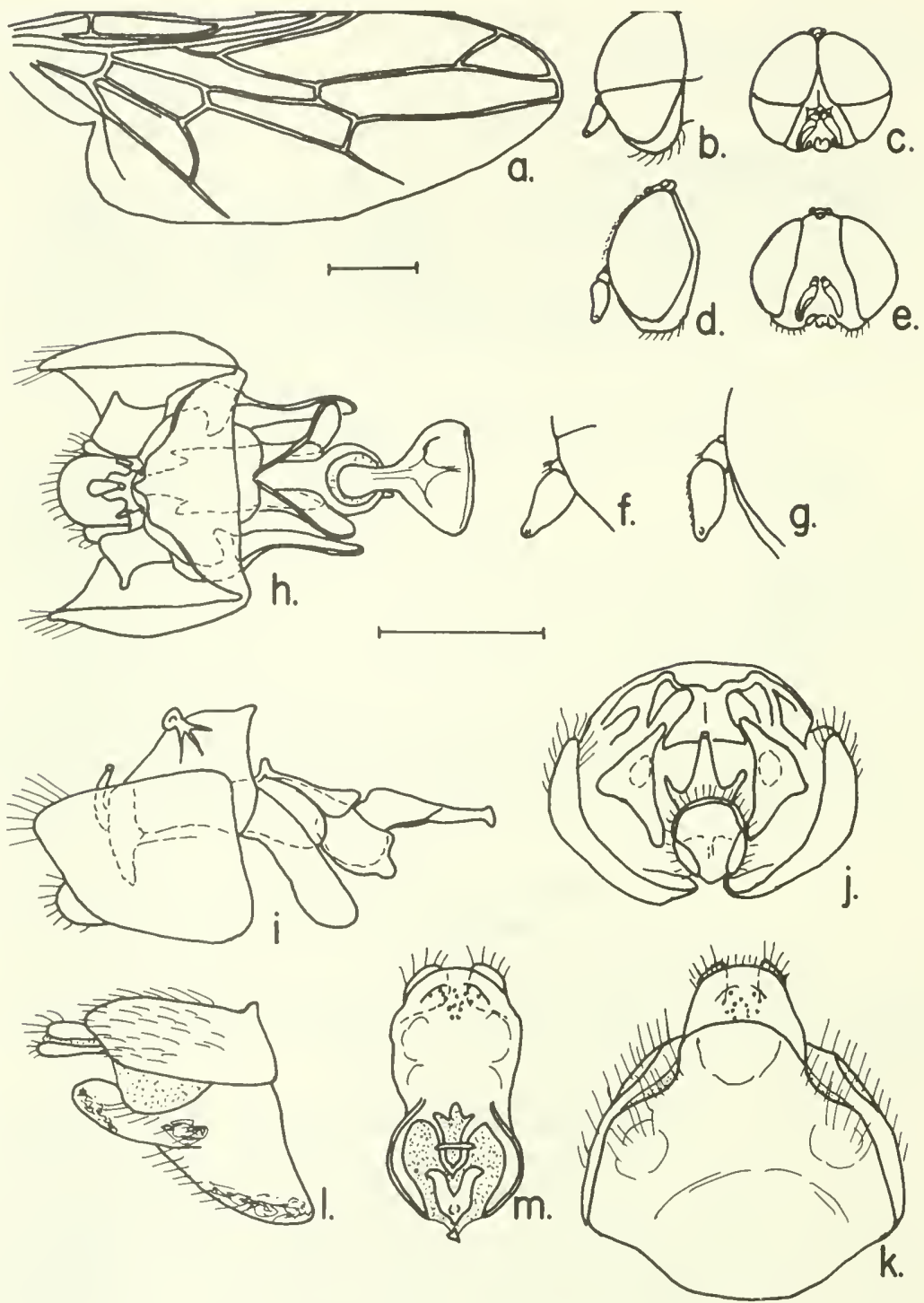

FIgUre 24.--Scenopinus albicinctus (Rossi), male, female: $a$, wing; $b, c$, male head, lateral and frontal aspects; $d, e$, female head, lateral and frontal aspects; $f$, $g$, enlarged details of male and female antennae; $h-j$, ventral, lateral and posterior aspects of male terminalia; $k$, ventral aspect of female 8 th sternum; $l$, lateral aspect of female 8 th and 9 th segments; $m$, female 9 th sternum and bursa. 


\section{Scenopinus angustifrons (Kröber)}

Figure 25 (after Kröber)

Omphrale angustifrons Kröber, 1913, p. 197.

The type of this species has been lost and no specimen agreeing with it has been seen.

Length: Female body $5.5 \mathrm{~mm}$.

Type-locality: Willowmore, Cape Prov., [Republic of] S. Africa. Type: (MNH) destroyed.
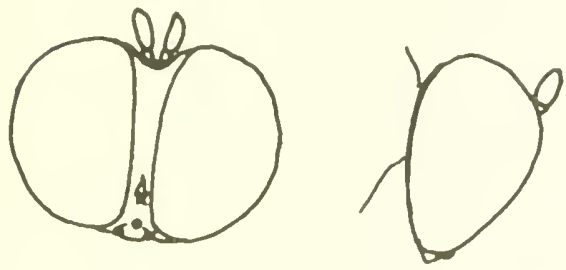

FIGURE 25.-Scenopinus angustifrons (Kröber), female: Wing and lateral and frontal aspects of head (after Kröber).

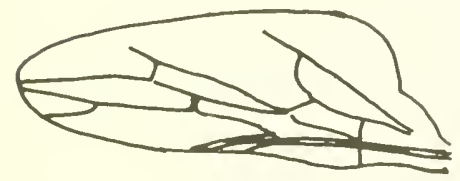

26. Scenopinus anthrax, new species

FigURE 26

MaLE.--Head red-brown; eyes red-brown above, black-brown below; frons very narrow, divided into a lanceolate upper portion and a triangular lower portion by bands of plumose hairs that extend dorsally from the oral margins to almost meet on the lower third of the frontal area. Mouthparts normal, palpi flattened, broad, extending the full length of the mouthparts; back of head coneave, little or no sclerotization showing even below; ocellar triangle prominent, ocelli clear. Antennae red-brown, third segment three times as long as 1 and 2 combined.

Thorax dorsum dark red-brown, humeral and supra-alar calli orange-brown; seutellum with orange-brown posterior rim, red-brown above. Wings hyaline, anterior veins red-brown and straw colored behind; halter stem red-brown, knob white with red-brown base. Legs with red-brown femora and tibiae; first tarsal segment red-brown, 2-4 orange, 5 red-brown.

Abdomen red-brown with no white bands. For details of terminalia see figure. 

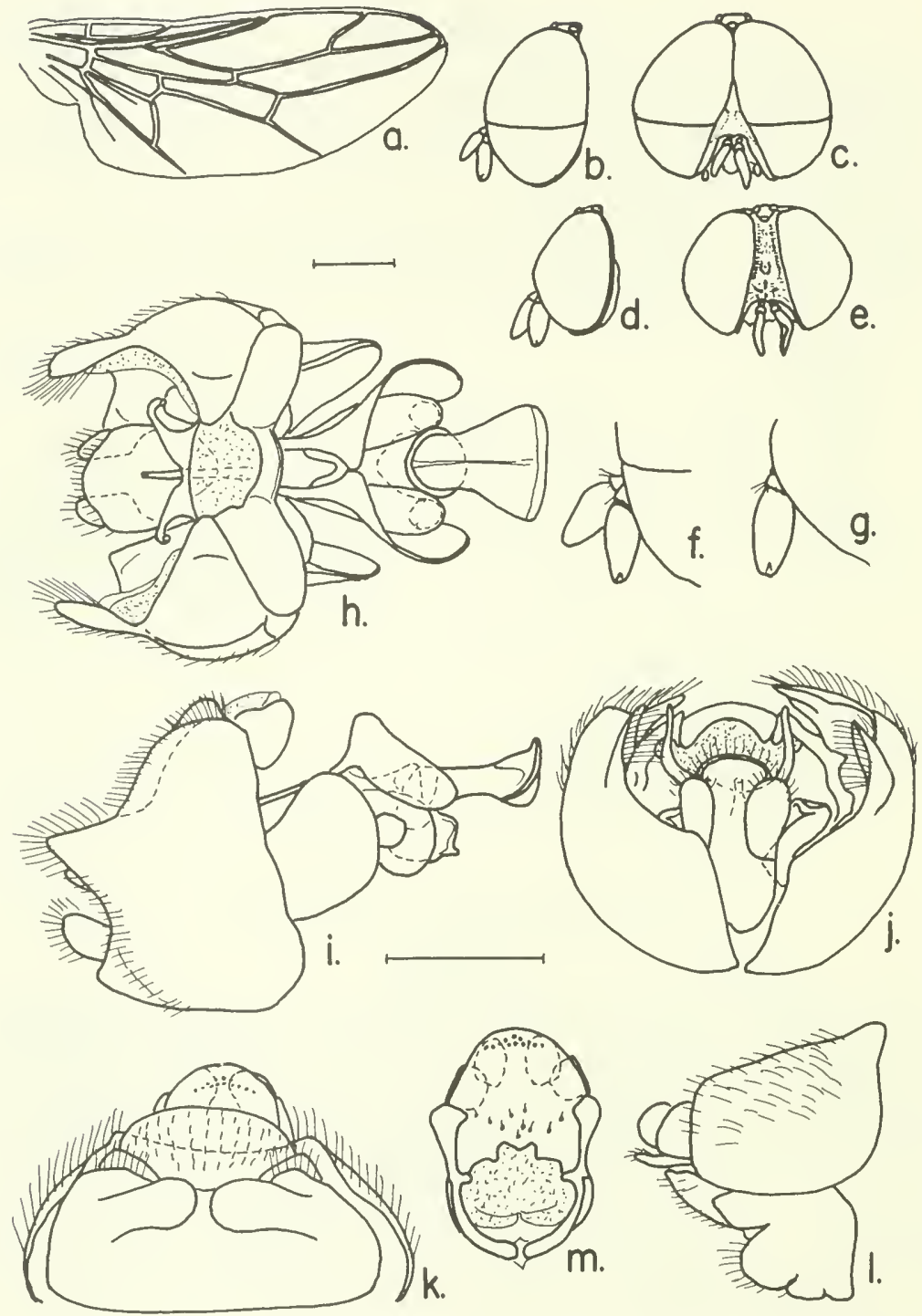

Figure 26.-Scenopinus anthrax, new species, male, female: $a$, wing; $b, c$, male head, lateral and frontal aspects; $d, e$, female head, lateral and frontal aspects; $f, g$, enlarged details of male and female antennae; $h-j$, ventral, lateral and posterior aspects of male terminalia; $k$, ventral aspect of female 8th sternum; $l$, lateral aspect of female 8 th and 9 th segments; $m$, female 9th sternum and bursa.

Female.-Head red-brown, eyes red-brown. Frons only as wide as ocellar tubercle, punctured with a shallow median pit; ocellar triangle not prominent ocelli orange; postocular ridge narrow; mouthparts as 
in male. Antennae as in male except last segment black-brown, pollinose.

Thorax dorsum black, transversely striated, with numerous short hairs giving a silvery appearance; humeral and supra-alar calli redbrown. Halter stem brown, knob red-brown with a brown pollinose bloom. Legs short and stout, femora and tibiae red-brown, tarsi orange-brown except last segment dark. Wing brown, fumose; veins brown. Sternum of eighth segment orange-brown, sculptured as in figure, bursa as figured.

Length: Male body 3.2-3.8 mm., wing 2.4-2.6 mm.; female body $3.2-4.5 \mathrm{~mm}$., wing $2.3-3.2 \mathrm{~mm}$.

Type-locality: Bekily, Reg. Sud de L'lle, Madagascar; March 1933 (A. Seyrig).

Holotype: Male (MNHN).

Allotype: Female Vila Pery, Mozambique; 24 November 1928 (P. Lesne) (MNHN).

Paratypes: $\sigma^{7}$ \& copulatory pair, Bekily, Reg. Sud de L'lle, Madagascar; April 1938 (A. Seyrig). 1 o' of same data but October 1936. 1 or Plaines de Fiherera; 1905 (F. Geay) in (MNHN). 2 ㅇ Madagascar Nord, Montagne d'Ambre 1000 M., det. Diego-Suarez; 23 Norember-4 December 1957 (B. Stuckenberg) in (NMP).

\section{Scenopinus balteatus Lamb}

FigURe 27

Scenopinus balteatus Lamb, 1922, p. 363.

The male is characterized by a smooth, sword-shaped central ridge on the frons, a single white band on the abdomen and by the shape of the terminalia. The female may be recognized by the configuration of the eighth sternum and bursa. The halter of the male is tan, that of the female white.

Length: Male body $3 \mathrm{~mm}$., wing $2 \mathrm{~mm}$.; female body $3.7 \mathrm{~mm}$., wing $2.7 \mathrm{~mm}$.

Type-locality: Mahe, Cascade Estate; 800-1500 ft., Seychelles (Percy Sladen Exp.).

Types: (BMNH).

\section{Scenopinus biroi Kertés.}

Figure 29

Scenopinus biroi Kertész, 1899, p. 173.

This species is common to New Guinea and Australia; may be recognized by its dark body and bright yellow lags.

Mats.-Head black, frons small, triangular, eyes with large upper and small lower facets. 'Thorax black; wings brown; legs yellow. 

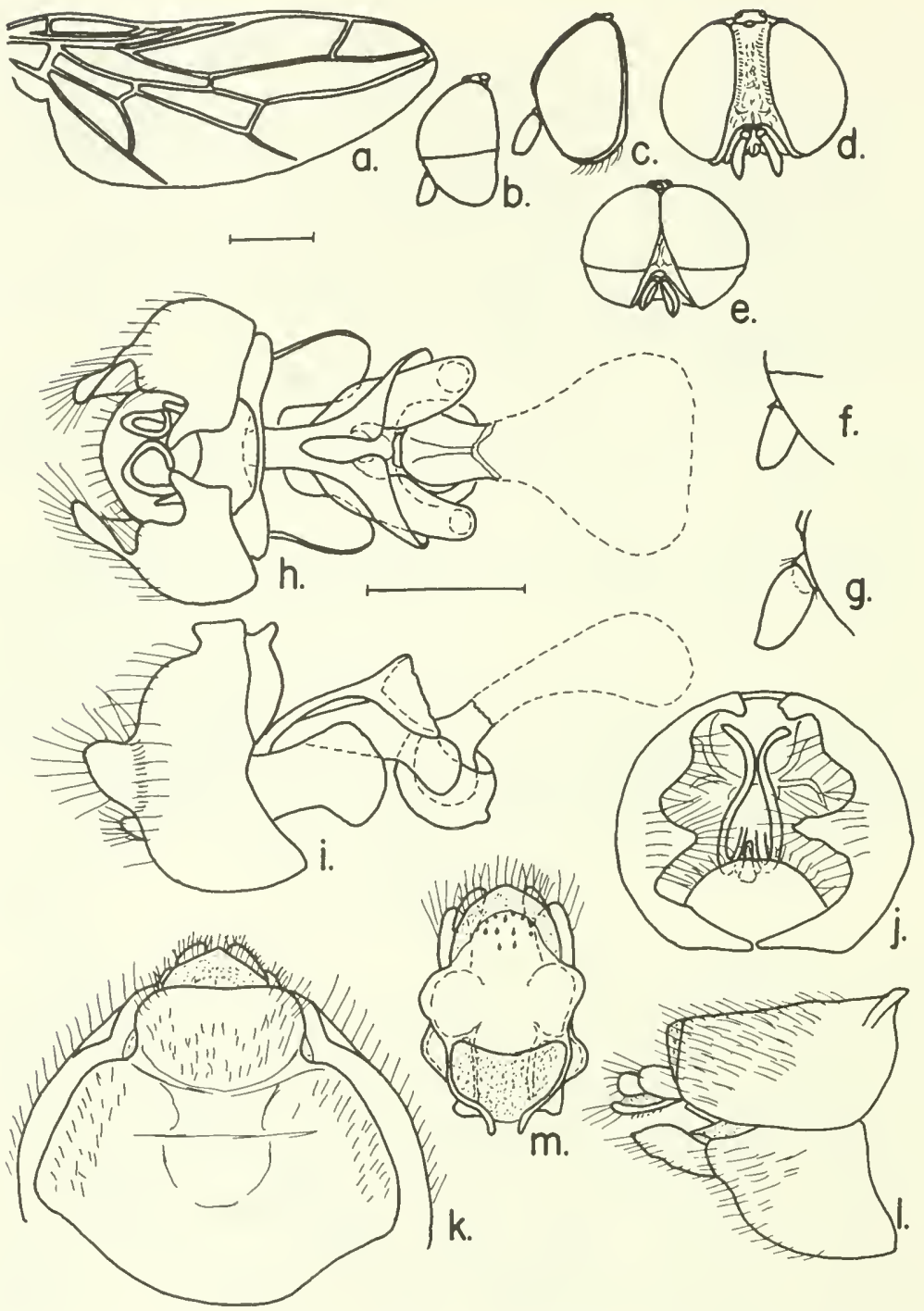

Figure 27.- Scenopinus balteatus Lamb, male, female: $a$, wing; $b$, $c$, lateral and frontal aspects of male head; $d, e$, lateral and frontal aspects of female head; $f, g$, enlarged details of male and female antennae; $h$, $i$, ventral and lateral aspects of male terminalia, cut ejaculatory syringe suggested by dashed outline; $j$, posterior aspect of male sternum; $k$, ventral aspect of female 8 th and 9 th segments; $l$, lateral aspect of female 8 th and 9 th segments; $m$, female 9 th sternum and bursa.

Genital segments as figured.

Length: Female body $2.5 \mathrm{~mm}$., wing $2.2 \mathrm{~mm}$.; male smaller. Type-locality: Friedrich-Wilhelmshafen and Erima, New Guinea. 
Type: (MNH) destroyed.

Paratypes: 2 우, (USNM) 24178, Kröber exchange. Male redeseribed and figured, National Park, Sidney, emerged 20 November 1922, from pupa found in Autechinus (Phascogale) flavipes (a small mouselike animal) (CSIRO); 3 ㅇ, Cairns, Queensland, on window (J. F. Illingworth) in (USNM).

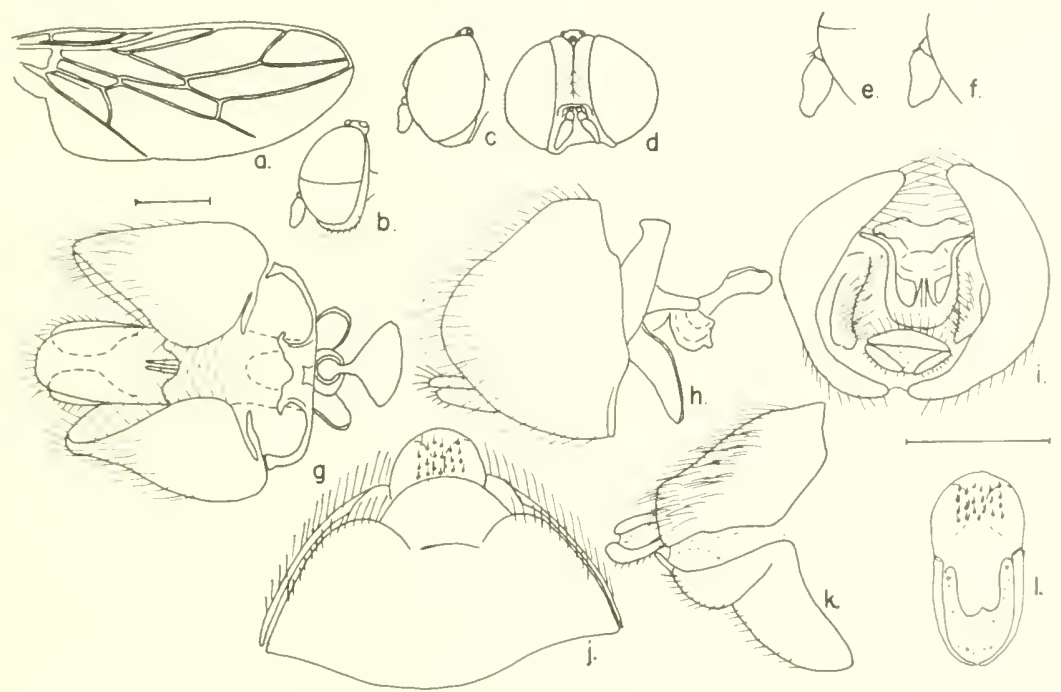

Figure 28.-Scenopinus biroi Kertész, male, female: $a$, wing; $b$, lateral aspect of male head; $c, d$, lateral and frontal aspects of female head; $e$, $f$, enlarged details of male and female antennae; $g-i$, ventral, lateral and posterior aspects of male terminalia; $j$, ventral aspect of female 8 th sternum; $k$, lateral aspect of female 8 th and 9 th segments; $l$, female 9 th sternum and bursa.

29. Scenopinus bolgarti, new species

Figure 29

This speeies from West Australia is placed in the Albicinctus Group on the basis of the male and female terminalia. It differs from the usual members of the group, however, in the failure of $\mathrm{M} 1+2$ to attain the tip of the wing or unite with $\mathrm{R} 5$, and in the shape of the male antenna. Though presumed to be opposite sexes of the same species, lack of wings on the female prevents positive identification.

MaLe.- Head black, eyes with brown upper facets and black-brown lower field; separated by a narrow band of frons which is rugose, sunken below the eye margins, with a shallow pit above the antennae. Ocellar tuberele elongate, dusted olivaceous; ocelli red-orange, back of the head dusted with silvery gray pollen; mouthparts brown, well developed, palpi short. Antenna with segment 1, dark brown, very 


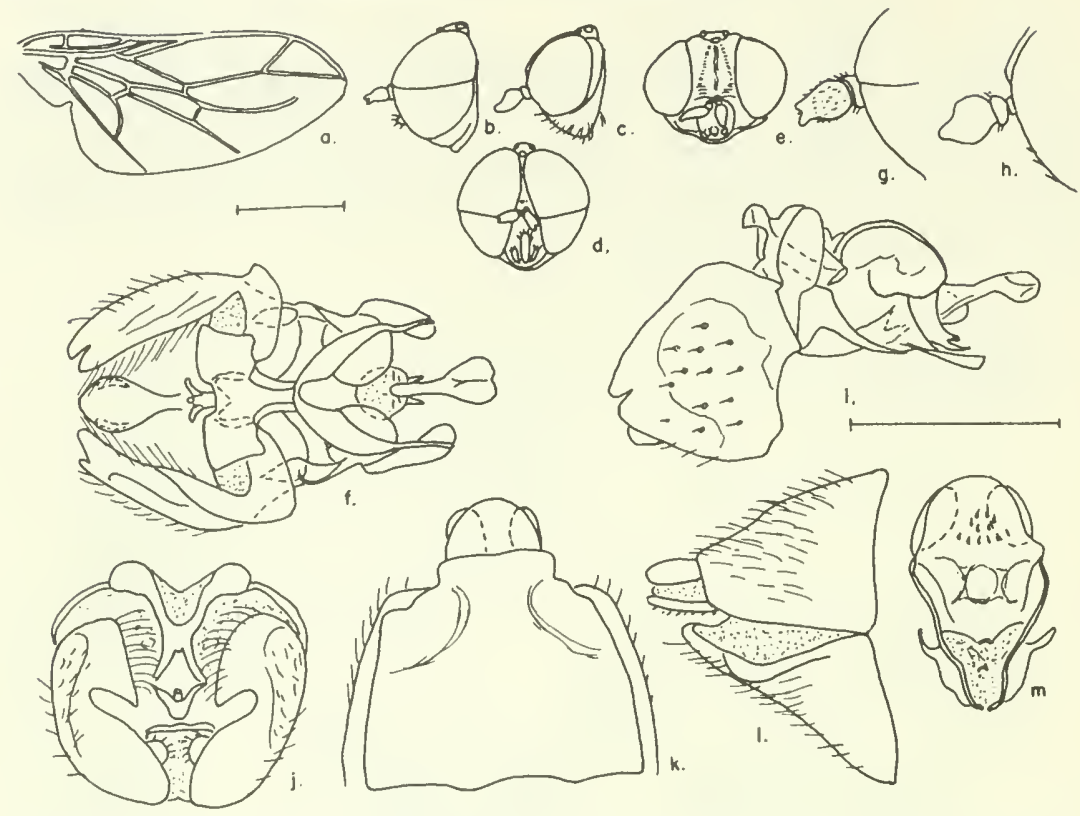

Figure 29.-Scenopinus bolgarti, new species, male, female: $a$, wing; $b, d$, lateral and frontal aspects of male head; $c, e$, lateral and frontal aspects of female head; $g, h$, enlarged details of male and female antennae; $f, i, j$, ventral, lateral and posterior aspects of male terminalia; $k$, ventral aspect of female 8th sternum; $l$, lateral aspect of female 8 th and 9 th segments; $m$, female 9 th sternum and bursa.

short; 2, brown, wider than long and twice as long as $1 ; 3$, brown, powdery, pear-shaped with two distinct points.

Thorax black, covered with dark brown scales; dorsum dark brown with light brown lateral stripes, whitish above humeral callus and posterior portion of mesonotum; humeral and supra-alar calli straw colored; scutellum black; pleural areas black-brown, covered with scales. Wings smoky white, veins very light brown anteriorly and nearly clear posteriorly, vein $\mathrm{M} 1+2$ fading before joining $\mathrm{R} 5$ at the tip of wing. Halter stem light brown, knob red-brown, scaly. Legs with fore femur red-brown, scaly, flattened, fore tibia and tarsus yellow-brown; middle and hind legs as above except femur normally shaped.

Abdomen with second segment broad, red-brown, scaly, posterior margin white; remaining segments with a thin dark band anteriorly, white posteriorly, giving the appearance of a nearly white dorsum. Sternites also with white posterior margins. Ninth tergum with white margins and a red-brown scaled median area, and some long hairs; for details see figure.

Female.-Head black, eyes black-brown; frons divided by a median groove, slightly elevated above the lateral margins which are sunken 
below the eyes; a triangular pollinose patch, covered with fine hairs, having its base above the antennae and extending to the median ocellus. Ocellar tubercle black, not prominent, ocelli orange-red. Antenna with first segment short, black; second short black-brown; third black-brown, over twice as long as first and second combined, pear-shaped and widest at its base.

Thorax black, shining, with fine hairs; humeral cal'us orange-brown. Halter with stem red-brown, knob dark red-brown with a ereamy brown band dividing the upper and lower halves. Wings brownish at base but broken off, veins brown. Legs with femora and tibiae dark red-brown, tarsi tan darkening at tips.

Abdomen red-brown; see figure for details of eighth sternum and bursa.

Length: Male body $2 \mathrm{~mm}$., wing $1.5 \mathrm{~mm}$.; female body $2.5 \mathrm{~mm}$., wing missing

Type-locality: Bolgart, W. Australia; 14 December 1961 (L. B. Britton and A. Douglas).

Holotype: Male and female allotype (BMNH)

\section{Scenopinus bouvieri (Séguy)}

Figure 30

Omphrale bouvieri Séguy, 1920, p. 317.

This species is quite similar to $S$. balteatus Lamb but differs in details of the frons, the shorter length of the median crossvein, and in details of the eighth sternum. The bursa have sinilar configurations but differ in minute details.

The type was taken in Paris from the nest of a pigeon. A specimen examined from Loango, French Congo, agrees in all details with the type and, in line with the agreement in the shape of the bursal cavity with the Albicinctus group, would suggest that this species is primarily African in affinities.

MaLE-Unknown.

Length: Female body $3.5 \mathrm{~mm}$., wing $2.5 \mathrm{~mm}$.

Type-locality: Paris (? introduced from Africa).

Type: (MNHN).

Material examined: Female Loango, Foret du Mayrombe, French Congo; 1911 (Vodon) (MNHN).

\section{Scenopinus brunneus (Kröber)}

Figure 31

Omphrale brunnea Kröber, 1913, p. 192.

This species, described originally from East Africa, appears to be distributed across equatorial Africa from the Indian Ocean to the 

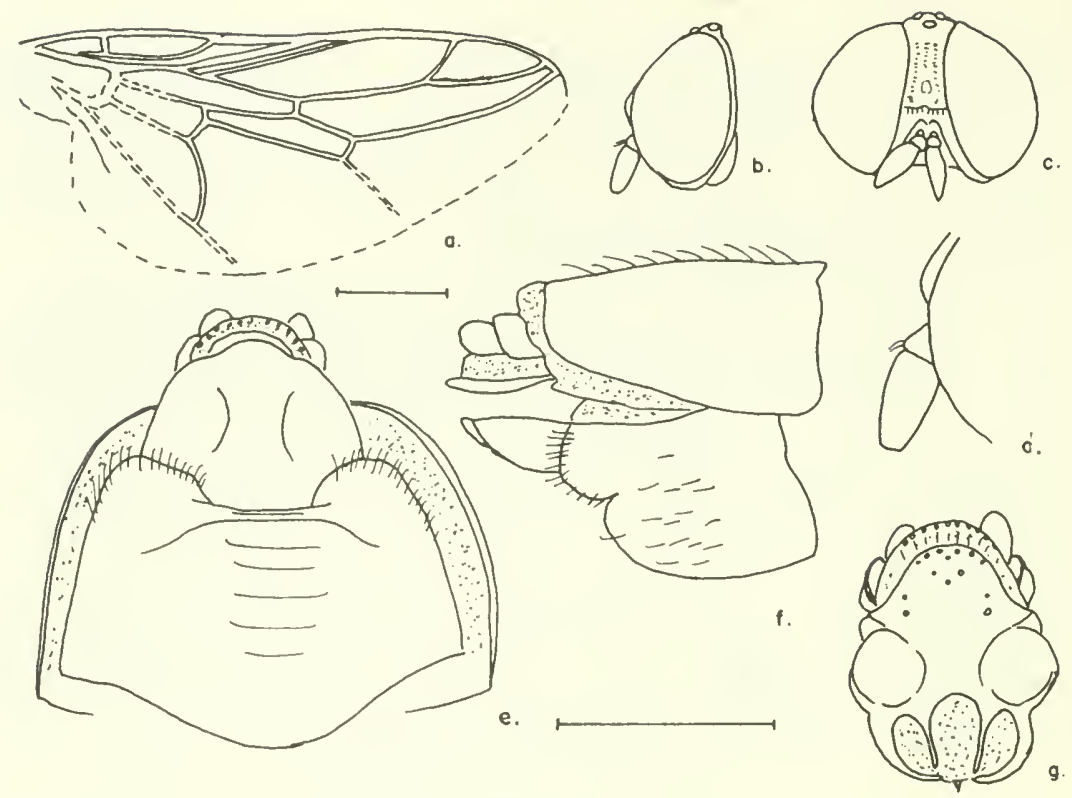

FigUre 30.-Scenopinus bouvieri (Séguy), female: $a$, wing; missing portions filled in by dashed lines; $b, c$, lateral and frontal aspects of head; $d$, enlarged detail of antenna; $e$, ventral aspect of 8 th sternum; $f$, lateral aspect of 8 th and 9 th segments; $g, 9$ th sternum and bursa.

Atlantic. The type specimen is teneral and a good deal smaller than the average. The ground color of other specimens is black or black-brown. The antennae are colored as follows: first segment brown; second brown-orange; third brown-orange at base darkening to black-brown at tip. Halter tan dorsally and white ventrally. Front and middle legs black-brown with first four tarsal segments yellow-brown and last segment red-brown; hind leg with tarsi entirely red-brown.

MALE-Unknown.

Length: Female body $3-4.5 \mathrm{~mm}$., wing $2.2-3 \mathrm{~mm}$.

Type-locality: Waboniland, East Africa.

Type: (NMV).

Material examined: 19, Njala, Sierra Leone, 1926 (E. Hargreaves) (ZMUH); 1ㅇ, Lihete Sllomele, Congo Belge, July 1936 (J. Ghesquiere) (IRSNB); 4ㅇ, Njala, Sierra Leone, 1926, March 1936, April 1936 (E. Hargreaves); Moramba, Sierra Leone, 27 February 1925 (E. Hargreaves); 19, laboratory, Accra, Gold Coast, March 1920 (J. W. S. Macfie); 19, Bembay, Senegal, February 1940 (J. Risbec); 1우, Cico, Nyasaland, April 1916 (R. C. Wood); 19, Chipinda Pools, S. Rhodesia (lower Lundi River), 23 October 1960 (R. Goocher); all in (BMNH). 

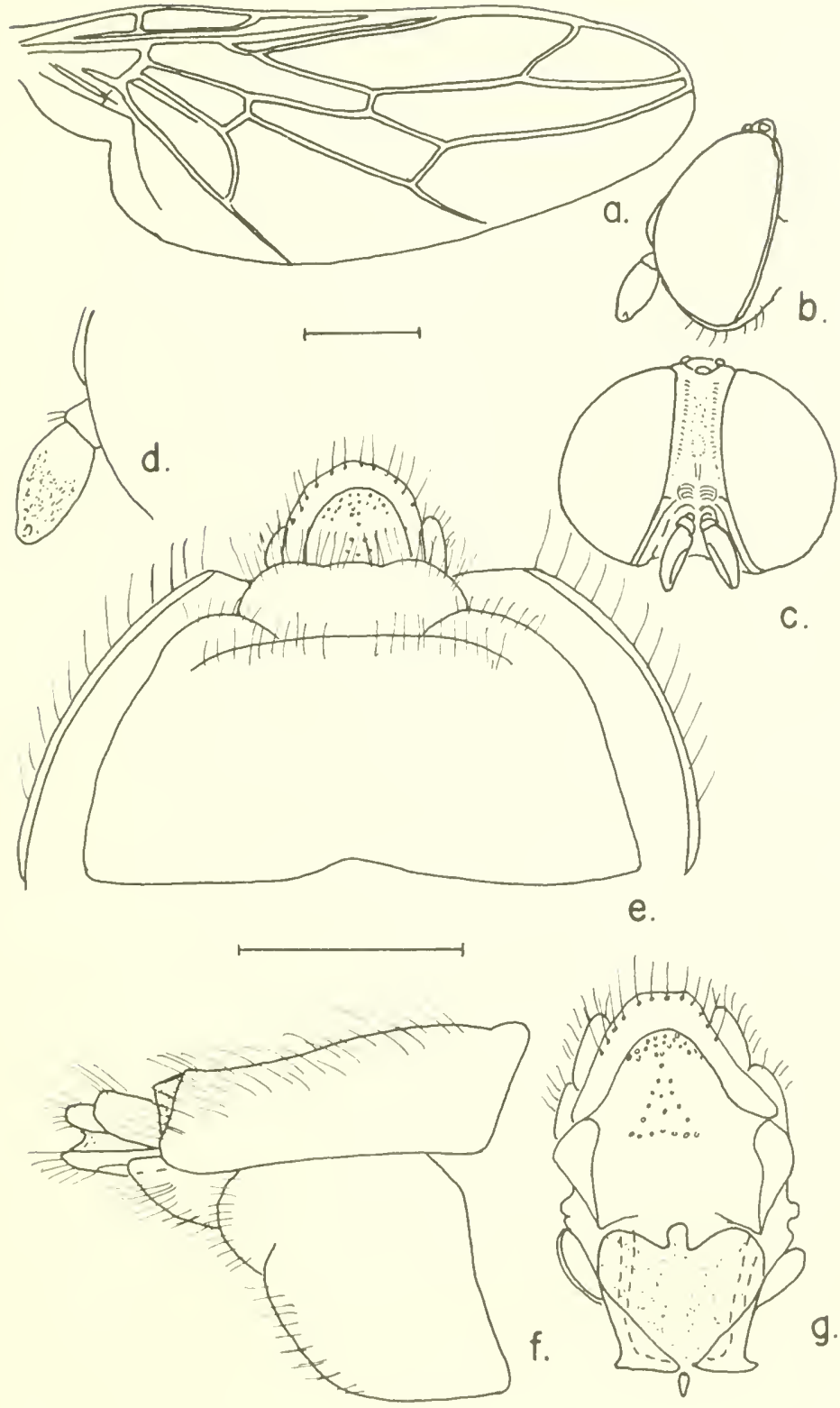

Figure 31.-Scenopinus brunneus (Kröber), female: $a$, wing; $b$, $c$, lateral and frontal aspects of head; $d$, enlarged detail of antenna; $e$, ventral aspect of 8 th sternum; $f$, lateral aspect of 8 th and 9 th segments; $g$, 9th sternum and bursa. 


\section{Scenopinus bulbapennis, new species}

FIGURE 32

MALE.-Head black; eyes red-brown above, black-brown below; frons narrow, triangular, extending two-thirds the distance from the antennae to the ocellar triangle, rugose, with a median groove extending from the antennal base to an elliptical depression at the top of the frons; ocellar tubercle red-brown, ocelli orange-red; back of head dusted gray pollinose; oral opening bordered by silvery pile extending one-third the distance up the frons and cutting off a triangular area above the antennae. Mouthparts brown, medium size; palpi half the length of the oral opening. Antennae black-brown, first segment short, second wider than long, third oval, slightly broader at base, pollinose.

Thorax with dorsum black, rugose with a pollinose patch above the humeral callus which is red-brown with a yellow posterior tip; supraalar callus yellow-brown; pleura black-brown. Wings smoky, veins brown; halter stem brown, knob brown. Legs with all segments dark red-brown.

Abdomen black-brown, second segment pollinose, third and fourth with narrow white bands on posterior margin. Terminalia as in figures.

Female.-Head black; eyes black-brown, the postocular ridge narrow; frons rugose, with a groove extending between lateral swellings on the lower frons through the flattened upper frons to the median ocellus; silvery pile laterad of oral opening extending into the frontal area above the base of the antennae. Ocellar triangle black, rugose, with orange-red ocelli; back of the head convex. Antennae as in male.

Thoracic features as in male. Abdomen dark red-brown. See figure for details of eighth sternum and bursa.

Length: Male body $2.7 \mathrm{~mm}$., wing $2.1 \mathrm{~mm}$.; female body $3 \mathrm{~mm}$., wing $2.1 \mathrm{~mm}$.

Type-locality: Sierra Nevada Highway, Spain 2200 m.; 27 July 1960 (J. R. Vockeroth).

Holotype: Male (CNC) 8631.

Allotype: Female and paratypes $2 \sigma^{7} \sigma^{7}$ same data as type (CNC).

33. Scenopinus canarius, new species

Figure 33

Scenopinus brevicornis Frey (not Loew), 1937, p. 53.

Both specimens of this species had been identified as $S$. brevicornis Loew, but differed in the wing venation and shape of the ninth tergum.

MALE.-Head dark brown; eyes red-brown to black-brown above, darker below; frons triangular with a brown pollinose covering, a shallow groove located in its center; back of the head concave above, 

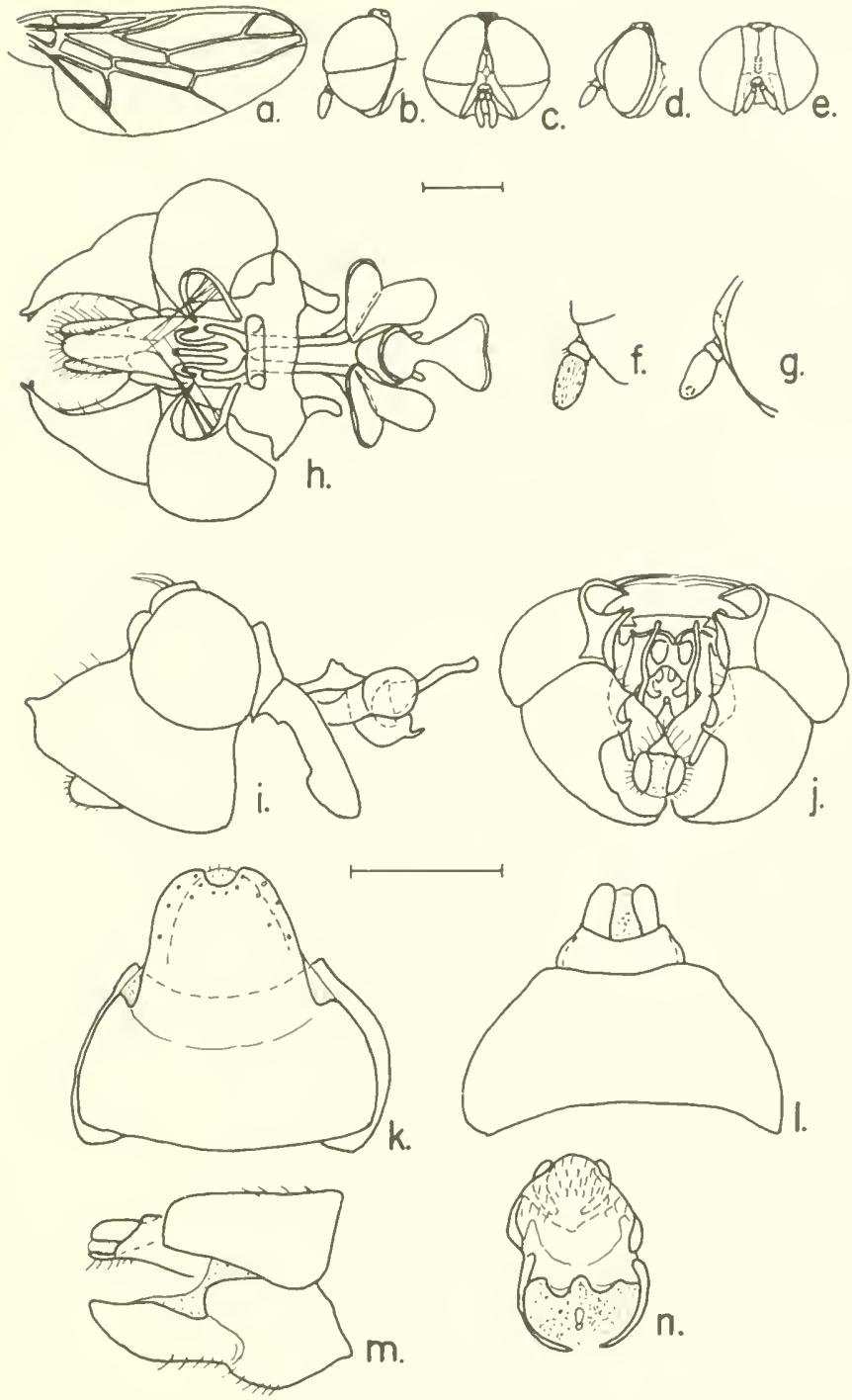

$m$.

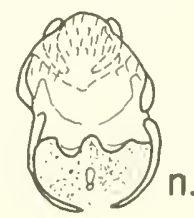

Figure 32.-Scenopinus bulbapennis, new species, male, female: $a$, wing; $b, c$, lateral and frontal aspects of male head; $d, e$, lateral and frontal aspects of femalc head; $f$, g, enlarged details of male and female antennac; $h-j$, ventral, lateral, and posterior aspects of male terminalia; $k$, ventral aspect of female 8 th sternum; $l$, dorsal aspect of female 8 th and 9 th segments; $m$, lateral aspect of female 8 th and 9th scgments; $n$, female 9 th sternum and bursa.

convex below, dusted with gray pollen and bearing scattered golden hairs. Oral cavity bordered with brown pile, mouthparts of medium length, dark brown; palpi brown; ocellar triangle dark red-brown, sub- 


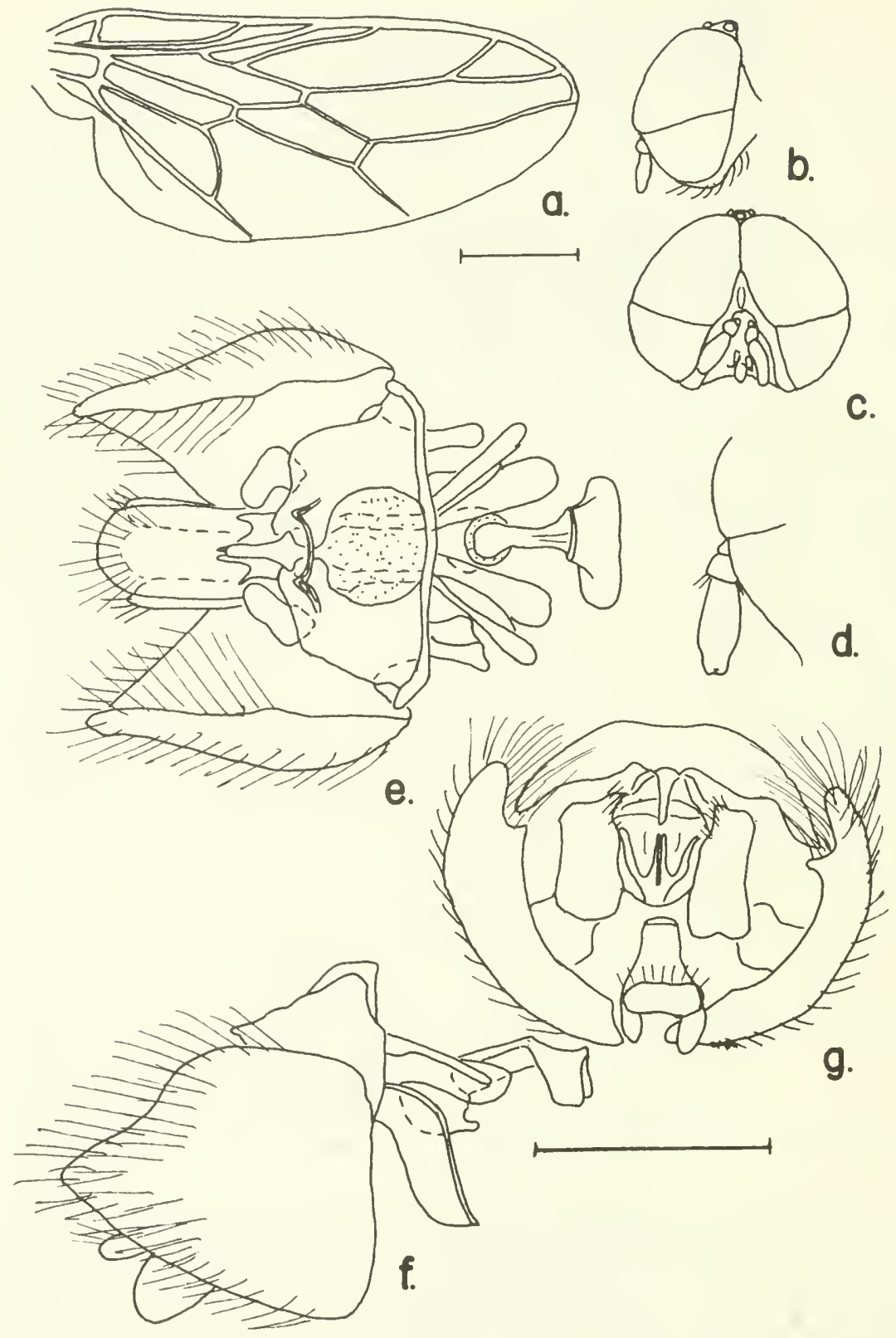

FigUre 33.-Scenopinus canarius, new species, male: $a$, wing; $b, c$, lateral and frontal aspects of head; $d$, enlarged detail of antenna; $e-g$, ventral, lateral and posterior aspects of terminalia. 
shining, ocelli red. Antennae dark brown, first segment small; second twice as long and wide as the first; third pollinose and twice as long as 1 and 2 combined.

Thorax dorsum black-brown, dusted with brown pollen, covered with moderately long golden hairs of medium density; humeral callus similar except posterior angle yellow, with several anteriorly directed hairs; supra-alar callus yellow-brown; pleura red-brown dusted with bronze pollen. Wings hyaline with brown microtriehia, veins brown; halter stem brown, knob cream. Legs red-brown throughout, covered with golden hairs.

Abdomen red-brown, segments 3-5 with wide white bands twothirds width of segment. Terminalia differing from brevicornis in size and shape of ninth segment claspers, and shape of posterior margin of ninth tergum-see figure.

Female.-Unknown.

Length: Male body $2.8-3.2 \mathrm{~mm}$., wing 2.1-2.3 mm.

Type-locality: Gr. Canaria, Los Palmas (R. Frey).

Holotype: Male (ZMUH).

Paratype: Male Cabrea Diaz, Canary Island (N.MV).

\section{Scenopinus curtipilosus, new species}

Figure 34

Female,-Head black-brown; eyes black-brown; frons broad, shagreened, with a central groove, sculptured as in the figure; ocellar triangle not prominent, ocelli red; postocular ridge narrow. Mouthparts well developed, pubescence surrounding oral eavity extending only halfway to eye, remainder shining. Antenna with first segment red-brown, short; second segment orange-brown, twice as large as first; third segment red-brown, three times as long as 1 and 2 combined, narrow tapering.

Thorax with dorsum black, rugose with a thin covering of short hairs; humeral and supra-alar calli orange; pleural areas black-brown. Wings hyaline, veins straw yellow; halter stem brown, knob tan. Legs with femora and tibiae red-brown with knee orange, tarsi orange-yellow.

Abdomen red-brown, middle segments with thin white membrunous posterior margins. Eighth segment with red-brown sternum; bursa as figured.

MALE.-Unknown.

Length: Female body $3.5 \mathrm{~mm}$., wing $2.3 \mathrm{~mm}$.

Type-locality: El Elisah (El Sliectch), Egypt; 21-27 April 1939 (H.C.E.).

Holotype: Female (CUC). 

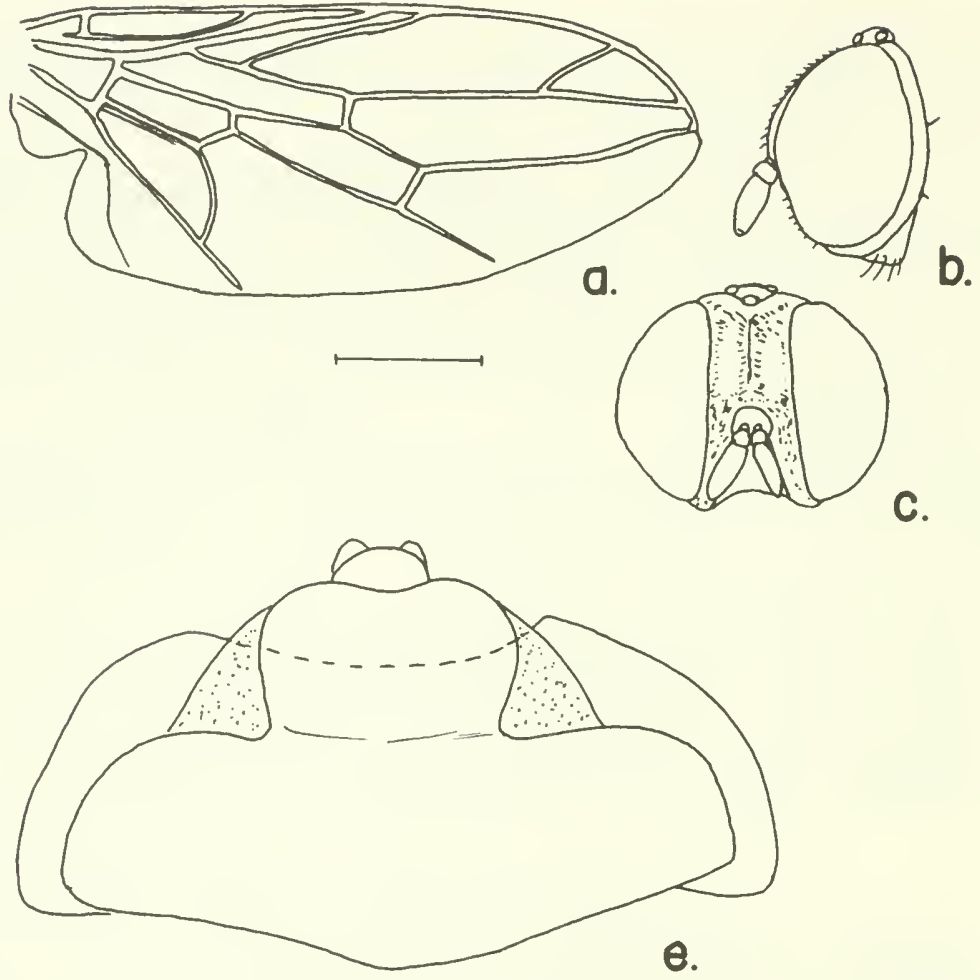

C.

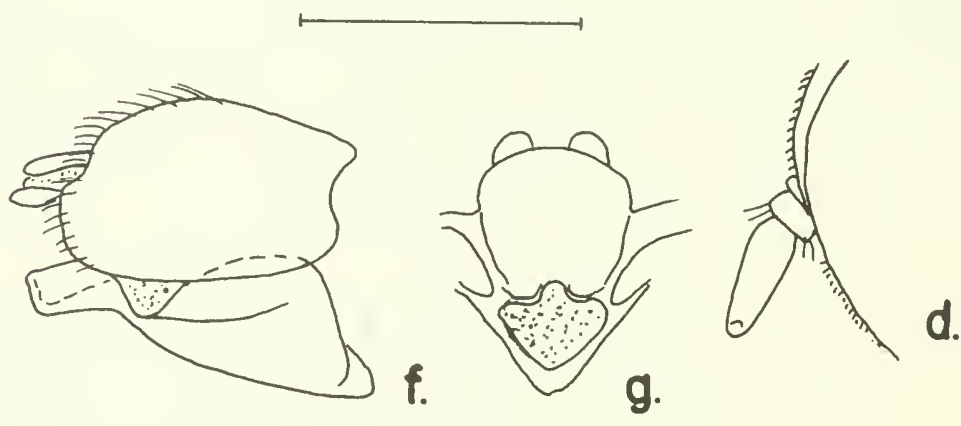

FIGURE 34.- Scenopinus curtipilosus, new species, female: $a$, wing; $b, c$, lateral and frontal aspects of head; $d$, enlarged detail of antenna; $e$, ventral aspect of 8 th sternum; $f$, lateral aspect of 8 th and 9 th segments; $g$, 9th sternum and bursa.

\section{Scenopinus daruini, new species}

Figure 35

Female.-Head black-brown; eyes black-brown, extending to the back of the head so there is no postocular ridge; frons granular, narrower than the ocellar triangle, with a median depression one- 

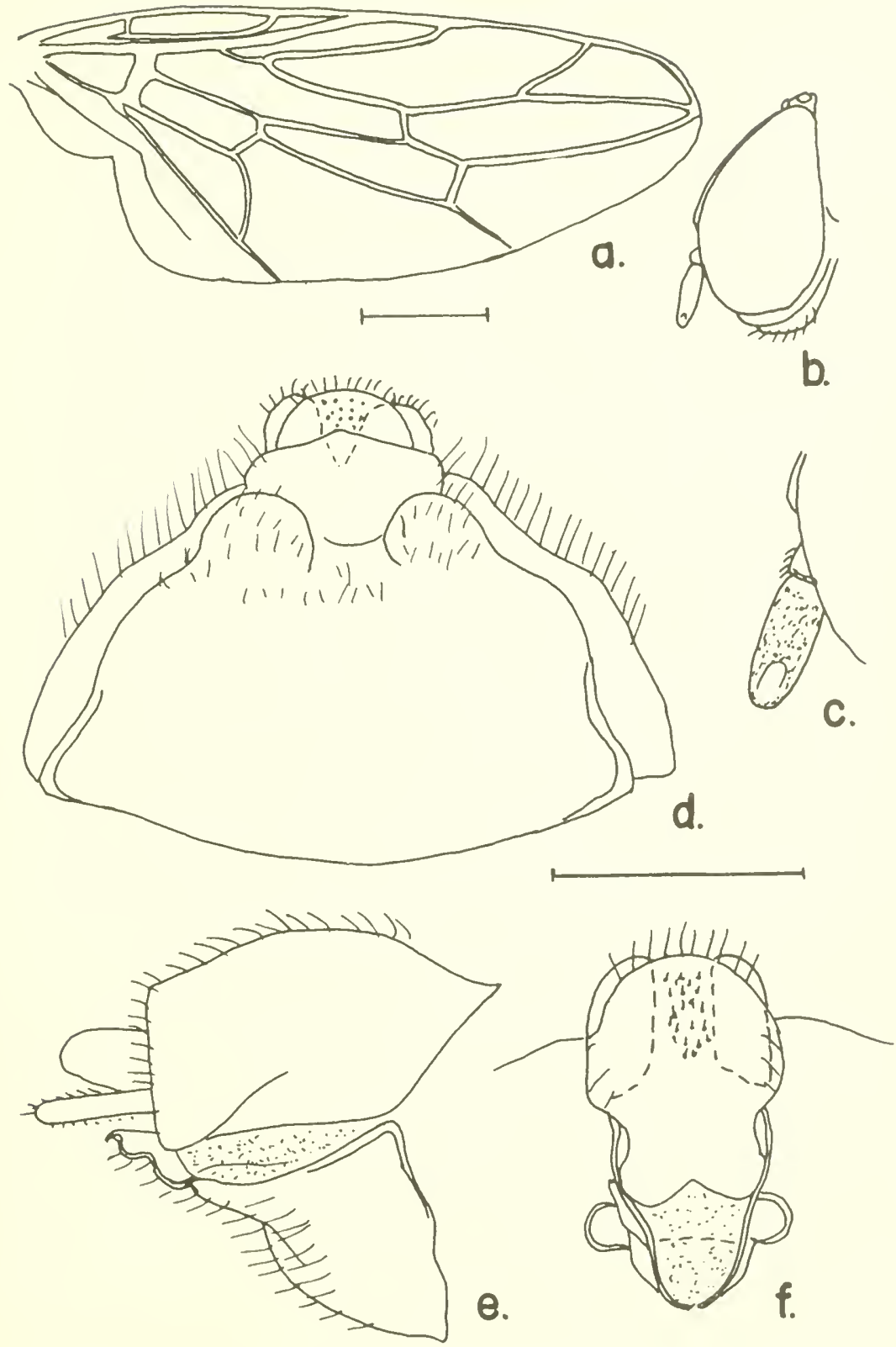

FigURE 35.-Scenopinus darwini, new species, female: $a$, wing; $b$, lateral aspect of head; $c$, enlarged detail of antenna; $d$, ventral aspect of 8 th sternum; $e$, lateral aspect of 8 th and 9 th segments; $f, 9$ th sternum and bursa. 
quarter of the distance from antenna to ocellus; ocellar tubercle black-brown, slightly raised; ocelli red-brown. Oral cavity bordered by gray pollinose hairs; mouthparts black-brown, filling oral cavity. Antenna with first segment brown, short; second segment yellowbrown, short; third segment black-brown, elongate, three times as long as 1 and 2 combined.

Thorax with dorsum black, covered with short hairs that give it a granular appearance; humeral and supra-alar calli red-brown; scutellum red-brown, hairy like the dorsum, not distinctly set off from scutum by a deep groove; pleural areas red-brown. Wings brownish, hyaline, veins red-brown, halter stem red-brown, knob red-brown, large. Legs with femora and tibiae red-brown, tarsi orange.

Abdomen red-brown, subshining; see figure for configuration of eighth sternum and bursa.

Male.-Unknown.

Length: Female body $3.5+\mathrm{mm}$., wing $2.7 \mathrm{~mm}$.

Type-locality: Darwin, N. T., Australia, 9 March 1916 (G. F. Hill).

Holotype: Female (USNM) 67455 .

\section{Scenopinus evansi, new species}

Figure 36

This specimen was identified as S. balteatus Lamb by van Emden, but the resemblance is superficial and differences in the head, wings, and particularly eighth sternum and bursa remove it from that species.

Female.--Head black; eyes black-brown, extending to back of head; frons slightly ridged from laterad of the antenna bases to the median ocellus, with a small triangular shining spot on the lower third, as wide as ocellar tubercle at its narrowest point. Ocellar tubercle distinct, ocelli orange-red. Mouth-parts two-thirds length of oral opening; palpi round and slim, a little shorter than the rostrum. Antenna red-brown, first segment short; second segment twice as large as the first; third segment oval, 2.5 times as long as broad.

Thorax with dorsum black; humeral and supra-alar calli orange; pleural areas red-brown. Wings brown-fumose, veins brown; halter stem brown, knob red-brown, shining. Legs with coxae through tibiae red-brown, tarsi orange-brown.

Abdomen red-brown; for details of eighth sternum and bursa see figure.

MaLe.-Unknown.

Length: Female body $3.5 \mathrm{~mm}$., wing $2.9 \mathrm{~mm}$.

Type-locality: N. Rhodesia (Sylvester Evans).

Holotype: Female (BMNH). 

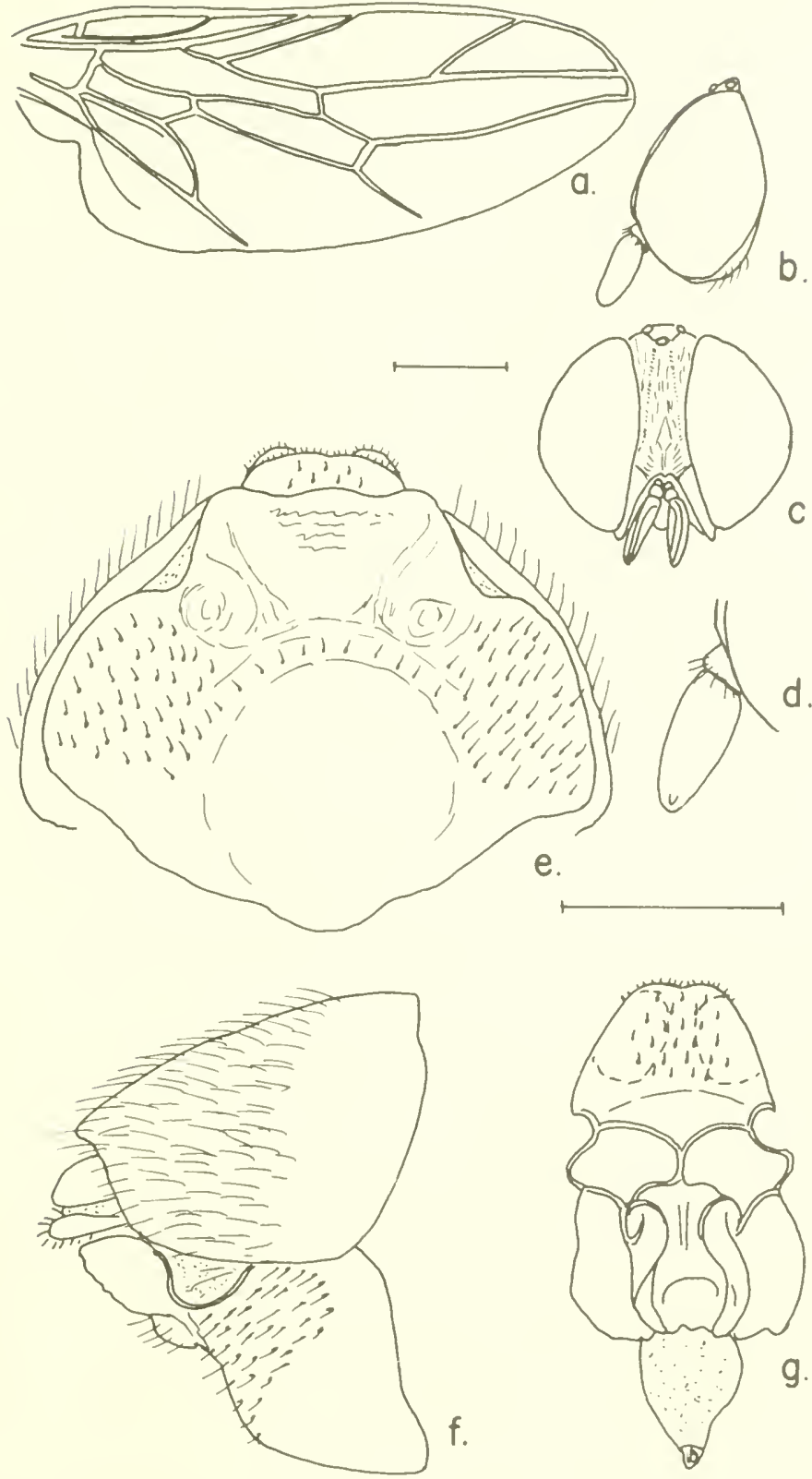

Figure 36.-Scenopinus evansi, new species, female: $a$, wing; $b, c$, lateral and frontal aspects of head; $d$, enlarged detail of antenna; e, ventral aspect of Sth sternum; $f$, lateral aspect of 8 th and 9th segments; $g$, 9th sternum and bursa. 
Paratypes: 4 ㅇ ㅇ, Ruo, Nyasaland, 14 April 1916, (R. C. Wood); 2 우, Ruo, Nyasaland, 29 April 1916, (R. C. Wood); all in (BMNH).

\section{Scenopinus flavipes (Kröber)}

Figure 37

Omphrale flavipes Kröber, 1939, p. 398.

This species is known only from the female type which is figured. The third segment of the antenna was lost and Kröber's detail is included; see figure for details.

MaLe.-Unknown.

Length: Female body $3 \mathrm{~mm}$., wing $2.3 \mathrm{~mm}$.

Type-locality: Rabai, Kenya; August 1930, (van Someren).

Type: (BMNH).
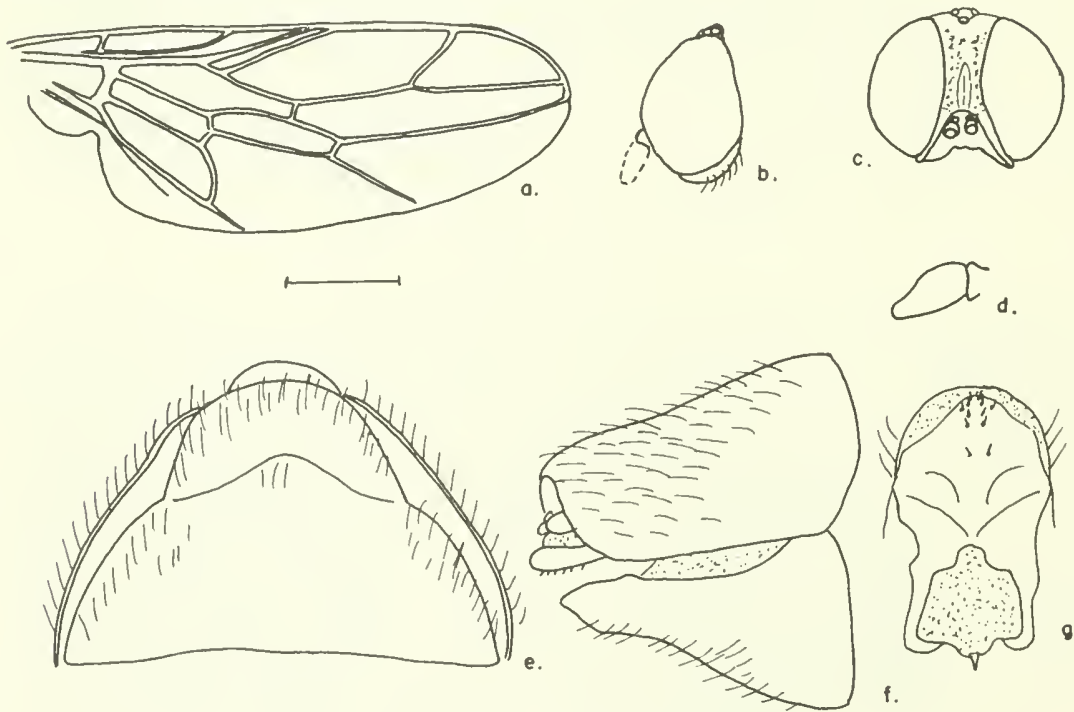

f.

FigURE 37.-Scenopinus flavipes (Kröber), female: $a$, wing; $b, c$, lateral and frontal aspects of head; $d$, detail of antenna (after Kröber); $e$, ventral aspect of 8 th sternum; $f$, lateral aspect of 8 th and 9th segments; $g$, 9th sternum and bursa.

\section{Scenopinus fragosifrons, new species}

\section{Figure 38}

MALE.-Head black-brown; frons large, triangular, rugose, with a faint median groove above antennae to the top of the anteriorly sloping part of the frons; eyes red-brown, with large upper and 
smaller lower facets, protruding above antennae and extending to the back side of the head (see figure). Ocellar tubercle slightly elevated and distinct, ocelli red-brown. The antennae, located on the lower receding portion of the face, with short red-brown first segment; second orange-brown and twice as large as the first; third red-brown, pear-shaped and twice as long as the first two combined. Mouthparts well developed.

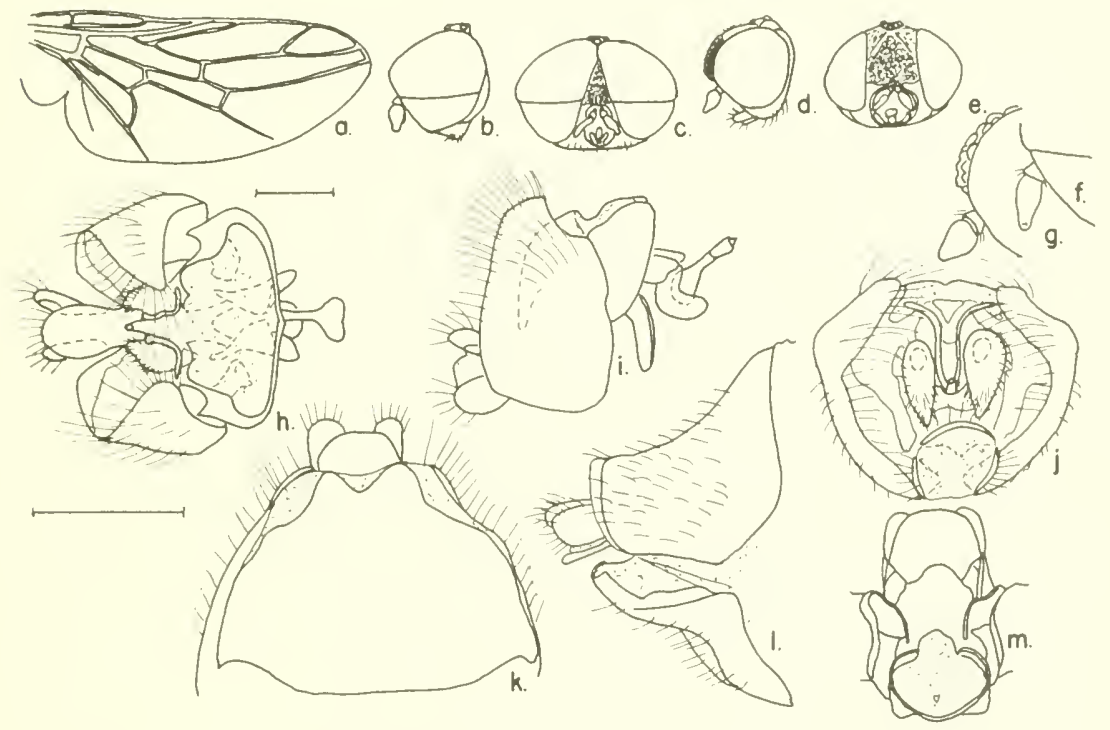

Figure 38.-Scenopinus fragosifrons, new species, male, female: $a$, wing; $b$, $c$, lateral and frontal aspects of male head; $d, e$, lateral and frontal aspects of female head; $f$, $g$, enlarged details of male and female antennae; $h-j$, ventral, lateral and posterior aspects of male terminalia; $k$, ventral aspect of female 8 th sternum; $l$, lateral aspect of female 8 th and 9 th segments; $m$, female 9 th sternum and bursa.

Thorax black-brown, shining, with a few short hairs, humeral and supra-alar calli orange-brown. Wings milky with anterior veins tan, remaining veins very light and faint. Halter stem brown, knob redbrown with a creamy band separating the upper and lower halves. Legs, fore and middle, with coxa to tibia black-brown, tarsus redbrown covered with short stiff spines; hind leg with coxil to tibia black-brown; first tarsal segment orange-brown, three times as long as second segment; remaining segments red-brown; all tarsal segments densely covered with short stiff spines.

Abdomen with seeond segment red-brown with short pilose hairs above and long white hairs laterally; segments $3-5$ with broad white bands medially, lateral portions completely sclerotized; remaining segments red-brown. For terminal segments see figure. 
Female.-Head black-brown, flattened and receding below the antennae; eyes red-brown; mouthparts well developed extending only half the length of the oral cavity. Frons broad, swollen above the antennae; nubbly portion narrowing dorsally to the width of the ocellar tubercle, dorso-lateral portions with transverse ridges like a crackle finish; postocular ridge moderate y wide; ocellar tubercle black-brown, prominent; ocelli red-brown. Antennae as in male except all segments red-brown.

Thorax as in male; tarsi uniformly light red-brown.

Abdomen red-brown; for details of eighth sternum and bursa see figure.

Length: Male body $3.3 \mathrm{~mm}$., wing $2.2-2.7 \mathrm{~mm}$.; female body 4.5 mm., wing $2.8 \mathrm{~mm}$.

Type-locality: Yanchep, W. Australia, $32 \mathrm{mi}$. north of Perth; 20-31 December 1935 (R. E. Turner).

Holotype: Male; allotype female; and paratype $1 \sigma^{\top}, 1$ 으, (same data but 24 November and 2 December), (BMNH).

\section{Scenopinus gromieri, new species}

\section{Figure 39}

Female.-Head red-brown; eyes brown, with a well defined postocular rim; frons broad, nearly one-third the width of the head, shining, reminiscent of $S$. glabrifrons but smaller in size yet larger than S. phaidimos; ocellar tubercle prominent; ocelli orange. Antennae red-brown, first segment short and small; second twice as large as first; third segment four times as long as one and two combined, half as broad as long. Mouthparts well developed, palpi short.

Thorax black-brown, granular; humeral and supra-alar calli yellowbrown; pleural area red-brown. Wing hyaline, dusted with brown; veins brown anteriorly, strawyellow posteriorly; halter stem brown, knob white. Front leg with coxa, trochanter and femur straw colored, tibia orange-brown, tarsus red-brown; middle leg with coxa, trochanter and femur straw colored, remaining segments red-brown; hind leg with all segments red-brown.

Abdomen red-brown; see figure for details of eighth sternum and bursa.

MALE.-Unknown.

Length: Female body 3.3-4.2 mm., wing 3.5-3.7 $\mathrm{mm}$.

Type-locality: Cameroun N. O., Plateau de Dchany 1500 m., Saison Seche; 1 November 1942, (Dr. Gromier).

Holotype: Female (MNHN).

Paratypes: 3 우 우, Chilanga, N.W. Rhodesia; 2 우 우, 4 October 1913, in grain store in house 1 o , 20 November 1913, on window in house; all (R. C. Wood) (BMNH). 

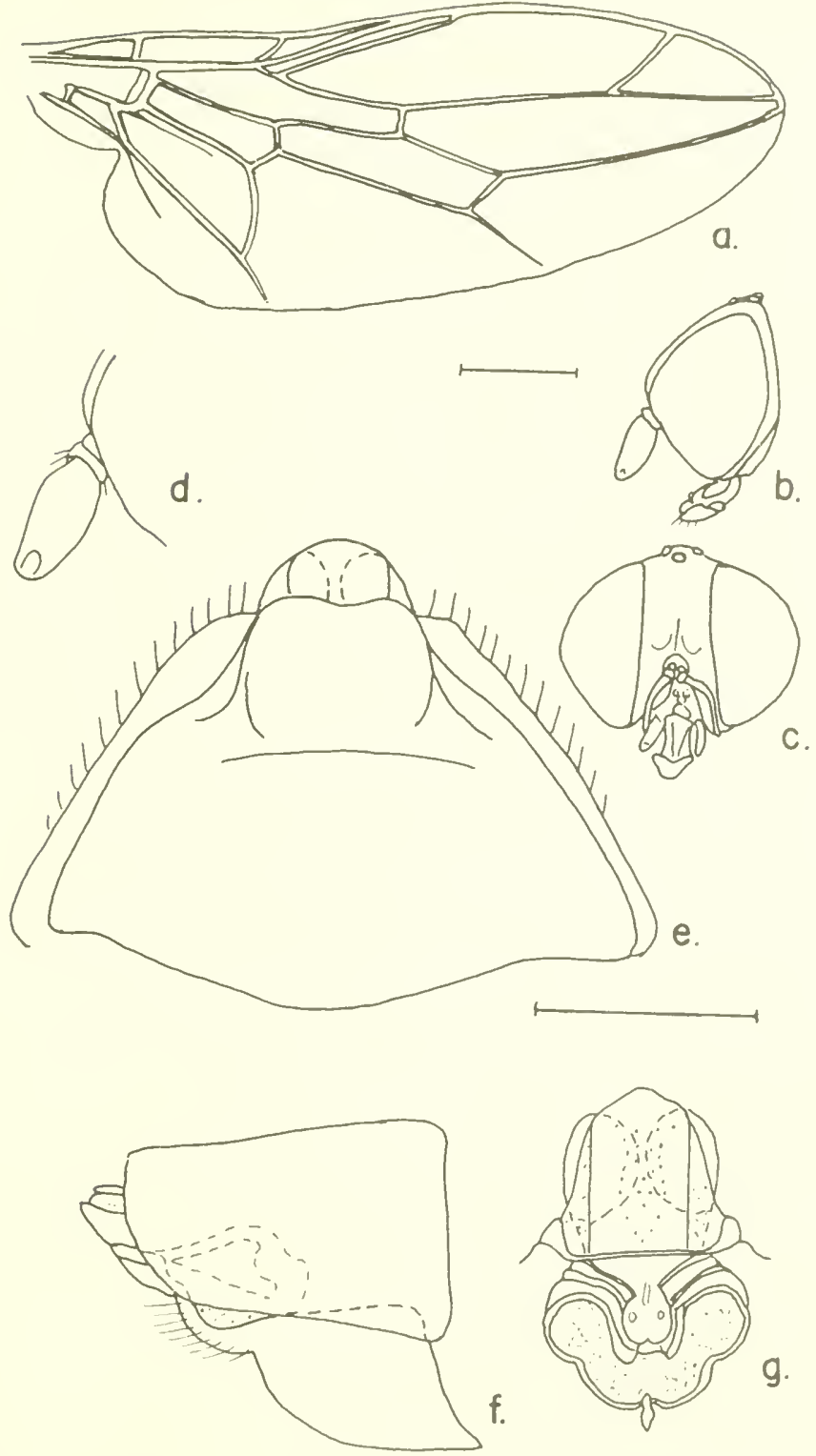

Figure 39.-Scenopinus gromieri, new species, female: $a$, wing; $b, c$, lateral and frontal aspects of head; $d$, enlarged detail of antenna; $e$, ventral aspect of 8 th sternum; $f$, lateral aspect of 8 th and 9 th segments; $g, 9$ th sternum and bursa. 


\section{Scenopinus inquilinus Séguy}

Figure 40

Scenopinus inquilinus Séguy, 1931, p. 113.

This medium sized fly is easily distinguished in the male by the single white band on the abdomen, the antlerlike shape of the male aedeagal parameres, and shape of the ninth tergum. The female can probably be positively identified only by the bursal cavity. Their larvae have been found in Polyporus, in June and July, with adults in July.

Length: Male body $3.3 \mathrm{~mm}$., wing $2.3 \mathrm{~mm}$.; female body $3.75 \mathrm{~mm}$., wing $2.5 \mathrm{~mm}$.

Type-locality: Nova Choupanga près Chemba, Mozambique; 24 August 1929 (P. Lesni), a copulating pair.

Type: (MNHN).

Material examined: $1 \sigma^{7}, 3$ \% $\%$, same data as type except $23 \mathrm{July}$; 1 ㅇ, Vila Pery, 24 November (MNHN); $1 \sigma^{\gamma}$, Luaba, Mozambique, June and July 1957, (Usher and Stuckenberg); 1 क , Trelawney, Southern Rhodesia, 14 December 1952, (N. J. Myers) (BMNH).

\section{Scenopinus katbergi, new species}

Figure 41

Female.-Moderately large fly. Head black-brown, eyes brown; a narrow postocular ridge; frons granular with a median shining band widening on the upper part. White pilose bands bordering the oral cavity extending to lower edge of frons above the antennal bases. Ocellar tubercle prominent; ocelli clear; back of head covered with gray pollen. Antennae with first segment black-brown, short; second reddish brown, a little larger than first; third red-brown, elongate oval, half again as long as wide.

Thorax with dorsum black, pitted, covered with short hairs; humeral and supra-alar calli orange-brown; pleural areas red-brown, pitted and covered with short hairs. Wings brown with brown veins, appearing to have veins $\mathrm{R} 2$ as well as R3; R4 branches from basal third of cell; halter stem red-brown, knob red-brown. Legs with femora and tibiae red-brown; fore tarsus orange-brown, middle and hind tarsi straw colored.

Abdomen red-brown; eighth sternum destroyed, bursal cavity as illustrated.

Male.-Unknown.

Length: Female body $4.3 \mathrm{~mm}$., wing $3.4 \mathrm{~mm}$.

Type-locality: Katberg, east Cape Province, $4000 \mathrm{ft}$.; December 1932 (R. E. Turner).

Holotype: Female (BMNH) 

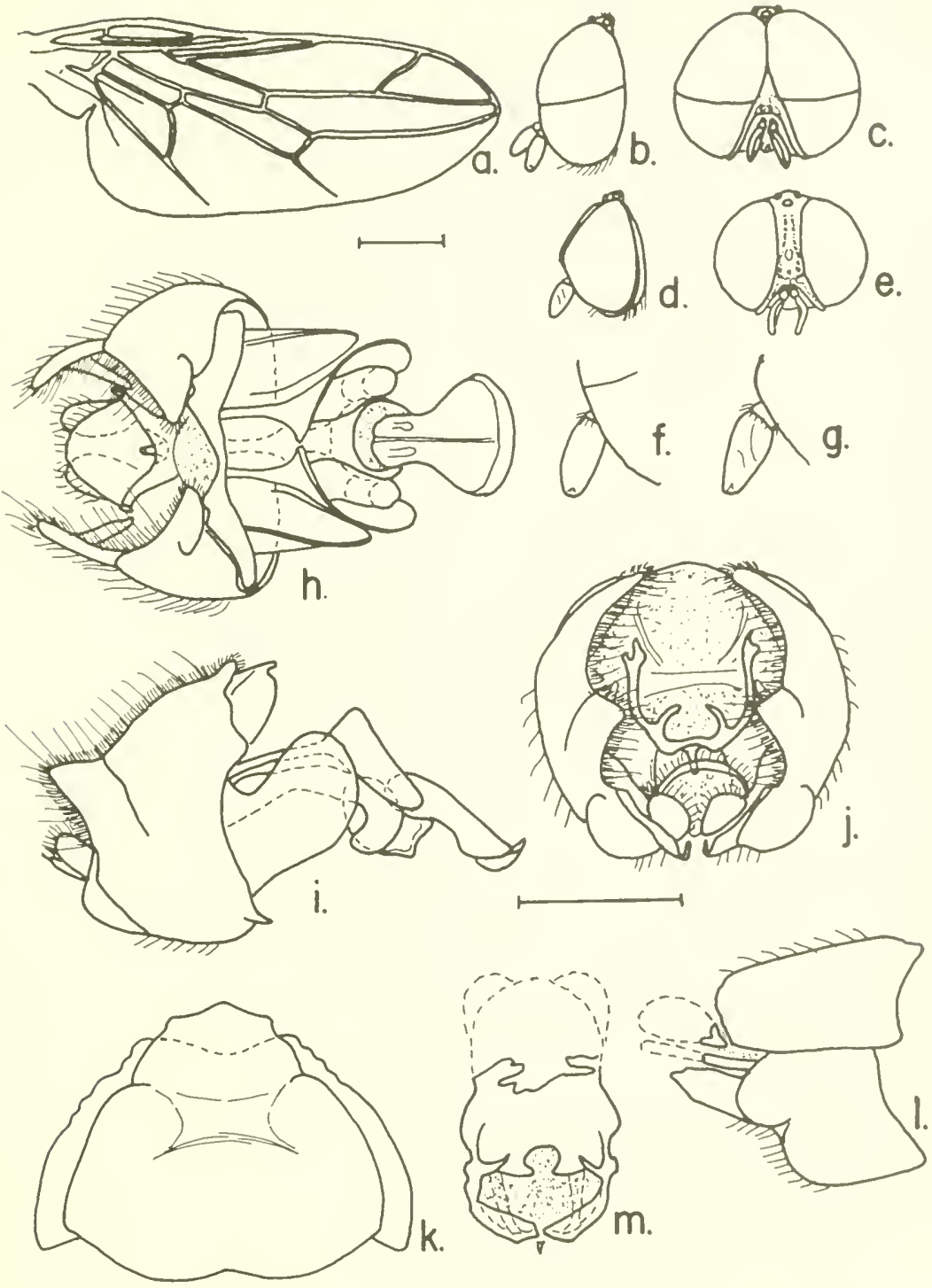

Figure 40.-Scenopinus inquilinus Séguy, male, female: $a$, wing; $b, c$, lateral and frontal aspects of male head; $d, e$, lateral and frontal aspects of female head; $f, g$, enlarged details of male and female antennae; $h-j$, ventral, lateral and posterior aspects of male terminalia; $k$, ventral aspect of female 8th sternum; $l$, lateral aspect of female 8 th and 9 th segments; $m$, remains of female 9 th sternum and bursa. 

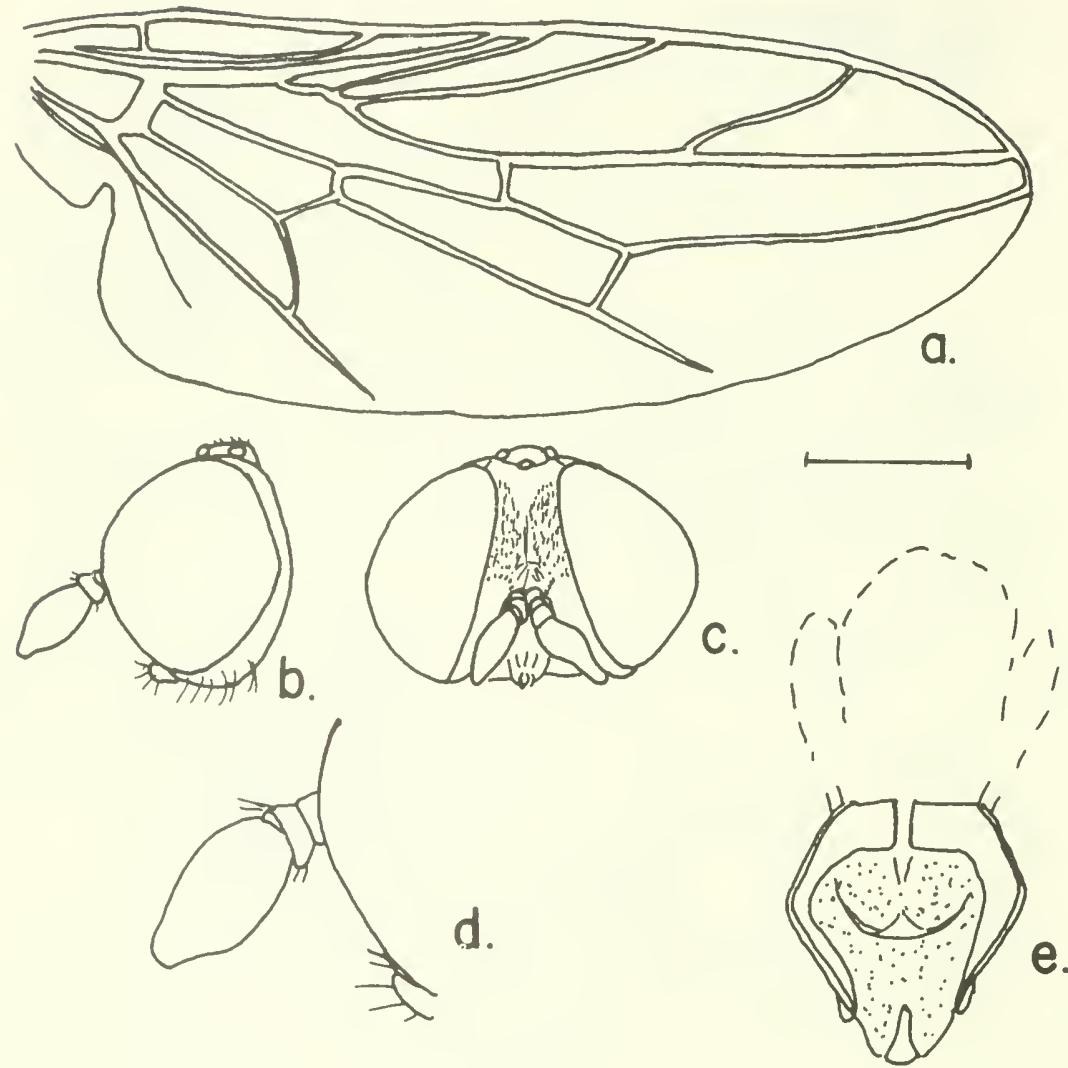

Figure 41.-Scenopinus katbergi, new species, female: $a$, wing; $b$, $c$, lateral and frontal aspects of head; $d$, enlarged detail of antenna; $e$, bursa, 9th sternum lost.

\section{Scenopinus keiseri, new species}

Figure 42

Female.-Head black; eyes black-brown, extending to back of the head so only the narrowest postocular ridge is formed. Frons rugose, depressed above antennae and then swelling, a pit in center, one-third the distance from the antennae to the median ocellus, median portion raised above the eye margins. Ocellar triangle not prominent; ocelli orange. Mouthparts brown, well developed, filling the oral opening; palpi as long as the mouthparts, last segment broader than the basal segments (see figure). First antennal segment brown, short; second orange-brown, twice as large as first; third segment brown, elongate oval, twice as long as broad. 


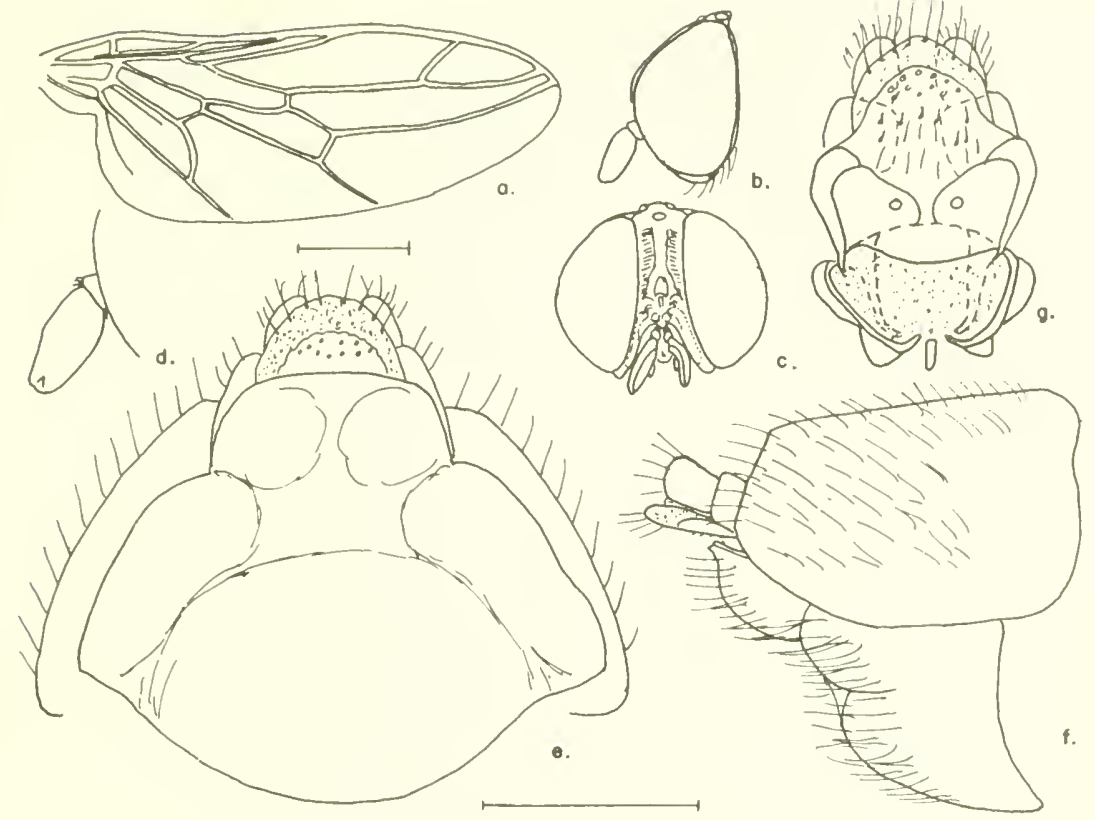

FigURE 42.-Scenopinus keiseri, new species, female: $a$, wing; $b, c$, lateral and frontal aspects of head; $d$, enlarged detail of antenna; $e$, ventral aspect of 8 th sternum; $f$, lateral aspect of 8 th and 9th segments; $g, 9$ th sternum and bursa.

Thorax with dorsum black; humeral callus orange along posterior rim, supra-alar callus brown; seutellum black above with a brown rim; pleural areas black-brown. Wings faint brown fumose; veins brown, vein $R 4$ branching beyond the middle, cell $R 5$ tilted toward the front of the wing at the tip. Halter with stem brown; knob cream above and white below, to all white. Legs black-brown with orange-brown tarsi, fore tibia a little lighter.

Abdomen dark red-brown; 8th segment red-brown, sternum and bursal as figured.

MALE.-Unknown.

Length: Female body $3.2-4.4 \mathrm{~mm}$., wing $2.3-2.8 \mathrm{~mm}$.

Type-locality: Maroantsetra, Madagascar; 18-19 November 1957, (F. Keiser).

Holotype: Female (NגIB).

Paratypes: 6 \%o, same data as type (NMBB); 1 \%, same data as type (USNMI); 2 ९ᄋ, I'erinet, Madagascar, December 1955, (B. Stuckenberg) in (NMP). 


\section{Scenopinus limpidipennis Loew}

Scenopinus limpidipennis Loew, 1874, p. 416.

The type and allotype of this small species from Persia have not been located so no additional information concerning the species can be given.

Length: Male body $1 \frac{2 / 3}{\mathrm{~mm}}$., wing $1 \frac{1}{2} \mathrm{~mm}$.; female body $2 \mathrm{~mm}$. Type-locality: Schahrud, Iran (Persia).

Type deposited: ? (not in Berlin).

\section{Scenopinus lucidus Becker}

Figure 43

Scenopinus lucidus Becker, 1902, p. 39.

This species has been returned to the genus Scenopinus from Lucidomphrale Kröber because of its complete agreement with the members of the Albicinctus group. Its distinguishing feature, the long aedeagal parameres of the male, serves as a good species character. The female agrees in all ways with Scenopinus and with the characters of the Albicinctus group. One specimen was identified by Kröber as $S$. glabrifrons, which it only superficially resembles; this gives some idea of how difficult is the identification of females.

The details of the eighth sternum and particularly the bursa serve to characterize the female. Just posterior to the membranous portion of the bursa, on the midline, is a shell-like structure, that extends down from the roof of the bursa, which is characteristic of this species. (Hardy, 1960, p. 326-328 gives a good description of this species.)

Length: Male body 2.3-3 mm., wing 2-2.5 mm.; female body 3.5-4 mm., wing 2.5-3.3 $\mathrm{mm}$.

Type-locality: Mariout, Egypt.

Type: (ZMH).

Material examined from: Hawaii (USNM) (PHT); Meadi, Egypt, 24 April 1917, (Efflatoun) (SEE); Christmas Island, November 1957, (F. L. Hill), Elizabethville, Belgian Congo, (BMNH); Cape Verde Islands (ZMUH); also from Algeria, Uganda, and northern Nigeria.

\section{Scenopinus madagascariensis Enderlein}

Figure 44

Scenopinus madagascariensis Enderlein, 1934, p. 429.

Female.-Head, cream below, black on upper frons and back of head; eyes red-brown, a very narrow postocular rim fringed with hairs; frons pollinose, granular, covered with short hairs, lower half orange, extending dorsally between ventral extensions of black-brown 

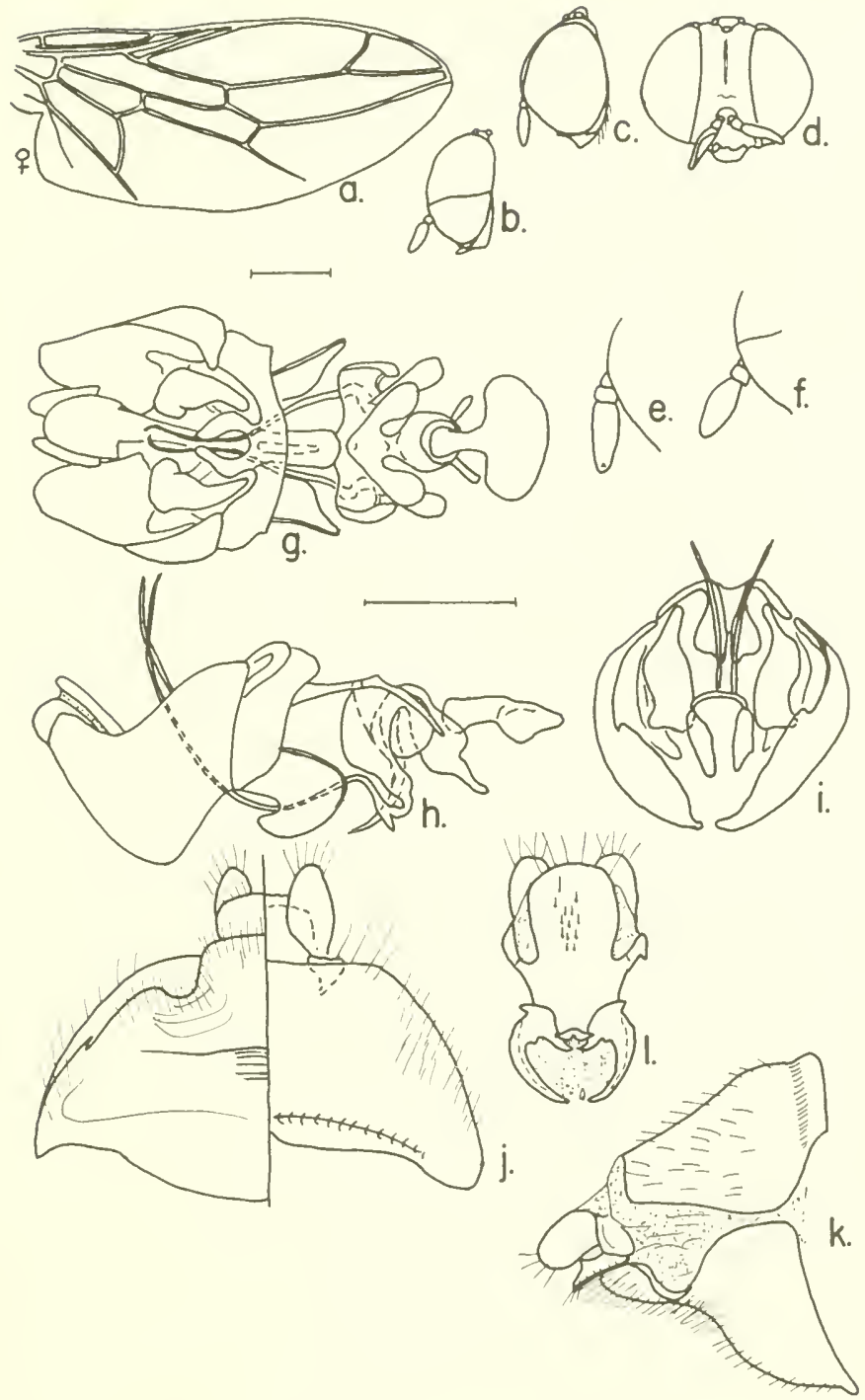

Figure 43.-Scenopinus lucidus Becker, male, female: $a$, wing; $b$, lateral aspect of male head; $c, d$, lateral and frontal aspects of female head; $e, f$, enlarged details of male and female antennae; $g-i$, ventral, lateral and posterior aspects of male terminalia; $j$, ventral left and dorsal right aspects of female 8th segment; $k$, lateral aspect of female 8th and 9th segments; $l$, female 9 th sternum and bursa.

of upper frons; ocellar tubercle black-brown, granular, not set off, ocelli orange; mouthparts brown, half the length of the oral cavity; palpi shorter, cream-orange. Antennae with first segment orange, 

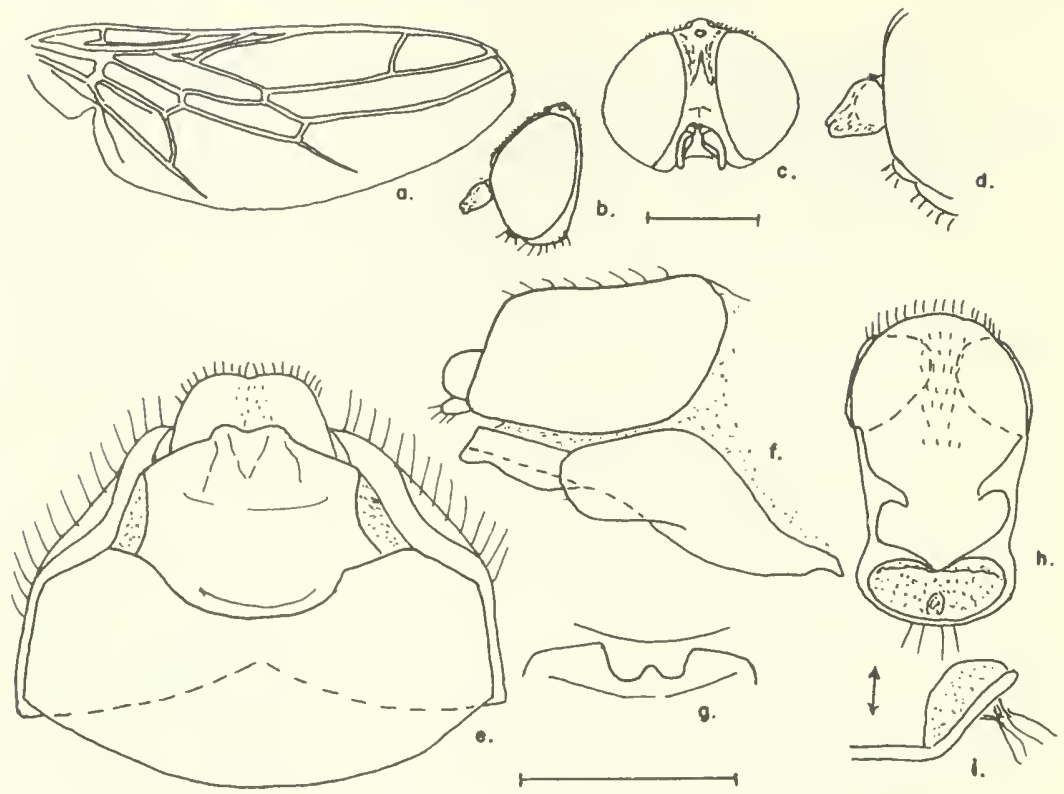

Figure 44.-Scenopinus madagascariensis Enderlein, female: $a$, wing; $b, c$, lateral and frontal aspects of head; $d$, enlarged detail of antennae; $e$, ventral aspect of 8 th sternum; $f$, lateral aspect of 8 th and 9 th segments; $g$, detail of posterior margin of 8 th sternum; $h$, 9th sternum and bursa; $i$, lateral aspect of bursal area.

short; second orange, larger than first; third segment pear-shaped, split at tip, orange basally darkening to black-brown distally.

Thorax dorsum with a black-brown ground heavily dusted with yellow-brown pollen; humeral and supra-alar calli cream; scutellum orange, granular; pleura red-brown, granular. Wings brownish hyaline, veins brown; halter stem cream, knob brown above, cream below. Legs with fore leg orange; middle leg orange except tarsus red-brown; hind leg orange except coxa and tarsus red-brown.

Abdomen red-brown shining, base of segments black-brown, widest at middle rounding posteriorly, flattened; see figure for details of terminalia.

Male.-Unknown.

Length: Female body $2.6 \mathrm{~mm}$., wing $2.3 \mathrm{~mm}$.

Type-locality: Madagascar, Diego-Suarez (S. V. Fredericks).

Type: (DEI).

46. Scenopinus minutus, new species

FIGURE 45

MALE.-Head black-brown; eyes black-brown above, black below; frons short, subshining with a small dimple below the center; ocellar 


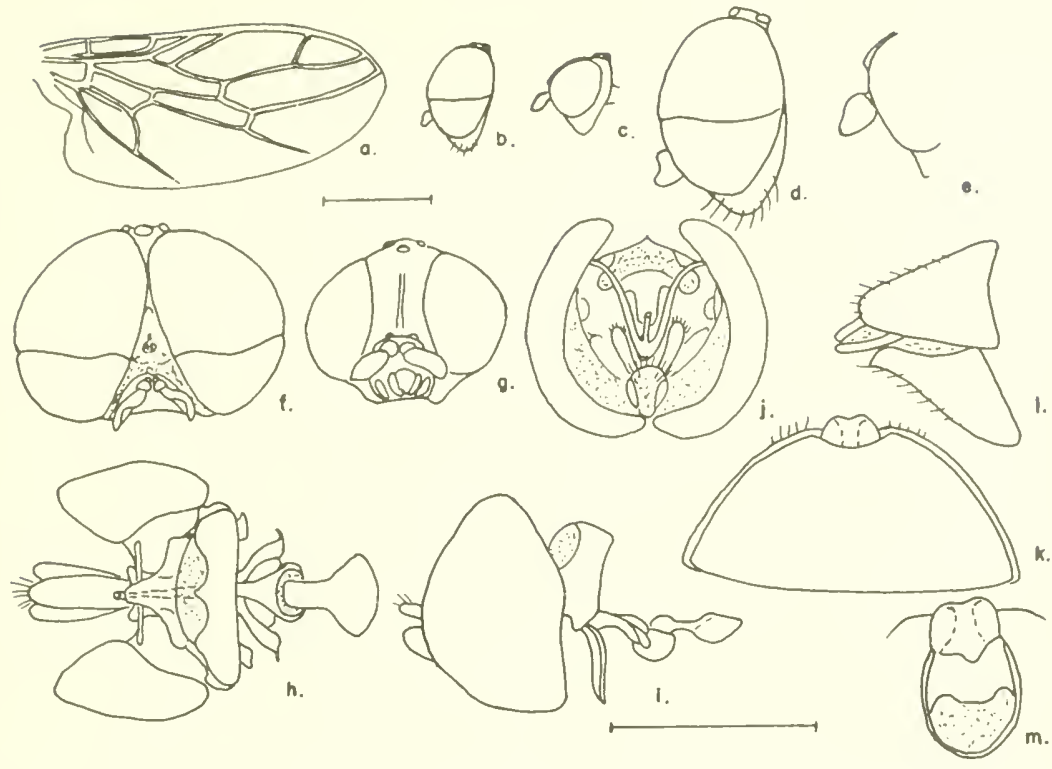

Figure 45.-Scenopinus minutus, new species, male, female: $a$, wing; $b$, lateral aspect of male head; $c$, lateral aspect of female head; $d$, enlarged detail of male head and antenna; $e$, enlarged detail of female antenna; $f, g$, enlarged frontal aspects of male and female head; $h-j$, ventral, lateral and posterior aspects of male terminalia; $k$, ventral aspect of female 8th sternum; $l$, lateral aspect of female 8 th and 9 th segments; $m$, female 9 th sternum and bursa.

tubercle elevated, black-brown, shining; ocelli red-brown; mouthparts well developed, filling oral cavity. Antennae black-brown, third segment broader at base, over twice as long as first two combined; see figure.

Thorax black-brown, shining; humeral and supra-alar calli redbrown. Wing hyaline, whitish, veins tan to nearly clear; halter stem black-brown, knob red-brown. Legs with femora black-brown, remainder yellow-brown.

Abdomen black-brown, segments 3-5 with white bands, the first indistinct. 'Terminalia black-brown; for details, see figure.

Fenale.-Head red-brown; eyes black-brown; a well developed postocular flange; frons shining with a median longitudinal depression. Ocellar tubercle not prominent; ocelli red-brown. Mouthparts brown, well developed, filling oral cavity. Antennae brown to black-brown.

'Thorax as in male; the wings a little darker.

Abdomen all segments black-brown shining; for details of eighth sternum and bursa, see figure.

Length: Male body $1.7 \mathrm{~mm}$., wing $1.4 \mathrm{~mm}$.; female body $1.7 \mathrm{~mm}$., wing $1.4 \mathrm{~mm}$. 
Type-locality: Male, Bronte, New South Wales, Australia; 27 December 1954, (D. K. McAlpine).

Holotype: Male (AMS).

Allotype: Female, Como, New South Wales, Australia; December 1923, (H. Petersen) sweeping flowers, (USNM).

Paratypes: $1 \sigma^{7}, 1$ 우 (AMS); $1 \sigma^{7}, 3$ 우우, (USNM); ( $\sigma^{7} \sigma^{7}$ same data as holotype, $\odot \circ$ same data as allotype).

\section{Scenopinus monodi (Séguy)}

Figure 46

Omphrale nonodi Séguy, 1933, pp. 122-127.

This species is known from the type male, allotype female and four paratype females.

MALE.-With front depressed; antennal segments 1 and 2 orange, the third segment missing but presumably orange-brown as in the female. Eyes of male red-brown above and black-brown below. Body covered with short white hairs; wings white, veins light yellowish; knob of the halter white. Abdomen with three solid white bands. Terminalia as figured.
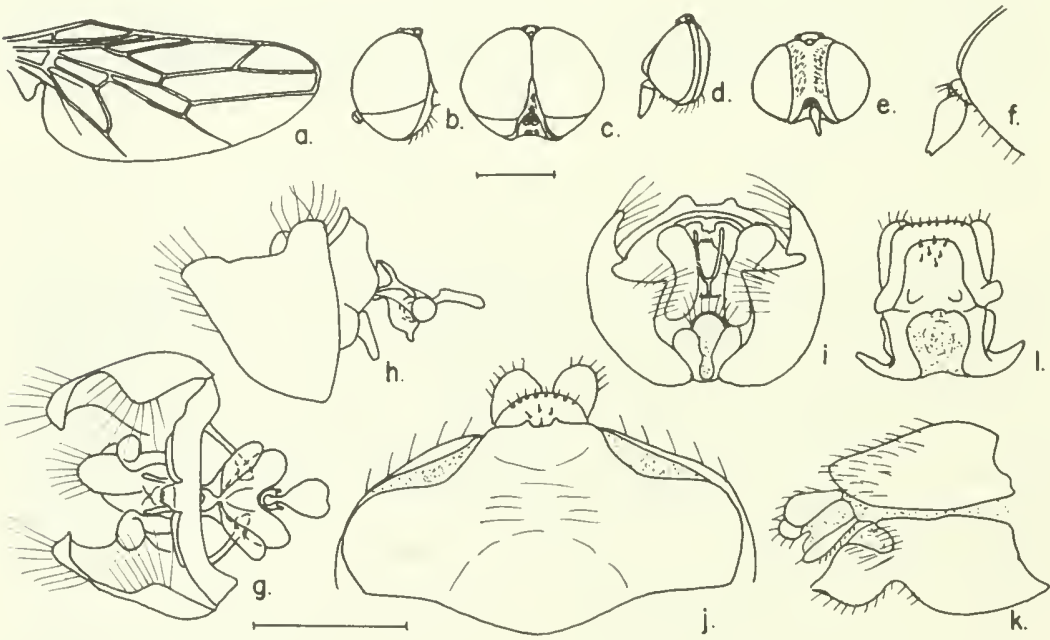

Figure 46.-Scenopinus monodi (Séguy), male, female: $a$, wing; $b, c$, lateral and frontal aspects of male head; $d, e$, lateral and frontal aspects of female head; $f$, enlarged detail of female antenna; $g-i$, ventral, lateral and posterior aspects of male terminalia; $j$, ventral aspect of female 8 th sternum; $k$, lateral aspect of female 8 th and 9 th segments; $l$, female 9 th sternum and bursa.

Female.-With frons broad covered with white hairs pointing ventro-laterally. Thorax as in male. Abdomen red-brown, eighth 
sternum short, broad; see figure for details of eighth sternum and bursis.

Length: Male body $2.5 \mathrm{~mm}$., wing $2 \mathrm{~mm}$.; female body $3 \mathrm{~mm}$., wing $2 \mathrm{~mm}$.

Type-locality: Entre 'Tabankort et in Tassit, Sahara Soudanise; 28 December 1927, (Angieras and Draper).

Types: (MNHN).

\section{Scenopinus niveus Becker}

Figure 47

Scenopinus niveus Becker, 1907, p. 61.

This species is known only from the type-locality. The type was not found, but a long series of over a dozen specimens, all males, from the type-locality was seen in the Museum of Natural History, Paris.

MALE.-The male of this species is distinguished by the wing, where reins $R 5$ and $M 1+2$ are parallel; by the five white bands on the abdomen and the antennae.

Female.-Unknown.

Length: Male body $2.5 \mathrm{~mm}$., wing $2 \mathrm{~mm}$.

Type-locality: Gafsa, Tunisia.

Type deposited: Coll. Becker (not located).

Material examined: See above.
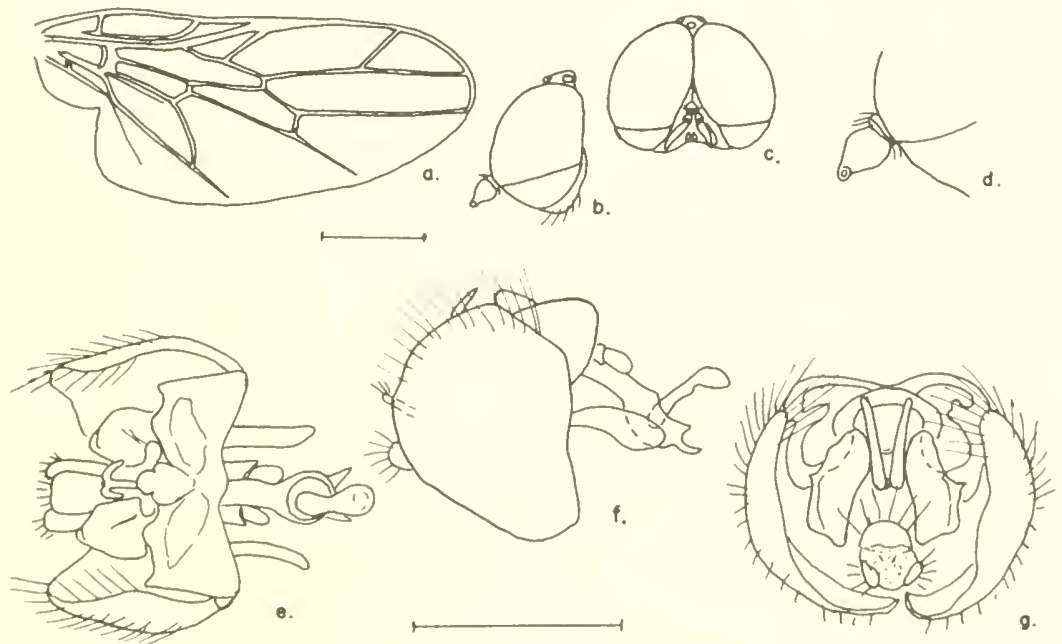

Figure 47.-Scenopinus niveus Becker, male: $a$, wing; $b, c$, lateral and frontal aspects of head; $d$, enlarged detail of antenna; $e-g$, ventral, lateral and posterior aspects of terminalia. 


\section{Scenopinus norrisi, new species}

FIGURE 48

FeMale.-Head black; eyes black-brown; postocular ridge narrow; front granular and no wider than the ocellar triangle, with a small median pit located one-third the distance from the antennae to the median ocellus. Oral opening bordered on each side by a band of gray pubescence which begins on the lower frontal areas above and to each side of the antennal sockets and extends ventrally between the eye margin and the oral opening. First antennal segment very short, black-brown; second segment orange-brown, two to three times size of first; third segment elongate, more than twice as long as broad, orangebrown basally darkening to brown distally, blunt on the end. Mouthparts well developed, nearly filling the oral cavity, dark brown; palpi long, exceeding over one-half the length of the oral opening.
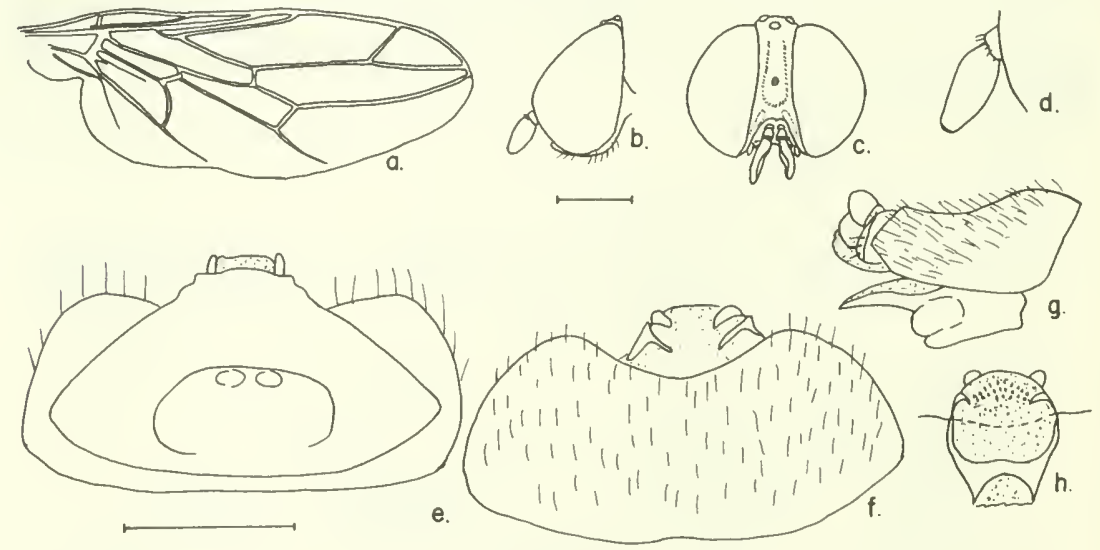

FIGURE 48.-Scenopinus norrisi, new species, female: $a$, wing, $b, c$, lateral and frontal aspects of head; $d$, enlarged detail of antenna; $e$, ventral aspect of 8 th sternum; $f$, dorsal aspect of 8 th and 9 th segments; $g$, lateral aspect of 8 th and 9th segments; $h$, 9th sternum and bursa.

Thorax black-brown, covered with a thin pile of short hairs. Wings hyaline, with veins brown, space between $R 1$ and $R 2+3$ appears filled, R4 branching beyond the middle of the cell; halter stem brown, knob brown. Legs black-brown with tarsi orange-brown.

Abdomen uniformly dark brown, thinly covered with posteriorlydirected hairs; see figure for details of the eighth sternum and bursal plate.

MaLe.-Unknown.

Length: Female body $4.5 \mathrm{~mm}$., wing $3.5 \mathrm{~mm}$.

Type-locality: Brisbane, Queensland, Australia; 14 January 1954 (K. R. Norris). 
Holotype: Female (CSIRO).

Paratypes: 1 \&, Brisbane, 24 January 1960, (Hasler) (UQue); 1 q, Redlynch, Queensland, 26 September 1938, (BMNH).

\section{Scenopinus oldenbergi (Kröber)}

Figure 49

Omphrale oldenbcrgi Kröber, 1913, p. 190.

It is my opinion, based on the characters of the antenna and bursal plates, that this species is not European in origin but is more likely African and therefore must be placed in the Albicinetus group.

MaLe.-Unknown.

Length: Female body $4 \mathrm{~mm}$., wing $2.2 \mathrm{~mm}$.

Type-locality: Berlin, 3 August?, Oldenberg.

Type: (DEI).
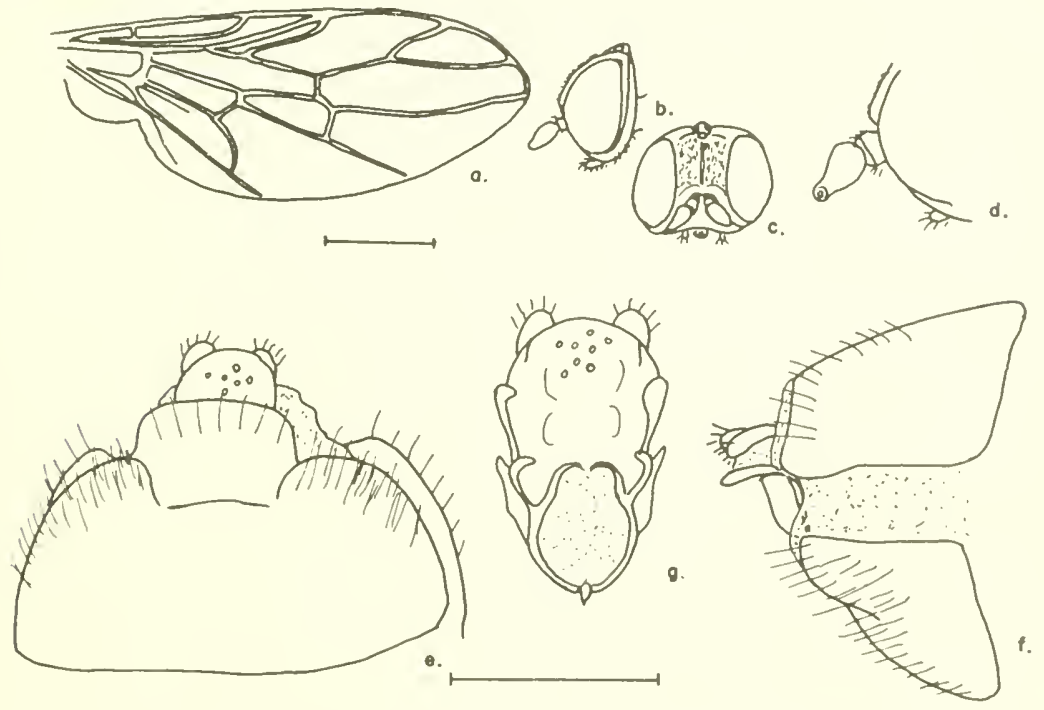

FigURE 49--Scenopinus oldenbergi (Kröber), female: $a$, wing; $b, c$, lateral and frontal aspects of head; $d$, enlarged detail of antenna; $e$, ventral aspect of 8 th and 9 th segments; $f$, lateral aspect of 8 th and 9 th segments; $g, 9$ th sternum and bursa.

\section{Scenopinus opacus deMeijere}

Figuire 50

Scenopinus opacus deMeijere, 1924, p. 14.

This species from Sumatra is one of the few from the Malaysian Archipelago and is quite distinctive, particularly in the male terminalia. 'These are moderately large black flies with orange antennae 

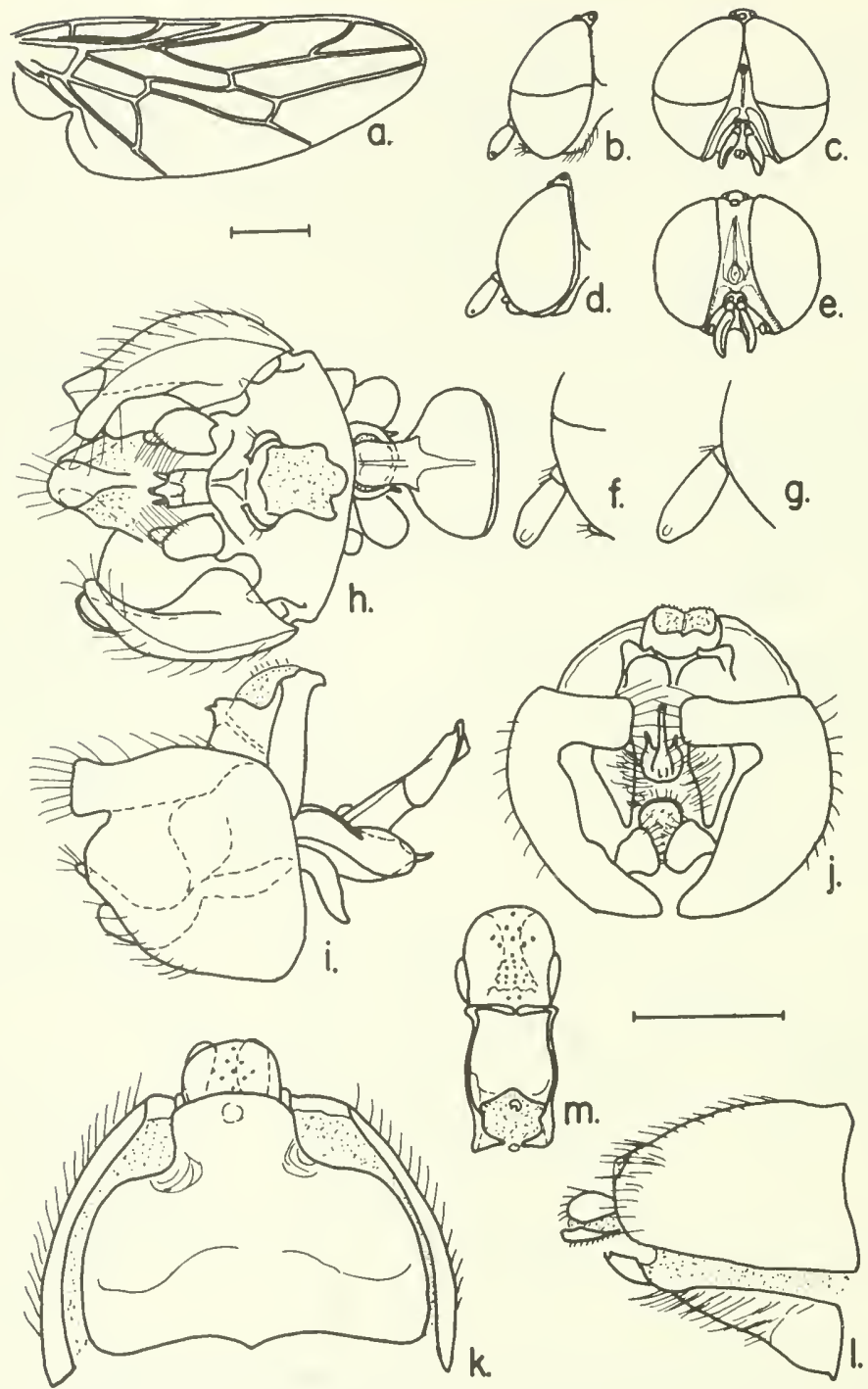

Figure 50.-Scenopinus opacus deMeijere, male, female: $a$, wing; $b, c$, lateral and frontal aspects of male head; $d, e$, lateral and frontal aspects of fernale head; $f, g$, enlarged details of male and female antennae; $h-j$, ventral, lateral and posterior aspects of male terminalia; $k$, ventral aspect of female 8th sternum; $l$, lateral aspect of female 8 th and 9 th segments; $m$, female 9 th sternum and bursa.

and orange-brown to yellow tarsi; wings brown; see figure for details. Length: Male body $3.5 \mathrm{~mm}$., wing $2.7 \mathrm{~mm}$.; female body $4.2 \mathrm{~mm}$., wing $3.5 \mathrm{~mm}$. 
Type-locality: Fort de Kock, Sumatra; December 1920 (E. Jacobson).

Types and paratypes: (ZMUA).

\section{Scenopinus palmulapalpus, new species}

\section{FIGURE 51}

Female.-Robust; head black-brown; eyes black-brown, with little or no postocular flange; frons much broader than the ocellar triangle, slightly swollen above the antennae into two bulges separated by a shallow groove leading to a shallow depression, appearing shining but in reality slightly granular. Ocellar triangle not set off; ocelli orange. Face silvery pilose laterad of antennae. Mouthparts well developed; palpi over half as long as oral opening, broadly flattened (paddle-like), covered with a velvety pile. First and second antennal segments red-brown, third segment orange-brown at base darkening at tip, about three times as long as broad.

Thorax dorsum black, rugose, transversely striated; posterior tip of humeral callus and supra-alar callus yellow-brown; pleural areas black-brown. Wings brown fumose, veins brown, vein $\mathrm{M} 1+2$ bending forward to close cell R5 with a bottleneck; halter stem brown; knob red-brown, shining. Fore leg with coxa to tarsus yellow-brown; middle leg light brown; hind leg coxa to tibia red-brown, tarsus light brown.

Abdomen red-brown, eighth segment hairy; see figure for details of sternum and bursal plates.

MaLE.-Unknown.

Length: Female body 3.4-3.8 mm., wing 2.3-2.7 mm.

Type-locality: Pietermaritzburg, Natal; 2 April 1918, (Hardenberg).

Holotype: Female (NMP).

Paratypes: 2 ㅇ, Pietermaritzburg, 17 November 1952, (B. Stuckenberg) 16 February 1956, (B. Stuckenberg), (NMP); 1 \%, Pietermaritzburg, 16 November 1954, (B. Stuckenberg) (USNM).

\section{Scenopinus papuanus (Kröber)}

Figure 52

Omphrale papuana Kröber, 1912, p. 25.

Scenopinus niger Grimshaw (not De Geer), 1901, p. 11.-D. E. Hardy, 1958, p. 11. Seenopinus zeylanieus Senior-White, 192:24, p. 205.

Specimens of this species from Hawaii were for a long time identified as $S$. niger and it was not until 1958 that Hardy was able to clear up 

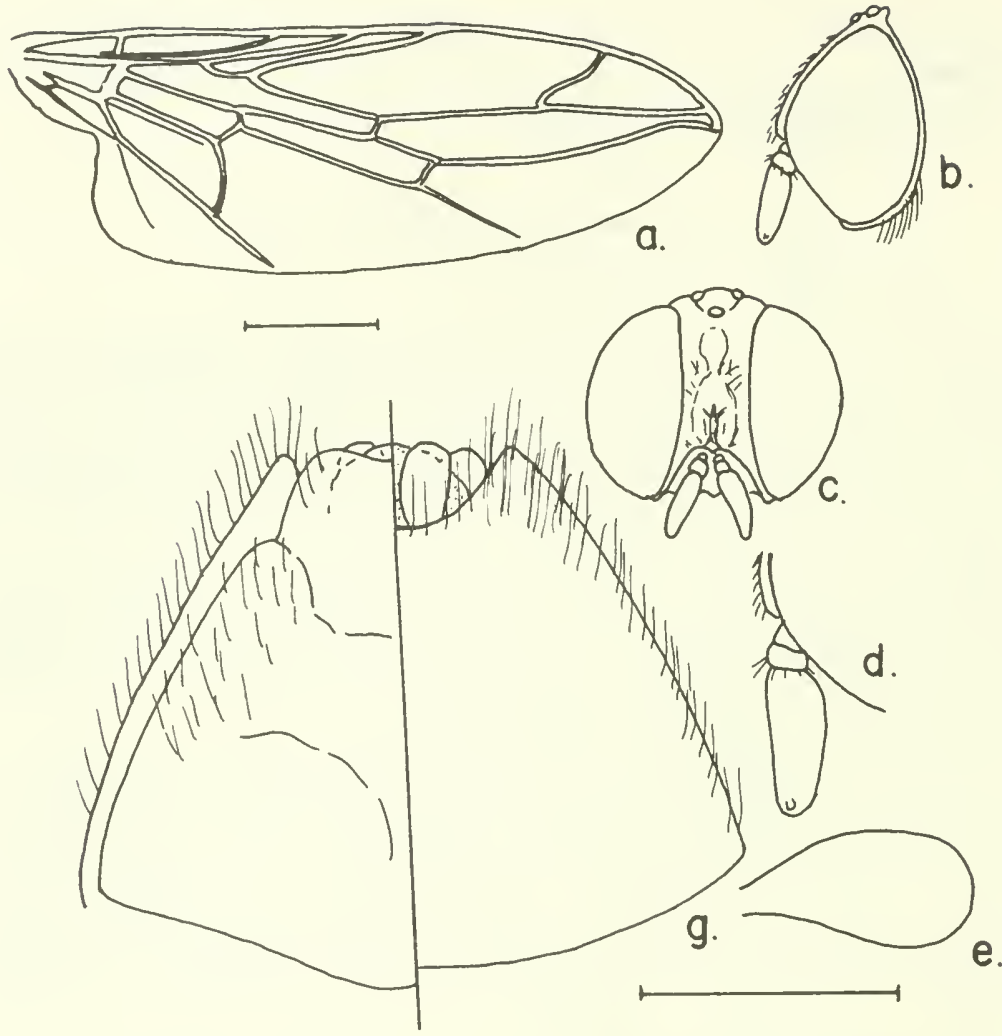

e.
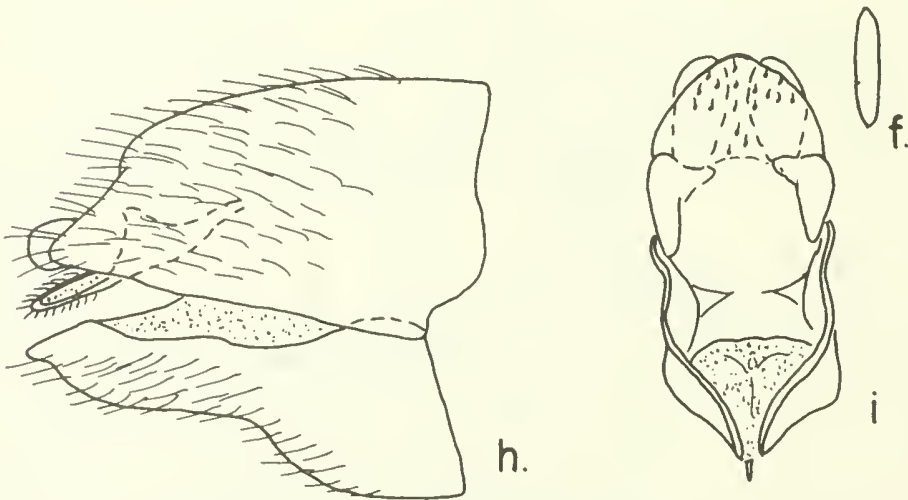

Figure 51.-Scenopinus palmulapalpus, new species, female: $a$, wing; $b, c$, lateral and frontal aspects of head; $d$, enlarged detail of antenna; $e, f$, lateral and frontal details of palpus; $g$, ventral left and dorsal right aspects of 8 th and 9 th segments; $h$, lateral aspect of 8 th and 9 th segments; $i$, 9th sternum and bursa.

the synonomy and describe the male. On examination of the type $\sigma^{7}$ of $S$. zeylanicus in the British Museum, I found that this species is a synonym of $S$. papuanus. 
Specimens have also been examined from Cocos (Keeling) Islands, Christmas Island (BMNH), Guam (USNM), and Hawaii (PH'T) establishing its distribution from Ceylon to Hawaii.

Length: $\sigma^{7}$ 우 body $3.2-4 \mathrm{~mm}$., wing $2.7-3.5 \mathrm{~mm}$.

Type-locality: Kanshirei, Formosa; April (H. Sauter) (restricted by Hardy, 1960, p. 331).

Type: (DEI).

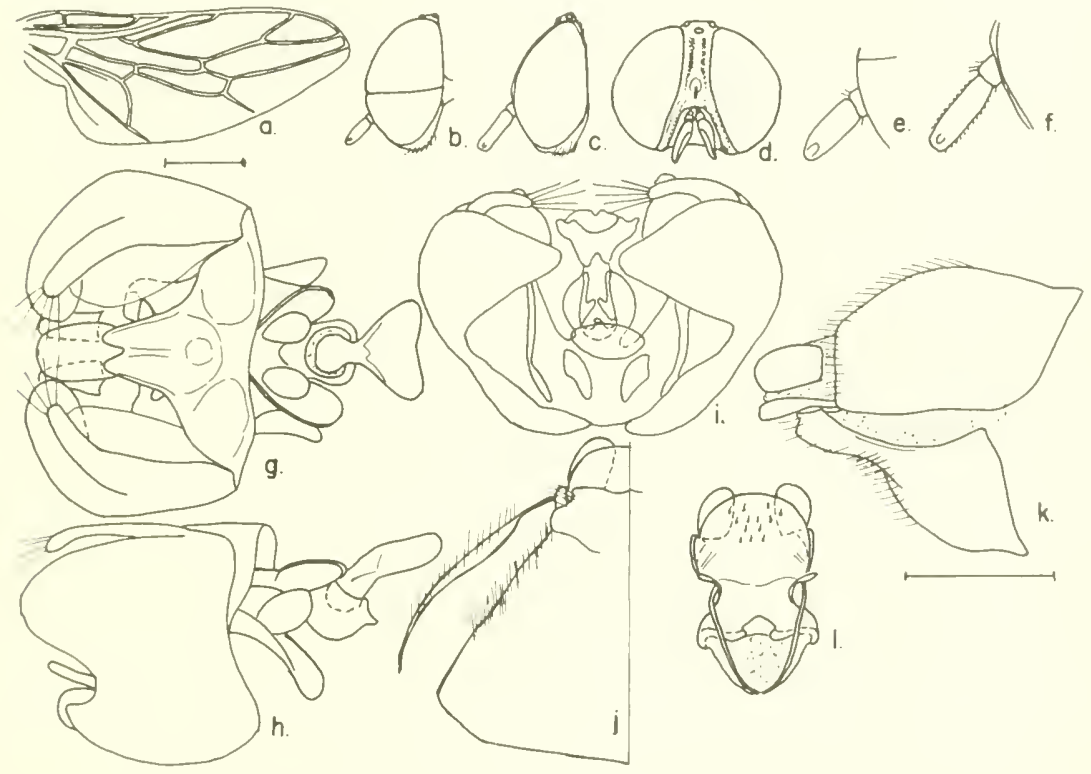

Figure 52.-Scenopinus papuanus (Kröber), male, female: $a$, wing; $b$, lateral aspect of male head; $c, d$, lateral and frontal aspects of female head; $e, f$, enlarged details of male and female antennae; $g-i$, ventral, lateral and posterior aspects of male terminalia; $j$, ventral aspect of female 8 th sternum; $k$, lateral aspect of female 8 th and 9 th segments; $l$, female 9 th sternum and bursa.

\section{Scenopinus patrizi (Séguy)}

Figure 53

Omphrale patrizi Séguy, 1932, p. 499.

This species is known only from the type. Frons broad and shining black. Band of white present along the side of the thorax extending from head to halteres which are white; see figure for details of the head, wing, eighth sternum and bursa.

Male: Unknown.

Length: Fenale body $2.5 \mathrm{~mm}$, wing $2 \mathrm{~mm}$.

'Type-locality: Aujila [Augila], Libia; $\Lambda$ pril 1931, (Patrizi).

Type: (MCSNG). 

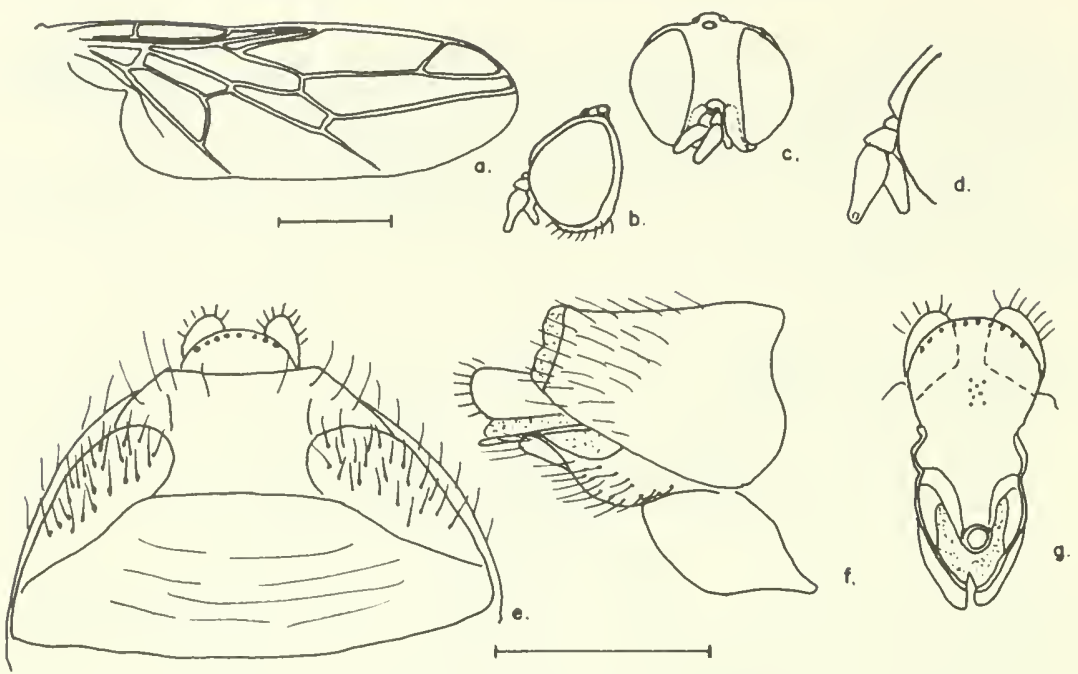

F1Gure 53.-Scenopinus patrizi (Séguy), female: $a$, wing; $b, c$, lateral and frontal aspects of head; $d$, enlarged detail of antennae; $e$, ventral aspect of 8 th sternum; $f$, lateral aspect of 8 th and 9th segments; $g$, 9th sternum and bursa.

\section{Scenopinus perkinsi G. H. Hardy}

Figure 54

Scenopinus perkinsi G. H. Hardy, 1942, p. 202.-Paramonov, 1955, p. 651, description of male.

This species is known only from Australia where it was originally collected on the windows of the Brisbane Museum. The male was taken as a pupa from a Spice Finch nest and another specimen has been seen from a sparrow's nest. The male is distinguished by a pair of pubescent bulges on the insides of the tergal plates surrounding the terminalia.

Length: Male body $3.5 \mathrm{~mm}$., wing $2.5 \mathrm{~mm}$.; female body $4-5 \mathrm{~mm}$., wing $3 \mathrm{~mm}$.

Type-locality: Brisbane, Queensland (F. A. Perkins).

Type: Female (UQue) destroyed.

Specimens examined: 1 o $\sigma^{\pi}$ Woolstoncraft, near Sydney, New South Wales, emerged 12 June 1950 (K. A. Hindwood); 1 \%, Brisbane, Queensland (F. A. Perkins); (CSIRO).

\section{Scenopinus phaidimos, new species}

FiguRe 55

MALE.-Head black; eyes black, very distinctly divided into large upper and smaller lower facets; frons small, reduced to a narrow 


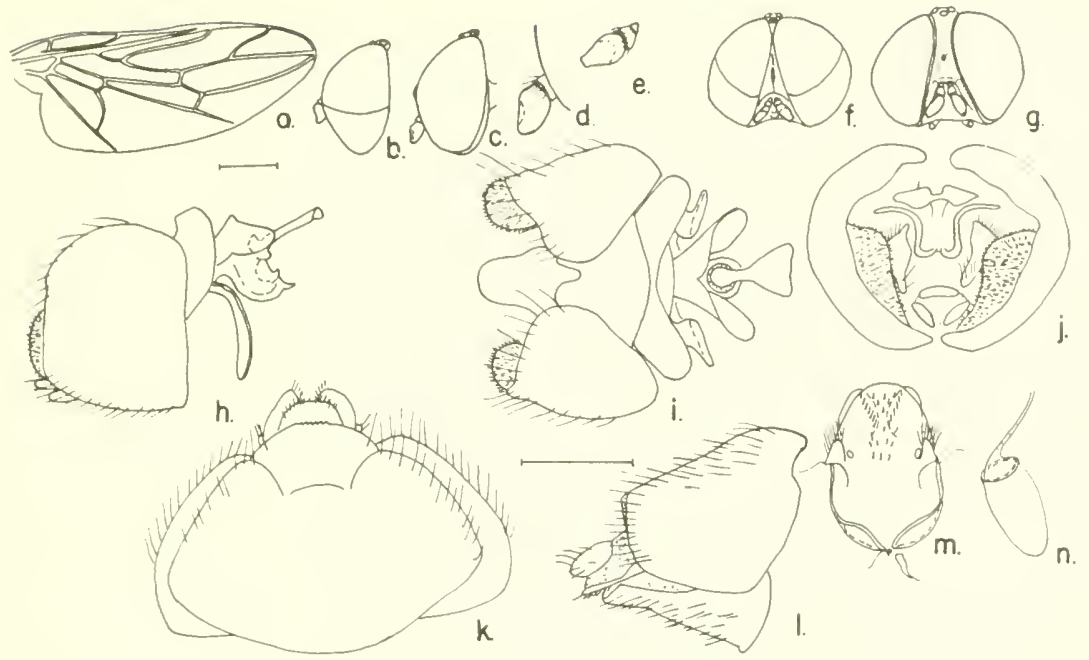

Figure 54.-Scenopinus perkinsi, G. H. Hardy, male, female: $a$, wing; $b$, c, lateral aspects of male and female head; $d$, enlarged detail of female antenna; $e$, enlarged detail of inner surface of male antenna; $f, g$, anterior aspects of male and female head; $h-j$, ventral, dorsal and posterior aspects of male terminalia (note swellings on inside dorsal surface of 9 th tergum); $k$, ventral aspect of female 8 th and 9 th segments; $l$, lateral aspect of female 8 th and 9 th segments; $m$, female 9 th sternum and bursa; $n$, female accessory organ.

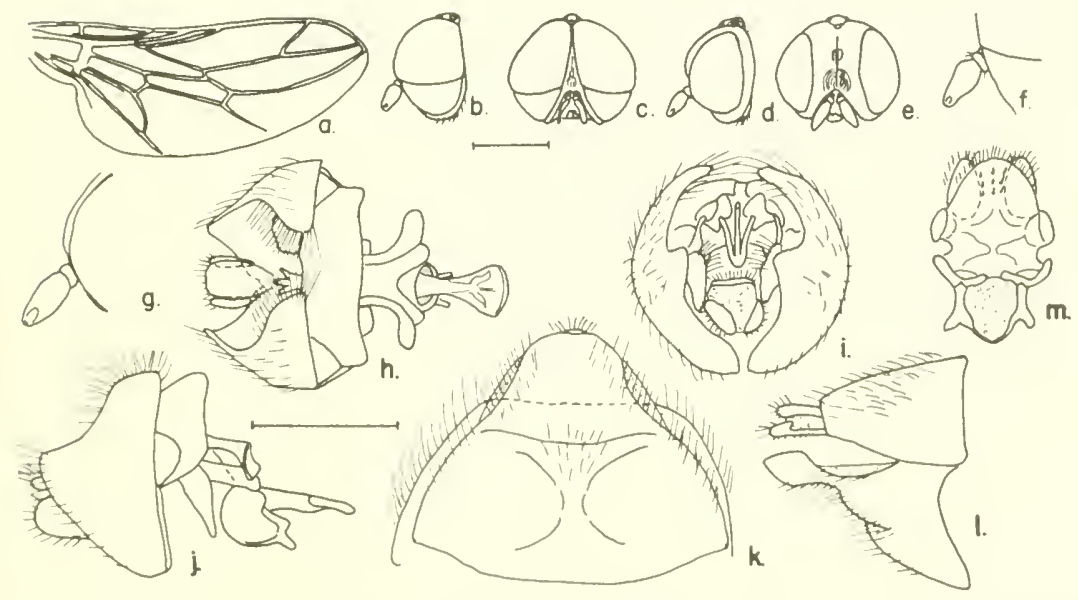

Figure 55.-Scenopinus phaidimos, new species, male, female: $a$, wing; $b, c$, lateral and frontal aspects of male head; $d, e$, lateral and frontal aspects of femalc head; $f, g$, cnlarged details of male and female antennac; $h-j$, ventral, lateral and postcrior details of male terminalia; $k$, ventral aspect of femalc sternum; $l$, latcral aspect of femalc 8 th and 9 th scgments; $m$, femalc 9 th sternum and bursa. 
triangle above the antennae, rugose with a median groove; ocellar triangle elevated, ocelli orange-brown. First antennal segment short, black; second larger, red-brown; third black-brown, pear-shaped, with a distinct depression on the outer side at the tip.

Thorax black, shining; humeral callus with a small red-orange patch on posterior edge. Wings hyaline, veins tan; halter stem tan, knob white. Legs black with moderate bristles, tarsi orange-brown darkening distally; middle and hind legs with the first tarsal segment subequal to $2-5$ combined.

Abdomen black, shining, segments 3-5 white along posterior margins. Terminalia black with a few long hairs; see figure for details.

Female.-Head black; eyes red-brown; postocular ridge broad shining; frons swollen, shining, broader than either eye when viewed from the front, with a broad median groove ending in a pit on lower third of head. Ocellar tubercle distinct, set off, ocelli red-brown.

Thorax, legs, wing and halter as in male.

Abdomen, black, shining, flattened, eighth sternum longer than tergum; see figure for details of eighth sternum and bursa.

Length: Male body $2.4 \mathrm{~mm}$., wing $2.1 \mathrm{~mm}$.; female body $3.2 \mathrm{~mm}$., wing $2.5 \mathrm{~mm}$.

Type-locality: $20 \mathrm{mi}$. N. of Sereflikochisar (Ankara area), Turkey, 24 June 1962, $900 \mathrm{~m}$. (Guichard and Harvey).

Holotype: Male (BMNH).

Allotype: $\odot$, and $\odot$ paratype, Eskisahir, Kaymaz, Turkey, 800 m.; 27 July 1962, (Guichard and Harvey) (BMNH).

\section{Scenopinus spurrelli, new species}

FIgURE 56

Female.-Head black; eyes red-brown; postocular ridge narrow; back of head pollinose; frons broad subshining, with sparse hairs laterad of a median groove; ocellar tubercle shallow, ocelli whitish; antennae red-brown, first segment short, second twice as large as first, third soft pilose, tapering to tip from a broader base.

Thorax black, shining, with short hairs, humeral and supra-alar calli red-brown on margins. Wing smoky brown, veins brown; halter stem black-brown with a $\mathrm{V}$-shaped bracket extending posteriorly to hold knob which is white. Legs with coxae and trochanters dark redbrown, femora orange-brown, tibiae and tarsi light orange-brown.

Abdomen black-brown; see figure for details of eighth sternum and bursa.

MaLe.-Unknown.

Length: Female body $4.6 \mathrm{~mm}$., wing $3.3 \mathrm{~mm}$. 

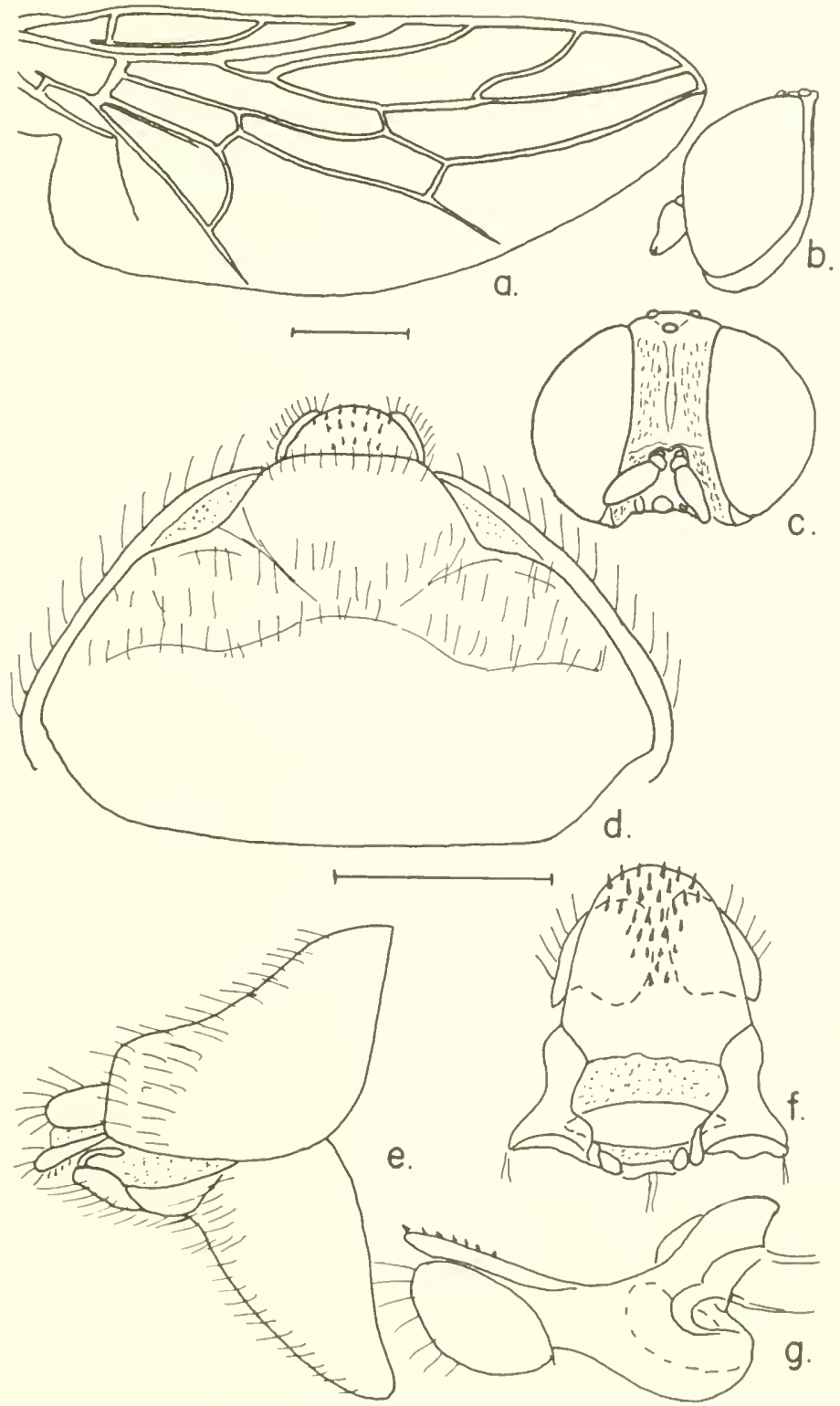

FigURE 56.--Scenopinus spurrelli, new species, female: $a$, wing; $b$, $c$, lateral and frontal aspects of head; $d$, ventral aspect of 8 th sternum; $e$, lateral aspect of 8 th and 9 th segments; $f$, 9th sternum and bursa; $g$, lateral view of 9 th segment and bursa, showing inner pocket. :318-16s o-69- 
Type-locality: Wilkur, Victoria, Australia; 2 December 1955, (Spurrell).

Holotype: Female (VMM).

\section{Scenopinus squamosus Villeneuve}

Figure 57

Scenopinus squamosus Villeneuve, 1913, p. 111.

Omphralosoma squamosa (Villeneuve).-Kröber, 1937, p. 222.

The presence of scales on the body is insufficient reason for erecting a new genus for a single species, especially when the shape of the antenna, wing venation, and bursal conformation agree with the other members of the Albicinctus group. It is, therefore, being returned to the genus Scenopinus.
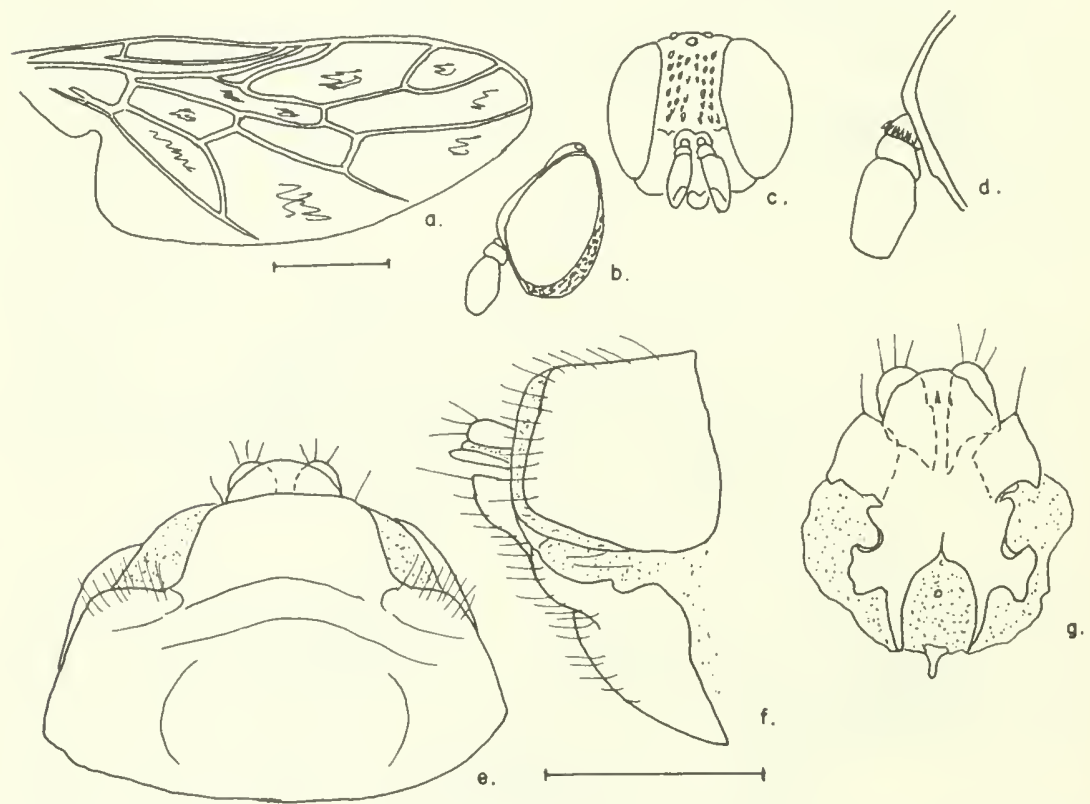

Figure 57.-Scenopinus squamosus Villeneuve, female: $a$, wing; $b$, $c$, lateral and frontal aspects of head; $d$, enlarged detail of antenna; $e$, ventral aspect of 8 th sternum; $f$, lateral aspect of 8 th and 9 th segments; $g$, 9th sternum and bursa.

In addition to the scales, the presence of dusky patches on the center of the cells of the wings helps to identify this species. The abdomen has white posterior bands on the segments, the halteres are black.

For details of head and eighth segment and bursa, see figure.

Male.-Unknown.

Length: Female body $2-3 \mathrm{~mm}$., wing $2.2 \mathrm{~mm}$. 
Type-locality: Ainn-Sefra (Oran), Algeria; May and June [1897] (M. Bleuse).

Type: (IRSNB).

Material examined: 1 , Ghardaïa, Algeria; May 1897, (IRSNB).

\section{BREVICORNIS group}

Key to Species of the BREviconnss group

\section{PALAEARCTIC SPECIES (MALES)}

1. Wing smoky brown or white.

Wing hyaline .

S. fraternus (Kröber)

2. Wing milky white

Wing smoky brown . . . . . . . 5

3. Halter knob white; antenna black, cell R5 open at tip . . . . . . . . . 4

Halter knob white; antenna black; cell R5 constricted at tip

S. brevicornis Loew

4. Antenna (spindle form) pointed.

S. nitidulus Loew

Antenna oval

S. parallelus, new species

5. Halter knob white or with tan bar.

S. halteralis Frey

Halter knob red-brown.

6. Halter knob whitc; antenna black, body clothed with medium long thin hairs
S. pilosus (Séguy)

Halter knob with a tan bar, antenna brown, body with sparse hairs

S. unifasciatus (Kröber)

\section{PALAEARCTIC SPECIES (FEMALES)}

1. Wing smoky brown . . . . . . . . . . . . . . . . . . 2 Wing milky

S. brevicornis Loew

2. Halter knob white, antenna black or brown

Halter knob tan, antenna black-brown ..... S. lincinus, new species

3. Antenna black . . . . . . . . . . . . . . . . . . . . 4

Antenna brown . . . . . . . . . . S. unifasciatus (Kröber)

4. Halter knob long; tip of antenna pointed; vein R4 branching well beyond middle of cell R5 . . . . . . . . . . . . S. nitidulus Loew

Halter knob round; tip of antenna rounded; R4 branching from near middle of cell R5 . . . . . . . . . . . S. fraternus (Kröber)

\section{ETHIOPIAN SPECIES (MALES)}

1. Wing smoky white.

Wing smoky brown. . . . . . . . . . . S. fryeri, new species

2. Halter knob white, antenna black, vein $\mathrm{M} 1+2$ ending before tip of wing . . 3

Halter knob red-brown, antenna yellow-brown, vein $\mathrm{M} 1+2$ ending behind tip of wing. . . . . . . . . . . . S. turneri, new species

3. Cell R5 constricted beyond vein R4 . . . . . . . S. minusculus (Séguy)

Cell R5 not constricted beyond vein R4 . . . . . S. tarsalis (Kröber)

\section{ETIIOPIAN SPECIES (FEMALES)}

1. Wing hyaline . . . . . . . . . . . . . . . . . . . 2

Wing smoky white or brown . . . . . . . . . . . . . . . . 3

2. Halter knob yellow-brown, antenna brown-black . . . S. tarsalis (K̈röber)

Halter knob reddish yellow, antenna dark brown with yellow tip

S. nitidifrons (Kröber) 
3. Wing white. . . . . . . . . . . . . . . . 4

Wing brown . . . . . . . . . . . . . . . . 5

4. Halter knob white, antenna black, 8th sternum short

Halter knob cream, antenna black-brown, 8th sternum long

S. minusculus Séguy

S. Iongiventris (Kröber)

5. Halter knob tan, velvety, white below, antenna black-brown, velvety, cell R5 constricted at tip by $\mathrm{R} 5$ dipping down toward M1+2

S. reduncus, new species

Halter knob tan, antenna black-brown, cell R5 curving sharply anteriorly, vein $\mathrm{M} 1+2$ ending well before tip of wing . . . . S. lincinus, new species

\section{Scenopinus brevicornis Loew}

Figures 58,59

Scenopinus brevicornis Loew, 1873, p. 146.

This species is known only from the type-locality in Turkistan. Loew described both sexes; however, I have seen only the type male. Kröber (1924) described and illustrated a female which is illustrated here. On the basis of the wing venation, it is doubtful that this specimen is actually the female of $S$. brevicornis as it does not agree very closely with wings of the type. Two male specimens from the Canary Islands which Frey identified as $S$. brevicornis are a new species, $S$. canarius.
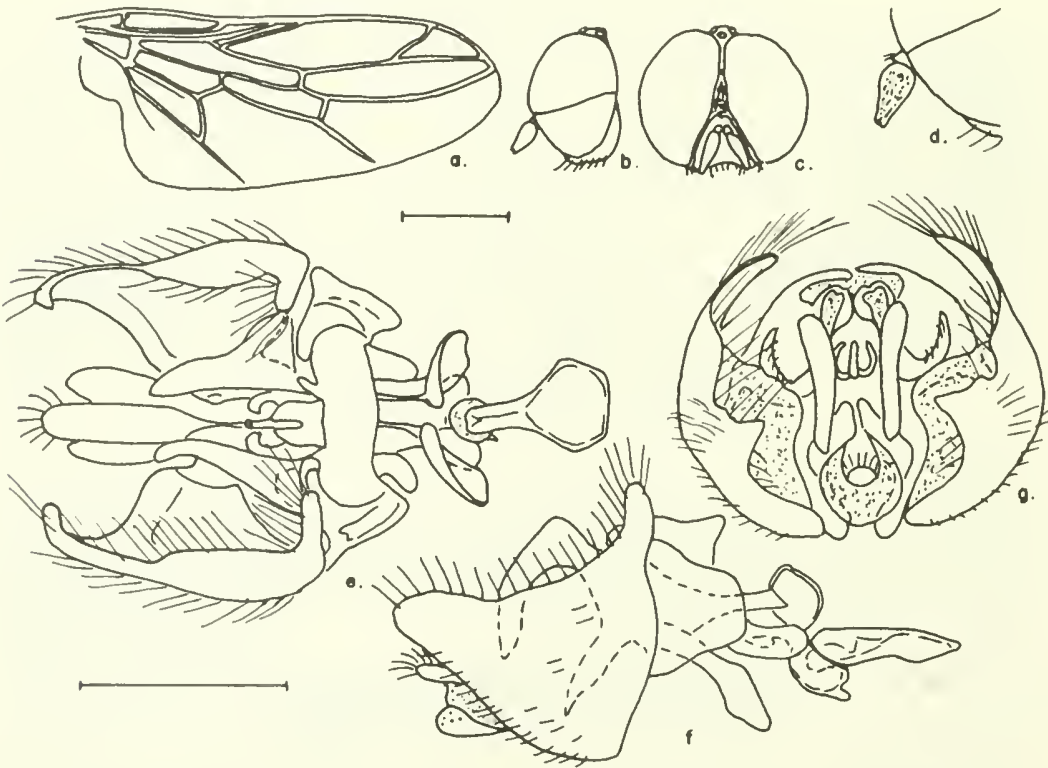

FigURE 58.-Scenopinus brevicornis Loew, male: $a$, wing; $b, c$, lateral and frontal aspects of head; $d$, enlarged detail of antenna; $e-g$, ventral, lateral and posterior aspects of terminalia. 

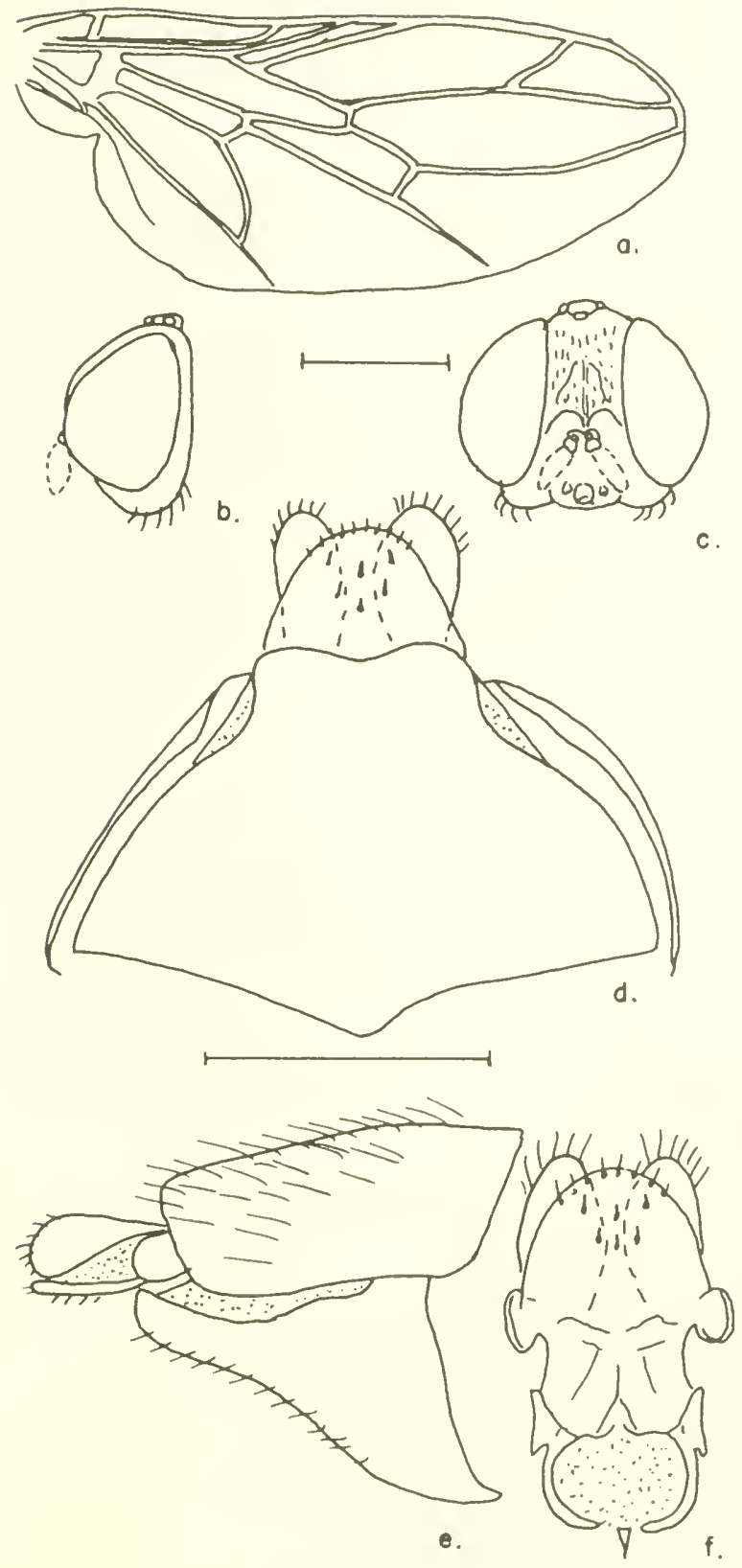

Figure 59.- Scenopinus brevicornis Locw, female: $a$, wing; $b$, c, lateral and frontal aspects of head; $d$, ventral aspect of 8th sternum; $e$, lateral aspect of 8 th and 9 th segments; $f$. 9 th sternum and bursa. 
Length: Male body $2.5 \mathrm{~mm}$., wing $2 \mathrm{~mm}$., female body $3 \mathrm{~mm}$., wing $2.2 \mathrm{~mm}$.

Type-locality: Warsaminor, Turkistan.

Type: (ZMH).

Specimen examined: 1 \& Mariout, Egypt; 1 September 1921 (Efflatoun) deposited in (SEE).

\section{Scenopinus fraternus (Kröber)}

Figures 60,61

Omphrale fraterna Kröber, 1923, p. 81.

Kröber remarks on the similarity of the male of this species with that of S. nitidulus. Certainly in the details of the head, wing and external genitalia they agree in most respects. The principal difference lies in the internal genital structures where a marked difference in the size of the ejaculatory pump is evident.
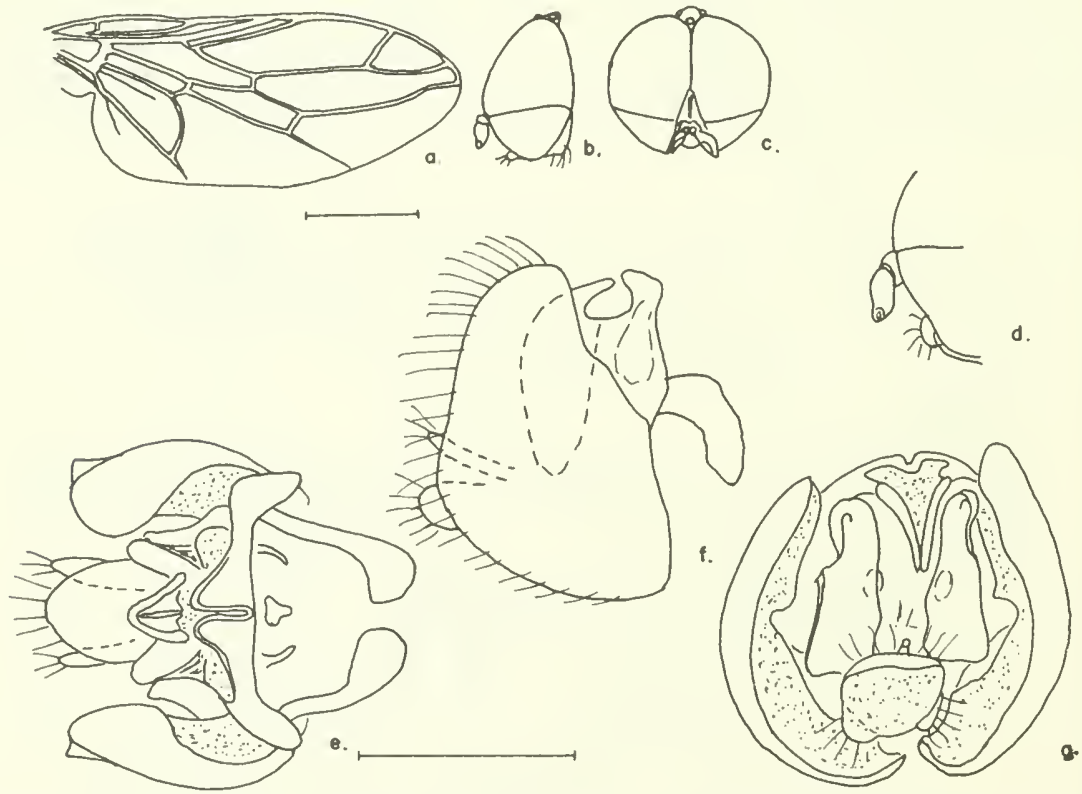

Figure 60.-Scenopinus fraternus (Kröber), male: $a$, wing; $b, c$, lateral and frontal aspects of head; d, enlarged detail of antenna; $e-g$, ventral, lateral and posterior aspects of terminalia.

There is some doubt, however, as to whether the female is of the same species as the male. The wings do not agree at all well in the two specimens; see figures. 
Length: Male body $2.5 \mathrm{~mm}$., wing $2 \mathrm{~mm}$.; female body $3.2-3.5$ mm., wing $2-2.1 \mathrm{~mm}$.

Type-locality: Male Saila, Egypt; 4 April 1923 (Fayoum).

Holotype: Male (SEE).

Allotype: Female, Ramleh, 25 June 1922.

Paratypes: 1 \%, Nouzha, 5 July 1921; 1 \%, Ezbet el Nakhl, 18 April $1922,(\mathrm{SEE})$.
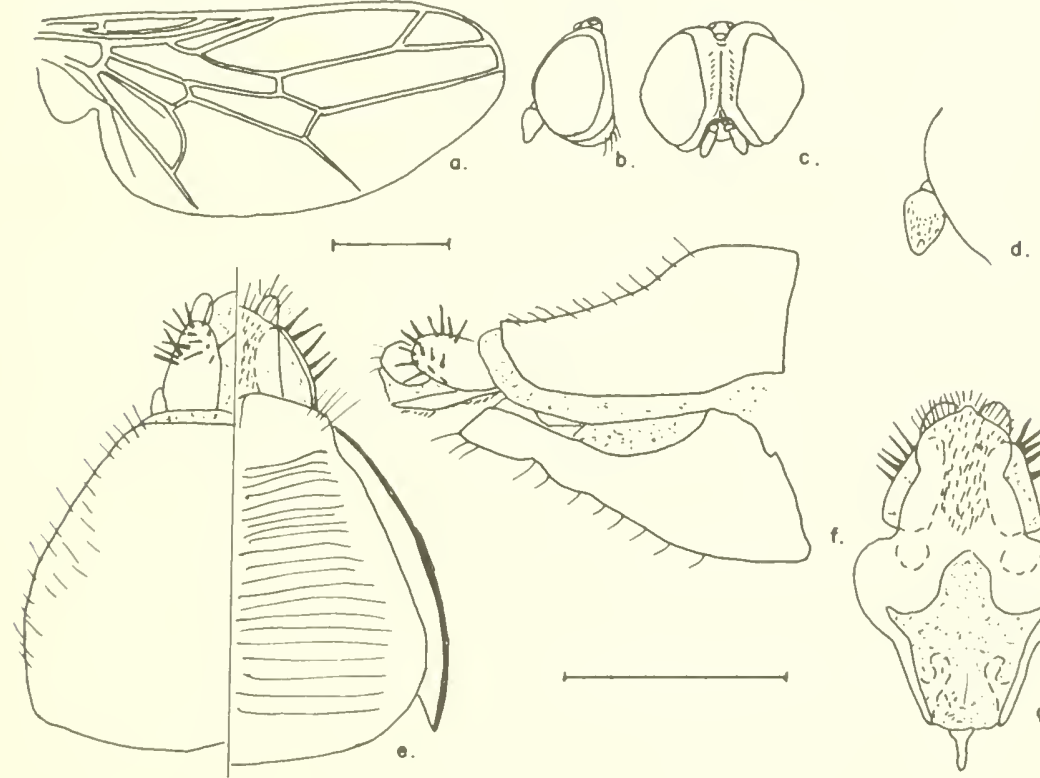

FigUre 61.-Scenopinus fraternus (Kröber), female: $a$, wing; $b, c$, lateral and frontal aspects of head; $d$, enlarged detail of antenna; $e$, dorsal left and ventral right aspects of 8 th and 9 th segments; $f$, lateral aspect of 8 th and 9 th segments; $g, 9$ th sternum and bursa.

\section{Scenopinus fryeri, new species}

\section{Figure 62}

Scenopinus longiventris Lamb (not Kröber), 1922, p. 362.

This specimen carries a determination label as S. longiventris Kröber but details of the head and wing hare led me to describe it as a new species.

Female.-Head dark red-brown; eyes red-brown, with a prominent postocular ridge; back of head concave; frons broad, finely rugose, swollen basally and laterad of the ocellar tubercle, and with a median depression. Mouthparts well developed; ocellar tubercle dark redbrown, not sharply set off from the frons, ocelli orange-red. Antennae with first two segments red-brown; first short, second twice as large; 
third segment black-brown, pear-shaped, as in figure, and covered with golden hairs.

Thorax dark red-brown with a few sparse hairs; humeral callus orange. Wings smoky brown; halter stem brown, knob tan. Legs dark red-brown with lighter red-brown tarsi. Abdomen red-brown, subshining; see figure for details of terminal segments and bursa.
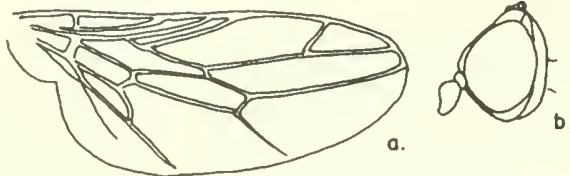

b.
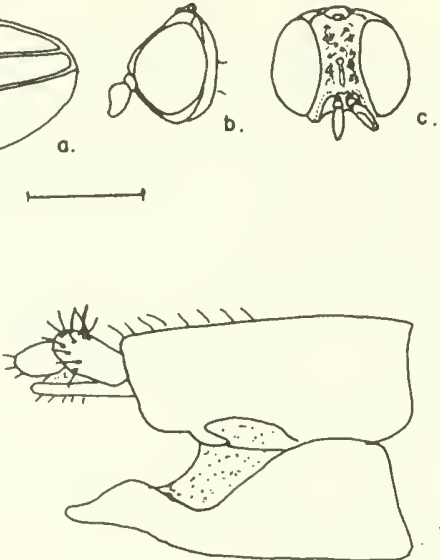

f.

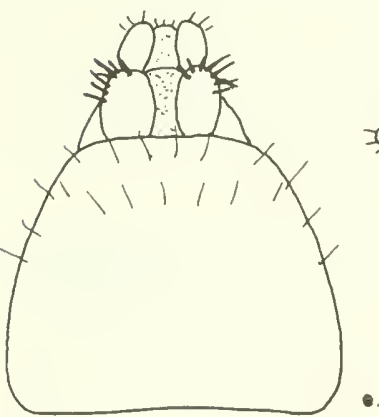

FIGURE 62.-Scenopinus fryeri, new species, female: $a$, wing; $b$, $c$, lateral and frontal aspects of head; $d$, enlarged detail of antenna; $e$, dorsal aspect of 8 th and 9th terga; $f$, lateral aspect of 8 th and 9th segments; $g$, ventral aspect of 9 th sternum and bursa.

\section{MaLE.-Unknown.}

Length: Female body $2.7 \mathrm{~mm}$., wing $2 \mathrm{~mm}$.

Type-locality: Aldabra Island, Seychelles; 1908-09 (J. C. Fryer). Holotype: Female (BMNH).

\section{Scenopinus halteralis Frey}

Figure 63

Scenopinus halteralis Frey, 1937, p. 53.

This small fly from the Canary Islands is known only from the male and is one of the smallest scenopinids seen. The specimen figured is one of six paratypes.

Length: Male body $1.5 \mathrm{~mm}$., wing $1.3 \mathrm{~mm}$.

Type-locality: La Esperianza. Tenerife, Canary Islands; 16 August (P. Stora).

Type: (ZMUH). 

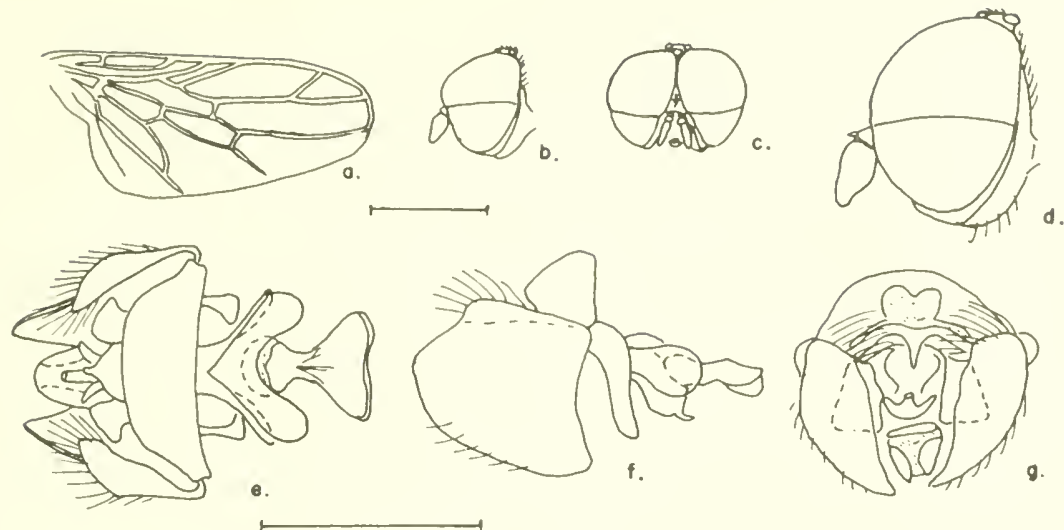

Figure 63.- Scenopinus halteralis Frey, male: $a$, wing; $b$, $c$, lateral and frontal aspects of head; $d$, enlarged details of head and antenna; $e-g$, ventral, Iateral and posterior aspects of terminalia.

\section{Scenopinus lincinus, new species}

Figure 64

This is one of several species which have female terminalia differing from those of most of Scenopinus, in that the sternum is a little longer than the tergum, rounded, and the ninth tergites have short stiff hairs or spines. Based on the configuration of the bursal plates, all appear to be distinct species. The present species is closely related to $S$. fraternus and $S$. nitidulus as previously mentioned, as well as $S$. fryeri, S. reduncus and perhaps $S$. longiventris. The males of the last three are unknown and the similarity of the males of the first two have already been mentioned.

Fenale.-Head black-brown; eyes dark red-brown; a broad, sunken postocular ridge; frons broad, subshining, with a median dimple; ocellar tubercle set off from frons; ocelli red-brown. First antennal segment black-brown, short; second segment red-brown, twice as large as first; third segment black-brown, pear-shaped, covered with gray pollinose scales, with a ventro-lateral pit.

Thorax black-brown, subshining; humeral callus red-brown, supraalar callus tan. Wings smoky brown; veins brown, R5 and $\lambda[1+2$ both curving forward to end before the tip of the wing; halter stem brown, knob tan. Legs black-brown; femora with sparse short hairs; tibae and tarsi with short hairs.

Abdomen red-brown, subshining; for details of the terminalia see figure.

MaLe.-Unknown. 

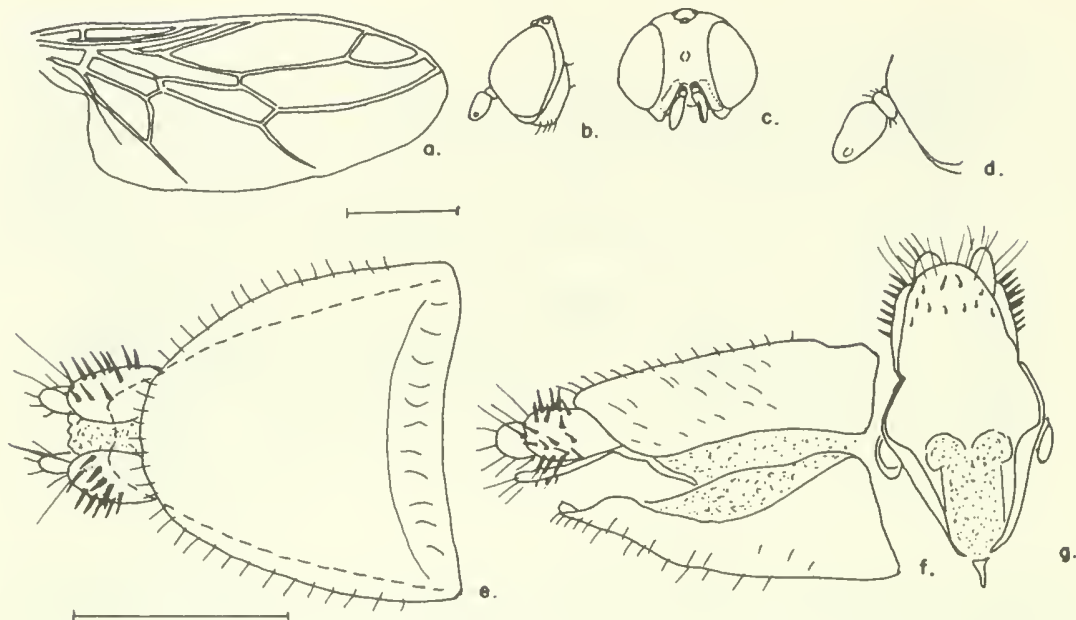

Figure 64.-Scenopinus lincinus, new species, female: $a$, wing; $b$, $c$, lateral and fronta aspects of head; $d$, enlarged detail of antenna; $e$, dorsal aspect of 8 th and 9 th terga; $f$ lateral aspect of 8 th and 9 th segments; $g$, ventral aspect of 9 th sternum and bursa.

Length: Female body $3 \mathrm{~mm}$., wing $1.8 \mathrm{~mm}$.

Type-locality: Ambobitantely, Madagascar; 8 June 1959, (F. Keiser).

Holotype: Female (NMB).

\section{Scenopinus longiventris (Kröber)}

FIgURe 65 [after Kröber]

Omphrale longiventris Kröber, 1913, p. 206.

The type of this species has been lost and no material from the type locality has been seen. One specimen from the Seychelles identified as this species by Lamb (1922) has been described as a new species $S$. fryeri on the basis of Kröber's figures. See note under $S$. lincinus.

Length: Female body $3 \mathrm{~mm}$.

Type-locality: Colombo, Ceylon.

Type: (MNH) destroyed.

\section{Scenopinus minusculus (Séguy)}

FIGURE 66

Omphrale minuscula Séguy, 1934, p. 74.

Scenopinus longiventris Lamb (not Kröber), 1922, p. 362.

MaLe.-This small fly is typical of members of the group. Frons rugose with flat, slightly elevated shining ridge as in figure, last antennal segment covered with short hairs.

Thorax shining; wings milky; halter white; legs dark except tarsi light. 

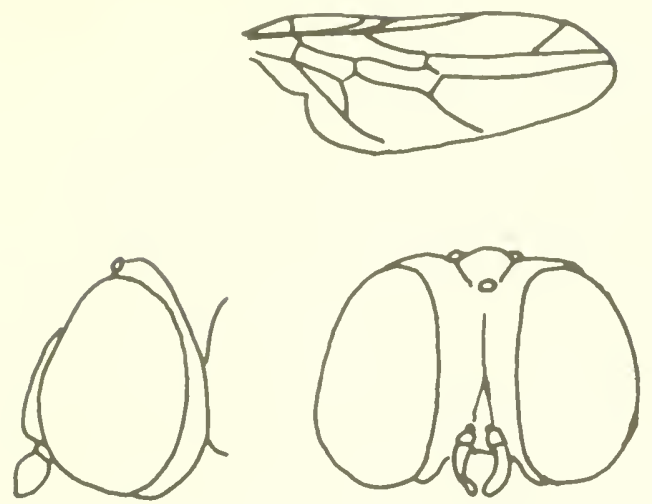

FigURE 65.-Scenopinus longiventris (Kröber), female: Wing and lateral and frontal aspects of head (after Kröber).

Abdomen with three white bands; terminalia as figured.

Fenale.-New. Head brown; eyes brown; frons broad shining with a central depression; postocular ridge narrow; ocellar triangle indistinet. Antenna as male.

Thorax brown, as male.

Abdomen brown; eighth sternum cleft along posterior margin; see figure for details of eighth sternum and bursa.

Length: Male body $1.5 \mathrm{~mm}$., wing $1.5 \mathrm{~mm}$.; female body $2.7 \mathrm{~mm}$., wing $1.9 \mathrm{~mm}$.

Type-locality: Maromandia, d'Analalava, Madagascar; 1921, (R. Decary).

Type: (MNHN).

Female description based on $९$, Bikiley, Reo sud de I'lle; September 1926, (A. Seyrig) (MNHN).

Also examined: 1 or Aldabra Island, Seychelles (J. C. Fryer) (BMNH).

\section{Scenopinus nitidifrons (Kröber)}

Omphrale nitidifrons Kröber, 1913, p. 194.

'The type of this species has been lost. It is my opinion, however, that this is in reality the female of $S$. tarsalis Kröber on the basis of the descriptions, the locality and collection data, and general shape of the wings. It is not uncommon to have slight differences in the coloration of wings, halteres and legs in the member's of this group.

See S. tarsalis (Krö̈ber) and figure 71, p. 107. 

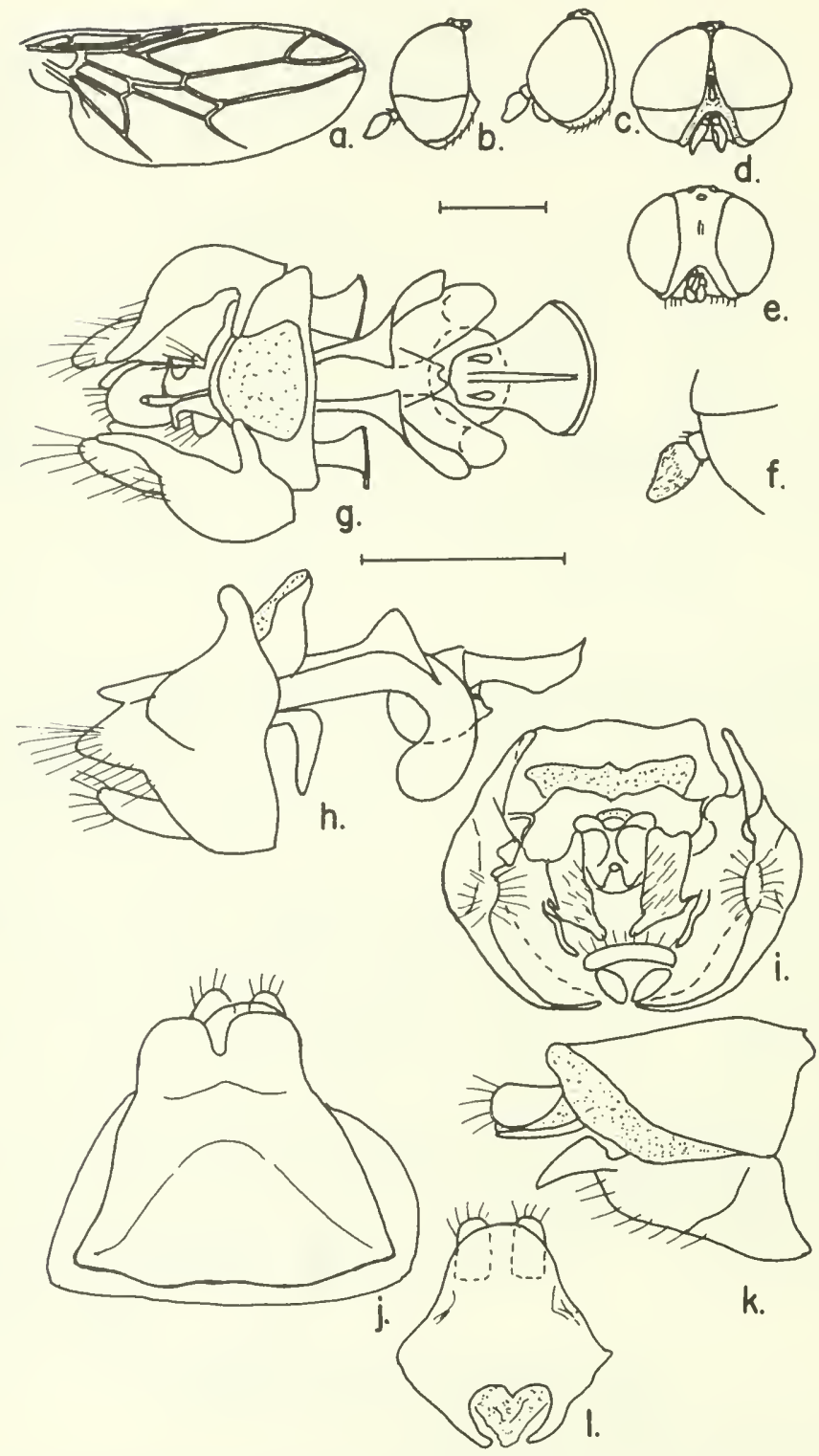

Figure 66.-Scenopinus minusculus (Séguy), male, female: $a$, wing; $b$, $d$, lateral and frontal aspects of male head; $c, e$, lateral and frontal aspects of female head; $f$, enlarged detail of male antenna; $g-i$, ventral, lateral and posterior aspects of male terminalia; $j$, ventral aspect of female 8th sternum; $k$, lateral aspect of female 8 th and 9 th segments; $l$, female 9 th sternum and bursa. 


\section{Scenopinus nitidulus Loew}

Figure 67

Scenopinus nitidulus Loew, 1873, p. 149. Kröber, 1913, p. 193.

This species appears to be correctly identified in most collections. Specimens have been seen from Egypt, Palestine, and Crete. The type male comes from the Transcaspian Region and was examined by me; the fentales agree. Kröber redescribed this species, including the female sex from Crete.

Length: Male body $2 \mathrm{~mm}$., wing $1.5 \mathrm{~mm}$.; female body $2-2.5 \mathrm{~mm}$, wing $2 \mathrm{~mm}$.

Type-locality: Balfrush, Iran (Christoph).

Type: (ZMH).

68. Scenopinus parallelus, new spccies

Figure 68

MALE.-Head black; eyes red-brown above, black-brown below; frons small, triangular, shining, flat; ocellar tubercle elevated, shining; ocelli clear. Mouthparts well developed; palpi short; oral eavity bordered by gray pubescence. First antennal segment very short, black; second larger, red-brown; third segment black-brown, pearshaped with a fine hairy covering.

Thorax dorsum black-brown with fine hairs; humeral callus redbrown; pleural areas red-brown. Wings white, veins tan anteriorly, faint posteriorly; veins $\mathrm{R} 5$ and $\mathrm{M} 1+2$ run parallel to each other to tip of wing. Halter stem brown, knob white. Legs brown with lighter tarsi.

Abdomen red-brown, segments $3-5$ with broad white posterior bands, with a distinct red-brown band between. Terminalia redbrown; see figure for details.

Female.-Unknown.

Length: Male body $2.2 \mathrm{~mm}$., wing $1.7 \mathrm{~mm}$.

Type-locality: Villa Cisneros, Río de Oro, Spanish Sahara; June (L. Berland).

Holotype: Male and two paratypes (MNHN), one paratype (USNM).

\section{Scenopinus pilosus (Séguy)}

Figure 69

Omphrale pilosa Séguy, 1930, p. 111.

This species is known only from the type and is characterized by the body being thinly covered with medium long hairs, and by the wing, where $M 1+2$ bends posteriorly to end well behind the tip of the wing. See figure for details of male terminalia, head, and wings. 

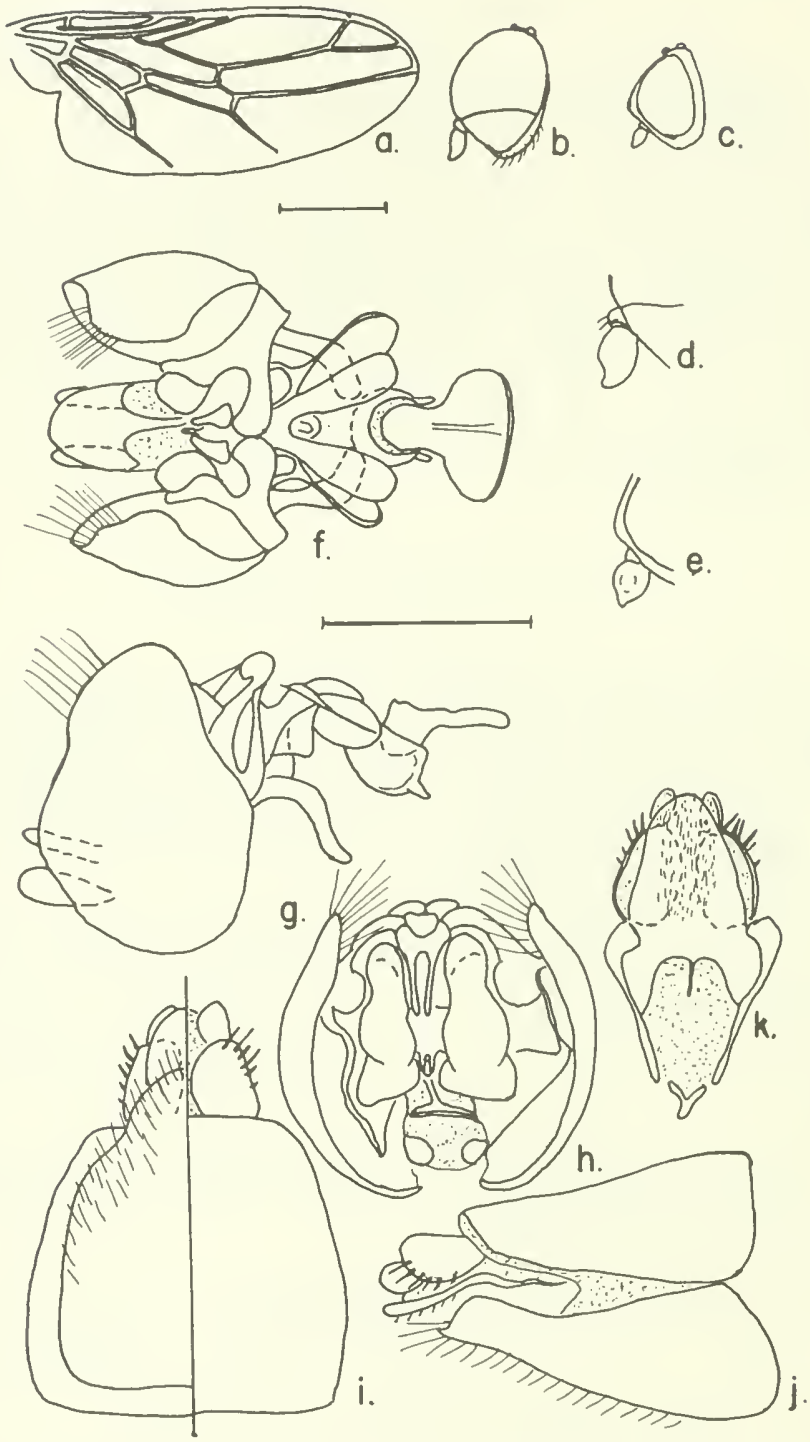

Figure 67.-Scenopinus nitidulus Loew, male, female: $a$, wing; $b$, lateral aspect of male head; $c$, lateral aspect of female head; $d, e$, enlarged details of male and female antennae; $f-h$, ventral, lateral and posterior aspects of male terminalia; $i$, ventral right and dorsal left aspects of female 8 th and 9 th segments; $j$, lateral aspect of female 8 th and 9 th segments; $k$, female 9 th sternum and bursa.

FEMALE.-Unknown.

Length: Male body $2 \mathrm{~mm}$., wing $1.8 \mathrm{~mm}$. 

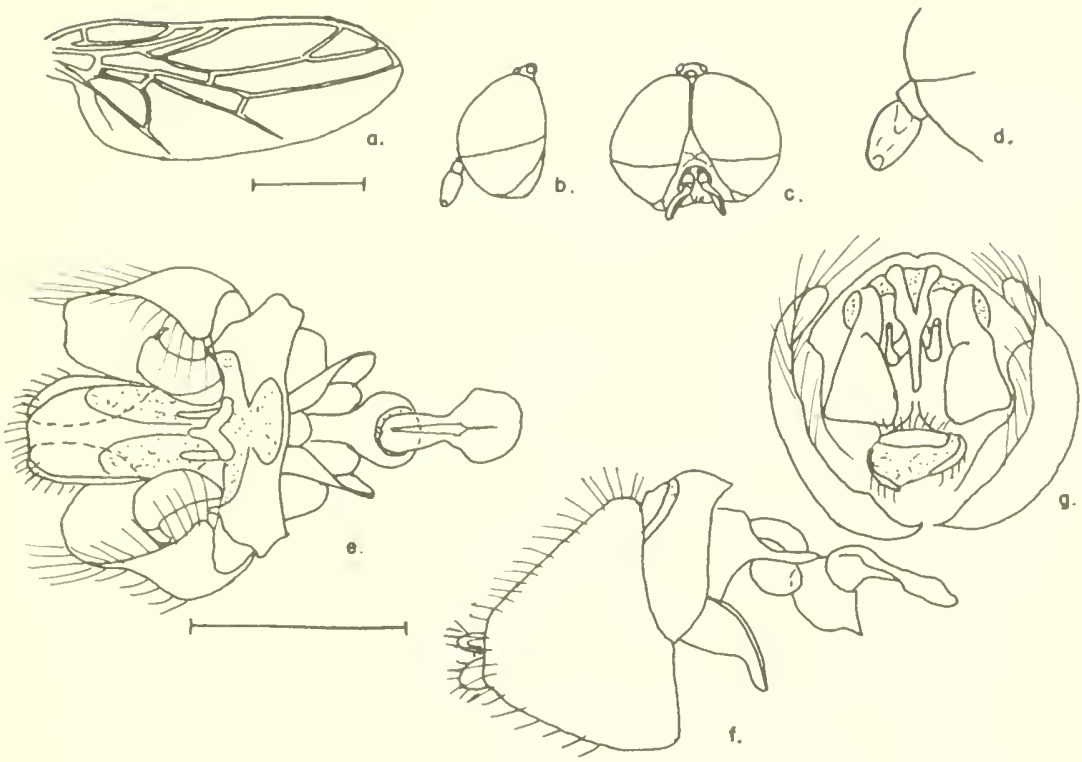

FIGURE 68.-Scenopinus parallelus, new species, male: $a$, wing; $b, c$, lateral and frontal aspects of head; $d$, enlarged detail of antenna; $e-g$, ventral, lateral and posterior aspects of terminalia.
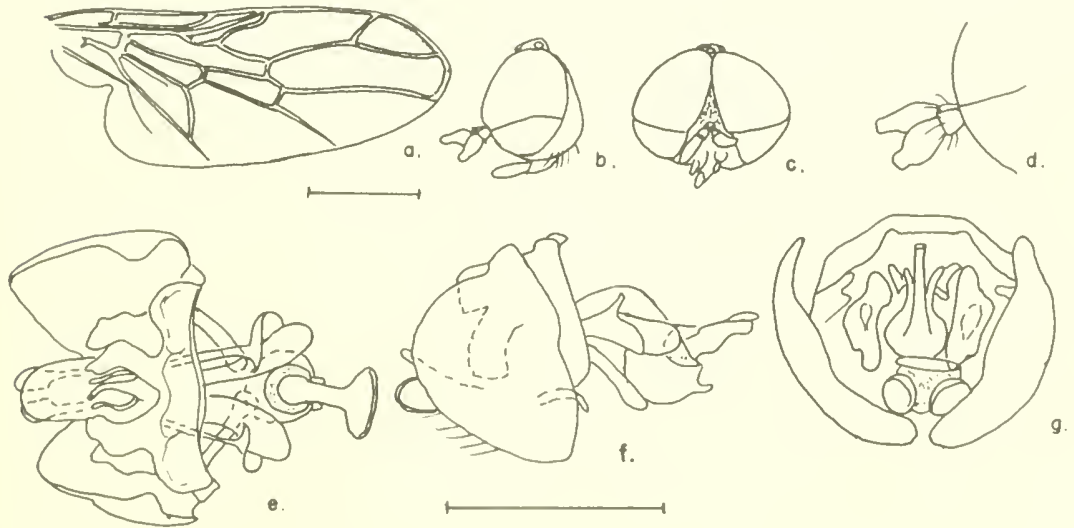

Figure 69.-Scenopinus pilosus (Séguy), male: $a$, wing; $b, c$, lateral and frontal aspects of head; $d$, enlarged detail of antenna; $e-g$, ventral, lateral and posterior aspects of terminalia.

Type-locality: Bou Knadel, Morocco (Athiery).

Type: (MNHN). 


\section{Scenopinus reduncus, new species}

FIGURE 70

This species is closely related to $S$. lincinus, S. fraternus, S. fryeri, $S$. nitidulus and perhaps to $S$. longiventris. It can be separated by the wing venation where cell $R 5$ is sharply narrowed at the tip of the wing and by the shape of the bursal plate.
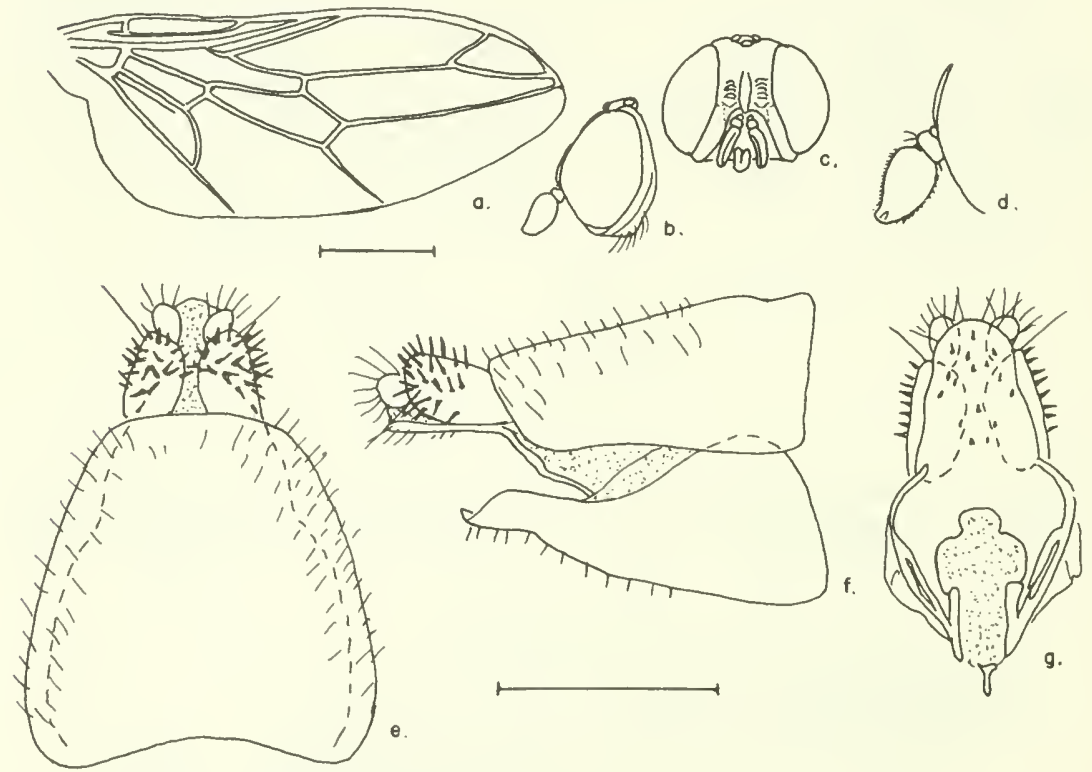

Figure 70.-Scenopinus reduncus, new species, female: $a$, wing; $b, c$, lateral and frontal aspects of head; $d$, enlarged detail of antenna; $e$, dorsal aspect of 8 th and 9th terga with outline of 8 th sternum; $f$, lateral aspect of 8 th and 9 th segments; $g$, ventral aspect of 9 th sternum and bursa.

Female.-Head black-brown; eyes black-brown, with a narrow, sunken postocular ridge; frons broad subshining, with a median depression on the lower half, ocellar triangle not set off, median ocellus sunken; ocelli red-orange. Mouthparts well developed, brown; palpi shorter than rostrum and labellum; back of head concave, pollinose. Antennae black-brown; first segment short; second twice as large as first; third pear-shaped, velvety with a distolateral pit.

Thorax black-brown, subshining, a few sparse hairs. Humeral callus with a tan lateral spot. Wings smoky-brown, veins brown; halter stem tan, knob tan, velvety above, white below. Legs blackbrown with red-brown tarsi.

Abdomen red-brown subshining. See figure for details of eighth and ninth segments and bursa. 
MaLE.-Unknown.

Length: Female body $3.4 \mathrm{~mm}$., wing $2.5 \mathrm{~mm}$.

Type-locality: Ambobitantely. Madagascar; \& June 1958, (F. Leiser).

Holotype: Female (NMB).

\section{Scenopinus tarsalis (Kröber)}

Figure 71 (after Kröber)

Omphrale tarsalis Krö̈ber, 1913, p. 196.

I have not seen this species as the type has been destroyed. However, it is my belief that $S$. nitidifrons probably is a female of this species. From examination of the plate figures and collection data, it is lard to see why these were identified as separate species. The slight differences in wing renation, and coloration of the halteres and legs is common among members of the Scenopinidae.
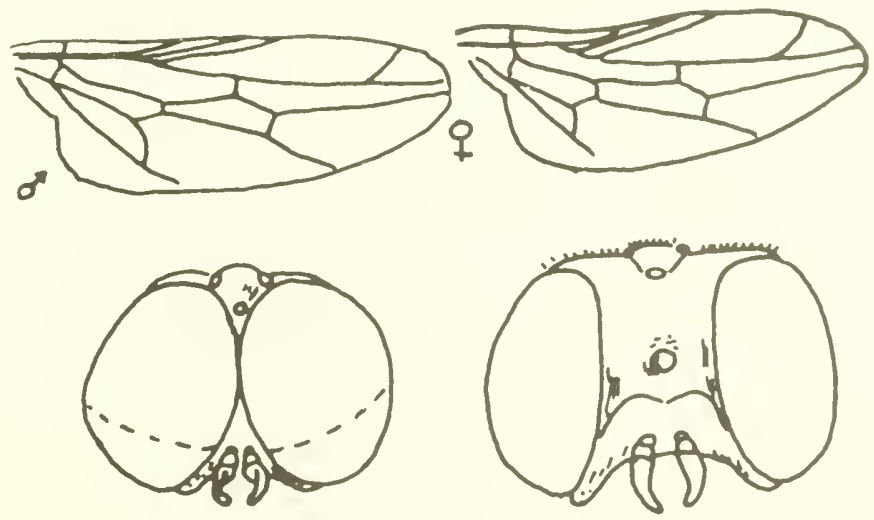

Figure 71.-Scenopinus tarsalis (Kröber), male, female: Wing and head of male (tarsalis) and of female (as nitidifrons) (after Kröber).

Length: Male body $1.5-2 \mathrm{~mm}$., wing ?; क body $2.5 \mathrm{~mm}$., wing ?. Type-locality: Assab (on lower Rad Sea), Eritrea (Katona).

Type: (MNH) destroyed.

72. Scenopinus turneri, new species

FIGURE 72

MALE.-Head black-brown, eyes red-brown above, darker below; frons elongate triangular, granular with a median shining groore; ocellar tubercle red-brown, elevated, with redish ocelli. Mouthparts normal. First two antennal segments black-brown; first short; second flairing, twice as long as first; third segment red-brown, pear-shaped. 
Thorax black, granular with short white hairs. Humeral callus red-brown; wings smoky hyaline, veins brown; halter stem blackbrown, knob red-brown. Legs with all segments dark red-brown.

Abdomen red-brown, segments 3-5 with wide white dorsal bands separated by narrow strips of red-brown. Terminalia red-brown; see figure for details.

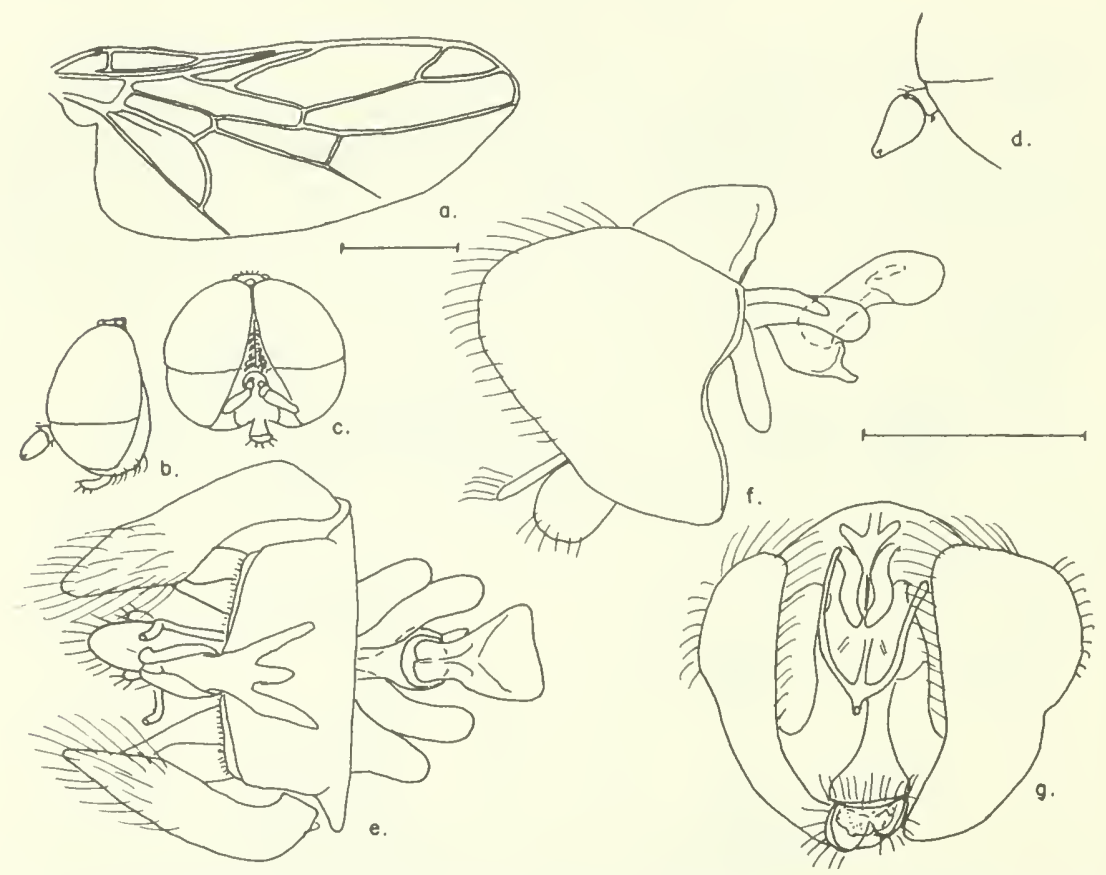

Figure 72.-Scenopinus turneri, new species, male: $a$, wing; $b, c$, lateral and frontal aspects of head; $d$, enlarged detail of antenna; $e-g$, ventral, lateral and posterior aspects of terminalia.

Female.-Unknown.

Length: Male body $2.8 \mathrm{~mm}$., wing $2.2 \mathrm{~mm}$.

Type-locality: Aliwal, n. Cape Province, [Republic of] South Africa; December 1922, (R. E. Turner).

Holotype: Male (BMNH).

\section{Scenopinus unifasciatus (Kröber)}

Figure 73

Omphrale unifasciata Kröber, 1913, p. 195.

The type of this species has been lost. The specim en figured from Cyprus agrees with Kröber's figures for S. unifasciatus and is presumed 
to be that species. The previously unknown female is also believed to belong to this pecies.

MaLE.-Head black; eyes dark red-brown above, black below; frons rugose with a median furrow ending in a shallow pit where the eyes become contiguous. Ocellar tubercle prominent, with red ocelli. Antennae with first s ${ }^{2}$ gment short, brown; second red-brown, twice as large as the first; last segment brown, pear-shaped, ending in a single point (Kröber says a truneated cone).
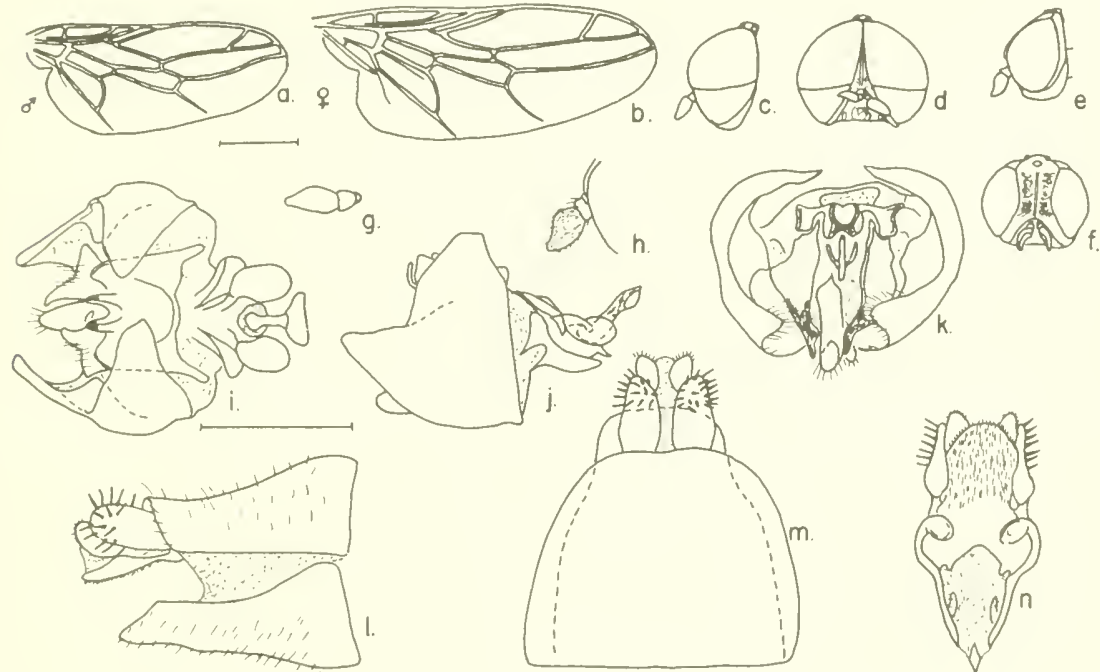

Figure 73.-Scenopinus unifasciatus (Kröber), male, female: $a$, male wing; $b$, female wing; $c, d$, lateral and frontal aspects of male head; $e, f$, lateral and frontal aspects of female head; $g, h$, enlarged details of male and female antennae; $i-k$, ventral, lateral and posterior aspects of male terminalia; $l$, lateral aspect of female 8 th and 9 th segments; $m$, dorsal aspect of female 8 th and 9 th tergites with 8 th sternum outlined; $n$, female 9 th sternum and bursa.

'Thorax dorsum black, rugose with sparse white hairs; humeral and supra-alar calli red-brown; pleura black-brown. Wings smoky brown, veins brown; halter stem black-brown, knob white with a tan base. Legs uniform red-brown throughout.

Abdomen black-brown, granulose, segments $3-5$ with posterior white bands. 'Terminalia black; see figure for details.

Fenale.-Head red-brown; eyes brown, with an medium broad postocular ridge; frons rugose with a smooth median groove extending to the median ocellus which is depressed, and swelling on either side of ocellar triangle, hairs on lower frons directed ventrolaterally. Ocellar triangle not set off, ocelli orange-red. Mouthparts brown, well developed; sides of oral opening lined with brown pubeseence. Antennae 
red-brown, first segment small; second twice as large in all dimensions, fringed with long hairs; third segment pear-shaped covered with a dense pile of short golden hairs.

Thorax dorsum black-brown with a scattering of hairs; humeral callus red-brown with white posterior border; supra-alar callus tan; pleural areas red-brown; wings brown fumose, veins brown; halter stem brown, knob white. Legs red-brown, femur with thinly scattered hair; tibia densely haired, tarsi yellow-brown basally darkening distally.

Abdomen red-brown, shining, with a few hairs; eighth segment with short stiff hairs directed outward; ninth tergum with heavy spinelike hairs. See figure for details of eighth sternum and bursa.

Length: Male body $2.2 \mathrm{~mm}$., wing $1.8 \mathrm{~mm}$. (Kröber gives length $2.5 \mathrm{~mm}$., wingspan $3 \mathrm{~mm}$.); female body $3.5 \mathrm{~mm}$., wing $2.3 \mathrm{~mm}$.

Type-locality: Island of Poros, Greece.

Type: (MNH) destroyed.

Male redescribed from Yermasoyia Hills, Cyprus; 11 September 1951, (G. A. Marromoustabis) in (BMNH).

Female described from Adana, Karates, Turkey, sea level; 7 June 1960, (Guichard \& Harvey) in (BMNH).

VELUTINUS group

Key to Species of the velutinus group

NEARCTIC SPECIES (MALES)

1. Wing hyaline . . . . . . . . . . . . . . . . 2

Wing brown or white . . . . . . . . . . . . 11

2. Halter knob white . . . . . . . . . . . . . . . . . . 3

Halter knob other color . . . . . . . . . . . . . . . . . . 6

3. Abdomen with three white bands . . . . . . . . . . . 4

Abdomen with two white bands . . . . . . S. werneri, new species

4. Posterior margin of 9 th tergum excavated . . . . . . . . . . . 5 Posterior margin of 9th tergum smoothly rounded

S. beameri (D. E. Hardy)

5. 9th tergum with a flaplike notch on ventral posterior border, antenna lnng

S. electus Adams

9th tergum without a ventral notch ...... S. whittakeri James

6. Halter knob brown or red-brown . . . . . . . . . . . . . . . . . . 7

Halter knob tan or yellow . . . . . . . . . . . . . . 10

7. Halter knob red-brown, 9 th tergum variable . . . . . . . . . 8

Halter knob brown, 9th tergum smoothly rounded

S. beameri fuscus (D. E. Hardy)

8. Abdomen with three white bands . . . . . . . . . . 9 Abdomen with two white bands . . . . . . S. gossypius, new species

9. First band narrow, second and third broad . . . S. hagai, new species First band broad, second and third narrow . . . S. magdalenai, new species 
10. Halter knob tan, posterior margin of 9 th tergum toothed ventrally

S. serratus, new species

Halter knob yellow, posterior ventral tip of 9 th tergum long with a single noteh . . . . . . . . . . . S. mirabilis Adams

11. Wing brown or smoky brown . . . . . . . . . . . . . . . 12

Wing white or milky white . . . . . . . . . . . . . . . . . . 17

12. Halter knob white. . . . . . . . . . . . . . . . . . 13

Halter knob black-brown or red-brown. . . . . . . . . . . . . 14

13. Posterior margin of 9 th tergum with a long dorsal point, paraneres long, wiry. . . . . . . . . . . . S. cochisei, new speeies

Posterior margin of (9th tergum with a ventral noteh and point, parameres long, wiry . . . . . . . . . . . S. kuiteri (D. E. IIardy)

14. Halter knob red-brown . . . . . . . . . . . . . . 15

llalter knob brown to black . . . . . . . . . S. valgus (1). E. llardy)

15. Abdomen with three white bands . . . . . . . . . . . . . . . . 16

Abdomen with two white bands.......... S. nubilipes Say

16. Bands on abdomen relatively broad. . . . . S. flandersi, new species

Bands on abdomen narrow. . . . . . . . . . . S. rossi, new species

17. Halter knob white. . . . . . . . . . . . . . . . . . . 18

Halter knob brown, tan, or eream . . . . . . . . . . . . . . . . 24

18. Abdomen with three white bands . . . . . . . . . . . . . . . . . 19

Abdomen with two white bands. . . . . . . . S. pecki, new species

19. All white bands broad . . . . . . . . . . . . . . . . 20

First band narrow, second and third wide. . . . S. alalacteus, new speeies

20. Body without scales . . . . . . . . . . . . . 21

Body with flattened seales. . . . . . . S. albifasciatus (D. E. Hardy)

21. Small flies under $3 \mathrm{~mm}$; veins separated at tip of wing . . . . . . . . 22 Small flies over $3 \mathrm{~mm}$; veins $\mathrm{R} 5$ and $\mathrm{M1}+2$ elose at tip of wing

S. cretatus, new species

22. Small flies under $3 \mathrm{~mm}$, but over $2 \mathrm{~mm}$.

small flies under $2 \mathrm{~mm}$. long .

23. Veins $R 5$ and $M 1+2$ widely separated at end of wing

S. chico, new species

S. weemsi, new species Veins $R 5$ and $M I+2$ moderately separated $=r-m$ cross vein

S. vanduzeei, new species

24. Halter knob brown or red-brown.

Halter knob orange-yellow. . . . . . . . S. seftoni, new species

25. Halter knob red-brown . . . . . . . . . . . . . . . 26

llalter knob orange-yellow . . . . . . . . S. seftoni, new species

llalter knob brown, hind margin of the 9 th tergum produeed on the midpoint

S. cooki, new species

26. Third antennal segment short .

S. barberi, new species

Third antennal segment long and narrow.

S. butleri, new speeies

\section{NEARCTIC SPECIES (FEMALES)}

1. Wing hyaline . . . . . . . . . . . . . . . . 2

Wing brown or white . . . . . . . . . . . . . . . . 9

2. Halter knob white . . . . . . . . . . . . . . 3

IIalter knob other color. . . . . . . . . . . . . . . . . . 4

3. Lateral depressions on Sth tergum and sternum. S. beameri (1). E. Hardy)

No lateral depression on Sth tergum . . . . . . S. whittakeri James

4. Halter knob brown or red-brown . . . . . . . . . . . . . . . . . 5

Halter knob tan or yellow. . . . . . . . . . . . . . . 8 
5. Cell R5 tapering to edge of wing .

Cell R5 sharply constricted before the end of the cell

S. gossypius, new species

6. Legs with tibia red-brown .

Legs with tibia orange-brown to brown .

S. magdalenai, new species

7. Eighth tergum flat with lateral depressions

S. beameri fuscus (D. E. Hardy)

Eighth tergum rounded without depressions . . . . S. valgus (D. E. Hardy)

8. Halter knob tan, tip of cell R5 sharply closed

S. howdeni, new species

Halter knob yellow, tip of cell R5 open

. S. mirabilis Adams

9. Wing brown or smoky brown

Wing white or milky white .

10. Halter knob light

Halter knob dark

11. Halter knob cream or tan.

12. Halter knob white knob eream, antenna long, straight. .

. .

Halter knob tan, antenna short, pear-shaped .

13. Cell R5 narrowed at edge of wing

Cell R5 open at edge of wing .

14. Halter knob red-brown to black-brown polished

Halter knob red-brown above white below .

15. Tarsi light red-brown

Tarsi straw yellow

16

16. Halter knob white Halter knob brown or tan . . . . . . . . . . . . . . . . . . . . . . . . . . . . . . . . . 21

11

17. Halter knob all white. . . . . . . . . . . . . . . 18

Halter knob with base tan. . . . . . . S. weemsi, new species

18. Body without flattened scales . . . . . . . . . . . . . . 19

Body with flattened scales. . . . . . S. albifasciatus (D. E. Hardy)

19. Third antennal segment not parallel-sided . . . . . . . . . . . 20

Third antennal segment uniform width . . . . . . S. chico, new species

20. Third antennal segment oval, widest at middle. . S. alalacteus, new species Third antennal segment pear-shaped, widest at base

S. cretatus, new species

21. Halter knob brown or red-brown . . . . . . . . . . . . . 22

Halter knob orange-yellow . . . . . . . . S. seftoni, new species

22. Halter knob red-brown . . . . . . . . . . . . . 23

Halter knob brown above, white below . . . . . . S. pecki, new species

23. Antenna black-brown elongate oval, frons swollen above antenna with a broad median depression on lower fourth . . . . . S. rossi, new species Antenna red-brown, short, frons swollen above antenna with a median groove dividing lower two-fifths . . . . . . . S. barberi, new species

\section{NEOTROPICAL SPECIES}

1. Males . . . . . . . . . . . . . . . . . . 2

Females . . . . . . . . . . . . . . . 6

2. Wing hyaline, abdomen with two or three white bands . . . . . . . . 3 Wing milky white, two white bands on abdomen. . . S. pygmaeus Loew

3. Halter knob brown or red-brown, abdomen with three white bands . . . 4 Halter knob white, abdomen with two white bands (Hawaii)

S. adventicius (D. E. Hardy)

4. Halter knob red-brown, abdomen with some narrow white bands . . . . 5 
Halter knob dark brown, abdomen with three broad white bands

S. velutinus (Kröber)

5. Abdomen with three narrow white bands. . . . . S. buscki, new species Abdomen with first two bands broad, third narrow. . S. schultzi Enderlein

6. Wing lyyaline. . . . . . . . . . . . . . . . . 7

Wing brown or white. . . . . . . . . . . . . . . . 11

7. HaIter knob red-brown or brown . . . . . . . . . . . . . . . . 8 Italter knol, white (Howaii) . . . . . . . S. adventicius (1). E. IIardy)

S. Halter knob red-brown . . . . . . . . . . . . . . . . . . . . . .9

Halter knob brown . . . . . . . . . . . . . . . . . 10

9. Eighth sternum with a prominent nipple.ike swelling before end

S. schulzi Enderlein Eighth sternum without such swelling .

S. buscki, new species

10. Halter knob dark brown

S. velutinus (Kröber) Hlalter knob brown above, white below . . . . . . . S. fijianus (Kröber)

11. Wing milky white, halter white .

S. pygmaeus Loew

Wing brown, halter brown .

12. Antenna with third segment very small

S. curticornis (Kröber) Antenna with third segment very large . . . . S. magnicornis (Kröber)

74. Scenopinus adventicius D. E. Hardy

\section{Figure 74}

Scenopinus adventicius D. E. Hardy, 1960, p. 329.

This dark-winged species, along with S. papuanus, has been erroneously identified as niger (DeGeer), particularly in the more frequently captured females. It can be distinguished by its smaller size and by R4 branching well beyond the middle of the cell.
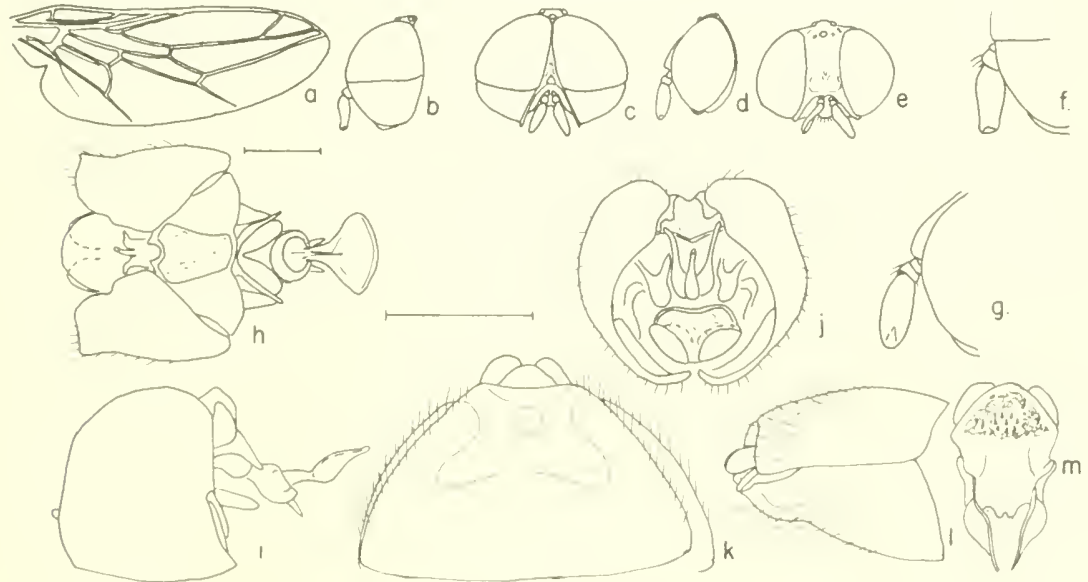

Figure 74.-Scenopinus adventicius 1). E. Hardy, male, female: $a$, wing; $b, c$, lateral and frontal aspects of malc head; $d, e$, lateral and frontal aspects of female head; $f, g$, enlarged details of male and female antennae; $h-j$, ventral, lateral and posterior aspects of male terminalia; $k$, ventral aspect of female Sth sternum; $l$, lateral aspect of female 8 th and 9 th segments; $m$, female 9 th sternum and bursa. 
Length: Male body 3-3.7 mm., wing 2.3-2.6 mm.; female body 4-4.5 mm., wing $3.5 \mathrm{~mm}$.

Type-locaity: Honolulu, Oahu, Hawaii; January 1953, (D. E. Hardy).

Types: B. P. Bishop Museum, Honolulu.

75. Scenopinus alalacteus, new species

Figure 75

MaLE.-Head black-brown; eyes red-brown abore, black-brown below, extending to back of head; frons subshining, narrow, triangular, extending halfway to ocellar tubercle, with a median depression; ocellar triangle black-brown, elevated, ocelli clear; back of head concave, lower portion with long white hairs; mouthparts brown, nearly filling oral cavity, palpi tan, nearly as long as rostrum. Antennae red-brown: first segment short; second twice as large as first; third oval, twice as long as first two combined.

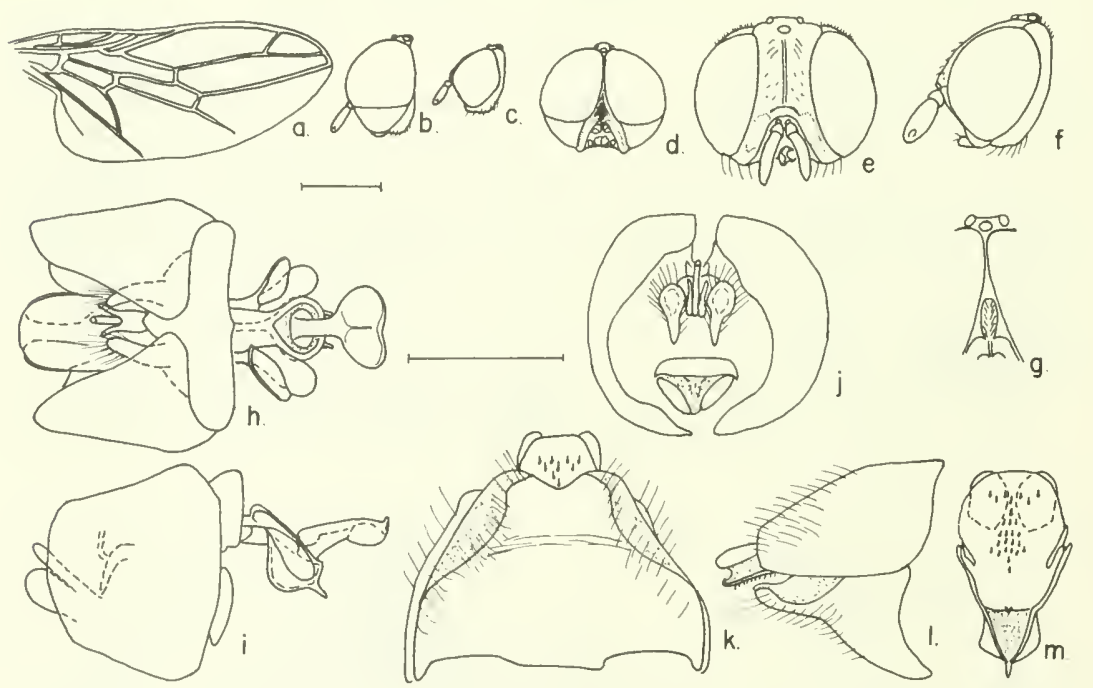

F1GURE 75.-Scenopinus alalacteus, new species, male, female: $a$, wing; $b, d$, lateral and frontal aspects of male head; $c$, lateral aspect of female head; $e, f$, enlarged frontal and lateral aspects of female head; $g$, enlarged detail of male frons; $h-j$, ventral, lateral and posterior aspects of male terminalia; $k$, ventral aspect of female 8 th sternum; $l$, lateral aspect of female 8 th and 9 th segments; $m$, female 9 th sternum and bursa.

Thorax dorsum black-brown with a patch of silvery pile above the humeral callus, humeral and supra-alar calli tan; pleura redbrown. Wings milky white, veins tan; halter stem brown, knob white. Legs red-brown except tarsi straw colored at base, darker at tip. 
Abdomen red-brown, segment 3 with a narrow white band, broad bands on segments 4 and 5 . For details of terminalia see figure.

Fenale.-Head dark red-brown; eyes red-brown with a broad postocular flange elevated above the eyes on the top of the head; frons slightly swollen above antennae, a median groove extending nearly to median ocellus; ocellar tubercle broad, flattened and not distinctly separated from the dorsal areas of the frons. Mouthparts as in male; oral cavity surrounded by a band of silvery pile which extends over the antennae in a narrow band; back of head coneave; extensive genae below eyes. Antennae red-brown, as in male.

Thorax, wings, and legs as in male.

Abdomen red-brown; see figure for details of segment $S$ and bursal plate.

Length: Male body $2.5-3 \mathrm{~mm}$., wing $2-2.2 \mathrm{~mm}$.; female body 2.6-3.1 mm., wing 1.9-2 $\mathrm{mm}$.

Type-locality: Glenns Ferry, Idaho; 14 June 1927.

Holotype: Male (USNM) 67476.

Allotype: Female same but 8 July 1927, (USNM).

Paratypes: $2 \sigma^{7} \sigma^{7}, 3$ क९, Glenns Ferry, Idaho, 8 July, and 5 September 1927, in (USNM); 1 б', Sparks, Nevada, 28 June 1923, (E. P. Van Duzee) (CAS); 1 व , Adelaide, Idaho, 26 July 1929, (UCalB).

\section{Scenopinus albifasciatus (D. E. Hardy)}

Figure 76

Omphralosoma albifasciata D. E. Hardy, 1944a, p. 41.

Except for the presence of scalelike hairs, this species agrees in all other respects with other members of the Velutinus group.

Length: Male body $2.3 \mathrm{~mm}$., wing $1.7 \mathrm{~mm}$.; female body $2.66 \mathrm{~mm}$., wing $2 \mathrm{~mm}$.

Type-locality: Seeley, California; 17 July 1940, (R. H. Beamer).

Allotype: Female, Jacumba, California; 12 August 1935, (R. H. Beamer).

Paratype: $1 \sigma^{7}$, same data as type.

Types: (UKan).

I have seen a long series from Arizona in (USNM), (UAriz) swept from alfalfa. Also $1 \sigma^{7}$, Mesilla Park, New Mexico (C. N. Ainslie) (USNM).

\section{Scenopinus barberi, new species}

\section{Figure 77}

MALE.-Head dark red-brown; eyes brown above, red-brown below, reaching the back of the head, contiguous for a greater distance than the height of the frons, which is triangular with an elongate depression in the upper half; ocellar tubercle red-brown, ocelli clear. Mouthparts 

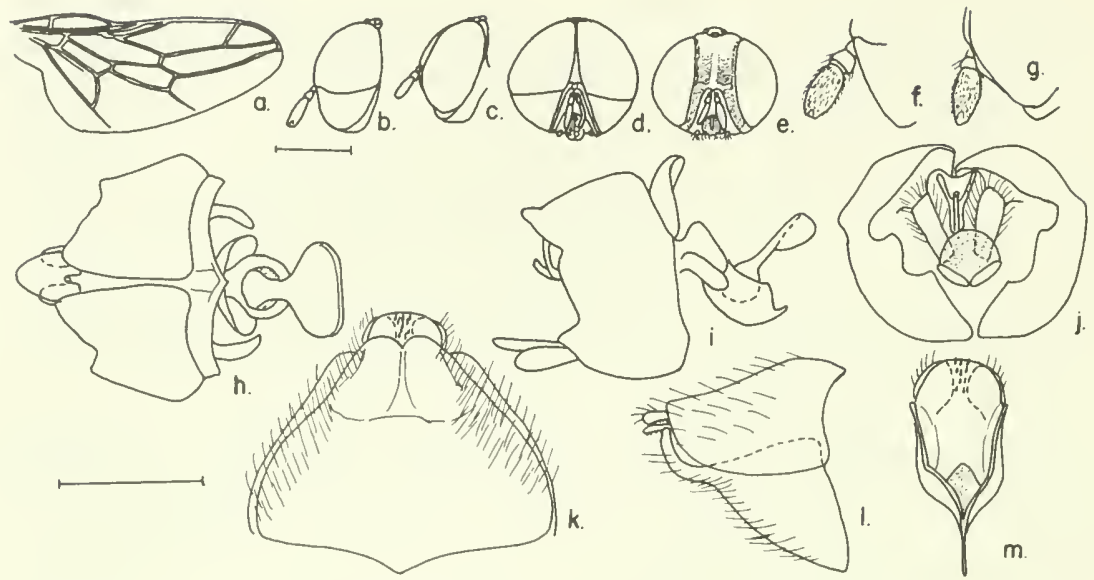

Figure 76.-Scenopinus albifasciatus (D. E. Hardy), male, female: $a$, wing; $b, d$, lateral and frontal aspects of male head; $c, e$, lateral and frontal aspects of female head; $f, g$, enlarged details of male and female antennae; $h-j$, ventral, lateral and posterior aspects of male terminalia; $k$, ventral aspect of female 8 th sternum; l, lateral aspect of female 8th and 9th segments; $m$, female 9th sternum and bursa.
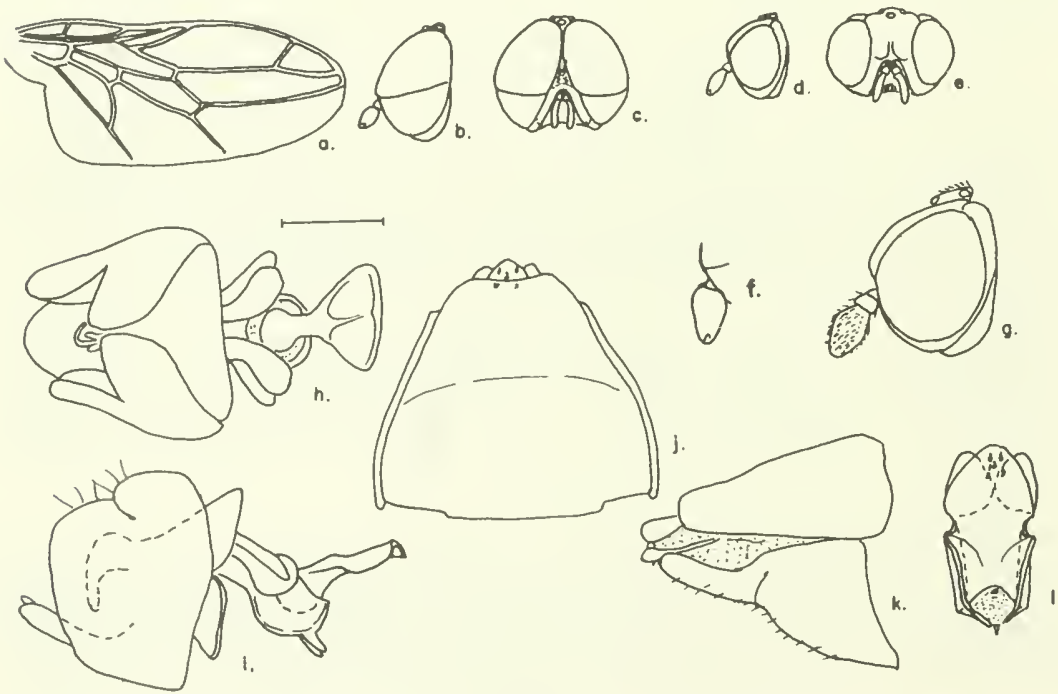

Figure 77.-Scenopinus barberi, new species, male, female: $a$, wing; $b$, $c$, lateral and frontal aspects of male head; $d, e$, lateral and frontai aspects of female head; $f$, enlarged detail of male antenna; $g$, enlarged lateral view of female head; $h, i$, ventral and lateral aspects of male terminalia; $j$, ventral aspect of female 8 th sternum; $k$, lateral aspect of female 8 th and 9 th segments; $l$, female 9 th sternum and bursa. 
brown, well developed, palpi orange-brown, two-thirds as long as rostrum; an extensive postgenal area on lower part of the head. Antennae red-brown; first segment small; second bell-like, much larger; third pear-shaped, less than twice as long as broad.

Thorax red-brown, humeral and supra-alar calli red-orange. Wings opaque, with milky microtrichia, veins light brown; halter stem brown, knob red-brown. Legs red-brown with lighter tarsi.

Abdomen red-brown, segments $3-5$ with broad white stripes separated by thin sclerotized bands. Ninth tergum similar to $S$. electus but more prominent and posterior emargination different; see figure for details.

Female.-Head orange-brown, eyes red-brown; frons very broad, wider than the eye when viewed from the front, rugose, swollen over the antennae and with a median groove dividing the lower two-fifths of the frontal area; ocellar tubercle flattened and not distinctly separated, ocelli clear. Mouthparts well developed but lighter in color than the male; antennae as male except lighter.

Thorax dorsum orange-brown; humeral callus orange; pleura orange. Wing as in male; halter stem brown, knob brown. Legs orange-brown with straw-yellow tarsi.

Abdomen orange-brown, subshining; eighth segment red-brown. See figure for details of sternum and bursa.

Length: Male body $2.2 \mathrm{~mm}$., wing $1.7 \mathrm{~mm}$.; female body $2.7 \mathrm{~mm}$., wing $1.6 \mathrm{~mm}$.

Type-locality: Bright Angel, Arizona; 10 July, (H. S. Barber).

Holotype: Male in copulo with allotype female (USNM) 67479.

Paratype: 1 \%, same data (USNM).

78. Scenopinus beameri (D. E. Hardy)

79. Scenopinus beameri var. fuscus (D. E. Hardy)

FIGURE 78

Omphrale beameri D. E. Hardy, 1944a, p. 43.

Omphrale beameri var. fusca D. E. Hardy, 1944a, p. 43.

These two forms are similar except for the coloration of the halteres.

Length: Male body $2.3-2.5 \mathrm{~mm}$., wing 2-2.3 $\mathrm{mm}$.

Type-locality: of beameri, Olancha, California, 25 August 1940, (R. H. Beamer); of rar. fusca, Onyx, California, 23 July 1940, (R. H. Beamer).

Types: (UKan).

I have seen a long series of undetermined specimens from the same localities and collection dates as the types and paratypes in (UKan). Also: 1 \& $1 \sigma^{7}$, Fallon, Nevada, 12 August 1940, (L. Lipovsky \& E. Kenaga); 1 o, Oak Creek Canyon, Arizona, 9 July 1941, (L. H. 


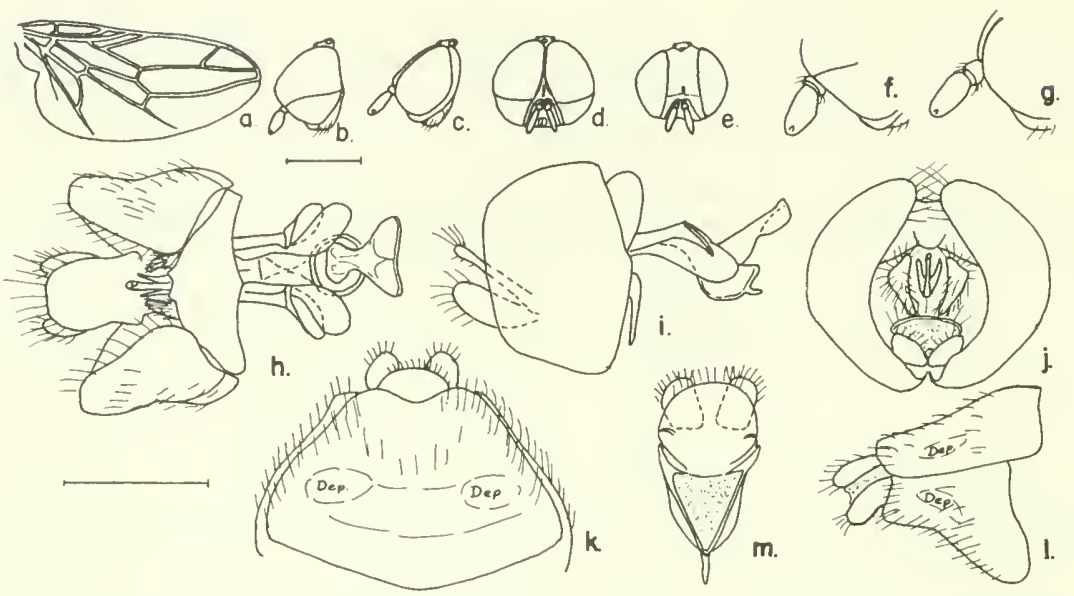

Figure 78.-Scenopinus beameri (D. E. Hardy), male, female: $a$, wing; $b$, $d$, lateral and frontal aspects of male head; $c, e$, lateral and frontal aspects of female head; $f, g$, enlarged details of male and female antennae; $h-j$, ventral, lateral and posterior aspects of male terminalia; $k$, ventral aspect of female 8 th and 9 th segments (Dep. $=$ depression); $l$, lateral aspect of female 8 th and 9 th segments; $m$, female 9 th sternum and bursa.

Banker); $1 \sigma^{\pi}, 1$ \%, in copula, Prescott, Arizona, 20 June, (H. S. Barber) (USNM).

\section{Scenopinus bryanti, new species}

\section{FIGURE 79}

Female.-Head dark red-brown; eyes black-brown, with a thin postocular rim; frons rugose, swollen above the antennae, with a median elongate depression on the lower half, thinly covered with short hairs; mouthparts well developed, palpi long but not as long as rostrum; a band of silvery pile around the oral opening not extending to eye margins or above antennal bases. Ocellar triangle two-thirds width of frons and set off from frontal area; ocelli orange-red. Antennae red-brown; first segment short; second twice as large; third not twice as long as broad; see figure.

Thorax dorsum dark red-brown; humeral and supra-alar calli and scutellum red-brown; pleurum red-brown. Wings hyaline, dusted with brown, veins brown; veins $\mathrm{R} 5$ and $\mathrm{M} 1+2$ widely separated on wing margin, cell R4 small. Legs with red-brown femora and tibiae, tarsi light red-brown.

Abdomen red-brown, eighth tergum concave on posterior margin. See figure for details of eighth segment and bursa.

MALE.-Unknown.

Length: Female body $2.8 \mathrm{~mm}$., wing $2.2 \mathrm{~mm}$. 

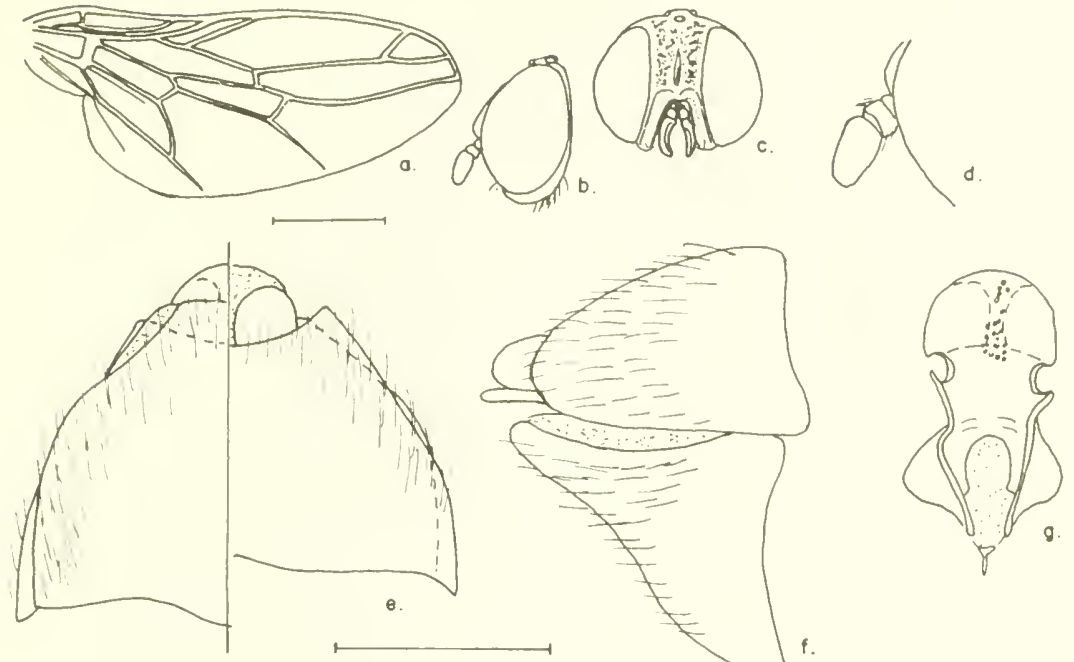

Figure 79.-Scenopinus bryanti, new species, female: $a$, wing; $b$, $c$, lateral and frontal aspects of head; $d$, enlarged aspect of antenna; $e$, ventral left and dorsal right aspects of 8 th and 9 th segments; $f$, lateral aspect of 8 th and 9th segments; $g$, 9th sternum and bursa.

Type-locality: 'Tueson, Arizona; 23 April 1937, (Bryant). Holotype: Female (CAS) 8927.

\section{Scenopinus buscki, new species}

\section{Figure 80}

MALE.-Head black-brown; eyes bright red-brown above, blackbrown below, reaching the back of the head; frons small, triangular, with a median groove extending from above the antemne to a median pit in the upper fourth of the frons; postgenal areas small; mouthparts red-brown; palpi very nearly as long as rostrum; silvery pile between eye and oral cavity extending dorsally to lower angles of frons. First antennal segment small, black-brown; second twice as large as first, red-brown; third segment red-brown, over twice as long as broad, square-tipped and covered with scales. Ocellar tubercle prominent; ocelli red-brown.

Thorax dorsum black-brown, with silvery pile above the humeral callus and extending in a thin band along the tergal margin behind the callus; humeral and supra-alat calli red-brown; pleura red-brown. Wings hyaline, reins light brown; R5 and M1 +2 close together bending forward to end in the margin of the wing before the tip; halter stem red-brown, knob red-brown, shining. Legs with femora and tibiae red-brown, fore and middle tarsi orange, hind tarsus straw yellow. 

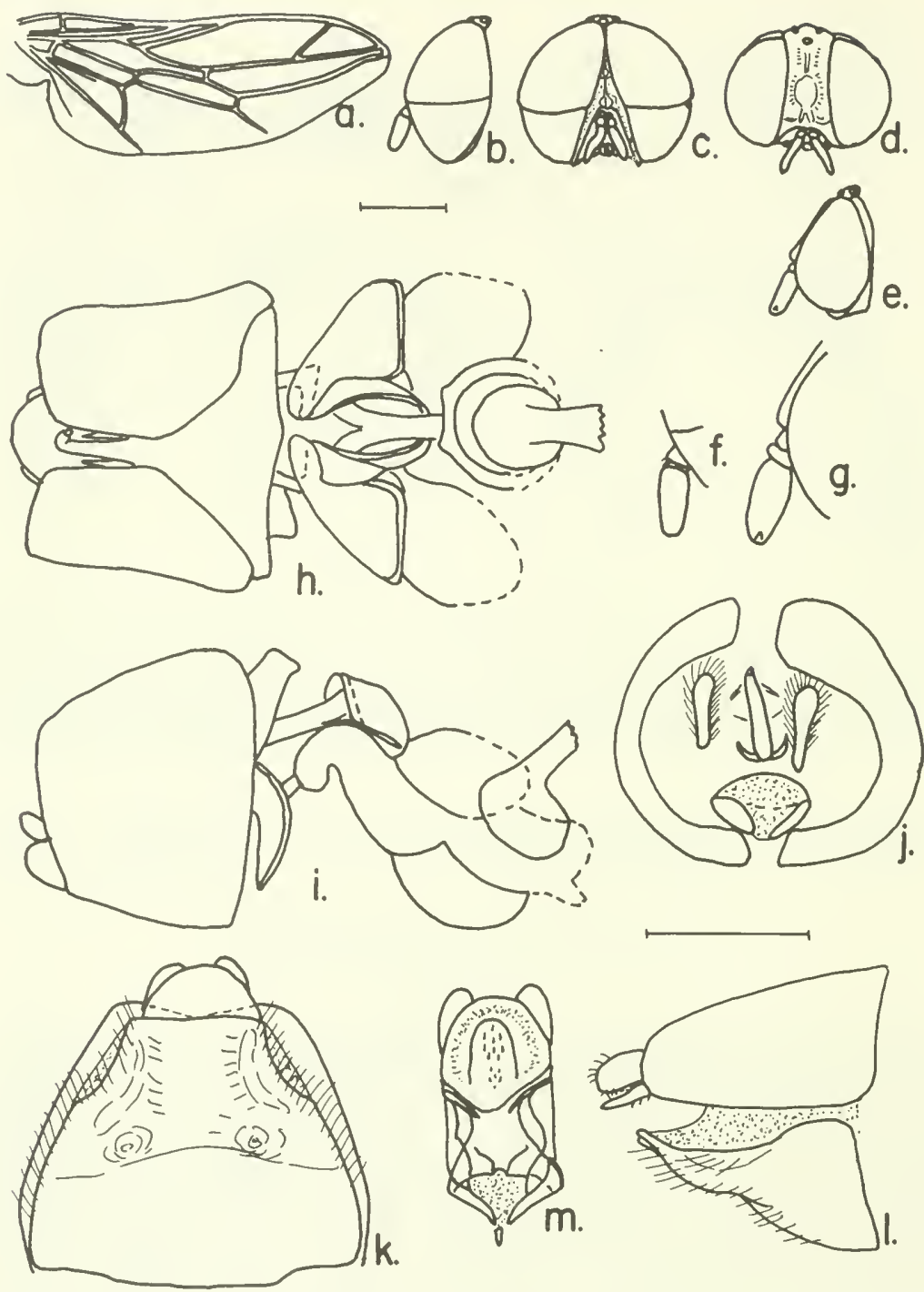

Figure 80.-Scenopinus buscki, new species, male, female: $a$, wing; $b$, $c$, laterai and frontal aspects of male head; $d, e$, frontal and lateral aspects of female head; $f, g$, enlarged details of male and female antennae; $h-j$, ventral, lateral and posterior aspects of male terminalia (apodeme of ejaculatory syringe lost on dissection); $k$, ventral aspect of female 8th sternum; $l$, lateral aspect of female 8 th and 9 th segments; $m$, female 9 th sternum and bursa.

Abdomen red-brown; segments $3-5$ with narrow white bands on posterior half of segments. See figure for details of ninth tergum and internal structures which are very large. 
Female--Head dark red-brown; eyes black-brown with a thin postocular ridge; frons swollen above the antennae, with a median groove extending into a large shallow median depression; genal area small; mouthparts brown, large and well developed; oral eavity bordered by a silvery pile that extends to base of antennae; ocellar tubercle not prominent, median ocellus set in a depression. Antennae as in the male.

Thorax, wing, halter and legs as in male except tarsi yellow-orange.

Abdomen red-brown. Sea figure for details of eighth segment and bursa.

Length: Male body $3.5 \mathrm{~mm}$., wing $2 \mathrm{~mm}$.; female body $3.5-4.5$ mm., wing $2.3-2.8 \mathrm{~mm}$.

Type-locality: La Chorrera, Panama; 17 May 1912, (August Busck).

Holotype: Male, allotype female, same data (USNM) 67480.

Paratypes: 3 oㅇ, Cabima, Panama, 22 and 26 May, 28 August 1911 (A. Busck); 1 \%, Corozal, C.Z., Panama, April 1911 (A. Busck); 1 \%, Kingston, Jamaica, 8 October 1882 (M. Grabham); 1 \% in auto from Mexico, 11 February 1952, at Brownsville, Texas; all in (USNM).

\section{Scenopinus butleri, new species}

FIGURE 81

This species is close to $S$. mirabilis but differs in the length as well as the shape of the third antennal segment and in the aedeagus and ninth segment claspers.

Male.--Head black; eyes red-brown above, dark red-brown below; frons narrow, triangular, rugose, subshining, a few hairs on either side of lower frons tend to make it look narrower; ocellar tubercle prominent, ocelli orange-red. Antennae with first antennal segment black-brown, moderately long; second segment black-brown, long, the first two half as long as the third; third segment red-brown, elongate, truncated, three times as long as widest point.

Thorax dorsum black, a deep lateral groove above the wing base; humeral callus red-brown; pleural areas black-brown. Wings smoky hyaline, veins light brown; R5 and M1 +2 widely separated, $M 1+2$ ending at tip of wing. Legs with femora and tibiae black-brown, fore and middle tarsi dark red-brown, hind tarsi red-brown.

Abdomen black-brown, segments 3-5 with broad white stripes; ninth segment black-brown; see figure for details. Aedeagus short and stout, parameres long and stout, ninth segment elaspers stout with depressed area of tip next to aedeagus, longer tip lateral; cup of syringe blackish.

Feniale.-Unknown.

Length: Male body $2.7 \mathrm{~mm}$., wing $2.5 \mathrm{~mm}$. 


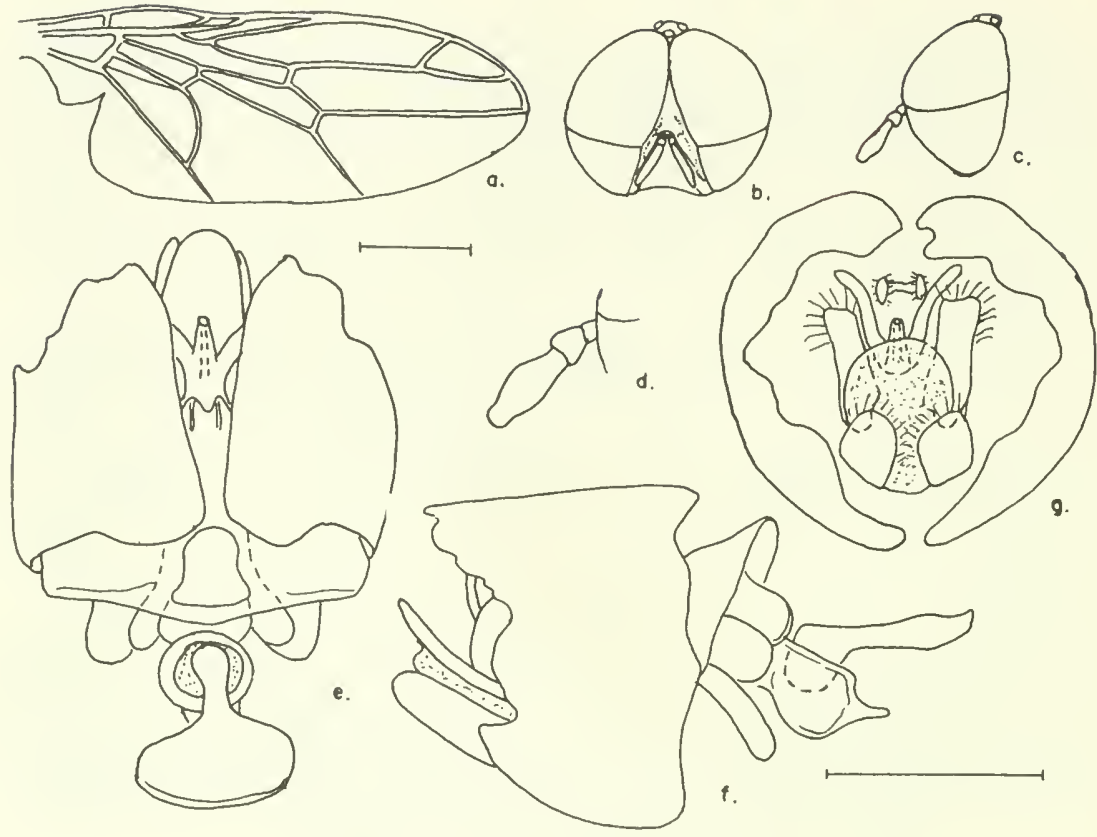

Figure 81.-Scenopinus butleri, new species, male: $a$, wing; $b$, $c$, frontal and lateral aspects of head; $d$, enlarged detail of antenna; $e-g$, ventral, lateral and posterior aspects of terminalia.

Type-locality: Cochise Stronghold, Dragoon Mts., Arizona; 24 April 1957, (F. Werner and G. Butler).

Holotype: Male (USNM) 68009.

\section{Scenopinus chico, new species}

Figure 82

This very small species from the Southwest has been given the Spanish diminutive as its specific name.

MaLE.--Head black; eyes brown-black above, black below; frons shining, swollen above the antennae and extending as a narrow band to the ocellar tubercle, which is prominent, shining, with orange ocelli. Mouthparts dark brown, well developed; oral cavity with silvery pilosity extending to the base of the antennae; back of head concave. First antennal segment short, black; second segment brown, larger than first; third segment brown, long slender, twice as long as 1 and 2 combined.

Thorax dorsum black, with flat silvery scalelike hairs, a thick patch on the posterior portion of the dorsum; humeral callus with a redbrown margin; pleural areas dark red-brown. Wings smoky white, 


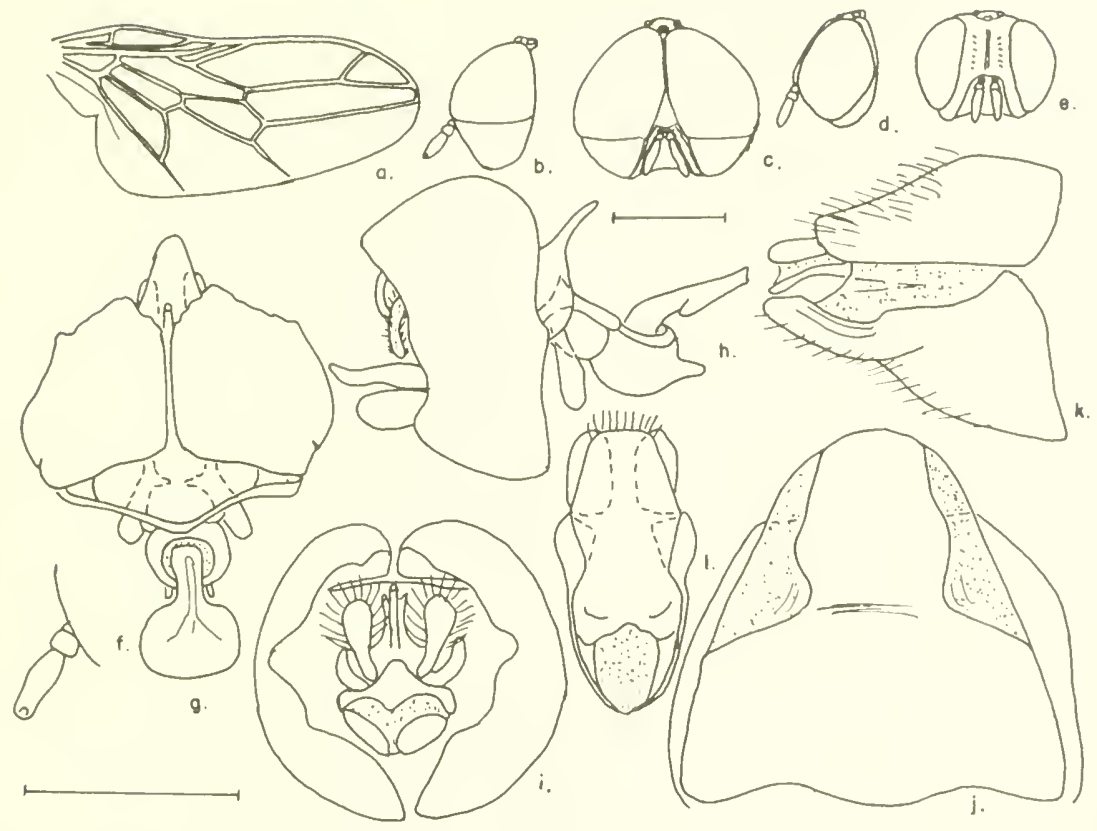

Figure 82.-Scenopinus chico, new species, male, female: $a$, wing; $b$, $c$, lateral and fronta! aspects of malc head; $d, e$, lateral and frontal aspects of female head; $f$, enlarged detail of antenna; $g-i$, ventral, lateral and posterior aspects of male terminalia; $j$, ventral aspect of female 8th sternum; $k$, lateral aspect of female 8 th and 9th segments; $l$, female 9th sternum and bursa.

veins straw yellow; $R 5$ and $M 1+2$ widely separated; halter stem brown, knob white. Legs with basal portions through the femora red-brown, tibiae light brown, tarsi straw yellow with darker tips.

Abdomen short, compressed, dark red-brown; segments 3-5 with broad white bands dorsally, remainder red-brown. For details on shape of ninth tergum and genital apparatus, see figure.

Fendat- - Head black-brown; eyes black-brown; with the narrow nostocular ridge depressed below the level of the eyes; frons broad, subshining, rugose with a median groove extending from the antennac to the median ocellus; ocellar triangle slightly elevated, ocelli clear; monthparts well dereloped. Antennae as in the male.

Thorax dorsum red-brown with thin scalelike hairs, sparse, no dorsal patch as in the male. Other characters as in the male.

Abdomen red-brown, shining, with a few hairs. See figure for details of eighth segment and bursa.

Length: Male body 2-2.2 mm., wing 1.6-1.8 mm.; female body $2.7 \mathrm{~mm}$., wing $1.8 \mathrm{~mm}$. 
Type-locality: El Centro, California; 27 June 1917, (J. M. Aldrich).

Holotype: Male (USNM) 67474.

Allotype: Female, Palm Springs, California, 10 April 1946, (A. L. Melander).

Paratypes: $2 \sigma^{7} \sigma^{7}$, same data as type; $1 \sigma^{7}$, Las Vegas, Nevada, 9 September 1930, (E. W. Davis) (USNM); $10^{\pi}$, Palm Springs, California, 3 April 1955, (W. R. M. Mason) (CNC); $10^{x}$, Calexico, California, 11 September 1952, (E. I. Schlinger); $1 \sigma^{7}$, Borrego, San Diego Co., California, 3 May 1956, (M. Wasbauer) (UCalD); $1 \sigma^{7}$, near Segurra, California, 14 April 1949, (Timberlake); $1 \sigma^{7}, 2$ miles s...-?, Imperial Co., California, 24 May 1936, (F. R. Platt) (PHT); $1 \sigma^{7}$, Sentinel, Arizona, 23 July 1941, (R. H. Beainer) (UKan).

\section{Scenopinus cochisei, new species}

\section{Figure 83}

MALE.-Head black-brown; eyes dark brown-red above, blackbrown below; frons small, triangular, extending half-way to the ocellar triangle, shining, margined with shallow pits along the eye margin; ocellar tubercle prominent, ocelli clear. Mouthparts brown, well developed, the palpi red-brown, shorter than the rostrum; antennae

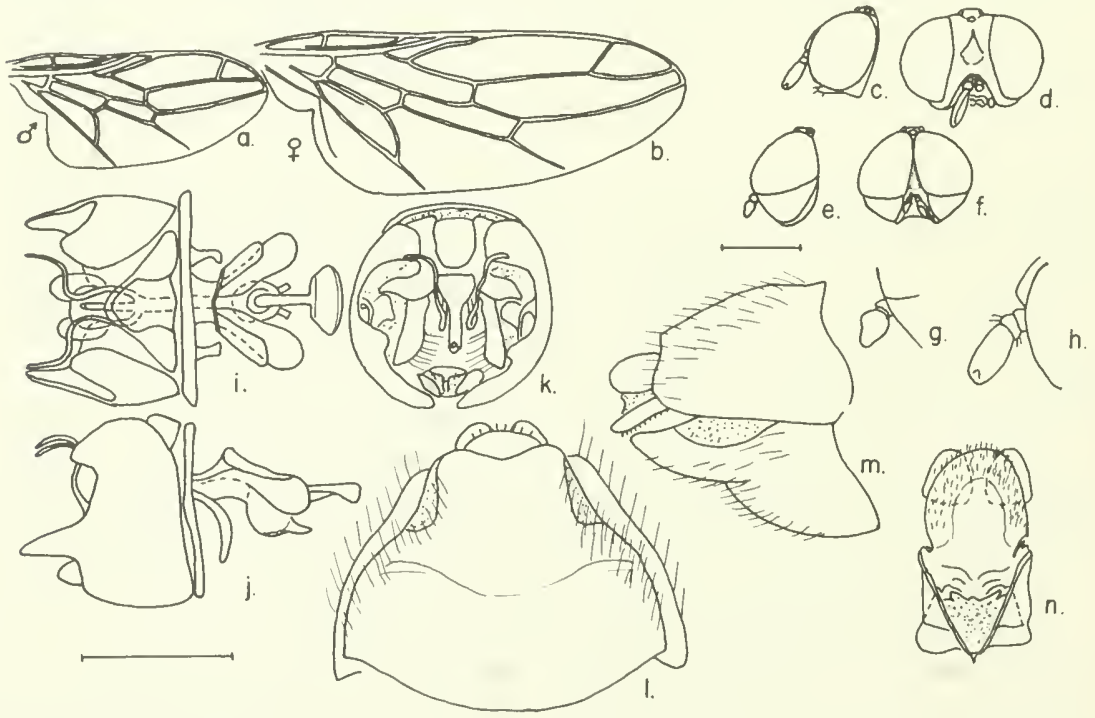

Figure 83.-Scenopinus cochisei, new species, male, female: $a$, male wing; $b$, female wing; $c, d$, lateral and frontal aspects of female head; $e, f$, lateral and frontal aspects of male head; $g, h$, enlarged details of male and female antennae; $i-k$, ventral, lateral and posterior aspects of male terminalia; $l$, ventral aspect of female 8 th sternum; $m$, lateral aspect of female 8 th and 9 th segments; $n$, female 9 th sternum and bursa. 
with first segment very small, black-brown; second segment brown, rounded, much larger than the first; third segment black-brown. pear-shaped only a little longer than broad.

Thorax dorsum black-brown, humeral and supra-alar calli redbrown; pleural areas dark red-brown. Wings smoky, veins tan; halter stem red-brown, knob white. Legs dark red-brown, except tarsi which are orange-brown.

Abdomen short, red-brown, segments 3-5 extensively white dorsally; ninth tergum with dorsal points; aedeagal parameres long, like $S$. mirabilis. See figure for details of terminalia.

Female.-Head red-brown; eyes black, with a narrow pollinose postocular ridge; frons broad, subshining, red-brown below, black above, with a broad shallow depression on the lower portion. Ocellar tubercle flat but marked off from frontal area; mouthparts extending only half the length of the oral cavity; palpi sub-equal; inner surface of oral cavity pollinose; lateral portions to the eye broad, shining. Antennae with first segment dark red-brown, subshining; second segment red-brown, pollinose, as long as first segment but wider; third segment red-brown, pollinose, about twice as long as broad, very little taper.

Thorax dorsum dark red-brown; humeral callus with a posterior orange patch; supra-alar callus orange-brown, wings hyaline, smoky brown; veins brown; halter stem dark brown, knob creamy with tan margins. Legs with femora dark red-brown, remainder red-brown. Abdomen red-brown. See figure for details of eighth segment and bursa.

Length: Male body $2 \mathrm{~mm}$., wing $1.7 \mathrm{~mm}$.; female body $4 \mathrm{~mm}$., wing $3 \mathrm{~mm}$.

Type-locality: Chiricahua Mts., Arizona; 4 July 1940, (L. C. Kuitert).

Holotype: Male (UKan) 6289.

Allotype: Female, Rustlers Park, Chiricahna Mts.; 5 July 1940, (L. C. Kuitert) (UKan).

Paratype: Male Calexico, California; 8 April 1947, (A. L. Melander) (USNM).

\section{Scenopinus cooki, new species}

Figure 81

MALE.-Head dark red-brown; eyes red-brown above, black-brown below; frons small, triangular, with a large elongate median depression, shining above, and an inverted triangle below. Ocellar triangle red-brown, prominent, ocelli orange. Back of head concave, only a narrow postgenal strip showing behind lower half of eye. Mouthparts large, brown; palpi red-brown long; white pubescence between oral opening and eye margin extending into points above the antennae. 

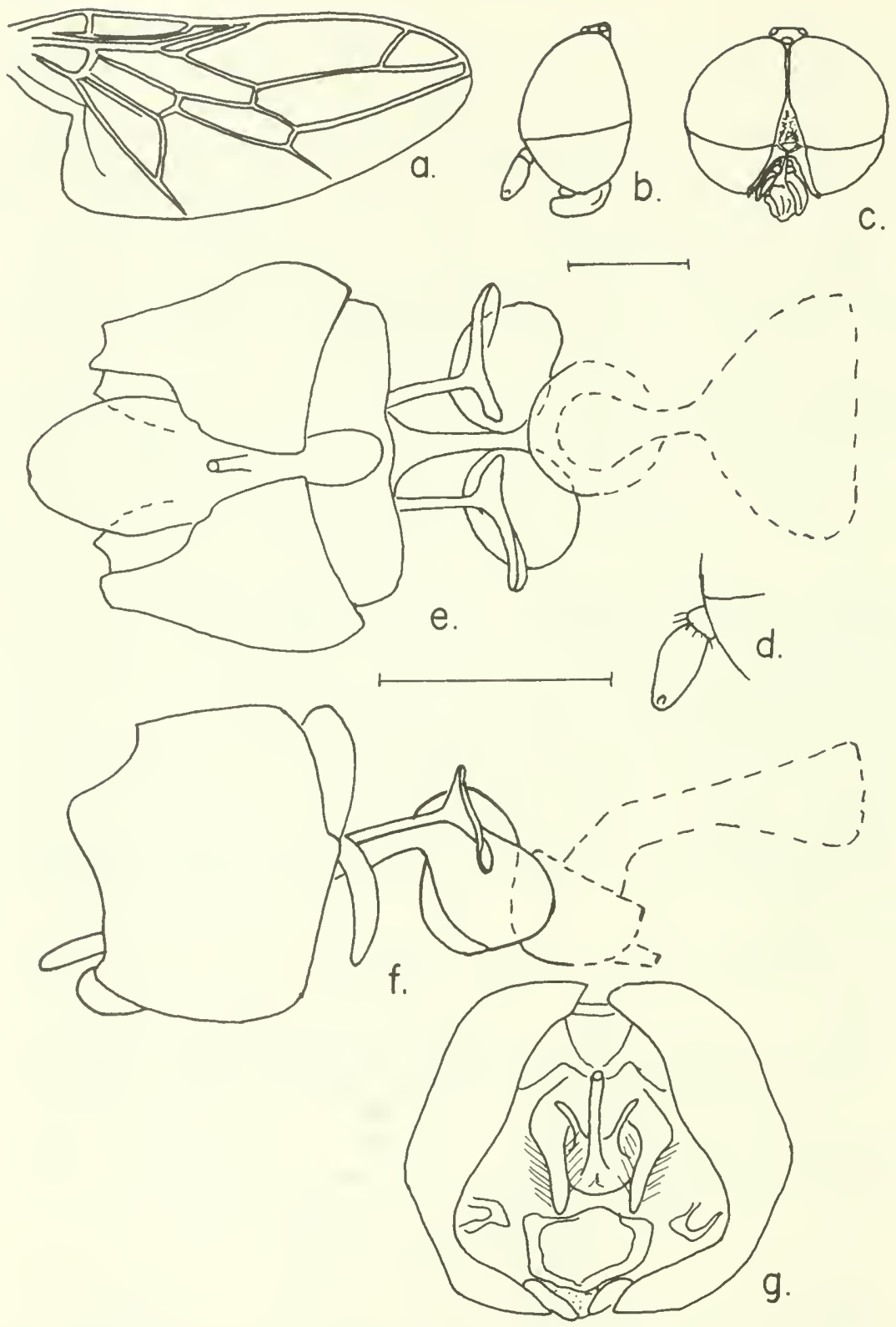

Figure 84.-Scenopinus cooki, new species, male: $a$, wing; $b, c$, lateral and frontal aspects of head; $d$, enlarged detail of antenna; $\ell-g$, ventral, lateral and posterior aspects of terminalia, severed portion of ejaculatory mechanism outlined. 
Antennae red-brown, first segment short, second lighter distally, wider than long, third segment pear-shaped, over twice as long as broad, over twice as long as the first two segments combined.

Thorax dorsum dark red-brown, rugose with transverse striations, very thinly haired, a small patch of silvery pubescence above the humeral callus; humeral and supra-alar calli orange; scutellum dark red-brown above, lighter below; pleural areas red-brown. Wings milky, reins tan, halter stem brown, knob dark brown. Legs with femora brown, tibiae orange-brown; tarsi cream basally, orangebrown distally.

Abdomen dark red-brown, segments 3-5 broadly white margined, ninth tergum with a medioventral swelling on posterior margin; see figure for details.

Female.-Unknown.

Length: Male body $3 \mathrm{~mm}$., wing $2.1 \mathrm{~mm}$.

Type-locality: Patagonia, Arizona; 11 July 1950, (Paul P. Cook).

Holotype: Male (UKan) 6290.

\section{Scenopinus cretatus, new species}

Figure 8;

MALE.-Head red-brown; eyes brown above, red-brown below, upper area twice as extensive as lower; frons triangular, rugose, extending half the distance to the ocellar tubercle; mouthparts

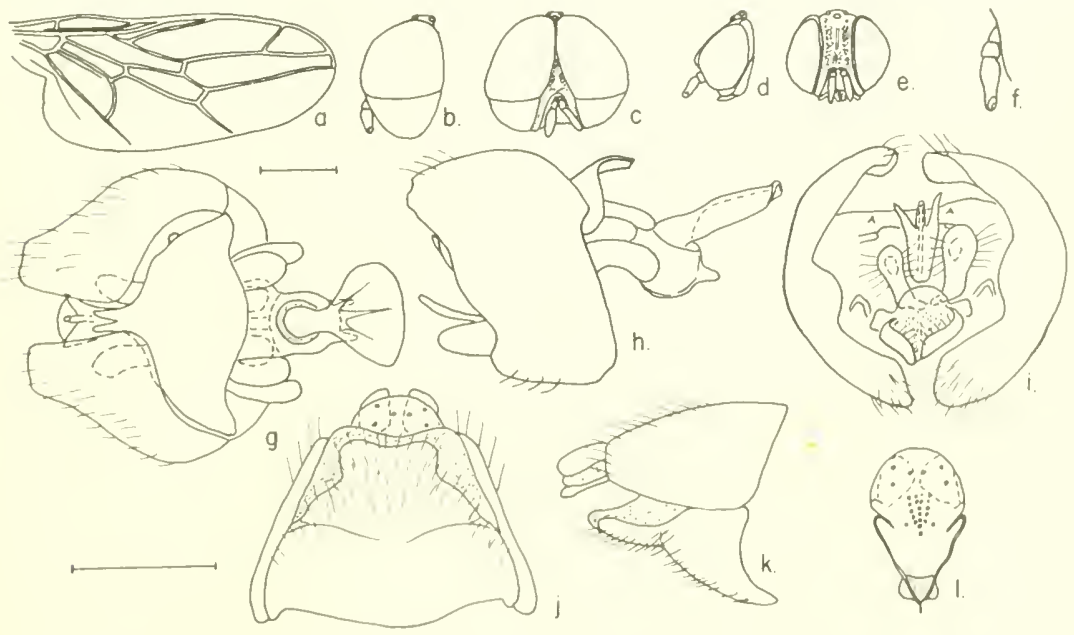

Figure 85.-Scenopinus cretatus, new species, male, female: $a$, wing; $b$, $c$, lateral and frontal aspects of male head; $d, e$, lateral and frontal aspects of female head; $f$, enlarged detail of antenna; $g-i$, ventral, lateral and posterior aspects of male terminalia; $j$, ventral aspect of female 8 th sternum; $k$, lateral aspect of female 8 th and 9 th segments; $l$, female 9 th sternum and bursa. 
developed, but short, less than half the length of the oral opening; palpi short; margin of face between oral opening and eye silvery pilose to above the antennal base; back of head concave. Ocellar tubercle not prominent, ocelli clear; antennae red-brown, first segment short; second twice as large as first; third elongate, pear-shaped, over twice as long as first two combined.

Thorax dorsum black, rugose with scattered light hairs; humeral and supra-alar calli orange-brown; pleural areas red-brown. Wings milky, veins tan; halter stem brown, knob white. Legs red-brown except proximal portion of tarsi orange-brown.

Abdomen red-brown, segments $3-5$ broadly white except at lateral margins where triangular pieces of sclerotized tissue remain. Terminalia red-brown; see figure for details of structures.

Female.-Head black, eyes red-brown; a medium wide subshining postocular band extending into a broad postgenal area below and behind the eyes; frons broad, slightly narrower than the eye when viewed from the front, swollen above the antennae, with a median groove and depression above the swelling, groove extending to just below the median ocellus, surface rugose subshining; ocellar tubercle not distinctly separated or elevated, ocelli clear to amber; mouthparts red-brown, short, with short palpi; silvery pile between oral opening and eye margin. Antennae as in the male.

Thorax as in male; wing veins darker:

Abdomen red-brown subshining; for eighth segment details and bursa, see figure.

Length: Male body $3.2 \mathrm{~mm}$., wing $2.3 \mathrm{~mm}$.; female body $3 \mathrm{~mm}$., wing $2.3 \mathrm{~mm}$.

Type-locality: \& mi. s. Lovelock, Nevada; 30 May 1958, (T. R. Haig).

Holotype: Male, allotype female, same data, (USNM) 67475.

Paratype: $\sigma^{7}$ Adelaide, Idaho; 7 July 1927, (UCalD).

\section{Scenopinus curticornis (Kröber)}

Figure 86

Omphrale curticornis Kröber, 1913, p. 202.

This species from Brazil is known only from the type and is easily distinguished by the extremely short third antennal segment.

MaLE.-Unknown.

Length: Female body $4.5 \mathrm{~mm}$., wing $2.8 \mathrm{~mm}$.

Type-locality: Brazil; in Winthems Coll. as pygmaeus Loew.

Type: (NMV). 

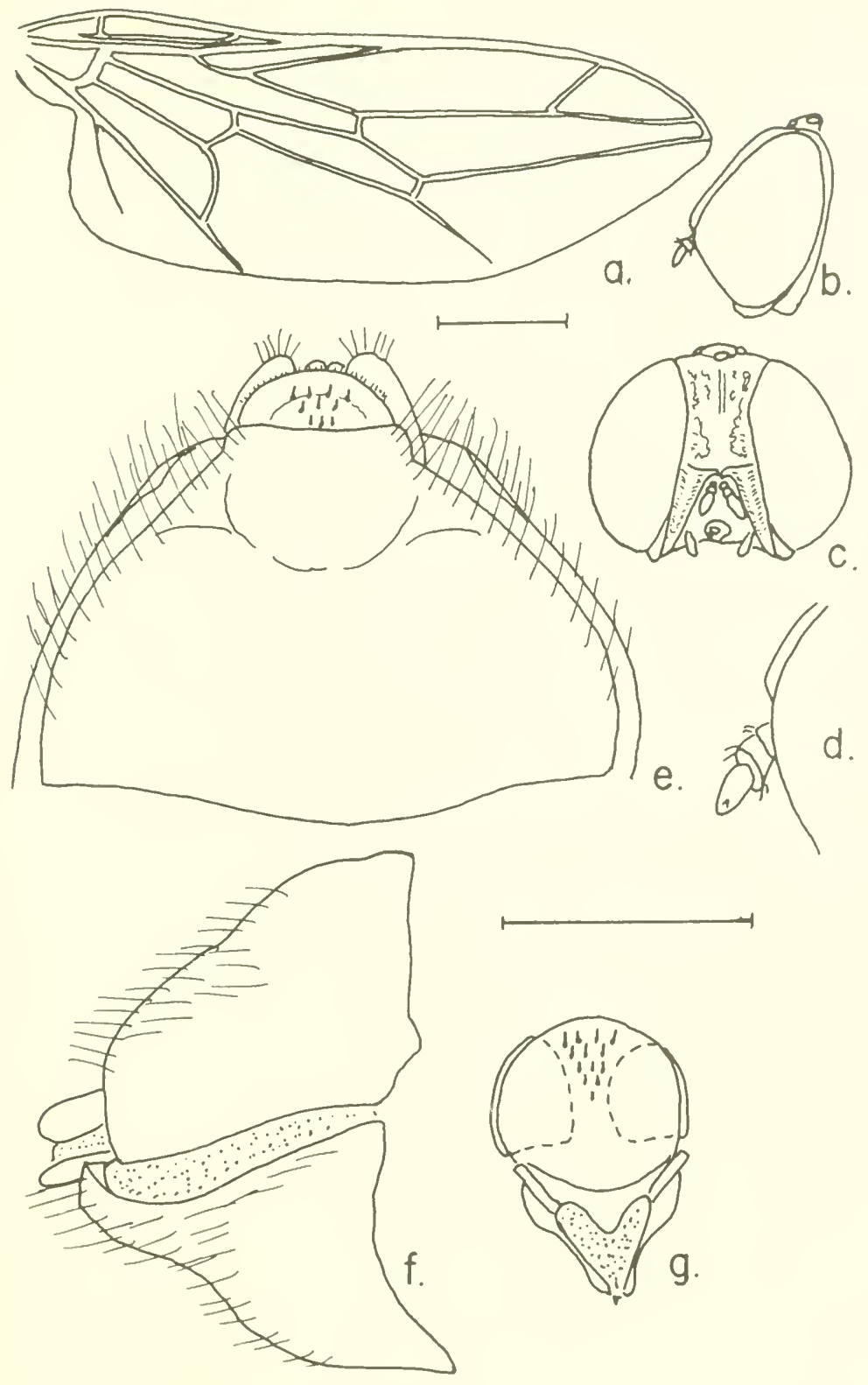

Figure 86,-Scenopinus curticornis (Kröber), female: $a$, wing; $b$, $c$, lateral and frontal aspects of head; $d$, enlarged detail of antenna; $e$, ventral aspect of 8 th sternum; $f$, lateral aspect of 8 th and 9th segments; $g$, 9 th sternum and bursa. 


\section{Scenopinus electus Adams}

\section{FiguRe 87}

Scenopinus electus Adams, 1904, p. 445.

This species is noted by its elongate straight antennae and by the fold in the ventral posterior margin of the ninth tergum. The type and allotype have not been examined and no females fitting the species have been seen.

Length: Male body 2.8-3.3 mm., wing 2-2.3 mm.; female body $2.5 \mathrm{~mm}$.

Type-locality: Bill Williams Fork, Arizona (F. H. Snow).

Types: (UKan).

The following specimens have been seen: $1 \sigma^{7}$, Gilliland Ranch, Phoenix, Arizona, 17 May 1940, citrus sweeps (Lot No. 40-12517) (USNM) ; $1 \sigma^{7}$, Isla Partida, Gulf of California, Mexico, 23 March 1953 (P. H. Arnaud); $1 \sigma^{7}$, Los Frailes, Baja California, Mexico, 18 March 1953 (P. H. Arnaud) (CAS); $1 \sigma^{7}$, Cedros (island), Baja California, Mexico, 3 June 1925 (H. H. Keifer) (UCa1B); $1 \sigma^{7}$, Blythe, California, 24 April 1955 (D. F. Hardwick) (CNC).

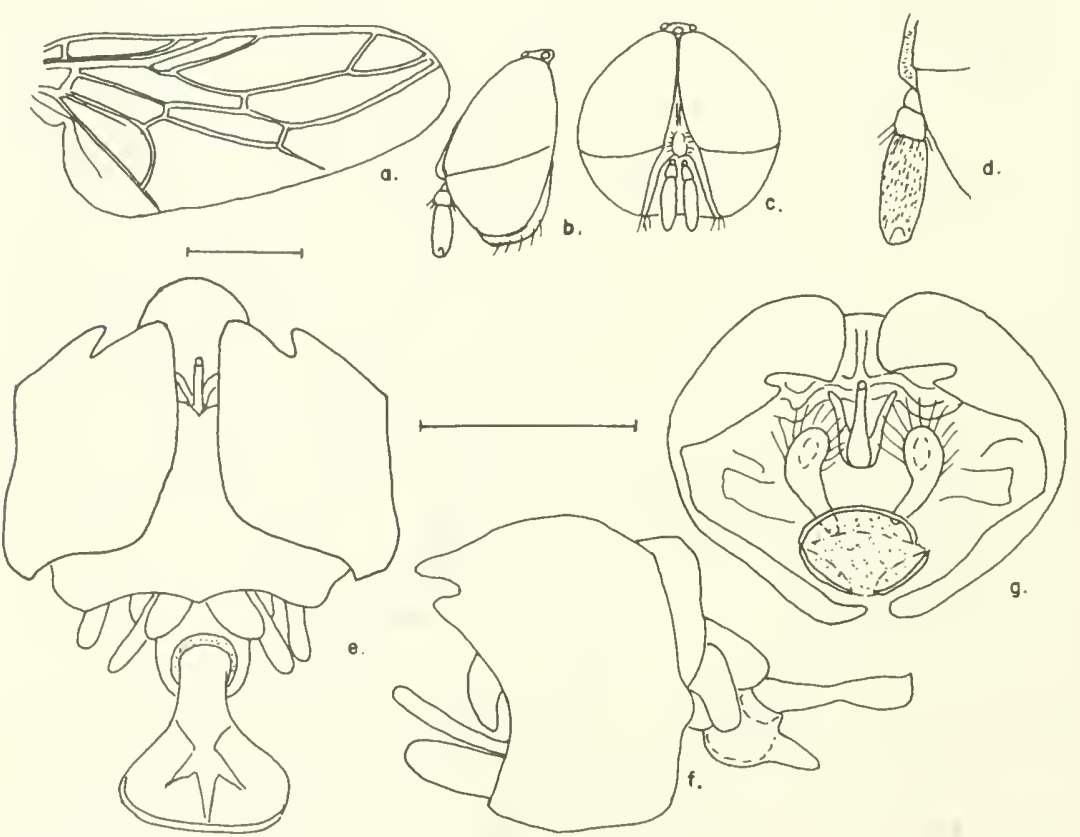

Figure 87.-Scenopinus electus Adams, male: $a$, wing; $b, c$, lateral and frontal aspects of head; $d$, enlarged detail of antenna; $e-g$, ventral, lateral and posterior aspects of terminalia. 


\section{Scenopinus femoratus Macquart}

Scenopinue femoratus Macquart, 1835, p. 7.

Examination of the Macquart collection in the Museurn of Natural History, Paris, failed to bring this species to light although other Scenopinidae identified by him were in the collection.

Length: Female body $2.25 \mathrm{~mm}$.

Type-locality: Brazil.

\section{Scenopinus fijianus (Ḱ̈̈̈ber)}

Figure 88

Omphrale fijianus Kröber, 1939, p. 399.

The type was examined and figured as far as possible, the antennae and abdomen of the type are missing so could not be figured; a copy of Kröber's detail of the antenna is included in the plates. A specimen in the (USNM), remored from an airplane in quarantine on Oahu, Hawaii, which agrees with the wing of the type, is figured.

Length: Female body $3 \mathrm{~mm}$., wing $2.5 \mathrm{~mm}$.

Type-locality: Sura, Fiji Islands; \& March 1928 (H. S. Simonds).

Type: (BMNH).
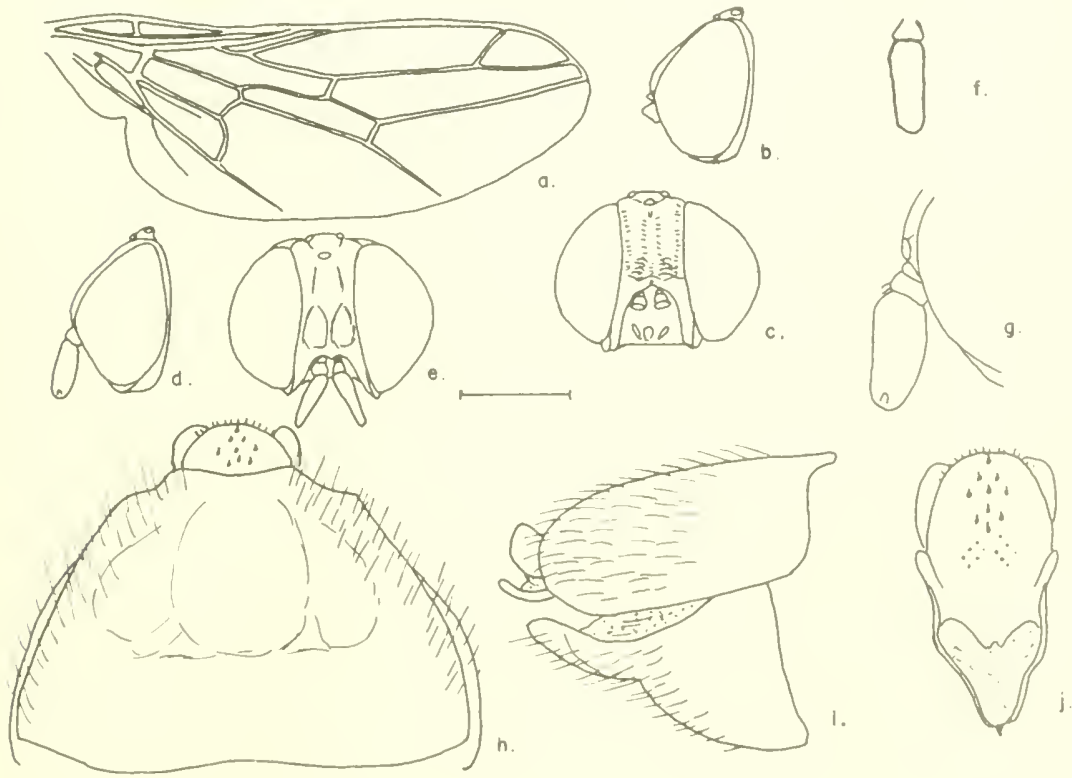

Figure 88.-Scenopinus fijianus (Kröbcr), female: $a$, wing (type); $b$, c, lateral and frontal aspects of head (type); $d, e$, lateral and frontal aspects of specimen agrecing with Kröber figures; $f$, detail of antenna (after Kröber); $g$, detail of antenna of specimen agrecing with type, (abdomen of type lost); $h$, ventral aspect of 8 th stcrnum; $i$, lateral aspect of 8 th and 9 th segments; $j, 9$ th sternum and bursa. 


\section{Scenopinus flandersi, new species}

Figure 89

MaLE.-Head black-brown; eyes red-brown above, dark red-brown below; frons subshining, extending narrowly from antennal base between silvery pile to broader area, then narrowing to a thin line
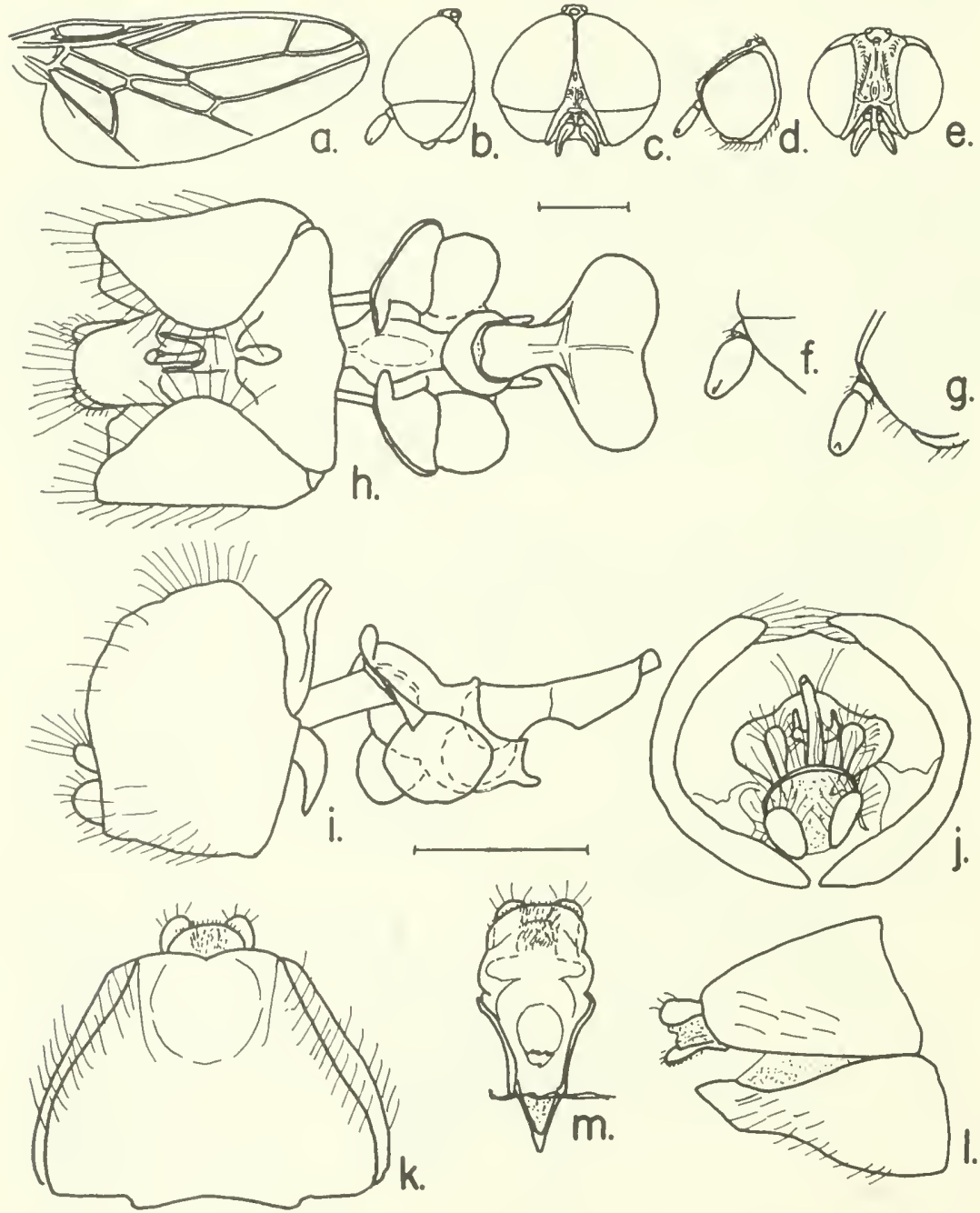

Figure 89.-Scenopinus flandersi, new species, male, female: $a$, wing; $b$, $c$, lateral and frontal aspects of male head; $d, e$, lateral and frontal aspects of female head; $f$, $g$, enlarged details of male and female antennae; $h-j$, ventral, lateral and posterior aspects of male terminalia; $k$, ventral aspect of female 8th sternum; $l$, lateral aspect of female 8 th and 9 th segments; $m$, female 9 th sternum and bursa. 
halfway to the prominent ocellar tubercle, ocelli orange-brown; postgena narrow below and behind the eyes; mouthparts brown, well developed, filling the oral carity; palpi brown, nearly as long as the rostrum; oral cavity bordered by silvery pile which extends onto the frons well above the antennal basc. Antennae dark red-brown, first segment short, second twice as large as the first, third approximately twice as long as broad, narrowing distally; see figure.

Thorax dorsum black with a patch of silvery pile above the humeral callus; tips of humeral callus and the supra-allar calli orange; pleural areas red-brown. Wings smoky hyaline, veins tan, fading before end of the wing; halter stem black-brown, knob creamy white. Legs with femora and tibiae red-brown, tarsi straw yellow.

Abdomen dark red-brown, segments 3-5 with medium broad white bands along posterior edge. For details of terminalia, see figure.

Female.-Head dark red-brown, eyes red-brown, with a narrow postocular ridge; frons rugose, subshining, swollen above the antennae and depressed medially just above swelling, extending as a slight median depression or line to median ocellus; ocellar tubercle not prominent, ocelli red-brown; oral cavity bordered by a silvery pile which extends above the antennae; mouthparts large, well developed; palpi long, genal area small. Antennae as in the male.

Thorax dorsum black-brown, with a silvery pilose area above the humeral callus which is red-brown; supra-alar callus tan. Pleural areas red-brown. Wings hyaline, brownish, veins brown; halter stem brown, knob red-brown. Legs with femora and tibiae red-brown, tarsi straw yellow.

Abdomen red-brown; see figure for details of eighth segment and bursa.

Length: Male body $3 \mathrm{~mm}$., wing $2 \mathrm{~mm}$.; female body $3.4-4 \mathrm{~mm}$., wing $2.2-2.4 \mathrm{~mm}$.

Type-locality: Redlands, California; 1 May 1953 (S. Flanders), ex elm branch.

Holotype: Male (CAS) 8916 (ex $\left.\left[\mathrm{PH}^{\prime} \mathrm{T}\right]\right)$.

Allotype: Female same data (CAS).

Paratypes: $1 \sigma^{7}, 1 \%$, same data as type (USNM); 2 ㅇ, same data as type; $1 \sigma^{7}$, Sierra Madre, Monterey Co., California, 20 October 1923 (Armitage) (PH'T); $1 \sigma^{x}$, Long Beach, California, 14 August 1949 (A. L. Melander) (USNM).

\section{Scenopinus gossypius, new species}

Figure 90

This species is widely distributed across the sonthern United States, from the Atlantic to the Pacific. Information appended to the speci- 
mens indicates that is has been swept from cotton and reared from cotton squares; it may be a predator of the boll weevil or boll worm.

MaLE.-Head red-brown to black-brown; eyes red-brown above, black-brown below; frons narrow, rugose, with a median groove ending in a shallow pit at the upper extremity; ocellar triangle only slightly elevated, ocelli orange; mouthparts well developed, light brown, palpi thin, elongate; oral opening bordered with silvery pile. First antennal segment short, brown; second segment larger, light brown; third segment brown, slightly tapering, $2 \frac{1}{2}$ times longer than one and two combined; see figure.

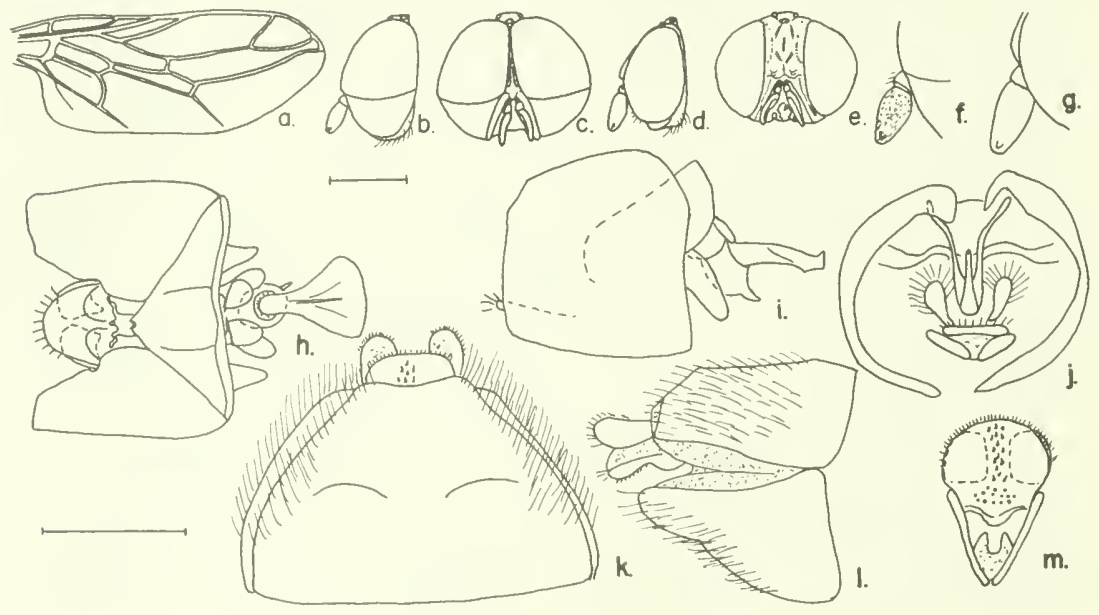

Figure 90.-Scenopinus gossypius, new species, male, female: $a$, wing; $b, c$, lateral and frontal aspects of male head; $d, e$, lateral and frontal aspects of female head; $f, g$, enlarged details of antennae; $h-j$, ventral, lateral and posterior aspects of male terminalia; $k$, ventral aspect of female 8th sternum; $l$, lateral aspect of female 8 th and 9 th segments; $m$, female 9 th sternum and bursa.

Thorax dorsum, red-brown to black-brown, striated, a thin patch of silvery pile above the humeral callus which has a thin straw colored posterior margin. Wings smoky hyaline, veins brown, $\mathrm{R} 5$ and $\mathrm{M} 1+2$ constricting distally and then widening shightly at wing margin to give a bottle shape to cell R5; halter with stem dark brown to brown, knob red-brown to orange-brown above, light below. Legs with coxae through the femora ground color, tibiae grading from orange-brown anteriorly to red-brown on hind pair, tarsi straw colored darkening distally.

Abdomen, black-brown to red-brown with two white bands on segments 4 and 5, sparsely covered with posteriorly directed hairs. See figure for details of terminalia; close to $S$. velutinus but differs in shape of aedeagus, ninth tergum, and ejaculatory process. 
Female.--Head, black-brown to red-brown; eyes black-brown with a very narrow postocular ridge; frons rugose, with two swellings on either side of mid-facial groove above antennac extending into a median depression, above which a faint median groove extends to median ocellus; ocellar triangle shallow but set off from frons, ocelli orange.

Thorax, wings, halteres, and legs as in male.

Abdomen, black-brown to red-brown, thinly covered with posteriorly directed hairs. For details of eighth segment and bursa, see figure.

Length: Male body 3-3.5 mm., wing 2.3-2.5 mm.; female body $3.5-4.2 \mathrm{~mm}$., wing $2.5-3 \mathrm{~mm}$.

Type-locality: Dallas, Texas; $24 A_{p}$ ril 1907 (W. W. Yothers)

Holotype: Male (USNM) 67473.

Allotype: Female Dallas, Texas; 5 July 1909 (W. W. Yothers) (USNM).

Paratype males: $1 \sigma^{7}$. Dallas, Texas, 24 April 1907 (W. W. Yothers); $10^{7}$, Kerrville, Texas, 11 June 1953 (L. J. Bottimer), $4 \sigma^{7} \sigma^{7}$, Los Angeles, California, 1928 (H. M. Armitage) (on window in propagation room) (USNM); $1 \sigma^{7}$, Jacksonville, Florida (Mrs. A. T. Slosson) (AMNH).

Paratype females: 46 specimens from the following localities: Alachua Co., Florida; Gainesville, Florida; Monticello, Florida; Quiney, Florida; Tifton, Georgia; Jekyll Island, Georgia; Clark Co., Georgia; Selma, Alabama; Florence, Alabama; Rivers, Tennessee; West Point, Mississippi; Belzono, Mississippi; Utica, Mississippi; Ecuador Parish, Louisiana; Galveston, Texas; Coma Island, Texas; Brownsville, Texas; Austin, Texas; Hearney, Texas; Kerrville, Texas; Calvert, Texas; Mesilla, New Mexico; Nogales, Arizona; Riverside, California; Los Angeles, California; Olancha, California; Claremont, California; all in (USNM). 2 o , Jacksonville, Florida (Mrs. A. 'T. Slosson) (AMNH). 1 o, Clarke Co., Georgin, 17 September 1937 (Horace O. Lund) (UGa). 1 \%, I Ja Jolla, California, 13 July 1941 (E. L. 'Todd). 1 9, Green River Camp, lower Santa Ana (Co., California, 11 May 1933 (E. P. VanDuzee) (C'S ) 1 q, ('ompton, Los Angeles Co., California, 31 July 1952 (E. Swift) (UCalD). 1 \%, Riverside. California (Timberlake) (PH'T). 1 o, (iuamuchil, Sinaloa, Mexico, s May 1963 (R. ('. Bechtel, E. I. Schlinger) (UCalB). 1 q, Manning, South Carolina, 1 April 1945 (C'. Sabrosky) (CSC).

\section{Scenopinus hagai, new speeies}

Figure: 91

MALE.- Head black-brown; eves red-brown above, black-brown below; frons subshining, nenrly divided above the antemus by the dorsal extension of silvery pilosity surrounding the oral carity, an 
shallow shining depression on upper third of frons; ocellar tubercle prominent, ocelli clear; mouthparts brown, well developed; palpi nearly as long as labellum. First antennal segment brown, short; second segment orange-brown, twice as large as first; third segment brown, elongate oval, twice as long as wide.

Thorax dorsum black-brown with a patch of silvery pile above the orange humeral callus; scutellum and pleural areas red-brown. Wings hyaline, veins yellow; halter stem brown, knob creamy to dark brown above, white below. Legs red-brown through the femora, tibiae light brown, tarsi straw yellow.

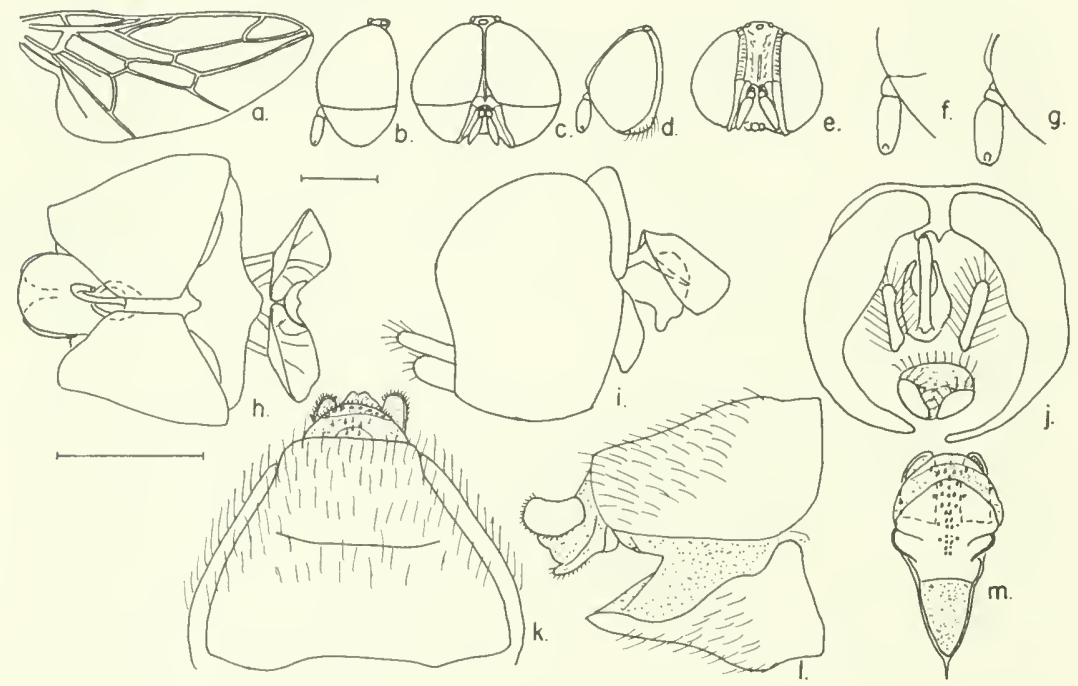

Figure 91.-Scenopinus hagai, new species, male, female: $a$, wing; $b, c$, lateral and frontal aspects of male head; $d, e$, lateral and frontal aspects of female head; $f, g$, enlarged details of male and female antennae; $h-j$, ventral, lateral and posterior aspects of male terminalia (ejaculatory syringe apodeme missing); $k$, ventral aspect of female 8 th sternum; $l$, lateral aspect of female 8 th and 9 th segments; $m$, female 9 th sternum and bursa.

Abdomen dark red-brown, segments $3-5$ with thin white posterior bands which increase in width toward the tip of the abdomen. For details of terminalia, see figure. Differs from $S$. gossypius in larger ejaculatory mechanism, parameres, and shape of ninth tergum.

Female,-Head black-brown; eyes red-brown with a narrow postocular rim; frons broad, swollen above the antennae, a median groove through the lower third; back of head and rim of post-ocular flange pollinose; mouthparts red-brown, well developed as in the male; silvery pile bordering oral opening, extending above the antennae onto the frontal area; ocellar tubercle depressed, not prominent, ocelli red-brown. Antennae with first segment short, black-brown; 
second segment larger, red-brown; third segment, black-brown, pilose, elongate oval, over twice as long as first two segments combined.

Thorax dorsum black-brown, with a pilose patch above the humeral callus which is red-brown anteriorly with an orange posterior border: supra-alar callus yellow-orange; scutellum red-brown; pleural areas dark red-brown; wings brownish, veins brown; halter stem brown, knob red-brown above, white below. Legs: femora red-brown, tibiae brown, tarsi straw yellow.

Abdomen dark red-brown. See figure for details of eighth segment and bursa.

Length: Male body $2.7 \mathrm{~mm}$., wing $2.1 \mathrm{~mm}$.; female body $3.5 \mathrm{~mm}$., wing $2.3 \mathrm{~mm}$.

Type-locality: Ýma, Arizona; 6 July 1953 (Haga) on cotton. Holotype: Male (USNM) 68007.

Allotype: Female Yuma, Arizona, 21 July 1953 (Haga) (USNM).

\section{Scenopinus houdeni, new spccies}

Figure 92

FEMALE.-Head black; eyes black-brown, with a narrow subshining postocular band; frons rugose, with a narrow shining band along the eye margins, swollen above the antennae, with a median groove extending to the median ocellus, swollen between the ocellar tubercle and upper corner of the eye; ocellar triangle flattened, cut off from frons; ocelli orange. Mouthparts well developed; oral opening surrounded by a white pubescence which extends over antennal bases; genae shining. Antennae black-brown, first segment small; second segment twice as large, subshining; third segment granular, over twice als long as wide.

Thorax dorsum black-brown, striated, with a white pubescent patch above the lumeral callus, which is orange-brown; pleural areas red-brown, subshining; wings hyaline, reins brown, cell R5 narrowing sharply at tip of wing; halter stem red-brown, knob tan. Legs with foreleg brown through tibia, tarsus crean, darkening distally; middle leg with coxis and femur red-brown, tibia brown, tarsus cream, darkening distally; hind leg red-brown except tarsus cream, darkening distally.

Abdomen red-brown. See figure for details of eighth segment and bursia.

MALE.-Unknown.

length: Female body $4.4 \mathrm{~mm}$., wing $3 \mathrm{~mm}$.

Type-locality: S.W. Res. Sta., Portal, Arizona; 26 June 1956 (H. and A. Howden).

Holotype: Female (CNC) 8958. 

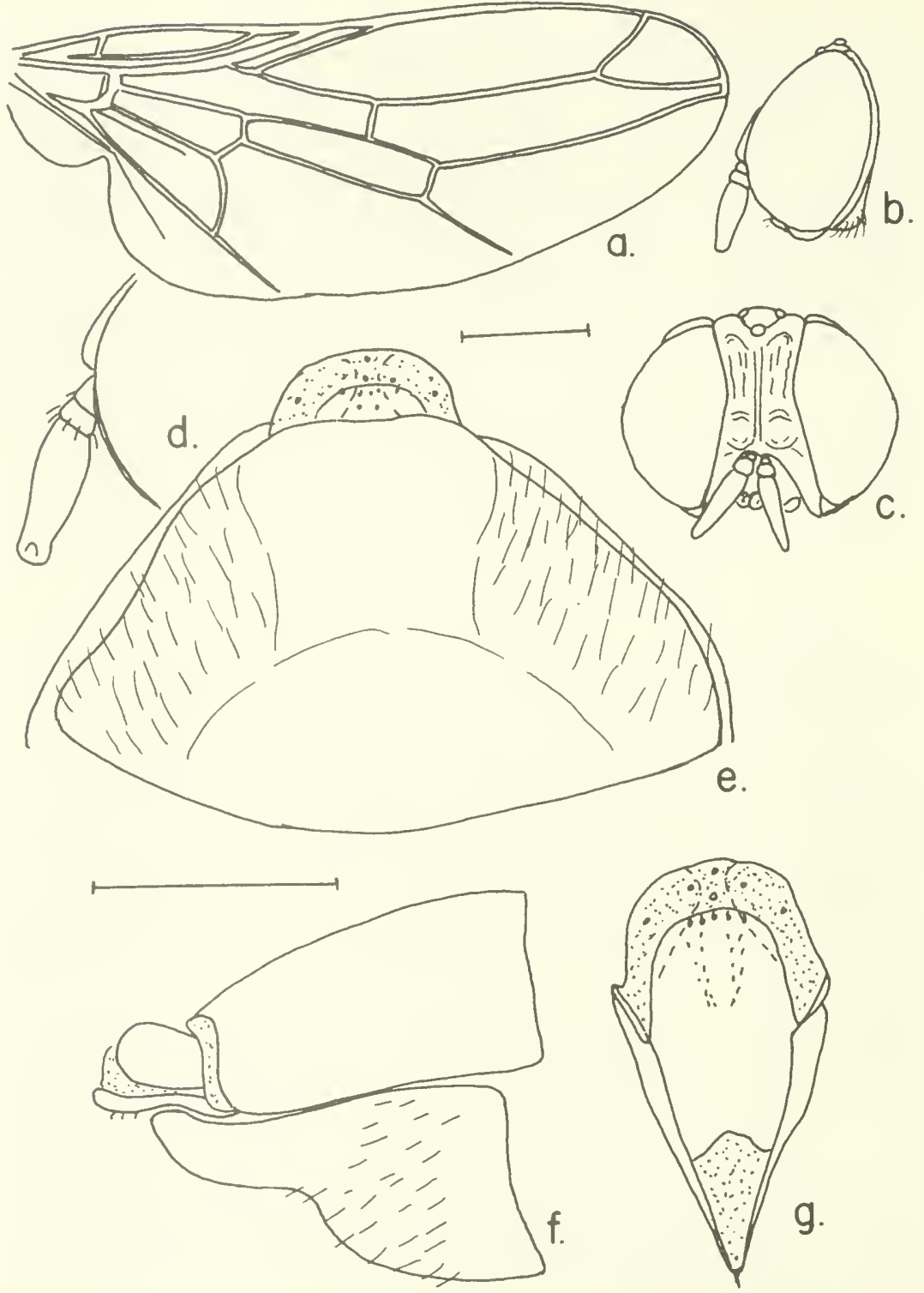

Figure 92.-Scenopinus howdeni, new species, female: $a$, wing; $b, c$, lateral and frontal aspects of head; $d$, enlarged detail of antenna; $e$, ventral aspect of 8 th sternum; $f$, lateral aspect of 8 th and 9 th segments; $g$, 9th sternum and bursa. 


\section{Scenopinus kuiterti (D. E. Hardy)}

FigLre 93

Omphrale kuiterti I). E. Hardy, 1944a, p. 46.

The male of this speries is distinguished by the long aedeagal parameres and the point on the ventral margin of the ninth tergum. It can be distinguished from $S$. cochise $i$ by the shape of the ninth tergum and the longer antemne. The female was heretofore unknown and the description follows.

Female.-Head black; eyes red-brown with a narrow postocular rim behind the eyes; frons smooth, shining along eve margins, genae and swelling over the antennal base; transversely lugose over most of frontal area with a shallow median depression; ocellar triangle flat, set off from frons; ocelli orange. Mouthparts brown, well developed, palpi black-brown, half the length of oral cavity; no silvery pile along oral opening. First antennal segment black-brown, short; second, red-brown; third, rec'-brown, slim, over twice as long as first two segments combined.

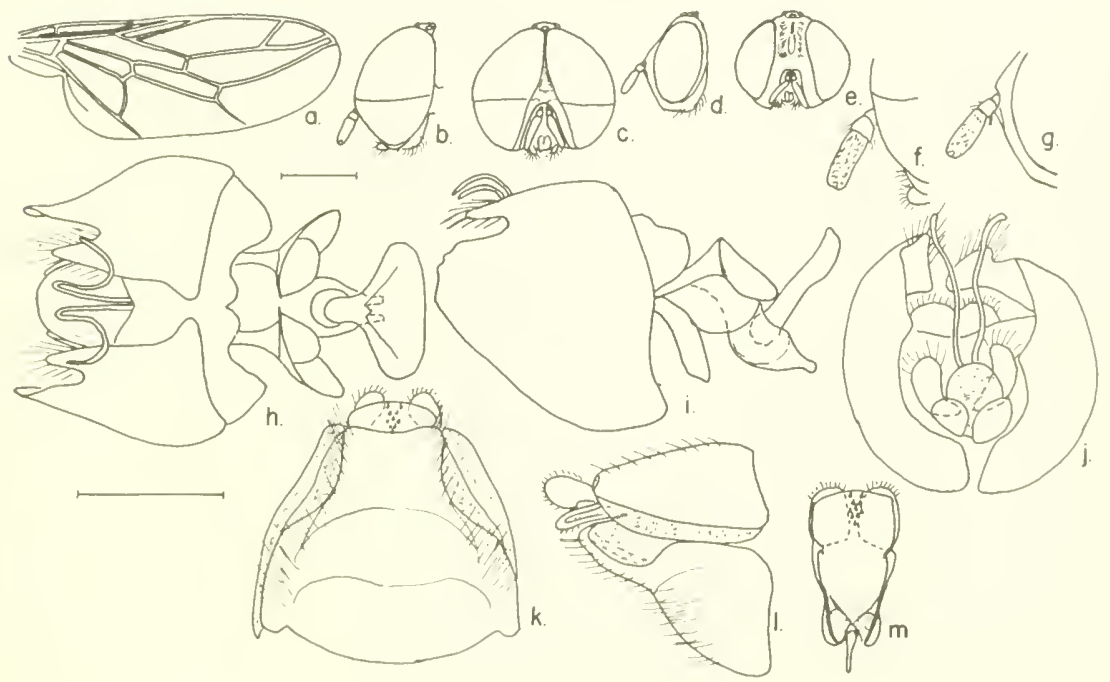

FigUre 93.--Scenopinus kuiterti (D. E. Hardy), male, female: $a$, wing; $b$, $c$, lateral and frontal aspects of male head; $d, e$, lateral and frontal aspects of female head; $f, g$, enlargecl details of male and female antennae; $h-j$, ventral, lateral and posterior aspects of male terminalia; $k$, ventral aspect of female 8 th sternum; $l$, lateral aspect of female 8 th and 9 th segments; $m$, female 9 th sternum and bursa.

Thorax dorsum black, rugose, humeral and supra-alar calli redbrown; pleural areas dark red-brown. Wing brown fumose, reins brown; halter stem brown, knob (ream. Legs red-brown, tarsi cream. 
Abdomen red-brown. See figure for details of eighth segment and bursa.

Length: Female body 2.3-2.7 mm., wing $1.8-2 \mathrm{~mm}$.

Type-locality: Buckeye, Arizona; 16 July 1940 (L. C. Kuitert). Type: (UKan).

Female described from Andreas Canyon, Riverside Co., California; 10 May 1954 (Timberlake) (CAS) no. 8917 (Ex [PH'T]).

Other specimens seen: $1 \sigma^{7}$, Black Mountain, Arizona, 13 July 1932 (R. H. Beamer) (UKan); 1 \%, Morongo Valley, San Bernardino Co., California, 30 August 1956 (Timberlake) (PHT); 2 우, Las Cruces, New Mexico, 9 and 20 July 1960 (J. G. Watts) (USNM); $1 \sigma^{7}$, Mesilla, New Mexico, September 1896, from granary (Th. D. A. Cockerell) (USNM); $10^{7}$, El Paso, Texas, 13 May, (Cockerell) (USNM); $10^{7}$, Mesilla Park, New Mexico (C. N. Ainslie) Webster no. 5095 (USNM); $10^{7}$, San Diego Co., California, 23 May, (E. P. Van Duzee) (CAS); 1 or, Mesa, Arizona, 9 June 1955 (G. D. Butler) swept/alfalfa (UAriz); $1 \sigma^{7}$, Kyrene, Arizona, $11 \mathrm{July} 1955$ (O. L. Barnes) swept/alfalfa (UAriz); $1 \sigma^{\pi}$, Casa Grande, Arizona, 20 June 1956 (G. D. Butler) swept/alfalfa (UAriz); $1 \sigma^{7}$, Helendale, California, 19 April 1959 (Timberlake) (PH'T).

\section{Scenopinus magdalenai, new species}

Figure 94

MALE.-Head black; eyes red-brown above, dark red-brown below; frons subshining, extending one-third the distance from the antenna to the ocellar triangle, with a converging groove above the antennae and a pit at the apex of the frontal triangle; ocellar triangle set low at back of head; ocelli red-brown. Mouthparts black-brown, well developed; back of head concave, subshining; little or no genal area. Antemnae with first segment black, short; second segment short, redbrown; third segment black-brown with short hairs, elongate, over twice as long as wide.

Thorax dorsum black, with silvery pilose area above the humeral callus; humeral and supra-alar calli red-brown; pleural area blackbrown. Wings hyaline, veins brown; halter stem brown, knob redbrown; legs with all femora dark red-brown; tibiae and tarsi of first two pairs orange-brown; hind legs with tibiae brown, tarsi yellow.

Abdomen black-brown, segment 3 with broad white posterior margin, segments 4 and 5 with very narrow bands. See figure for details of terminalia. Primary difference is in structure of ejaculatory syringe and accessory structures.

Female.-Head black, eyes dark red-brown with a narrow postocular ridge and well-developed genae behind and below the eye; frons 

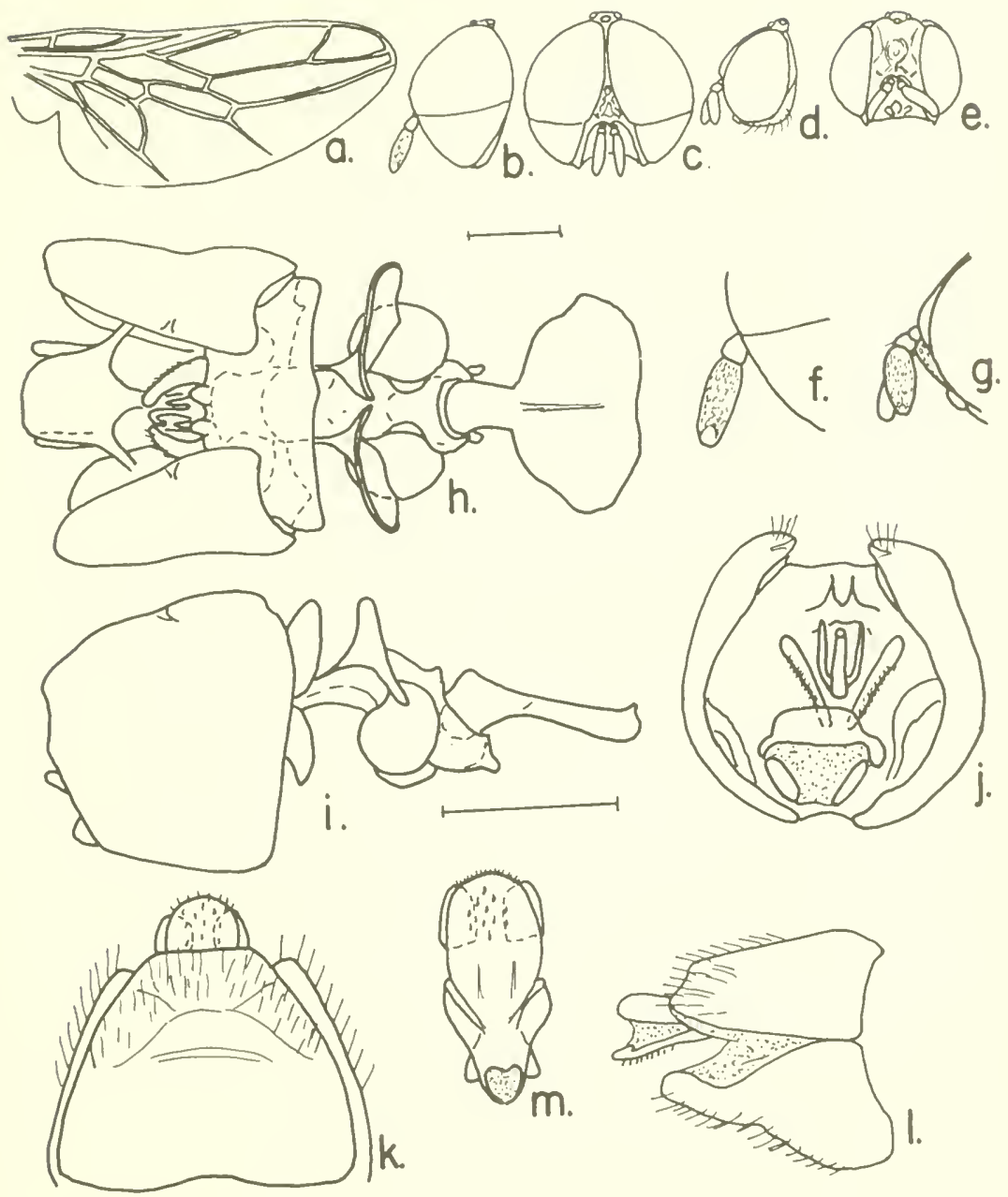

FigUre. 94.--Scenopinus magdaienai, new species, male, female: $a$, wing; $b$, $c$ lateral and frontal aspects of malc head; $d$, $e$, lateral and frontal aspects of female head; $f, g$, enlarged details of male and female antennac; $h-j$, ventral, lateral and posterior aspects of male terminalia; $k$, ventral aspect of female 8 th sternum; $l$, lateral aspect of female 8 th and 9 th segments; $m$, female 9 th sternum and bursa.

granular, subshining with the portion above the antennae bulging, split by a median groove extending to a median depression on lower third of the frontal area; antemne as in male.

Thorax as in male except halter knob light red-brown.

Abdomen black-brown. See figure for details of eighth segment and bursa. 
Length: Male body $3 \mathrm{~mm}$., wing $2.2 \mathrm{~mm}$.; female body $3 \mathrm{~mm}$., wing $2.1 \mathrm{~mm}$.

Type-locality: María Magdalena (island), Tres Marías, Mexico; 20 May 1925 (H. H. Keifer).

Holotype: Male (CAS) 8922 on loan from (UCalB).

Allotype: Female same data (CAS).

\section{Scenopinus magnicornis (Kröber)}

FIGURE 95

Omphrale magnicornis Kröber, 1913, p. 202.

The type of this species is much smaller than other material seen by me and is distinguished by its large bulbous third antennal segment. As yet no male has been associated with it. It is close to $S$. velutinus but separable by the shape of the antenna and bursal plate.

Length: Female body 3.5 (type) $-4.4 \mathrm{~mm}$., wing 2.6 (type) $-3 \mathrm{~mm}$.

Type-locality: Amerika (Costa Rica) (in Winthems Coll. as pygmaeus Lw.).

Type: (NMV).

Other specimens seen: 1 ㅇ, San Jose, Costa Rica; 1000-1200 m., 15 November 1931 (F. Nevermann) in house (IOC); 4 와, La Suiza de Turrialba, Costa Rica (Pablo Schild) (USNM); 1 \%, Lima, Peru, 11 May 1961 (N. L. H. Krauss) (USNM).
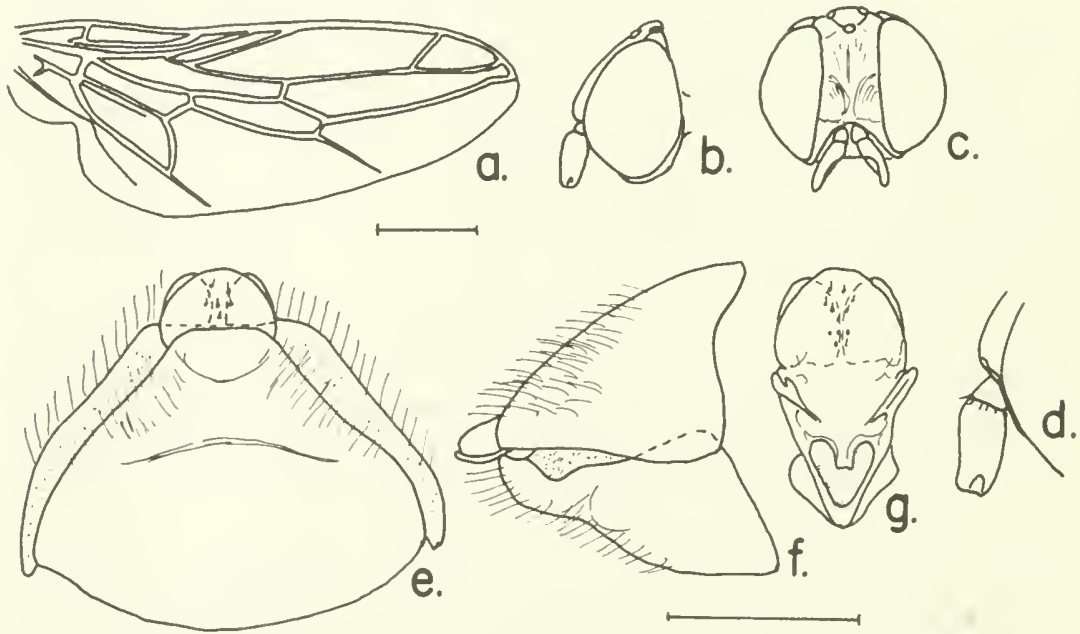

Figure 95.- Scenopinus magnicornis (Kröber), female: $a$, wing; $b$, c, lateral and frontal aspects of head; $d$, enlarged detail of antenna; $e$, ventral aspect of 8 th sternum; $f$, lateral aspect of 8 th and 9th segments; $g$, 9th sternum and bursa. 


\section{Scenopinus mirabilis Adam-}

Figure 96

Scenopinus mirabilis Adams, 1904, p. 44.5.

Scenopinus nubilipes Cresson. [not Say] 1907, p. 111.

Scenopinus ramaleyi James, 1935, 1. 22.2.

Close study of the terminalia of a series of males distributed orer a wide geographical area indicates that individuals with the characteristic shape of the ninth tergum, excavated dorsal posterior margin, and notch at the rentral tip, are apparently undergoing speciation. I place $S$. ramaleyi in synonomy with $S$. mirabilis on the basis of the short aedeagus with weak parameres and ninth segment claspers with a long median knob on tip flanked laterally by an equally wide depressed portion. The character given by Hardy for separation is much too variable to be relied upon.

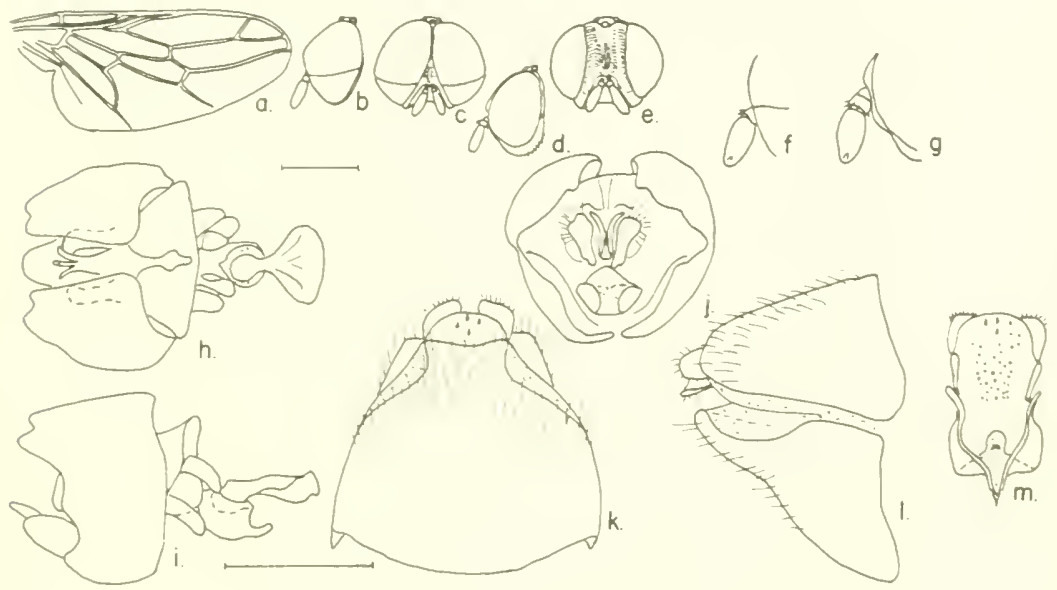

Figure 96.-Scenopinus mirabilis Adams, male, female: $a$, wing; $b$, $c$, lateral and frontal aspects of male head; $d, e$, lateral and frontal aspects of female head; $f, g$, enlarged details of male and female antennae; $h-j$, ventral, lateral and posterior aspects of male terminalia; $k$, ventral aspect of female Sth sternum; $l$, lateral aspect of female 8 th and 9th segments; $m$, female 9 th sternum and bursa.

The third antennal segment is oval, being about twice as long as wide, cell R5 open at tip of wing by at least the width of the r-m cross rein. Size of cell $R 4$ rariable.

Length: Male body 2.3-2.5 $\mathrm{mm}$., wing $2-2.3 \mathrm{~mm}$; female body $3.4-4 \mathrm{~mm}$., wing $2.5 \mathrm{~mm}$.

Type-locality: Bill Williams Fork, Arizona (F. H. Snow).

Types: (UKan). 
I have identified specimens from the following localities: $30^{7} \sigma^{7}$, 2 ㅇ ․ Escondido, California, 15 July 1941 (E. L. Todd) (UKan); $1 \sigma^{7}$, Albuquerque, New Mexico, 5 July 1941 (Burt Hodgden) (UKan); $10^{\top}$, Adelaide, Idaho, 21 July 1927 (USNM); $10^{\top}, 1 \%$, Halsey, Nebraska, 1 July 1957 (R. Henzlik) (USN.M); $1 \sigma^{7}$, Tucson, Arizona, 4 May 1942 (A. L. Melander) (USNM); $1 \sigma^{7}$, Calabasas, 6 mi. w. Nogales, Arizona, 1 August 1961 (Werner, Nutting) (UAriz); $10^{7}$, Helendale, California, 21 May 1955 (W. R. M. Mason) (CNC); $10^{x}, 2$ 우 오, Medicine Hat, Alberta, 15 July 1956 (O. Peck) (CNC); $2 \sigma^{x} \sigma^{x}, 2$ ๆ $\odot$, Alamagordo, New Mexico, 25 April-15 May 1902, (ANS).

\section{Scenopinus nubilipes Say}

\section{FIGURE 97}

Scenopinus nubilipes Say, 1829, p. 170.

The type of this specimen has been lost for many years and, as a result, most American collections contain numerous specimens identified as this species. My original aim was to study the pupal

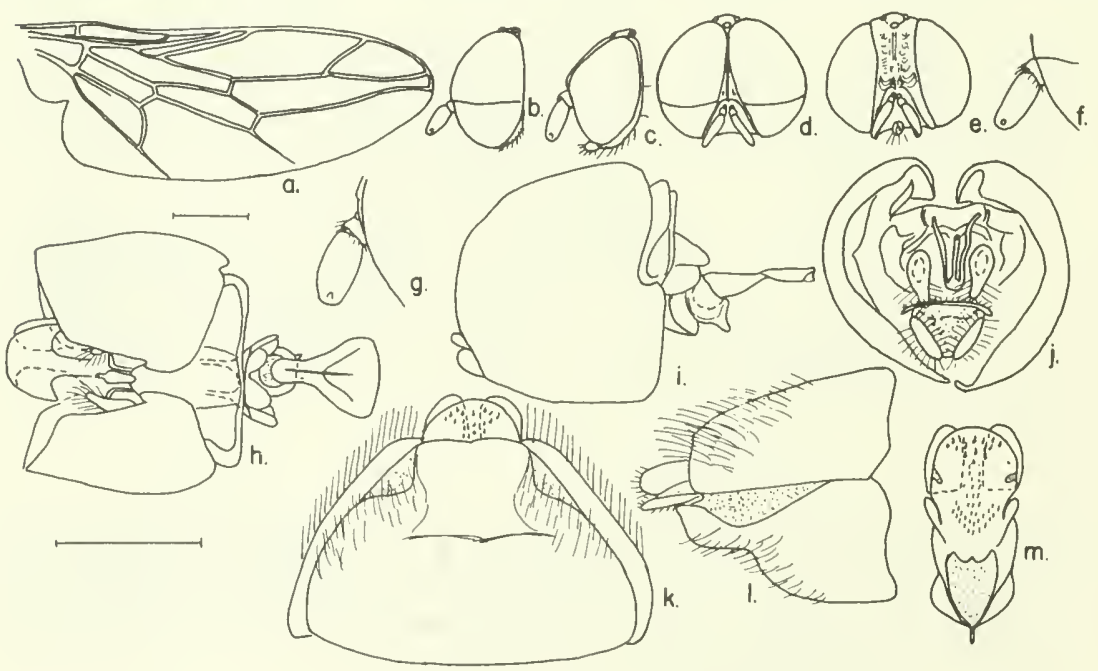

Figure 97.-Scenopinus nubilipes Say, male, female: $a$, wing; $b, d$, lateral and frontal aspects of male head; $c, e$, lateral and frontal aspects of female head; $f$, $g$, enlarged details of male and female antennae; $h-j$, ventral, lateral and posterior aspects of male terminalia; $k$, ventral aspect of female 8th sternum; $l$, lateral aspect of female 8 th and 9 th segments; $m$, female 9 th sternum and bursa.

skins of North American Scenopidae. This necessitated a more detailed study of the genital structures where differences were more obvious. This, in turn, necessitated descriptions of new species and resulted in this paper. After due consideration of Say's description 
and noting the type-locality, I have selected the following specimen as the neotype of the species.

Male.-Head black, eyes red-brown above, black-brown below; frons small, triangular, extending less than half the distance from the antennal base to the ocellar triangle, rugose with a median groove entering a pit at the dorsal point; back of head concave: mouthparts brown, well developed, filling oral cavity; palpi shorter; ocellar tubercle prominent, ocelli orange-red. Antennae black-brown, first segment short; second segment with an orange distal rim; third segment elongate with a lateral distal pit; see figure.

Thorax dorsum black with transverse striations and a few sparse hairs; humeral and supra-alar calli orange; pleural areas dark redbrown. Wings dusty brown, veins brown; halter stem brown, knob red-brown to black-brown, polished. Legs with femora black-brown, tibiae red-brown, tarsi orange anteriorly to straw colored posteriorly.

Abdomen red-brown, segments 3 and 4 with broad white stripes. For details of ninth tergum and accessory organs, see figure.

Female.-Head black, eyes black-brown, with a narrow postocular rim; frons broad, under one-third the width of the head, slightly swollen, rugose with a median depression from the antenna to the ocellar triangle, a pit in its lower third; mouthparts well developed; back of head concave; ocellar tubercle flat, set off; ocelli orange-red. Antennae as in male.

Thorax as in male.

Abdomen red-brown. For details of eighth segment and bursa see figure.

Length: Male body $3.7 \mathrm{~mm}$., wings $2.7 \mathrm{~mm}$.; female body $4.3-$ $4.5 \mathrm{~mm}$., wing $3 \mathrm{~mm}$.

Neotype locality: Urbana, Illinois; 15 March 1959 (G. T. Riegel).

Neotype: Male (INHS).

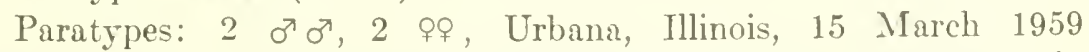
(G. T. Riegel) reared from granary trash, all with pupal skins, in (USNM) and (INHS); $2 \sigma^{7} \sigma^{7}, 3 \% \%$, Lafayette, Indiana, 24 June 1957 (L. Chandler) (PU); 1 ه', Spencer Co., Indiana, 10 April 1953 (Montgomery) bean flowers (USN.M); $10^{x}, 1$ \& , Lawrence, Kansas, 15. May 1896, 13 June 1898 (H. Kahl) (CNC); 1 क , Toloma, Illinois, 10 May 1927 (CAS).

\section{Scenopinus pecki, new species}

Figure 9 S

MaLe.-Head black, eyes brown above, black below; frons slightly swollen, shining. with punctures on either side next to the eye; mouthparts brown, well developed; oral opening bordered by silvery pile that extends to above the antennal bases; ocellar tubercle shin- 
ing, ocelli reddish; first two antennal segments black-brown, the first smaller than the second, the third segment black, oval, twice as long as the first two combined.

Thorax dorsum black, subshining; humeral and supra-alar calli brown; wings smoky, veins brown to translucent; halter stem tan, knob white; legs with femora and tibiae black, tarsi light brown.

Abdomen black, shining, segments 3 and 4 white above, black below, ninth segment black, normally hairy. See figure for details of ninth tergum and aedeagal structure.

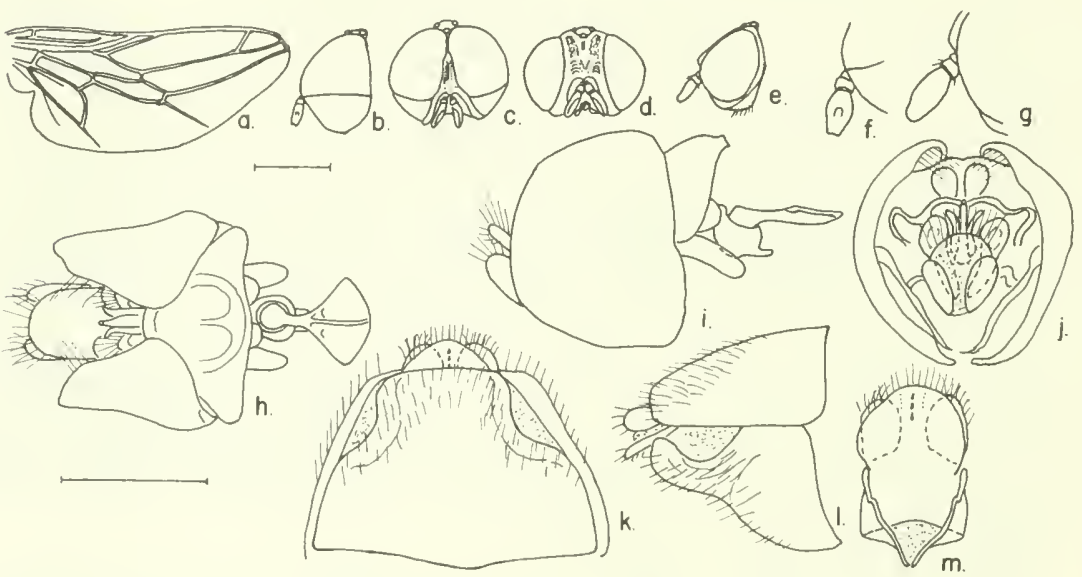

FIGURE 98.-Scenopinus pecki, new species, male, female: $a$, wing; $b, c$, lateral and frontal aspects of male head; $d, e$, frontal and lateral aspects of female head; $f, g$, enlarged details of male and female antennae; $h-j$, ventral, lateral and posterior aspects of male terminalia; $k$, ventral aspect of female 8 th sternum; $l$, lateral aspect of female 8 th and 9 th segments; $m$, female 9th sternum and bursa.

Female.-Head black, shining; eyes red-brown, with a narrow postocular ridge; frons subshining with transverse striations, with a slight swelling over base of antennae; ocellar tubercle set off, not prominent; ocelli red; mouthparts normal; oral opening surrounded by silvery pile. Antennae as in the male.

Thorax as in male except halter stem black, knob light brown above, white below.

Abdomen black-brown; see figure for details of eighth segment and bursa.

Length: Male body 2.3-2.8 mm., wing $2 \mathrm{~mm}$; female body $3.3 \mathrm{~mm}$., wing $1.8 \mathrm{~mm}$.

Type-locality: Scandia, Alberta, Canada; 10 July 1956 (O. Peck) swept from range grass.

Holotype: Male (CNC) 8957. 
Allotype: Female, same data as type.

Paratypes: $12 \sigma^{7} \sigma^{7}$, same data as type; $2 \sigma^{7} \sigma^{7}$, Lethbridge, Alberta, 14 July 1956 (O. Peck) (CNC); 3 ○ $\sigma^{7}, 1$ \& , Thermopolis, Wyoming, 26 July 1960 (R. J. Lavigne) (USNM).

\section{Scenopinus pygmaeus Loew}

\section{Figure 99}

Scenopinus pygmaeus Loew, 1857, p. 90.

Scenopinus albidipennis Loew, 1S69, p. 32.

This species, first described from Surinam, appears to be distributed over the Caribbean region. Examination of the genitalia of the type of albidipennis showed it to be identical with that of S. pygmaeus. The type of $S$. albidipennis is somewhat teneral which may have led Loew to describe it as a new species.

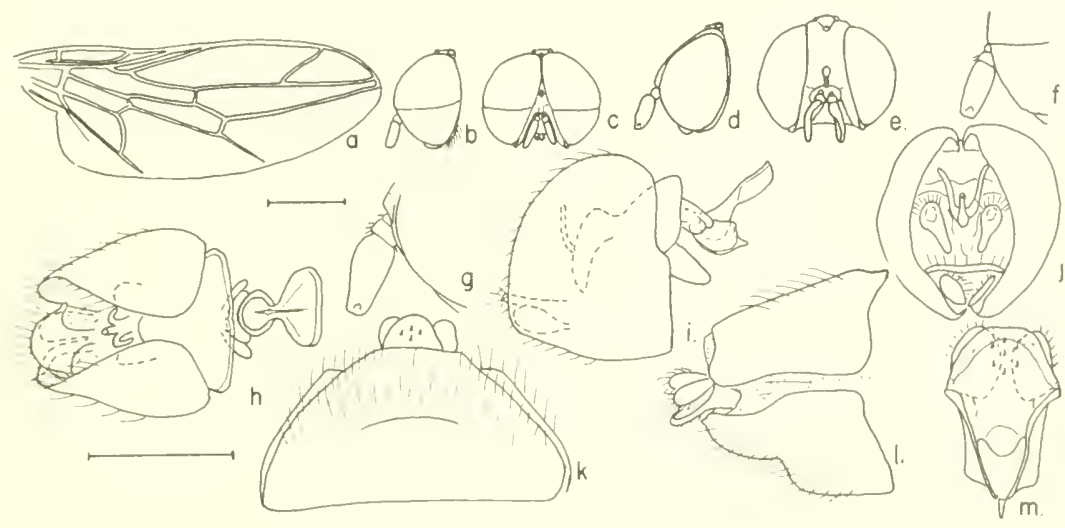

Figure 99.-Scenopinus pygmaeus Loew, male, female: $a$, wing; $b, c$, lateral and frontal aspeets of male head; $d, e$, lateral and frontal aspects of female head; $f, g$, enlarged details of male and female antennae; $h-j$, ventral, lateral and posterior aspects of male terminalia; $k$, ventral aspect of female 8 th sternum; $l$, lateral aspect of female 8 th and 9 th segments; $m$, female 9 th sternum and bursa.

A redescription of the male follows with the description of the hitherto unknown female.

MALE.-Head black, eyes red-violet above, blackish below; frons small, subshining, with shallow pit at the upper two-thirds of frons; the pile surrounding the oral opening extending above the antennae and nearly reaching the midline from either side; ocellar tubercle prominent, ocelli red. Antennae are red-brown; first segment short; second, twice size of first; third elongate, over twice as long as the first two combined, velvety. 
Thorax dorsum black, rugose, only a few very fine hairs along lateral margin of tergum; humeral callus with a small posterior patch of yellow-brown; pleural areas black-brown; wings hyaline to milky, veins pale tan, faint; halter stem black, knob white. Legs with femora red-brown, tibiae orange-brown, tarsi straw colored darkening posteriorly.

Abdomen dark red-brown, shining, segments 4 and 5 with narrow white posterior bands, all segments with short reddish hairs. See figure for details of ninth tergum and genital structures.

FEMALE.- - Head black, eyes black-brown, with a narrow postocular ridge; frons swollen above antennae, with swelling divided by a deep median groove ending in a pit in the lower third of the frontal area, remainder of frons rugose; ocellar tubercle flat, rugose; median ocellus sunken, ocelli red-brown; mouthparts brown, well developed; palpi black-brown, long; oral opening bordered by silvery pile which extends over the antennal bases below the swellings on the frons. Antennae as in male except third segment thickened at base, velvety.

Thorax dorsum black, rugose, a patch of white pubescence anterior to the humeral callus, a few fine hairs on lateral margin; pleural areas dark red-brown; wings brownish hyaline, veins brown; halter stem red-brown, knob white to creamy. Legs with femora red-brown, tibiae red-brown lightening posteriorly, tarsi light red-brown anteriorly lightening to tan posteriorly.

Abdomen red-brown; see figure for details of the eighth segment and bursa.

Length: Male body 2.3-2.8 mm., wing 1.7-2.3 mm.; female body 3-3.5 mm., wing $2.3-2.6 \mathrm{~mm}$.

Type-locality: Surinam.

Type: (ZMH).

Material examined: $1 \sigma^{7}$, Cuba (Gundlach) as type of S. albidipennis Loew (MCZ) no. 1086; $1 \sigma^{7}$, Mina Carlata, Trinidad Mt., Cuba, 11-16 July 1939 (C. T. Parson) in (MCZ); $1 \sigma^{7}, 3$ 우, Mazaruni Clearing, British Guiana, 9 July, 15 and 21 September 1937, in colony house (Richards and Smart) (BMNH); $10^{7}, 1$ 우, La Suiza de Turrialba, Costa Rica (Pablo Schild) Higuito, San Mateo, Costa Rica, (Pablo Schild) (USNM); $7 \sigma^{7} \sigma^{7}, 15$ ๆ̊, Palisades, Kingston, Jamaica, November 1957, February and September 1958, July and August 1964 (T. H. Farr) (SMIJ).

\section{Scenopinus rossi, new species}

Figure 100

MALE.-Head black-brown; eyes dark brown above, red-brown below; frons with lower half smooth shining, bordered on each side by the dorsal extension of lateral silvery pubescence surrounding the oral 
cavity, upper half of frons with an elongate median depression; ocellar tubercle prominent, ocelli red-orange; mouthparts brown, well developed, extending the length of the oral eavity; palpi nearly as long as rostrum; a narrow gena on lower part of the head. Antennae blackbrown, first segment small; second segment twice as large as first; third segment twice as long as wide, slightly tapering, covered with short golden hairs.

Thorax dorsum black, with a patch of silvery pile above the humeral callus which has a red-brown posterior margin, supra-alar callus redbrown; pleural areas black-brown. Wings smoky hyaline, reins light brown anteriorly fading posteriorly; halter stem brown, knob redbrown. Legs red-brown except tarsi straw yellow, fore tibia a little lighter than others.

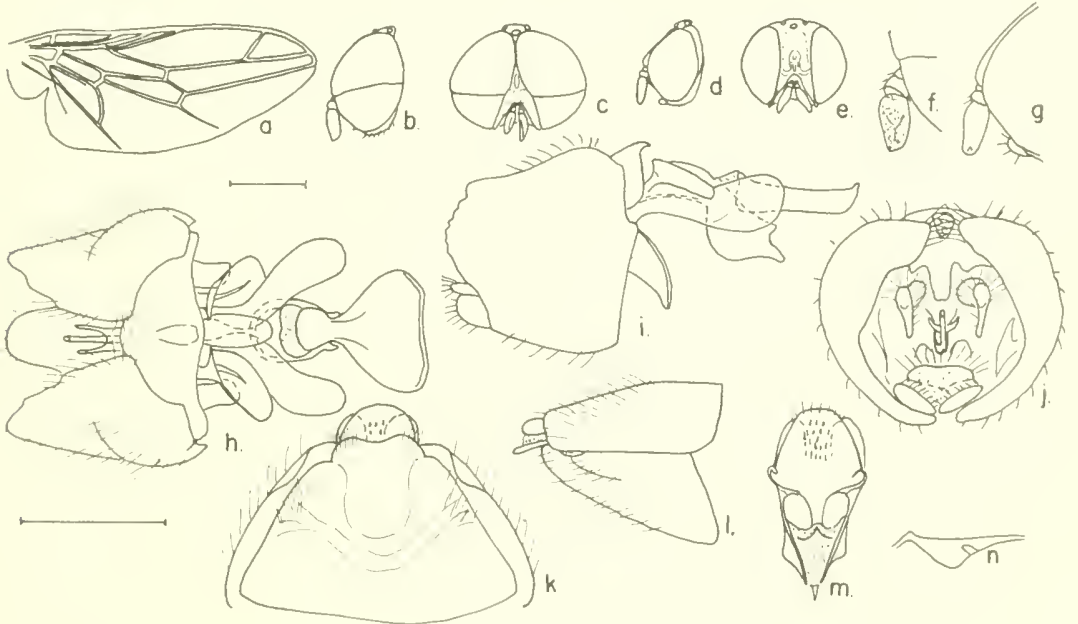

Figure 100.-Scenopinus rossi, new species, male, female: $a$, wing; $b, c$, lateral and frontal aspects of male head; $d, e$, lateral and frontal aspects of female head; $f, g$, enlarged details of male and female antennac; $h-j$, ventral, lateral and posterior aspects of male terminalia; $k$, ventral aspect of female 8th sternum; $l$, lateral aspect of female 8 th and 9 th segments; $m$, female 9 th sternum and bursa; $n$, sketch showing central peg in membranous portion of bursa.

Abdomen red-brown, segments $3-5$ with narrow white posterior bands. For details of ninth tergum and genital structure, see figure.

Female.- Head black-brown; eyes red-brown with a narrow postocular band; frons broad, slightly rugose, subshining, swollen above the antennae and with a broad median depression on the lower fourth; ocellar tubercle broad and not prominent, median ocellus sunken, ocelli whitish to orange. Mouthparts and antennae as in the male. 
Thorax, wings, halter, and legs as in male.

Abdomen red-brown, eighth segment red-brown, sparsely covered with hairs. See figure for details of sternum and bursa.

Length: Male body $2.7 \mathrm{~mm}$., wing $2.1 \mathrm{~mm}$.; female body $3.2 \mathrm{~mm}$., wing $2.2 \mathrm{~mm}$.

Type-locality: 6 mi. n. Victoria, Tampico, Mexico; 17 November 1946 (M. S. Ross).

Holotype: Male (CAS) 8923.

Allotype: Female, Revolution, 9 mi. s.e. of Buena Vista, Chiapas, Mexico; 23 March 1953 (R. E. Bechtel, E. I. Schlinger) in (CAS).

Paratypes: 1 \% , same data as allotype (UCalB); $1 \sigma^{7}, 2$ mi. s.e., of Revolution, Chiapas, Mexico, 22 March 1953 (R. E. Bechtel, E. I. Schlinger) (UCalB).

\section{Scenopinus schulzi Enderlein}

Figure 101

Scenopinus schulzi Enderlein, 1934, p. 429.

Omphrale caenofrons Kröber, 1937, p. 229.

This very common South American species was described from the female; now the male has been found and is described below with a redescription of the female.

Male.-Head red-brown; eyes red-brown, darker below; frons narrow triangular, striated; with white pilose bands laterad of oral opening approaching above the antennal bases, area between antennal bases and pilose bands smooth shining; ocellar tubercle red-brown, prominent, ocelli orange; mouthparts well developed, orange-brown; palpi nearly as long as rostrum, orange basally, black-brown distally. Antennae red-brown; first segment short; second twice as large as first; third elongate, three times as long as first two combined, darker at tips.

Thorax dorsum black with a silvery pilose area above humeral callus which is red-brown, as is the supra-alar callus; pleural areas black-brown, shining. Wings hyaline, veins brown; halter stem brown, knob mahogony brown; fore and middle legs orange-brown, hind leg with coxa and femur red-brown, remainder orange.

Abdomen dark red-brown, segments 3 and 4 with moderately wide white posterior margins, segment 5 with a very narrow white margin, terminalia black, cleft so there is a wide dorsal and a narrow ventral piece; see figure for details.

Female.-Head black; eyes reddish black, with a very narrow postocular ridge; frons broader than the ocellar triangle, with a shallow pit on the lower portion, subshining, with transverse rugose striations below the pit, red-brown area anterior to the center of the 
pit on swelling above the antennae. Ocellar tubercle prominent, set off from frons, ocelli vellow-orange. First antenmal segment orangebrown, very short; second segment twice size of first, orange; third segment three times as long as broad, orange with a black tip.

Thorax dorsum black; humeral callus with a yellow spot, supraalar callus cream; pleura red-black. Wings brown fumose, veins brown; halter stem brown, knob, dorsal surface red-brown, ventral surface brown.

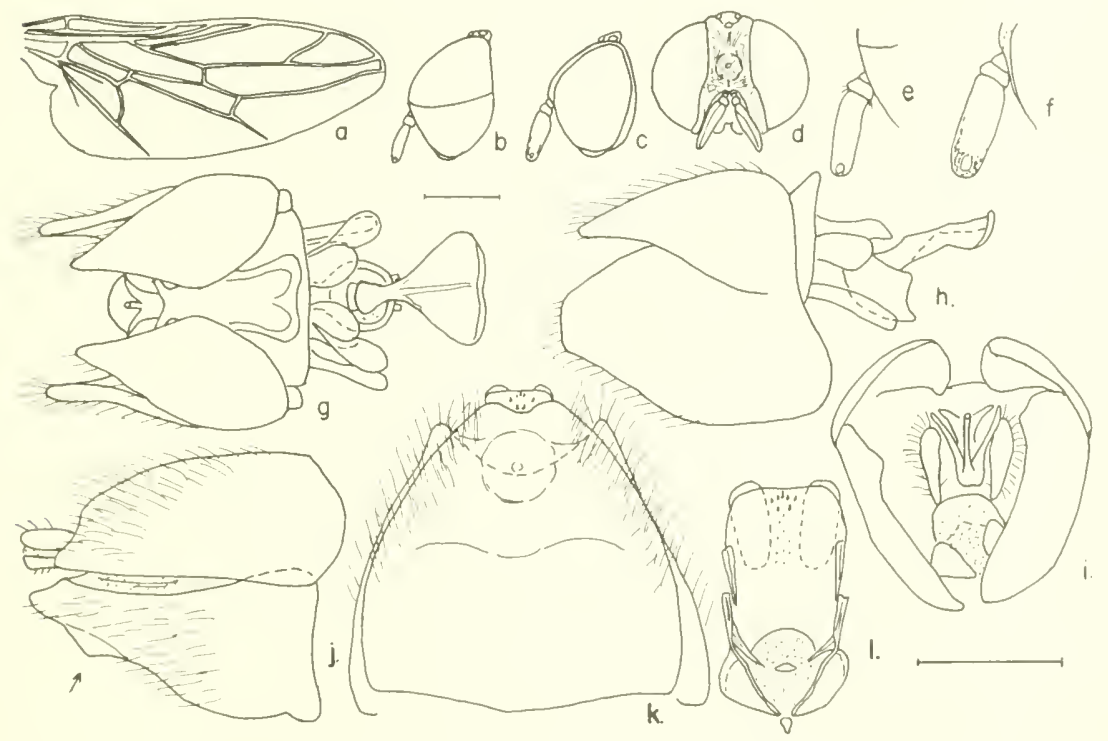

Frgure 101.-Scenopinus schulzi Enderlein, male, female: $a$, wing; $b$, lateral aspect of male head; $c, d$, lateral and frontal aspects of female head; $e, f$, cnlarged details of male and female antennae; $g-i$, ventral, lateral and posterior aspects of male terminalia; $j$, lateral aspect of female 8 th and 9 th segments; $k$, ventral aspect of female 8 th sternum; $l$, female 9 th sternum and bursa.

Abdomen red-brown, eighth segment with concave posterior margin on tergum, sternum with a raised bump before the end. See figure for details of eighth segment and bursal plate.

Length: Male body 3-4 $\mathrm{mm}$., wing 2.3-2.8 mm.; female body 2.5-2.75 mm., wing $2-2.25 \mathrm{~mm}$. (actual range body $2.5-5.3 \mathrm{~mm}$., wing $2-3.5 \mathrm{~mm}$.).

Type-locality: Para, Brazil; 1 and 7 December 1893 (Albert Schulz).

Type: (ZMH).

Other specimens seen: $2 \sigma^{7} \sigma^{7}, 3$ 우, Maracaju, Mato Grosso, Brazil, February 1937 (USNM); Varneys, Saint Helena, 22 specimens cap- 
tured between 11 April and 26 November 1958, including a pair in copula (A. Loveridge) (BMNH); $2 \sigma^{7} \sigma^{7}, 1$, Nova Teutonia, Brazil, $27^{\circ} 11^{\prime}$ S. $52^{\circ} 23^{\prime}$ W., 28 October and 3 November 1936 (Fritz Plaumann) (BMNH); 9 ф̊, Nora Teutonia, Brazil, November 1944, March 1946, November 1949, October 1956, October 1957, September and November 1958 (Plaumann) (CNC); $1 \sigma^{7}$, Boa Vista Fundode Figueiras, Cape Verde Islands, 30 January 1954 (University Exped.) in (ZMUH).

\section{Scenopinus seftoni, new species}

\section{FIgURE 102}

This is another species similar to $S$. mirabilis but wing tip with cell R5 more constricted, halteres orange-yellow to tan. Aedeagus stronger and parameres weaker, ninth segment claspers pointed. Female eighth tergum and sternum excavated behind.

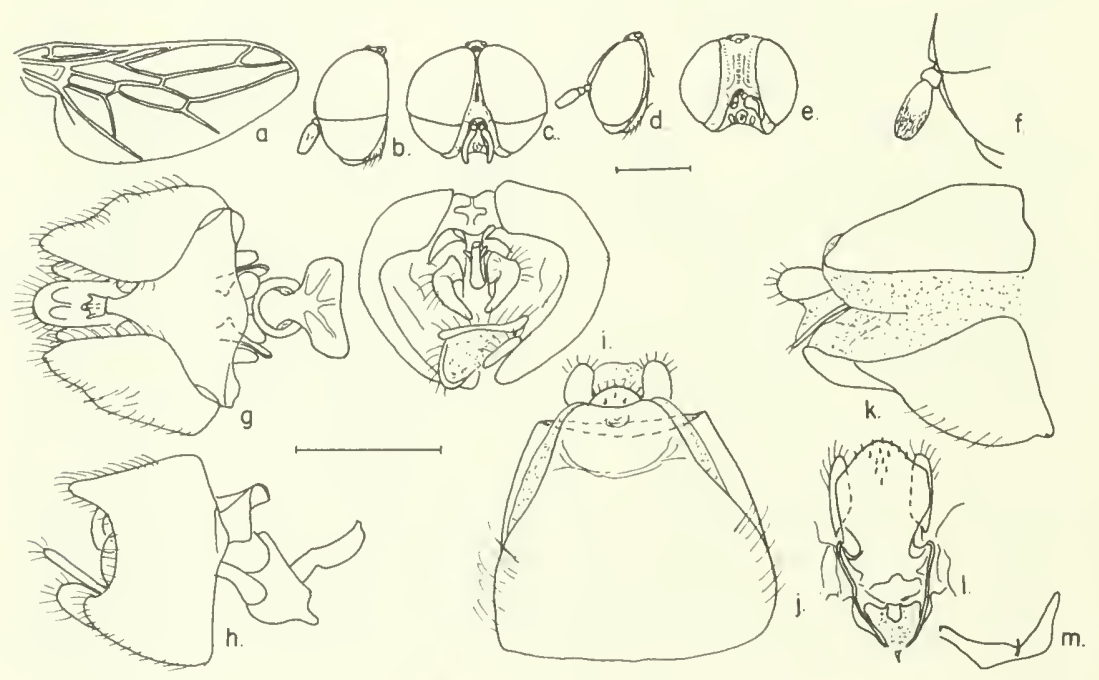

Figure 102.-Scenopinus sefioni, new species, male, female: $a$, wing; $b, c$, lateral and frontal aspects of male head; $d, e$, lateral and frontal aspects of female head; $f$, enlarged detail of male antenna; $g-i$, ventral, lateral and posterior aspects of male terminalia; $j$, ventral aspect of female 8 th sternum; $k$, lateral aspect of female 8 th and 9 th segments; $l$, female 9 th sternum and bursa; $m$, lateral sketch of bursa and central peg.

MALE.-Head black, eyes red-brown above, black-brown below, frons subshining, swollen below, a median groove in upper half; ocellar tubercle prominent, shining; ocelli red-brown; mouthparts brown, moderately large, palpi half the length of oral opening which is fringed by black-brown pollen; lower gena strongly developed, shining. Antennae black-brown, first segment short, second larger, 
third segment pubescent, oval, twice as long as wide and truncated on the end.

'Thorax dorsum black with a few sparse hairs, humeral callus redbrown; pleural area dark red-brown; wing milky hyaline, veins tan; cell R5 sharply narrowed at end (see figure), distance from $r-m$ to m cross vein twice as long as r-m; halter stem red-brown, knob tan to cream yellow. Legs: femora and tibiae dark red-brown with yellowbrown knee, tarsi straw yellow, darkening distally.

Abdomen dark red-brown, segments $3-5$ with broad white stripes; segments with a few lateral white hairs; ninth tergite black-brown, cup of ejaculatory syringe blackish, aedeagus with a strong penis flanked by weak parameres, ninth segment claspers pointed.

FEMAle.-Head black; eves red-brown with a narrow postocular rim; frons broad, slightly swollen above the antennal bases, rugose, with shallow grooves either side of median ridge; ocellar tubercle shallow, set off; ocelli red-brown. Mouthparts brown, as in male; oral opening bordered by brown pile as in male. Antennae as in male.

Thorax dorsum and pleurum as in male; wings hyaline tinged brownish, veins brown; halter stem red-brown, knob orange-yellow. Legs with femora and tibiae dark red-brown, knees yellow, tarsi orange-yellow, darkening distally.

Abdomen dark red-brown, eighth segment with posterior margins of both sternum and tergum excarated; see figure for details of eighth segment and bursa.

Length: Male body 2-2.5 mm., wing 1.5-2 mm.; female body 2.8 mm., wing $2.2 \mathrm{~mm}$.

Type-locality: Espírutu Santo (island), Gulf of California, Mexico $\left(24^{\circ} 30^{\prime}\right.$ N. $110^{\circ} 40^{\prime}$ W.) ; 23 March 1953 (P. H. Arnaud) Sefton Orca Exped. to Gulf of California.

Holotype: Male (CAS) 8928.

Allotype: Female Isla Partida, Gulf of California, Mexico $\left(24^{\circ} 30^{\prime}\right.$ N. $110^{\circ} 40^{\prime}$ W.) ; 23 March 1953 (P. H. Arnaud) Sefton Orea Exped. to Gulf of California (CAS).

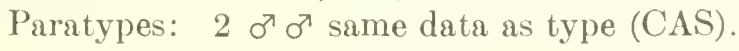

105. Scenopinus serratus, new species

FIGURE 103

Male.-Head black-brown; eyes amber brown above, brown below; frons small, triangular, extending over halfway to the median ocellus, with a median groove below ending in a central pit, ocellar tubercle red-brown, prominent, set on back top of head, ocelli clear; mouthparts creamy, palpi red-brown; lower part of gena narrowly developed. First segment of antenna small, red-brown; second segment orange- 

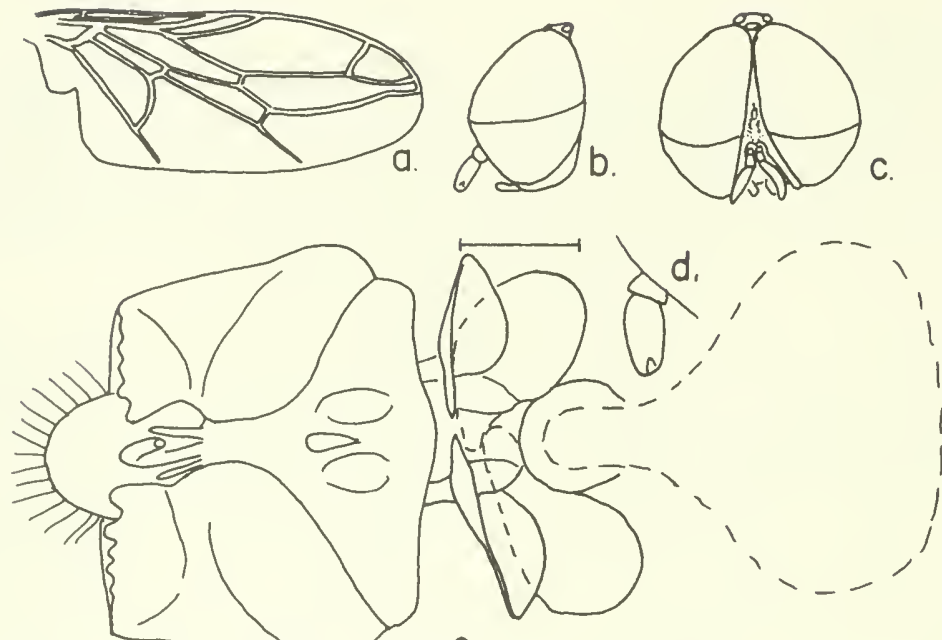

e.

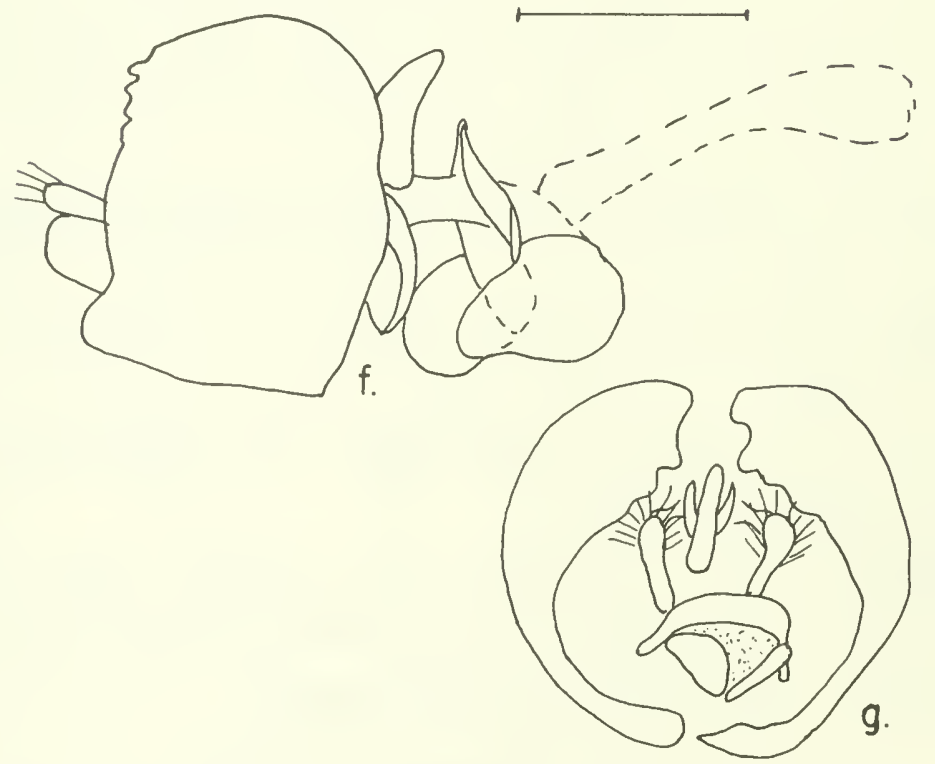

FIGURE 103.-Scenopinus serratus, new species, male: $a$, wing; $b$, c, lateral and frontal aspects of head; $d$, enlarged detail of antenna; $e-g$, ventral, lateral and posterior aspects of terminalia, missing portion of ejaculatory syringe outlined in dashed lines.

brown, twice as large as the first; third segment orange-brown dusted with white, elongate oval, twice as long as wide.

Thorax dorsum black with a patch of silvery pile above the humeral callus which is red-brown with an orange tip; pleural areas dark redbrown. Wings hyaline, veins tan; halter stem tan, knob tan-brown 
above, white below. Legs with femora light red-brown, tibiae orangebrown, tarsi straw yellow.

Abdomen with second segment black-brown, velvety; segments 3-5 with medium wide posterior white bands, remainder of abdomen black-brown; ninth tergum with serrated edges; see figure for details.

Fenale.-Unknown.

Length: Male body $2.7 \mathrm{~mm}$., wing $1.9 \mathrm{~mm}$.

Type-locality: Casa Grande, Arizona;20 June 1956 (G. D. Butler) swept alfalfa.

Holotype: (USNM) 67477.

\section{Scenopinus valgus (D. E. Hardy)}

\section{Figure 104}

Omphrale valga D. E. Hardy, 1944a, p. 50.

None of the types or paratypes of this species has been seen, but specimens which agree with Hardy's figures have been found and are illustrated. A series of three males and two females from Friday Harbor, Washington, was found and is figured. The female is described for the first time.

MaLE.-Abdomen with segments 3-5 with every narrow posterior white borders. Tergum of ninth segment as figured.

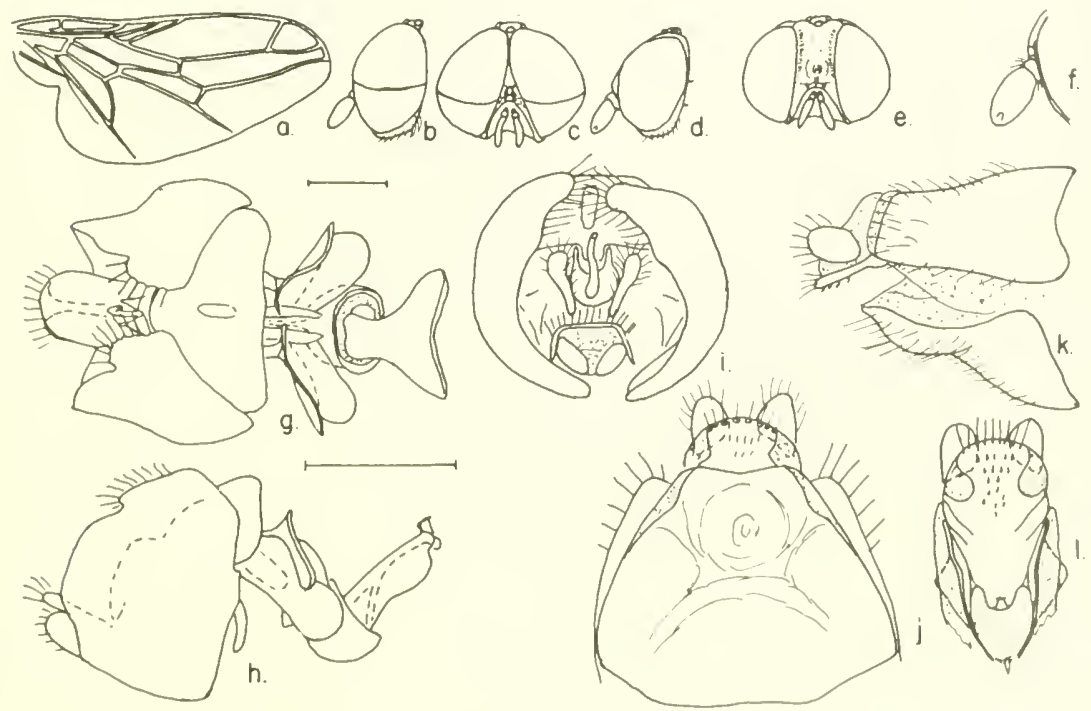

Figure 104.-Scenopinus valgus (D. E. Hardy), male, female: $a$, wing; $b$, c, lateral and frontal aspects of male head; $d, e$, lateral and frontal aspects of female head; $f$, enlarged detail of antenna; $g-i$, ventral, lateral and posterior aspects of male terminalia; $j$, ventral aspect of female 8th sternum; $k$, lateral aspect of female 8 th and 9 th segments; $l$, female 9 th sternum and bursa. 
Female.-Head red-brown; eyes dark red-brown with a narrow postocular rim; frons rugose, swollen above antemnae, with shallow ventral groove ending in a pit on the lower fourth of the frontal area; ocellar tubercle indented, ocelli orange; oral opening bordered by silvery pile ending squarely at base of swelling on front.

Thorax dorsum dark red-brown; humeral callus orange-tipped; pleural areas red-brown; wing hyaline, veins brown anteriorly, faint behind. Halter stem brown, knob red-brown. Legs red-brown with tarsi yellow-brown basally, darkening distally.

Abdomen red-brown, shining. For details of eighth segment and bursa, see figure.

Length: Female body $3 \mathrm{~mm}$., wing $2.3 \mathrm{~mm}$.; male body $2.6 \mathrm{~mm}$., wing $2.1 \mathrm{~mm}$.

Type-locality: Yosemite National Park, California; 1 August 1940 (R. H. Beamer).

Type: (UKan).

Specimens seen: $1 \sigma^{7}$, Clayton, Shasta Co., California, 15 July 1918 (E. P. Van Duzee) (CAS); $2 \sigma^{7} \sigma^{7}, 3$ ๆ , Friday Harbor, Washington, 25 July 1928 (M. Shackleford) (AMNH); 1 \&, Victorville, California, 30 May 1944 (A. L. Melander) (USNM); 1 ㅇ, s. fork Santa Ana River, California, 30 July 1942 (A. L. Melander) (USNM).

\section{Scenopinus vanduzeei, new species}

FIGURE 105

Scenopinus nubilipes Cole (not Say), 1923, p. 462.

This species is closely allied to S. mirabilis and can be distinguished by the shorter truncate antennae, the free portion of $\mathrm{R} 5$ being much longer than $\mathrm{R} 4$, the portion of $\mathrm{M}$ between the $\mathrm{r}-\mathrm{m}$ and $\mathrm{m}$ cross veins longer, and the aedeagus which has a strong median lobe flanked by shorter parameres; cup of ejaculatory syringe blackish.

MALE.-Head dark red-brown; eyes red-brown above, dark redbrown below; frons narrow, triangular, without a median groove; ocellar tubercle prominent, ocelli clear to red-brown. Antenna with first two segments red-brown; first segment half as large as second; third segment dark red-brown, less than twice as long as wide, flattened, a dimple in the center of the tip.

Thorax dorsum black; humeral callus red-brown, pleura dark redbrown. Wings milky white, veins light brown, halter stem red-brown, knob white. Legs: foreleg with femur red-brown, tibia with distal third orange-brown, tarsi orange; middle leg with femur and tibia red-brown, tarsus orange-brown; hind leg with femur and tibia redbrown, tarsus straw yellow darkening distally.

Abdomen dark red-brown, segments $3-5$ with broad white bands. See figure for details of ninth segment and aedeagus. 
Fenale.-Head dark red-brown; eyes red-brown with only a narrow postocular rim; frons rugose, slightly swollen above the antennae, no median groove; ocellar tubercle depressed, not cut off from frons, ocelli orange. Mouthparts brown, not large; palpi short; pile around oral opening brown, short. Antennae as in male.

Thorax dark red-brown; humeral callus red-brown. Wings smoky brown, veins brown; halter stem red-brown, knob white. Legs with femora and tibiae red-brown, tarsi light red-brown.

Abdomen red-brown. See figure for details of eighth segment and bursa.

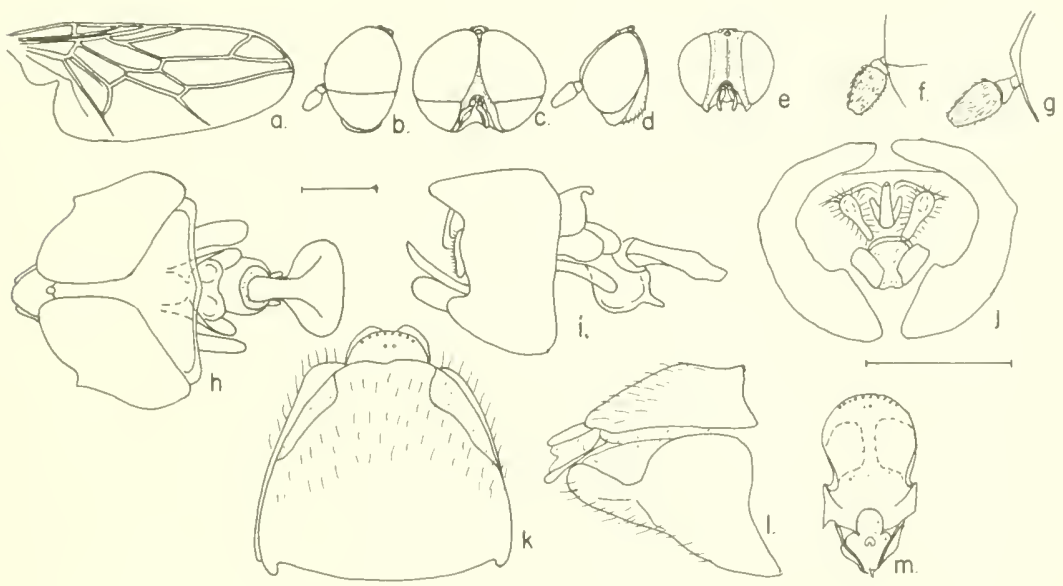

Figure 105.-Scenopinus vanduzeei, new species, male, female: $a$, wing; $b, c$, lateral and frontal aspects of male head; $d, e$, lateral and frontal aspects of female head; $f, g$, enlarged details of male and female antennae; $h-j$, ventral, lateral and posterior aspects of male terminalia; $k$, ventral aspect of female 8 th sternum; $l$, lateral aspect of female 8 th and 9 th segments; $m$, female 9 th sternum and bursa.

Length: Male body $2.3 \mathrm{~mm}$., wing $1.8 \mathrm{~mm}$.; female body $3.3 \mathrm{~mm}$., wing $1.8 \mathrm{~mm}$.

Type-locality: Mejia (island), Gulf of (alifornia, north of Angel de la Guarda, 30 April 1921 (E. P. Van Duzee) $\left(29^{\circ} 30^{\prime}\right.$ N. $113^{\circ} 40^{\prime}$ W.).

Holotype: Male (CAS) 8929.

Allotype: Female, same data (CAS).

\section{Scenopinus velutinus (Kröber)}

\section{Figure 106}

Omphrale velutina Kröber, 1913, p. 203.

Omphrale nubilipes Kröber (not Say), 1928a, p. 2.

The type of this species has been lost. There is, however, a paratype male in the U.S. National Museum and a long series of females from the type-locality which have been used to figure this species. 
Length: Male body $3.5 \mathrm{~mm}$., wing $2.5 \mathrm{~mm}$.; female body $3.5-4$ $\mathrm{mm}$., wing $2.5-2.7 \mathrm{~mm}$.

Type-locality: Costa Rica.

Type: Coll. Kröber (lost).

Specimens seen: 21 of, Higuito, San Mateo, Costa Rica (Pablo Schild) (USNM) ; 1 o, 2 mi. n.e. Guadelupe Atodia, Chiapas, Mexico, 24 March 1953, (R. C. Baker, E. I. Schlinger) (UCalB); 1 \%, Constant Spring, Saint Andrew, Jamaica, W.I., 23 August 1964 ('T. H. Farr) (SMIJ).

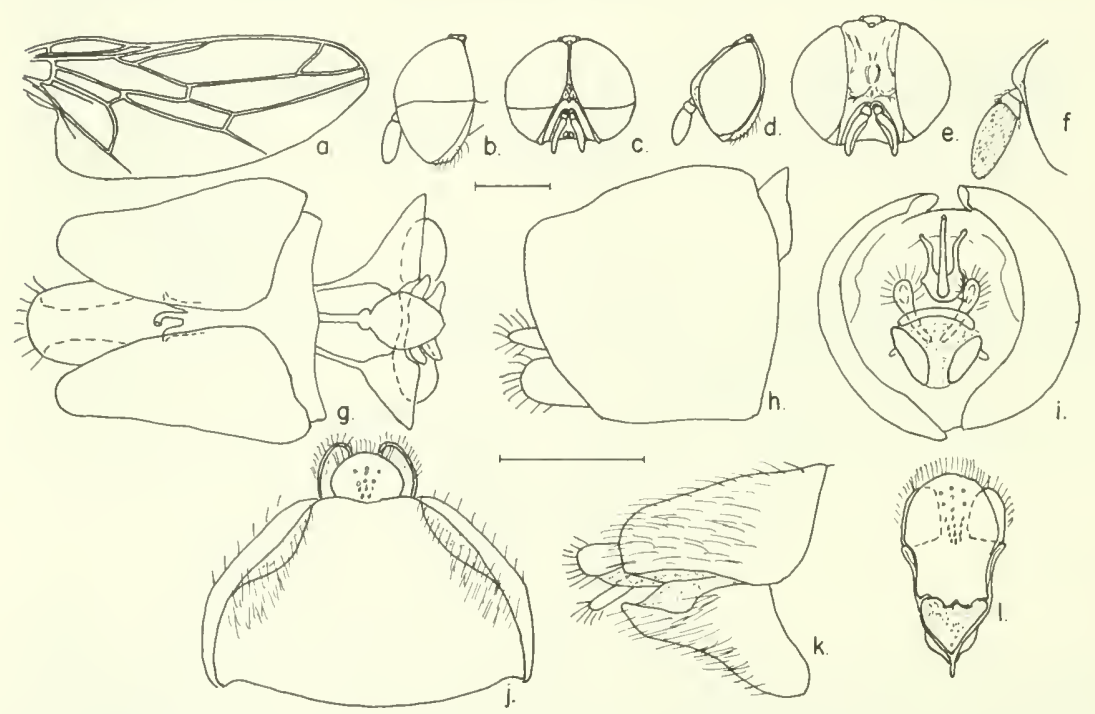

Figure 106.-Scenopinus velutinus (Kröber), male, female: $a$, wing; $b, c$, lateral and frontal aspects of male head; $d, e$, lateral and frontal aspects of female head; $f$, enlarged detail of antenna; $g-i$, ventral, lateral and posterior aspects of male terminalia, ejaculatory mechanism lost on dissection; $j$, ventral aspect of female 8 th sternum; $k$, lateral aspect of female 8 th and 9th segments; $l$, female 9 th sternum and bursa.

\section{Scenopinus weemsi, new species}

FIGURE 107

This small species appears to be closely related to $S$. mirabilis but apparently has been isolated long enough to be recognized as a distinct species.

MALE.-Head black-brown; eyes black-brown above, black below; frons narrow triangular, slightly swollen in the middle, rugose but subshining; ocellar tubercle black, prominent, ocelli orange; silvery pile surrounding oral opening. First two antennal segments red-brown; first short; second about twice as large; third segment dark red-brown, pear-shaped, wider at base, twice as long as wide, truncate at tip. 
Thorax dorsum black with a thin powder of white, humeral and supra-alar calli red-brown to orange-brown; pleura red-brown to black-brown, dusted with white in exposed areas. Wings milky white, veins very faint, nearly white, $R 5$ and $M 1+2$ broadly separated, $\Lambda 1+2$ ending behind the tip of the wing; halter stem brown, knob white. Legs with femora and tibiae dark red-brown, tarsi straw yellow.

Abdomen dark red-brown, segments $3-5$ very broadly membranous white, with thin sclerotized anterior bands. For details of ninth segment, see figure.

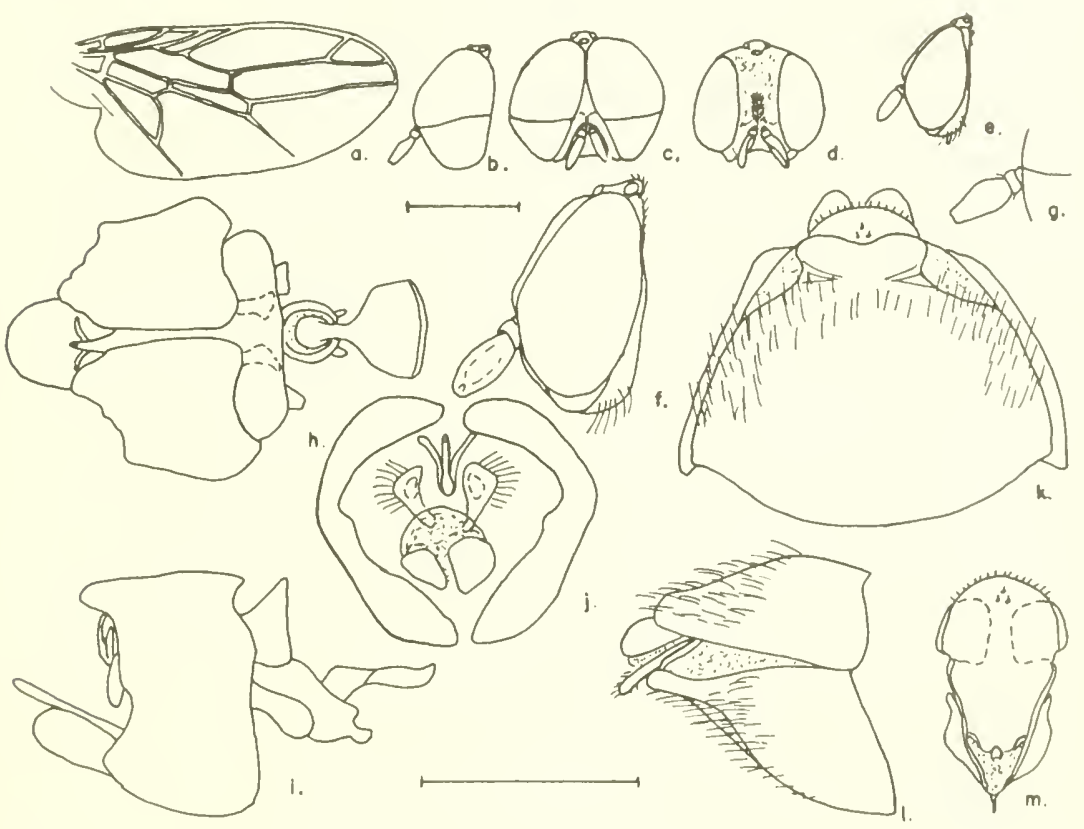

Figure 107.-Scenopinus weemsi, new species, male, female: $a$, wing; $b, c$, lateral and frontal aspects of male head; $d, e$, frontal and lateral aspects of female head; $f$, enlarged lateral aspect of female head and antenna; $g$, enlarged detail of male antenna; $h-j$, ventral, lateral and posterior aspects of male terminalia; $k$, ventral aspect of female 8 th sternum; $l$, lateral aspect of female 8 th and 9 th segments; $m$, female 9 th sternum and bursa.

Female.-Head black-brown; eyes black-brown, with a very thin postocular ridge fringed with hairs; back of head concave, covered with a silvery pile, frons broad, rugose, slightly swollen, with a median groove extending about halfway up the frontal area, lower fourth of frons red-brown. Ocellar tubercle not set off from frons, ocelli orange. Antennae as in male.

Thorax dorsum red-brown, otherwise as in male; pleura as in male, halter stem brown, knob white with tan dorsal portion. Legs as in male. 
Abdomen red-brown, subshining. See figure for details of the eighth segment and bursa.

Length: Male body 2-2.2 mm., wing $1.5 \mathrm{~mm}$.; female body 2.8 mm., wing $1.7-2 \mathrm{~mm}$. Jr.).

Type-locality: Putnam Co., Florida; 6 July 1956 (H. V. Weems,

Holotype: Male (USNM) 67478.

Allotype: Female same data as type (USNM).

Paratypes: $3 \sigma^{x} \sigma^{x}$, same data as type (USNM); $2 \sigma^{x} \sigma^{x}, 1$, Gainesville, Florida, 25 April 1952 (O. Peck) (CNC).

\section{Scenopinus werneri, new species}

\section{Figure 108}

This species is of interest as it is one of the few recorded to have been captured by ultra violet light traps.

MaLe.--Head red-brown; eyes yellow-brown above, brown below extending to but not around the back of the head; frons subshining, swollen, extending nearly to ocellar triangle, with a shallow pit at the midpoint. Ocellar tubercle black-brown, prominent, ocelli amber; first antennal segment brown, short; second segment larger, yellowbrown; third segment brown, pear-shaped.
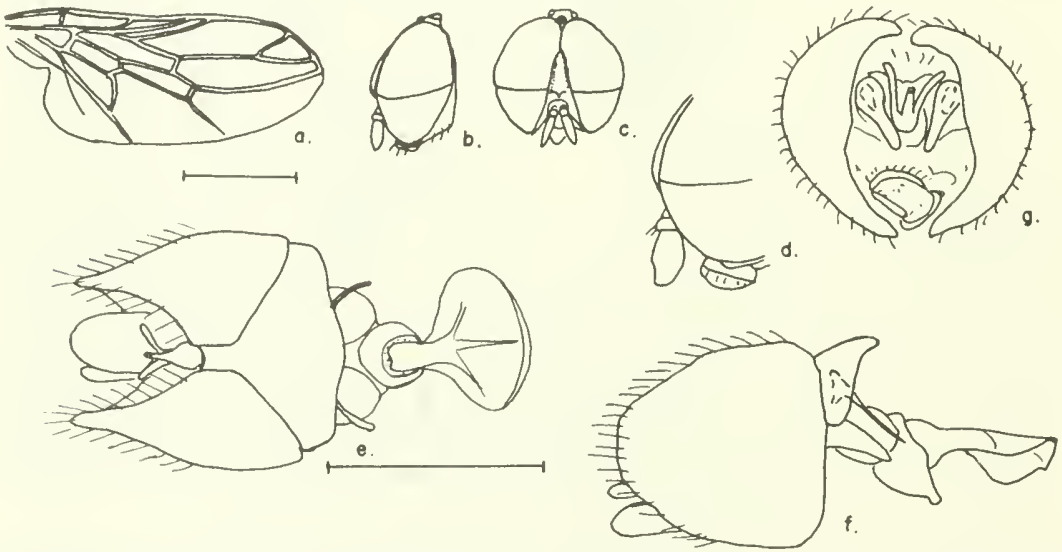

Figure 108.--Scenopinus werneri, new species, male: $a$, wing; $b, c$, lateral and frontal aspects of head; $d$, enlarged detail of antenna; $e-g$, ventral, lateral and posterior aspects of terminalia.

Thorax dorsum black-brown, subshining with faint transverse striations; humeral callus tan; pleura red-brown; wings hyaline, veins yellow-brown; halter stem brown, knob with base brown, remainder white. Legs with fore and middle femora and tibiae orange-brown, tarsi tan; hind leg darker red-brown, tarsus tan. 
Abdomen red-brown, segments 3 and 4 with white bands, remainder red-brown. See figure for details of ninth segment.

Female.-Unknown.

Length: Male body $2 \mathrm{~mm}$., wing $1.6 \mathrm{~mm}$.

Type-locality: 8 mi. n. Vail, Pima Co., Arizona; 30 August 1962 (F. Werner and W. L. Nutting) u.v. trap.

Holotype: Male (USNM) 67481.

Paratype: Male same data (UAriz).

\section{Scenopinus whittakeri (James)}

\section{Figure 109}

Omphrale whittakeri James, 1955, p. 47.

Dr. James was kind enough to submit two of his paratypes for figuring. As James points out, this species is close to $S$. mirabilis but the whole hind margin of the ninth tergum is more sloping and the ventral extension is not prominent.

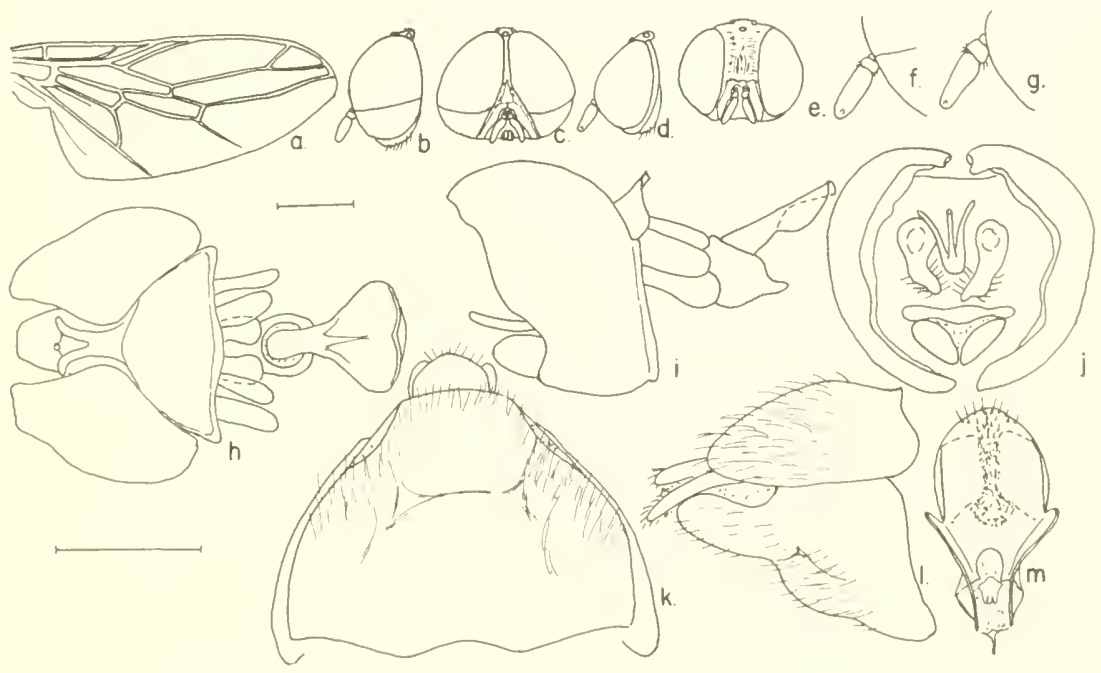

FIGURE 109.- Scenopinus whittakeri (James), male, female: $a$, wing; $b$, $c$, lateral and frontal aspects of male head; $d, e$, lateral and frontal aspects of female head; $f, g$, enlarged details of male and female antennae; $h-j$, ventral, lateral and posterior aspects of male terminalia; $k$, ventral aspect of female 8 th sternum; $l$, lateral aspect of female 8 th and 9 th segments; $m$, female 9 th sternum and bursa.

Length: Male body $3 \mathrm{~mm}$., wing $2.3 \mathrm{~mm}$.; female body $3.5 \mathrm{~mm}$., wing $2.5 \mathrm{~mm}$.

Type-locality: Hanford, Benton Co., Washington; sagebrush, 640 ft., 6 May 1952, Ss8-5 (R. H. Whittaker).

Type: (WSU) 176. 
Allotype: Female, same data, 30 July 1952, Sc20-22.

Other specimen seen: $1 \sigma^{7}$, Lowden, Washington; 22 June 1921 (A. L. Melander) (USNM).

\section{Genus Caenoneura Kröber}

Caenoneura Kröber, 1923, p. 75.

Type-species, Caenoneura robusta Kröber (monobasic). The genus Caenoneura Krröber is distinguished by the peculiar wing venation which is crowded to the leading edge of the wing. Both members of this genus come from the circum-Mediterranean area.

\section{Caenoneura robusta Kröber}

Figdre 110

Caenoneura robusta Kröber, 1923, p. 75.

This species is easily recognized by the peculiar venation of the wing with all of the $\mathrm{R}$ veins and $\mathrm{M} 1+2$ ending in the leading edge of the wing. The male has scalelike hairs on the frons and ocellar triangle and five white bands on the abdomen.
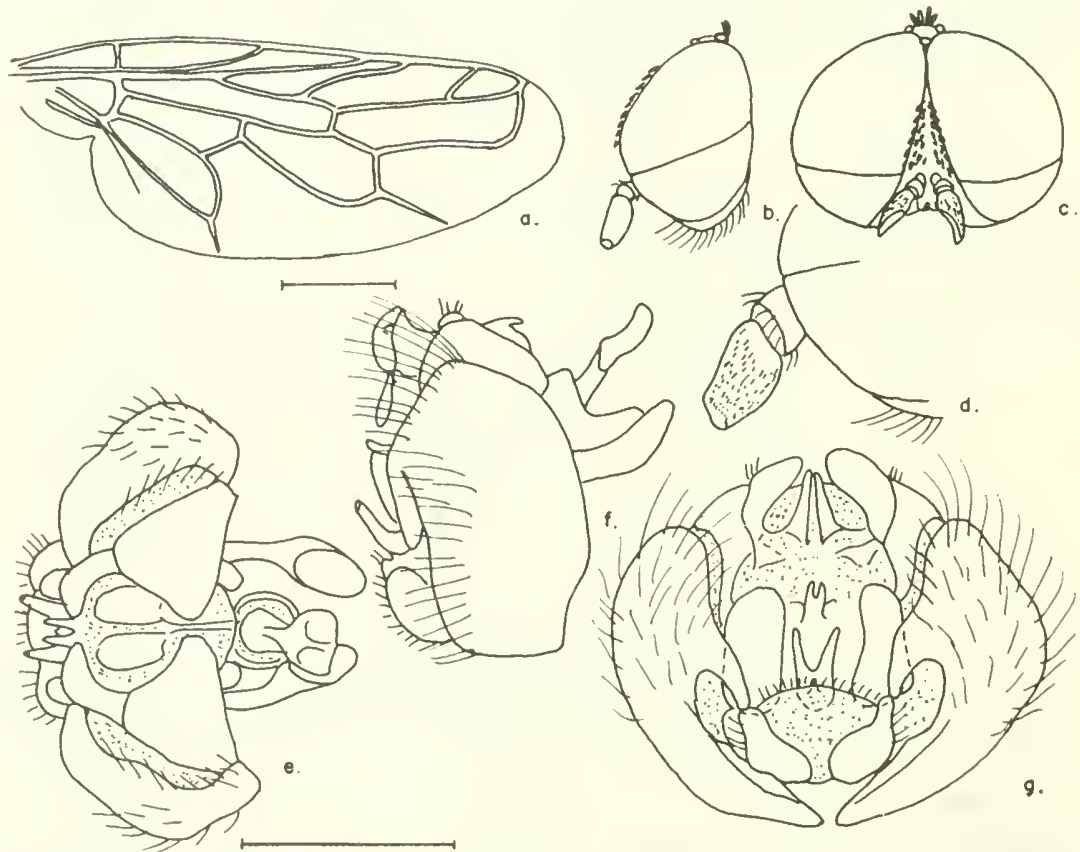

Frgure 110.-Caenoneura robusta Kröber, male: $a$, wing; $b$, $c$, lateral and frontal aspects of head (note scale-like hairs); $d$, enlarged detail of antenna; $e-g$, ventral, lateral and posterior aspects of terminalia. 
Length: Male body $3 \mathrm{~mm}$., wing $2.4 \mathrm{~mm}$.

Type-locality: Egypt.

Type: (SEE).

113. Caenoneura nigra, new species

Figure 111

Fenale.-Head black; eyes black, with a narrow postocular rim; frons broad, roughened, with a row of punctures along the eye margin and a faint median groove. Mouthparts well developed, black-brown; oral opening wider than long, fringed with silvery pile. Ocellar tubercle prominent, ocelli reddish. First two antennal segments black, short; third segment brown-black, over twice as long as first two combined, truncate.
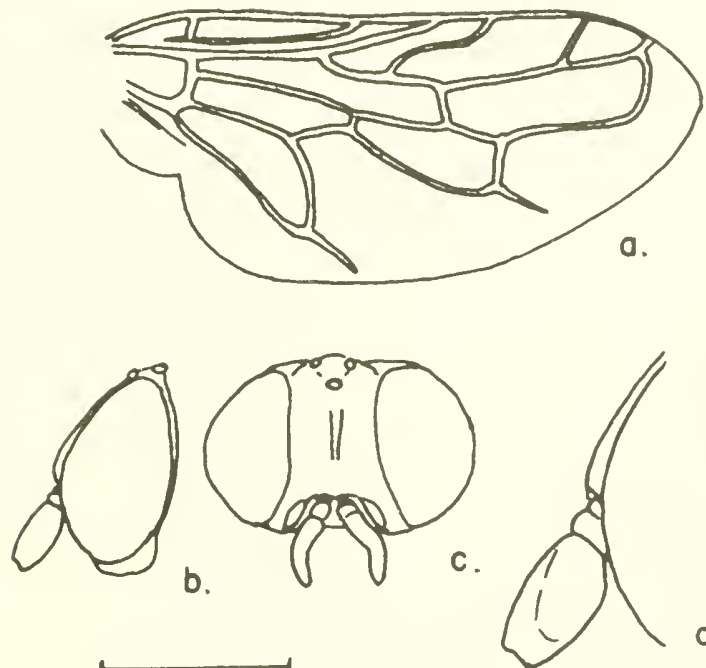

d.

Figure 111.-Caenoneura nigra, new species, female: $a$, wing; $b, c$, lateral and frontal aspects of head; $d$, enlarged detail of antenna.

Thorax black, rugose; humeral and supra-alar calli brown, scutellum not sharply cut off from general tergal area; wings smoky brown, veins dark brown, eharacteristic of genus. Halter stem black, knob brown, round. Legs with femora and tibiae black, tarsi brown.

Abdomen black, broad, and rounded.

MaLe.-Unknown.

Length: Female body $2.1 \mathrm{~mm}$, wing $1.7 \mathrm{~mm}$. 
Type-locality: Sierra Nevada Highway, Spain; 1600 m., 27 July 1960 (J. R. Vockeroth).

Holotype: Female (CNC) 8629.

\section{Genus Pseudomphrale Kröber}

Pseudomphrale Kröber, 1913, p. 180.

Typo-species, Scenopinus clausus Loew (monobasic). The genus Pseudomphrale Kröber is at present poorly defined as only one member of the genus is available and the author was unable to obtain permission to dissect the genitalia for study. The remaining species have not been located so that the characters that could be used to distinguish the members of this genus cannot be determined at present. The only common character possessed by all the species is the closed cell R5 and this character is common to ten other genera. The members of this genus are found in the Middle East.

\section{Pseudomphrale clausa (Loew)}

Scenopinus clausus Loew, 1873, p. 150.

The type of this species could not be located.

Length: Male body $1.6 \mathrm{~mm}$., wing $1.5 \mathrm{~mm}$.

Type-locality: Samarkand; 19 June (Fedtschenko).

Type: Presumed lost as Kröber did not figure this species.

\section{Pseudomphrale crenata (Becker)}

Omphrale crenata Becker, 1913, p. 550.

The type of this species could not be found.

Length: Female body $3.5 \mathrm{~mm}$., wing ?

Type-locality: vicinity of Tschachbar, Makran Coast of Indian Ocean, Baluchistan; 12-16 March 1901 (Zarundy).

Type: ? Leningrad.

\section{Pseudomphrale dubiosa (Becker)}

Omphrale dubiosa, Becker, 1913, p. 551.

The type of this species could not be found.

Length: Male body $3 \mathrm{~mm}$.

Type-locality: vicinity of Tschachbar, Makran Coast of the Indian Ocean, Baluchistan; 12-16 March 1901 (Zarundy).

Type: ? Leningrad. 


\section{Pseudomphrale longirostris (Becker)}

Omphrale longirostris Becker, 1913, p. 549.

The type of this species could not be found.

Length: Female body $3.5 \mathrm{~mm}$.

'Type-locality: vicinity of 'T'sehachbar, Makran Coast of the Indian Ocean, Baluchistan; 12-16 March 1901 (Zarundy). Southern part of the Mountain Cove Kuch-i-tuftan; 5 May 1901 (Zarundy).

Type: ? Leningrad.

It seems highly probable that one of the females belongs to $P$. dubiosa and that only two species exist.

\section{Pseudomphrale palaestinensis Kröber}

FIgURE 112

Pseudomphrale palaestinensis Kröber, 1937, p. 229.

The exact position of this species is in doubt at the present time as I did not have permission to dissect the type specimen nor was I able to compare it with other members of the group. The long aledeagal parameres are reminiscent of North American Brevitrichia but without a more detailed study of the ninth tergum and internal structures little more can be said.

Length: Male body $3 \mathrm{~mm}$, wing $2 \mathrm{~mm}$.

Type-locality: Scopusberg, Jerusalem.

Type: (SMNS).

\section{Genus Brevitrichia D. E. Hardy}

Brevitrichia D. E. Hardy, 1944a, p. 32.

'Type-species, Pseudatrichia griseola Coquillett (original designation). 'The genus Brevitrichia Hardy is characterized by small flies with the thorax covered with a fine granular dusting which is brown to gray. Head higher than long and antennae generally pear-shaped and ending in two points with a median sensory peg. Cell R5 of the wing closed and rein R4 branched from the base of cell. In the male, ninth tergum bilobed, open below and aedeagus in the form of two clongate bristles. Female eighth segment elongate; sternum excarated posteriorly. The member's of this genus are found west of the Rocky Mountains in the United States and Mexico.

\section{Key to Species of Brevitrichia (males)}

1. Wing hyaline. . . . . . . . . . . . . . . . . . 2 Wing smoky white or brown . . . . . . . . . . . . . . 5

2. Halter knob tan . . . . . . . . . . . . . . 3 IIalter knob cream .. . . . . . . . . . B. arnaudi, new species

3. Abdomen black-brown or red-brown . . . . . . . . . . . . . . 4 Abdomen white............ B. oculivirida, new species 

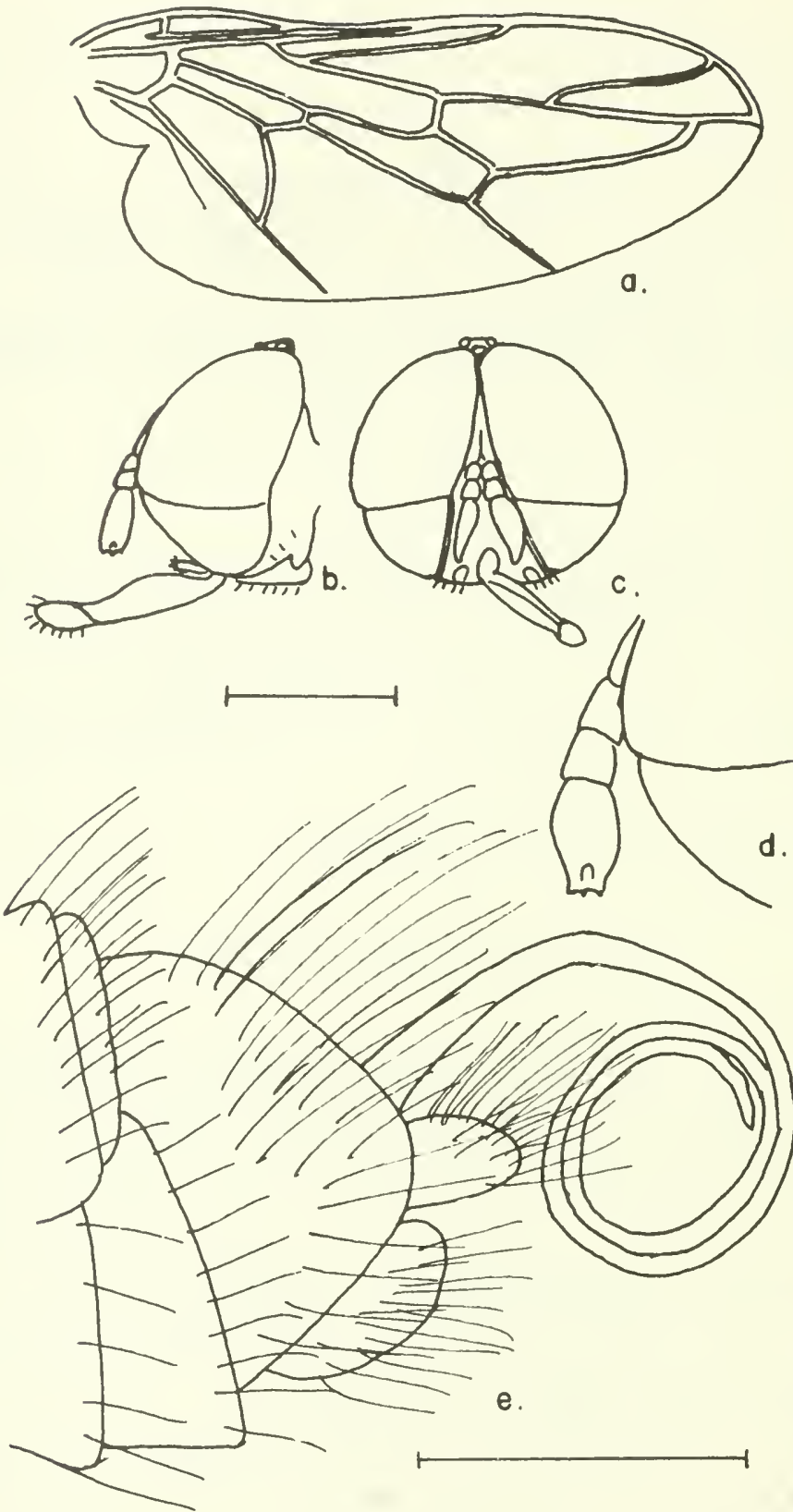

Figure 112.-Pseudomphrale palaestinensis Kröber, male: $a$, wing; $b$, $c$, lateral and frontal aspects of head; $d$, enlarged detail of antenna; $e$, lateral aspect of undissected terminalia. 
4. Abdominal segments black-brown with white posterior margins

B. halli, new species

Abdominal segments red-brown with ereamy posterior margins

B. ordwayi, new species

5. Wing smoky brown. . . . . . . . . . . . . . . . 6

Wing smoky white. . . . . . . . . . . . . . . . . 7

6. Halter knob tan. . . . . . . . . B. hodgdeni, new species

Halter knob tan with eream ventral surface. . B. griffini, new speeies

7. Halter knob white . . . . . . . . . . . . . . . . . 8

Halter knob cream or tan . . . . . . . . . . . . . 10

8. Abdomen pristine white. . . . . . . . . . . . . . . . . 9

Abdominal segments black with white posterior margins. B. insulana (Cule)

9. R4 branching beyond $r-m$ cross vein equal length of $r-m$

B. addacifons, new species

$\mathrm{R} 4$ branching beyond $\mathrm{r}-\mathrm{m}$ eross vein twice length of $\mathrm{r}-\mathrm{m}$

B. castanea, new species

10. Halter knob tan. . . . . . . . . . . . . . . . . . . . 11

Halter knob cream. . . . . . . . . . . . . . . . . . . 13

11. Halter knob all tan. . . . . . . . . . . . . . . . . . . 12

IIalter knob tan above cream below, abdominal segments red-brown with cream posterior margins. . . . . . . . B. yucatani, new species

12. Abdomen white. . . . . . . . . B. pruinosa, new species

Abdomen cream with eentral red-brown " $\mathrm{T}$ "s. . . B. griseola (Coquillett)

13. Halter knob all eream. . . . . . . . . . . . . . . . . 14

Ilalter knob cream, marked or lighter below, or yellow . . . . . . . . 18

14. Abdomen marked with brown or cream . . . . . . . . . . . . . . 15

Abdomen white above. . . . . . . . . B. boharti, new species

15. Abdomen white with narrow anterior brown bands . . . . . . . . 16

Abdomen red-brown . . . . . . . . . . . . . . . . . . . . 17

16. R4 branching beyond $\mathrm{r}-\mathrm{m}$ about length of $\mathrm{r}-\mathrm{m}$. . . B. davisi, new species $\mathrm{R} 4$ branching beyond $\mathrm{r}-\mathrm{m}$ twice length of $\mathrm{r}-\mathrm{m}$. . . B. downeyi, new species

17. Abdomen with central red-brown " $T$ "s fading to white

Abdomen with segments red-brown with posterior bands eream

B. beameri, new species

18. Halter knob white or yellow below . . . . . . . . . . . . . . . . 19

Halter knob with tan margins. . . . . . B. timberlakei, new species

19. Halter knob white below . . . . . . . . . . B. minuta, new species

Halter knob yellow below . . . . . . . . . . . . . . . . 20

20. Abclomen yellow with black basil bancls. . . . . . B. helenae (James)

Abdominal segments brown with creamy margins. B. schlingeri, new species

\section{Key to Species of Brecitrichia (females)}

1. Wing hyaline .. . . . . . . . . . . . . . . . . 2

Wing smoky brown or white . . . . . . . . . . . . . 10

2. Halter knob tan, cream or orange . . . . . . . . . . . . . . . . 3

Halter knob white, 7 spines on 8 th tergum . . . . B. flocki, new species

3. Halter knob eream . . . . . . . . . . . . . . . . . . . . 4

Halter knob tan or orange . . . . . . . . . . . . . . . 8

4. Halter knob all eream . . . . . . . . . . . . . . . . 5

Halter knob cream above tan below, sth tergum with 7 spines

B. downeyi, new species 
5. Abdomen brown or orange . . . . . . . . . . . . . . . 6

Abdomen brown grading to tan posteriorly . . . . . . . . . . . 7

6. Abdomen brown with white posterior bands; 8 th tergum with 7 spines

B. arnaudi, new species

Abdomen orange; Sth tergum with 7 spines and much hair

B. dicksoni, new species

7. Eighth tergum with 8 spines and a dorsal pit . . . B. boharti, new species Eighth tergum with 6 spines ....... B. schlingeri, new species

8. Halter knob tan

Halter knob orange, 8 th tergum with 8 spines . . B. davisi, new species

9. Halter knob tan above cream below, 8 th tergum with 8 spines and a ventral pit . . . . . . . . . . . B. beameri, new specics Halter knob entirely tan, 8th tergum with 9 short stiff spines

10. Wing smoky white

11. Halter knob tan . . . . . . . . . . . . . . . 12

Halter knob cream, abdomen with red-brown "T"s; 8th tergum with 6 spines and much hair. . . . . . . . . . . . B. coquilletti, new species

12. Halter knob lighter below. . . . . . . . . . . . . . . . . 13

Halter knob all tan, abdomen dark red-brown; Sth tergum with 1 dorsal spine and 7 pits . . . . . . . . . B. hodgdeni, new species

13. Halter knob cream below . . . . . . . . . . . . . . . . 14

Halter knob white below; Sth tergum with 7 spines . B. griffini, new species

14. Abdomen brown; Sth tergum with 8 spines . . . B. melanderi, new species

Abdomen red-brown with white lateral patches grading to all red-brown; 8th tergum with 4 spines. . . . . . . B. yucatani, new species

15. Halter knob yellow-brown, cream or tan . . . . . . . . . . . 16

Halter knob white, 8th tergum with 9 spines and a ventral tuft of hairs

B. insulana (Cole)

16. Halter knob cream or tan . . . . . . . . . . . . . . 17

Halter knob yellow-brown, 8 th tergum without spines but with 8 pits

B. aspinosa, new species

17. Halter knob cream or tan . . . . . . . . . . . . . 18

Halter knob tan; abdomen red-brown, Sth tergum with 5 spines

B. ordwayi, new species

18. Halter knob entirely cream . . . . . . . . . . . . . . . 20

Halter knob cream with tan lateral bands . . . . . . . . . . . 19

19. Abdomen brown with white lateral patches, 8th tergum with hair only

B. addacifons, new species

Abdomen with red-brown "T"s grading to yellow-brown, 8th tergum with

6 spines . . . . . . . . . B. timberlakei, new species

20. Abdomen brown grading to tan or with red-brown " $T$ "s . . . . . . . 21

Abdomen black and white or red-brown and white bands . . . . . . . 22

21. Abdomen brown grading to tan; 8th tergum with a fringe of hair only

B. minuta, new species

Abdomen cream with red-brown central " $T$ "s grading to orange posteriorly;

8th tergum with 7 spincs and very short hair . . . B. kerni, new species

22. Abdominal segments red-brown with white posterior bands; 8 th tergum with

6 spincs . . . . . . . . . . B. scitulaesca, new species

Abdominal segments black with white posterior bands; 8th tergum with
8 spines
B. griseola (Coquillett) 


\section{Brevitrichia addacifons, new species}

Figure 113

MALE.-Head cream; eyes red-brown, metallic above, metallic black-oreen below; frons small, triangular; ocellar tubercle brown, pollinose; ocelli clear to red. MLuthparts well developed, haustellum red-brown, remainder eream; antenna as figured; first segment brown, second segment orange-brown, third segment brown.

'Thorax dorsum black-brown with brown and tan pollinose scales, lateral margins yellow; humeral and supra-alar calli cream; mesoscutellum mostly black-brown and gray pollinose, lateral margins yellow; pleural areas pollinose with yellow, red-brown and brown. Wings smoky, veins tan, see figure; halter stem brown, knob cream with a tan lateral band. Legs red-brown with pollinose scales.

Abdomen second segment with a broad anterior band of black with a broad central posterior stem and narrow lateral extensions like a " $T$," remainder of posterolateral portion pristine white, remaining. segments white dorsally. Ninth tergum with base black, remainder white pollinose. See figure for details of genital structures.

Female.-Head cream; eyes red-brown, metallic, with a moderately broad postocular ridge without spots of eolor; frons broad, unmarked, a few white hairs; ocellar triangle set off, red-brown, pollinose; ocelli clear to red-brown; groove at upper angle of eye directed toward back of ocellar triangle, fading, not reaching back of head, a central notch in back of ocellar triangle. Antennae with first two segments cream, third red-brown, shaped as shown in figure.

Thorax dorsum red-brown, eovered with gray pollinose scales in the center, with two lateral tan bands, area above humeral callus and the lateral margins cream, area in front of scutellum orange with two anteriorly directed arms; humeral and supra-alar calli white. Mesoscutellum red-brown orer middle half, lateral angles (ream pollinose. Pleura with prothorax white; anepisternum white, with usmal dark patch; katepisternum red-brown, with white dorsal border. Wings hyaline, smoky, reins clear; halter stem brown, knob white. Legs femora red-brown, tibiae and tarsi tan-brown.

Abdomen segments brown with white lateral patches. Eighth segment yellow-brown, shaped as figured. Ninth tergum without bristles, only long thin hair; see figure.

Length: Male body $2.7 \mathrm{~mm}$., wing $2 \mathrm{~mm}$.; female body $2.8 \mathrm{~mm}$., wing $1.8 \mathrm{~mm}$.

Type-locality: Antelope Springs, 8 mi. s.w. Deep Springs, Imperial Co., California; 1 July 1961 (G. J. Stage).

Holotype: Male (UCalD) 75 . 
Allotype: Female same locality, 29 June 1961 (J. Powell). Paratype: $1 \sigma^{7}$, same data as type (UCalD).
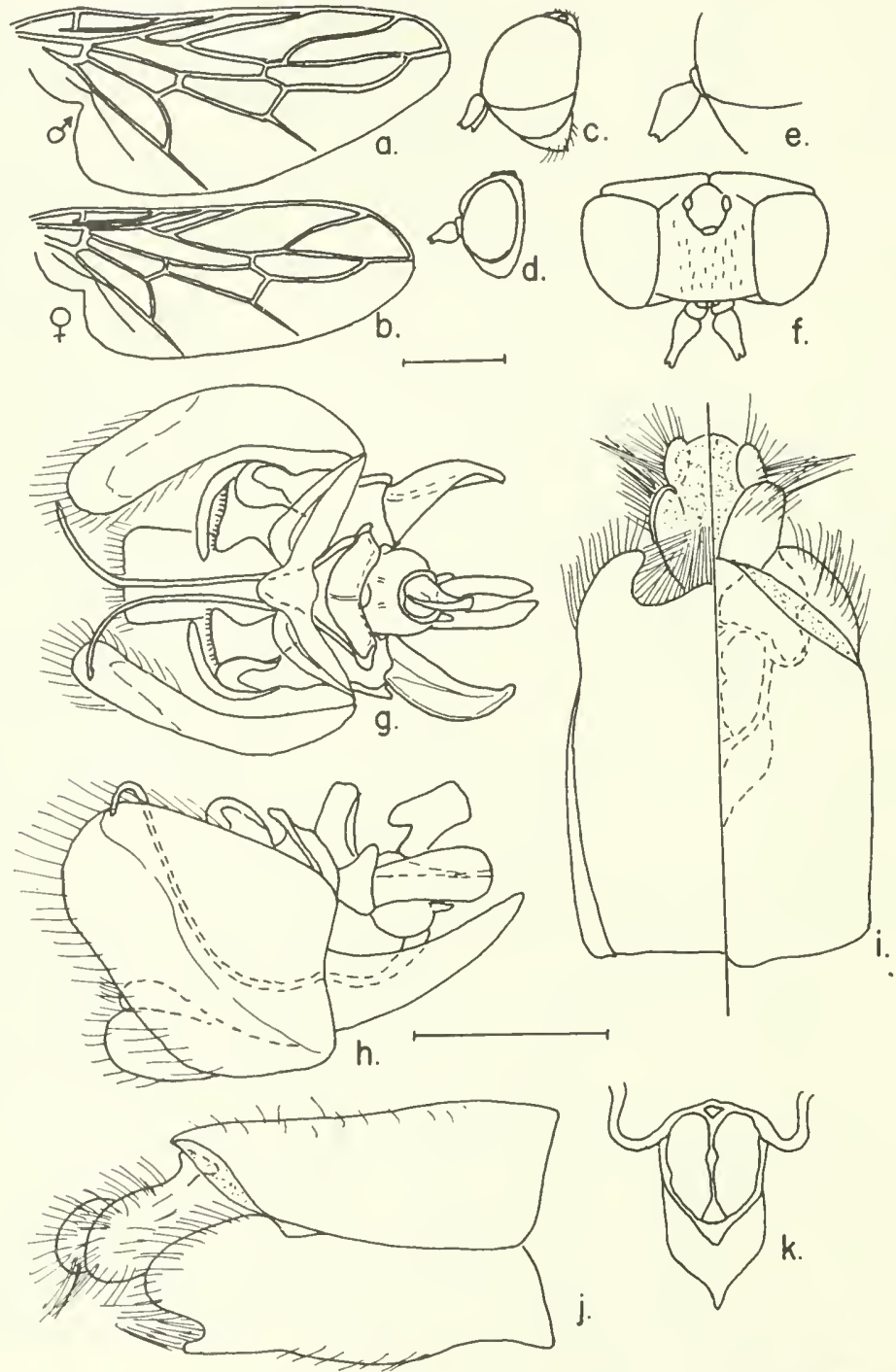

Figure 113.-Brevitrichia addacifons, new species, male, female: $a$, male wing; $b$, female wing; $c$, lateral aspect of male head; $d$, lateral aspect of female head; $e$, enlarged detail of antenna; $f$, dorsal aspect of female head; $g$, $h$, ventral and lateral aspects of male terminalia; $i$, ventral left and dorsal right aspects of female 8 th and 9 th segments; $j$, lateral aspect of female 8th and 9th segments; $k$, bursal structure. 


\section{Brevitrichin arnatsdi, new speeies}

FIGIRE 11.1

MALE.-Head brown; eyes black, with a green metallic glint above and a red metallie glint below (brown in dried specimens); frons tan, small, triangular; ocellar tuberele tan, pollinose; ocelli orange. Antennae with all segments brown; see figure for details on shape.

Thorax dorsum black-brown, covered with tan pollinose seales, with a slight longitudinal striping; humeral and supra-alar calli cream; mesoseutellum cream, with a brown patch oecupying the middle third. Pleura with prothorax cream; anepistermum cream, katepisternum red-brown. Wings hyaline, veins tan; halter stem cream, knob cream. Legs with femora light brown with a tan knee; tibiae tan; tarsi tan, darkening distally.

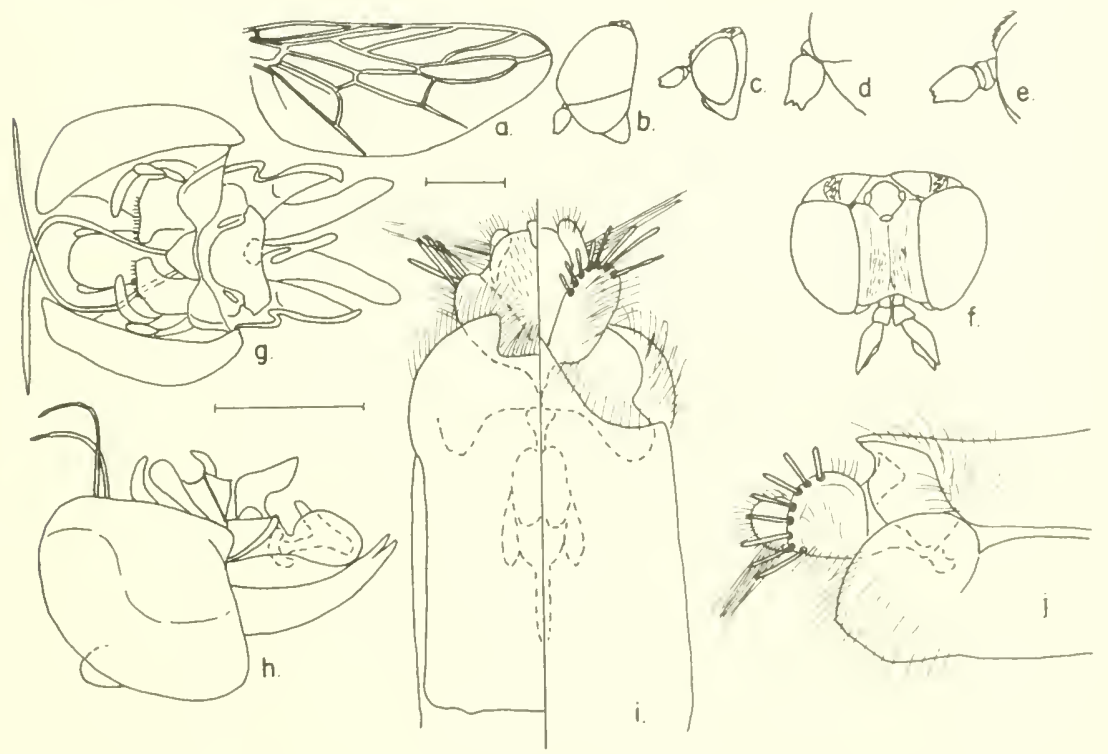

FIgURE 114.-Brevitrichia arnaudi, new species, male, female: $a$, wing; $b$, lateral aspect of male head; $c$, lateral aspect of female head; $d, e$, enlarged details of male and female antennae; $f$, dorsal aspect of female head; $g, h$, ventral and lateral aspects of malc terminalia; $i$, ventral left and dorsal right aspects of female 8 th and 9 th segments, bursal structure outlined; $j$, lateral aspect of female 8 th and 9 th segments.

Abdomen segments brown with vellow-brown membranes along posterior margins. Ninth teroum cream with a brown pateh basally which extends along the open margin; see figure for details.

Female.-Head tan; eyes metallic green to brown in dried specimens; postocular ridge broad, with a brown patch behind the eye; 
frons broad a little wider than the ocellar triangle, with a median groove running the entire length, a brown central band clothed with a few sparse hairs, grooves from upper angle of eye extending to back of head laterad of the midline. Ocellar tubercle red-brown, with tan pollinose scales, ocelli orange. Antennal segments brown, shaped as in figure.

Thorax dorsum red-brown ground, covered with longitudinal red-brown pollinose bands; humeral and supra-alar calli orange to cream, with a light area between. Pleural areas as in male; wings as in male; legs as in male; halter cream.

Abdomen segments brown, with light membranous margins; eighth segment orange-brown, ninth tergum with 8 stiff spines sparse hairs, 10th tergum with a thick pencil of long hairs at base.

Length: Male body $2.5 \mathrm{~mm}$., wing $1.8 \mathrm{~mm}$.; female body $4 \mathrm{~mm}$., wing $2.3 \mathrm{~mm}$.

Type-locality: Los Frailes, Baja California, Mexico; 18 March 1953 (P. H. Arnaud) Sefton Orca Exped. to Gulf of California.

Holotype: Male (CAS) 8930.

Allotype: Female on same pin, sama data.

Paratypes: $10^{x}$, Cabo San Lucas, Baja California, Mexico, 16 March 1953 (P. H. Arnaud); 2 ㅇ ㅇ, Los Frailes, Baja California, Mexico, 18 March 1953 (P. H. Arnaud) (CAS).

\section{Brevitrichia aspinosa, new species}

\section{Figure 115}

Female.-Head cream; eyes red-brown, probably metallic in life; postocular ridge moderately wide, continuous behind ocellar triangle, with a wide brown spot behind each eye; frons broad, with a median groove bordered by bands of tan; sparse hairs over entire frons; ocellar triangle red-brown, ocelli clear; grooves from upper corner of eyes extending to lateral ocelli. Antennae with first two segments brown; third segment orange-brown basally darkening to brown distally; see figure.

Thorax tergum red-brown with lateral margins yellow, two yellow streaks laterad of brown midline stripe posteriorly, all covered with gray pollen; humeral and supra-alar calli yellow. Scutellum tan, with a brown spot occupying the middle third. Pleura with prothorax red-brown and cream, mesanepisternum cream with large red areas, katepisternum red-brown with cream dorsal stripe, pollinose. Wings smoky, veins brown; halter stem tan, knob yellow-brown. Legs with femora red-brown, pollinose; knees yellow, tibiae and tarsi brown.

Abdomen red-brown with white membranous posterior margins. Eighth segment red-brown, ninth tergite with no spines but 8 pits; see figure. 


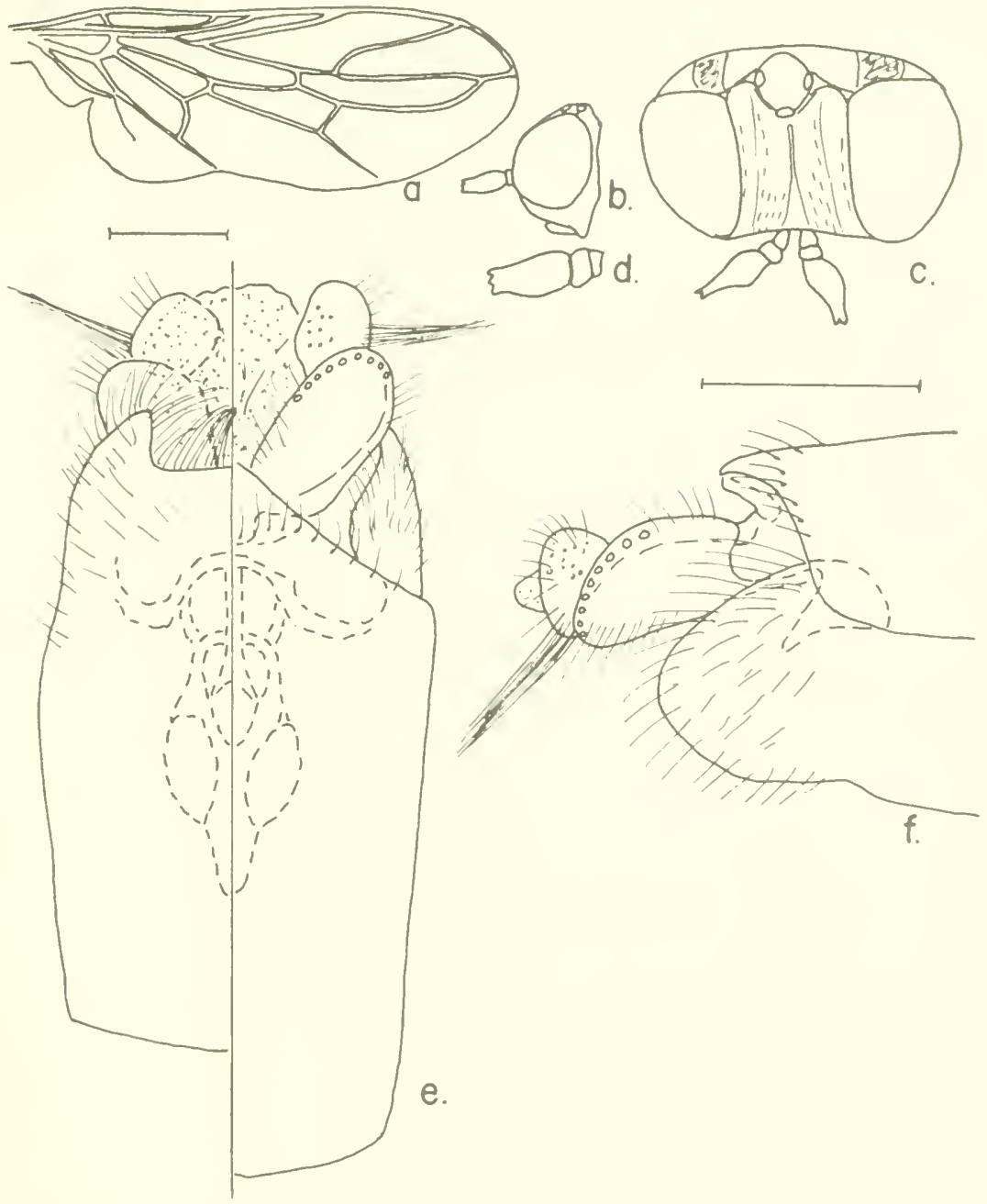

Figure 115.--Brevitrichia aspinosa, new species, female: $a$, wing; $b$, lateral aspect of head; $c$, enlarged detail of antenna; $d$, dorsal aspect of head; $e$, ventral left and dorsal right aspects of 8 th and 9 th segments, bursal structure outlined; $f$, lateral aspect of 8 th and 9 th segments.

MALE.--Unknown.

Length: Female body $4.7 \mathrm{~mm}$., wing $2.3 \mathrm{~mm}$.

Type-locality: 7 mi. w. Seligman, Arizona; 1 July 1952 (R. H. \& L. D. Beamer, C. Wemer, A. Wolf, W. LaBerge, C. Liang).

Holotype: Female (UKan) 6291. 


\section{Brevitrichia beameri, new species}

Figure 116

Pseudatrichia griseola Cresson (not Coquillett), 1907, p. 113.

MALE.-Head cream; eyes red-brown above, black-brown below; frons tan, small, triangular; ocellar tubercle black-brown, covered with gray pollen, ocelli red-brown. Antennae red-brown; see figure for details.

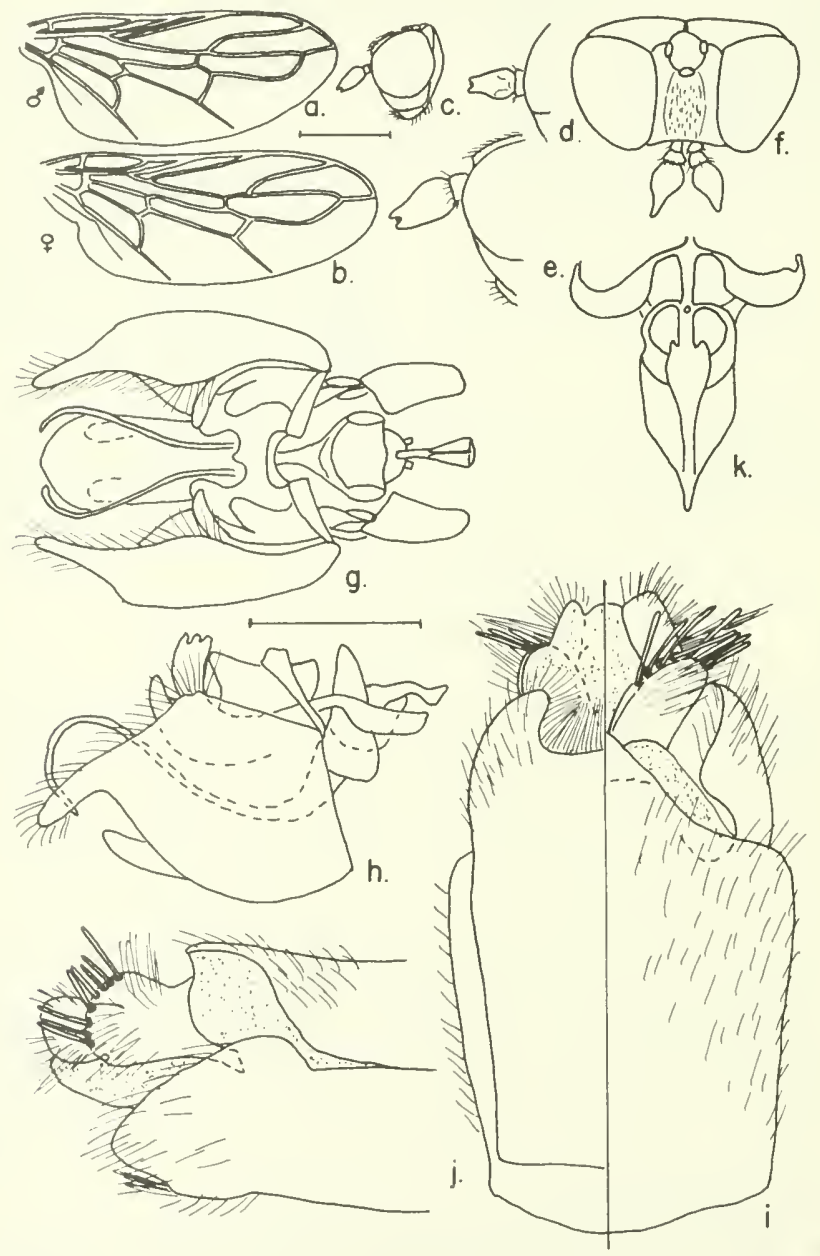

Figure 116.-Brevitrichia beameri, new species, male, female: $a$, male wing; $b$, female wing; $c$, lateral aspect of female head; $d$, enlarged detail of male antenna; $e$, enlarged detail of female antenna; $f$, dorsal aspect of female head; $g, h$, ventral and lateral aspects of male terminalia; $i$, ventral left and dorsal right aspects of female 8 th and 9th segments; $j$, lateral aspect of female 8 th and 9th segments; $k$, bursal structure. 
Thorax dorsum black-brown, covered with gray pollen, hairs sparse, short; humeral and supra-alar calli cream; scutellum broadly red-brown, covered with gray pollen, lateral margins cream. Pleura red-brown, with patches of yellow, covered with gray pollen; wing smoky, veins tan; halter stem tan, knob creamy white; legs red-brown, covered with gray pollen.

Abdomen red-brown, segments with narrow cream-colored membranous posterior margins; ninth tergum distinctive, ending in points; see figure for details.

Female.-Head cream; eyes red-brown, with green metallic sheen; frons broad with a median yellow-brown band covered by anteriorly directed hairs; postocular ridge moderately broad, without a brown patch, separated from frous by a shallow groove from the corner of the eye to back of lateral ocellus. Ocellar tubercle red-brown, covered with a gray pollen; antennae red-brown; see figure for details.

Thorax dorsum, pleura, and humeral callus as in male. Wing hyaline, veins light brown; halter stem light brown, knob cream below, tan above.

Abdomen red-brown, eighth segment red-brown, shining; ninth tergum with 8 stiff spines and a ventral pit. See figure for details.

Length: Male body $2.5 \mathrm{~mm}$., wing $1.7 \mathrm{~mm}$.; female body $3.7 \mathrm{~mm}$., wing $2.3 \mathrm{~mm}$.

Type-locality: $25 \mathrm{mi}$. w. Tularosa, New Mexico; 1 July 1940 (R. H. Beamer).

Holotype: Male (UKan) 6292.

Allotype: Female, paratype female, Alamogordo, New Mexico; 15 May 1902 (Viereck and Rehn) (ANS).

123. Brevitrichia boharti, new species

Figure 117

MALE.-Head cream; eyes metallic blue-green above, darker below, frons small, triangular; ocellar tubercle red-brown, dusted gray pollinose; back of head brown. Antennae with first segment tan, second and third segments orange-brown; see figure for details.

Thorax dorsum black-brown, dusted with olive pollen, anterior portion above humeral callus tan; humeral and supra-alar calli tan; mesoscutellum tan, with brown central spot covering half of the upper surface. Propleuron crean, mesanepisternum cream, with one brown patch, mesokatepisternum red-brown. Wings smoky, reins tan; halter stem red-brown, knob cream. Legs with femora brown to black-brown, with light knees, tibiae and tarsi tan to brown, darkening distally. 
Abdomen segment two with basal half red-brown, with a narrow median band extending to posterior margin, remainder white; remaining segments white above; ninth tergum white, with a brown spot at base; see figure for details.

Female.-Head cream; eyes metallic blue-green to brown, with a broad postocular ridge, with a band of brown behind eye; back of head brown-black; frons very broad, with a brown band up the middle, a faint median groove on lower half, a shallow groove extending from corner of eye to median ocellus. Ocellar tubercle redbrown; ocelli orange. Antennal segments orange-brown. See figure for details.

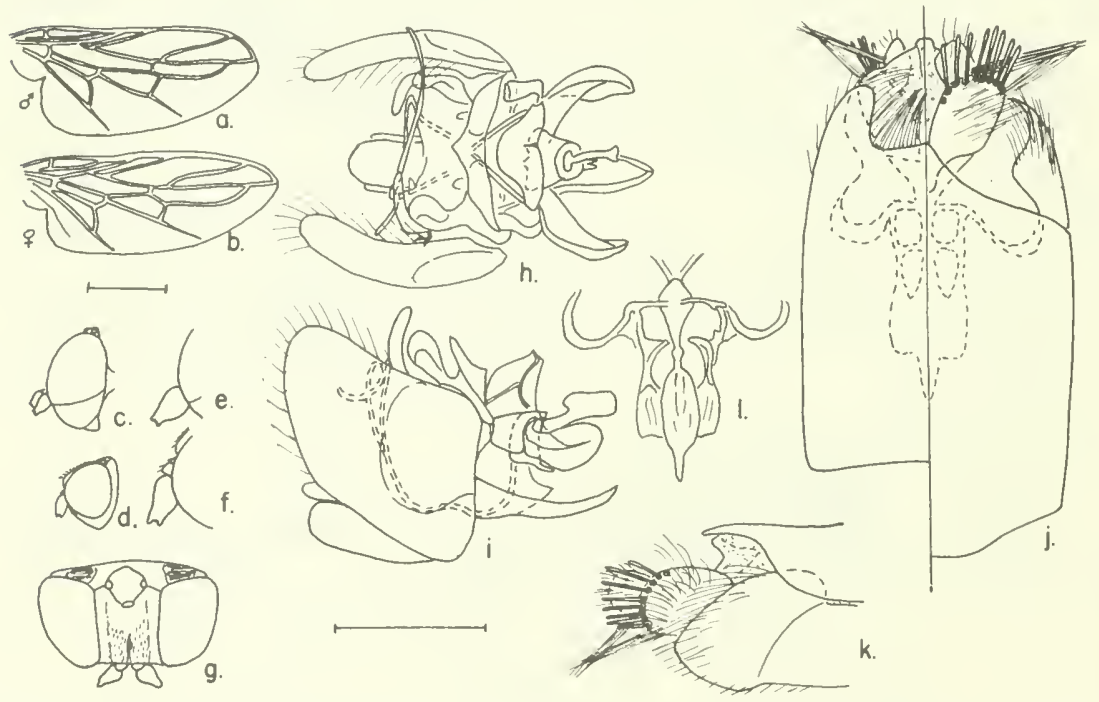

Figure 117.-Brevitrichia boharti, new species, male, female: $a$, male wing; $b$, female wing; $c, d$, lateral aspects of male and female heads; $e, f$, enlarged aspects of male and female antennae; $g$, dorsal aspect of female head; $h, i$, ventral and lateral aspects of male terminalia; $j$, ventral left and dorsal right aspects of female 8th and 9th segments; $k$, lateral aspect of female 8 th and 9th segments; $l$, bursal structure.

Thorax dorsum red-brown, with a dusting of tan pollen, a lighter tan patch above humeral callus; humeral and supra-alar calli tan to yellow. Scutellum tan, with a brown median spot. Pleural areas as in male. Wings hyaline, veins brown; halter stem tan to brown, knob cream; legs as in male.

Abdomen second segment broad, red-brown, with a light patch on the mid-lateral portions; other segments brown basally, tan 
distally; eighth segment red-brown; ninth tergum with 8 stiff spines and al dorsal pit. See figure for details.

Length: Male body $2.7 \mathrm{~mm}$., wing $2.2 \mathrm{~mm}$.; female body $4.7 \mathrm{~mm}$., wing $2.4 \mathrm{~mm}$.

Type-locality: Anza, Riverside Co., California; 5 July 1956 (R. N. Bohart).

Holotype: Nale (UCalD) 76.

Allotype: Female on same pin as type.

Paratypes: 1 \&, Palm Springs, California; 4 May 1953 (W. R. M. Mason) (CNC) ; 1 \%, 3 mi. s. of Palm Springs, 29 August 1951 (Timberlake) (PHT).

\section{Brevitrichia castanea, new species}

Figure 118

MaLE.-Head cream, eyes red-brown above, black-brown below; frons small, triangular; mouthparts well developed; ocellar tubercle red-brown, ocelli orange. Antennae with first two segments yellowbrown, third segment missing.

Thorax dorsum red-brown, with granular pollinose, lateral margins cream; scutellum all but the lateral corners red-brown; pleural areas with prothorax cream; mesanepisternum cream with usual redbrown spot; mesokatepisternum red-brown with cream band above. Wings smoky, veins tan; halter stem brown, knob white. Legs with femora red-brown, with yellow knees; tibine and tarsi brown.

Abdomen second segment red-brown basally with median central stem narrowing to a point posteriorly, with a narrow lateral base, remainder pristine white; remaining segments white dorsally. Ninth tergum red-brown, with a narrow posterior margin of white. See figure for details.

Female.-Unknown.

Length: Male body $2.5 \mathrm{~mm}$., wing $1.7 \mathrm{~mm}$.

Type-locality: Glens Ferry, Idaho; 5 August 1927.

Holotype: Male (USNM) 67487.

\section{Brevitrichia coquilletti, new species}

FIGURE 119

Psendatrichia griseola Coquillett, 1900, p. 501, (in part).

MaLE.-Head cream; eyes red-brown above, black-brown below; frons very narrow, triangular; ocellar tubercle red-brown, covered with granular gray pollen. Antennae with first two segments brown, third yellow-brown to red-brown; see figure for shape.

Thorax dorsum red-brown; a median band extending two-thirds of the way to the scutellum, bordered on either side by narrower 

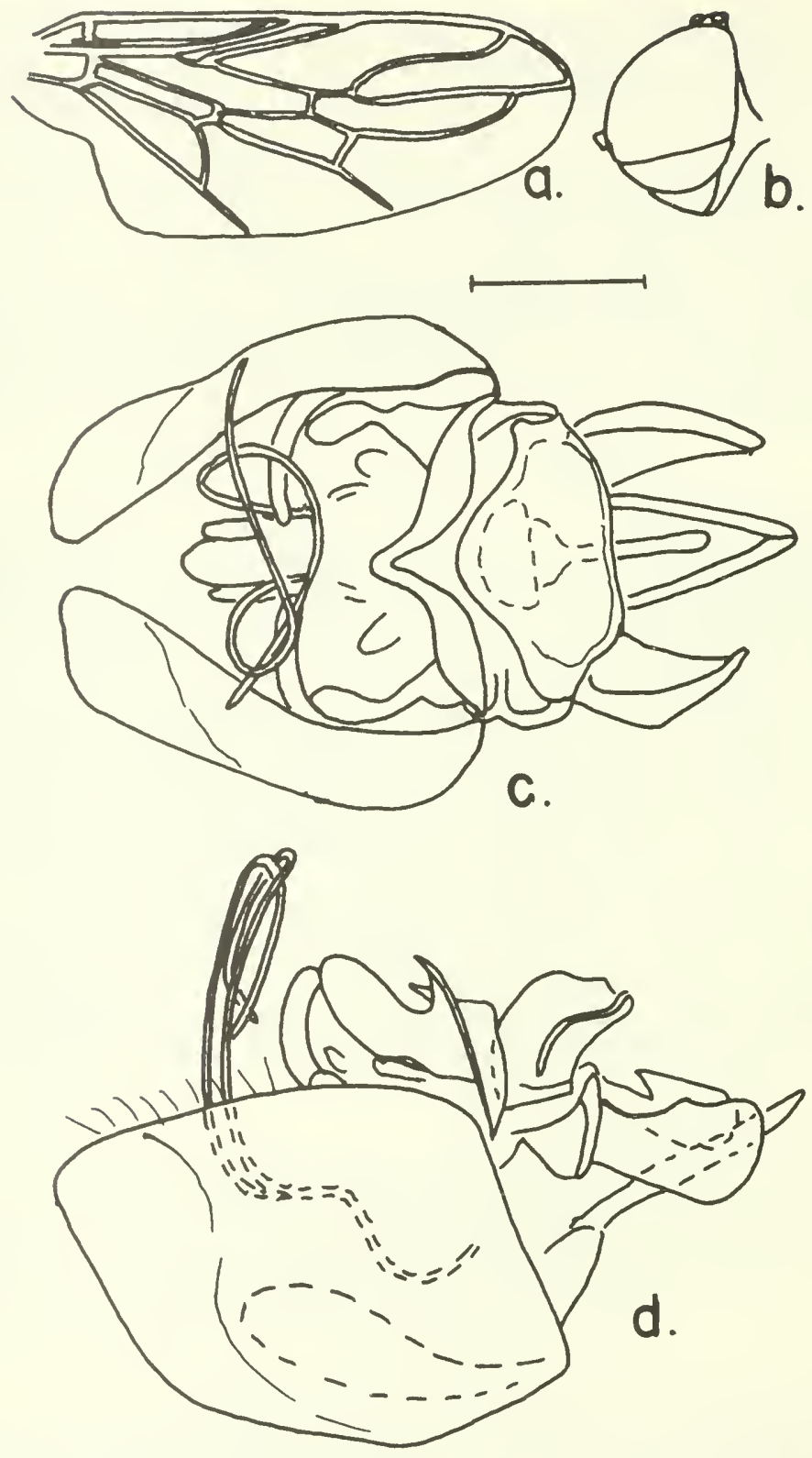

FIGURE 118.-Brevitrichia castanea, new species, male: $a$, wing; $b$, lateral aspect of head; $c, d$, ventral and lateral aspects of terminalia. 


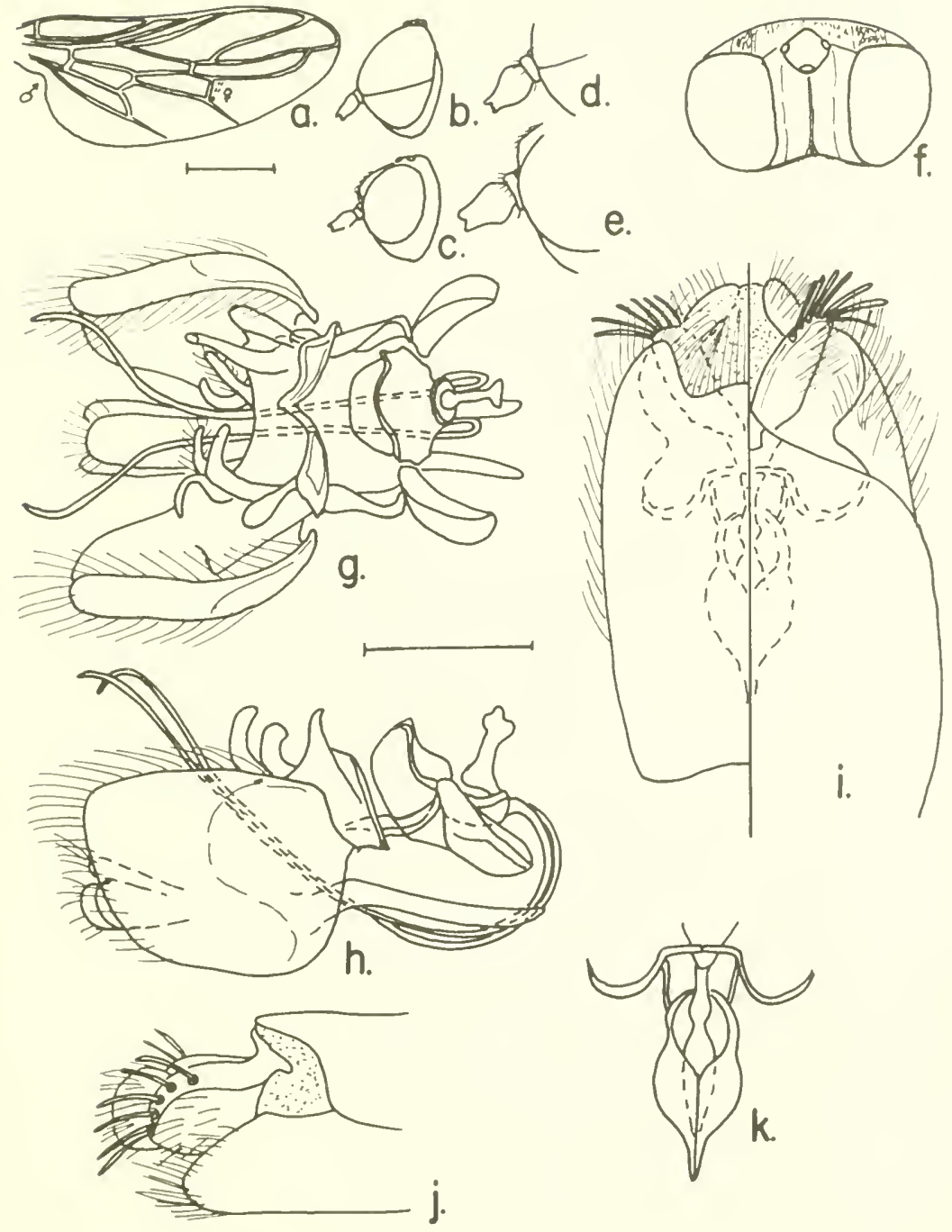

FIGURE 119.-Brevitrichia coquilletti, new species, male, female: $a$, wing; $b$, lateral aspect of male head; $c$, lateral aspect of female head; $d, e$, enlarged details of male and female antennae; $f$, dorsal aspect of female head; $g, h$, ventral and lateral aspects of male terminalia; $i$, ventral left and dorsal right aspects of female 8 th and 9th segments; $j$, lateral aspect of female 8 th and 9 th segments; $k$, bursal structure.

bands extending from just behind the humeral callus, nearly attaining the lateral margins of the scutcllar sulcus, remaining areas yellow, covered with gray pollen, hairs thin and indistinct; humeral and supra-alar calli cream; scutellum yellow, with a median band of red-brown which continues anteriorly across sulcus, fading along 
the midline. Pleural areas of prothorax cream, mesanepisternum yellow with a red-brown patch; mesokatepisternum red-brown with a yellow band above, all covered with granular pollen. Wings smoky, veins tan; halter stem brown, knob cream; legs yellow-brown, becoming brown distally.

Abdomen second segment with red-brown "T" with white lateral and posterior margins, remaining segments with red-brown "T"s fading posteriorly, mostly white; ninth tergum with red-brown basal spot, remainder white, with long hairs; see figure for details.

Female.-Head cream; eyes red-brown to metallic, with a broad postocular band extending across back of head, brown patches from corner of eyes to back of head; frons broad, with a median groove bordered by two bands occupying a little more than half of the frontal width, separated from postocular ridge by a shallow sulcus from the corner of the eye to the back of lateral ocelli, ocellar triangle red-brown, pollinose; ocelli orange to red. Antennae (missing on allotype) first two segments brown, third orange. See figure for shape.

Thorax dorsum with red-brown median and lateral stripes as in male, separated by orange stripes, lateral margins yellow-orange, all covered by gray pollen; humeral and supra-alar calli cream; scutellum yellow, with a median stripe. Pleural areas as in male. Wings smoky brown, veins tan; halter stem cream, knob cream. Legs as in male.

Abdomen with median red-brown "Ts," which become fainter posteriorly; lateral and posterior areas tan. Eighth segment red-brown; ninth tergum with 6 stiff spines and much hair; see figure for details.

Length: Male body $2.7 \mathrm{~mm}$., wing $2 \mathrm{~mm}$. ; female body $4 \mathrm{~mm}$., wing $2.1 \mathrm{~mm}$.

Type-locality: Los Angeles, California (Coquillett) as paratype of Pseudatrichia griseola.

Holotype: Male (USNM) 67483.

Allotype: Female on same pin.

Paratypes: $10^{7}$, Corcoran, California, 22 July 1947 (W. W. Wirth); $2 \sigma^{7} \sigma^{7}$, West Side Sta., California, 25 April 1930, on L. alyssoides; 1 , Victorville, California, 30 May 1944 (A. L. Melander) (USNM).

\section{Brevitrichia davisi, new species}

\section{FIgURE 120}

MALE.-Head cream; eyes red-brown above with blue-green metallic luster, lower half more intensely green; frons narrow, triangular; ocellar tubercle red-brown, frosted with gray pollen, ocelli orange. Antennae with first two segments tan, third segment lost.

Thorax dorsum with black-brown mid-dorsal band, flanked by two lateral bands, area above humeral callus tan, lateral margins and 

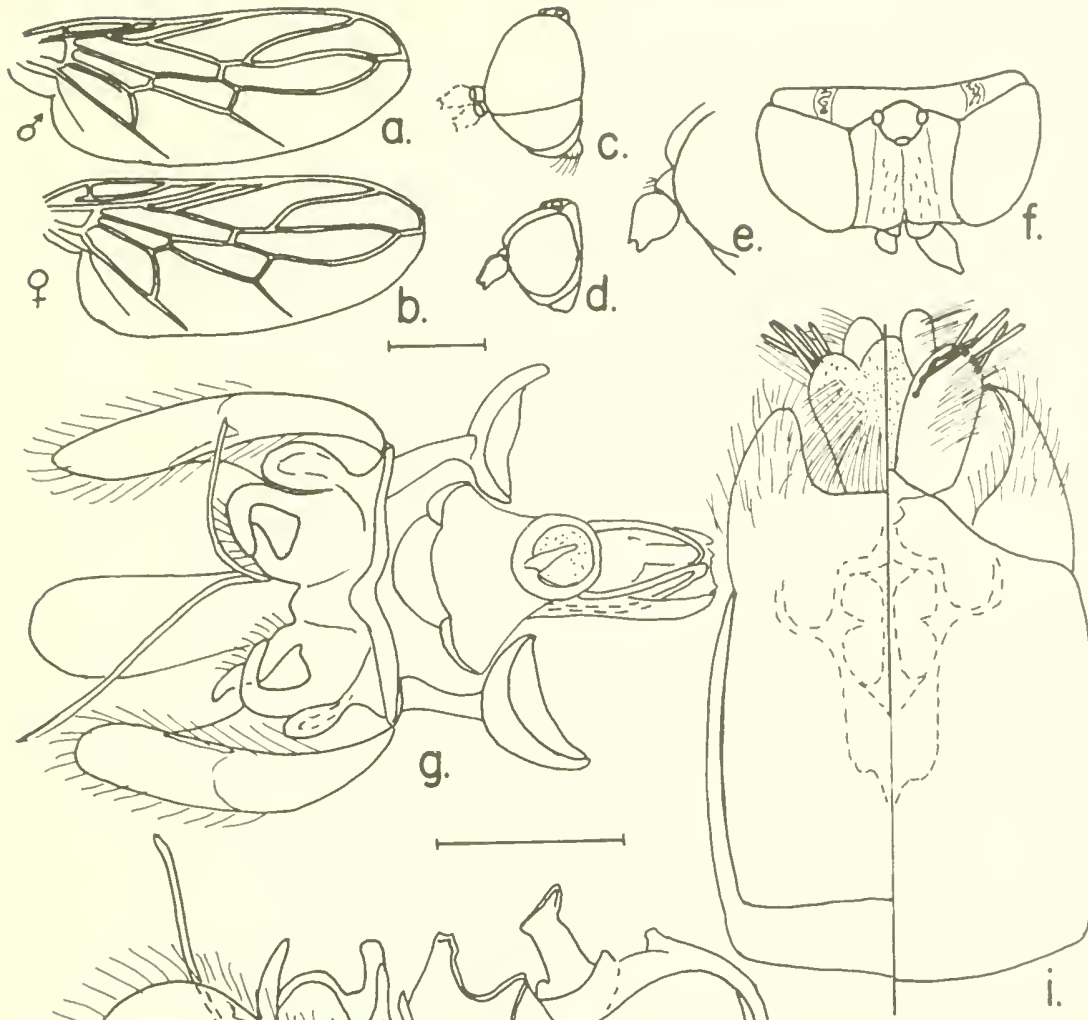

e.
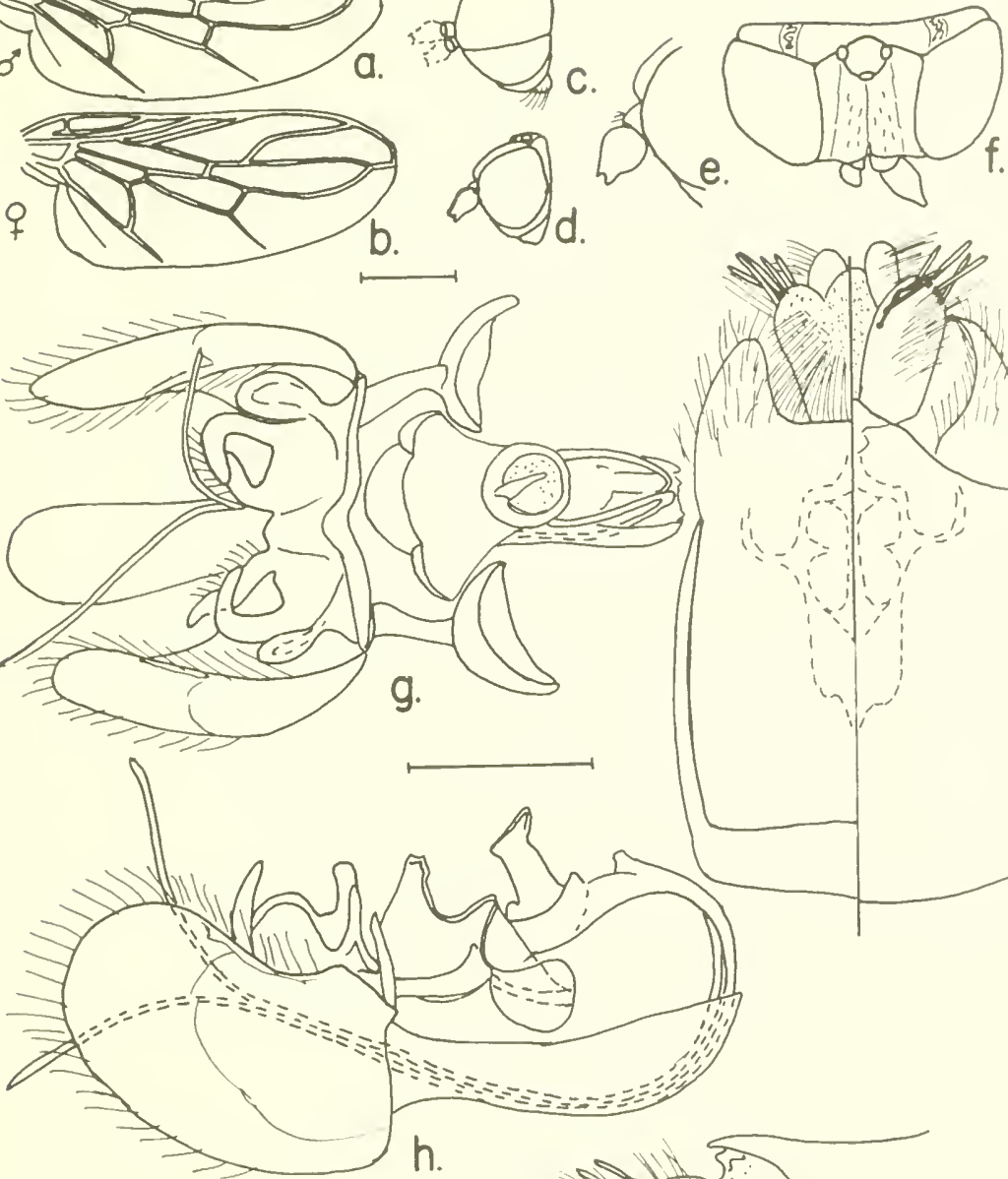

g.

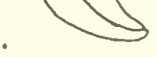

Figure 120.-Brevitrichia davisi, new species, male, female: $a$, male wing; $b$, female wing; $c$, lateral aspect of male head; $d$, lateral aspect of female head; $e$, enlarged detail of female antenna; $f$, dorsal aspect of female head; $g, h$, ventral and lateral aspects of male terminalia; $i$, ventral left and dorsal right aspects of female 8 th and 9 th segments, bursal structure outlined with dashed lines; $j$, lateral aspect of female 8th and 9 th segments.

anterior to scutellum yellow, frosted with gray and olive pollen; humeral and supra-alar calli cream, scutellum cream, with red-brown 
median stripe extending across scutellar sulcus into a point. Pleural areas with prothorax cream; mesanepisternum largely cream, with a red-brown spot; mesokatepisternum red-brown, with a broad cream band dorsally; all covered with gray pollen. Wings smoky, veins crean; halter stem brown, knob cream. Legs: femora light red-brown, pollinose; tibiae tan; tarsi tan, turning brown distally.

Abdomen second segment red-brown basally, with a central stem and lateral extensions in the form of a " $T$," remainder creamy white; segment three with a narrow anterior band of red-brown, remainder of segment and rest of abdomen white above. Ninth tergum yellow, with a tan basal patch. See figure for details.

Female.-Head tan; eyes red-brown, with a metallic sheen; postocular ridge medium broad, extending across back of head, brown patches laterad of corner of eye; frons broad, with a darker tan median band flanking a median groove, sulcus from upper angles of eyes to back of lateral ocelli; ocellar tubercle red-brown, dusted with gray pollen; ocelli orange-red. Antennae with first two segments brown, third segment orange-brown. See figure for details.

Thorax dorsum with a black band on midline extending two-thirds of the distance to scutellum, separated by thin orange-brown bands from lateral black bands beginning behind the humeral callus but not attaining the scutellar sulcus, remainder orange-brown, dusted gray pollinose; humeral and supra-alar calli orange-brown; pleural areas with prothorax orange, mesokatepisternum black, with orange dorsal band, all dusted gray pollinose. Wings hyaline, veins brown; halter stem brown, knob orange. Legs with femora red-brown, pollinose; tibiae tan; tarsi tan basally, brown distally.

Abdomen with segments red-brown basally with "T"'-shaped markings, lateral areas and posterior margins tan; eighth segment orangebrown; ninth tergum with 8 stiff spines and much fine hair. See figure for details.

Length: Male body $3.2 \mathrm{~mm}$., wing $2.3 \mathrm{~mm}$.; female body $3.7 \mathrm{~mm}$., wing $2.2 \mathrm{~mm}$.

Type-locality: Leeds, Utah; 15 September 1931 (E. W. Davis)

Holotype: Male (USNM) 67482.

Allotype: Female, Saint George, Utah; 15 June 1930 (E. W. Davis) (USNM).

\section{Brevitrichia dicksoni, new species}

Figure 121

Female.-Head tan; eyes black-brown; postocular ridge narrow separated on the midline behind ocellar tubercle, with faint brown bands laterad of the midline; front broad, with two bands of brown hairs on either side of a bare midline, not attaining ocellar triangle; 
sulcus from corner of eye to lateral ocellus separating frons from postocular area; ocellar tubercle red-brown, pollinose; ocelli red. Antennae with first segment tan, second light brown, third brown. See figure for details.
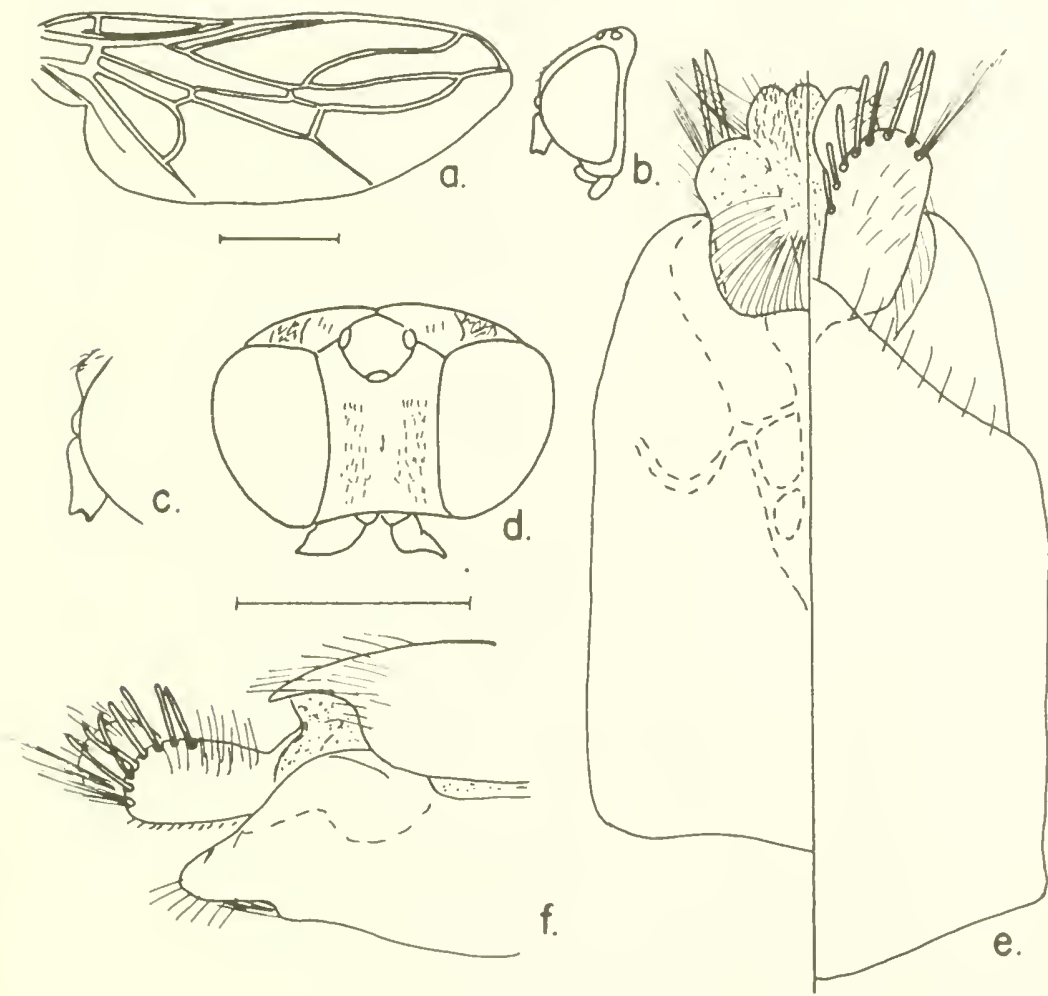

FIGURE 121,-Brevitrichia dicksoni, new species, temale: $a$, wing; $b$, lateral aspect of head; $c$, enlarged detail of antenna; $d$, dorsal aspect of head; $e$, ventral left and dorsal right aspects of 8 th and 9 th segments, bursal structure outlined on ventral surface; $f$, lateral aspect of 8 th and 9 th segments.

Thorax dorsum orange-yellow, a little darker on either side of the midline anteriorly, with a thin lateral red-brown stripe extending from the humeral callus to the seutellum, pollinose, dorsum with short stiff hairs; humeral callus cream and orange with numerous short hairs on the dorsal surface. Scutellum orange, with narrow median red-brown band. Pleural areas with prothorax cream, mesanepisternum orange, with red-brown central patch; mesokatepisternum with only the lowest portion red-brown, remainder orange, pollinose. Wings hyaline, veins eream to brown; halter stem tan, knob eream. Legs orange-brown, except tarsi tan. 
Abdomen second segment broad, orange, with median brown spot, granular; remainder orange, eighth segment orange, shining; ninth tergum with 7 stiff spines and a ventral tuft of hairs; see figure.

Male.-Unknown.

Length: Female body $4 \mathrm{~mm}$., wing $2.1 \mathrm{~mm}$.

Type-locality: $5.7 \mathrm{mi}$. w. of Glacier, California; 25 July 1960 (R. C. Dickson).

Holotype: Female (CAS) 8937 (ex [PHT]).

Paratype: 1 \%, same data as type (PHT).

\section{Brevitrichia downeyi, new species}

Figure 122

MaLE.-Head cream; eyes brown above, black below, may be metallic in life; frons small, triangular; ocellar tubercle red-brown, frosted tan pollinose, ocelli brown-red. Antennae with first two segments brown, third segment yellow-brown. See figure for details.

Thorax dorsum black-brown, frosted gray pollinose, yellow bands dividing dark area into three parts, pronotum cream above humeral callus, with a black band separating it from the callus. Humeral and supra-alar calli cream, scutellum cream with a narrow median dark stripe. Pleura with prothorax cream; mesanepisternum cream, with a black-brown spot; mesokatepisternum black-brown; all frosted gray pollinose. Wings smoky, veins tan; halter stem brown, knob cream. Legs femora light brown, frosted, with a light knee; tibiae tan basally darkening to brown distally, tarsi brown.

Abdomen with second segment with a black-brown proximal band with a central stem narrowing distally, with lateral extensions like a "T," remainder of margin white; third segment with a narrow basal brown band, remainder white; remaining segments white. Ninth tergum white, with a brown basal spot, many long hairs; see figure for details.

Female.-Head cream, eyes black-brown, may be metallic in life; postocular ridge broad, with a brown band laterad of the corner of the eye to the back of the head, sulcus from corner of eye extending to back of head, separated by one-half the width of the ocellar tubercle allowing front to reach the back of the head. Frons broad, with a median groove dividing a band of light brown, covered with short hairs; ocellar tubercle black-brown, frosted gray pollinose; ocelli red-orange; antennae all segments brown. See figure for details.

Thorax dorsum black-brown, with two longitudinal yellow stripes extending anteriorly between the yellow patch anterior to the scutellum to the yellow patches above the humeral calli, granular pollinose; humeral and supra-alar calli cream; scutellum creamyellow, with a narrow median brown patch. Pleural areas with 


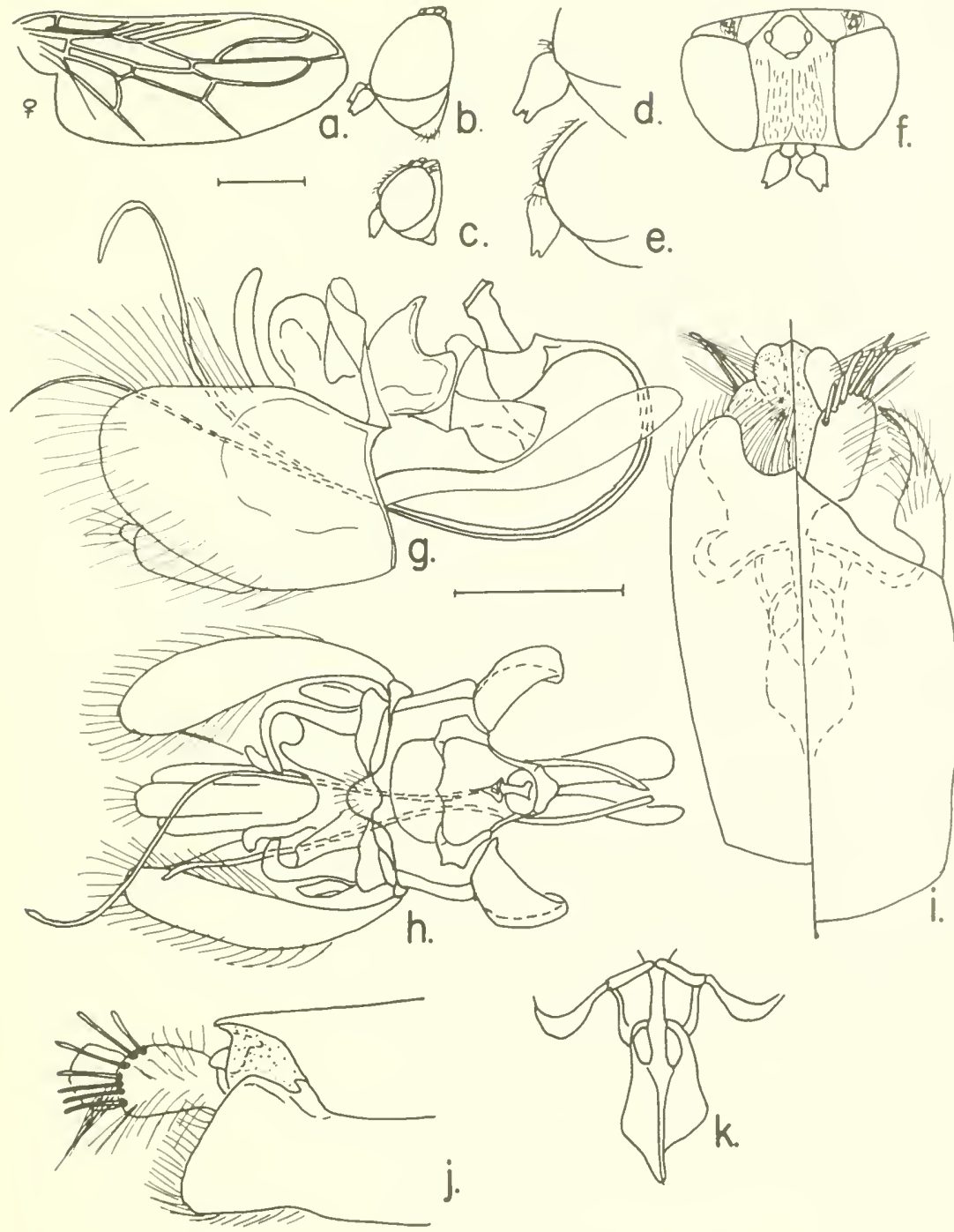

Ficure 122.-Brevitrichia downeyi, new species, male, female: $a$, wing; $b$, $c$, lateral aspeets of male and female heads; $d, \iota$, enlarged details of male and female antennae; $f$, dorsal aspect of female head; $g, h$, lateral and ventral aspeets of male terminalia; $i$, ventral left and dorsal right aspects of female 8 th and 9 th segments, bursal structure outlined; $j$ lateral aspect of female 8 th and 9 th segments; $k$, bursal structure.

prothorax cream, mesanepisternum cream with a black-brown patch, mesokatepisternum black-brown, granular pollinose. Wing hyaline, veins tan; halter stem brown, knob creamy white. Legs with femora brown; tibine light brown, tarsi dark brown. 
Abdomen brown, mottled tan. Eighth segment brown, ninth tergite with 7 stiff spines, moderately hairy. See figure for details. Length: Male body $3.3 \mathrm{~mm}$., wing $2 \mathrm{~mm}$.; female body $3.5 \mathrm{~mm}$., wing $2 \mathrm{~mm}$.

Type-locality: Davis, California; 16 August 1955 (J. C. Downey). Holotype: Male (UCalD) 76.

Allotype: Female, Davis, California; 14 August 1955 (A. T. McClay).

Paratype: $1 \sigma^{7}$, Davis, California; 14 July 1955 (E. I. Schlinger) (UCalD).

\section{Brevitrichia flocki, new species}

Figure 123

Female.-Head cream; eyes deep red-brown, medium broad postocular ridge, with a narrow brown band laterad of the corner of the eye, the two sides separated by median groove behind the ocellar tubercle; frons broad, with a deep median groove extending from the antennal base to the median ocellus, bordered by brown bands on either side; frons separated from postocular area by deep grooves extending from the corner of the eye to the median ocellus. Ocellar tubercle red-brown, pollinose; ocelli red. Antennae with first two segments red-brown, third deep red-brown; see figure for details on shape.

Thorax dorsum solid black-brown, with gray pollen and a yellow patch behind the humeral callus; humeral and supra-alar calli white. Scutellum red-brown with cream lateral margins. Pleura with prothorax cream; mesanepisternum red-brown with dorsal portion under wings orange; mesokatepisternum red-brown, with a dorsal yellow band. Wings hyaline, granular, veins brown; halter stem brown, knob white. Legs red-brown with knee of femur and base of tibia and tarsus yellow, pollinose.

Abdomen red-brown, with lighter posterior margins; eighth segment shining, a row of spines along margin of tergum; ninth tergum with 7 stiff spines, and long hairs over most of the surface. See figure for details.

MaLe.-Unknown.

Length: Female body $3.8 \mathrm{~mm}$., wing $2.2 \mathrm{~mm}$.

Type-locality: Santa Rita Mts., Arizona; 26 June 1940 (R. A. Flock).

Holotype: Female (USNM) 67485 .

\section{Brevitrichia griffini, new species}

Figure 124

Male.-Head cream; eyes red-brown above, black-brown below; frons extending only half the distance to the median ocellus, with 

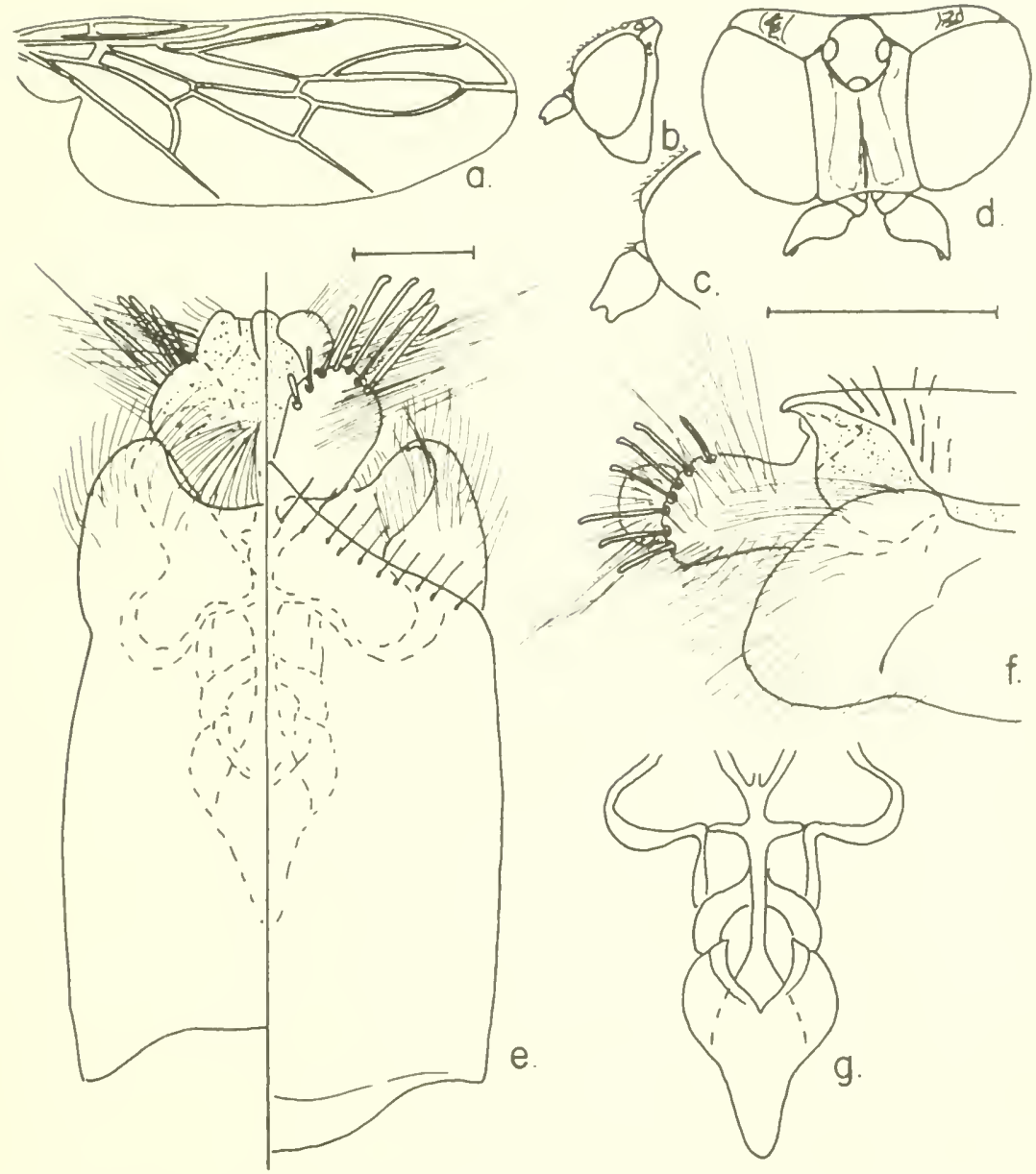

Figure 123.-Brevitrichra flocki, new species, female: $a$, wing; $b$, lateral aspect of head; $c$, enlarged detail of antenna; $d$, dorsal aspect of head; $e$, ventral left and dorsal right aspects of 8 th and 9 th segments; $f$ lateral aspect of 8 th and 9 th segments; $g$, bursal structures.

a small dark triangle at upper limit, flaring broadly around antennal bases to lower part of head around oral opening; ocellar tubercle black-brown, ocelli clear; back of head with central portion blackbrown, lateral areas cream. Antennae black-brown. See figure for details.

Thorax dorsum black-brown ground, with an orange patch over humeral callus, overlain by longitudinally striped brown and tan pollen, lateral margins with more yellow than female; humeral and supra-alar calli cream. Scutellum with a broad median band of 

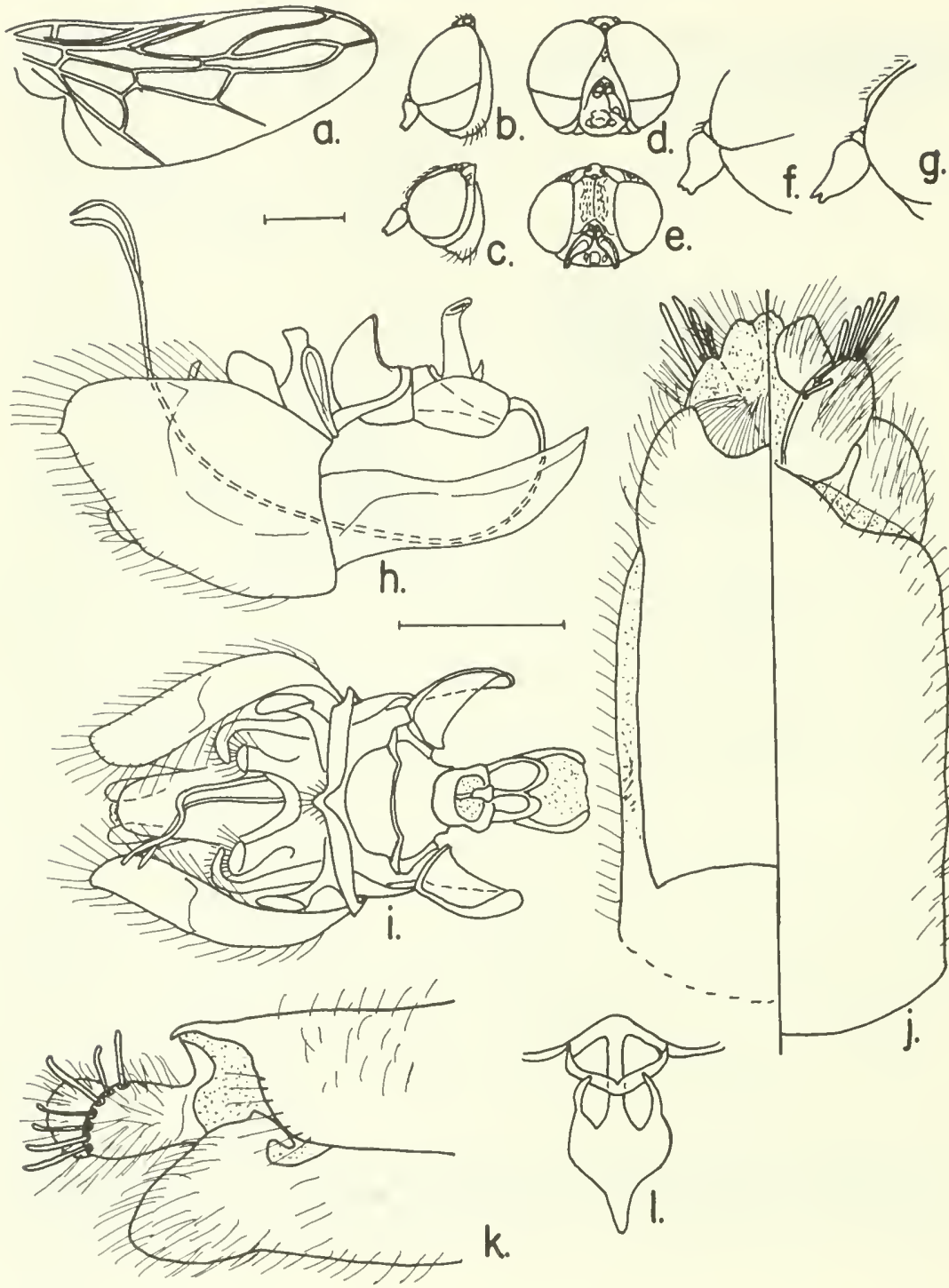

k.

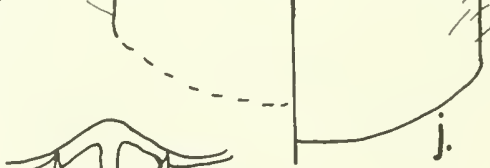

Figure 124.-Brevitrichia griffini, new species, male, femaie: $a$, wing; $b$, $d$, lateral and frontal aspects of male head; $c, e$, lateral and frontal aspects of female head; $f, g$, enlarged details of male and female antennae; $h, i$, lateral and ventral aspects of male terminalia; $j$, ventral left and dorsal right aspects of female 8 th and 9 th segments; $k$, lateral aspect of female 8 th and 9 th segments; $l$, bursal structure.

black-tan, lateral margins cream. Pleural areas of prothorax brown; mesanepisternum cream, with a dark central patch, mesokatepisternum black-brown, pollinose. Wings smoky brown, veins brown. 
Halter stem brown, knob tan above, cream below. Legs black-brown, pollinose; knees of femora yellow-brown.

Abdomen segments black-brown, pollinose, with thin creamy membranous posterior margins, ninth tergum with basal portion red-brown, remainder creamy; see figure for details.

Fenale.-Head yellow; eyes dark red-brown; postocular ridge moderately wide, brown bands from corners of eyes down over back of head, lateral areas yellow-orange, covered with red-brown anteriorly directed hairs; frons broad, nearly twice the width of the ocellar triangle, divided by a median groove which is bordered by a band of brown, with short golden brown hairs. Ocellar tubercle blackbrown, pollinose, ocelli red-orange. Antennae with first two segments brown, the second shorter than the first, third segment black-brown; see figure for details.

Thorax dorsum black-brown ground, covered with longitudinal bands of brown and tan pollen, an orange patch over humeral callus; humeral and supra-alar calli cream; scutellum with a broad median brown band, with lateral margins cream. Pleural areas with prothorax brown; mesanepisternum cream with a large dark brown patch; mesokatepisternum dark brown, pollinose. Wings smoky brown, veins brown; halter stem brown, knob tan above, cream below.

Abdomen red-brown, pollinose; eighth segment red-brown, shining; ninth tergum with 7 stiff spines, hairy; see figure for details.

Length: Male body $3.2 \mathrm{~mm}$., wing $2.3 \mathrm{~mm}$; female body $4.5 \mathrm{~mm}$., wing $2.5 \mathrm{~mm}$.

Type-locality: Mount Laguna, San Diego Co., California; 21 June 1963 (H. L. Griffin).

Holotype: Male (CAS) 8924, on loan from (UCalB).

Allotype: Female same data as type (CAS).

Paratype: 1 \% , Mt. Laguna, San Diego Co., California; 21 June 1963 (P. D. Hunt) (UCalB).

\section{Brevitrichia griseola (Coquillett)}

Figurf 125

Pseudatrichia griseola Coquillett, 1900, p. 501.

This species, as are most Brevitrichia, is limited in its distribution to a small geographical area, in this case along the middle reaches of the Rio Grande. Specimens were examined from near the type locality, near Las Cruces, New Mexico, and Lajitas, Texas in the Big Bend area, where wasps were provisioning their nests with them.

More detailed descriptions of the male and female follow. The paratype of Coquillett is now the new species B. coquilletti. 

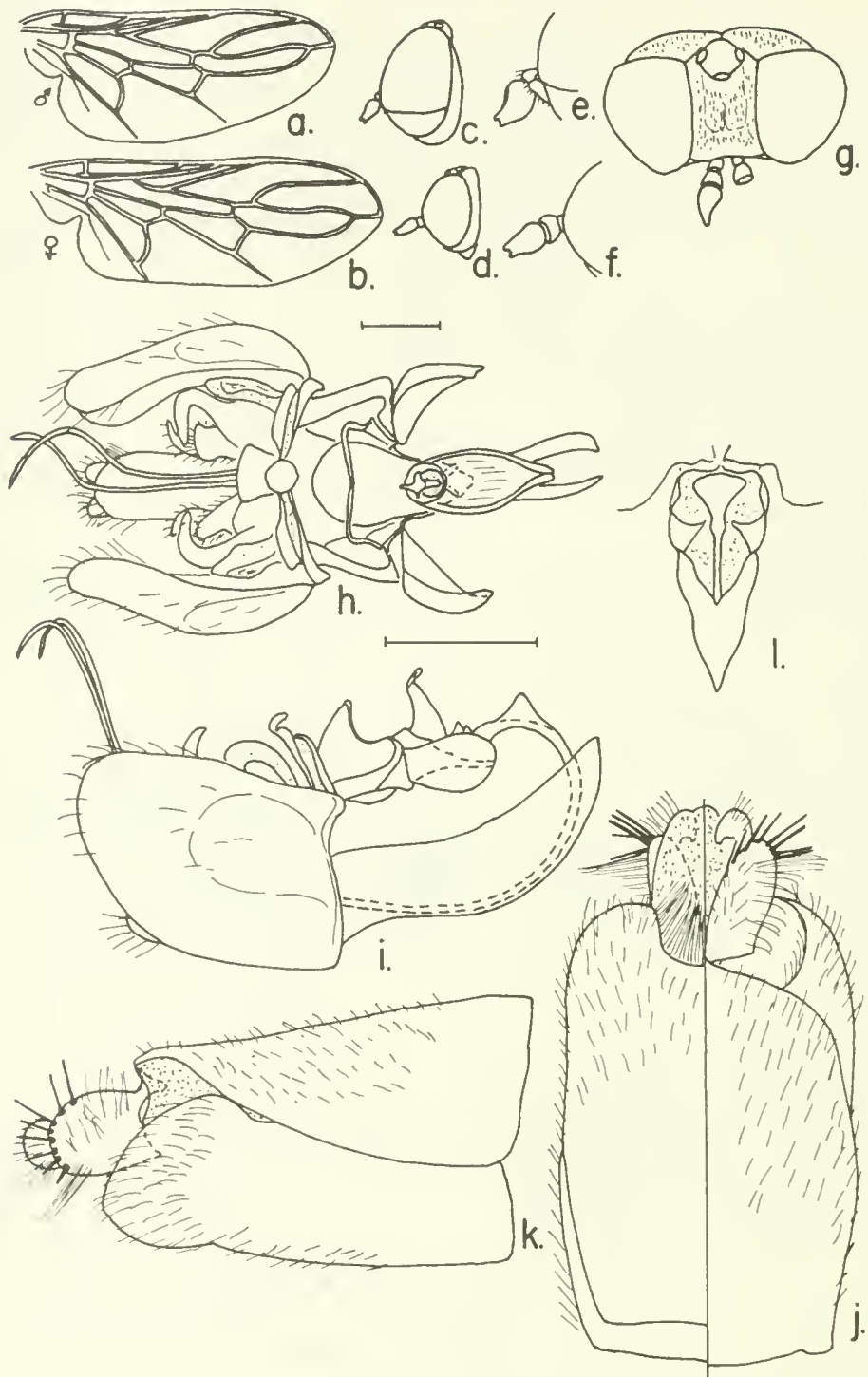

Figure 125.--Brevitrichia griseola (Coquillett), male, female: $a$, male wing; $b$, female wing; $c, d$, lateral aspects of male and female heads; $e, f$, enlarged details of male and female antennae; $g$, dorsal aspect of female head; $h, i$, ventral and lateral aspects of male terminalia; $j$, ventral left and dorsal right aspects of female 8 th and 9 th segments; $k$, lateral aspect of female 8 th and 9 th segments; $l$, bursal structure.

Male.-Head cream; eyes red-orange-brown, darker below; frons triangular, slightly more than one-third the distance from the antennal 
base to medium ocellus, with a small brown dash at peak; ocellar triangle black-brown, pruinose; ocelli red; a narrow postocular rim laterad of ocellar tubercle. Antennae with first segment brown, second segment red-brown, third segment brown. See figure for details.

Thorax dorsum black-brown, heavily dusted pruinose, a yellow spot above humeral callus; sides of dorsum yellow, two crescentshaped yellow areas extending from lateral angles of scutellum, nearly meeting but leaving a continuous black line down the midline; humeral callus cream, with a dark band dorsally. Scutellum yellow with a large median brown spot. Pleural areas dark brown ventrally, yellow dorsally. Wings smoky, veins brown; halter stem brown, knob cream to tan. Legs with femora red-brown, dusted pruinose; tibiae and tarsi orange, darkening to red-brown distally.

Abdomen with terga red-brown anteriorly, with a central stem and lateral arms in the form of a " $\mathrm{T}$," remainder of segments white; this pattern narrows posteriorly; ninth tergum brown basally, cream distally. See figure for details.

Fenale.-Head cream, eyes red-brown, postocular rim moderately wide, unmarked, with short brown hairs, the two halves divided on the midline behind the ocellar triangle; frons broad, with a brown median patch on upper two-thirds, covered with short hairs; upper part of frons cut off by shallow groores extending from the corners of the eyes to just behind the ocellar triangle; ocellar triangle blackbrown, dusted gray pruinose, ocelli red-brown.

Thorax dorsum red-brown, dusted gray pruinose, marked with extensive areas of yellow above the humeral callus, along the margins above the wing and the central postnotum, extending anteriorly as two thin bands; humeral callus cream; scutellum yellow with a median red-brown spot. Pleura red-brown ventrally, yellow above. Wings hazy brown, veins brown anteriorly becoming faint posteriorly; halter stem brown, knob cream. Legs with femora and tibiae redbrown; tarsi with first segment orange, remainder red-brown, dusted gray pollinose.

Abdomen with first three segments red-brown, with thin white membranous margins, next three segments tan; eighth segment redbrown; ninth tergum with 8 stifl spines; see figure for details.

Length: Male body $3.6 \mathrm{~mm}$., wing $2 \mathrm{~mm}$.; female body 4.1 mm., wing $2.5 \mathrm{~mm}$.

Type-locality: Mesilla (near Las Cruces), New Mexico; 25 May 1897 (T. D. A. Cockerell).

Type: (USNM) 4712 .

Material seen: $1 \sigma^{7}$, Las Cruces, New Mexico, 16 June 1917 (J. M. Aldrich); 1 o, 2 ㅇ, 1 mi. w. Lajitas, Brewster Co., Texas, 
23-30 April 1963 (H. E. Evans) collected from solitary wasp burrow; all in (USNM).

\section{Brevitrichia halli, new species}

Figure 126

MaLE.-Head tan, back of head brown; eyes metallic blue-black, darker below; front narrow triangular; ocellar tubercle black-brown, frosted; ocelli clear; antennae brown. See figure for details of shape.

Thorax dorsum black-brown, granular, with a yellow-orange band along lateral margins broken above wing bases; humeral callus yelloworange, scutellum with a broad red-brown triangle and yellow-orange lateral angles. Pleural areas mixed red-brown and yellow-orange, granular; wings clear, veins brown; halter stem tan, knob tan. Legs with femora brown, granular, with yellow knee; tibiae and tarsi brown.

Abdomen with segments black-brown, with thin posterior white bands; ninth tergum tan, with brown basal patch. See figure for details.

Female.-Head cream-yellow; back of head brown; eyes metallic blue-black, postocular ridge moderately wide, brown patches laterad of corner of eye; frons broad, with a median groove on lower half, a tan median patch, forked ventrally, with short anteriorly directed brown hairs. Antennae with first two segments brown, third segment black-brown. See figure for details.

Thorax dorsum black, overlain with brown and tan longitudinally striped pollinose scales; humeral and supra-alar calli tan; scutellum with a narrow median red-brown patch, lateral areas tan. Pleural areas black-brown covered with tan pollinose scales. Wings hyaline, veins brown; halter stem tan, knob tan. Legs with femora red-brown, knees yellow, covered with tan pollinose scales, remainder red-brown.

Abdomen red-brown, granular with white posterior membranous margins; eighth segment red-brown, ninth tergum with 9 stiff spines. See figure for details.

Length: Male body 2.6-3 mm., wing 1.9-2 mm.; female body $4.5 \mathrm{~mm}$., wing $2.4 \mathrm{~mm}$.

Type-locality: 4 mi. w. Pinon Flat, Riverside Co., California; 11 June 1954 (J. C. Hall).

Holotype: Male (UCalD) 77.

Allotype: Female on same pin with type.

Paratype: $1 \sigma^{7}$, Verdemont, California; 25 May 1948 (A. L. Melander) (USNM). 

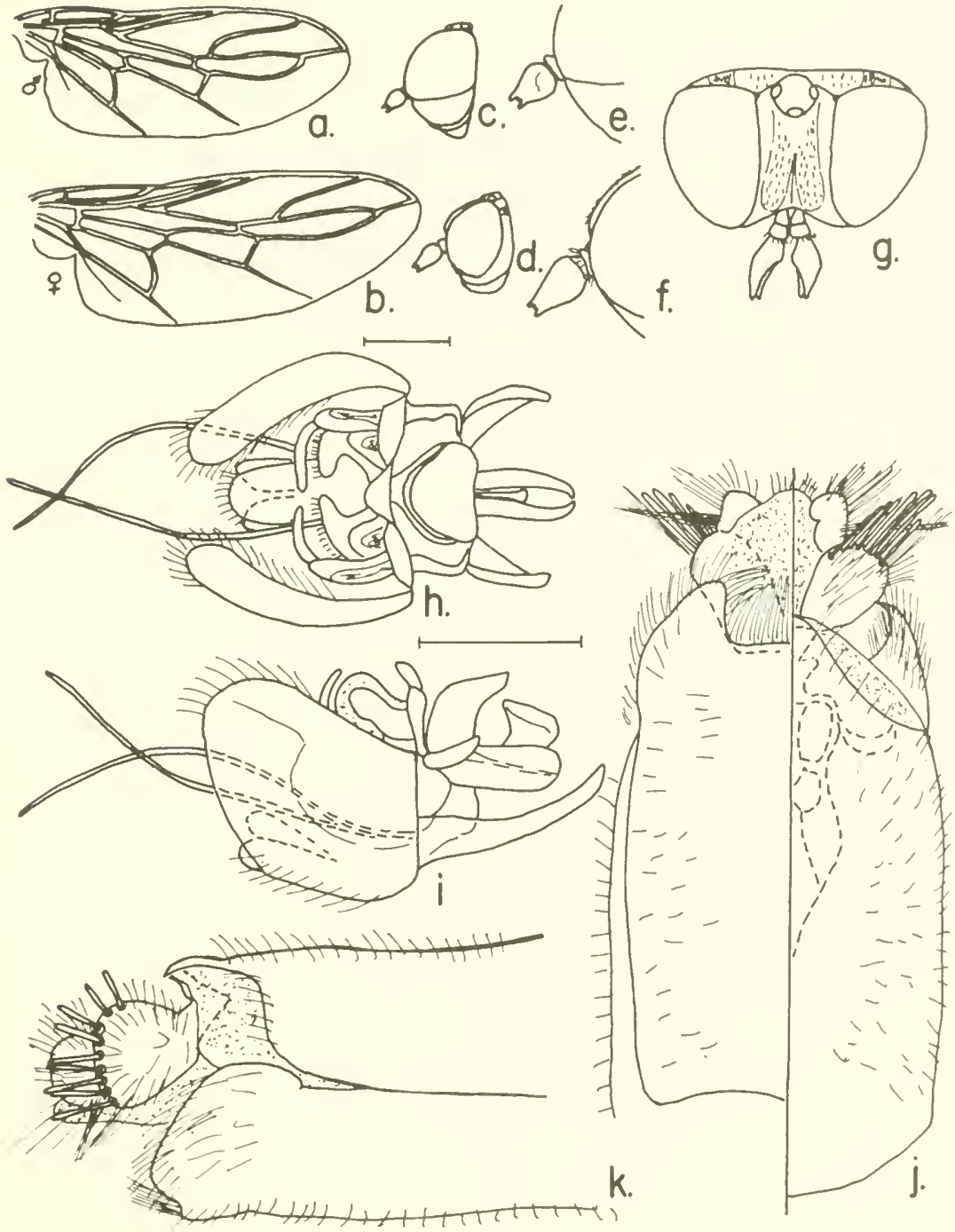

Figure 126.-Brevitrichia halli, new species, male, female: $a$, male wing; $b$, female wing; $c, d$, lateral aspects of male and female heads; $e, f$, enlarged details of male and female antennae; $g$, dorsal aspect of female head; $h$, $i$, ventral and lateral aspects of male terminalia; $j$, ventral left and dorsal right aspects of female 8 th and 9 th segments, bursal structures outlined; $k$, lateral aspect of female 8 th and 9 th segments. 


\section{Brevitrichia helenae (James)}

Figure 127

Pseudatrichia helenae James, 1938, p. 22.

I am indebted to Dr. James for the loan of the paratype male for figuring. All attempts to locate the type have failed.

Length: Male body 2-2.5 mm.; wing $1.8 \mathrm{~mm}$.

Type-locality: Roggen, Colorado; 29 May 1937 (Helen B. James).

Type: (CSU) lost.

Paratype: $1 \sigma^{\top}$, same data (M'TJ).

\section{Brevitrichia hodgdeni, new species}

FIGJRE 128

Male.-Head tan; eyes red-brown, with a metallic sheen, darker below; frons narrow, triangular; ocellar tubercle red-brown, ocelli redbrown; antennae black-brown. See figure for details.

Thorax dorsum black, covered with brown and tan pollinose scales in longitudinal bands; lateral margins yellow-orange; humeral and supra-alar calli orange; scutellum with a large central spot one-half of its width, lateral angles yellow-orange. Pleural areas red-brown and yellow in the usual arrangement, pollinose; wings smoky brown, veins brown; halter stem brown, knob tan-brown. Legs: femora red-brown, tibiae orange, tarsi orange basally to dark brown distally.

Abdomen dark red-brown, scarcely lighter along posterior margins; ninth segment red-brown, with tan margins; see figure for details.

Female.-Head tannish-brown, eyes dark red-brown, metallic, a broad postocular rim with a red-brown patch laterad of the corner of the eye; frons broad, with a median groove bordered by red-brown bands; sulcus from corner of eye to lateral ocelli cuts off frons from postocular ridge; ocellar tubercle black-brown, pollinose; ocelli black. Antennae black-brown. See figure for details.

Thorax as in male.

Abdomen as in male, eighth segment red-brown, shining; ninth tergum with one dorsal spine and 7 pits. See figure for details.

Length: Male body $3 \mathrm{~mm}$., wing $2.1 \mathrm{~mm}$.; female body $3.7 \mathrm{~mm}$., wing $2.2 \mathrm{~mm}$.

Type-locality: Lake City, California; 15 July 1941 (Burt Hodgden).

Holotype: Male (UKan) 6293.

Allotype: Female same data (UKan). 

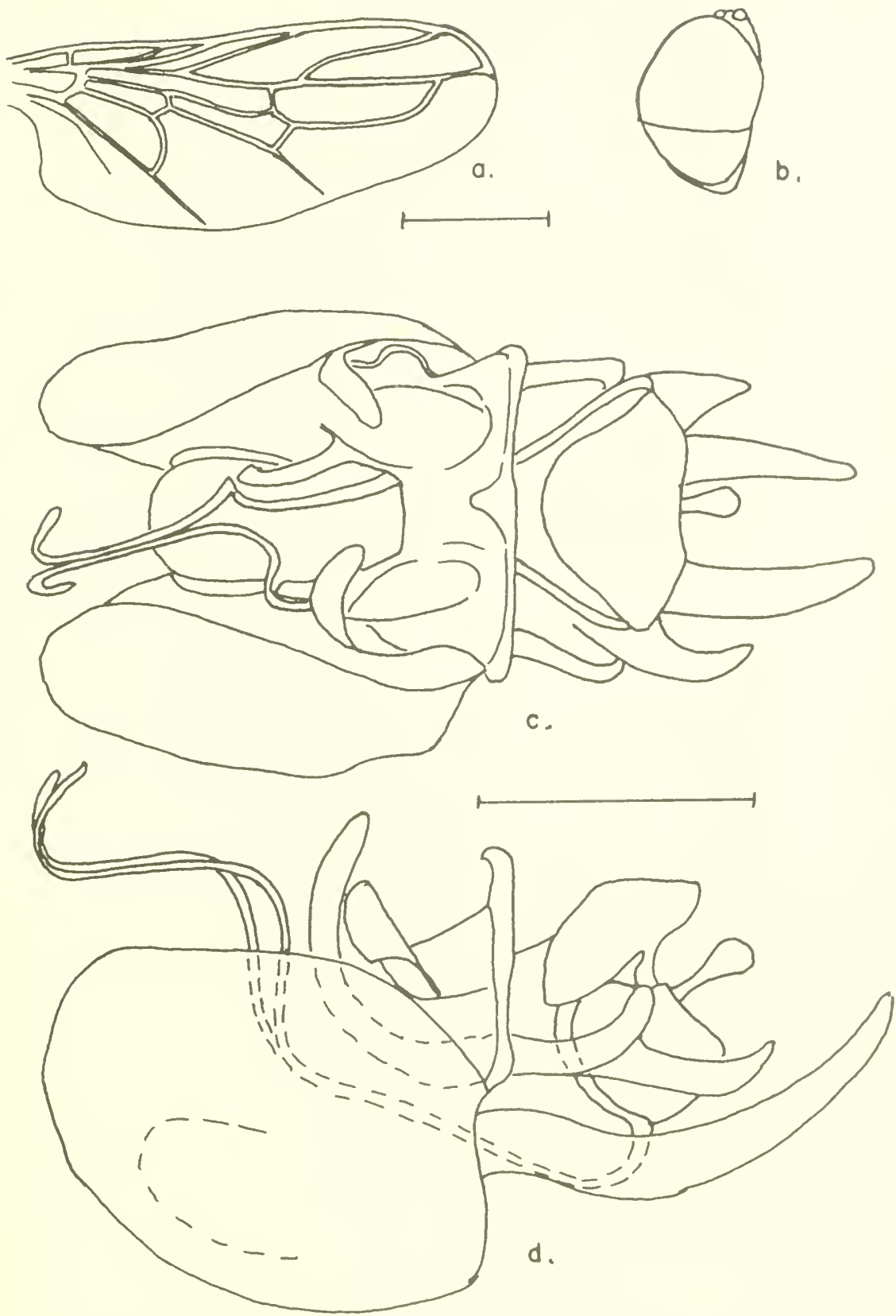

FIGURE 127.-Brevilrichia helenae (James), male: $a$, wing; $b$, lateral aspect of head; $c, d$, ventral and lateral aspects of terminalia. 


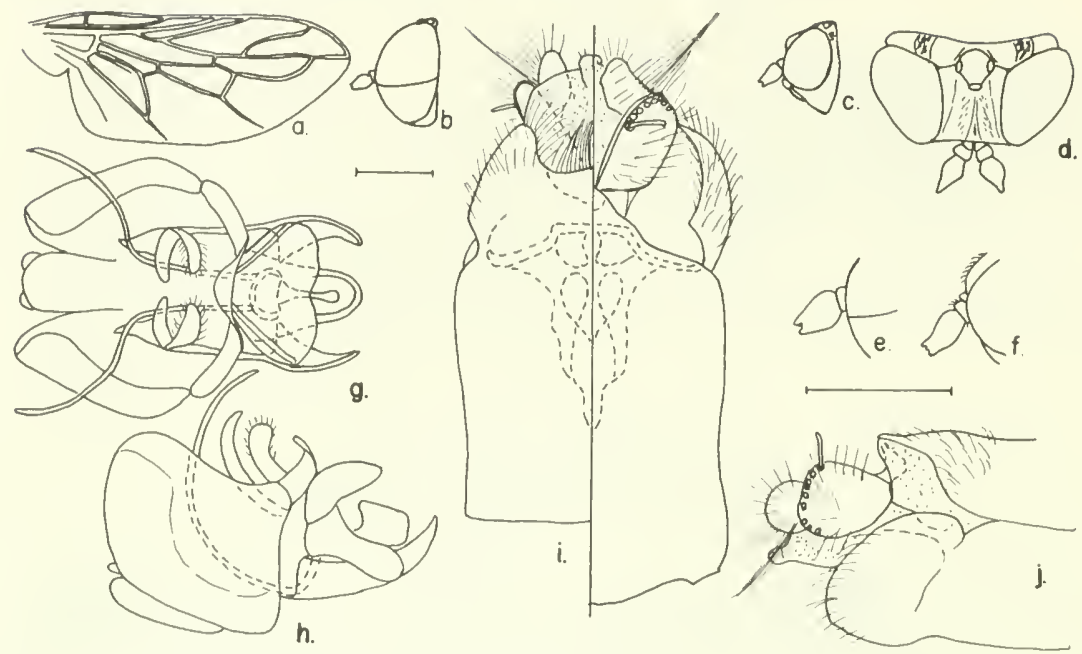

Figure 128.--Brevitrichia hodgdeni, new species, male, female: $a$, wing; $b, c$, lateral aspects of male and female head; $d$, dorsal aspect of female head; $e$, $f$, enlarged details of male and female antennae; $g, h$, ventral and lateral aspects of male terminalia; $i$, ventral left and dorsal right aspects of female 8th and 9th segments, bursal structure outlined with dashed lines; $j$, lateral aspect of female 8 th and 9 th segments.

\section{Brevitrichia insulana (Cole)}

FiguRE 129

Pseudatrichia insulana Cole, 1923, p. 462.

The type and allotype are figured. Female ninth tergum with 9 stiff spines.

Length: Male body $3 \mathrm{~mm}$., wing $2.3 \mathrm{~mm}$.; female body $5.8 \mathrm{~mm}$., wing $2.6 \mathrm{~mm}$.

Type-locality: Isla Raza, Gulf of California, Mexico; 21 April 1921 (E. P. Van Duzee).

Type: (CAS) 1339.

Allotype: Female (CAS) 1340.

Specimens seen: 1 ㅇ, Isla Partida, Gulf of California, Mexico, 23 March 1953 (P. H. Arnaud) (CAS); 1 \%, Rialto, San Bernardino Co., California, 24 July 1956 (J. C. Hall) (UCalD).

\section{Brevitrichia kerni, new species}

Figure 130

Female.-Head cream; eyes deep red-brown, postocular ridge moderately wide, a brown patch laterad of the corner of the eye; frons with a median groove extending from the antenna to the median 

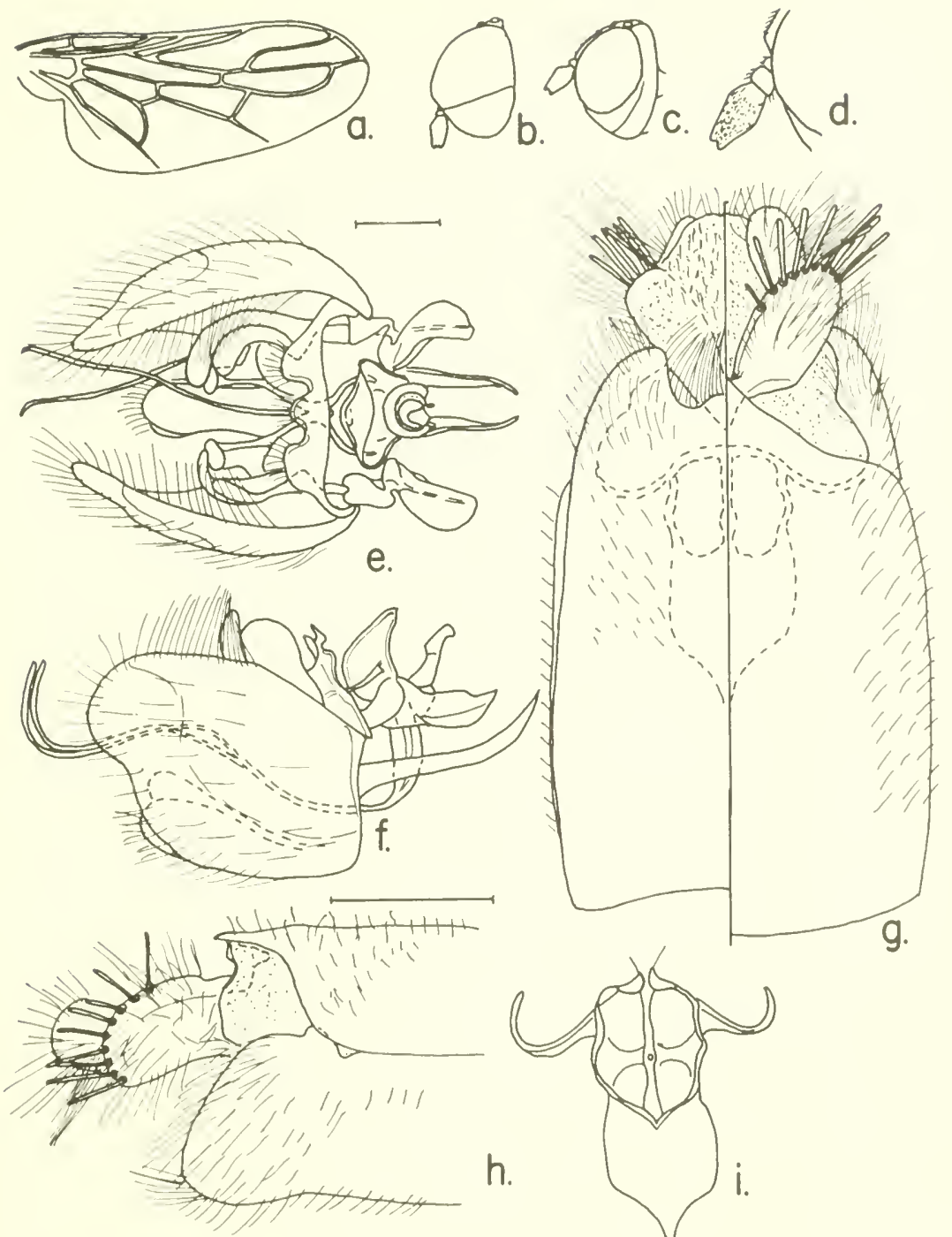

h.

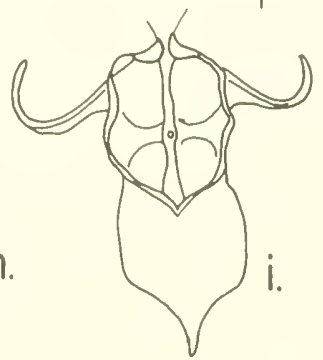

Figure 129,-Brevitrichia insulana (Cole), male, female: $a$, wing; $b, c$, lateral aspect of male and female head; $d$, enlarged detail of antenna; $e, f$, ventral and lateral aspect of male terminalia; $g$, ventral left and dorsal right aspects of female 8 th and 9 th segments, bursal structure outlined; $h$, lateral aspect of female 8 th and 9th segments; $i$, bursal structure.

ocellus, a band of short hairs on either side; ocellar tubercle red-brown, pollinose, ocelli clear; a groove from the corner of the eye to the back of the head cutting off a central piece nearly the width of the 

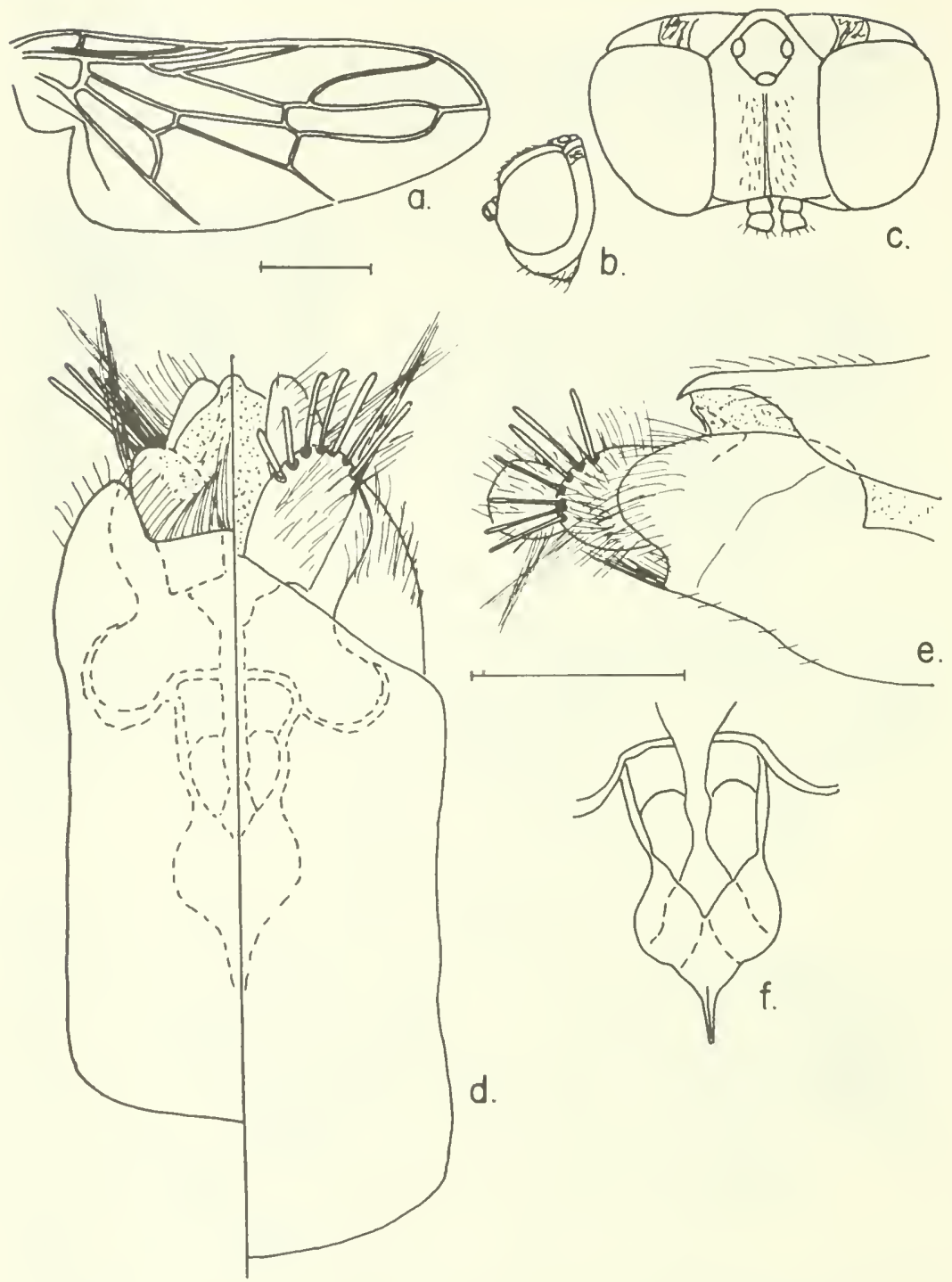

Figure 130.-Brevitrichia kerni, new species, female: $a$, wing; $b$, lateral aspect of head; $c$, dorsal aspect of head; $d$, ventral left and dorsal right aspects of 8 th and 9th segments, bursal structure outlined; $e$, lateral aspect of 8 th and 9th segments; $f$, bursal structure.

ocellar tubercle; antenna with first segment tan, second segment brown basally, tan distally, third segment missing.

Thorax dorsum with a median red-brown band extending twothirds the distance to the scutellum, bordered on each side by a redbrown band extending from behind the humeral callus to the scutel- 
lum, separated from the median band by a strip of orange, the whole covered with pollinose scales and a few short hairs; humeral and supraalar calli cream, with an orange patch between; scutellum cream, with a narrow median red-brown band. Pleura with prothorax cream; mesanepisternum cream, with a median red-brown patch; mesokatepisternum red-brown, with a dorsal cream band. Wings smoky, veins tan to brown; halter stem brown, knob cream. Legs with femora light brown, tibiae tan, tarsi tan basally, becoming darker distally.

Abdomen second segment cream, with a red-brown " $\mathrm{T}$ " in the anterior two-thirds, posterior segments cream becoming orange with red-brown "T"s becoming less distinct and constricted posteriorly. Eighth segment red-brown; ninth tergum with 7 stiff spines and very abundant hair; see figure for details.

Male.-Unknown.

Length: Female body $5 \mathrm{~mm}$., wing $2.3 \mathrm{~mm}$.

Type-locality: Kernville, California; 20 July 1940 (R. H. Beamer).

Holotype: Female (UKan) 6294.

\section{Brevitrichia melanderi, new species}

FIGURE 131

Female.-Head cream; eyes brown in dried specimen, postocular ridge narrow, unmarked by pigmentation, divided on midline behind ocellar tubercle, covered with short hairs; frons wider than ocellar triangle, with a "Y"-shaped brown patch with the arms above the antennae, middle of stem darker brown, brown area clothed with short hairs; ocellar tubercle red-brown, ocelli clear; a groove from corner of eye, extending just back of the ocellar triangle to meet the groove from the opposite side and one from the back of the head, anterior to the margin of the back of the head. Antennae with all segments red-brown. See figure for details of the head.

Thorax dorsum red-brown, probably covered with tan pollen in nongreasy specimens, an orange patch on prothoracic dorsum, humeral and supra-alar calli orange, with a connecting marginal band; scutellum orange, with a round red-brown spot covering the center. Pleura with prothorax orange, mesanepisternum orange with a redbrown patch, mesokatepisternum red-brown; wings brown, granular, veins brown; halter stem tan, knob cream below, tan above. Legs red-brown changing to brown distally.

Abdomen segments all brown with light tan posterior membranous margins; eighth segment red-brown; ninth tergum with 8 stiff spines. Sec figure for details. 

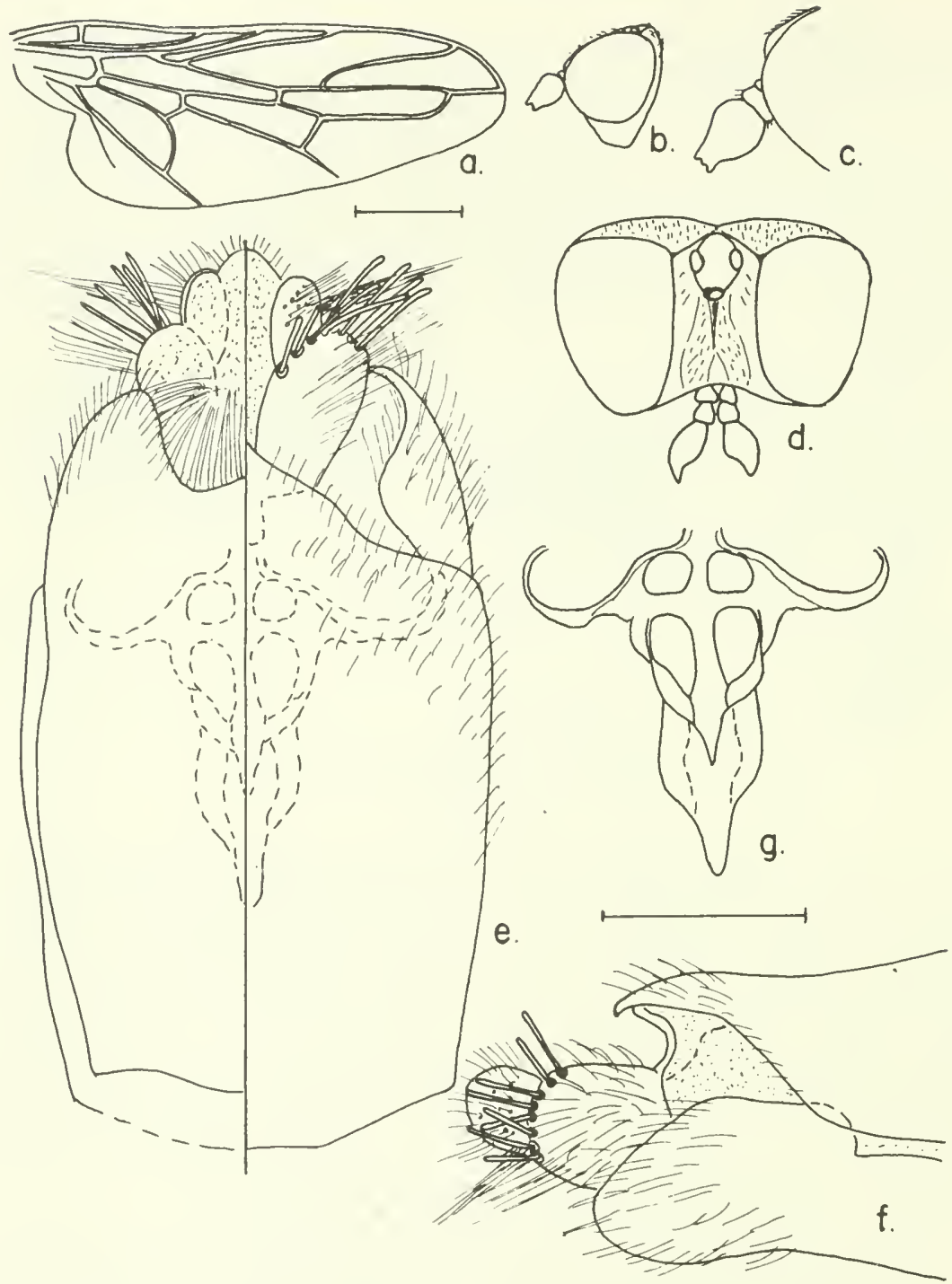

FIGURE 131.-Brevitrichia melanderi, new species, female: $a$, wing; $b$, lateral aspect of head; $c$, enlarged detail of antenna; $d$, dorsal aspect of head; $e$, ventral left and dorsal right aspects of 8 th and 9th segments, bursal structure outlined; $f$, lateral aspect of 8 th and 9th segments; $g$, bursal structure.

MALE.-Unknown.

Length: Female body $5 \mathrm{~mm}$., wing $2.4 \mathrm{~mm}$. 
Type-locality: Clouderoft, New Mexico; 27 May 1902 (A. L. Melander).

Holotype: Female (USNM) 67484.

\section{Brevitrichia minuta, new species}

Figure 132

MALE.-Head tan; eyes red-brown, with a metallic gleam above, darker below; frons triangular, with a small separate triangular area in front of median ocellus; ocellar tubercle red-brown, with a gray pollinose covering; ocelli red-brown; antennae with first two segments orange, third segment brown. See figure.

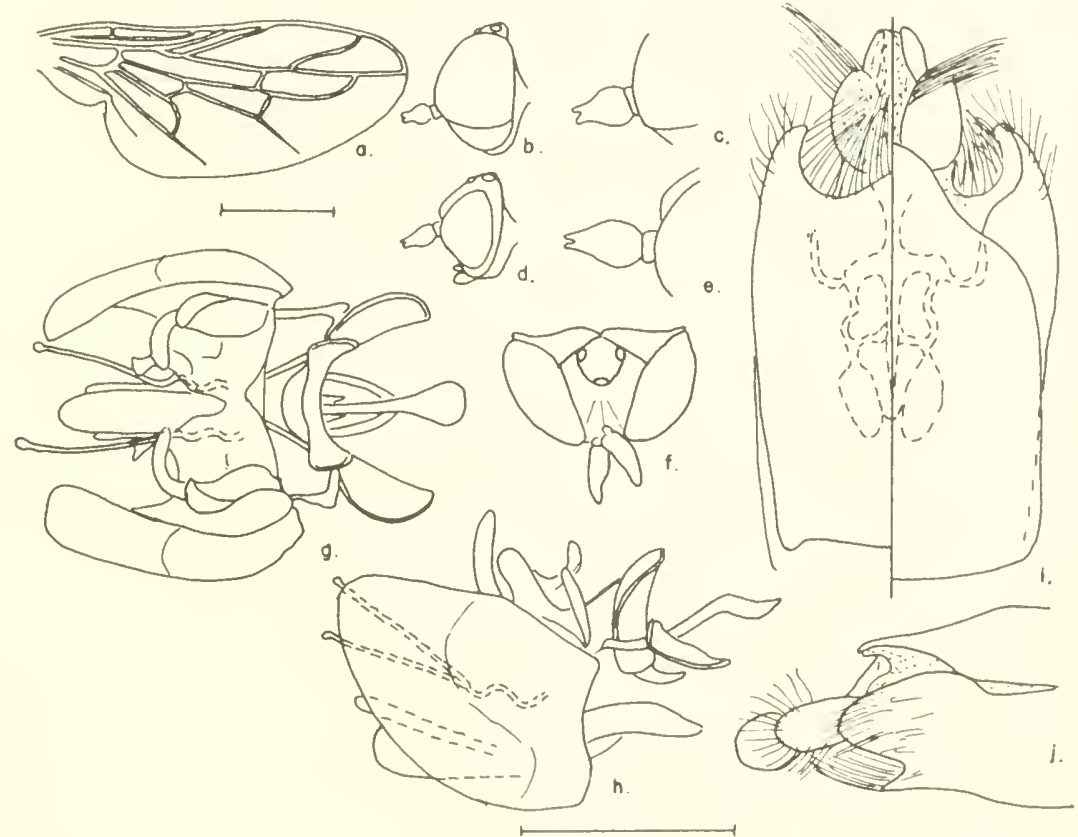

FIGURE 132.-Brevitrichia minuta, new species, male, female: $a$, wing; $b, d$, lateral aspects of male and female heads; $c, e$, enlarged details of male and female antennae; $f$, dorsal aspect of female head, frons collapsed; $g, h$, ventral and lateral aspect of male terminalia; $i$, ventral left and dorsal right aspects of female 8 th and 9 th segments, bursal structure outlined; $j$, lateral aspect of female 8 th 1 and 9 th segments.

Thorax dorsum black, densely covered with grayish white crustlike pollen, a white spot above the humeral callus; humeral and supra-alar calli white to yellow. Scutellum with black-brown dorsal surface, lateroposterior surface white or yellow, all granulose. Pleura with prothorax cream to white, mesopleuron black-brown covered with gray pollen; wings smoky, veins cream; halter stem brown, knob 
cream to white. Legs: femora black-brown, tibiae brown, tarsi brown darkening distally.

Abdomen red-brown with narrow cream to white bands along posterior margins; ninth tergum white with red-brown basal spot; aedeagal spines short, knobbed. See figure for details.

Female.-Head cream; eyes red-brown, metallic; postocular ridge moderately wide, unmarked, divided on the midline; frons broad, unmarked; ocellar tubercle red-brown, frosted gray pollen; ocelli orange; a groove running from corner of eye to back margin of ocellar tubercle. Antennae with first two segments orange, third segment brown. See figure for details.

Thorax dorsum red-brown, with a median and two lateral bands, yellow above humeral callus, lateral margins and median area ahead of scutellum tan, with two anterior bands nearly separating median and lateral bands; scutellum yellow, with a central triangular patch pointing posteriorly. Pleura with prothorax cream; mesanepisternum cream, with red-brown patch; mesokatepisternum red-brown; wings smoky white, veins cream; halter stem brown, knob cream. Legs as in the male.

Abdomen red-brown with tan posterior margins grading to yellowbrown posteriorly; eighth segment red-brown; ninth tergite with a marginal fringe of hairs instead of spines. See figure for details.

Length: Male body $2.5 \mathrm{~mm}$., wing $1.7 \mathrm{~mm}$.; female body $2.5 \mathrm{~mm}$., wing $1.7 \mathrm{~mm}$.

Type-locality: Beaver Dam, Arizona; 20 June 1939 (Timberlake).

Holotype: Male (CAS) 8919 (ex [PHT]).

Allotype: Female, same data (CAS).

Paratype: $1 \sigma^{7}$, Palm Springs, California; 24 June 1952 (Timberlake), (PHT).

\section{Brevitrichia oculivirida, new species}

Figure 133

MaLE.-Head tan; eyes blue-green, metallic above, darker below, very brilliant under the proper light; frons small, triangular; ocellar tubercle red-brown, covered with gray pollen; back of head brown. Antennae with first segment brown; second segment orange-brown; third segment black-brown; see figure for details.

Thorax dorsum black-brown, except for lateral margins yellow, covered with alternate longitudinal bands of tan and gray pollen, humeral and supra-alar calli cream, scutellum cream with a broad central spot of black-brown. Prothorax cream, mesanepisternum yellow with usual red-brown spot, mesokatepisternum red-brown, with upper margin yellow, pollinose; wings hyaline, veins tan; halter stem brown, knob tan. Legs red-brown except knees of femora yellow. 


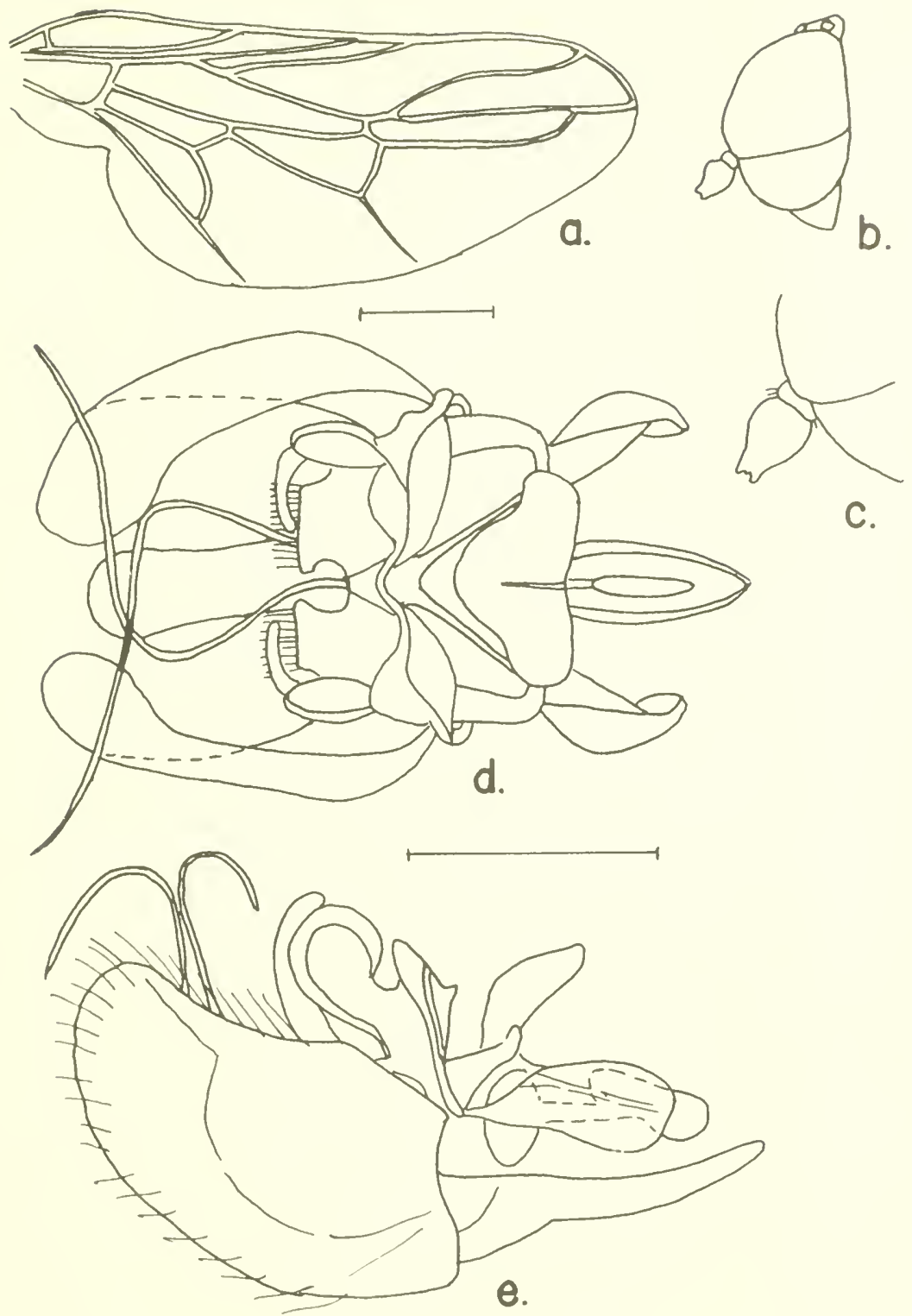

Figure 133.-Brevitrichia oculivirida, new species, male: $a$, wing; $b$, lateral aspect of head; $c$, enlarged detail of antenna; $d, e$, ventral and lateral aspects of terminalia.

Abdomen second segment with black-brown "T"-shaped figure, with short posterior lateral extensions at base of stem, lateral and posterior margins pristine white as is the rest of the abdomen; ninth tergum white, with dark basal band and spot. See figure for details. 
Female.-Unknown.

Length: Male body $4.3 \mathrm{~mm}$., wing $2.5 \mathrm{~mm}$.

Type-locality: Isla Ildefonso, Gulf of Calif., Mexico; 30 March 1953 (P. H. Arnaud).

Holotype: Male (CAS) 8931.

140. Brevitrichia ordwayi, new species

Figure 134

Male.-Head cream; eyes black-brown above, darker below; frons triangular, with a small tan triangle on the lower frontal area above the antennae; ocellar tubercle black-brown, dusted gray pollen, ocelli black-brown. Antenna with first segment red-brown; second segment black-brown; third segment reddish-brown, covered with short golden hairs. See figure for details.

Thorax dorsum black-brown, pollinose; a small yellow patch above humeral callus; lateral margins yellow, two short bands of yellow extending anteriorly from the lateral angles of scutellum; humeral callus buff, with a red-brown patch above; scutellum with a large red-brown patch medially, yellow on lateral angles. Prothorax yellow, mesanepisternum yellow, with a red-brown patch, mesokatepisternum red-brown, with a dorsal yellow band; wings hyaline, veins brown anteriorly tan posteriorly; halter stem brown, knob tan. Legs blackbrown pollinose, knee of femur yellow.

Abdomen segments dark brown with light posterior margins; ninth tergum tan, with a black-brown patch basally; see figure for details.

Female.-Head cream; eyes red-brown, metallic; postocular ridges medium wide with red-brown median patches, the two sides widely separated; frons tan, with a median groove bordered by a brown band that narrows toward the ocellar tubercle; ocellar tubercle red-brown, pollinose, ocelli red; a groove extending from the corner of each eye cutting off a central piece as wide as the ocellar tubercle. Antennae with first two segments brown, third segment orangebrown; see figure for details of head.

Thorax dorsum red-brown, heavily covered with gray pollen, spot above humeral callus yellow, lateral margins narrowly yellow between humeral and supra-alar calli, orange stripes extending anteriorly one-third the length of the dorsum from the scutellar groove, bordering a central stripe of red-brown; humeral and supraalar calli cream; scutellum yellow, with a median band of red-brown. Prothorax cream, mesanepisternum cream, with a central red-brown patch, mesokatepisternum red-brown, with a dorsal yellow stripe. 


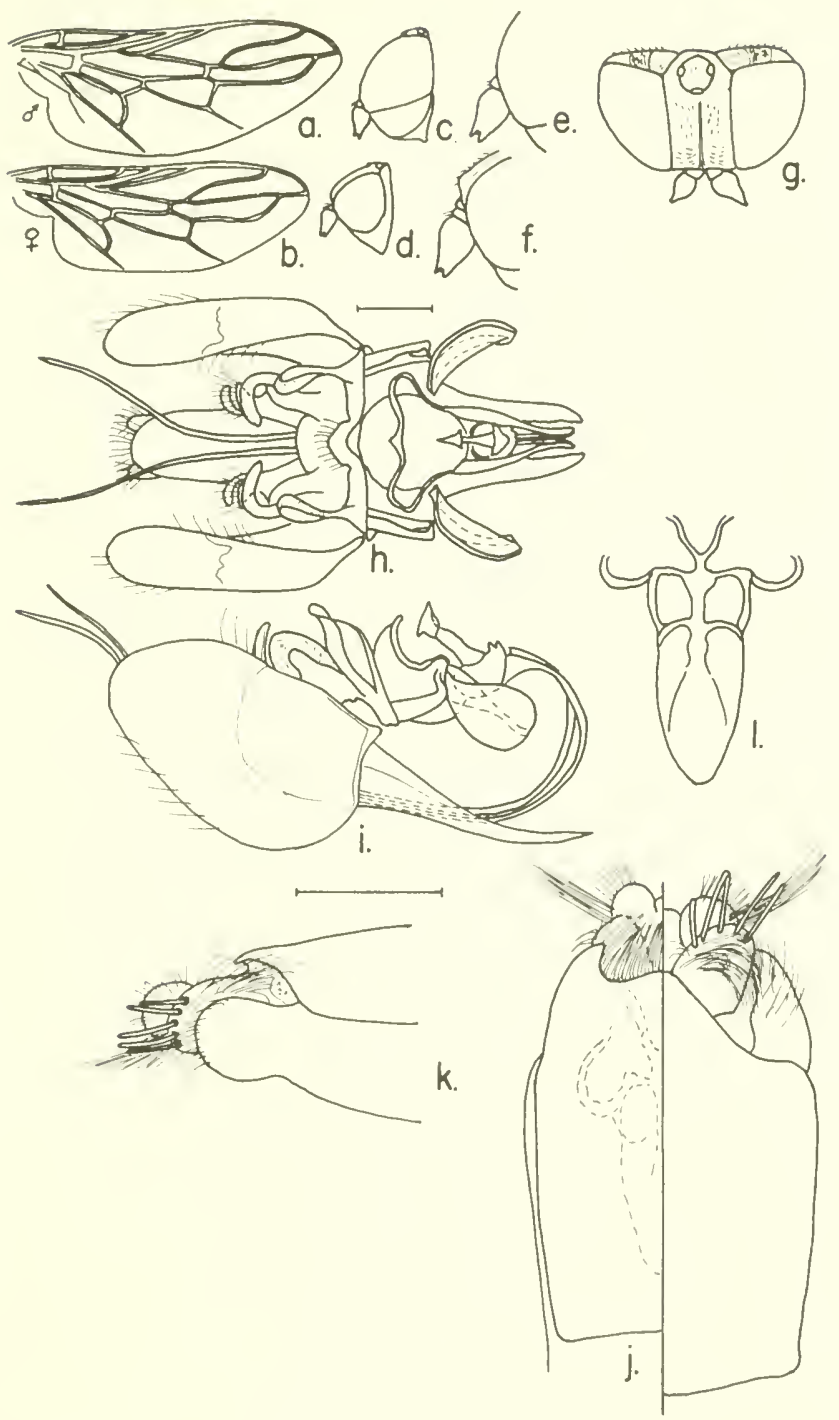

FIGURE 134.-Brevitrichia ordwayi, new species, male, female: $a$, male wing; $b$, female wing; $c, d$, lateral aspects of male and female heads; $e, f$, enlarged details of male and female antennae; $g$, dorsal aspect of female head; $h$, $i$, ventral and lateral aspects of male terminalia; $j$, ventral left and dorsal right aspects of female 8th and 9th segments; $k$, lateral aspect of female 8 th and 9 th segments; $l$, bursal structure.

Wings smoky white, veins red-brown; halter stem tan, knob tan. Legs with femora red-brown, pollinose; tibiae tan, tarsi tan darkening distally to brown. 
Abdomen second segment red-brown, with yellow-brown lateral patches, remaining segments red-brown; eighth segment red-brown, shining; ninth tergum with 5 stiff spines and much anteriorly directed long hair; see figure for details.

Length: Male body $3.5 \mathrm{~mm}$., wing $2.3 \mathrm{~mm}$.; female body $4.2 \mathrm{~mm}$., wing $2 \mathrm{~mm}$.

Type-locality: 2.5 mi. s. Willcox, Arizona; 29 May 1956 (S. Ordway) on mesquite.

Holotype: Male (CAS) 8920 (ex [PHT]).

Allotype: Female 18.2 mi. n.w. Oracle Junction, Pinal Co., Arizona; 6 September 1958 (Timberlake) (CAS) (ex[PH'T]).

\section{Brevitrichia pruinosa, new species}

FIgURE 135

MALE.-Head tan; eyes black-brown, with a metallic green cast above, darker below; frons small, triangular; mouthparts brown, well developed; palpi cream, short; ocellar tubercle black-brown, dusted gray pollinose; ocelli red. Antennae brown. See figure for details.

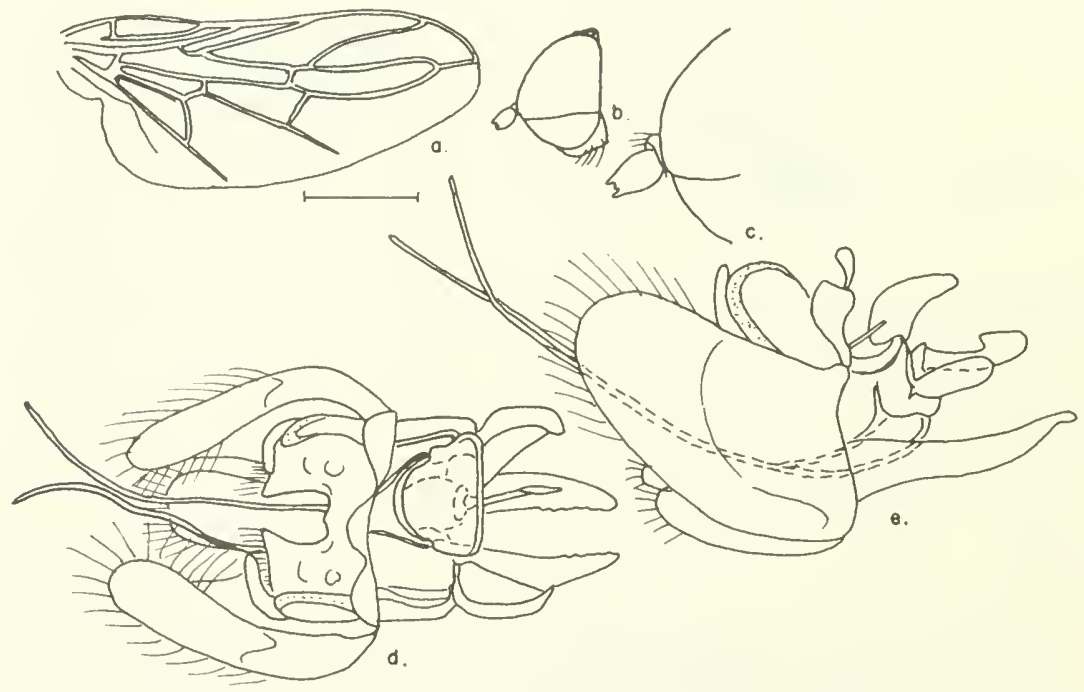

FIGURE 135.-Brevitrichia pruinosa, new species, male: $a$, wing; $b$, lateral aspect of head; $c$, enlarged detail of antenna; $d, e$, ventral and lateral aspect of terminalia.

Thorax black-brown, dusted with a central band of brown and lateral bands of gray pollen; humeral and supra-alar calli tan; scutellum black-brown, pollinose above, lateroventral margins yellow. 
Prothorax tan, mesanepisternum red-brown, except below wing tan, mesokatepisternum red-brown, all pollinose; wings smoky, veins tan (faint); halter stem brown, knob tan; legs with femora red-brown pollinose, tibine tan, tarsi tan, except brown at tips.

Abdomen second segment with a broad red-brown anterior margin with a thick median stem without substantial lateral extension, remainder of segment pristine white including posterior margin; remaining segments essentially white but with anterior and lateral margins red-brown; ninth tergum white, with a red-brown basal patch; see figure for details.

FeMale.-Unknown.

Length: Male body $2.6 \mathrm{~mm}$., wing $1.9 \mathrm{~mm}$.

Type-locality: Púlpito (anchorage), Baja California, Mexico; 20 Mareh 1953 (P. H. Arnaud) Sefton Orea Exped. to Gulf of California.

Holotype: Male (CAS) 8932.

Paratypes: $4 \sigma^{7} \sigma^{7}$, same data as type (CAS).

\section{Brevitrichia schlingeri, new species}

Figure 136

MALE.-Head cream; eyes red-brown, with metallic blue-green sheen, darker below; frons very narrow; ocellar tubercle red-brown, pollinose, ocelli red; antennae red-brown; see figure for details.

Thorax dorsum red-brown, solid except sides, covered with longitudinal bands of tan and brown pollen; humeral and supra-alar calli yellow; scutellum red-brown, except lateral margins yellow. Prothorax red-brown below humeral callus, then cream-yellow; mesanepisternum yellow, with a median red-brown patch; mesokatepisternum red-brown, with a yellow dorsal band, pollinose. Wing smoky hyaline, veins tan; halter stem brown, knob cream-yellow. Legs with femora red-brown, pollinose; tibine yellow-brown; tarsi yellow-brown, darkening to brown distally.

Abdomen segments all brown with narrow cream posterior bands; ninth tergum cream, with a tan patch basally which extends along the open margin; see figure for details.

Female.-Head cream; eyes red-brown, postocular ridge broud, continuing uninterruptedly behind ocellar tuberele, a tan pateh along the mid-dorsal portion behind the eyes; frons broad, with a "Y"-shaped orange median stripe and a triangular brown area above the antenure filling the arms of the "Y," a groove extending from the corner of the eye to the back edge of the lateral ocelli. Antennae with two basal segments brown, third segment black-brown: see figure for details. 


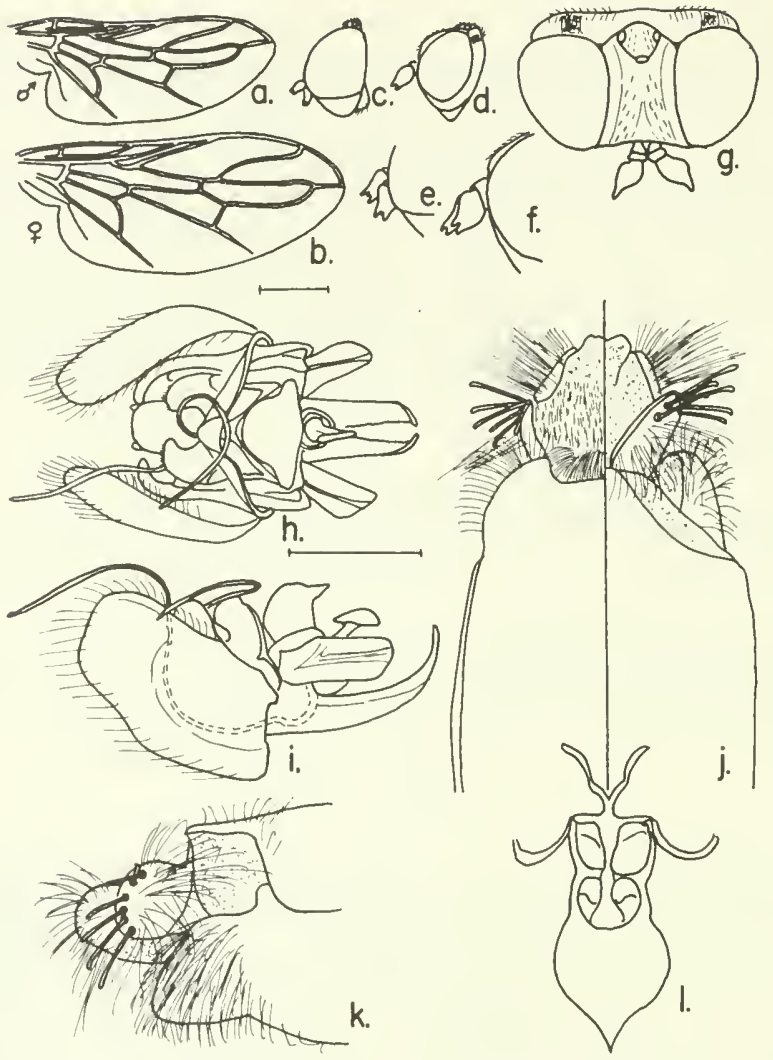

FIGURE 136.-Brevitrichia schlingeri, new species, male, female: $a$, male wing; $b$, female wing; $c, d$, lateral aspects of male and female head; $e, f$, enlarged details of antennae; $g$, dorsal aspect of female head; $h, i$, ventral and lateral aspect of male terminalia; $j$, ventral left and dorsal right aspects of female 8 th and 9th segments; $k$, lateral aspect of female 8 th and 9 th segments; $l$, bursal structures.

Thorax dorsum solid red-brown with areas of orange above humeral callus, margin and posterior third along the midline, covered with gray pollinose, except on greasy specimens; humeral and supra-alar calli cream; scutellum yellow, with a median triangular red-brown patch. Prothorax cream, mesanepisternum yellow, with a red-brown patch, mesokatepisternum red-brown, with a yellow dorsal margin; wings hyaline, veins brown; halter stem brown, knob cream-yellow. Legs with femora dark red-brown, pollinose; tibia yellow-brown; tarsi yellow, darkening to brown distally.

Abdomen second segment red-brown, with orange lateral areas, remaining segments red-brown anteriorly with orange posterior margins turning to orange-brown; ninth segment orange, sternum 
with shallow excavation; ninth tergite with 6 spinelike hairs and much long black hair; see figure for details.

Length: Male body $3.5 \mathrm{~mm}$., wing $2 \mathrm{~mm}$.; female body $4.5 \mathrm{~mm}$., wing $2.6 \mathrm{~mm}$.

Type-locality: Lancaster, Los Angeles Co., California; 22 July 1957 (E. I. Schlinger).

Holotype: Male (UCalD) 78 .

Allotype: Female, Kramer Hills, San Bernardino Co., California; 19 April 1959 (E. I. Schlinger) (UCalD).

Paratype: $1 \sigma^{x}, 5 \mathrm{mi}$. s. Lancaster, Los Angeles Co., California, 15 May 1956 (E. G. Linsley, J. W. MacSwain) (UCalB); 1 ㅇ, Pinto Flats, Imperial Co., California, 5 May 1958 (F. X. Williams) (CAS); 1 o, Blythe, California, 1 May 1955 (N. R. Richards) (CNC).

\section{Brevitrichia scitulaesca, new species}

Figure 137

Fenale.-Head cream, eyes dark red-brown; postocular ridge moderately wide, with a brown patch on either side; frons broad, with a median groove bordered by a tan band with sparse hairs; grooves from the corner of the eyes to the back of the head cut off a portion nearly as wide as the ocellar tubercle; ocellar tubercle black-brown, pollinose, ocelli red. Antennae all segments brown; see figure for details.

Thorax dorsum black-brown, dusted with brown pollen, an orange patch over the humeral callus, lateral margins cream, and two orange vittae, broader at base, extend from the lateral portions of the scutellar groove to the anterior margin of the dorsum dividing the dark areas into three fields; humeral and supra-alar calli white; scutellum orange with a median red-brown spot continuous with the median band of the dorsum. Prothorax white; mesanepisternum cream, with a median red-brown patch, mesokatepisternum redbrown, with a creamy dorsal band, all dusted gray pollinose. Wings smoky white, veins brown; halter stem tan, knob creamy white. Legs with femora red-brown, with yellow knees; tibiae tan-brown; tarsi tan-brown, darkening distally. All segments pollinose.

Abdomen segments red-brown, with broad white posterior bands; eighth segment red-brown; ninth tergum with 6 stiff spines, sparse hair. See figure for details.

Male.-Unknown.

Length: Female body $4 \mathrm{~mm}$., wing $2.3 \mathrm{~mm}$.

Type-locality: 1 mi. w. Lajitas, Texas; 23-30 April 1963 (H. E. Evans) in nest of digger wasp Slenostictia scitula.

Holotype: Female (USNM) 67486. 

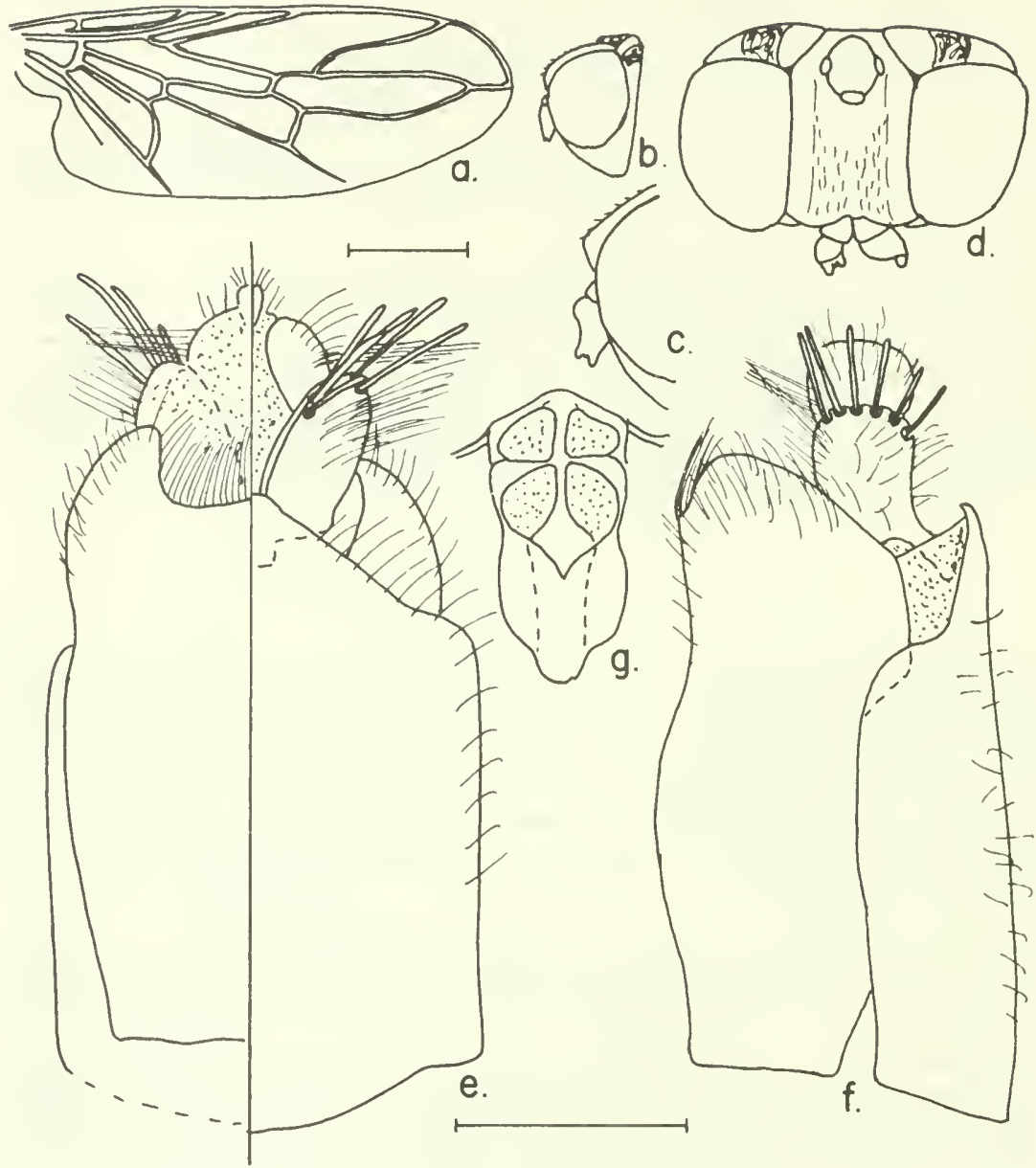

Figure 137.-Brevitrichia scitulaesca, new species, female: $a$, wing; $b$, lateral aspect of head; $c$, enlarged detail of antenna; $d$, dorsal aspect of head; $e$, ventral left and dorsal right aspects of 8 th and 9 th segments; $f$, lateral aspect of 8 th and 9th segments; $g$, bursal structure.

\section{Brevitrichia timberlakei, new species}

Figure 138

M ALE.-Head cream; eyes red-brown, with a blue-green metallic sheen, more intense below; frons narrow, triangular; ocellar tubercle red-brown, with gray pollen; ocelli red. Antennae with first two segments tan, third segment tan basally, brown distally.

Thorax red-brown, covered with gray-green pollen, area above humeral callus and in front of scutellum yellow, as well as marginal areas; humeral and supra-alar calli cream; scutellum yellow, with a 

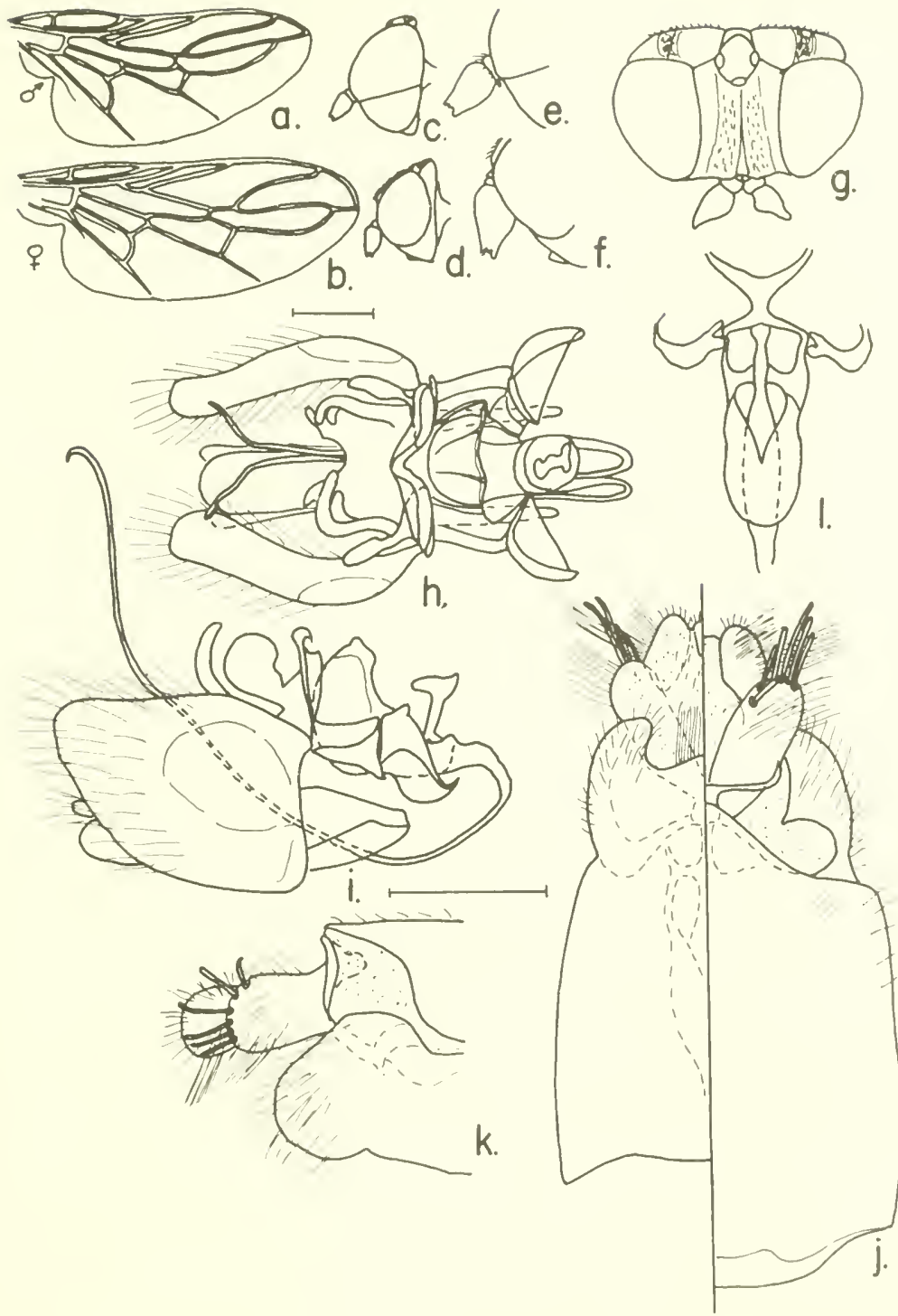

FIGURE 138.-Brevitrichia timberlakei, new species, male, female: $a$, male wing; $b$, female wing; $c, d$, lateral aspects of male and female heads; $e, f$, enlarged details of male and female antennae; $g$, dorsal aspect of female head; $h, i$, ventral and lateral aspects of male terminalia; $j$, ventral left and dorsal right aspects of female 8th and 9th segments; $k$, lateral aspect of female 8 th and 9 th segments; $l$, bursal structure.

thin median red-brown stripe. Prothorax cream, mesanepisternum yellow, with a median red-brown spot, mesokatepisternum red-brown, with a dorsal band of yellow, all dusted pollinose; wings smoky, 
veins tan; halter stem brown, knobs cream, with a marginal brown band. Legs: femora red-brown, pollinose; tibiae tan; tarsi tan, darkening to brown distally.

Abdomen second segment with a red-brown "T," with a broad lateral base, remainder and posterior portion of segment white, remaining segments with red-brown "T"'s then fading out to all white; ninth tergum white, with brown basal patch, hairs very long; see figure for details.

Female.-Head cream; eyes red-brown, probably metallic in life; postocular rim broad, with thin brown patch behind eyes; frons broad, with a tan "Y"-shaped band extending from antennae to ocellar triangle and the width of the latter; ocellar tubercle red-brown, pollinose; ocelli red; a groove extending from corner of eye to lateral ocelli and then nearly straight to back of head, cutting off a portion nearly as wide as ocellar tubercle separating the two postocular ridges. Antennae with first segment brown, second tan, third orange, darkening at the tips; see figure for details.

Thorax dorsum with red-brown central and two lateral bands separated by an orange stripe running between orange area above humeral callus to central area on posterior third of dorsum, lateral margins orange; all dusted with gray pollen; humeral and supraalar calli cream; scutellum yellow, with a narrow median band of red-brown, pollinose. Prothorax cream, mesanepisternum cream with red-brown patch, mesokatepisternum red-brown with a dorsal yellow stripe, all pollinose. Wings smoky, veins brown; halter stem tan, knob cream with tan marginal stripe. Legs with femora brown, pollinose; tibiae tan, tarsi tan, darkening to brown distally.

Abdomen second segment with a brown "T" with a red-brown central stem and broad base in a field of yellow-brown, red-brown " $\mathrm{T}$ " on third and fourth segments, turning to yellow-brown beyond; eighth segment yellow-brown, shining; ninth tergum with 6 spinelike hairs, somewhat hairy. See figure for details.

Length: Male body $3 \mathrm{~mm}$., wing $2 \mathrm{~mm}$.; female body $4.5 \mathrm{~mm}$., wing $2.2 \mathrm{~mm}$.

Type-locality: Riverside, California; 19 September 1950 (Timberlake).

Holotype: Male (CAS) 8921 (ex [PHT]).

Allotype: Female, same data.

145. Brevitrichia yucatani, new species

Fugure 139

Brevitrichia griseola D. E. Hardy (not Coquillett), 1944a, p. 34.

Male.-Head tan; eyes red-brown, with a metallic glint above, black-brown below; frons small; ocellar tubercle black-brown, ocelli 
red. Antennae with first segment brown, second orange, third orangebrown basally, darkening to black-brown, with short hairs; see figure.

Thorax dorsum black-brown, with yellow lateral margins; humeral and supra-alar calli yellow, scutellum yellow, with black-brown area covering central third. Prothorax yellow; mesanepisternum yellow with red-brown spot; mesokatepisternum red-brown with yellow dorsal band. Wings smoky, reins tan; halter stem tan, knob cream below, tan above. Legs with femora red-brown, tibiae tan, tarsi tan at base darkening distally.

Abdomen segments red-brown, with posterior white bands on segments; ninth tergum white, with red-brown spot on basal portion; see figure for details.

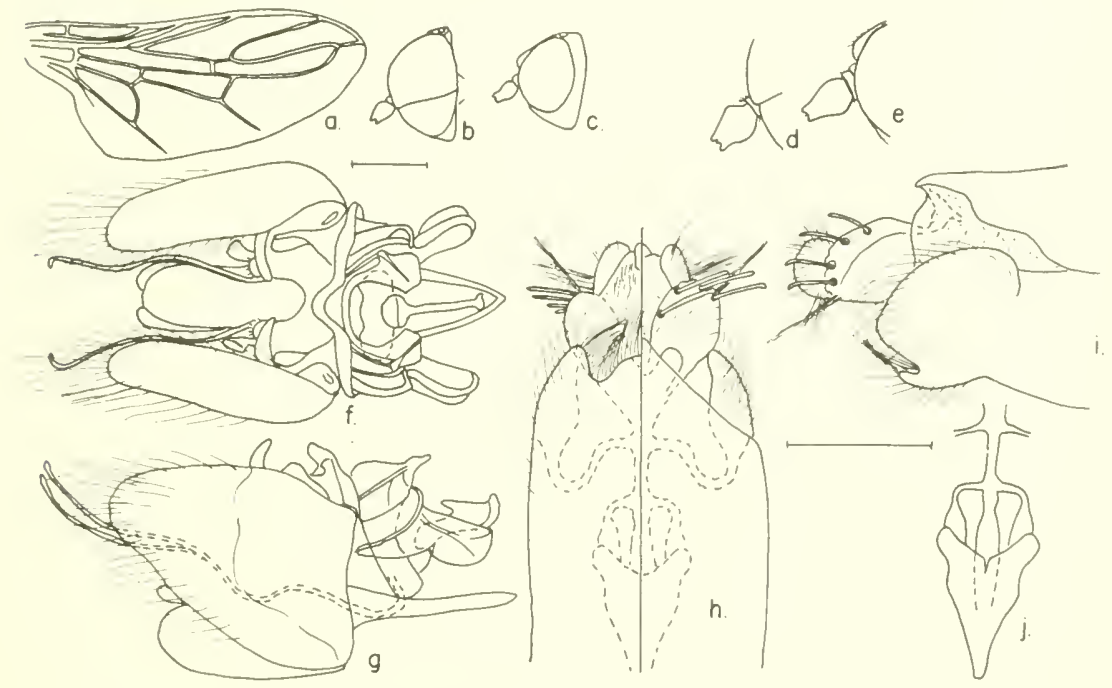

FigURE 139.-Brevitrichia yucatani, new species, male, female: $a$, wing; $b, c$, lateral aspects of male and female heads; $d, e$, enlarged details of male and female antennae; $f$, $g$, ventral and lateral aspects of male terminalia; $h$, ventral left and dorsal right aspects of female 8 th and 9 th segments; $i$, lateral aspect of female 8 th and 9 th segments; $j$, bursal structure.

Fexiale.--Head lost before descriptions made, last antennal segment orange.

Thorax dorsum black-brown, heavily dusted with gray pollen, a cream patch behind the humeral callus; humeral callus cream; scutellum yellow, with red-brown spot occupying middle half. Pleural areas as in male. Wings dusted brown, veins brown; halter stem tan, knob cream below, tan above.

Abdomen first four segments red-brown with white posterior bands, rest red-brown. Eighth segment red-brown, shining; ninth tergum with 4 stout spines; see figure for details. 
Length: Male body $3.5 \mathrm{~mm}$., wing $2.1 \mathrm{~mm}$.; female body $5.2 \mathrm{~mm}$., wing $2.5 \mathrm{~mm}$.

Type-locality: Suchiapa, Chiapas, Mexico; 25 March 1953 (R. C. Bechtel and E. L. Schlinger).

Holotype: Male (CAS) 8937.

Allotype: Female, El Rancho, Guatemala; 17 February 1932 (C. N. Ainslee) (USNM).

\section{Genus Metatrichia Coquillett}

Metatrichia Coquillett, 1900, p. 500.

Type-species, Scenopinus bulbosus Osten Sacken (original designation). The genus Metatrichia Coquillett is characterized by large robust flies with broad, flat, blunt abdomens. Cell R5 in the wing is closed, vein $\mathrm{R} 4$ branches from various points along the cell. The heads are higher than long and the front bulges at the middle projecting the antennae forward. 'The genus is represented in all regions but the Palaearctic.

\section{Key to the Species of Metatrichia}

Wing hyaline . . . . . . . . . . . . . . . 2

Wing brown or yellow brown . . . . . . . . . . . . . . . 4

2. Halter knob brown . . . . . . . . . . . . . . . . . . . . 3

Halter knob white, antenna yellow, pointed, thorax with white hairs, abdomen with white bars with anteriorly directed swellings laterally. (Africa)

$o^{7}$ M. stevensoni (Bezzi)

3. Body with flattened scale-like hairs (North America)

$\sigma^{2} \mathbf{M}$. bulbosa (Osten Sacken)

Body only sparsely covered with microscopic scales (Australia)

$\sigma^{2}$ M. waterhousei (Paramonov)

4. Wing brownish . . . . . . . . . . . . . . . . 5

Wing yellow-brown, halter knob cream, antenna dark red-brown, body without scale-like hairs (S. America). . . . . . . . o M. robusta (Krööber)

5. Halter knob brown or yellow-brown . . . . . . . . . . . . . . . 6

Halter knob orange-brown or tannish yellow . . . . . . . . . . . . 7

6. Halter knob brown, body covered with white flattened scale-like hairs (North America) . . . . . . . . . M. bulbosa (Osten Sacken)

Halter knob yellow-brown, antenna black-brown, velvety, body without flattened scales (S. America) . . . . . . . . 오․ M. robusta (Kröber)

7. Halter knob orange-brown, a very large fly over $7.5 \mathrm{~mm}$. (Africa)

\% M. lophrysoma (Speiser)

Halter knob tamish-yellow a moderate sized fly under $5.5 \mathrm{~mm}$., antenna orange at base dark at tip (Africa) . . . . . M. stevensoni (Bezzi) 
146. Metatrichia bulbosa (Osten Sacken)

Figure 140

Scenopinus bulbosus Osten Sacken, 1877, p. 275.

This is the most widespread North American species in the family Scenopinidae.

It is a robust species covered with flat scale-like hairs.

Length: Male body 4-4.5 $\mathrm{mm}$., wing 3-3.3 $\mathrm{mm}$.; female body $3.5-5.3 \mathrm{~mm}$., wing $3.2-4 \mathrm{~mm}$.

Type-locality: Missouri, in July (C. V. Riley).

Type: (MCZ) 1057.

I have examined specimens from the following localities: California; Isla San José and Púlpito (anchorage), Gulf of California, Mexico; Texas; New Mexico; Washington; Idaho; Nevada; Kansas; Nebraska (Scotts Bluff); Illinois; South Carolina; District of Columbia (Washington); Virginia (Mt. Vernon); West Virginia (Lost River State Park); Pennsylvania; New Jersey; New York (Babylon, Long Island); Connecticut; Massachusetts (Hollister); Vermont (Rupert Mt.); and Delaware. One specimen from Nogales, Arizona, was taken from a tunnel in a rose cane. No other clues as to their habits or habitat are known.

\section{Metatrichia lophrysoma (Speiser), new combination}

Figure 141

Pseudomphrale lophrysoma Speiser, 1920, p. 216.

The type of this species is presumed lost; a search of the material from the Stettin Collection now housed in (PAS) failed to produce it. However, two specimens exist in (AMNH) from the Belgian Congo which agree closely with Speiser's description and have been illustrated. 'This is the largest of all the Scenopinids examined by me.

Length: Female body 7-7.5 mm., wing $5.5 \mathrm{~mm}$.

'Type-locality: Willowmore, [Republic of] South Africa; November 1907 (H. Brauns).

Type: deposited in Stettiner Museum (lost).

Specimens seen: 2 우, Banana, Belgian Congo, $6^{\circ}$ S. $12^{\circ} 20^{\prime}$ E.; July 1915 (Lang and Chapin) (AMNH).

\section{Metutrichia robusta Kröber}

Figure 142

Metatrichia robusta Kröber, 1913, p. 180.

The type of this speries has been lost but I was fortunate to find a number of specimens of both the male and female for figuring and description. The female has not previously been described. 


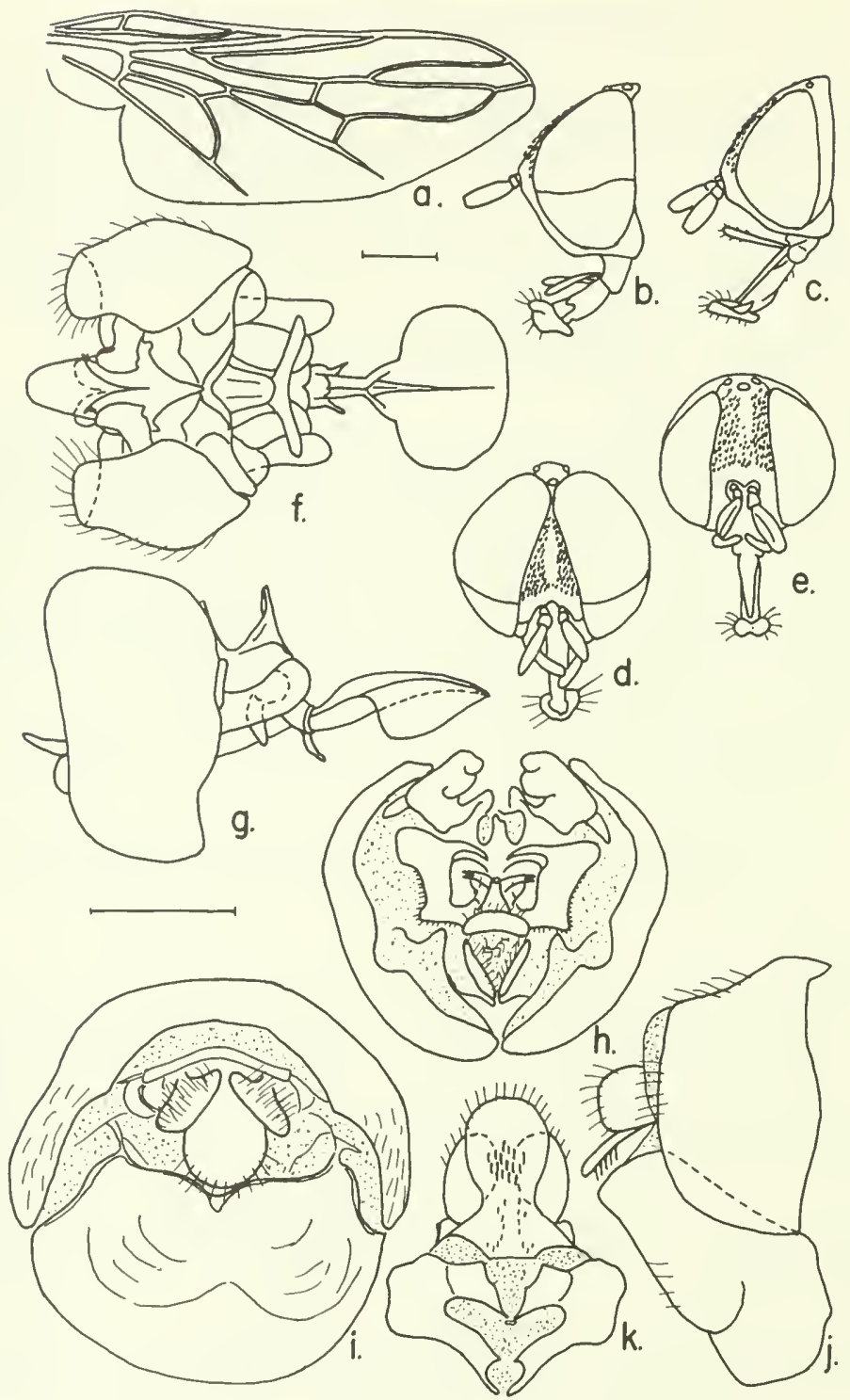

Figure 140.-Metatrichia bulbosa (Osten Sacken), male, female: $a$, wing; $b, c$, lateral aspects of male and female heads; $d, e$, frontal aspects of male and female heads; $f-h$, ventral, lateral and posterior aspects of male terminalia; $i$, posterior aspect of female 8 th and 9 th segments; $j$, lateral aspect of female 8 th and 9th segments; $k$, female 9th sternum and bursa.

Female.-Head black; eyes black-brown; a narrow postocular band; frons rugose, with a smooth median band, lower portion juts out extending the antemnae outward. Mouthparts red-brown, well 


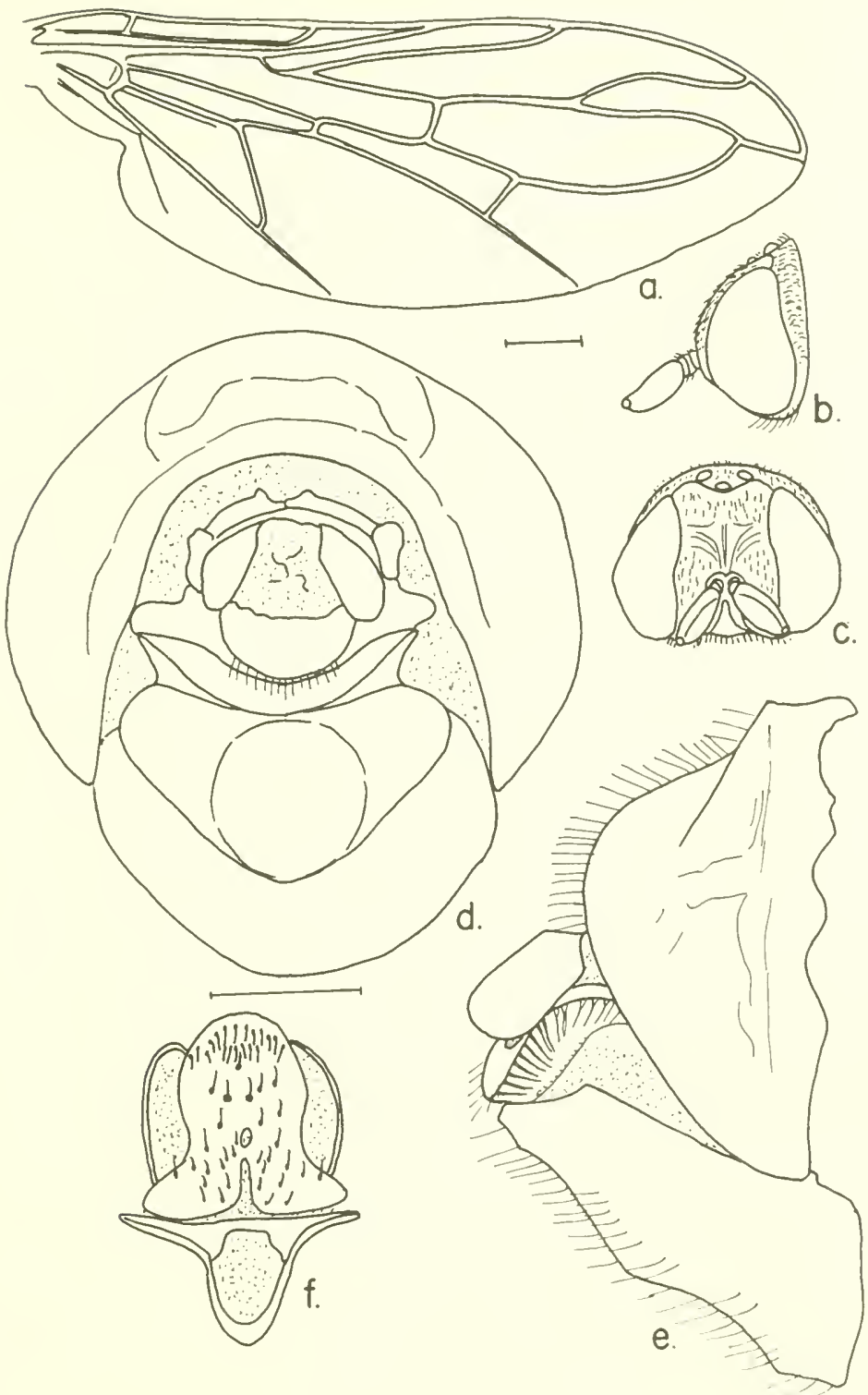

Figure 141.-Metatrichia lophrysoma (Speiser), female: $a$, wing; $b$, c, lateral and frontal aspects of head; $d$, posterior aspect of 8 th and 9 th segments; $e$, lateral aspect of 8 th and 9 th segments; $f, 9$ th sternum and bursa.

developed completely filling oral cavity; palpi as long as oral cavity with a fringe of tun hairs. Ocellar tubercle black, not elevated, medim 


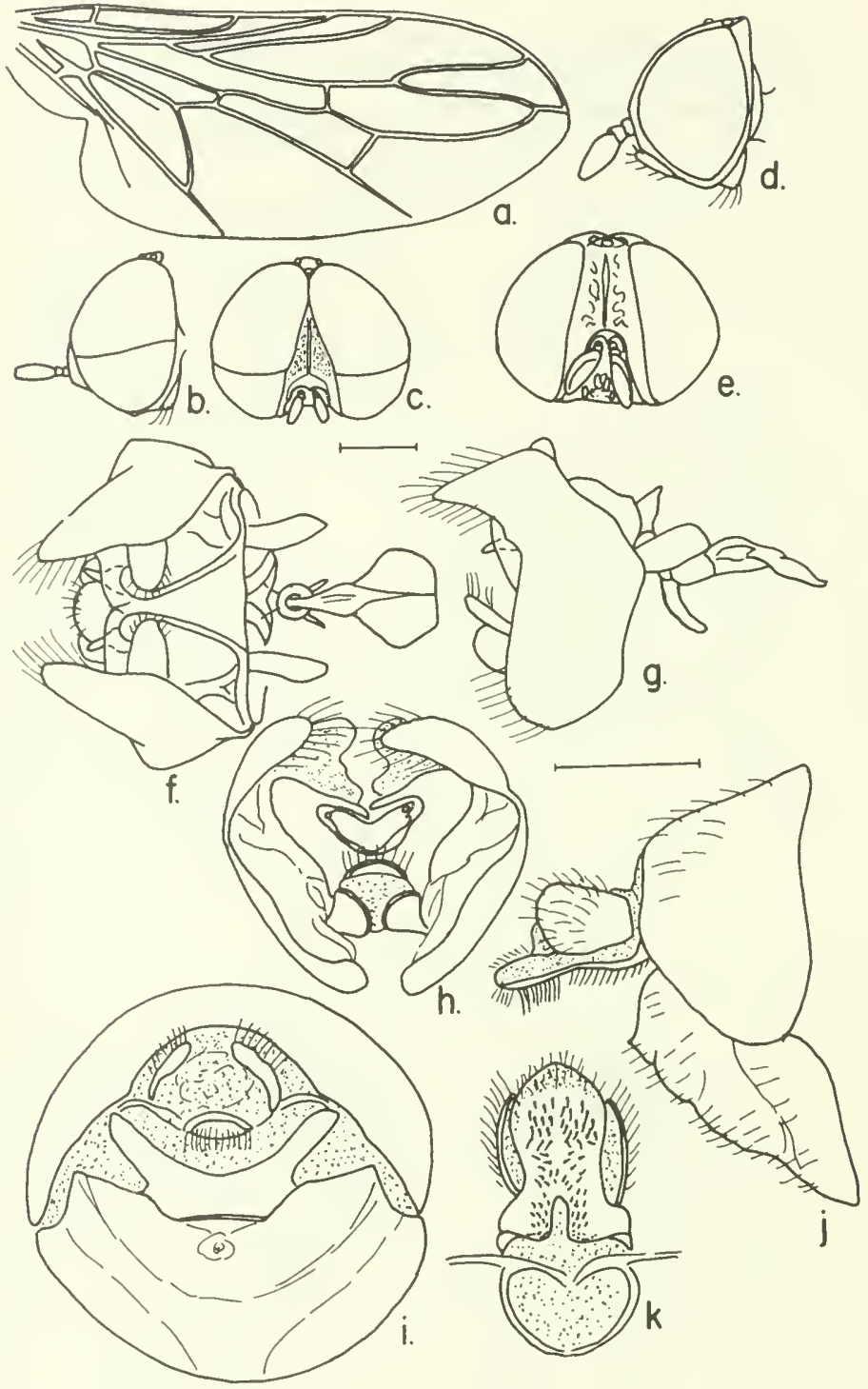

Figure 142.-Metatrichia robusta Kröber, male, female: $a$, wing; $b$, $c$, lateral and frontal aspects of male head; $d, e$, lateral and frontal aspects of female head; $f-h$, ventral, lateral and posterior aspects of male terminalia; $i$, posterior aspect of female 8th and 9th segments; $j$, lateral aspect of female 8 th and 9th segments; $k$, female 9 th sternum and bursa.

ocellus sunken, ocelli orange. Antennae black-brown, third segment oval, velvety.

Thorax black with a few thin hairs, humeral and supra-alar calli orange; an orange area below the wing. Wing brown, veins brown; halter stem brown, knob orange-brown. Legs with femora red-brown, 
tibiae red-brown, tarsi light red-brown anteriorly, posterior legs with yellow-brown tarsi.

Abdomen dark red-brown, with short reddish hairs, broad and thick, tip of abdomen blunt; see figure for details.

Kröber gives the length of the male as $7 \mathrm{~mm}$. and the wing-spread as $8 \mathrm{~mm}$. Measurements made by me are as follows:

Length: Male body $5 \mathrm{~mm}$, wing $3.6 \mathrm{~mm}$.; female body $5.4 \mathrm{~mm}$., wing $4 \mathrm{~mm}$.

Type-locality: Paraguay.

Type: (MNH) lost.

I have seen several specimens from Nova Teutonia, Brazil, $27^{\circ} 11^{\prime} \mathrm{S}$. $52^{\circ} 23^{\prime}$ W.; 15 April, 30 November, and 1s December 1959 (Fritz Plaumann) (CNC). Several from the same locality and collector in (BMNH), as well as specimens from Bemberg, Misiones, Argentina, 14 March 1945 (Hayward, Willink, V. Golbach) and a specimen labeled Patagonia (BMNH).

\section{Metatrichia stevensoni (Bezzi), new combination}

FIgURE 143

Pseudomphrale stevensoni Bezzi, 1925, p. 96.

Pseudomphrale africana Lindner, 1962, p. 2.

This species from Africa is characterized in the male by the peculiar markings on the abdomen, each segment having a posterior white border and an anterolateral white spot. Lindner redescribed the species as P. africana in 1962 and figured the abdomen. I am placing the Lindner name in synonomy as it disagrees with Bezzi's type only in the detail of the tip of the wing which is more elongated than in Lindner's specimen.

The females I am assigning to this species come from western Africa. On the basis of general wing charaeters, however, and using the distributional pattern of $M$. bulbosa in North America, I believe this placement correct.

Fenale.-Head black, eyes black-brown; frons broad, granular, covered with short anteriorly directed silvery seales, as is the moderately wide postoeular ridge. Monthparts large and well developed, postgenal area behind eyes orange, ocellar tubercle set off but not prominent, ocelli red. Antennae with first segment brown, twice as long as the second; second segment brown, short; third segment orange at base, black at tip, truneated, twice as long as first two combined. The frontal area does not project in this species as it does in $M$. bulbosa and M. robusta.

Thorax dorsum black, very granular with a elose pile of narrow seales, humeral and supra-alar calli orange, seutellum orange-brown, 


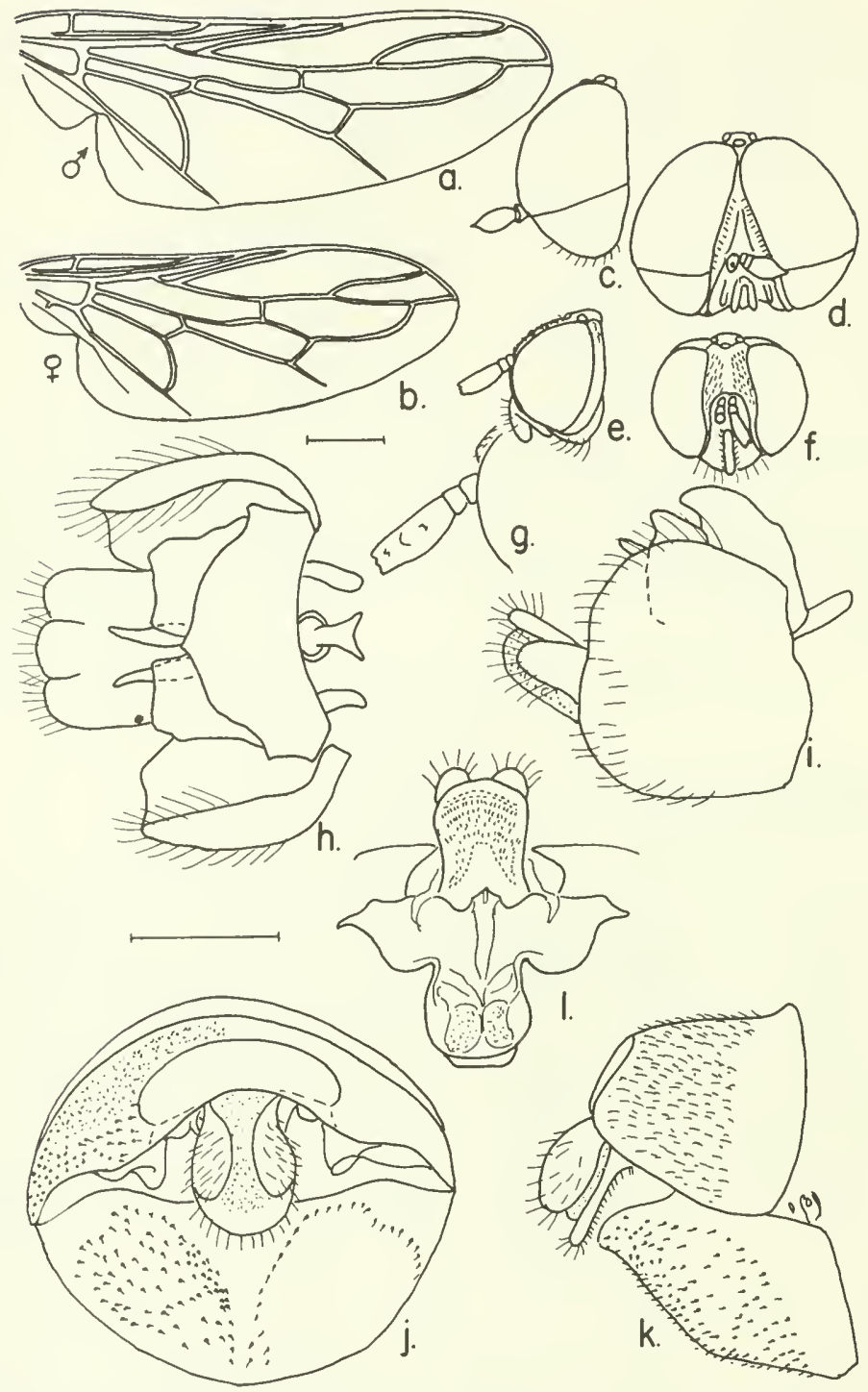

Figure 143.-Metatrichia stevensoni (Bezzi), male, female: $a$, male wing; $b$, female wing; $c, d$, lateral and frontal aspects of male head; $e, f$, lateral and frontal aspects of female head; $g$, enlarged detail of female antenna; $h, i$, ventral and lateral aspects of male terminalia; $j$, posterior aspect of female 8 th and 9 th segments; $k$, lateral aspect of female 8 th and 9 th segments; $l$, female 9 th sternum and bursa.

lighter along the posterior rim. Pleural areas black and orange-red. Wing brownish, veins brown; halter stem brown, knob tannishyellow. Legs red-brown except tarsi orange-yellow. 
Abdomen broad black-brown fading to red-brown posteriorly. See figure for details of eighth segment and bursa.

Length: Male body 5-5.5 mm., wing 3.5-4 mm.; female body $4.5 \mathrm{~mm}$., wing $3 \mathrm{~mm}$.

Type-locality: Matapos, Southern Rhodesia; 21 September 1924 (R. H. R. Stevenson).

Type: (MCSNM).

Other specimens seen: $10^{7}$, Dar es Salaam, Kenya, 18 November 1958-5 May 1959 (Lindner) Lindner's type of P. africana; $10^{7}$, Cholo, Nyasaland (R. C. Wood); $10^{7}$, Ruo, Nyasaland, 13 May 1916 (R. C. Wood) both in (BMNH); 2 q , Aus, South West Africa, January 1930 (R. E. Turner) (BMNH).

150. Metatrichia uaterhousei (Paramonov), new combination

FIgURE 144

Pseudomphrale waterhousei Paramonov, 1955, p. 640.

This specimen from Australia definitely is a Metatrichia and not Pseudomphrale as originally placed. It conforms in all ways to the genus. The shape of the head, large mouthparts, scales on thorax, robust body and genital structures, etc. leave no doubt as to its position or identity.

Length: Male body $5 \mathrm{~mm}$., wing $3.5 \mathrm{~mm}$.

Type-locality: Killara, New South Wales; 20 January 1935 (D. F. Waterhouse).

Type: (CSIRO).

\section{Genus Pseudatrichia Osten Sacken}

Pseudatrichia Osten Sacken, 1877, p. 276.

Atrichia Schrank of Loew, 1866, p. 42.

Tyr e-s recies Atrichia longurio Loew (monobasic). The genus Pscudatri hia Osten Sacken is characterized by a head that is longer then high, a long slender thorax and abdomen and the cell R5 closed before the end of the wing.

The proper interpretation of this genus has been confused from the beginning by Loew's mistaking the sex of the type of P. longurio as the male of the speries, whereas he was dealing with a female. This led to the concept of the genus as one where the males had the eyes widely separated instead of contiguous on the midline, separating the front from the ocellar tubercle. This necessitated the creation of such genera as Pseudomphrale. The fact that no use was made of genital structures in identifying the species of the family has led to the creation of many unjustified genera in the past. The most useful diagnostic characters are found in the shape of the head, wing venation, the male terminalia, and the eighth stermum of the female. 


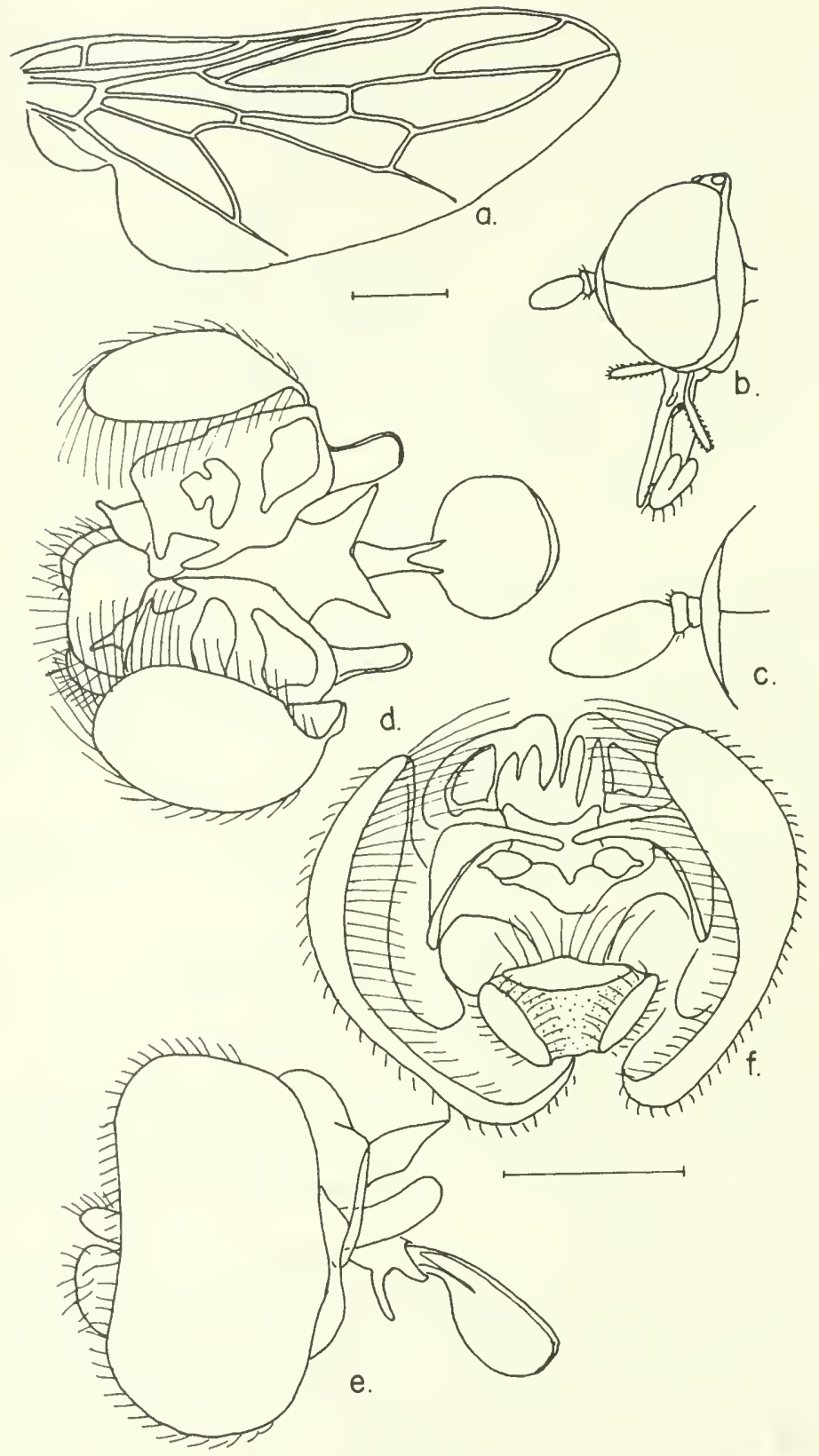

FIGURE 144.-Metatrichia waterhousei (Paramonov), male: $a$, wing; $b$, lateral aspect of head; $c$, enlarged detail of antenna; $d-f$, ventral, lateral and posterior aspects of terminalia.

The members of this genus are found only in the Nearctic and Neotropical regions. 


\section{Key to Species of Pseudatrichia (males)}

1. Wing brown fumose

Wing hyaline . . . . . . . . . . . . . . . 5

2. Halter knob with dorsal surface brown, red-brown, or black . . . . . . 3 Halter knob with base red-brown, remainder white

P. parvipennis, new species

3. Halter knob with dorsal surface brown or red-brown . . . . . . . . . 4 Halter knob black with tip white (Brazil) . . P. punctulata D. E. Hardy

4. Halter knob all red-brown (Costa Rica) . . . P. longiventris, new species Halter knob with dorsal surface brown, ventral surface white

P. toupeta, new species

5. Halter knob white . . . . . . . . . . . . . 6 Halter knob with at least the base brown . . . . . . . . . . . 7

6. Antenna red-brown. . . . . . . . . P. morlani, new species Antenna orange . . . . . . . . . . P. melanderi, new species

7. Halter knob with base red-brown, remainder white. . . . . . . . . s Halter knob with color at least along the dorsal rib . . . . . . . . . 11

8. Antenna red-brown. . . . . . . . . . . . . . . . . . 9

Antenna black-brown or orange . . . . . . . . . . . . . . 10

9. Ventral margin of 9 th tergum short, 9 th sternum with a thin comb of hairs

P. atombomba, new species Aedeagal struetures very large, 9 th sternum with a thick comb of hairs

P. cajoni, new species

10. Antenna black-brown .

P. unicolor Coquillett

Antenna orange-brown . . . . . . P. gracilipennis, new species

11. Dorsal rib of halter knob red-brown bleeding into white. . . . . . . 12

Dorsal rib of halter knob brown with no bleeding or dorsal surface brown. 13

12. Vein R4 ending well beyond end of cell R5 . . . P. barnesi, new species Vein R4 ending equal to end of cell R5 . . . . P. truncata, new species

13. Doral surface of halter knob red-brown, brown or black-brown. . . . 14 Only dorsal rib of halter knob red-brown, remainder white

P. bupennis, new species

14. Dorsal surface of halter knob brown or black-brown. . . . . . . . . . 15 Dorsal surface of halter knob red-brown . . . P. cockerelli, new species

15. Ventral surface of halter knob white. . . . . P. punctulata D. E. Hardy Ventral surface of halter knob black-brown, exeept a small white spot

P. peromysci, new species

\section{Key to Species of Pseudatrichia (females)}

1. Wing smoky brown . . . . . . . . . . . . . . . . 2 Wing hyaline . . . . . . . . . . . . . . . 6

2. Halter knob partly white . . . . . . . . . . . . . 3 Halter knob brown or red-brown . . . . . . . . . . . . . . . 4

3. Halter knob with base red-brown remainder white . P. jamesi, new species Halter knob with base and dorsal rib red-brown, bleeding into white

P. clouderofti, new species

4. Antenna red-brown ... . . . . . . . . . . . . 5

Antenna black, short, 7 th abdominal segment sharply constrieted at base (Brazil) . . . . . . . . . . . . P. punctulata 1). E. Mardy

5. Abdomen with 8th segment long and nurrow (Costa Rica)

P. longiventris, new speeies 
Abdomen with 8th segment only slight longer than wide, marked with black areas dorsally and ventrally (Mexico)

P. longurio Loew

6. Halter knob white . . . . . . . . . . . . . . . . 7

Halter knob with at least the base marked with brown . . . . . . . . 11

7. Antenna brown . . . . . . . . . P. albocincta Van Duzee Antenna red-brown, black-brown, or orange . . . . . . . . . . 8

8. Antenna red-brown or black-brown . . . . . . . . . . . . . . . 9 Antenna orange . . . . . . . . P. melanderi, new species

9. Antenna black-brown . . . . . . . . . . . . . . 10

Antenna red-brown . . . . . . . . P. morlani, new species

10. Head longer than high . . . . . . . . . . P. parva D. E. Hardy

Head higher than long. ......... P. bryanti, new species

11. Halter knob with base brown, remainder white . . . . . . . . . . . 12

Halter knob with more than just the base brown . . . . . . . . . . 17

12. Antenna red-brown or black-brown . . . . . . . . . . . 13

Antenna black . . . . . . . . . . . P. garretti, new species

13. Antenna red-brown ... . . . . . . . . . . . . 14

Antenna black-brown ................ . . 16

14. Vein R4 ending even with the end of cell R5 . . . . . . . . . 15 Vein R4 ending well beyond the end of cell R5 . P. biacristerna, new species

15. Vein R4 branching from just beyond the middle of cell R5

Vein R4 branching from near the distal fourth of cell R5

P. at ombomba, new species

P. cajoni, new species

16. Eighth sternum notched on the posterior midline . P. evergreeni, new species Eighth sternum gently rounded on posterior margin

P. unicolor, Coquillett

17. Halter knob with base and dorsal rib red-brown, remainder white . . . 18

Halter knob with dorsal surface cream, brown or black-brown . . . . 21

18. Red-brown not bleeding into the white . . . . . . . . . . . . . 19

Red-brown bleeding into the white . . . . . . . . . . . . . . . 24

19. Antenna black-brown . . . . . . . . . . . . . 20

Antenna black . . . . . . . . . . P. leechi, new species

20. Vein R4 ending opposite the end of cell R5 . . . P. bakeri, new species

Vein R4 ending well beyond the end of cell R5 . . P. barnesi, new species

21. Antenna brown, black-brown or black . . . . . . . . . . . . . . . 22 Antenna orange, vein R4 ending before the end of cell R5

P. saccharcupa, new species

22. Antenna brown or black-brown . . . . . . . . . . . . 2 23

Antenna black, R4 ending before the encl of cell R5 . P. convexa, new species

23. Antenna brown, R4 ending beyond the end of cell R5, small, under $5 \mathrm{~mm}$.

P. concava, new species

Antenna black-brown, R4 ending beyond the end of cell R5, large, over $7 \mathrm{~mm}$.

P. cockerelli, new species

24. Halter knob with dorsal rib red-brown, remainder cream . . . . . . 25

Halter knob with dorsal surface brown or black-brown . . . . . . . . 26

25. Antenna black-brown . . . . . . . . P. eaithales, new species

Antenna orange . . . . . . . . . . . P. howdeni, new species

26. Halter knob with dorsal surface brown, ventral surface white . . . . . 27

Halter knob all brown except for a small white ventral spot, antenna black

P. peromysci, new species

27. Antenna orange-brown, frons narrow only as wide as the ocellar tubercle

P. sabroskyi, new species 
Antenna orange-brown, frons broader than the width of the ocellar tubercle P. nordeni, new species

\section{Pseudatrichia albocincta Van Duzee.}

\section{FIGURE 145}

Pscudatrichia albocincta Van Duzce, 1926, p. 164.

Van Duzee's description was based on a single female erroneously considered to be a male. It is characterized by the silvery pile on back of the head and the three-pronged eighth sternal plate.

Length: Female body $6 \mathrm{~mm}$., wing $4 \mathrm{~mm}$.

Trpe-locality: Bradley, Monterey Co., California; 23 May 1920 (E. P. Van Duzee).

Type: Correct to read "female" (CAS) 1874.

Other specimens: 1 q, Teluchapi Pass, California; 8 .June 1929 (R. L. Usinger) (CAS).

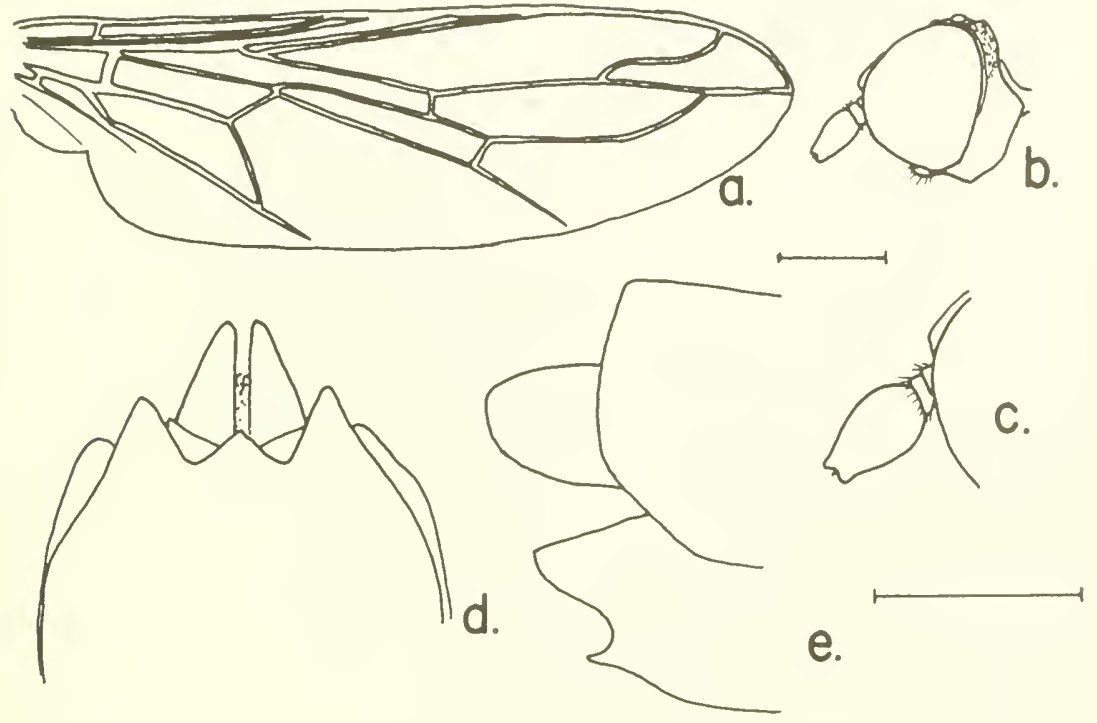

Figure 145.-Pseudatrichia albocincta Van Duzce, female: $a$, wing; $b$, lateral aspect of head; $c$, enlarged detail of antenna; $d$, ventral aspect of 8 th and 9 th sternum; $e$, lateral aspect of 8 th and 9 th segments.

152. Pseudatrichia atombomba, new speeies

FIGURE 146

P'seudatrichia unicolor Cresson (not Coquillett), 1907, p. 113.

MALE.-Head red-brown; eyes black-brown above, darker below; frons small, swollen above antennae narrowing to less than the width of the median ocellus; a narrow postocular ridge behind the 

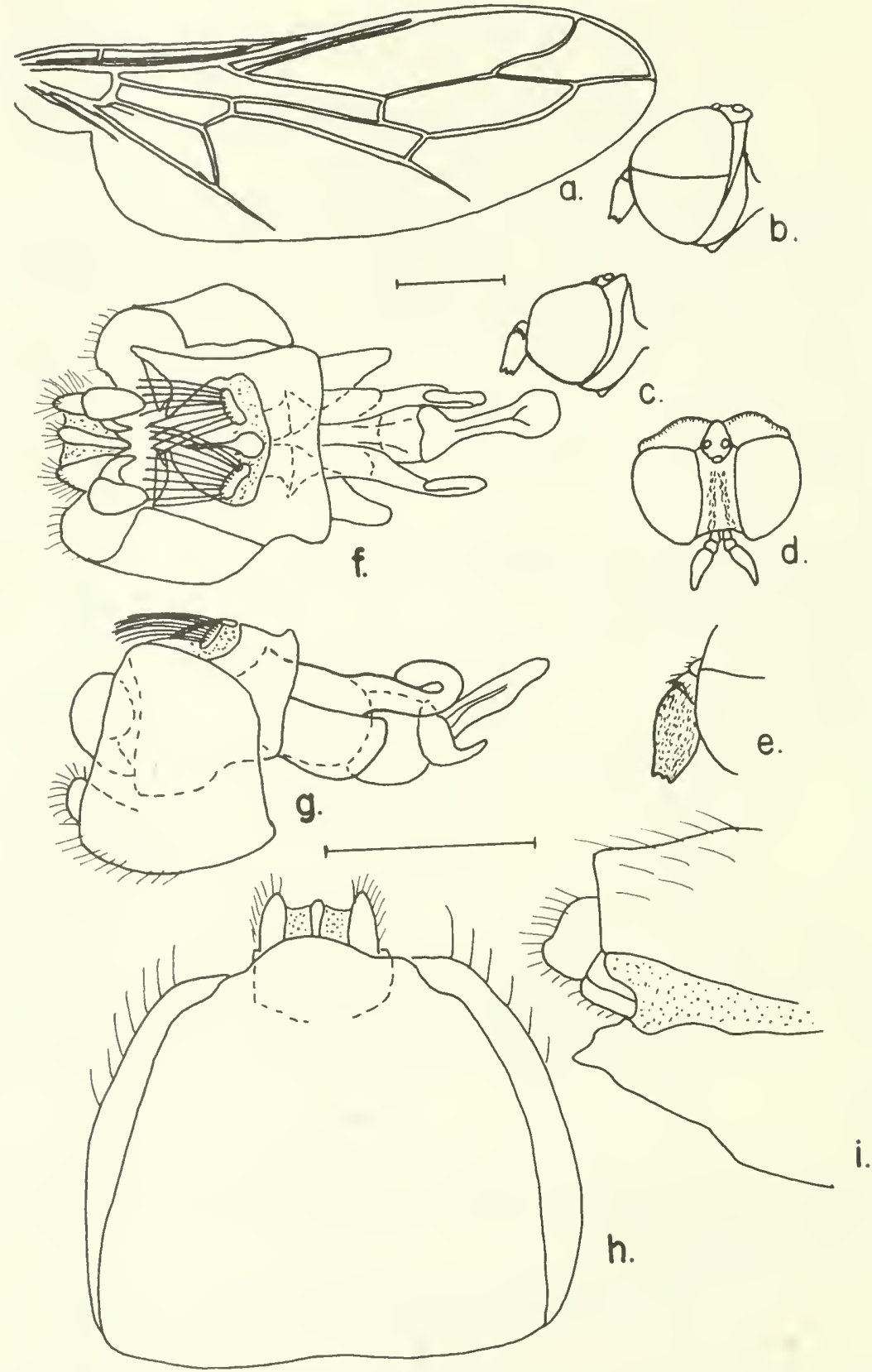

Figure 146.-Pseudatrichia atombomba, new species, male, female: $a$ wing; $b, c$, lateral aspects of male and female heads; $d$, dorsal aspect of female head; $e$, enlarged detail of antenna; $f, g$, ventral and lateral aspects of male terminalia; $h$, ventral aspect of female 8 th sternum; $i$, lateral aspect of female 8 th and 9 th segments. 
eyes; ocellar tubercle prominent, ocelli brown. Mouthparts red-brown, small, half the length of the oral opening, palpi as long as mouthparts. Antennae red-brown, the second segment lighter. See figure for details on shape.

Thorax dorsum black, transversely striated; humeral and supraalar calli red-brown; pleural areas dark red-brown. Wings clear, veins brown; halter stem brown, knob with base red-brown, remainder white. Legs with foreleg orange-brown with red-brown tarsus; middle leg orange-brown, a little darker than foreleg; hind leg red-brown, first segment of tarsus orange-brown, remainder darker.

Abdomen black, rugose, with a metallic sheen; remaining segments black, shining; ninth tergum red-brown, truncated with the ventral margin (upper) shorter; sternal comb sparse; aedeagal parameres large, bulbous with two anteriomesal spurlike processes; see figure for details.

Female.-Head red-brown; eyes brown; postocular ridge broad; frons swollen above antennae, with longitudinal and transverse striations, covered with short hairs; ocellar triangle cut off, not distinct, ocelli clear. Antennae as in the male.

Thorax as in male.

Abdomen first segment black, rugose, metallic; remaining segments black, shining. Eighth sternum dark red-brown, convex on posterior margins; see figure for details.

Length: Male body $4.7 \mathrm{~mm}$., wing $3 \mathrm{~mm}$.; female body $5.1 \mathrm{~mm}$., wing $3.2 \mathrm{~mm}$.

Type-locality: Alamogordo, New Mexico; 15 April 1902.

Holotype: Male (ANS).

Allotype: Female Alamogordo, New Mexico; 9 May 1902 (ANS).

\section{Pseudatrichia bakeri, new species}

FIGURE 147

Female.-Head black-brown; eyes black-brown; with a broad postocular ridge; frons striated, slightly wider than the ocellar triangle; mouthparts very short, brown, not exceeding half oral opening; palpi brown, shorter; ocellar triangle not prominent, cut off, ocelli orange. Antennae with first two segments black-brown, third segment missing.

Thorax dorsum black, transversely striated; humeral and supra-alar calli red-brown; pleural areas red-brown; wings hyaline, veins brown; halter stem red-brown, knob with red-brown dorsal rib bleeding into white ventral portion. Legs: front legs, femora and tibiae orange, tarsi red-brown; hind leg, basal half of femur orange, remainder of leg red-brown. 

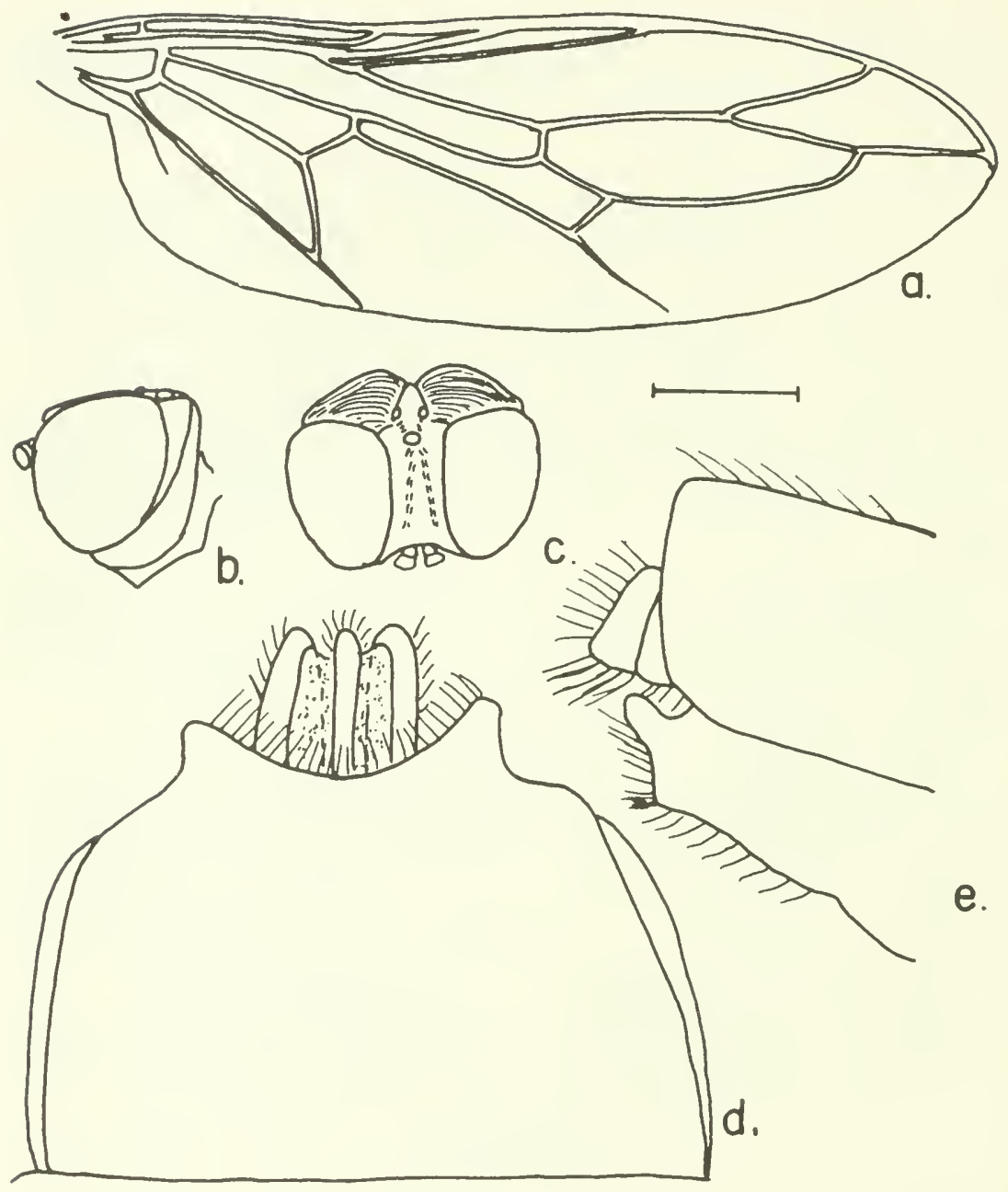

e.

Figure 147.-Pseudatrichia bakeri, new species, female: $a$, wing; $b$, lateral aspect of head; $c$, dorsal aspect of head; $d$, ventral aspect of 8 th sternum; $e$, lateral aspect of 8 th and 9 th segments.

Abdomen second segment black, punctured, with a purple metallic glint, remainder of abdomen same except last two segments shining. Eighth segment red-brown, concave on posterior margin of sternum with two rounded lateral points; see figure for details.

MALE.-Unknown. 
Length: Female body $5.3 \mathrm{~mm}$., wing $3.2 \mathrm{~mm}$.

Type-locality: Claremont, California (Baker).

Holotype: Female (USNM) 67466.

\section{Pseudatrichia barnesi, new species}

Figure 148

MaLe.-Head black; eyes black-brown above, darker below; frons shining, with a protuberance above the antennal socket, very narrow below the median ocellus; ocellar tubercle prominent, ocelli clear. Mouthparts red-brown, filling three-fourths of the oral carity; palpi dark red-brown, half the length of oral cavity. Antennae black-brown; see figure for details.

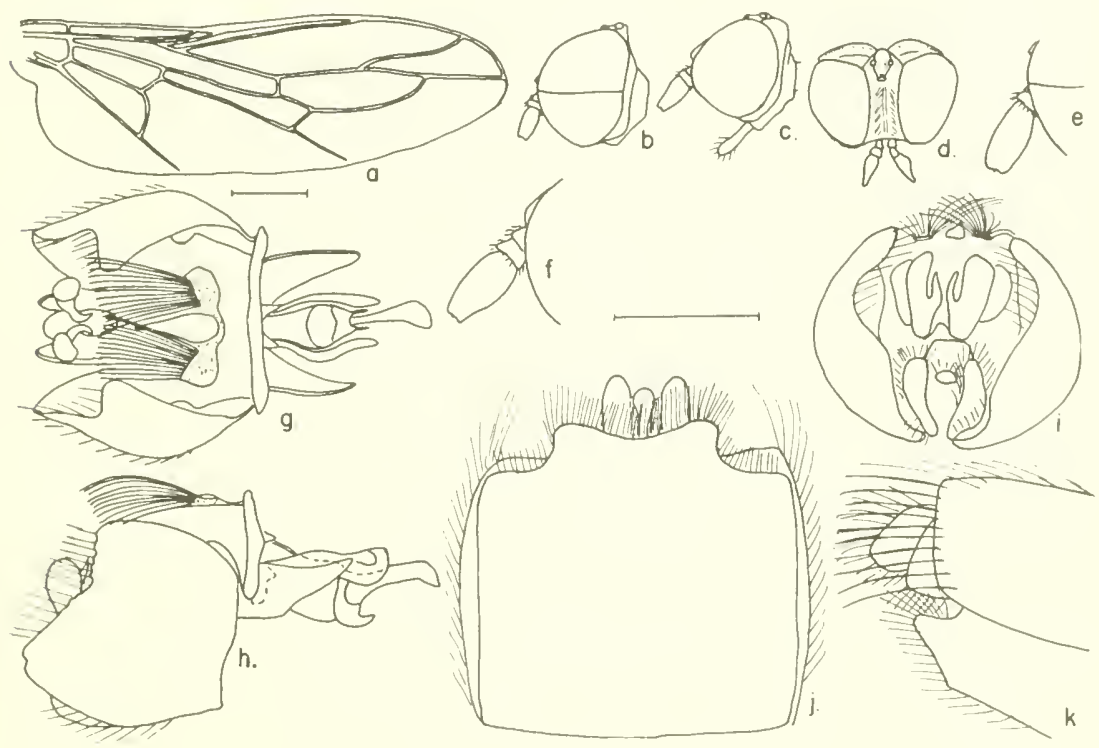

Figure 148.-P seudatrichia barnesi, new species, male, female: $a$, wing; $b, c$, lateral aspects of male and female heads; $d$, dorsal aspect of female head; $\ell, f$, enlarged details of male and female antennae; $g-i$, ventral, lateral and posterior aspects of male terminalia; $j$, ventral aspect of female 8 th sternum; $k$, lateral aspect of female 8 th and 9 th segments.

Thorax dorsum black, humeral and supra-alar calli orange-brown, pleural areas red-brown. Wings clear, veins light brown; halter stem brown, knob with dorsal edge brown bleeding into white ventral portion. Front leg with femur red-brown, tibia yellow-orange, tarsus brown; middle legs brown-orange; hind legs red-brown.

Abdomen second segment black, granular; remainder black; ninth tergum pointed; ventral margin shorter; fringe of hairs on sternum 
moderately thick; aedeagus with bilobed parameres with median barblike projections; see figure for details.

Female.-Head black; eyes black-brown; postocular ridge broad, subshining; frons slightly wider than ocellar triangle, striated and with a median depression; facial areas below antennae with silvery pile; ocellar triangle set off, not prominent; antennae black-brown; see figure for details.

Thorax as in male.

Abdomen as in male, except eighth sternum black-brown with a shallow concave posterior margin with rounded lateral points; see figure for details.

Length: Male body $5.2 \mathrm{~mm}$., wing $3.2 \mathrm{~mm}$.; female body 5.1-5.5 mm., wing $3.3-3.6 \mathrm{~mm}$.

Type-locality: 3 mi. s. Glennville, Kern Co., California; 18 February 1959 (A. M. Barnes) reared from woodrat nest.

Holotype: Male (USNM) 67464.

Allotype: Female, same data as type (USNM).

Paratype: $1 \sigma^{7}, 5$ o $ᄋ$, same data as type; $1 \sigma^{7}, 7$ mi. s., $5.6 \mathrm{mi}$. e. Tehachapi, Kern Co., California, 19 February 1953 (A. M. Barnes) (AMB).

\section{Pseudatrichia biacristerna, new species}

Figure 149

Female.-Head red-brown; eyes red-brown, with a wide postocular flange behind the eyes; frons shining, with two diverging bands of short hairs from median ocellus to antennal bases; ocellar triangle cut off, not prominent; ocelli orange; mouthparts well developed, palpi half the length of the oral cavity. Antennae red-brown, third segment covered with short hairs that reflect golden; see figure for details.

Thorax dorsum black, with transverse striations; humeral and supra-alar calli red-brown; pleura red-brown. Wings clear, veins brown; halter stem brown, knob white except for base red-brown; legs orange.

Abdomen black, metallic, intersegmental membrane brown medially, white laterally; eighth segment red-brown; sternum with two sharp lateral points; see figure for details.

MALE.-Unknown.

Length: Female body 5.5-6.5 mm., wing $3.7-4.3 \mathrm{~mm}$.

Type-locality: Santa Fe, New Mexico; August (T. D. A. Cockerell).

Holotype: Female (USN.M) 67469.

Paratypes: 2 q , Santa Fe, New Mexico, July, August (A. Boyle; Cockerell nos. 1405, 1935) (USNM); 1 \&, Santa Fe, New 


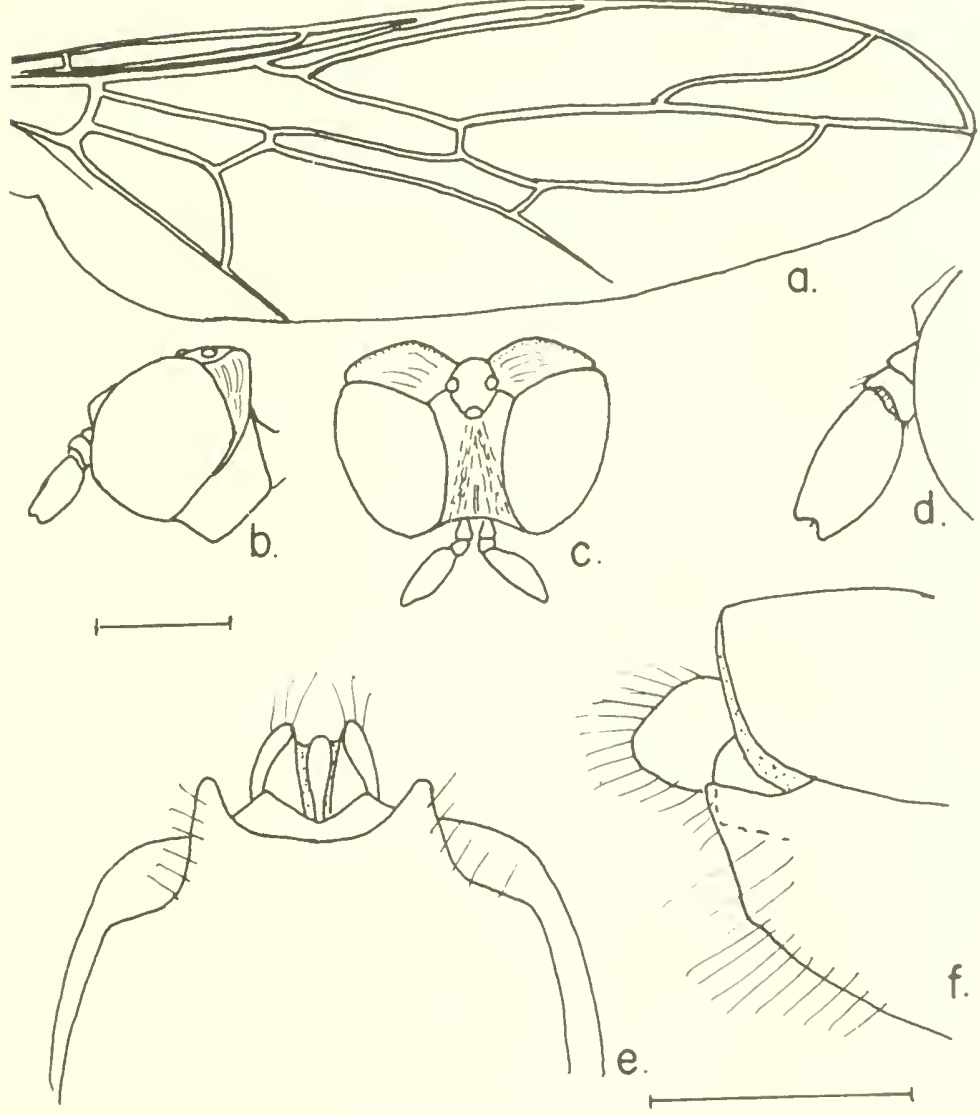

Figure 149.-Pseudatrichia biacristerna, new species, female: $a$, wing; $b$, lateral aspect of head; $c$, dorsal aspect of head; $d$, enlarged detail of antenna; $e$, ventral aspect of 8 th sternum; $f$, lateral aspect of 8 th and 9 th segments.

Mexico, August (Cockerell no. 1710) H. Kahl Coll., C. M. Acc. $12676(\mathrm{CNC})$.

156. P'seudutrichia bryanti, new species

FIgURE 150

Female.-Head black; eyes black, with a broad postocular flange; frons only as broad as ocellar tubercle, with striations running from eye margins toward the midline and median ocellus; ocellar tubercle cut off, not prominent, ocelli clear. Mouthparts orange-brown, nearly filling the oral cavity; palpi brown, half the length of the oral 'avity. Antennac black-brown, third segment with short recumbent hairs refleeting a golden sheen; see figure for details. 
Thorax dorsum black, with transverse striations; humeral and supra-alar calli red-brown; pleural areas red-brown. Wings clear, veins brown; halter stem brown, knob white. Forelegs with femora and tibiae orange, tarsi brown; middle leg with femur orange, tibia red-brown, tarsus brown; hind leg with femur orange basally, redbrown distally, tibia red-brown, first segment of the tarsus orange, remainder brown.
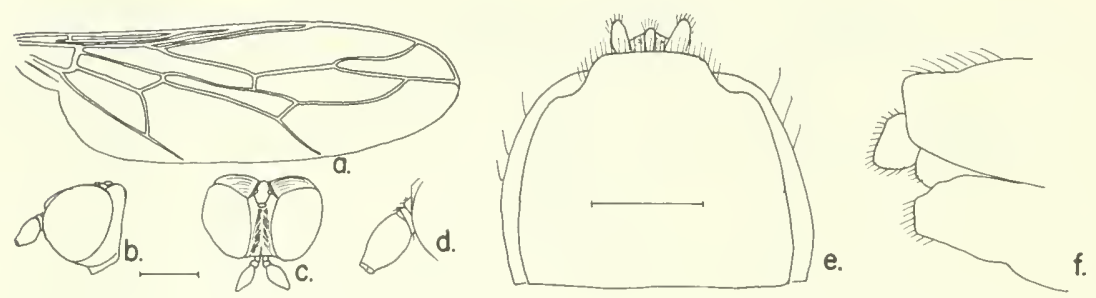

Figure 150.-Pseudatrichia bryanti, new species, female: $a$, wing; $b$, lateral aspect of head; $c$, dorsal aspect of head; $d$, enlarged detail of antenna; $e$, ventral aspect of 8 th sternum; $f$, lateral aspect of 8 th and 9 th segments.

Abdomen second segment black, metallic, with a small lateral white patch on the membrane; remaining segments black, metallic, with larger white patches. Eighth segment red-brown, sternum blunt; see figure for details.

MaLe.-Unknown.

Length: Female body 6-7 mm., wing 3.6-4 mm.

Type-locality: Santa Catalina Mts., Arizona; 15 June 1938 (Bryant).

Holotype: Female (CAS) 8933.

Paratypes: 1 \%, same data as type (CAS); 1 \%, S. Catalina Mts., Arizona, alt. $9000 \mathrm{ft} ., 6$ June 1926 (R. B. Streets) (USNM); 1 i, Cave Creek Canyon (S. W. Research Sta. of AMNH; $5000 \mathrm{ft}$.), Chiricahua Mts. Cochise Co., Arizona, 21 April 1959 (S. M. and S. N. Burns) (UCalD).

\section{Pseudatrichia bupennis, new species}

FIGURE 151

MaLE.-Head black; eyes brown-black above, black below; frons tapering from above the antennae to halfway to the median ocellus, rest relatively broad, equal to half the width of the median ocellus, relatively smooth with two rows of punctures; ocellar tubercle prominent, ocelli clear; mouthparts red-brown, palpi very slender, short; oral opening bordered by gray pubescence, laterad of antennae. 

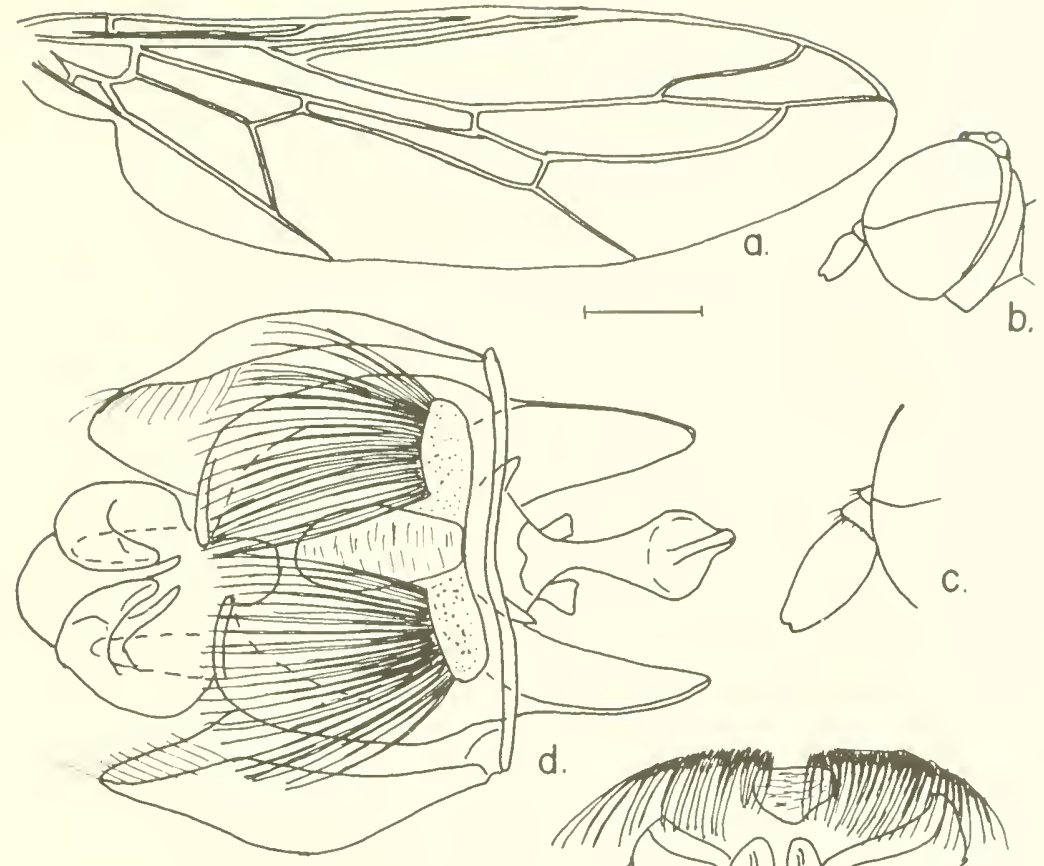

b.
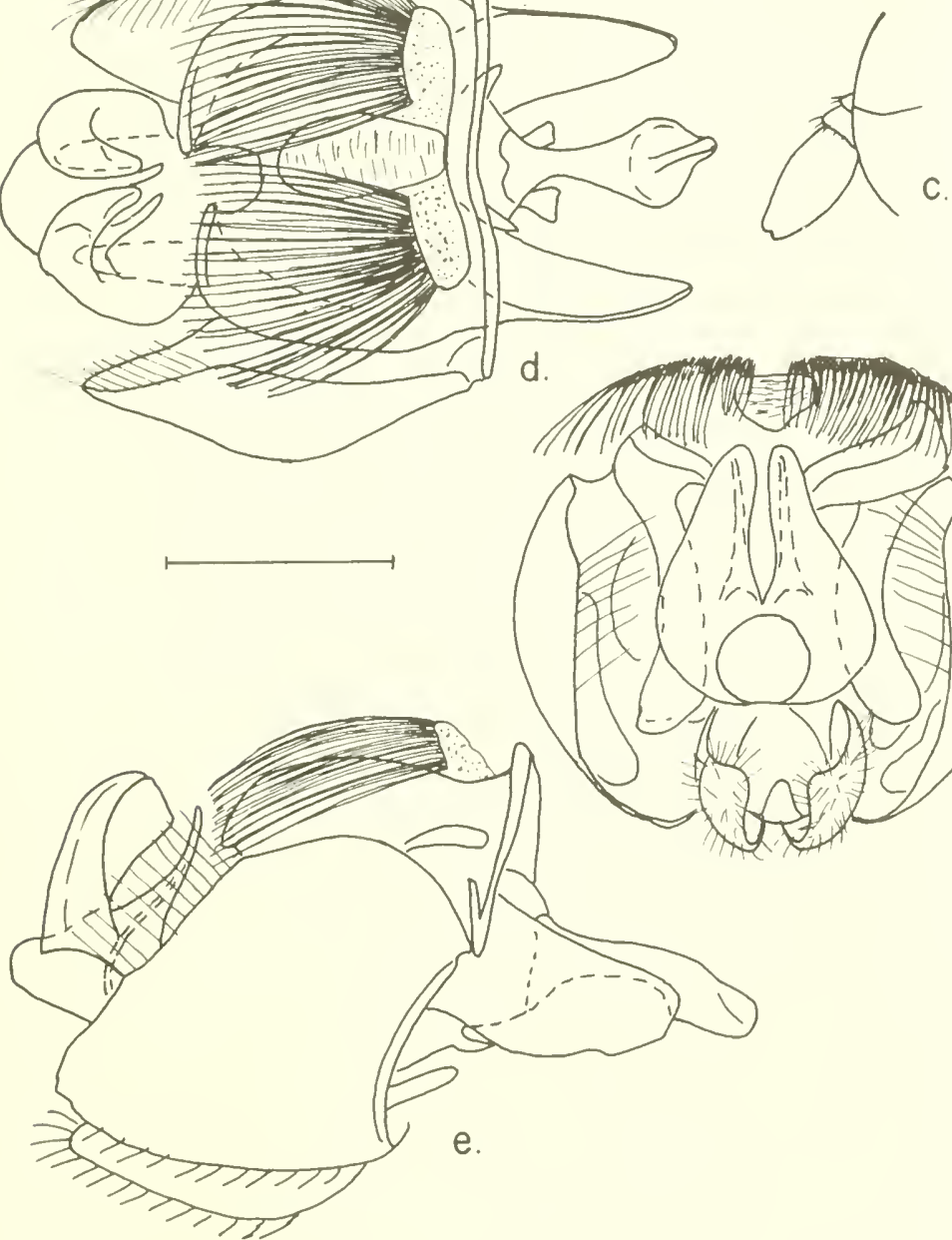

c.

Figure 151.-Pseudatrichia bupennis, new species, male: $a$, wing; $b$, lateral aspect of head; $c$, enlarged detail of antenna; $d-f$, ventral, lateral and posterior aspects of terminalia. 
Antennae with first segment black-brown, second and third segments red-brown; see figure for details.

Thorax dorsum black, striated; humeral and supra-alar calli orange-brown; pleural areas black-brown; wings clear, veins dark brown; halter stem black-brown; knob base and dorsal stripe brown, dorsal rib and remainder white.

Abdomen segments 2-5 black, rugose with purple metallic sheen; segments 6 and 7 black, shining, ninth tergite red-brown, pointed dorsally, sloping ventrally, sternal brush thick; aedeagus orange, very large, with two mesal peni prongs; see figure for details.

Female.-Unknown.

Length: Male body 5.5-6.5 mm., wing $3.7-4.5 \mathrm{~mm}$.

Type-locality: Keen Camp, Riverside Co., California; 17 May 1959 (E. I. Schlinger).

Holotype: Male (UCalD) 72.

Paratype: $1 \sigma^{7}$, Hastings Reservation, near Jamesburg, Monterey Co., Calif.; 3 May 1958 (D. D. Linsdale) (UCalB).

\section{Pseudatrichia cajoni, new species}

\section{MaLe.-Head lost.}

Figure 152

Thorax dorsum black, dusted with white hairs; humeral and supra-alar calli red-brown; pleural areas black; wings clear, veins brown; halter stem brown, knob white except base, brown. Forelegs, coxa to tibia straw yellow, tarsus brown; middle leg, coxa to tibia yellow-brown, tarsus brown; hind leg, coxa to tibia orange-brown, tarsus brown.

Abdomen, segments 2-5 black, with a purple metallic sheen; segments 6 and 7 black, shining; tergum of segment 9 red-brown, smoothly rounded dorsally and sloping below; sternal comb of hairs long and thick; aedaegus very large; see figure for details.

Fenale.-Head black, eyes red-brown; postocular flange not prominent, rounded shining; back of head convex, granulose; frons, with a smooth median band bordered on each side by a broad band of short hairs, eye margins smooth, wider than the ocellar tubercle. Ocellar tubercle prominent, set off, ocelli red. Mouthparts welldeveloped, red-brown; palpi half the length of the oral opening, sides of opening silvery pilose. Antennae red-brown, second segment shorter than first, third with silvery pubescence; see figure for details.

Thorax dorsum black, with pollinose patch above humeral callus and covered with short hairs giving it a dusty appearance; humeral and supra-alar calli orange-brown with a white membrane connecting them; prothorax black with white pollen in front of coxa, remainder of pleura black. Wings clear, veins brown, halter stem red-brown 


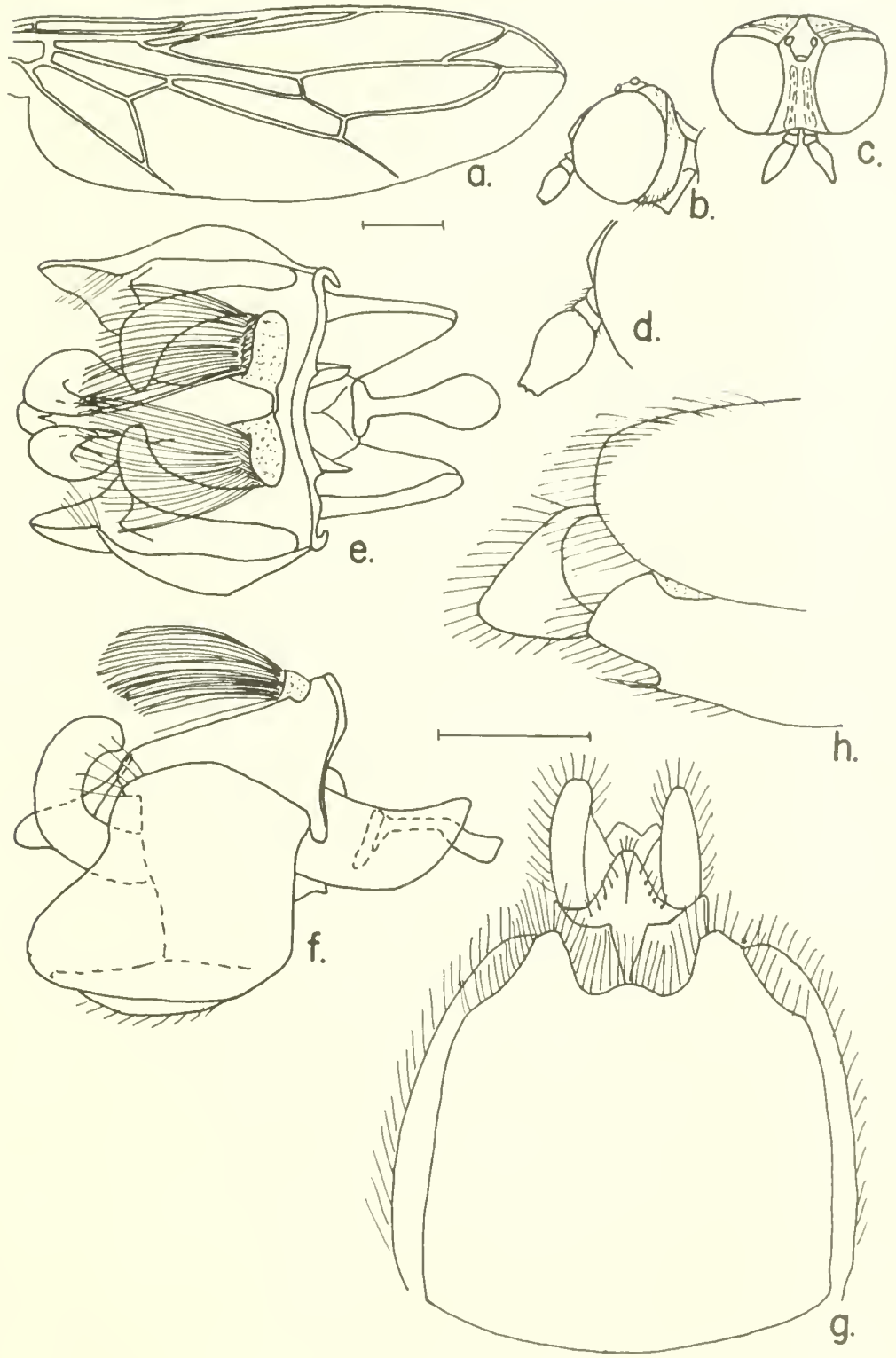

Figure 152.-Pseudatrichia cajoni, new species, male, female: $a$, wing; $b$, lateral aspect of female head; $c$, dorsal aspect of female head; $d$, enlarged detail of female antenna; $e, f$, ventral and lateral aspects of male terminalia; $g$, ventral aspect of female 8th sternum and 9 th segment; $h$, lateral aspect of female 8 th and 9 th segments.

$313-1690-69)-16$ 
knob white, except base red-brown. Front leg orange, except tarsus darkening to red-brown; middle leg orange-brown, tarsus darkening to red-brown; hind leg entirely red-brown.

Abdomen segments 2-5 black, with a metallic luster, covered with short hairs, lateral portions interrupted with white membrane. Eighth segment red-brown, eighth sternum deeply excavated along posterior margin; see figure for details.

Length: Male body $6 \mathrm{~mm}$., wing $4 \mathrm{~mm}$.; female body $7.3 \mathrm{~mm}$., wing $4.3 \mathrm{~mm}$.

Type-locality: 1 mi. w. Cajon, San Bernardino Co., California, 24 December 1957 (A. M. Barnes).

Holotype: Male (USNM) 67472.

Allotype: Female, 1 mi. e. Cajon, California, 24 December 1957 (A. M. Barnes) reared from larvae in woodrat's nest (USNM).

\section{Pseudatrichia cloudcrofti, new species}

\section{Figure 153}

Pseudatrichia unicolor Cresson (not Coquillett), 1907, p. 113.

Female.--Head red-brown, longer than high; back of head excavated, pollinose; eyes black-brown; postocular ridge moderately wide, subshining; frons dark red-brown, elongate, not wider than ocellar triangle which is cut off but not prominent, ocelli clear. Mouthparts well developed, orange-brown, extending a little over half the length of the oral opening; palpi orange, a little shorter. Antennae with first two segments red-brown, third segment orange; see figure for details.

Thorax dorsum dark red-brown, granular; humeral and supra-alar calli orange-brown; pleura red-brown. Wings dusted brown, veins brown; halter stem brown, knob base and dorsal rib brown, rest white. Foreleg coxa straw colored, remainder of leg orange-brown; middle and hind legs orange-brown.

Abdomen second segment red-brown, granular; remainder redbrown, shining. Eighth segment light red-brown, sternum with three points on posterior margin; see figure for details.

Male.-Unknown.

Length: Female body $7 \mathrm{~mm}$., wing $4.4 \mathrm{~mm}$.

Type-locality: Cloudcroft, New Mexico; 16 June 1902.

Holotype: Female (ANS).

160. Pseudatrichia cockerelli, new species

Figure 154

MaLE.-Head red-brown; eyes black, divided into larger upper and smaller lower facets along the midline. Frons triangular, subshining, 


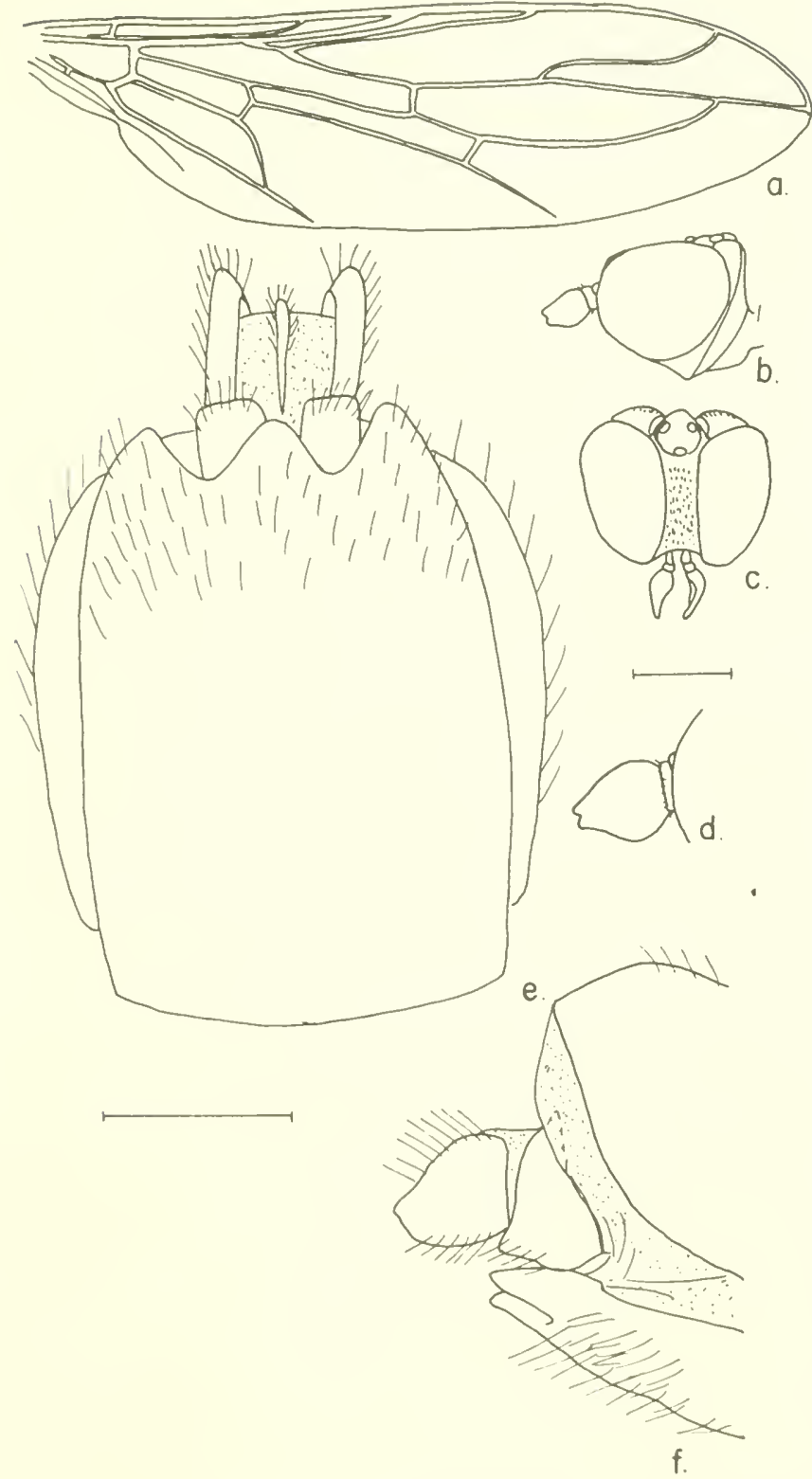

Figure 153.-Pseudatrichia cloudcrofti, new species, female: $a$, wing; $b$, lateral aspect of head; $c$, dorsal aspect of head; $d$, enlarged detail of antenna; $\ell$, ventral aspect of 8 th sternum and 9 th segment; $f$, lateral aspect of 8 th and 9 th segments. 


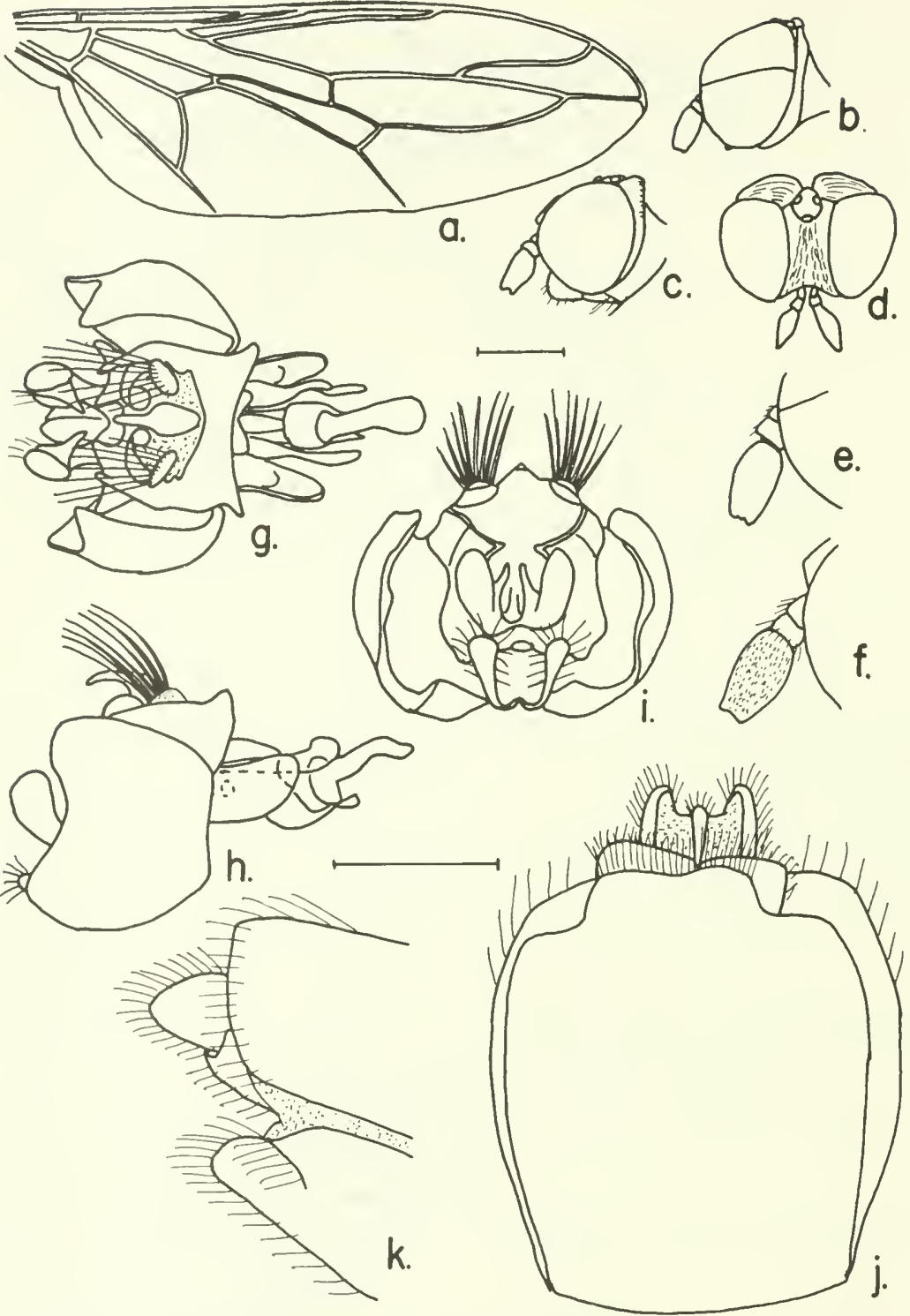

FIGURE 154.- Pseudatrichia cockerelli, new species, male, female: $a$, wing; $b, c$, lateral aspects of male and female heads; $d$, dorsal aspect of female head; $e, f$, enlarged details of male and female antennae; $g-i$, ventral, lateral and posterior aspects of male terminalia; $j$, ventral aspect of female 8th sternum and 9th segment; $k$, lateral aspect of female 8th and 9th segments.

with longitudinal striations; ocellar tubercle prominent, ocelli clear. Antennae with first two segments red-brown; third black-brown, pilose, twice as long as first two combined; see figure for details. 
Thorax dorsum black, with transverse striations; humeral and supra-alar calli red-brown; pleural areas red-brown. Wings hyaline, veins brown; halter stem brown, knob red-brown dorsally, white ventrally. Foreleg orange, with tarsus darkening to red-brown distally; middle and hind legs orange-brown, tarsi red-brown.

Abdomen second segment black-brown, with white lateral spots in posterior membrane; remaining segments black-brown with nearly equal white lateral margins. Ninth tergum concave along posterior margin, ninth sternum with a sparse comb of hairs; aedeagus bilobed with anteriorly directed medial spurs; see figure for details.

Fenale.-Head red-brown; eyes black brown; broad postocular ridge with transverse striations; frons wider than ocellar tubercle, with longitudinal striations, swollen above antennal base; ocellar triangle flat, set off, ocelli clear. Antennae as in male.

Thorax dorsum black, with transverse striations, humeral and supra-alar calli red-brown with orange anterior and posterior spots; pleura red-brown; wings hyaline, veins brown; halter stem brown, knob with a thin red-brown dorsal rib, remainder white. Legs as in male.

Abdomen second segment black-brown, granular; remaining segments black-brown with intersegmental membrane tan medially, white laterally, eighth segment red-brown, sternum truncated; see figure for details.

Length: Male body $7.2 \mathrm{~mm}$., wing $3.7 \mathrm{~mm}$.; female body $7.2 \mathrm{~mm}$., wing $4.1 \mathrm{~mm}$.

Type-locality: Florissant, Colorado; July 1919 (Cockerell).

Holotype: Male (USNM) 67470.

Allotype: Female, Florissant, Colorado; 7 July 1907 (S. A. Rohwer) (USNM).

161. Pseudatrichia concava, new species

Figure 155

Female.-Head red-brown; eyes black-brown, with a broad postocular ridge; frons with a shallow median groove; ocellar tubercle not set off, shallow; ocelli red. Antennae brown, third segment with golden hairs.

Thorax dorsum black, transversely striated; humeral and supra-alar calli red-brown; scutellum red-brown; pleural areas red-brown. Wings clear, veins brown; halter stem brown, knob base and dorsal rib brown, remainder white. First two pairs of legs straw yellow; hind leg with orange-brown femur, straw yellow tibia, tarsus yellow basally, darkening distally. 

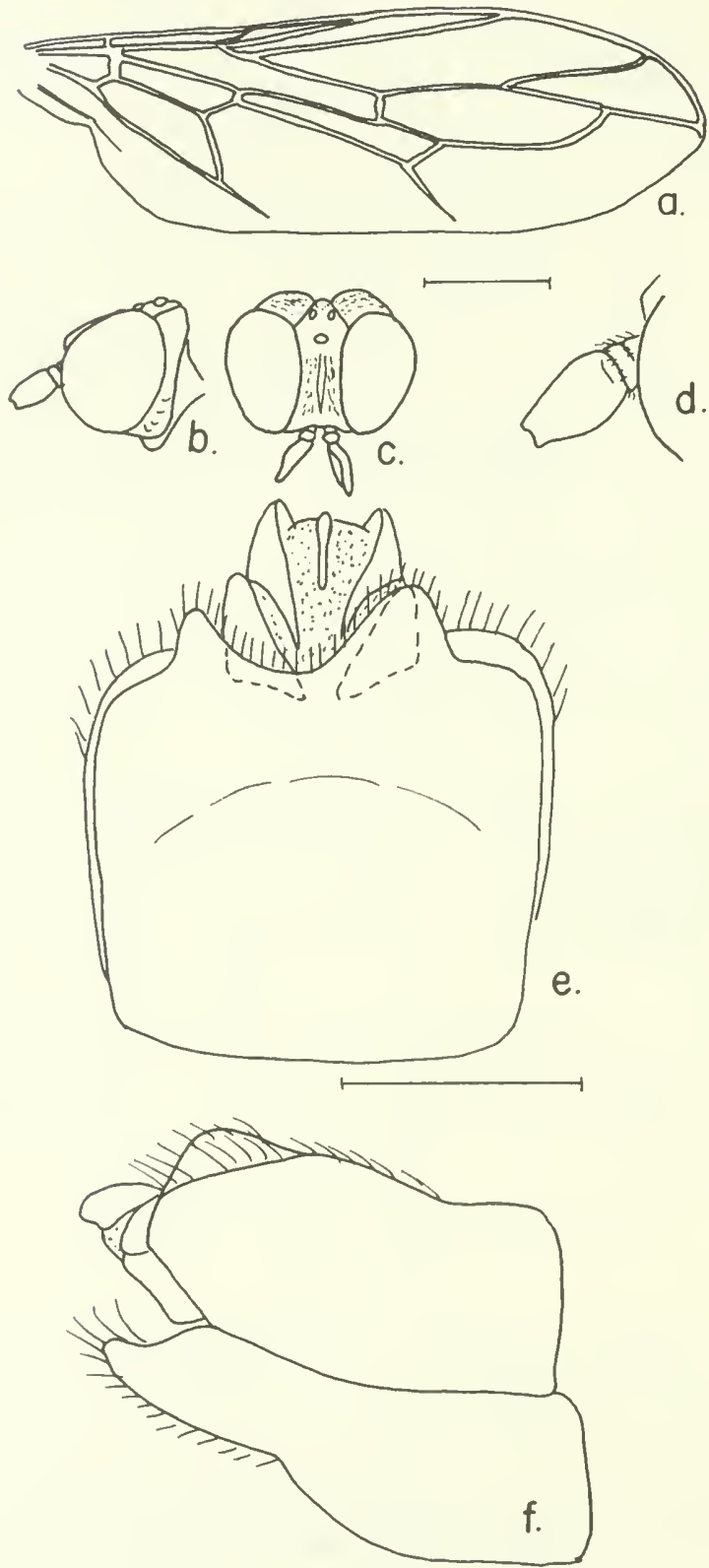

FIGURE 155.-Pseudatrichia concava, new species, female: $a$, wing; $b$, lateral aspect of head; $c$, dorsal aspect of head; $d$, enlarged detail of antenna; $\ell$, ventral aspect of 8 th sternum and 9 th segment; $f$, lateral aspect of 8 th and 9 th segments. 
Abdomen with segments 2-5 black, rugose with a purple metallic sheen; segments 6 and 7 subshining; eighth segment black, sternum hairy, concave on posterior margin; see figure for details.

MALE.-Unknown.

Length: Female body 4.5-5 mm., wing 3-3.2 mm.

Type-locality: 2 mi. n., 1.2 mi. w. Auberry, Fresno Co., California; 9 January 1958 (A. M. Barnes) reared from larva found in woodrat nest.

Holotype: Female (USNM) 67462.

Paratypes: 1 \%, same data as type; 1 \%, Hackamore, Modoc Co., California, 24 May 1938 (A. M. Barnes) reared, nest of Neotoma cinerea in (AMB); 1 \%, Stanford Univ., California, 3 November, 1900 (Melander); 1 \%, Yucca Valley, California, 5 October 1934 (A. L. Melander) both (USNM).

\section{Pseudatrichia convexa, new species}

Figure 156

Fenale.-Head black; eyes black-brown; postocular ridge with a flat rim; frons swollen above antennae, striated as in figure; ocellar triangle shallow, not cut off, ocelli red-brown. Mouthparts red-brown, palpi half as long as oral opening. Antennae black; see figure for details.

Thorax dorsum black, transversely striated; humeral and supraalar calli red-brown; pleural area red-brown. Wings clear, veins brown; halter stem brown, knob base and dorsal rib brown, remainder white. Front leg orange-brown, with black-brown tarsus, middle leg red-brown, tarsus black-brown; hind leg red-brown, base of first tarsal segment yellow-brown, remainder black-brown.

Abdomen segments 2, 3, 4 and the base of 5 black, rugose; remainder black, shining. Eighth segment black, sternum broad, with rounded posterior margin; see figure for details.

MALE.-Unknown.

Length: Female body $7 \mathrm{~mm}$., wing $4.4 . \mathrm{mm}$.

Type-locality: Lake City, Colorado; 21 August 1938, elev. 9000 ft. (Chas. L. Fluke).

Holotype: Female (USNM) 67458.

163. Pseudatrichia eaithales, new species

Figure 157

FEIALE.-Head black; eyes black-brown; postocular ridge broad, striated; frons with a thin median groove bordered by transverse striations; ocellar tubercle prominent, set off, ocelli brown; mouth- 


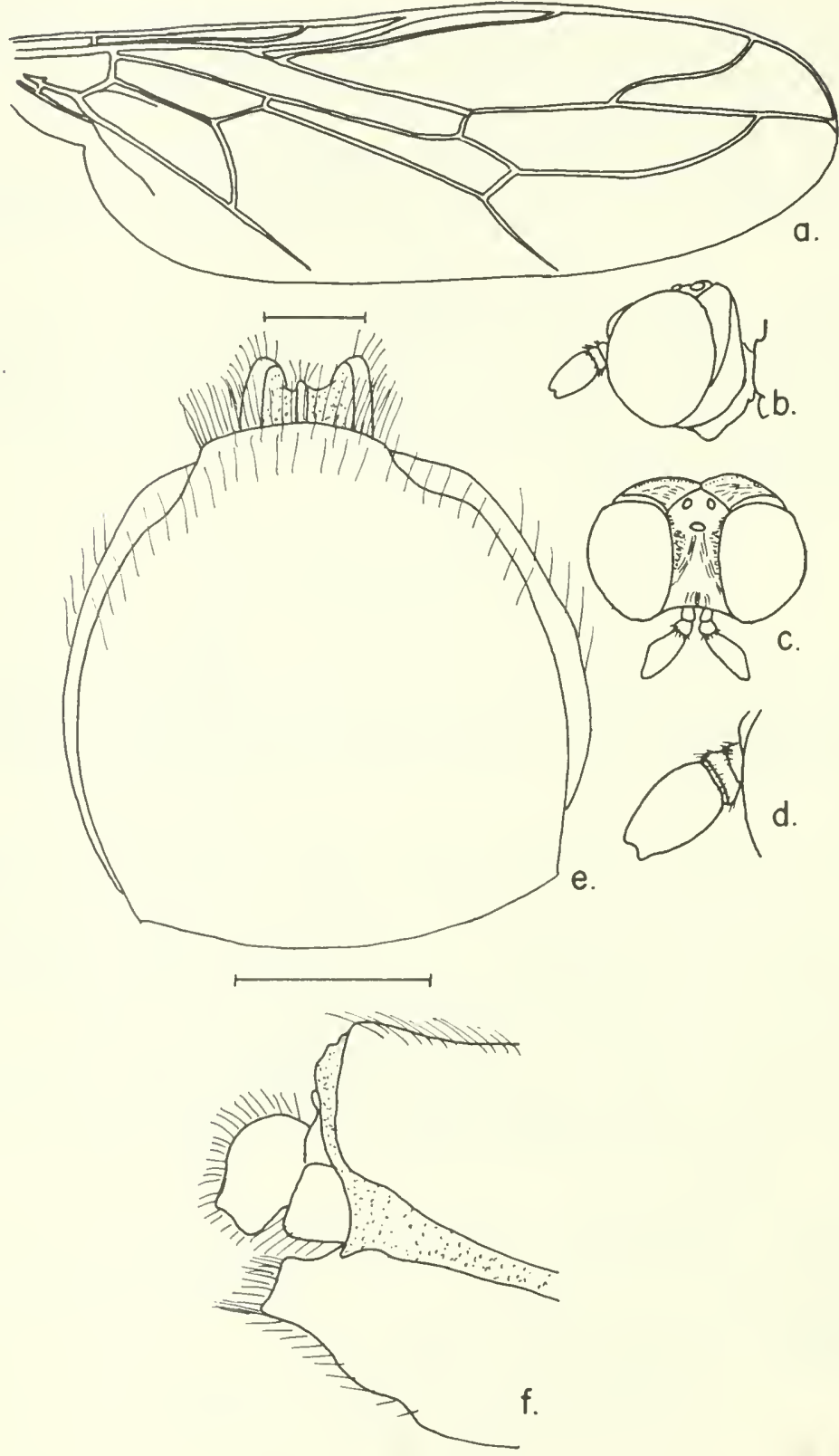

FIGURE 156.-Pseudatrichia convexa, new species, female: $a$, wing; $b$, lateral aspect of head; $c$, dorsal aspect of head; $d$, enlarged detail of antenna; $e$, ventral aspect of 8 th sternum; $f$, lateral aspect of 8 th and 9 th segments. 


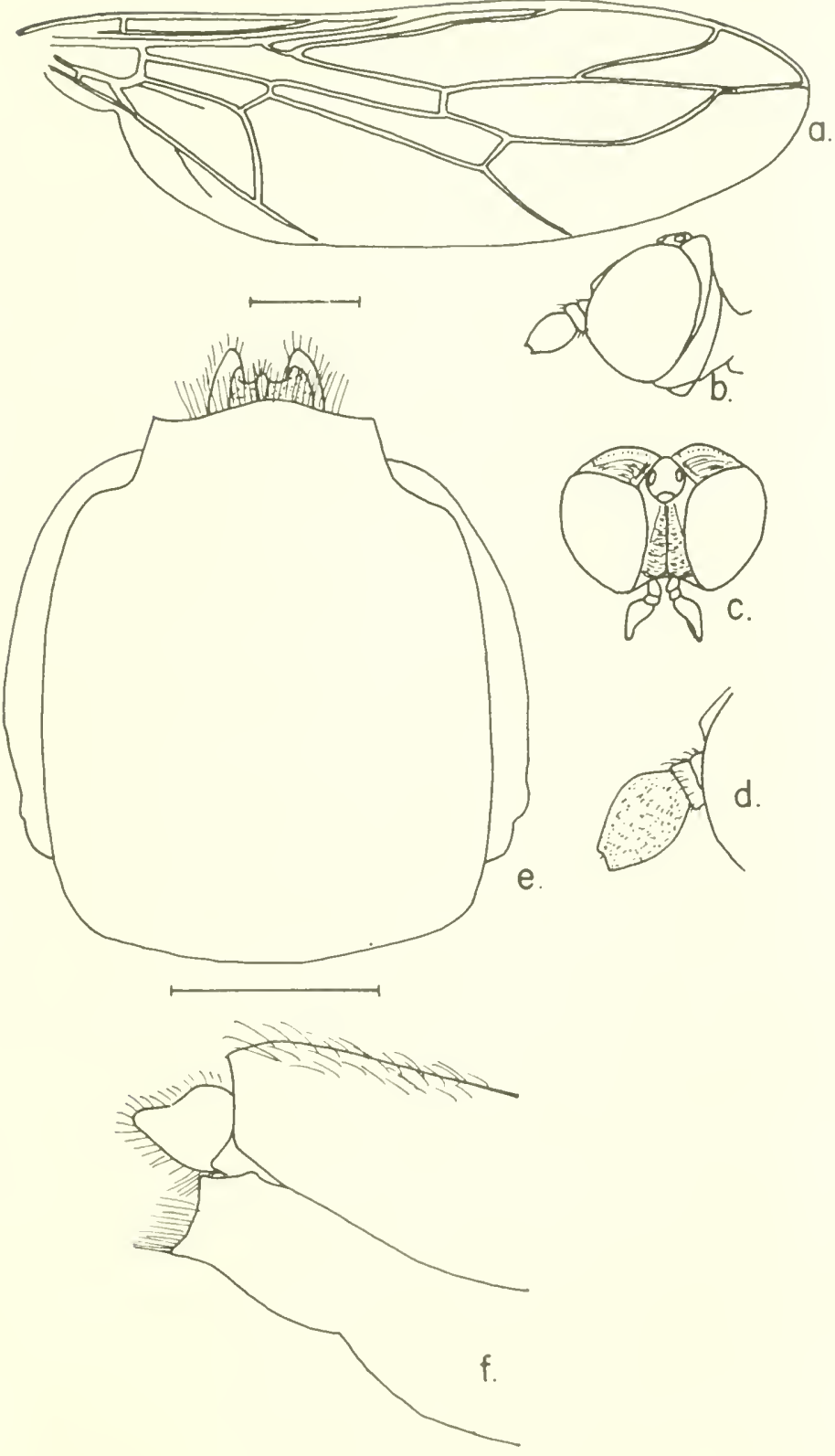

FIGURE 157.-Pseudatrichia eaithales, new species, female: $a$, wing; $b$, lateral aspect of head; $c$, dorsal aspect of head; $d$, enlarged detail of antenna; $e$, ventral aspect of 8 th sternum; $f$, lateral aspect of 8 th and 9 th segments. 
parts dark red-brown, well developed; palpi over half the length of oral opening. Antennae with first two segments black, third segment black-brown; see figure for details.

Thorax dorsum black, with transverse striations; humeral and supraalar calli red-brown; pleural areas red-brown. Wings clear, veins brown; halter stem brown, knob with base and dorsal rib brown, remainder cream. Front and middle legs orange-brown with brown tibiae, hind leg with all segments red-brown.

Abdomen segments 2-5 black, rugose, with a metallic purple sheen; remaining segments black, shining. Eighth segment dark red-brown, sternum slightly convex on posterior margin; see figure for details.

MaLE.-Unknown.

Length: Female body $6 \mathrm{~mm}$., wing $3.8 \mathrm{~mm}$.

Type-locality: Evergreen, Colorado; 5 August 1941 (M. T. James). Holotype: Female (USNM) 67549.

Paratype: 1 , Evergreen, Colorado; 21 July 1942 (M. T. James) (CSU).

\section{Pseudatrichia evergreeni, new species}

Figure 158

Female.-Head black; eyes brown-black; postocular rim broad; frons wider than ocellar triangle, swollen above the antennae, striated; ocellar tubercle prominent, set off, ocelli clear; mouthparts brown, well developed; palpi very slender, half as long as the oral opening. Antennae with first two segments red-brown, third segment blunt, blackbrown with a golden sheen from fine hairs; see figure for details.

Thorax dorsum black, transversely striated; humeral and supraalar calli red-brown; pleura dark red-brown. Wings clear, veins brown; halter stem brown, knob base brown, remainder including dorsal rib white. Front and middle legs red-brown, hind legs dark red-brown.

Abdomen segments 2-5 black, granular, with a metallic sheen; 6 and 7 shining; eighth segment black, posterior margin of sternum convex with a shallow depression in middle third; see figure for details.

MaLE.-Unknown.

Length: Female body $7 \mathrm{~mm}$., wing $4 \mathrm{~mm}$.

Type-locality: Evergreen, Colorado; 21 July 1942 (M. T. James). Holotype: Female (USNM) 67461.

Paratype: 1 o, Evergreen, Colorado; 3 August 1941 (M. T. James) (CSU).

\section{Pseudatrichia garretti, new species}

Figure 159

Female.-Head red-brown; eyes black-brown; postocular flange flat, moderately broad; frons swollen, wider than ocellar triangle, with grooves extending from laterad of the antennae to the median ocellus. 


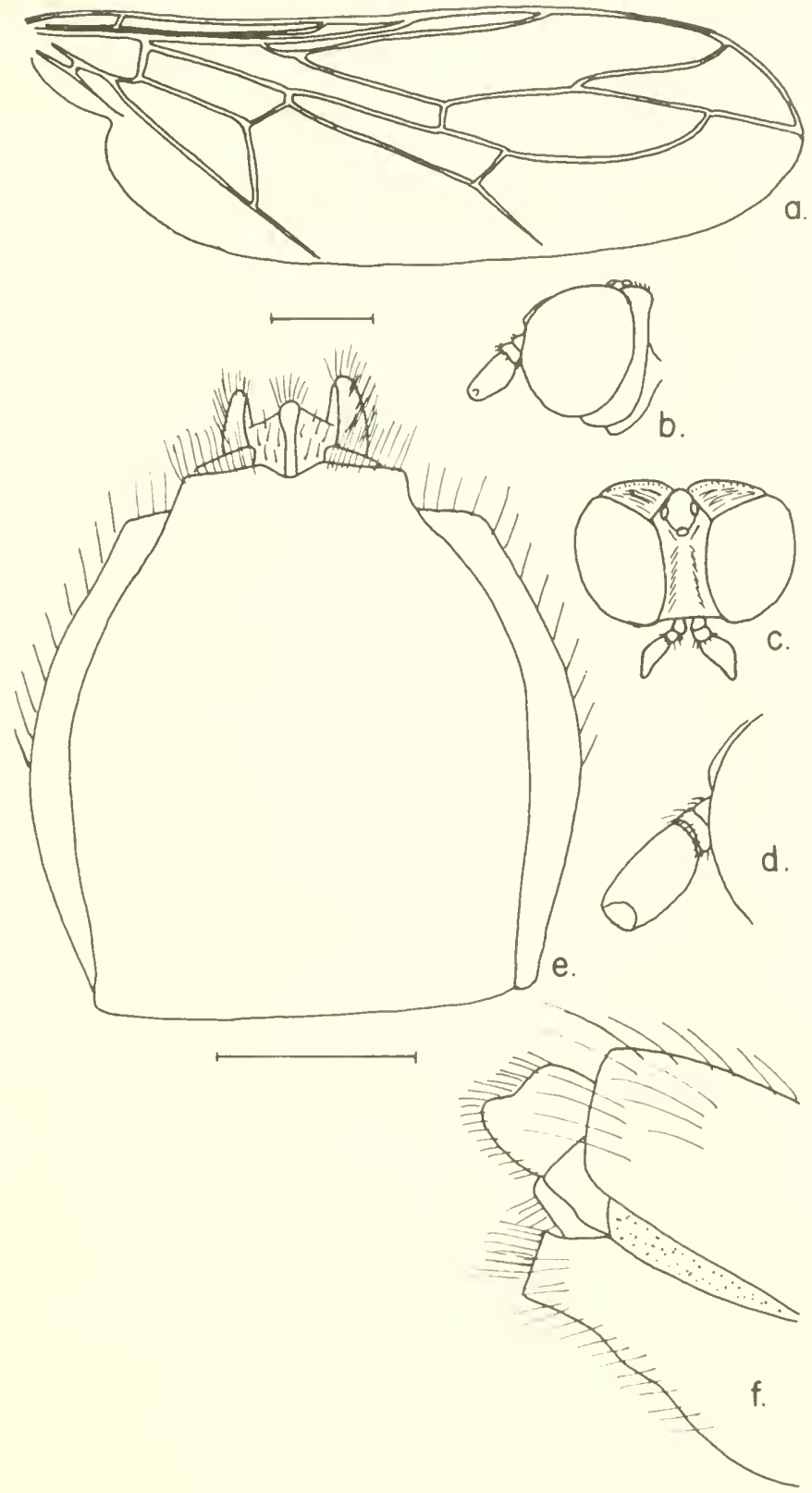

Figure 158.-Pseudatrichia evergreeni, new species, female: $a$, wing; $b$, lateral aspect of head; $c$, dorsal aspect of head; $d$, enlarged detail of antenna; $e$, ventral aspect of 8 th sternum and 9 th segment; $f$, lateral aspect of 8 th and 9 th segments. 


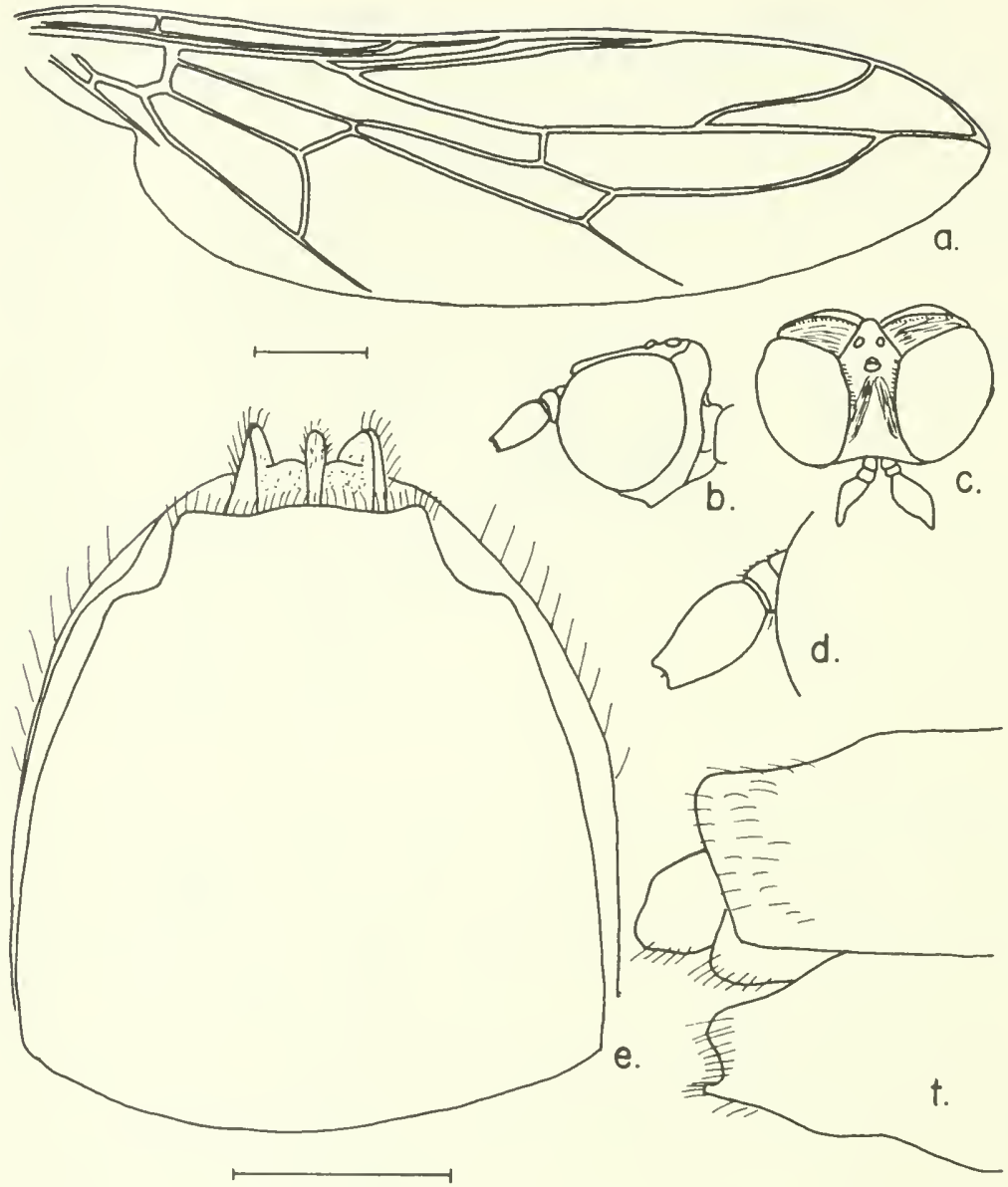

FIGURE 159.-Pseudatrichia garretti, new species, female: $a$, wing; $b$, lateral aspect of head; $c$, dorsal aspect of head; $d$, enlarged detail of antenna; $e$, ventral aspect of 8 th sternum; $f$, lateral aspect of 8 th and 9 th segments.

Ocellar tubercle flat, not cut off, ocelli clear. Mouth parts red-brown, well developed; palpi half as long as oral opening. Antennae with first two segments red-brown, third segment black with golden pile hairs.

Thorax dorsum black, with transverse striations; humeral and supraalar calli red-brown; scutellum dark red-brown; pleural areas redbrown. Wings clear, veins brown; halter stem brown, knob base brown but dorsal rib and remainder white. Front leg orange, except last tarsal segments brown; middle leg with femur orange, tibia orangebrown, last tarsal segments brown; hind leg all red-brown.

Abdomen second through fifth segments dark red-brown granular, submetallic, sixth and seventh segments dark red-brown. Eighth 
segment red-brown, sternum with posterior margin undulating; see figure for details.

MaLe.-Unknown.

Length: Female body $6.5 \mathrm{~mm}$., wing $4.2 \mathrm{~mm}$.

Type-locality: Keremeos, B.C., Canada; 26 June 1923 (C. B. Garrett).

Holotype: Female (CNC) 8633.

\section{Pseudatrichia gracilipennis, new species}

FIGURE 160

Male.-Head black, eyes brownish-black above, darker below, a thin postocular flange; frons slightly rounded, with a narrow transverse ridge just above the antennae, extending one-third the distance to the ocellar triangle; ocellar triangle prominent, ocelli brown; mouthparts red-brown, two-thirds the length of the oral opening, palpi slender, short, half as long as the mouthparts. Antennae with first segment red-brown, second and third orange-brown; see figure for details.

Thorax dorsum black, transversely striated, humeral and supraalar calli with orange-brown spots; pleural areas a very dark redbrown. Wings clear, veins brown; halter stem brown, knob base and dorsal rib brown, remainder white. Fore and middle legs straw colored with the tips of the tarsi red-brown, the second pair a little darker; hind leg orange-brown.

Abdomen second segment to the base of fifth dull black, rugose, remainder of fifth through seventh shining. Ninth segment black, tergum very pointed, sternal comb of hairs straight; aedeagus without large knobs; prongs long, thin; see figure for details.

Female.-Unknown.

Length: Male body $6.5 \mathrm{~mm}$., wing $3.5 \mathrm{~mm}$.

Type-locality: Davis, California; 23 June 1952 emerged 27 September 1952 (E. I. Schlinger and R. C. Bechtel).

Holotype: Male (UCalD) 73.

\section{Pseudatrichia houdeni, new species}

Figutre 161

Fenale.-Head black, longer than high; eyes black with red glints; postocular flange narrow; frons half the wirlth of the ocellar triangle, transversely striated; ocellar triangle flat, not cut off, ocelli clear. Mouthparts well developed, base brown, tip yellow; palpi yellow. Antennae with first two segments red-brown, third segment orange, notched at tip; see figure for details. 


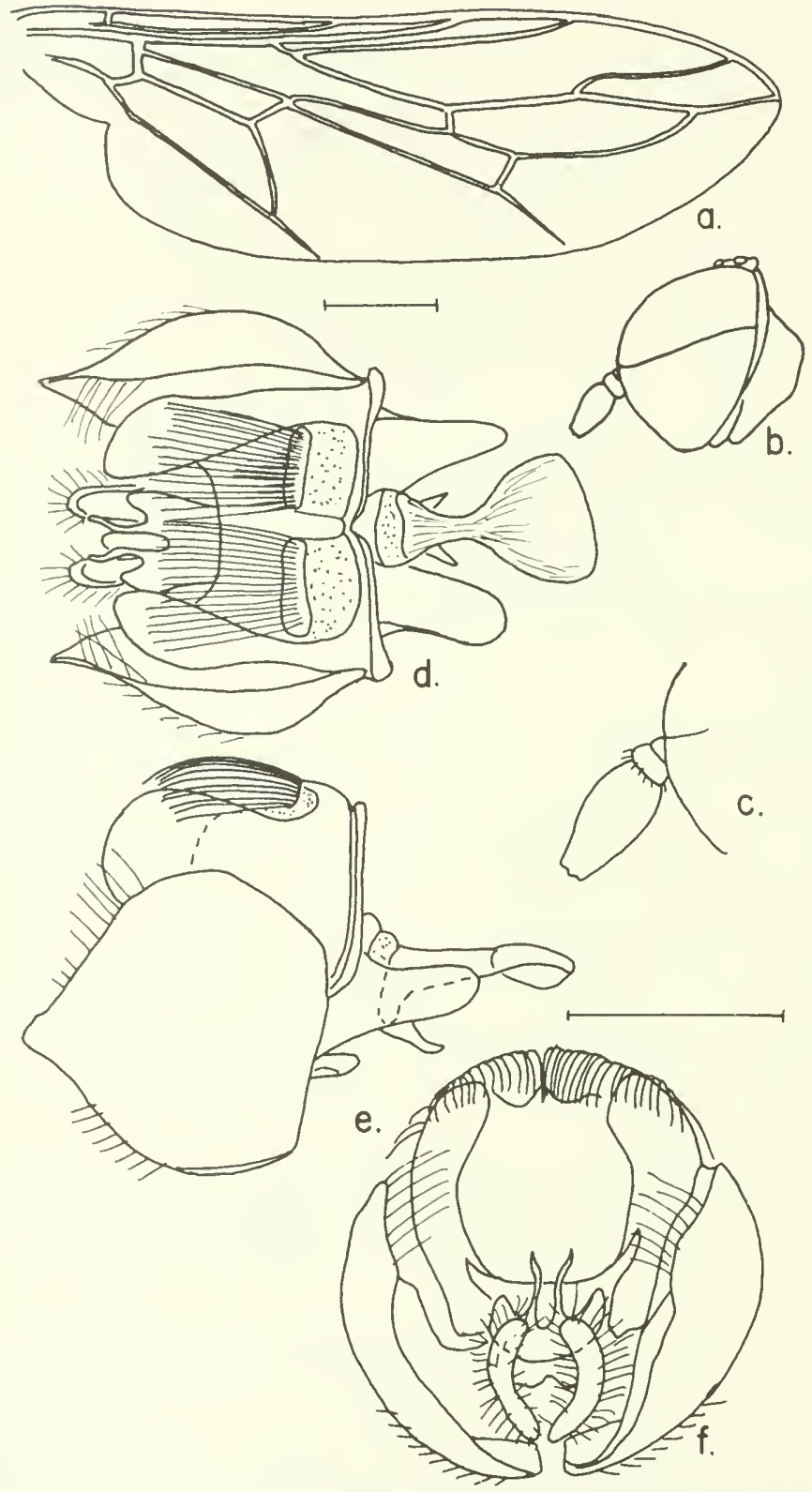

Figure 160.-Pseudatrichia gracilipennis, new species, male: $a$, wing; $b$, lateral aspect of head; $c$, enlarged detail of antenna; $d-f$, dorsal, ventral and posterior aspects of terminalia. 


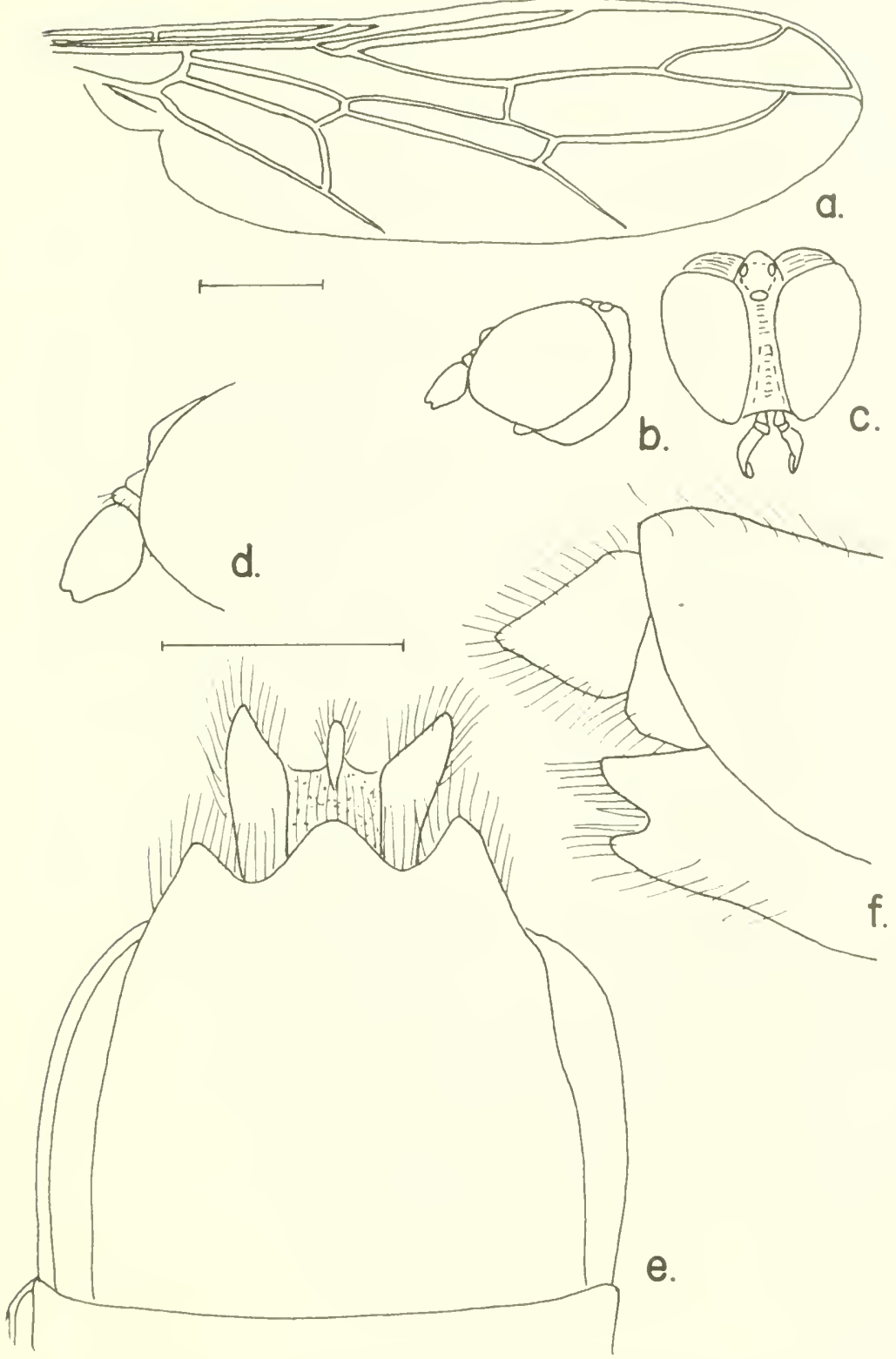

Figure 161.-Pseudatrichia howdeni, new species, female: $a$, wing; $b$, lateral aspect of head; $c$, dorsal aspect of head; $d$, enlarged detail of antenna; $e$, ventral aspect of 8 th sternum and 9 th segment; $f$, lateral aspect of 8 th and 9 th segments. 
Thorax dorsum black, granular, transversely striated; humeral and supra-alar calli orange-brown; pleural areas red-brown. Wing clear, veins brown; halter stem brown, knob with base and dorsal rib red-brown, remainder creamy white. Front leg orange; middle leg orange-brown, except last segment of tarsus brown; hind leg, coxa yellow, femur and tibia red-brown, tarsus yellow grading into brown distally.

Abdomen black, rugose, with purplish metallic glints; eighth segment red-brown, sternum with three points; see figure for details.

MaLE.-Unknown.

Length: Female body $5.5 \mathrm{~mm}$., wing $3.3 \mathrm{~mm}$.

Type-locality: Rustlers Park, Chiricahua Mts., Arizona; 8400 ft.; 11 June 1956 (H. and A. Howden).

Holotype: Female (CNC) 8634.

168. Pseudatrichia jamesi, new species

Figure 162

Female.-Head deep red-brown; postocular flange narrow; frons narrower than ocellar tubercle, transversely striated, a slight protuberance above antennae; ocellar triangle red-brown, distinct, cut off, ocelli clear. Mouthparts well developed, red-brown; palpi brown, half the length of the oral opening. Antennae with first segment red-brown, second and third segments orange, third darker at tip, tip truncated.

Thorax dorsum dark red-brown; humeral and supra-alar calli redbrown; pleural areas red-brown. Wings clear, with brown microtrichia, veins brown; halter stem brown, knob with base and dorsal rib redbrown, remainder white. Front leg, coxa tan, remainder of leg orangebrown, middle and hind legs with coxae tan, remainder red-brown.

Abdomen red-brown, granular, except segments six and seven shining, eighth segment red-brown, sternum deeply notched and 3pronged; see figure for details.

MaLE.-Unknown.

Length: Female body $6.6 \mathrm{~mm}$., wing $3.6 \mathrm{~mm}$.

Type-locality: Evergreen, Colorado; 21 July 1942 (M. T. James).

Holotype: Female (USNM) 67460.

169. Pseudatrichia leechi, new species

Figure 163

FEMALE.-Head black; eyes black-brown; postocular flange broad; transversely striated; frons wider than ocellar triangle with a band of striae passing from the anterior frontal area above antennae next to the eye to the lateral edges of the median ocellus in a "V" shape, remainder shining; ocellar triangle low, cut off, ocelli clear. Mouth- 

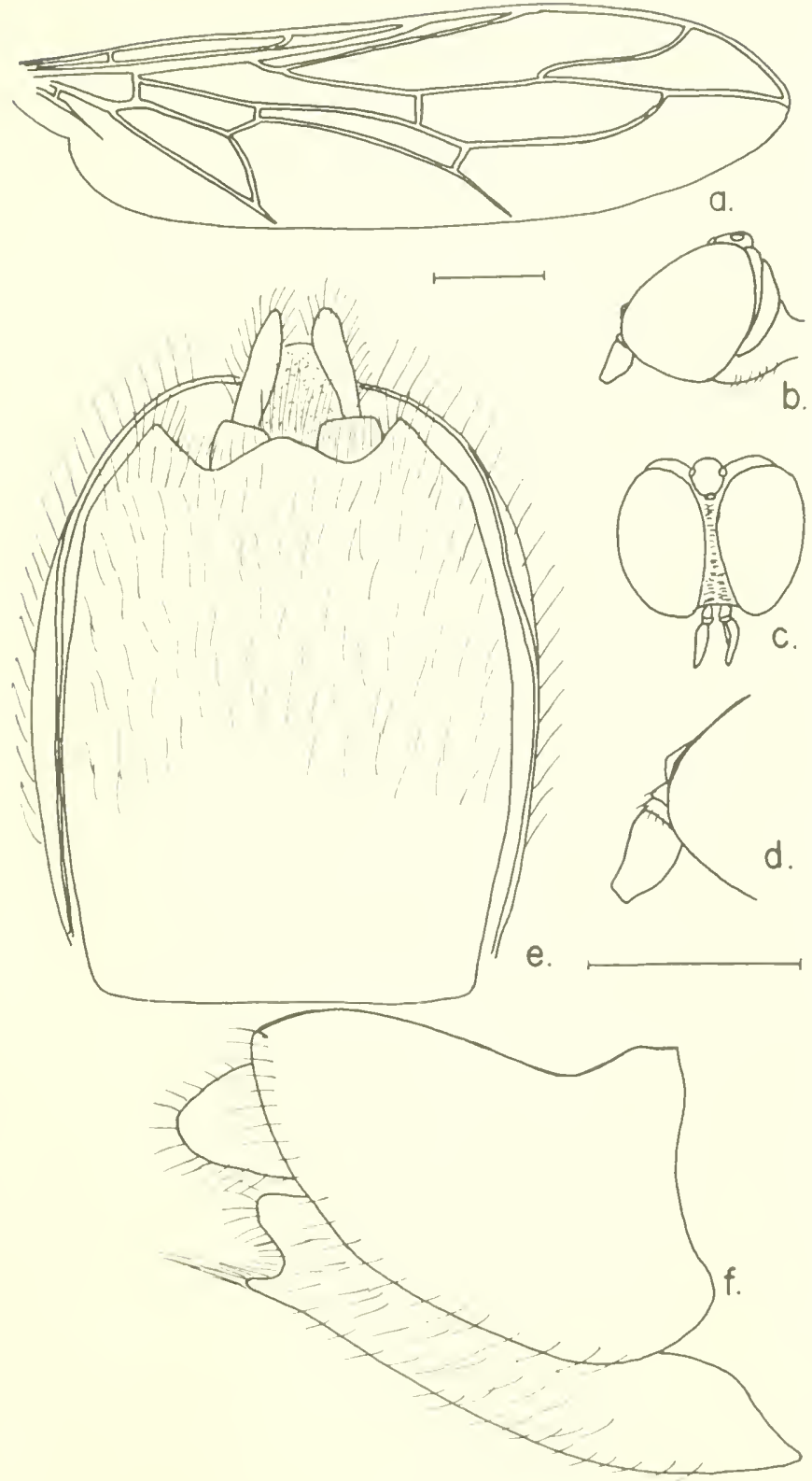

Figure 162.-Pseudatrichia jamesi, new species, female: $a$, wing; $b$, lateral aspect of head; $c$, dorsal aspect of head; $d$, enlarged detail of antenna; $e$, ventral aspect of 8 th sternum and 9 th segment; $f$, lateral aspect of 8 th and 9 th segments. 

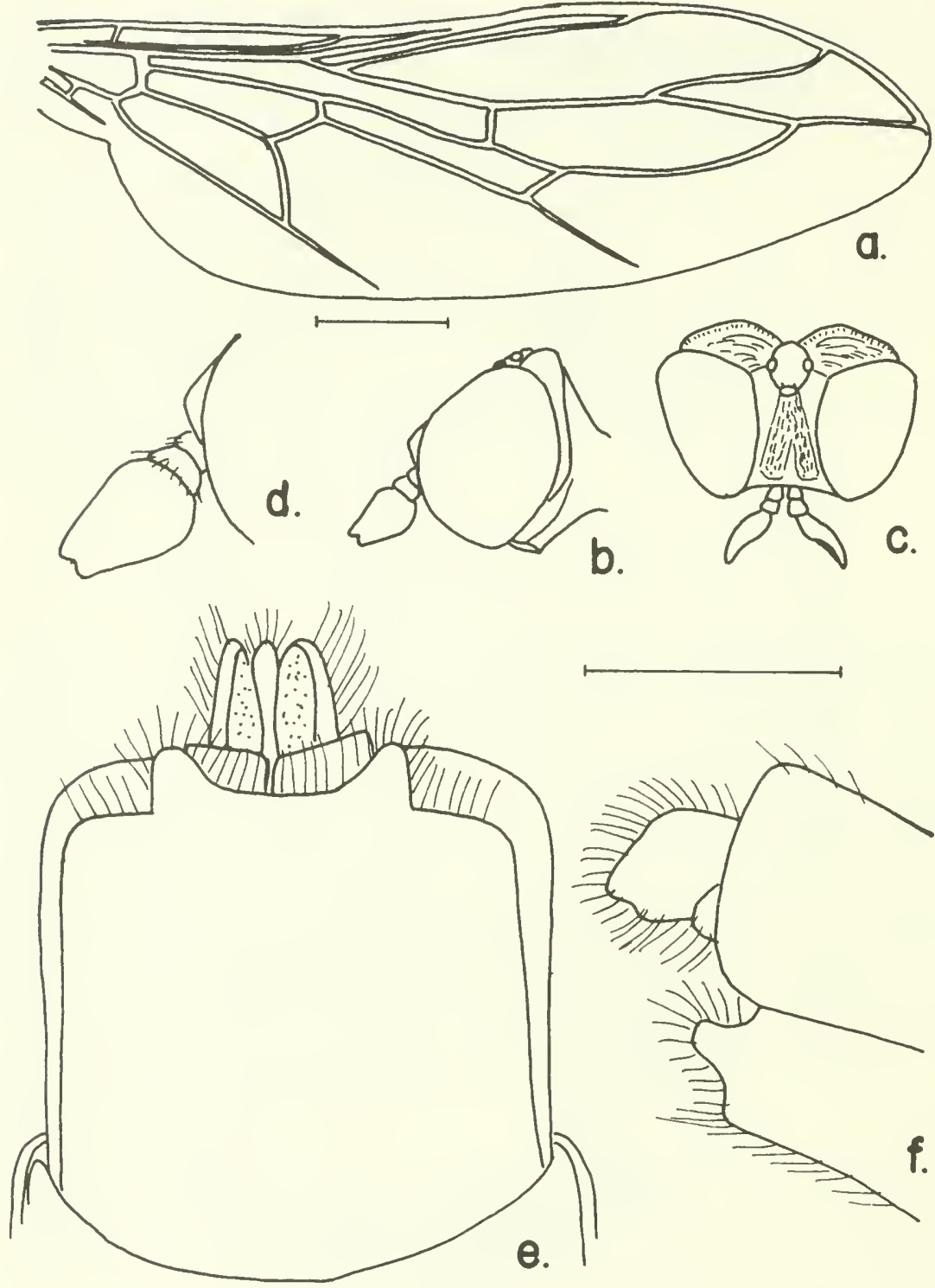

Figure 163.-Pseudatrichia leechi, new species, female: $a$, wing; $b$, lateral aspect of head; $c$, dorsal aspect of head; $d$, enlarged detail of antenna; $e$, ventral aspect of 8th sternum and 9 th segment; $f$, lateral aspect of 8 th and 9 th segments.

parts brown, well developed, nearly filling the oral cavity, palpi twothirds the length of the oral opening. Antenna with first two segments red-brown, third segment black, with short hairs that glint golden.

Thorax dorsum black, with transverse striations; humeral and supra-alar calli red-brown, pleura largely black. Wing clear, veins 
dark brown; halter stem brown, knob with dorsal rib red-brown, remainder white with some bleeding from dorsal rib. Front and middle legs orange-brown, tarsi red-brown; hind leg red-brown, tarsus with first segment orange, remainder red-brown.

Abdomen second segment black, granular, submetallic; membrane black except for extreme lateral margins white; remaining segments black, submetallic, posterior margins with large white patches on Iateral portions of membrane; eighth segment black, sternum broadly excavated with two rounded points midlaterally; see figure for details.

Male.-Unknown.

Length: Female body 5.1-6.1 mm., wing 3.2-4 mm.

Type-locality: Mill Valley, Marin Co., California; 29 July 1948 (H. B. Leech).

Holotype: Female (CAS) 8934.

Paratypes: 4 우, Mill Valley, California, 20 September 1947, 10 May 1955, 10 June 1957, 10 July 1957 (H. B. Leech) on window in house; 1 \%, Mill Valley, September 1948 (E. S. Ross); all (CAS).

\section{Pseudatrichia longiventris, new species}

Figure 164

Male.-Head red-brown, longer than high; eyes red-brown above, black-brown below, with a very narrow postocular flange; frons elongate, triangular, continuing as a thin band between the eyes to the ocellar tubercle, swollen above antennae, granular below, shining above; ocellar tubercle red-brown, granular; ocelli orange-red; back of head concave in center below ocellar tubercle, swollen laterally, dusted with gray pollen; antenna red-brown, first and second segments short, third segment oval, short.

Thorax dorsum black-brown, granular with a pollinose patch above humeral callus; humeral and supra-alar calli red-brown, scutellum dark red-brown; pleurum red-brown, shining. Wings brown, smoky; veins brown, halter stem red-brown, knob red-brown. Foreleg with femur red-brown, tibia and tarsus yellow-brown; middle leg with femur red-brown, tibia light red-brown, tarsus yellow-brown; hind leg with femur and tibia red-brown, tarsus yellow-brown.

Abdomen segments 2-4 dark red-brown, pebbly, with blue and green metallic glints under light; remainder red-brown, subshining without glints; segments 2 and 3 with white posterior membranes, remainder with orange-brown posterior membranes, segment 7 sharply constricted near base; see figure. Ninth segment withdrawn into seventh; for details see figure. Differs from Pseudatrichia punctulata in the shape of the ninth tergum and aedengal parameres. 
Female.-Head red-brown, longer than high; eyes dark red-brown, postocular flange broad but abruptly ending at lateral margin of eye; frons elevated above the antennae, narrow, no wider than the median ocellus; ocellar tubercle prominent, not sharply cut off from frons; ocelli red; back of head granular, subgenal and postlateral areas extensive, shining; mouthparts red-brown, three-fourths the length of the oral opening; palpi half as long. Antennae red-brown, the third segment small, oval.
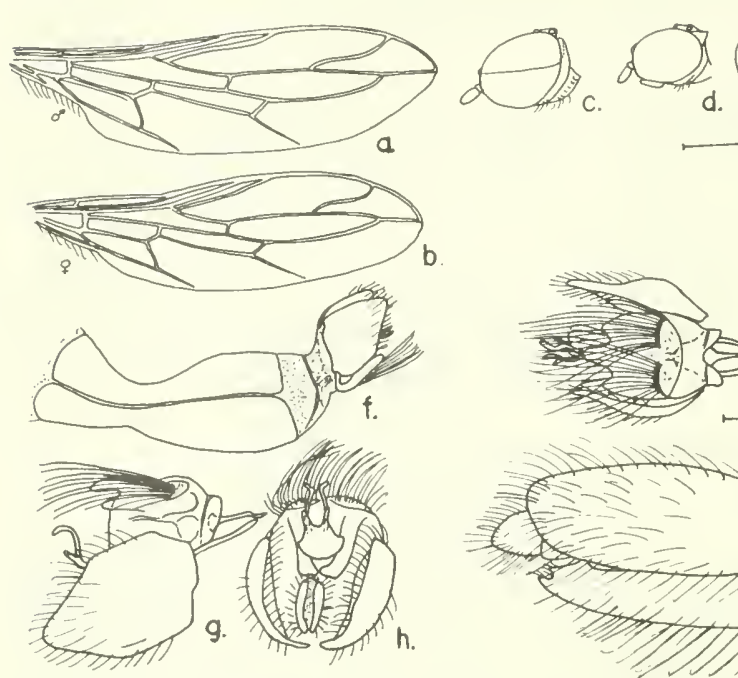

d.
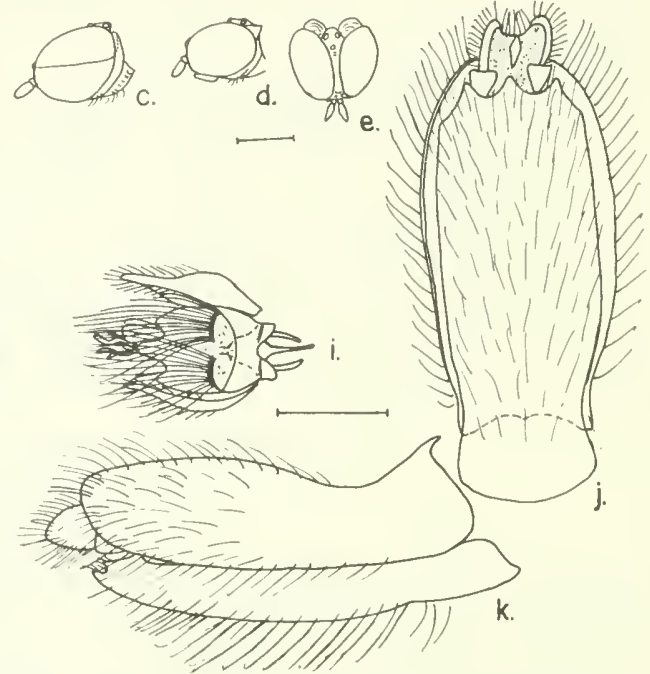

Figure 164.-Pseudatrichia longiventris, new species, male, female: $a$, male wing; $b$, female wing; $c, d$, lateral aspects of male and female head; $e$, dorsal aspect of female head; $f$, lateral aspect of 7 th, 8 th, and 9 th segments of male; $g$, lateral aspect of male terminalia; $h$, posterior aspect of male terminalia; $i$, ventral aspect of male terminalia; $j$, ventral aspect of female 8th sternum and 9th segment; $k$, lateral aspect of female 8 th and 9 th segments.

Thorax dorsum red-brown, elongate, elevated into a blunt point behind the head, depressed posteriorly in front of the scutellum; humeral and supra-alar calli orange-brown; scutellum orange-brown; pleural areas orange-brown. Wings brown, smoky, long and narrow; veins red-brown; halter stem brown, knob brown. Fore and middle legs orange-brown; hind leg with coxa orange-brown, remainder red-brown.

Abdomen red-brown, granular, subshining, with lateral margins of tergites black. Eighth segment red-brown, shining, very elongate, hairy, sternum ending in three points; see figure for details.

Length: Male body $8.5 \mathrm{~mm}$., wing $4 \mathrm{~mm}$.; fentale body $6.5 \mathrm{~mm}$., wing $3.7 \mathrm{~mm}$. 
Type-locality: Suiza, ('osta Rica; July 1926 (Pablo Schild).

Holotype: Male (USNM) 67456.

Allotype: Fenmle, same data except September (USNM).

\section{Pseudatrichia longurio (Loew)}

FIGURE 165

Atrichia longurio Loew, 1\$66, p. 42.

The type of this species was mistaken for a male, which resulted in a serious misinterpretation of the genus by most European dipterists. This species is one of the largest seen. The reader is referred to the figure for pertinent details.
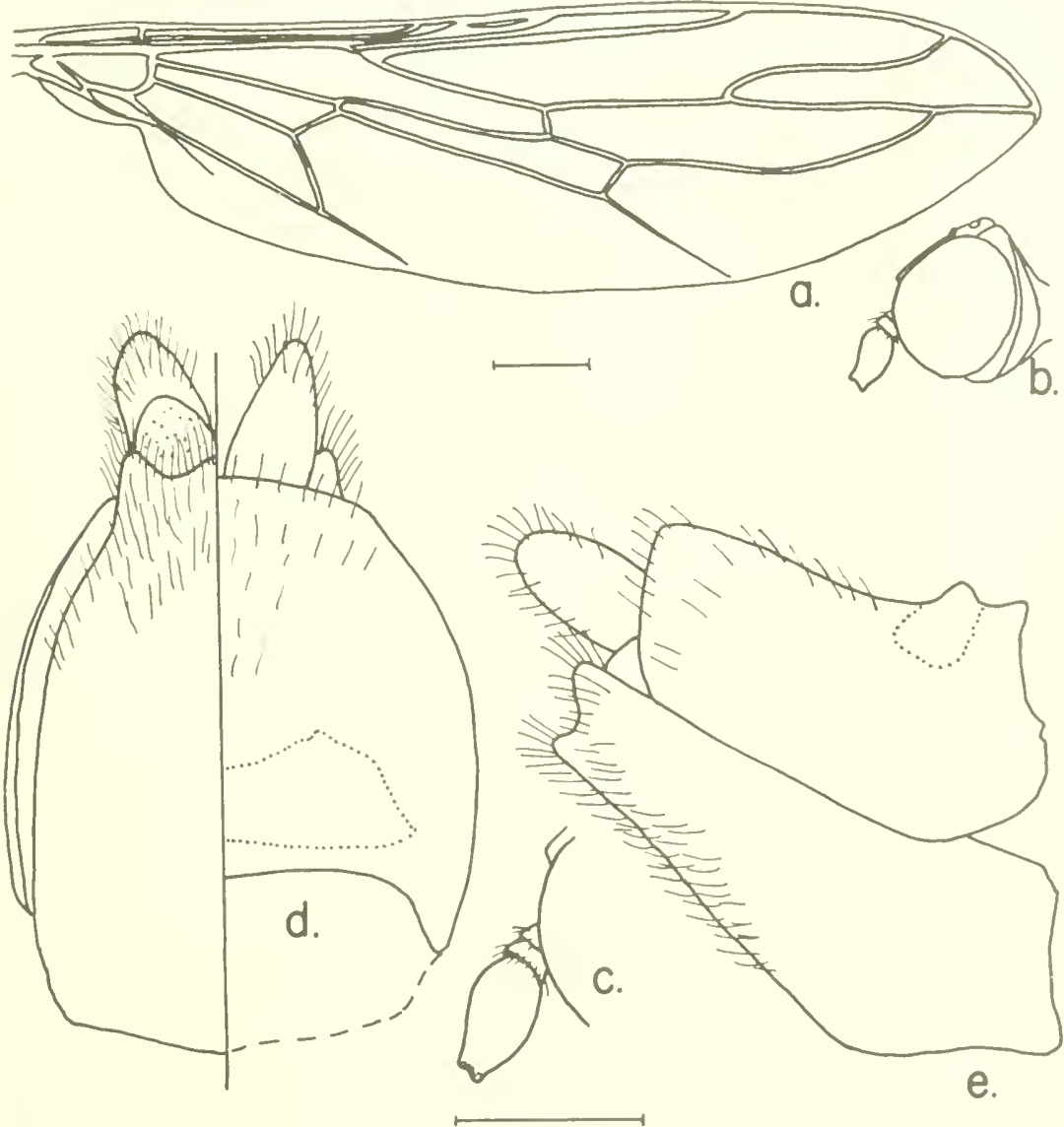

Figure 165.-Pseudatrichia longurio (Loew), female: $a$, wing; $b$, lateral aspect of head; $c$, enlarged detail of antenna; $d$, ventral left and dorsal right aspect of 8 th and 9 th segments, dotted lines outline a black patch on 8 th tergum; $e$, lateral aspect of 8 th and 9 th segments. 
MaLe.-Unknown.

Length: Female body 7.5-8.5 mm., wing $5.8 \mathrm{~mm}$.

Type-locality: Mexico.

Type: (ZMH).

\section{Pseudatrichia melanderi, new species}

Figure 166

Fenale.-Head black, longer than high; eyes black; postocular flange wide at center; back of head narrower than the bulge of the eyes; frons narrower than the ocellar triangle, with a median groove and oblique striations on lower half; ocellar triangle prominent, set off; ocelli orange. Mouthparts brown, shorter than oral cavity, palpi half as long. Antennae orange; see figure for details.

Thorax dorsum black, humeral and supra-alar calli red-brown; scutellum red-brown; prothorax light brown, remainder of pleura red-brown. Wings hyaline, veins light brown; halter stem brown, knob white. Legs orange, including coxae; hind legs slightly darker.

Abdomen segments 2-4 black, punctured, with a metallic purple sheen. Segments 5-7 becoming red-brown. Segment 8 with tergum red-brown, sternum orange, hairy, posterior margin two-pointed, with a slight elevation on the excavated median portion; see figure for details.

MaLE.-Head red-brown, higher than long; eyes black-brown above, black below; frons tapering to a point halfway to the median ocellus, separating the eyes; remainder of the distance with a thin raised ridge, lower portion with transverse striations; ocellar tubercle prominent, ocelli clear; antennae orange; see figure for details.

Thorax dorsum black-brown; humeral and supra-alar calli redbrown; scutellum red-brown; pleural areas red-brown. Wing clear, veins brown; halter stem brown, knob white. Legs as in female.

Abdomen second segment as female, remainder lost.

Length: Male body ?, wing $4 \mathrm{~mm}$.; female body $5.5-6 \mathrm{~mm}$., wing $3.5-3.7 \mathrm{~mm}$.

Type-locality: Clear Lake, California; 18 June 1935 (A. L. Melander).

Holotype: Male (USNM) 67465.

Allotype: Female Santa Clara Co., California (Harkins Collection) (CAS) 8925.

Paratype: 1 \%, Lucerne, Lake Co., California, 17 August 1958 (Hugh B. Leech) on rotting scar wood of Umbellulasia californica (CAS). 

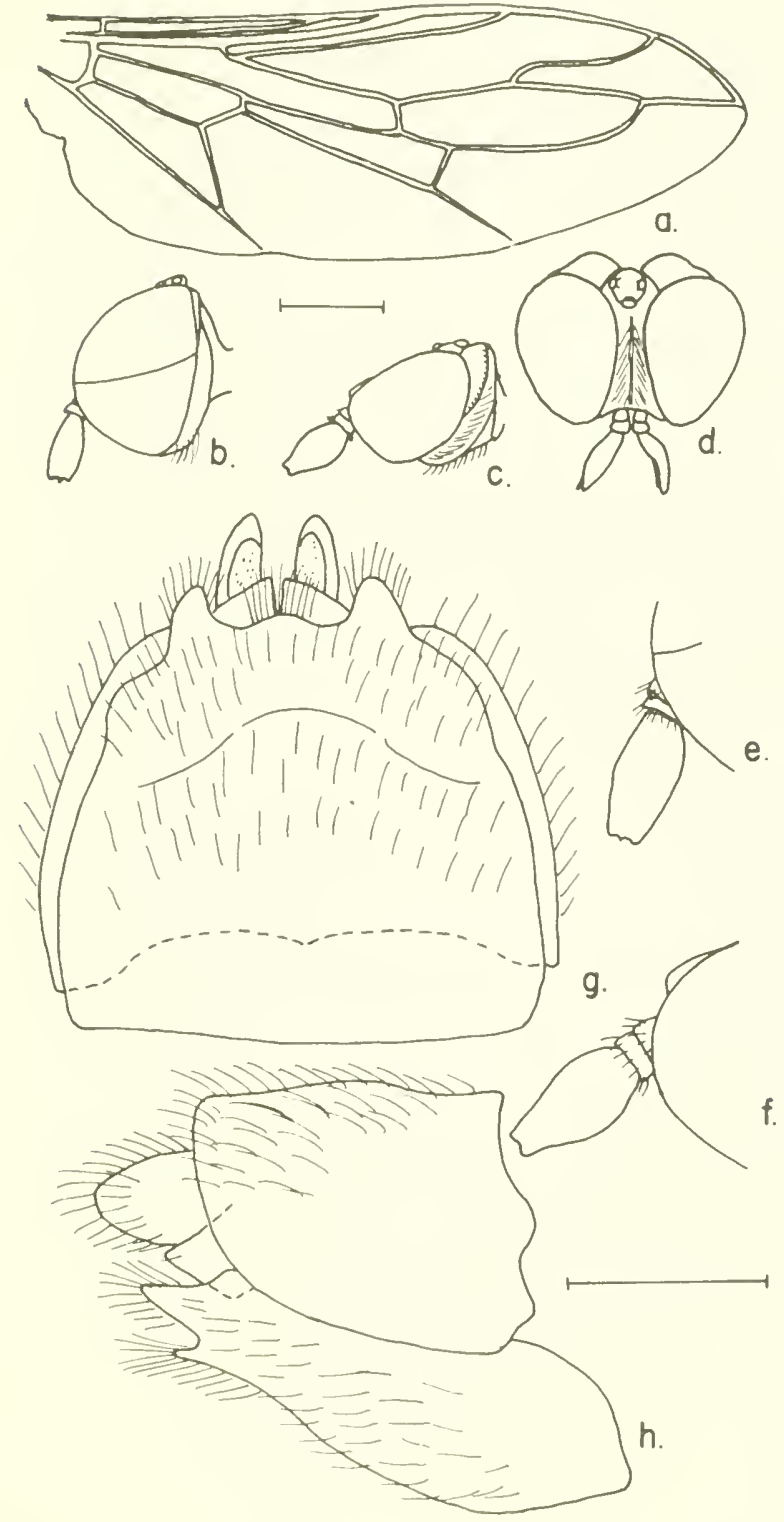

Figure 166.-Pseudatrichia melanderi, new species, male, female: $a$, wing; $b, c$, lateral aspects of male and female head; $d$, dorsal aspect of female head; $e, f$, enlarged details of male and female antennae; $g$, ventral aspect of female 8 th sternum and 9 th segment; $h$, lateral aspect of female 8th and 9th segments. 


\section{Pseudatrichia morlani, new species}

Figure 167

MALE.-Head, red-brown; eyes red-brown above, black-brown below; a narrow postocular flange behind eyes; frons narrow, shining, but continuing uninterrupted to the median ocellus; ocellar triangle prominent, ocelli clear. Antennae red-brown, last segment with short hairs, which give a golden glint, cupped at tip.

Thorax dorsum black, metallic, transversely striated, humeral and supra-alar calli orange-brown; scutellum red-brown; pleural areas red-brown. Wings clear, veins brown; halter stem brown, knob white. Forelegs yellow-brown with brown tarsi; middle legs, femora orangebrown, tibiae red-brown basally, orange distally, tarsi brown; hind legs with femora orange-brown basally, red-brown distally, tibiae red-brown, tarsi, first segment orange, remainder brown.

Abdomen segments $2-4$ black, rugose, with a purple metallic glint; segments 5-7 shining, ninth tergum red-brown, generally withdrawn into the seventh segment, posterior margin toothed dorsally and concave on ventral half; spines of ninth sternum sparse and coarse. Aedeagus bilobed with two median peni spurs. See figure for details.

Female.-Head black, eyes black-brown; postocular flange smooth and shining; frons red-brown, as wide as ocellar tubercle, with striations from the edge of the eye laterad of the antennae to the median ocellus, a few white hairs set in these striations; frons swollen above the antennae; ocellar tubercle flat, set off, ocelli clear; mouthparts well developed, red-brown, filling three-fourths of the oral cavity; palpi red-brown, half the length of oral cavity. Antennae red-brown, third segment clothed in short hairs with a golden glint; see figure for details.

Thorax as in male.

Abdomen black, metallic. Eighth segment red-brown, sternum truncated; see figure for details.

This species is close to Pseudatrichia unicolor, but differs in many ways.

Length: Male body 4.5-4.7 mm., wing 2.6-2.8 mm.; female body $4.2-4.8 \mathrm{~mm}$., wing $3-3.2 \mathrm{~mm}$.

Type-locality: Santa Fe Co., New Mexico; 13 January 1953 (H. B. Morlan) from Neotoma albigula nest.

Holotype: Male (USNM) 67468.

Allotype: Female, Santa Fe, New Mexico; 12 July 1952 (H. B. Morlan) from Neotoma albigula nest, (USNM).

Paratypes: $1 \sigma^{7}$, Santa Fe, July (Cockerell 1377); $1 \sigma^{7}$, Pecos, New Mexico, 17 June (Cockerell) at light; $3 \sigma^{7} \sigma^{7}, 6$ 우, 12 August, 18 Norember 1952, 13 and 17 January 1953, plus 7 pupal skins all with same data as type and allotype, all (USNM). 


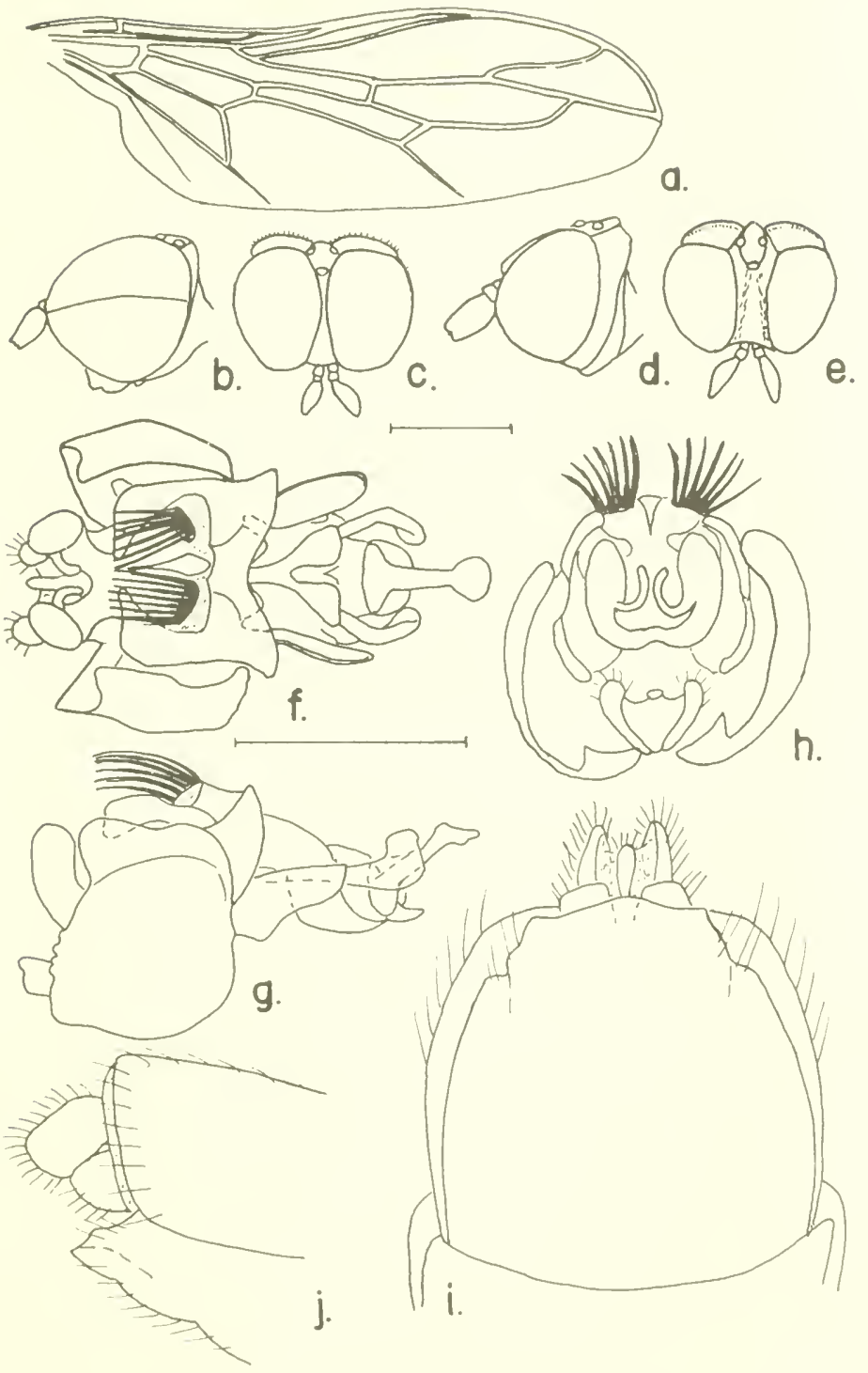

Figure 167.-Pseudatrichia morlani, new specics, male, female: $a$, wing; $b$, lateral aspect of male head; $c$, dorsal aspect of male head; $d$, lateral aspect of female head; $e$, dorsal aspect of female head; $f-h$, ventral, lateral and posterior aspects of male terminalia; $i$, ventral aspect of female 8th sternum and 9th segment; $j$, lateral aspect of female 8 th and 9 th segments. 


\section{Pseudatrichia nordeni, new species}

Figure 168

Female.--Head black; eyes black-brown, postocular flange broad; frons broader than ocellar triangle, swollen, with a long pit in front of median ocellus, and with longitudinal striations that give it a dull appearance; ocellar triangle flat, cut off; ocelli orange. Mouthparts small, only half the length of the oral opening, palpi short. Antennae with first two segments red-brown, third segment orange-brown, tapering, forked at tip; see figure for details.

Thorax dorsum black, transversely striated; humeral and supraalar calli brown-orange; pleura dark red-brown. Wings clear, veins brown; halter stem brown, knob with base and dorsal half brown, ventral half white. Legs with all coxae straw colored; front legs yellow-brown, middle legs orange-brown, hind legs red-brown.

Abdomen with segments 2-4 black, rugose, with a purple sheen; segments 5-7 black, shining; eighth segment black, hairy, eighth sternum three-pointed with the median point truncated; see figure for details.

MaLE.-Unknown.

Length: Female body $6.5 \mathrm{~mm}$., wing $4 \mathrm{~mm}$.

Type-locality: Norden, Nevada Co., California; 15 August 1951.

Holotype: o (CAS) 8935.

\section{Pseudatrichia parva D. E. Hardy}

Figure 169

Pseudatrichia parva D.E. Hardy, 1944a, p. 36.

This species is known only from the female, which is figured.

Length: Female body $3.7 \mathrm{~mm}$., wing $2.7 \mathrm{~mm}$.

Type-locality: Flagstaff, Arizona; 8 July 1941 (R. H. Beamer). Type: (UKan).

\section{Pseudatrichia parvipennis, new species}

FIgURE 170

MaLE.-Head black, eyes red-brown above, darker below; postocular ridge very narrow; frons short, swollen, extending one-third the distance to the ocellar triangle; ocellar tubercle raised, ocelli red; mouthparts red-brown, short, half the length of the oral opening, palpi shorter. Antennae orange-brown, third segment truncated; see figure for details.

Thorax dorsum black, transversely striated; humeral and supra-alar calli deep red-brown; pleura deep red-brown. Wings brownish, veins brown; halter stem brown, knob with base brown, dorsal rib and 

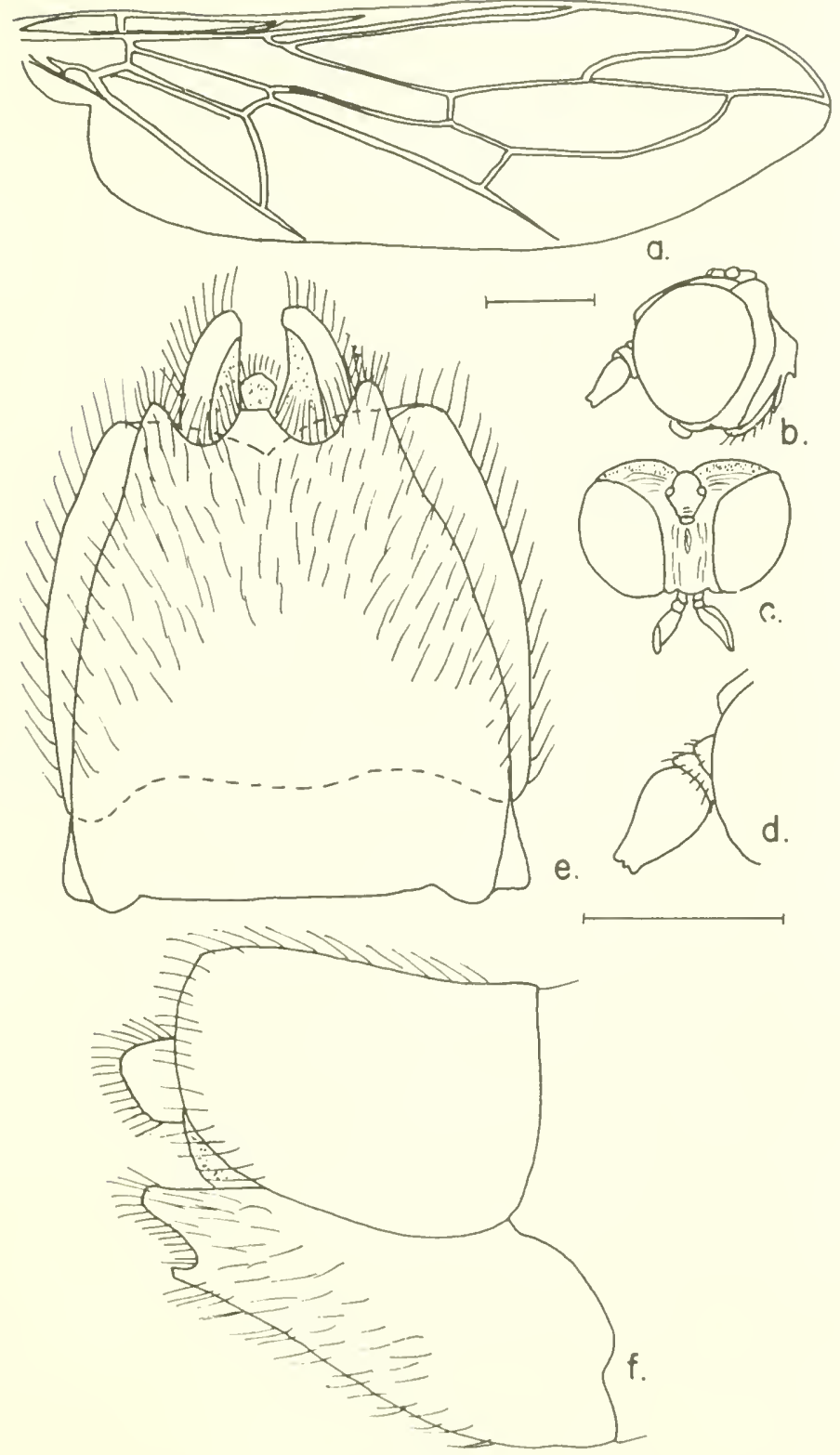

a. 


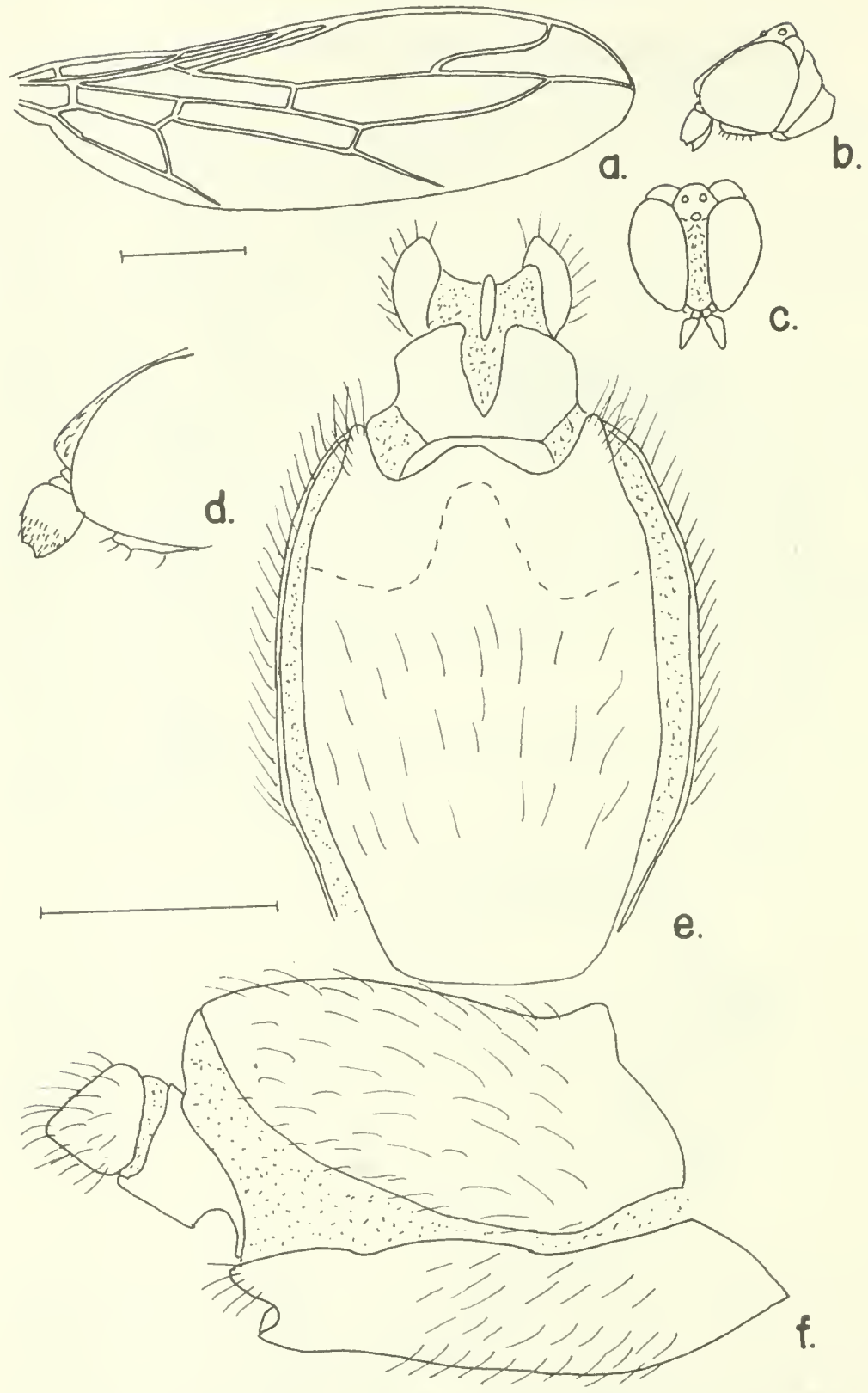

Figure 169-Pseudatrichia parva, D. E. Hardy, female: $a$, wing; $b$, lateral aspect of head; $c$, dorsal aspect of head; $d$, enlarged detail of antenna; $e$, ventral aspect of 8 th sternum and 9 th segment; $f$, lateral aspect of 8 th and 9 th segments. 

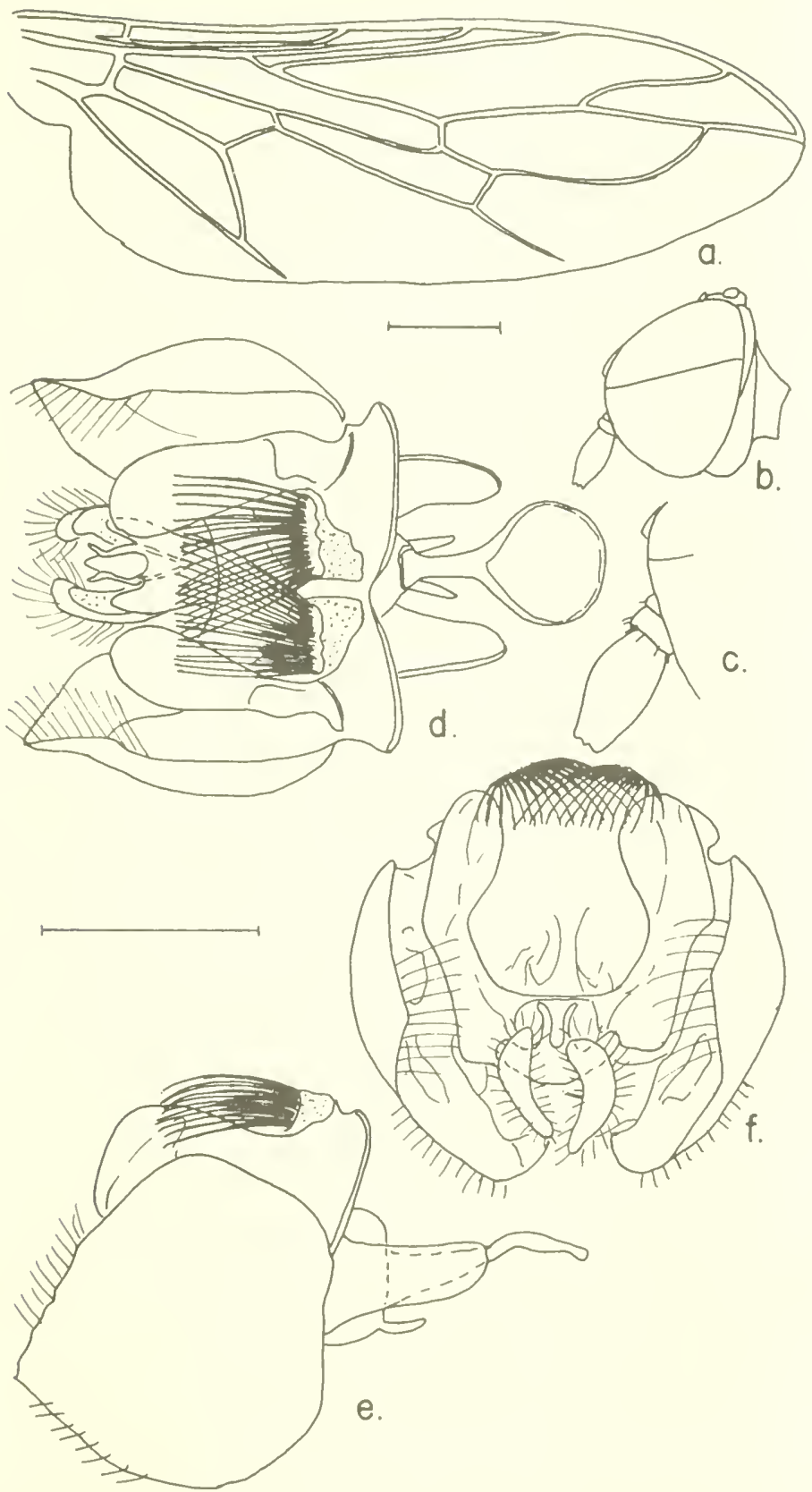

Figure 170.-Pseudalrichia parvipennis, new species, male: $a$, wing; $b$, lateral aspect of head; $c$, enlarged detail of antenna; $d-f$, ventral, lateral and posterior aspects of terminalia. 
Abdomen segments 2-5 black, rugose; segments 6 and 7 black, shining; uinth tergum red-brown, pointed dorsally; aedeagus with large lobes, but with two short wiry median peni; sternal brush of hairs fairly thick; see figure for details.

Female.-Unknown.

Length: Male body $6 \mathrm{~mm}$., wing $3.7 \mathrm{~mm}$.

Type-locality: Linden, San Joaquin Co., California; 7 August 1953 (W. H. Lange).

Holotype: Male (UCalD) 74 .

\section{Pseudatrichia peromysci, new species}

FIGURE 171

MALE.-Head black; eyes black-brown, black below; frons continuous to median ocellus but narrowed as eyes nearly touch threefifths of the way from antennae to median ocellus, widening above; ocellar tubercle prominent, ocelli clear. Mouthparts red-brown, three-fourths the length of the oral opening, palpi slender, half the length of oral opening. Antennae black, third segment covered with short pubescence that gives a golden glint.

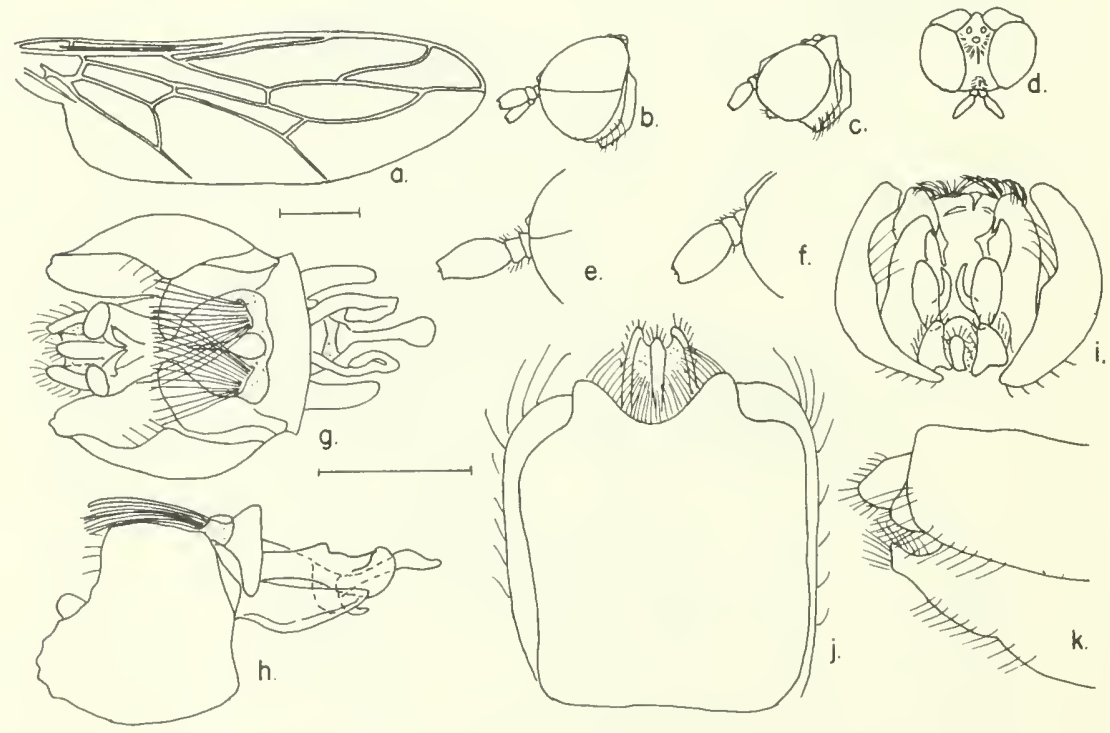

Figure 171.-Pseudatrichia peromysci, new species, male, female: $a$, wing; $b, c$, lateral aspects of male and female head; $d$, dorsal aspect of female head; $e, f$, enlarged details of male and female antennae; $g-i$, ventral, lateral and posterior aspects of male terminalia; $j$, ventral aspect of female 8 th sternum and 9 th segment; $k$, lateral aspect of female 8 th and 9 th segments. 
Thorax dorsum black, transversely striated; humeral and supra-alar calli red-brown; pleural areas black to red-brown. Wing clear, veins dark brown; halter stem black-brown, knob with black-brown base and dorsal rib, only a small portion of white below. Front and middle legs, coxae to tibiae orange-brown, tarsi black-brown; hind leg, coxa to tibia red-brown, first segment of tarsus orange-brown grading into black-brown.

Abdomen segments two through four black, punctured, with a metallic sheen; remaining segments more shining. Ninth tergum black, rounded but rough dorsally, receding ventrally; peni orange, sternal brushes thick; see figure for details.

Fenales.-Head black; eyes black-brown, postocular flanges broad, shining; frons subshining, swollen above antennae, a median cleft bordered by striations, striations on upper frons radiating from median ocellus; ocellar triangle red-brown, not cut off, ocelli clear. Antennae as in male.

Thorax as in male except knob of halter has much more white than male.

Abdomen as in male; eighth sternum orange-brown, deeply concave on posterior margin with two rounded lateral lobes; see figure for details.

Length: Male body 4.5-5 $\mathrm{mm}$., wing 2.5-3.1 mm.; female body $4.3-4.5 \mathrm{~mm}$., wing $2.5-2.7 \mathrm{~mm}$.

Type-locality: 3.5 mi. s., 10.2 mi. w. Arbuckle, Colusa Co., California; 15 January 1959 (A. М. Barnes) reared from larvae.

Holotype: ơ (USNM) 67463.

Allotype: $q$ same data (USNM).

Paratypes: $5 \sigma^{7} \sigma^{7}$, same data as type; $1 \sigma^{7}, 6.8 \mathrm{mi}$. s. 0.2 mi. w. Placelrille, Eldorado Co., California, 14 January 1959 (A. M. Barnes); $1 \sigma^{7}, 12.0$ mi. s. Grass Valley, Nevada Co., California, 14 January 1959 (all collected as larvae from nests of Neotoma peromyscus and reared out) ; 1 \% , 3.5 mi. n.e. Iompoc, Santa Barbara Co., California, 9 February 1961 (A. M. Barnes) as third instar larva (AMB) and (USNM).

\section{Pseudatrichia punctulata D. E. Hardy}

\section{FigURE 172}

Pseudatrichia punclulata D. E. Hardy, 1944b, p. 104.

'This species, described by Hardy, was only partially figured by him and a complete set of figures of the male and female terminalia are included here. 'The male of this species as well as I'. Longiventris is notable for the sharply constricted seventh abdominal segment so clearly illustrated by Hardy and in the sharply hooked aedeagal spines 


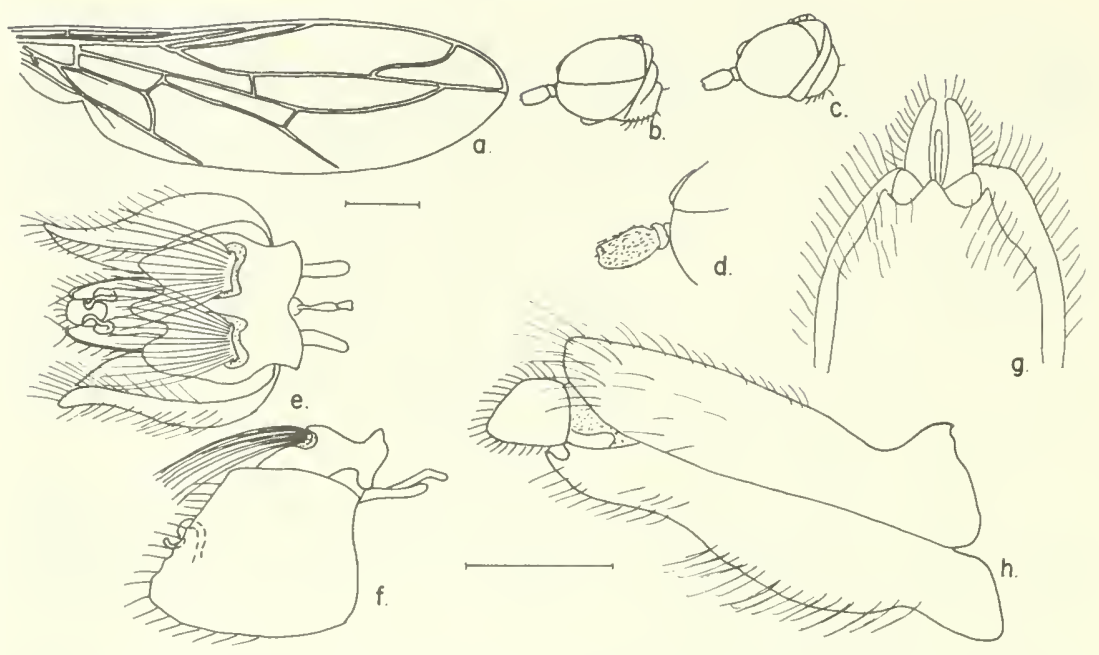

Figure 172.-Pseudatrichia punctulata, D. E. Hardy, male, female: $a$, wing; $b, c$, lateral aspects of male and female heads; $d$, enlarged detail of antenna; $e, f$, ventral and lateral aspects of male terminalia; $g$, ventral aspect of female 8 th sternum and 9 th segment; $h$, lateral aspect of female 8 th and 9 th segments.

they differ in the shape of the basal portion of the spines as well as in other small details. The eyes are divided as in all Scenopinidae into coarse upper facets and fine lower facets and the areas of union is bandlike. The female eighth sternum is much like that of $P$. longiventris but the female differs in other minor details particularly the eyes and width of the postocular ridge.

Length: Male body 6.6-7.3 mm., wing 3.7-3.9 mm.; female body 7.5-8.3 mm., wing $4-4.3 \mathrm{~mm}$.

Type-locality: Nova T'eutonia, Brazil; $27^{\circ} 11^{\prime}$ S. $52^{\circ} 23^{\prime}$ W.; 20 February 1940 (Fritz Plaumann).

Type: (UKan).

179. Pseudatrichia sabroskyi, new species

FIgURE 173

Female.-Head red-brown; eyes black-brown, postocular flange, narrow, rounded, depressed; back of head gray pubescent; frons subshining with faint median longitudinal striations; ocellar tubercle not prominent, cut off; ocelli orange; mouthparts a little over half the length of the oral cavity; palpi red-brown, slender, subequal in length to mouthparts. Antennae orange-brown; see figure for details.

Thorax dorsum black-brown, striated; humeral and supra-alar calli red-brown tipped with orange; scutellum red-brown; pleura red-brown. Wings clear, veins brown; halter stem brown, knob with 

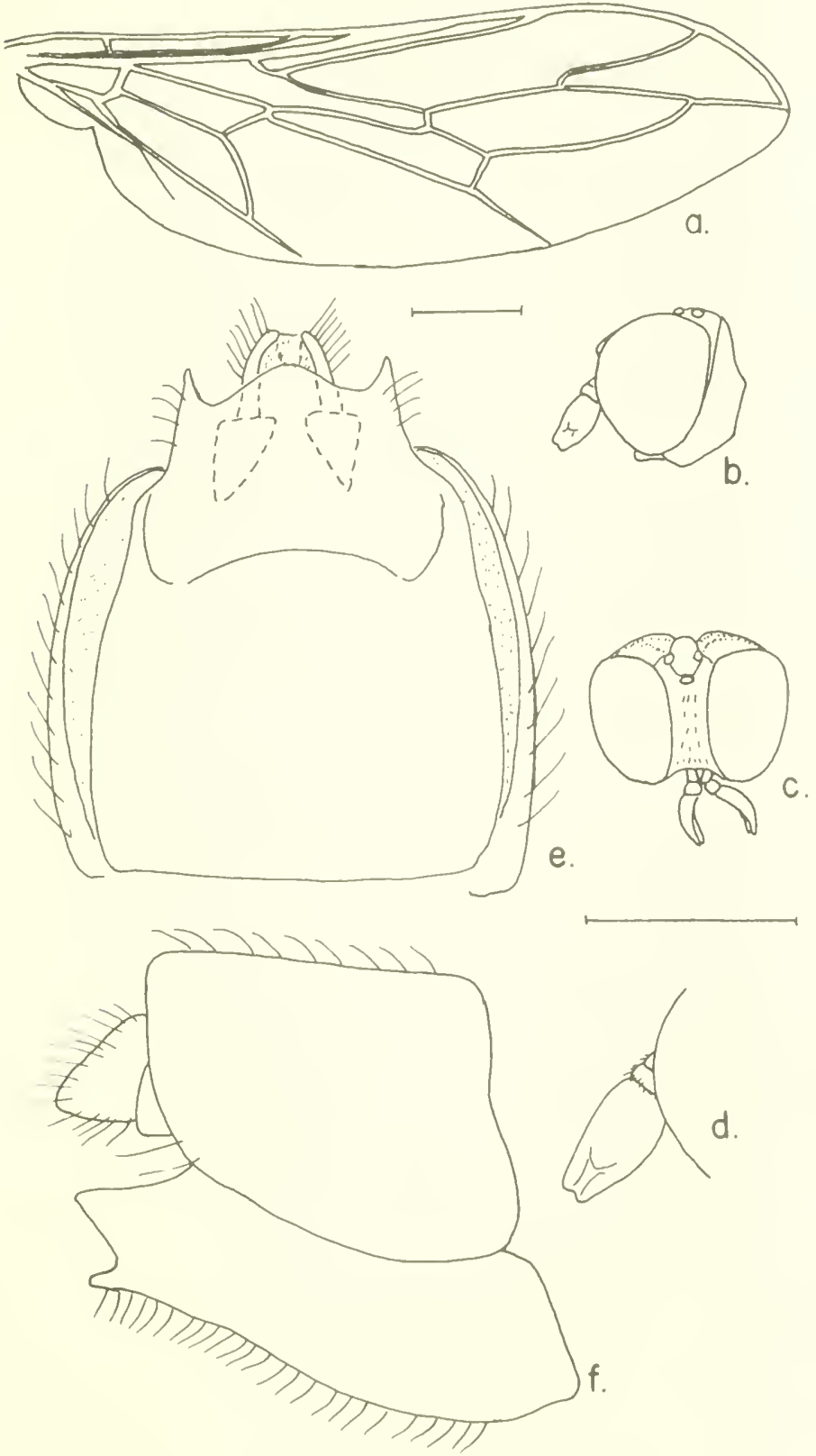

Figure 173.-Pseudatrichia sabroskyi, new species, female: $a$, wing; $b$, lateral aspect of head; $c$, dorsal aspect of head; $d$, cnlarged detail of antenna; $\ell$, ventral aspect of 8 th sternum; $f$, lateral aspect of 8 th and 9 th segments.

$313-1696-69-18$ 
base and dorsal half brown, remainder white. Front leg with coxa to tibia straw yellow, tarsus darker toward tips; middle leg orangebrown, hind leg red-brown.

Abdomen segment 2 dark red-brown, rugose, metallic; segments 3-5 red-brown, rugose, metallic; segments 6 and 7 red-brown, shining. Eighth segment orange-brown, sternum with two prominent lateral points and convex median swelling, nearly as long as the points; see figure for details.

MaLE.-Unknown.

Length: Female body $6 \mathrm{~mm}$., wing $3.6 \mathrm{~mm}$.

Type-locality: Antelope Mt. (6500 ft.), Harney, Lake Co., Oregon; 22 August 1931 (D. K. Frewing) ex Sabrosky Coll.

Holotype: Female (USNM) 67457.

\section{Pseudatrichia saccharcupa, new species}

Figure 174

Female.-Head red-brown; eyes black-brown, postocular flange medium wide; frons slightly swollen above the antennae, with faint shining median groove bordered by longitudinal striations; ocellar tubercle flat, not set off, ocelli red. Mouthparts brown; palpi redbrown, half the length of the oral opening. Antennae with first two segments red-brown, third segment red-orange with short hairs glinting golden.

Thorax dorsum black, with transverse striae; humeral callus redbrown with orange spot, supra-alar callus orange; pleural areas deep red-brown. Wings clear, veins red-brown; halter stem red-brown, knob base and dorsal rib red-brown, remainder white. Front leg orange with distal tarsal segments darker; middle leg with base of femur orange, remainder of leg red-brown; hind leg with all segments redbrown.

Abdomen black, rugose, with a purple metallic sheen, membranes brown on midline, white laterally; eighth segment red-brown, hairy, eighth sternum with three points, median one shorter, rounded; see figure for details.

MaLe.-Unknown.

Length: Female body $6.5 \mathrm{~mm}$., wing $4 \mathrm{~mm}$.

Type-locality: Sugar Bowl Lodge, Placer Co., California; 26 July 1951.

Holotype: Female (CAS) 8936.

Paratype: o same data but 19 August 1951 (CAS). 


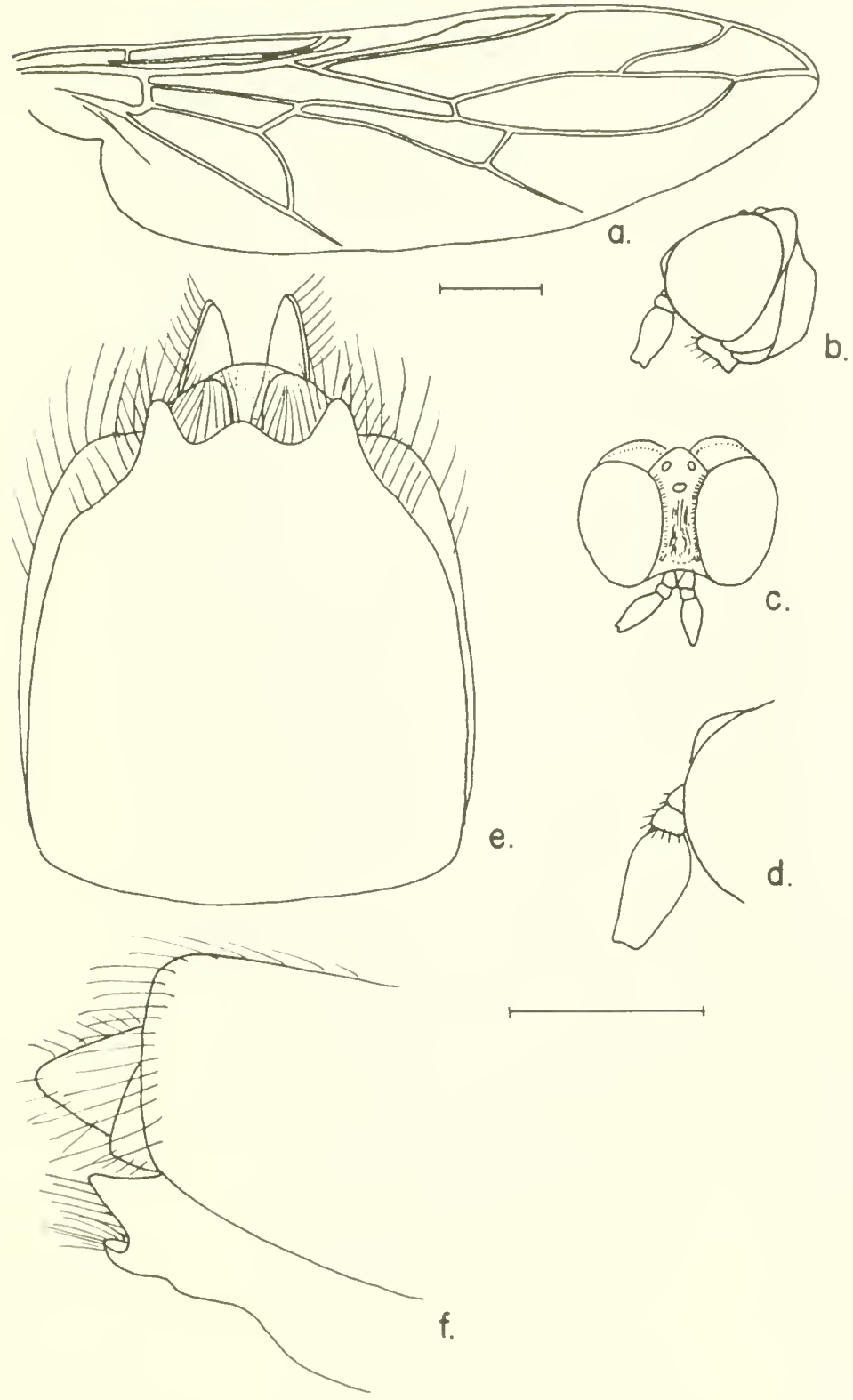

Figure 174.-Pseudatrichia saccharcupa, new specics, female: $a$, wing; $b$, lateral aspect of head; $c$, dorsal aspect of head; $d$, enlarged detail of antenna; $e$, ventral aspect of 8 th sternum and 9 th segment; $f$, latcral aspect of 8 th and 9 th segments. 


\section{Pseudatrichia toupeta, new species}

Figure 175

Male.-Head red-brown; eyes red-brown above a little darker below, nearly meeting on upper part of frons; frons rugose above antennae, continuing narrowly between eyes to ocellar triangle; ocellar tubercle black-brown, ocelli orange. Antennae with first two segments red-brown, third segment orange-brown, covered with short hairs giving a golden glint; see figure for details.

Thorax dorsum black-brown, rugose, transversely striated; humeral and supra-alar calli orange-brown; scutellum red-brown; pleural areas red-brown. Wings brownish, veins brown; halter stem brown, knob with dorsal portion light brown remainder white. Legs orange to orange-brown.

Abdomen red-brown, rugose with purple metallic glints; ninth tergum irregularly shaped; sternum with long black hair like a toupee, ninth segment claspers hairy, aedeagus with two strong prongs; see figure for details.

Female.-Unknown.

Length: Male body $6 \mathrm{~mm}$., wing $3.6 \mathrm{~mm}$.

Type-locality: "Colorado."

Holotype: Male (USNM) 67467.

182. Pseudatrichia truncata, new species

Figure 176

MaLE.-Head lost.

Thorax dorsum black, granular with fine transverse striations; humeral and supra-alar calli red-brown; pleural areas black. Wing clear, veins brown; halter stem brown, knob with basal portion redbrown, distal portion white with a bleeding of brown into it. Legs red-brown.

Abdomen second segment black with two small lateral white areas on the intersegmental membrane; remaining segments black with white areas on intersegmental membranes wider, central dark band maintained. Ninth tergum brown-black; sternum with a sparse comb of short thick hairs. Aedeagus bilobed with posteriorly directed spurlike prongs; see figure for details.

Female.-Unknown.

Length: Male body $5.2 \mathrm{~mm}$. est., wing $3.5 \mathrm{~mm}$.

Type-locality: Mexico City, Mexico; 18 May (Juan Muller).

Holotype: Male (USNM) 67471. 


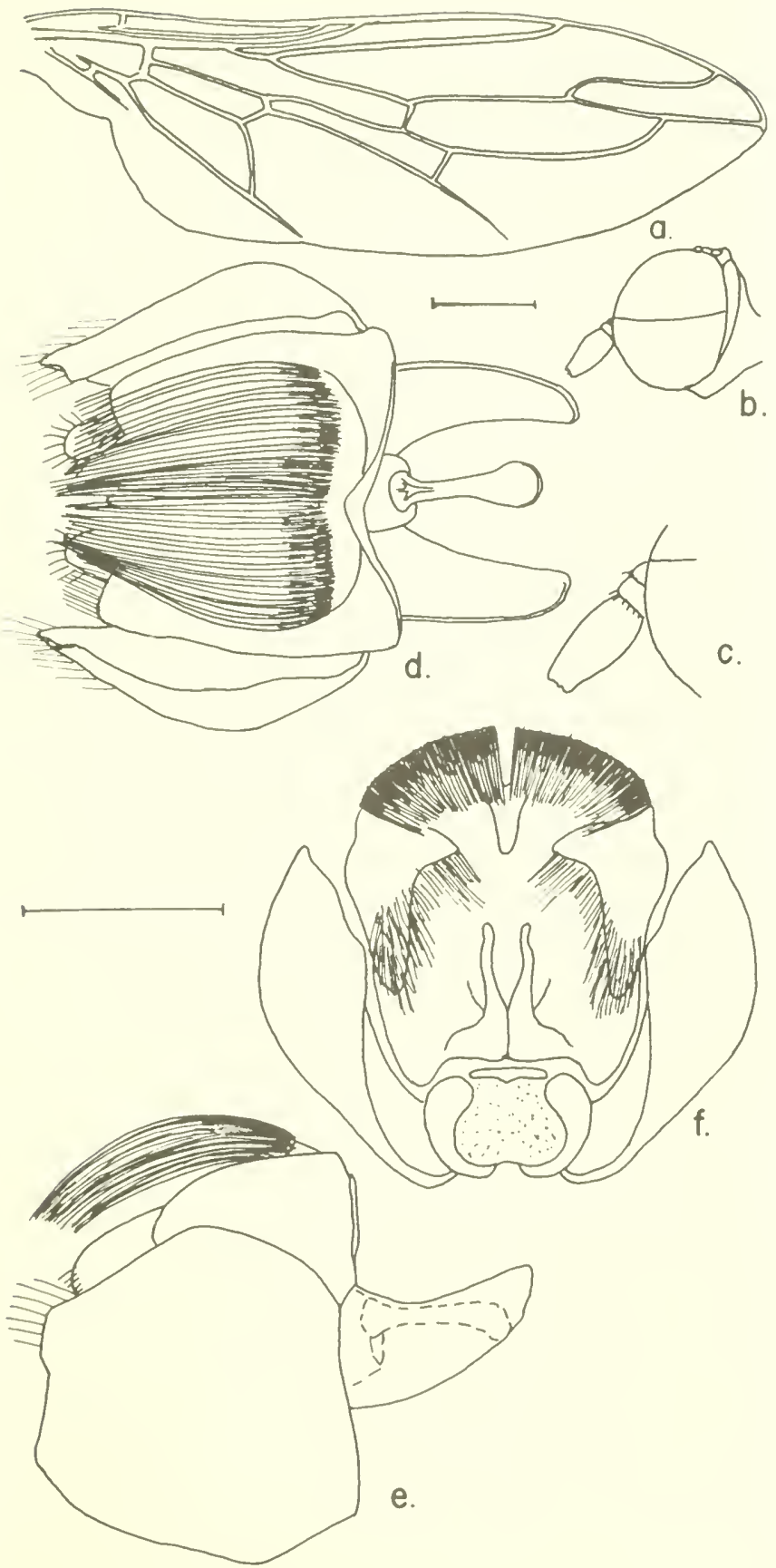

Figure. 175.-Pseudatrichia toupeta, new species, male: $a$, wing; $b$, lateral aspect of head; $c$, enlarged detail of antenna; $d-f$, ventral, lateral and posterior aspects of terminalia. 

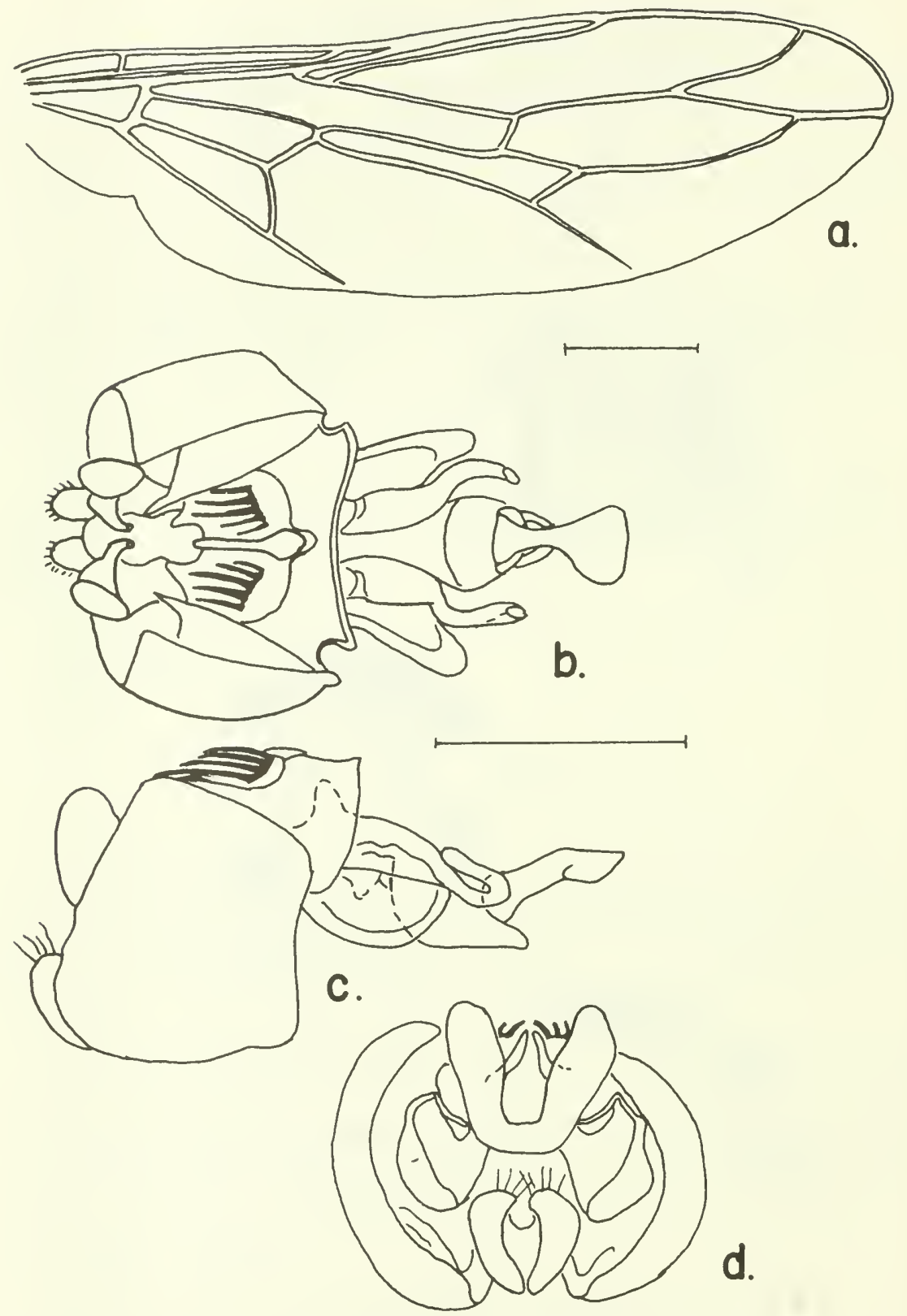

FigURE 176. - Pseudatrichia truncata, new species, male: $a$, wing; $b-d$, ventral, lateral and posterior aspects of terminalia. 


\section{P'seudatrichia unicolor Coquillett}

Figure 177

Pseudatrichia unicolor Coquillett, 1900, p. 500.

This species has previously been known only from the male, and though many specimens have been identified to this species the number remaining is limited to only a few from the inmediate vicinity of the type-locality. 'The female is described below.

Female.-Head black-brown; eyes red-brown, postocular ridge broad, fringed with hairs along posterior margin, transversely striated; frons wider than ocellar triangle, with median shining strip widest above antennae, bordered by uniform bands of longitudinal striations
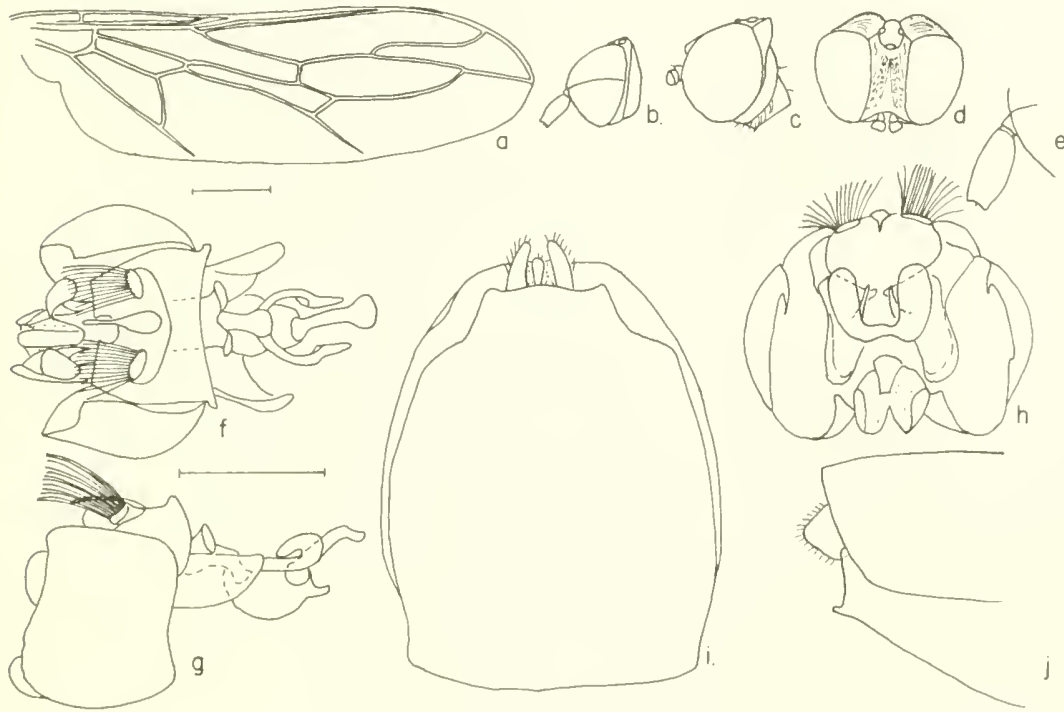

Figure 177.- Pseudatrichia unicolor Coquillett, male, female: $a$, wing; $b, c$, lateral aspects of male and female heads; $d$, dorsal aspect of female head; $e$, enlarged detail of male antenna; $f-h$, ventral, lateral and posterior aspects of male terminalia; $i$, ventral aspect of female 8th sternum and 9th segment; $j$, lateral aspect of female 8 th and 9 th segments.

from lower eye margin to median ocellus, bands with a few hairs; ocellar triangle not eleiated, set off, ocelli red-brown. Antenna with first two segments red-brown; third segment black-brown, with a pile of short hairs giving off a golden glint.

Thorax dorsum black-brown, transversely striated; humeral callus red-brown, supra-alar eallus orange; scutellum black with red-brown lateral margins; pleural areas red-brown. Wings hyaline, veins brown; halter stem brown; knob with brown base, remainder white. Front leg coxa through femur straw yellow, tibia yellow-brown, tarsus brown; 
middle leg with coxa yellow, femur and tibia yellow-brown, tarsus brown; hind leg with coxa orange-brown, femur red-brown, tibia brown, first tarsal segment yellow-brown, remainder brown.

Abdomen black-brown, rugose, eighth segment red-brown, sternum undulating along posterior margin, lateral lobes shallow; see figure for details.

Length: Male body 6-6.3 mm., wing $4 \mathrm{~mm}$.; female body 6.5 mm., wing $4.3 \mathrm{~mm}$.

Type-locality: Las Vegas, New Mexico; July 19-('T. D. A. Cockerell).

Type: (USNM) 4711.

Other specimens seen: $1 \sigma^{7}, 1$, 9 , Las Vegas, New Mexico, 3, 11 August (H. S. Barber); $1 \sigma^{7}$, Watrous, New Mexico, Cockerell no. 2503, all (USNM).

\section{Genus Belosta D. E. Hardy}

Belosta D. E. Hardy, 1944a, p. 37.

Type-species Belosta albipilosa Hardy (original designation). The genus Belosta D. E. Hardy is closely related to the genus Pseudatrichia from which it was removed because of the head being higher than long, atrophied mouthparts and generally hairy condition. It has a closed cell R5. The members of this genus are found in the western mountain area of the United States where the larvae are predators of rood attacking insects.

\section{Key to the Species of Belosta}

1. Males, eyes close together . . . . . . . . . . . . . . . . . . 2

Females, eyes widely separated . . . . . . . . . . . . . . 4

2. Halter knob white . . . . . . . . . . . . . . . . 3

Halter knob tan, thorax with short white hairs . . . . B. albipilosa Hardy

3. Halter knob all white, thorax with long white hair. . B. pilosa (Coquillett) Halter knob white above with a tan rim and ventral surface, thorax with very short seale-like hairs . . . . . B. viticolapennis, new species

4. Halter knob orange . . . . . . . . . . . . . . . . . . . . . . 5 Halter knob red-brown . . . . . . . . . . . . . . . . . . . 6

5. Thorax with mixed short red and white hairs, 7 th sternum short, abrupt B. albipilosa Hardy

Thorax with short white hairs only, 7 th sternum long, sloping

B. pilosa (Coquillett)

6. Halter knob red-brown except ventral tip white. . . B. telfordi, new species Halter knob red-brown above cream below . . . B. termitophaga, new species 


\section{Belosta albipilosa D. E. Hardy}

Figure 178

Belosta albipilosa D. L. Hardy, 1944a, p. 38.

This species, an active predator of wood boring insects, is adequately described by Hardy. Sclerotized portion of female accessory gland seren times as long as wide.

Length: Male body 4-5.5 mm., wing $3-3.8 \mathrm{~mm}$; female borly 5-6 mm., wing 3.5-4 $\mathrm{mm}$.

Type-locality: Riggins, Idaho; 18 May 1940 ('T. 'Terrell) taken on Pinus ponderosa.

Type: o (USNMI).

I have seen all of the type-series in the (USNM), as well as material from the following localities: 1 ㅇ, Wawona, California, on Thuja; 1 ॰ , Whitaker Forest, Sequoia Nat. Forest, California, 21 October 1940 (D. DeLeon) on Quercus kelloggi; 1 o, Stanislaus Nat. Forest, California, 27 May 1935 (W. H. Lange) on Pinus ponderosa; 1 \%, Sierra Nat. Forest, California (J. W. Bonberg) on Pinus ponderosa; 2 o $\sigma^{\top}$, Bandelier, New Mexico, 1957; 1 으, Krassel, Idaho, 18 September 1957 (M. M. Furniss) on Pseudotsuga menziesii; all in (USNM); 1 or, Junipero Sierra Pk., Santa Lucia Mts., Monterey Co., California, 3 July 1957 (H. B. Leech) on peak ca. $5800 \mathrm{ft}$. emerged from dead branches Pinus coulteri in (CAS); $4 \sigma^{7} \sigma^{7}, 1$ ㅇ, Krrassel, Idaho, emerged January and 16 and 27 June 1960 (M. M. Furniss) ex Pseudotsuga. menziesii where they were found to be predaceous on the larvae of Dendroctonus pseudotsugae, Hopk., U.S. Forest Serv. Res. Iab., Boise, Idaho.

\section{Belosta pilosa (Coquillett)}

Figute 179

I'sendatrichia pilosa Coquillett, 1902, p. 102.

Pseudatrichia flaviceps Coquillett, 1902, p. 102. New synonymy.

After a good deal of study on the paratypes of these two species as well as considering where and when eaptured, I have concluded that $B$. flaviceps is the female of $B$. pilosa. The wing venation corresponds as closely as in most species; the presence of short but rather dense pile on the female, the comparable size, etc., make it seem improbable for them to be separate species. I did not observe the black hairs on the male mentioned by Coquillett in his description. $A$ beautiful male was received, from Dr. Timberlake, which had the entire thorax and much of the abdomen covered with long white hairs, giving it a truly snowy appearance. Accessory gland of female has a flaring base, selerotized portion only as long as broad.

Lengtlı: Male body 4-5.5 mm., wing 3.6-4.5 mm.; female body $6 \mathrm{~mm}$., wing $4.6 \mathrm{~mm}$. 

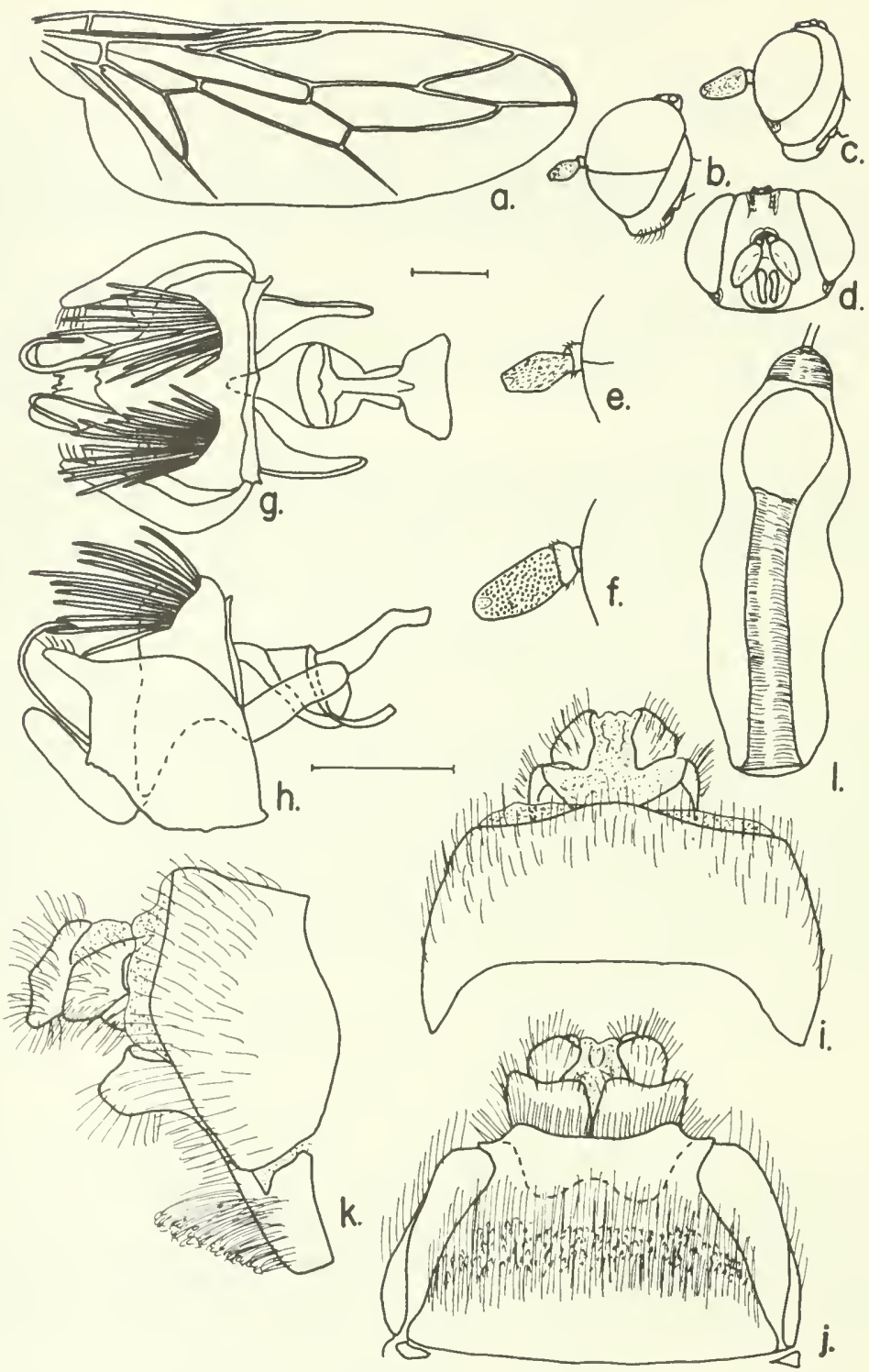

Figure 178.- Belosta albipilosa D. E. Hardy, male, female: $a$, wing; $b, c$, lateral aspects of male and female heads; $d$, frontal aspect of female head; $e, f$, enlarged details of male and female antennae; $g, h$, ventral and lateral aspects of male terminalia; $i$, dorsal aspect of female 8 th and 9th segments; $j$, ventral aspect of female 8 th and 9th segments; $k$, lateral aspect of female 8 th and 9 th segments; $l$, spermatheca.

Figure 179.-Belosta pilosa (Coquillett), male, female: $a$, wing of male; $b$, wing of female; $c, d$, lateral aspects of male and female heads; $e, f$, frontal aspects of male and female heads; $g, h$, enlarged details of male and female antennae; $i, j$, ventral and lateral aspects of male terminalia; $k$, ventral left and dorsal right aspect of female 8th and 9th segments; $l$, lateral aspect of female 8 th and 9 th segments; $m$, spermatheca. 

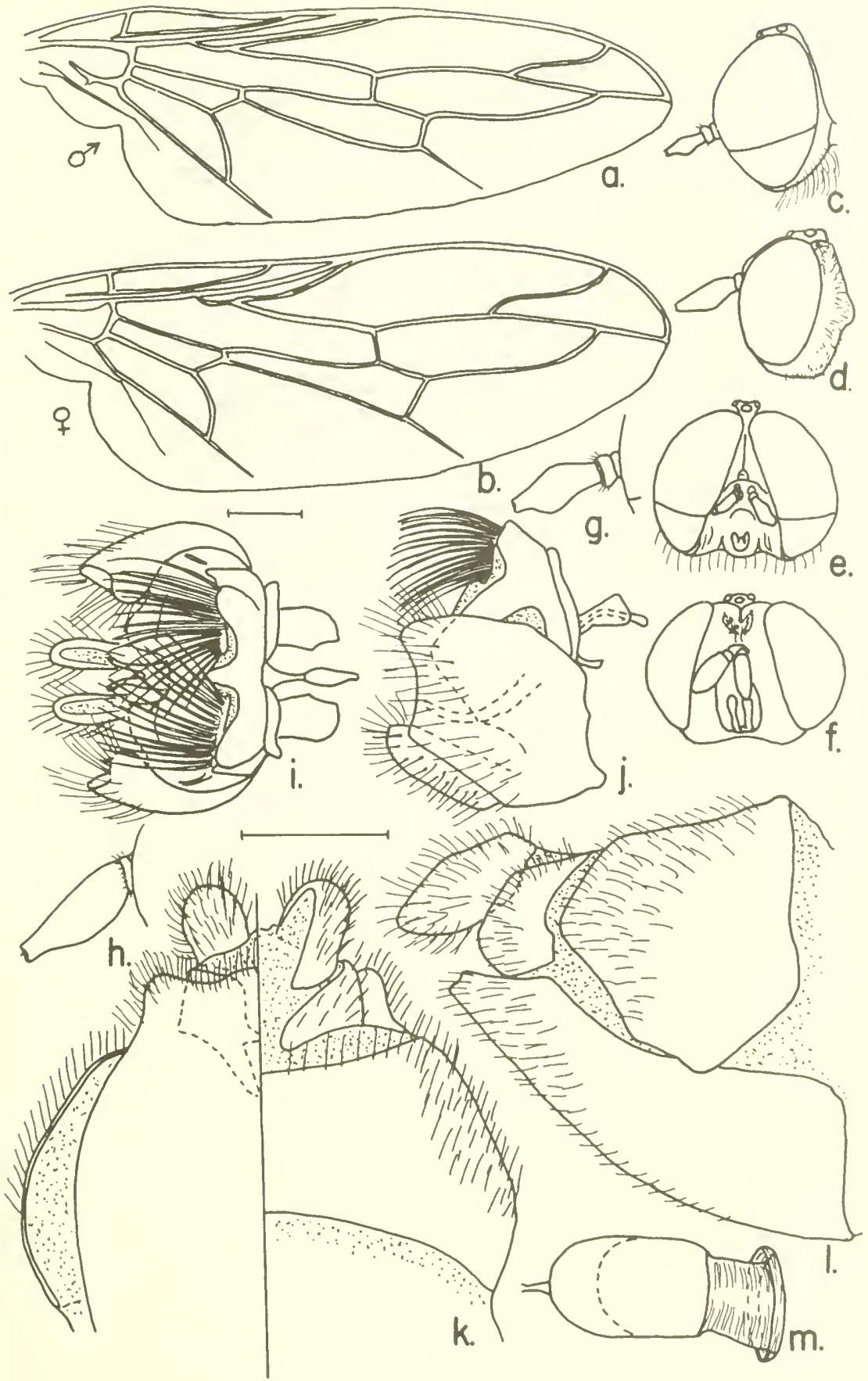
Type-locality: Williams, Arizona, 7 July (H. S. Barber); female as Pseudatrichia flaviceps, Williams, Arizona, 15 July (H. S. Barber).

Types: (USNM) 6194 and 6193.

Specimens examined: $1 \sigma^{7}, 1$ 앙, paratypes of the above specimens (USNM); 1 व , Mannix California, 25 April 1951 (Timberlake) (PHT); 1 or, Strawberry Valley, San Jacinto Mts., California, 12 July 1912 (J. C. Bridwell) (USNM).

\section{Belosta telfordi, new species}

Figure 180

Female.-Head brown; eyes black-brown; frons dark brown, ocellar tubercle red-brown, mouthparts atrophied, palpi bulbous. Antennae black-brown; see figure for details. (The head was collapsed so was removed, relaxed in $\mathrm{KOH}$, and replaced on the specimen.)

Thorax dorsum black-brown, with medium long white hairs in scattered patches; humeral callus black-brown; scutellum blackbrown. Pleural areas prothorax red-brown, mesanepisternum blackbrown with white hairs, katepisternum black-brown. Wings hyaline, veins brown; halter stem red-brown, knob red-brown except ventral tip white. Foreleg with femur black-brown with yellow-brown dorsal surface and knee, remainder of leg black-brown; middle and hind legs black-brown, femora with yellow knee.

Abdomen black-brown, intersegmental membranes with blackbrown midline and white lateral portions. Eighth sternum long, sloping; accessory gland short with flaring base, sclerotized portion twice as long as broad; see figure.

MaLe.-Unknown.

Length: Female body $6.5 \mathrm{~mm}$., wing $4.5 \mathrm{~mm}$.

Type-locality: Tucson, Arizona; 17 March 1957 (A. D. Telford). Holotype: Female (USNM) 68005.

\section{Belosta termitophaga, new species}

Figure 181

Female.-Head cream; eyes dark red-brown; frons very broad, tan, shining, with two longitudinal crescent-shaped marks, a brown patch on gena below the base of the eye; head behind the eye cream, center of back of head brown; mouthparts atrophied, palpi bulbous; ocellar tubercle red-brown, ocelli clear. Antennae with first segment short, brown; second segment tan; third segment brown, tapering, over three times as long as 1 and 2 combined.

Thorax dorsum black, with two anterior tan patches above the humeral callus, covered with medium long hairs, humeral and supraalar calli tan, scutellum red-brown. Propleura tan, mesopleural areas 


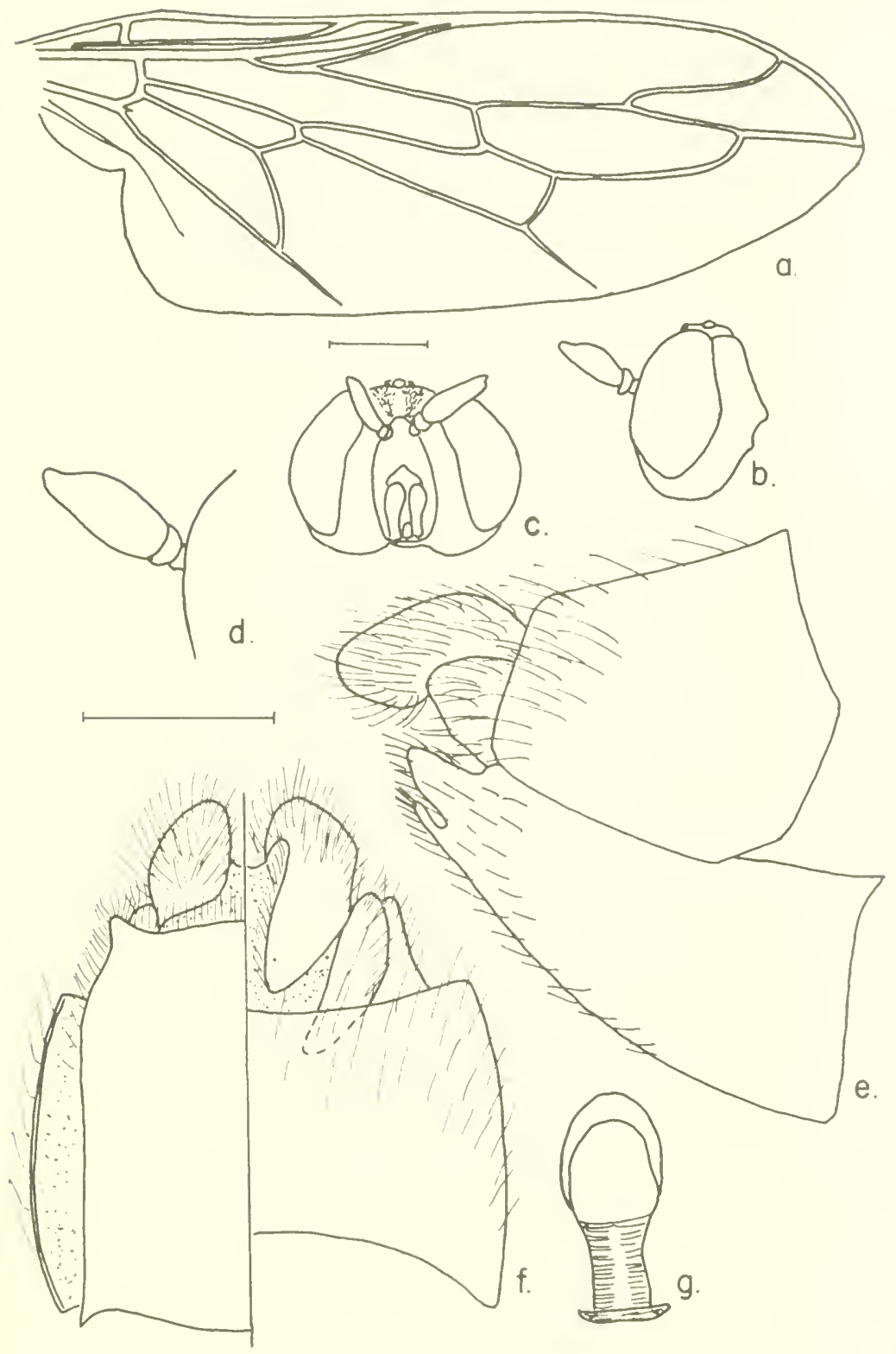

Figure 180.-Belosta telfordi, new species, female: $a$, wing; $b$, lateral aspect of head; $c$, frontal aspect of head; $d$, enlarged detail of antenna; $f$, ventral left and dorsal right aspect of 8 th and 9 th segments; $e$, lateral aspect of 8 th and 9 th segments; $g$, spermatheca. 

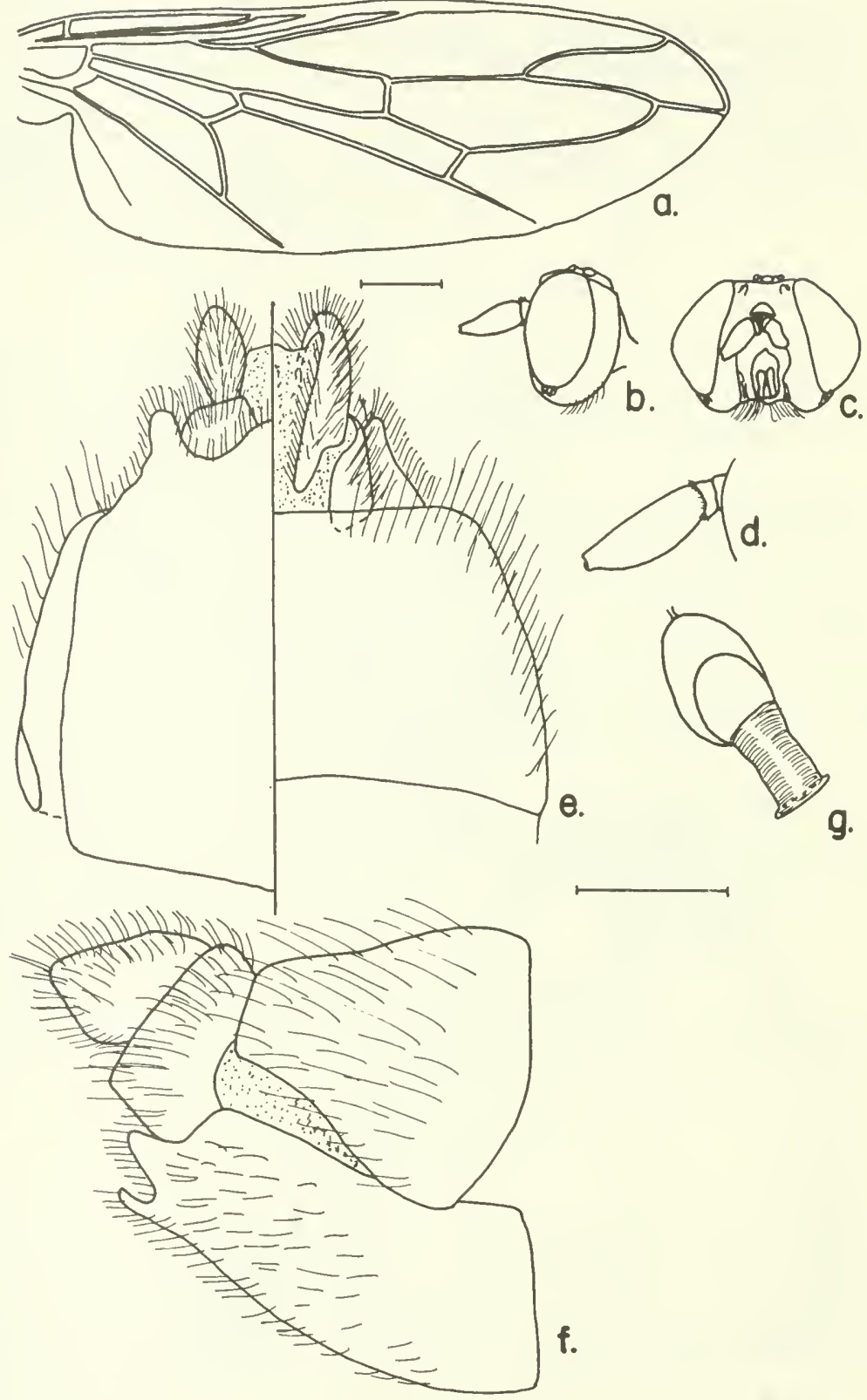

Figure 181.-Belosta termitophaga, new species, female: $a$, wing; $b$, lateral aspect of head; $c$, frontal aspect of head; $d$, enlarged detail of antenna; $e$, ventral left and dorsal right aspect of 8 th and 9 th segments; $f$, lateral aspect of 8 th and 9th segments; $g$, spermatheca. 
red-brown with white hairs. Wing hyaline, veins brown; halter elongate, stem red-brown, knob red-brown above, cream below. Legs with yellow-brown femora, tan tibiae, darker tarsi.

Abdomen red-brown with white intersegmental membranes which are dark along the midline. Eighth segment red-brown, sternum long, sloping with a trilobed posterior margin. Accessory gland with a flat flange and only about twice as long as wide; see figure for details.

MaLe.-Unknown.

Length: Female body 5.6-6.5 mm., wing 4.4-5.5 mm.

Type-locality: Tucson, Arizona; 12 April 1924 (A. A. Nichol) from Kalotermes hubbardi nest, reared.

Holotype: Female (USNM) 68004.

Paratypes: $3 \circ \%$, same data as type; 1 ㅇ, Tucson, Arizona, 13 April 1925 (C. 'T. Vorhies) from Kalotermes hubbardi nest. One paratype (USNM), remainder (UAriz).

188. Belosta viticolapennis, new species

FIgURE 182

Male.-Head red-brown; eyes brown above, black-brown below; frons cream with a tan triangle above the antenna, area between oral opening and eyes cream; mouthparts atrophied; palpi brown, bulbus; ocellar triangle prominent, ocelli clear; antennae light brown, shorter than other species, third segment diamond-shaped, over three times as long as first two segments combined; see figure for details.

Thorax dorsum red-brown, shining, with very short scalelike hairs, humeral and supra-alar calli cream; pleural areas red-brown. Wings hyaline, veins brown, R4 branching narrowly from R5 before curving to edge of wing; halter stem brown, knob white with tan rib and ventral surface. Legs: femora brown with cream knees, remainder brown.

Abdomen segments red-brown with white posterior membranous borders. Ninth tergum blocky, sternal spines sparse, stiff. Aedeagus with parameres extremely long and tendril-like; see figure for details.

Female.-Unknown.

Length: Male body $3 \mathrm{~mm}$., wing $2.2 \mathrm{~mm}$.

Type-locality: Williams, Arizona; 17 July (H. S. Barber).

Holotype: Male (USNM) 68006.

\section{Genus Propebrevitrichia, new genus}

Type-species, Propebrevitrichia turneri, new species. The genus Propebrevitrichia closely resembles the genus Brevitrichia; it differs in the point of branching of vein $\mathrm{R} 4$ which forks from beyond the middle of the closed cell R5 and by the elongate pointed female eighth sternum which is longer than the tergum. The members of this genus are found in the Ethiopian region. 

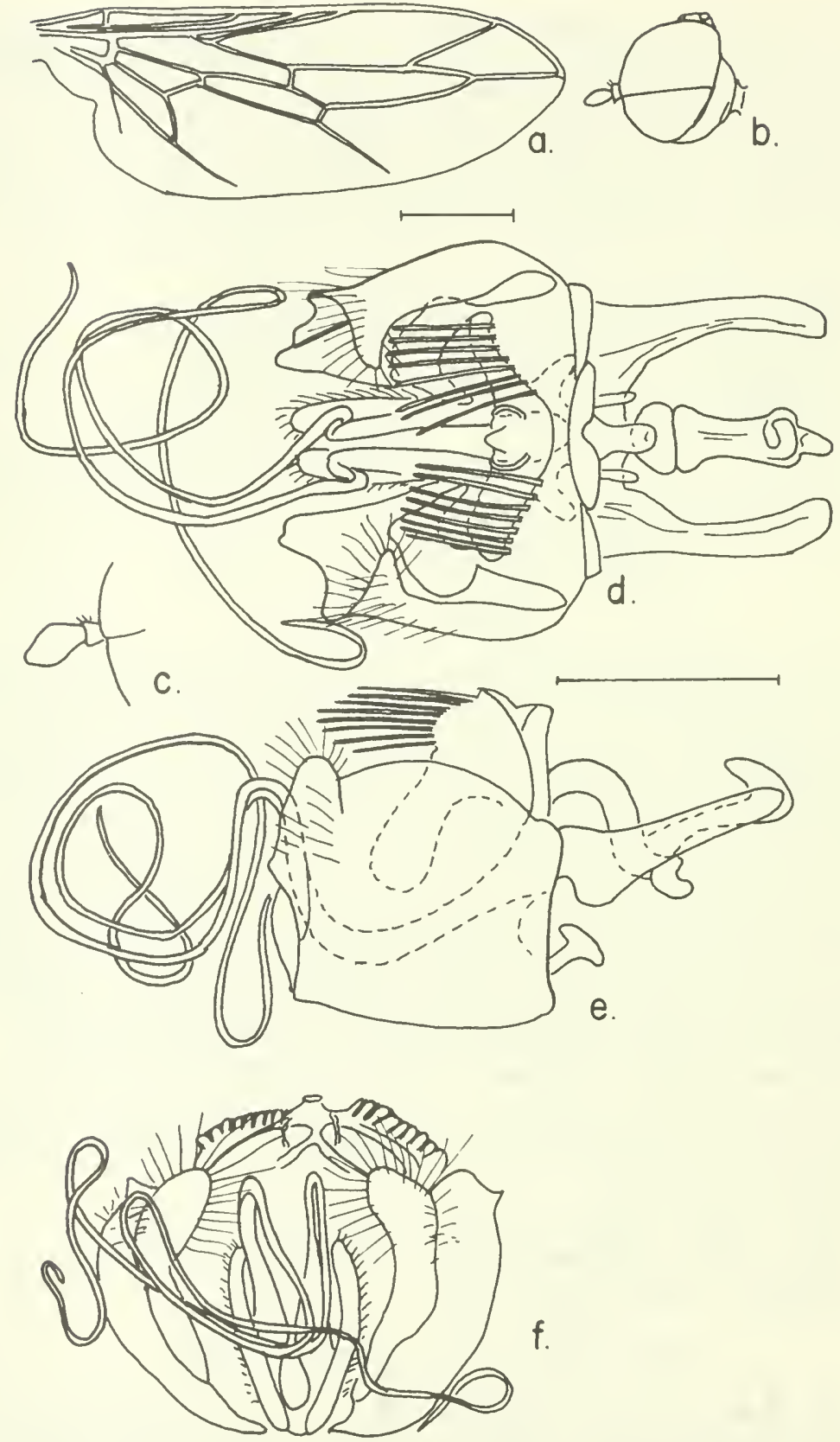

FIGURE 182.- Belosta viticolapennis, new species, male: $a$, wing; $b$, lateral aspect of head; $c$, enlarged detail of antenna; $d-f$, ventral, lateral, and posterior aspects of terminalia. 


\section{Key to Species of Propebrevitrichia}

1. Males . . . . . . . . . . . . . . . . . . . . 2

Female frons broad, twice the width of the ocellar triangle, abdomen redbrown covered with tan scales; segments $1-5$ with white posterior bands; Sth sternum elongate, orange-red, exceding the dorsum; 9th tergum with 3 stiff spines... . . . . . . . P. turneri, new specic

2. Thorax black-brown dusted gray pollinose; abdomen dark red-brown, dusted gray pollinose, posterior membranes white or tan; 9th tergite with basal third dark remainder white with two dark spots, all dusted gray pollinose

P. stuckenbergi, new species

Thorax red-brown, covered with golden brown seales bordered on either side of the midline by two brown bands, abdomen red-brown covered with tan seales, half of segments 2 and 3 white, remainder of segments white dorsally; ninth tergum with basal portion brown, covered with brown seales, remainder white . . . . . . . . P. turneri, new species

\section{Propebrevitrichia stuckenbergi, new species}

\section{FIGURE 183}

MaLe.-Head black-brown; eyes light brown above, dark brown below; frons dusted gray pollinose, wide at the base narrowing rapidly, a shallow pit just below the halfway point between the ocellar
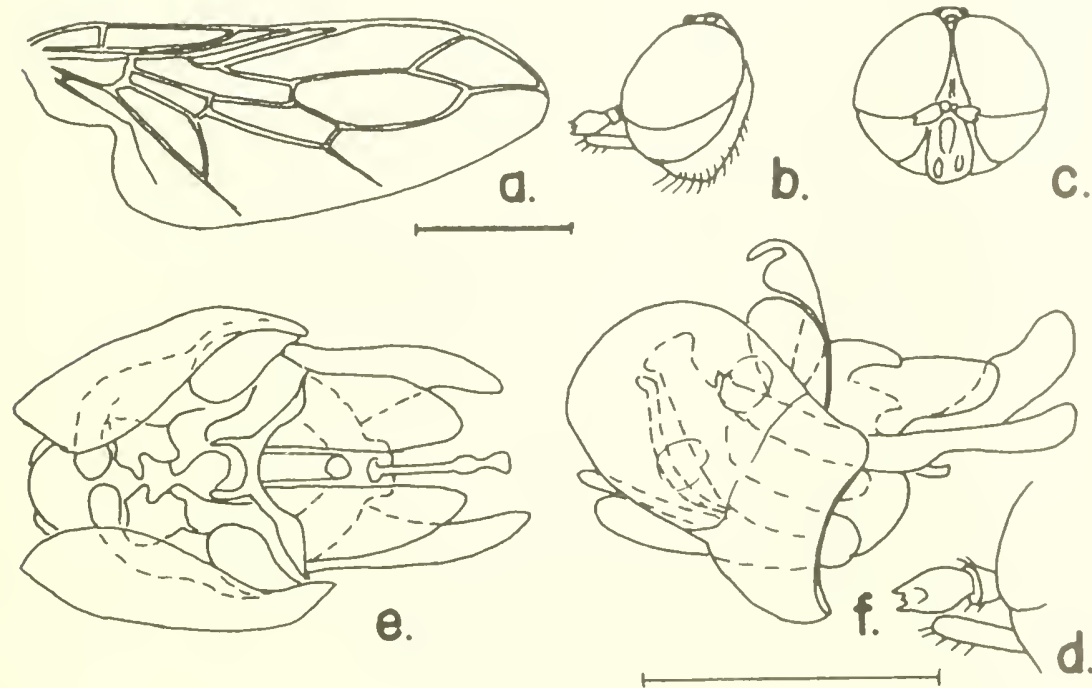

Figure 183.-Propebrevitrichia stuckenbergi, new species, male: $a$, wing; $b$, lateral aspect of head; $c$, frontal aspect of head; $d$, enlarged detail of antenna; $e, f$, ventral and lateral aspects of terminalia.

triangle and antemue; ocellar triangle black-brown, dusted gray pollinose, large and prominent; ocelli dark; back of head dusted gray pollinose; mouthparts well developed, rostrum long and slender, 
flabellum not expanded; palpi short. Antennae black-brown, first segment short, second twice as long and wide as first, third segment pear-shaped with a bitruncated terminal portion with a median peg; see figure for details.

Thorax dorsum black-brown, dusted gray pollinose; humeral callus brown with a cream lateral margin; scutellum black-brown; pleura black-brown. Wings milky white, veins tan along anterior portion nearly white behind; halter stem brown, knob immaculately white. Legs all black-brown dusted pollinose, with tan joints.

Abdomen second segment dark red-brown dusted pollinose, with a narrow white or tan posterior membranous margin, remaining segments dark red-brown dusted pollinose, with large crescents of white membrane on dorsal portion occupying over half the length of the segment, sterna sclerotized. Ninth tergum with dark brown basal third, remainder white with two brown spots at about the midportion, aedeagus not exposed; see figure for details.

Female.-Unknown.

Length: Male body $2.2 \mathrm{~mm}$., wing $1.7 \mathrm{~mm}$.

Type-locality: Karroo, at Junction of Calvinia-Sutherland Rd. near Inverdoorn Ceres, w. Cape Prov., [Republic of] South Africa; 23 October 1959 (B. and P. Stuckenberg).

Holotype: Male (NMP).

190. Propebrevitrichia turneri, new species

FIGURE 184

MaLE.-Head brown; eyes tan above, light brown below; frons small, triangular, with a median groove, covered with light brown scales; back of head convex laterally, covered with tan scales; genae covered with brown scales and long hairs; mouthparts brown, long; palpi tan, half the length of the rostrum; ocellar tubercle dark brown, covered with tan scales; ocelli orange. Antennae with first two segments brown, short, second twice as large as the first; third segment red-brown, latero-basal portion orange, covered with scales, ending in two points.

Thorax red-brown, covered with golden brown scales, with two brown bands laterad of the midline; humeral and supra-alar calli tan; pleural areas red-brown, covered with tan scales. Wings smoky, iridescent when reflecting light; veins tan; halter stem tan, knob white. Legs with femora red-brown, eovered with tan scales, knees tan; tibiae and tarsi red-brown with tan scales.

Abdomen second segment red-brown, covered with tan scales, a membranous white posterior border; third segment with anterior half red-brown scaled, posterior half white, membranous; fourth segment nearly all white, remaining segments white; ninth tergum 
white with basal portion brown scaled, aedeagal prongs not exceeding side pieces; see figure for details.

Female.-Head red-brown; eyes orange-brown; postocular ridge narrow; frons broad, swollen, with a median depression extending between antennae and median ocellus, with scattered hairs; genal areas to back of head yellow; other areas covered with golden scales. Ocellar tubercle covered with golden scales, set off from frontal area; ocelli red-brown. Antenna as in male.

Thorax as in male.

Abdomen red-brown covered with tan scales segments three to five with posterior bands of white remainder without, eighth segment orange-red, subshining, elongate; sternum longer than tergum, coming to a point; ninth tergum with three stiff spines and a few hairs; see figure for details.

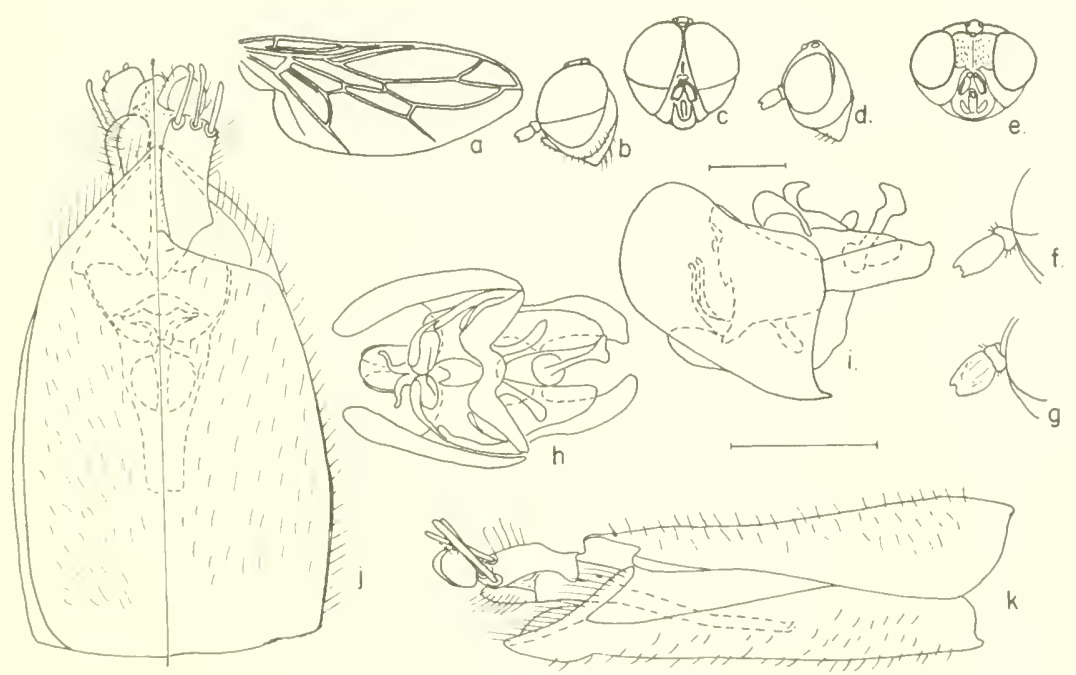

Figure 184.-Propebrevitrichia turneri, new species, male, female: $a$, wing; $b, d$, lateral aspects of male and female heads; $c$, $e$, frontal aspects of male and female heads; $f, g$, enlarged details of male and female antennae; $h, i$, ventral and lateral aspects of malc terminalia; $j$, ventral left and dorsal right aspect of female 8 th and 9 th segments; $k$, lateral aspect of female 8 th and 9 th segments.

Length: Male body $2.5 \mathrm{~mm}$., wing $1.8 \mathrm{~mm}$.; female body $2.8 \mathrm{~mm}$., wing $1.9 \mathrm{~mm}$.

Type-locality: Mossel Bay, s. Cape Prov., [Republic of] South Africa; 4 December 1938 (R. E. 'Tumer).

Holotype: Male (BMNH).

Allotype: Female Mossel Bay, s. Cape Pror., [Republic of] South Africa; 20 Oetober 1938 (R. E. 'Turner). 
Paratypes: $7 \sigma^{7} \sigma^{7}, 5$ ㅇ 우, Mossel Bay, s. Cape Prov., [Republic of] South Africa, October, December 1938 (R. E. Turner); 1 \&, Worcester, s.w. Cape Prov., [Republic of] South Africa, December 1933 (R. E. Turner) all (BMNH).

\section{Genus Heteromphrale Kröber}

Heteromphrale Kröber, 1937, p. 221.

Type-species Pseudatrichia chilensis Kröber (original designation). The genus Heteromphrale is closely related to the preceding genus and Brevitrichia but may be distinguished from Brevitrichia by the elongate female eighth sternum and from Propebrevitrichia by the basal forking of vein $\mathrm{R} 4$. The male genitalia is more robust than in the other two genera. This genus is Neotropical in distribution.

191. Heteromphrale cyanops (Edwards), new combination

Figure 185

Pseudomphrale cyanops Edwards, 1932, p. 259.

This species is distinguished by the wing venation which is similar to Brevitrichia and by the much heavier ninth tergum, short peni and aedeagal parameres, and larger heavier internal structures associated with the aedeagal syringe; see figure for details.

Length: Male body $2.5 \mathrm{~mm}$., wing $2 \mathrm{~mm}$.

Type-locality: Montevideo, Uruguay; 21 January 1927 (F. and M. Edwards).

Type: (BMNH).

\section{Heteromphrale chilensis (Kröber)}

Figure 186

Pseudatrichia chilensis Kröber, 1928b, p. 31.

Heteromphrale chilensis (Kröber), Kröber, 1937, p. 221.

This species is recognized on the basis of the wing venation which is similar to that of Brevitrichia and on the basis of the spines on the ninth tergum. The long eighth sternum separates it from species of Brevitrichia; see figure for details.

Length: Female body $5 \mathrm{~mm}$., wing $2.6 \mathrm{~mm}$.

Type-locality: Concepción, Chile (P. Herbst).

Type: (ZMH).

\section{Genus Prepseudatrichia, new genus}

Type-species Prepseudatrichia mateui, new species. The genus Prepseudatrichia is most interesting in that the head and thorax are distinctly Pseudatrichia-like, while the wings are typical of Scenopinus. Both the male and female genitalia are distinctive. 


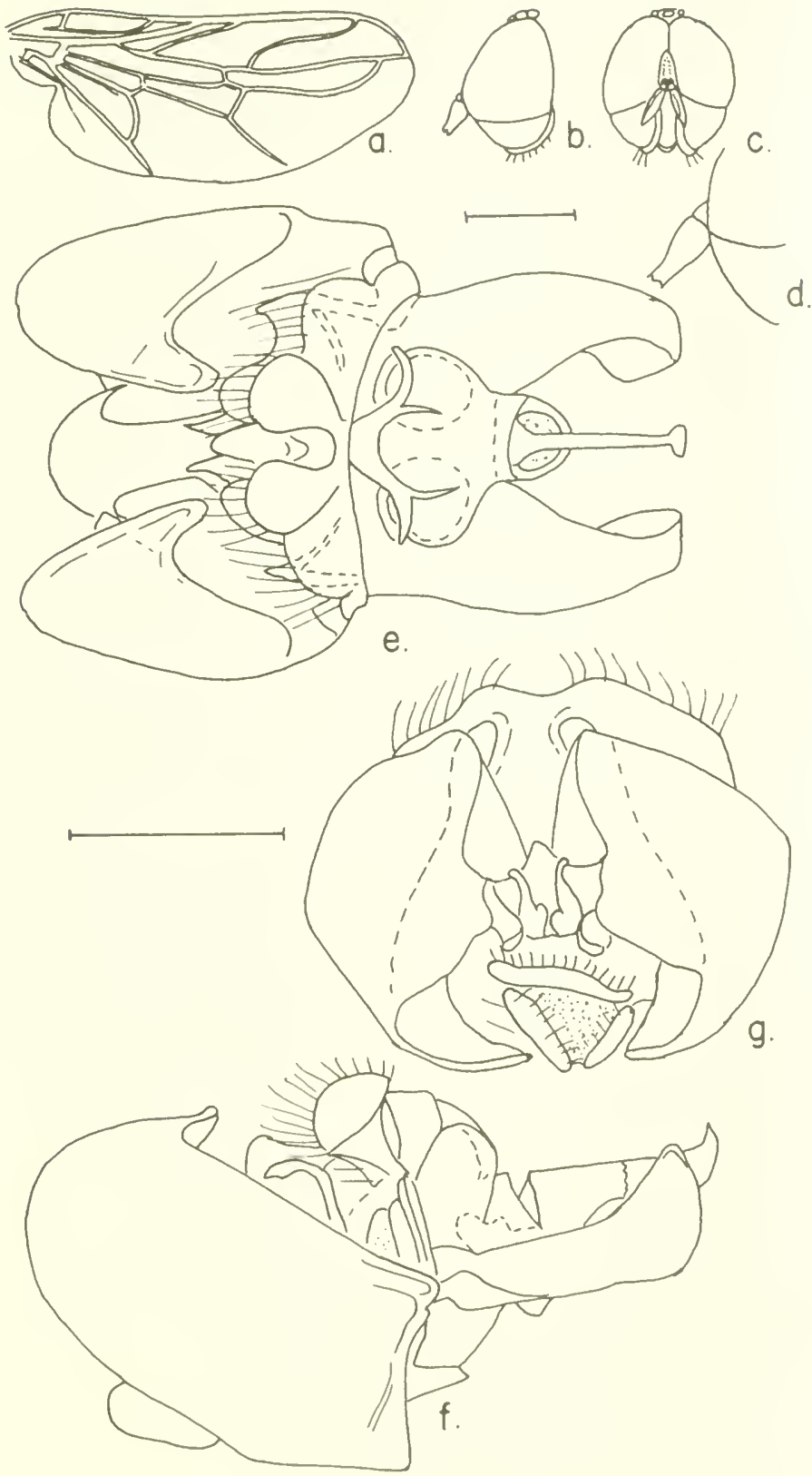

Figure 185.- Heteromphrale cyanops (Edwards), male: $a$, wing; $b$, lateral aspect of head; $c$, frontal aspect of head; $d$, lateral aspect of antenna; $e-g$, ventral, lateral and posterior aspects of terminalia. 

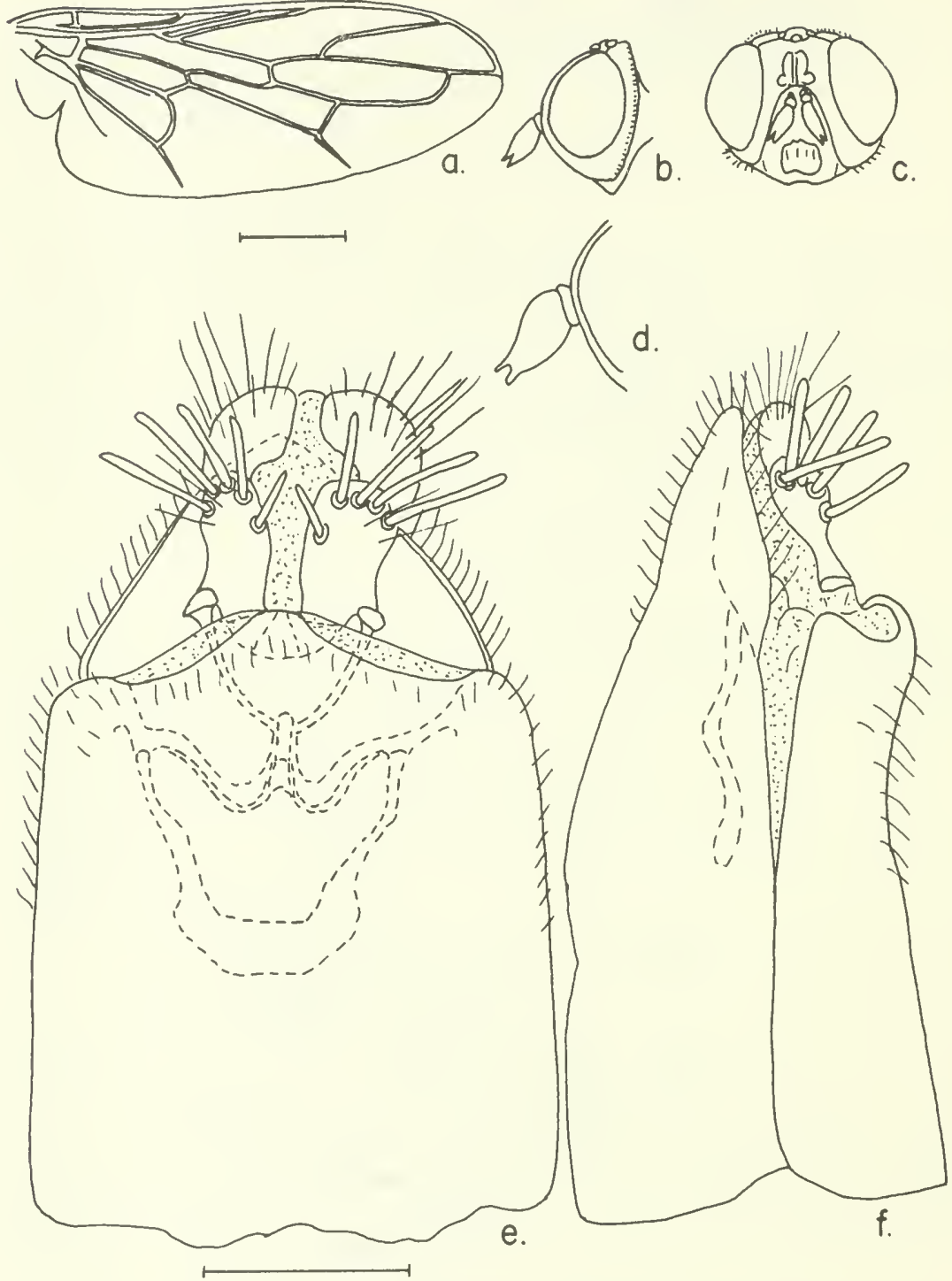

Figure 186.-Heteromphrale chilensis (Kröber), female: $a$, wing; $b$, lateral a spect of head; $c$, frontal aspect of head; $d$, enlarged detail of antenna; $e$, dorsal aspect of 8 th and 9 th segments, sternum and bursal structures outlined; $f$, lateral aspect of 8 th and 9 th segments.

This genus has been reared from wood borers attacking Acacia trees and is Ethopian in distribution. 


\section{Key to the Species of Prepseudatrichia}

1. Females . . . . . . . . . . . . . . . . . . 2

Males, halter knob black-brown, thorax black, striated, legs straw ycllow darkening to orange-brown posteriorly . . . . . P. mateui, new species

2. Thorax black, striated

Thorax black with green and purple metallic glints, halter knob red-brown, velvety, legs straw yellow with tarsi red-brown. . P. violacea, new speeies

3. Halter knob mahogany-brown, legs reddish, antemne orange, cell $\mathrm{Cu}$ ending abruptly.

P. stenogaster Séguy

Halter knob red-brown to black, shining, legs straw yellow darkening to orange-brown posteriorly, cell $\mathrm{Cu}$ long ending in a point

P. mateui, new species

\section{Prepseudatrichia mateui, new species}

Frgure 187

Male.-Head black, longer than high; eyes red-brown above, black-brown below, close but not meeting on the midline; frons very narrow, slightly swollen above the antennae, a median groove above; ocellar tubercle prominent; ocelli clear; a white patch above the antennal bases; oral opening large; mouthparts cream, well developed, with long hairs on flabellum; palpi long and slender. Antenna blackbrown; first segment short; second longer than first; third granular, truncated not twice as long as wide; see figure for details.

Thorax black, striated; dorsoventrally compressed, particularly in prescutal area; a pollinose patch above the humeral callus; humeral callus red-brown, narrow; pleural areas black-brown, shallow, the front and middle legs more widely separated than normal. Wings hyaline, veins brown, similar to Scenopinus; halter stem brown to black-brown, knob red-brown to black, shining. Front leg straw yellow with brownish yellow tarsus darkening distally; middle leg with coxa and femur straw yellow tibia and tarsus brownish yellow darkening distally; hind leg with all segments orange-brown, first tarsal segment yellowish, rest red-brown.

Abdomen second segment red-brown to black, segments three and four with white posterior bands extending to lateral margins. Ninth segment red-brown to black, hairy. Both external and interual structures separate this species from all others; see figure for details.

Fenale.--Head black, l'ugose, longer than high; eyes yellow-brown; with prominent postocular ridge, subshining; frons broad, rugose, with a bulge above the antennae, a white patch above the antennal base, wider than the ocellar trimgle which is not prominent; ocelli brown, monthparts as in the male. Antennae black-brown, third segment pear-shaped, darker at tip; see figure for details.

Thorax as in male; legs as in male but darker. 


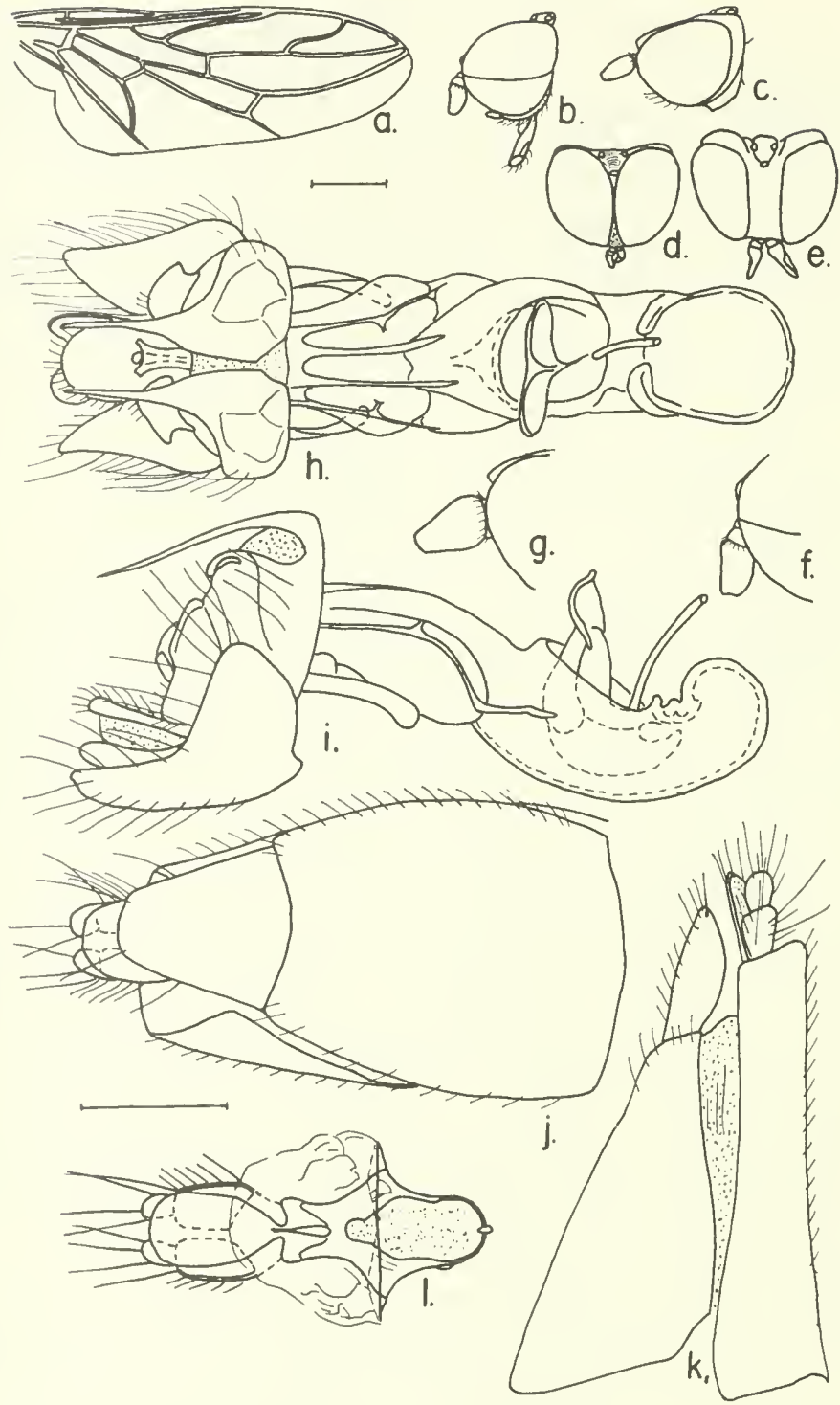

Figure 187.-Prepseudatrichia mateui, new species, male, female: $a$, wing; $b, c$, lateral aspects of male and female heads; $d, e$, dorsal aspects of male and female heads; $f, g$, enlarged details of male and female antennae; $h, i$, ventral and lateral aspects of male terminalia; $j$, ventral aspect of female 8 th sternum and 9 th segment; $k$, lateral aspect of female 8 th and 9 th segments; $l$, female 9 th sternum and bursa, floor of cavity outlined.

Abdomen red-brown to black. Eighth segment elongate, tip of sternum and ninth tergum with a few long hairs; bursa with a large oval membranous area; see figure for details. 
Length: Male body $5 \mathrm{~mm}$., wing $2.3 \mathrm{~mm}$.; female body $4.5 \mathrm{~mm}$., wing $2.3-2.7 \mathrm{~mm}$.

Type-locality: 'Temba, Rgueibat, Sahara; 1 August 1958 (J. Mateu) emerged in the laboratory from a tumel in the wood of Acacia raddiana Sgn. parasitized by wood-boring larvae.

Holotype: Male (MNHN).

Allotype: Female, Oued el Arfejd, Sahara Occ.; 11 April 1962 (J. Mateu) emerged in the laboratory, also from tunnels in wood of Acacia raddiana.

Paratypes: 1 o $\sigma^{7}$, Mare (=pond) de Biliharo Ennedi (Mourdi), North Chad, 12 January 1959 (J. Mateu); 1 or, Oued Trick (Osugarta Mountains), 7 April 1961 (J. Mateu) parasite of Anthaxia angustipennis (Col. Buprestidae); deposited in (MNHN); 1 o', Beni Abbes, Sahara (Algeria), 14 May 1962 (J. Mateu) retained by me (USNM).

All of these flies were reared from branches of Acacia which contained wood-boring larvae, mainly Buprestidae, Bostrichidae and Cleridae.

\section{Prepseudatrichia stenogaster (Séguy), new combination}

Figure 188

Scenopinus stenogaster Séguy, 1931, p. 114.

This species, originally described in the genus Scenopinus, resembles that genus only in the character of the wing, the head is longer than high, the thorax dorso-ventrally compressed and the round slim abdomen agrees with Pseudatrichia in appearance. It is placed in this new genus on the basis of agreement with females of the other species; see figure for details.

Length: Female body $5.5 \mathrm{~mm}$., wing $2.25 \mathrm{~mm}$.

Type-locality: Nova Choupanga près Chemba, Zambezi, Mozambique; July 1929 (P. Lesne) collected as a larva from the trunk of Sterculia, pupated 6 July, adult emerged micl-July.

Type: (MNHN).

\section{Prepseudatrichia violacea, new speeies}

FigURE 189

FEmale.-Head blackish brown, longer than high; eyes light brown, probably darker in life; postocular ridge moderately wide, prominent; frons narrow, only as wide as ocellar triangle, rugose, lower along eye margin than center, reflecting purple glints, a flattened area above antennae ending in a point one-third the distance to the median ocellus. Ocellar triangle prominently set off. Mouthparts light brown, palpi tan, well developed filling the oral cavity. Antennae with first two segments dark brown, short; third segment lost. 

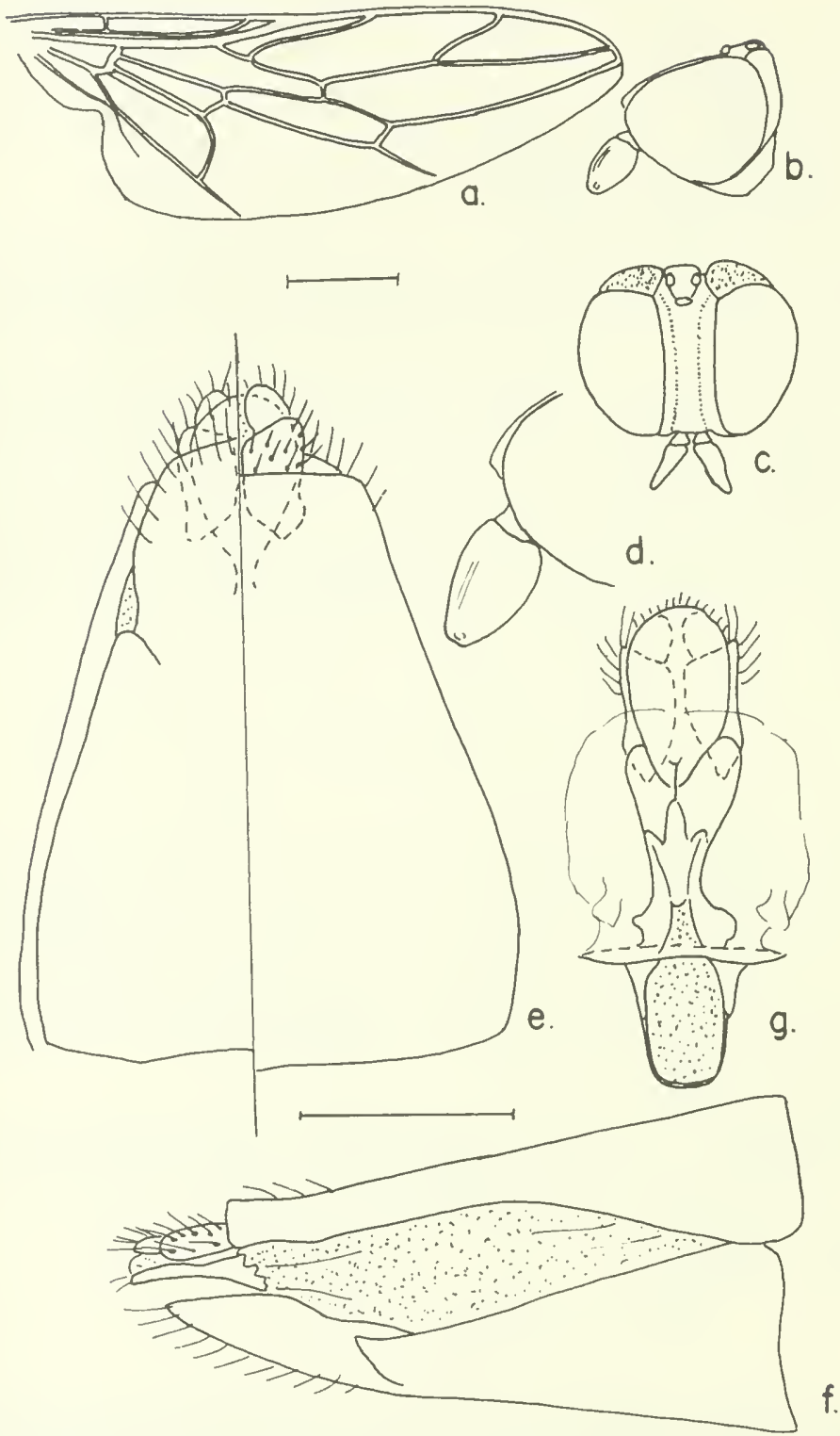

Figure 188.-Prepseudatrichia stenogaster (Séguy), female: $a$, wing; $b$, lateral aspect of head; $c$, dorsal aspect of head; $d$, enlarged detail of antenna; $e$, ventral left and dorsal right aspects of 8 th and 9 th segments; $f$, lateral aspect of 8 th and 9 th segments; $g, 9$ th sternum and bursa, floor of cavity outlined. 

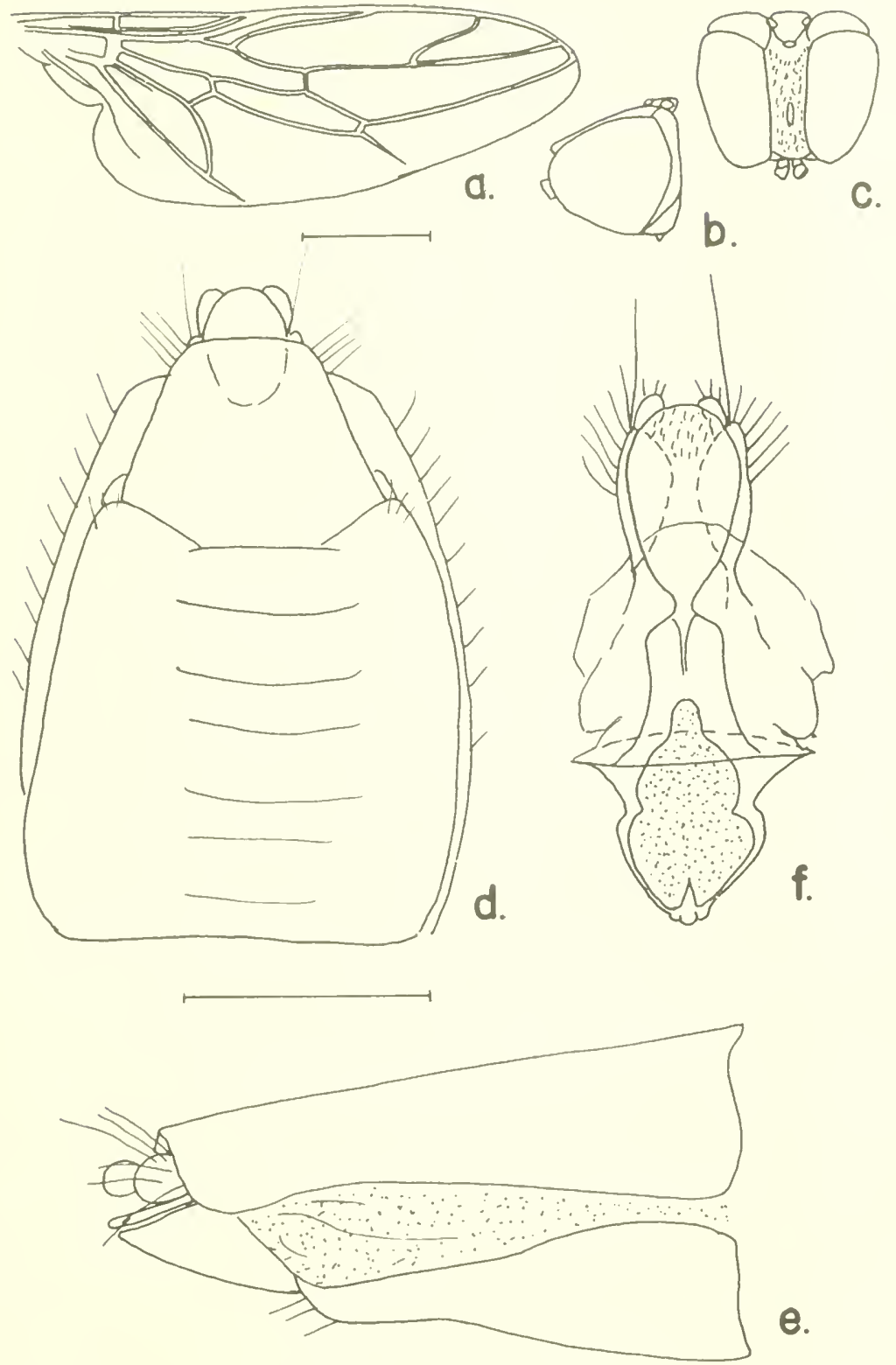

8.

Figure 189.- Prepseudatrichia violacea, new species, female: $a$, wing; $b$, lateral aspect of head; $c$, dorsal aspect of head; $d$, ventral aspect of 8 th sternum and 9 th segment; $e$, lateral aspect of 8 th and 9 th segments; $f$, 9th sternum and bursa, with floor of cavity outlined. 
Thorax compressed, dorsum black with brilliant green and purple metallic glints, prescutellar area depressed, lateral margins of dorsum and pleural areas with sparse, white bulbous hairs particularly dense above the humeral callus; humeral and supra-alar calli light brown; scutellum black with purple glints. Wings hyaline, veins brown; halter stem brown, knob red-brown, velvety. Front and middle legs with femora and tibiae yellow, tarsi red-brown; hind legs missing.

Abdomen segments red-brown, eighth segment elongate, tapered; see figure for details of sternum and bursal plate.

MaLE.-Unknown.

Length: Female body $4 \mathrm{~mm}$., wing $2.3 \mathrm{~mm}$.

Type-locality: Temba, Tagant Mauriton (Chad), (J. Mateu) on Acacia scorpiodes.

Holotype: Female (MNHN).

\section{Genus Seguyella, new genus}

Type-species Omphrale galactica Séguy. The genus Seguyella resembles members of the genus Scenopinus but differs in venation of the wing, male and female terminalia, and in having a notched third antennal lobe. Vein R5 extending straight from the cross vein to before the tip of the wing and vein M1 +2 parallel or slightly diverging to end in the wing margin well behind the tip of the wing. Vein M3 + Cu1 short or missing beyond $m$ cross vein. The members of this genus are found in the Ethiopian and Oriental regions.

\section{Key to the Species of Seguyella}

1. Males, eyes contiguous along midline, wings hyaline . . . . . . . . . . 2

Females, eyes separated by broad frons, wings brown . . . . . . . . . 3

2. Halter knob brown, elongate, abdomen with dorsal portion of segments $3-7$ white, terminalia black .......... S. galactica (Séguy)

Halter knob red-brown, shining, rounded, abdomen with dorsal portion of third segments red-brown, segments $4-7$ white, terminalia red-brown

S. turneri, new species

3. Thorax black covered with small flat gray scales, halter knob orange-brown, wing black-brown, abdomen red-brown covered with flat gray scales (India)

S. chinchona, new species

Thorax red-brown pollinose, halter knob tan pollinose, wing smoky brown, abdomen red-brown, granular . . . . . . S. turneri, new species

196. Seguyella chinchona, new species

Figure 190

Female.-Head black, higher than long; eyes black-brown; frons shining, width of ocellar triangle below and flaring dorsally around ocellar triangle to back of eyes; ocellar tubercle black, pollinose with red-brown ocelli; oral opening covered with silvery pile which extends 

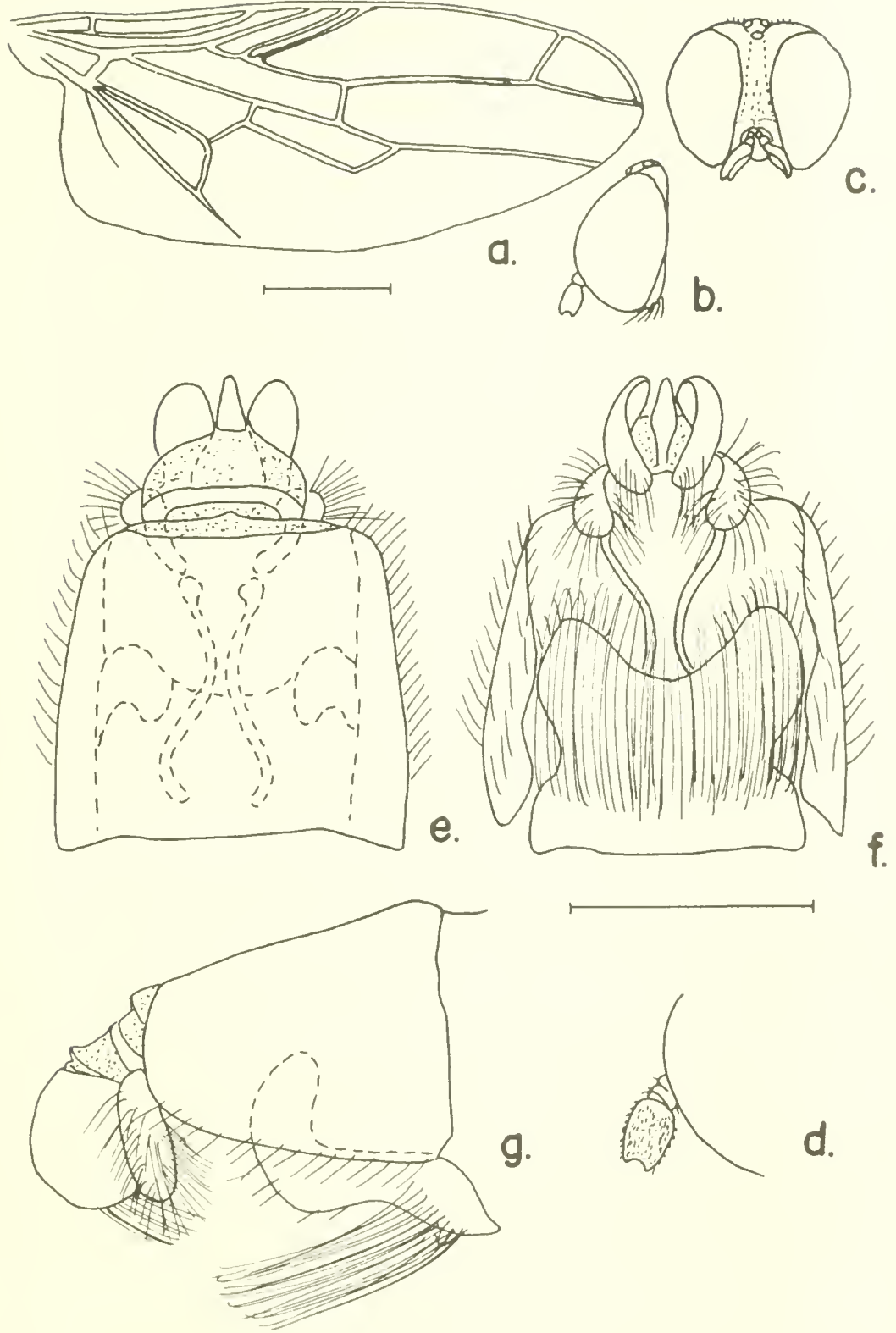

d.

Figure 190.-Seguyella chinchona, new species, female: $a$, wing; $b$, lateral aspect of head; $c$, frontal aspect of head; $d$, enlarged detail of antenna; $e$, dorsal aspect of 8 th and 9 th segments; $f$, ventral aspect of 8 th and 9th segments; $g$, lateral aspects of 8 th and 9 th segments. 
over the antennal bases, mouthparts brown, filling the oral cavity; palpi two-thirds as long as mouthparts; back of head concave. Antennae red-brown; first two segments short subequal; third segment pilose, cupped on end, less than twice as long as wide; see figure for details.

Thorax dorsum black, covered with small flat gray scales, humeral and supra-alar calli red-brown; pleural areas dark red-brown. Wings black-brown, very dark, veins black-brown, M1 +2 ending behind the tip of the wing and M3 + Cu1 ending at the $\mathrm{m}$ cross vein; halter stem red-brown, knob orange-brown. Legs orange-brown.

Abdomen red-brown covered with flat gray scales dorsally, eighth segment with dorsum much longer than sternum, sternum with a brush of long hairs from proximal margin, distal margin turning upward. Ninth segment pendulous, hairy basally; see figure for details.

MALE.-Unknown.

Length: Female body $3.2 \mathrm{~mm}$., wing $2.4 \mathrm{~mm}$.

Type-locality: Chinchona, Anamali Hills, S. India; (3500 ft.) May 1950 (P. S. Nathan).

Holotype: (CNC) 8630 .

197. Seguyella galactica (Séguy), new combination

FigURE 191

Omphrale galactica Séguy, 1938, p. 334.

This species can be distinguished by its peculiar wing venation, the sharply pointed ninth terga and the broadly flaring tenth sternum; the penis consists of two short straight prongs with short constricted tips; see figure for details.

Length: Male body $1.8 \mathrm{~mm}$., wing $2.2 \mathrm{~mm}$.

Type-locality: Elgon Saw Mill, Camp II on the east slope, Mt. Elgon (2470 m.), Kenya (C. Aranbourg, P. A. Chappius and R. Jeannel).

Type: (MNHN).

\section{Seguyella turneri, new species}

Figure 192

Female.-Head orange-brown; eyes red-brown; frons red-brown, broad and shining, with a lighter median triangle, widest at the base and narrowing to the median ocellus; frons continuous with postocular flange and distance from eye margin to ocellar tubercle nearly as wide as tubercle itself; ocellar tubercle orange-brown, pollinose; ocelli red-brown. Mouthparts well developed; antennae red-brown, first segment short; second twice the size of first; third twice as long as 


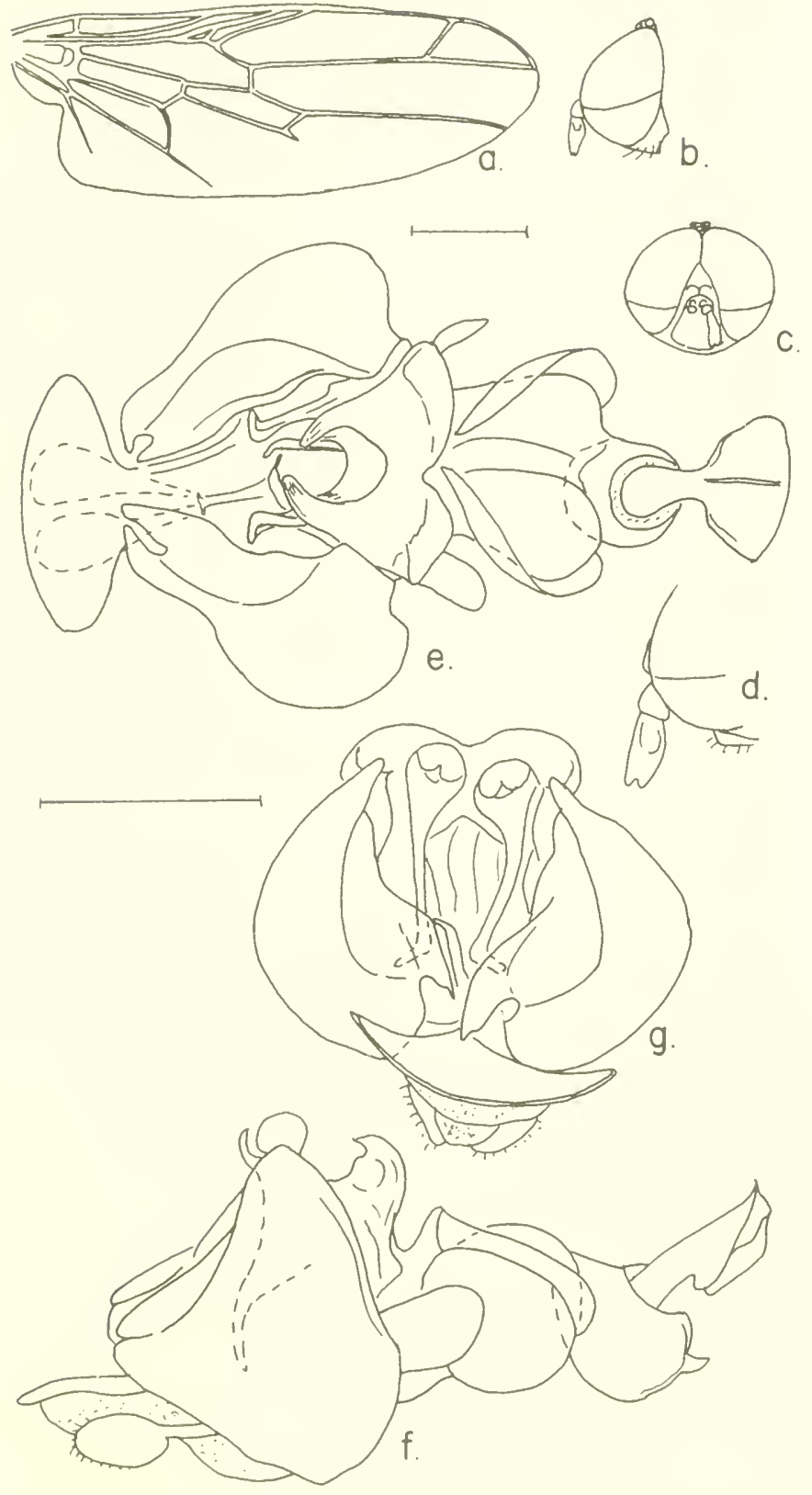

Figure 191.-Seguyella galactica (Séguy), male: $a$, wing; $b$, lateral aspect of head; $c$, anterior aspect of head; $d$, enlarged detail of antenna; $e-g$, ventral, lateral and posterior aspects of terminalia. 


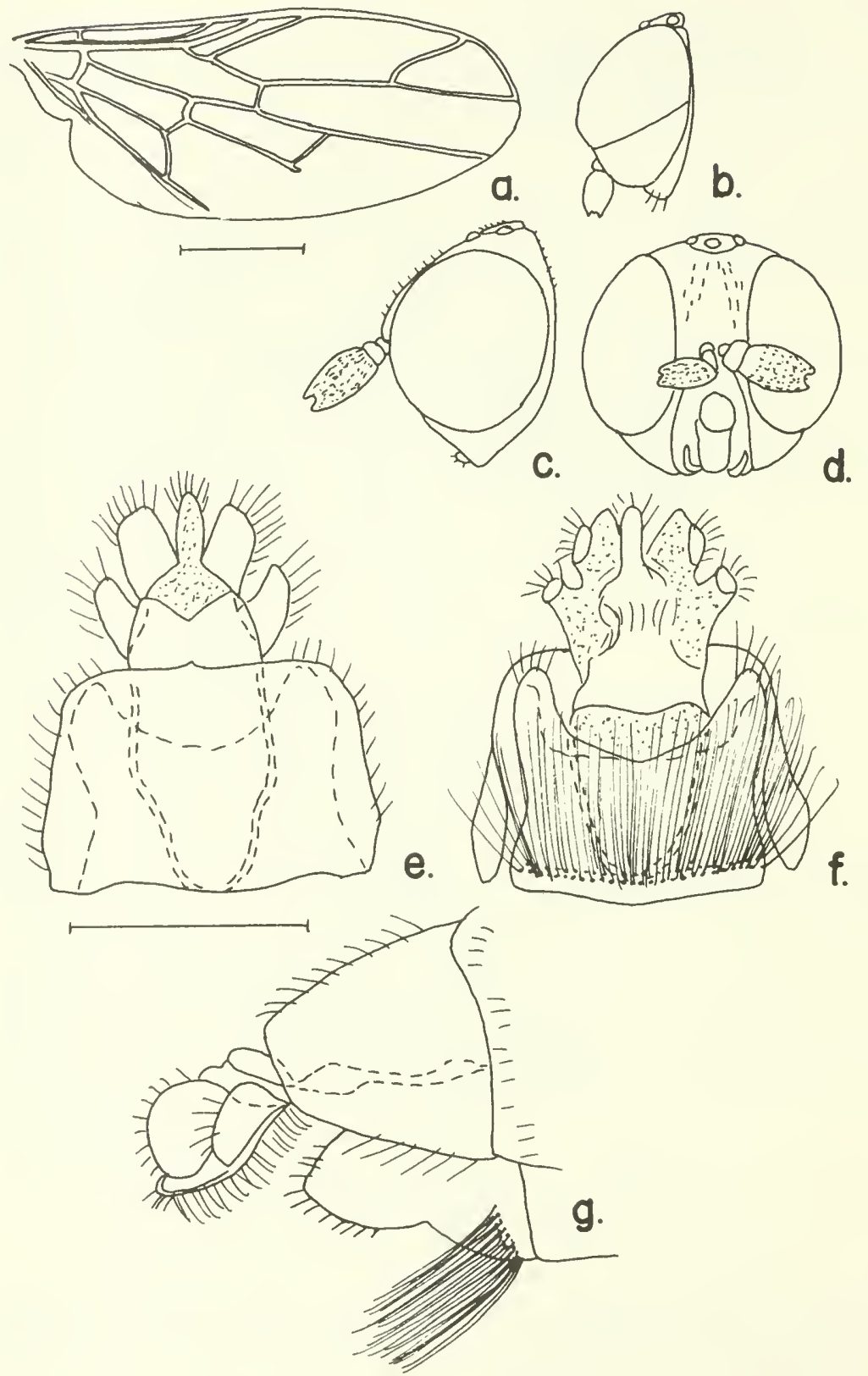

Figure 192.- Seguyella turneri, new species, male, female: $a$, wing; $b$, lateral aspect of male head; $c$, enlarged lateral aspect of female head; $d$, enlarged frontal aspect of female head; $e$, dorsal aspect of female 8th and 9th segments; $f$, ventral aspect of female 8 th and 9 th segments; $g$, lateral aspect of female 8 th and 9 th segments. 
first two combined, covered with short hairs, ending in two points; see figure for details.

Thorax dorsum red-brown, pollinose; humeral callus orange; scutellum orange-brown, pollinose; pleura red-brown. Wings smoky brown, veins brown, faint posteriorly; vein $\mathrm{Ml}+2$ ending behind the tip of the wing, vein $\mathrm{M} 3+\mathrm{Cu} 1$ ending just beyond the $\mathrm{m}$ cross vein; halter stem orange-brown, knob tan, pollinose. Legs light red-brown throughout.

Abdomen red-brown, granular; eighth tergum and sternum subequal, sternum with a basal band of long hairs. Ninth tergum fourlobed, drooping; see figure for details.

Male.-Very small, head black-brown; eyes red-brown, darker below; frons small triangular, red-brown above antennae darkening to black-brown; ocellar tubercle black-brown, prominent, granular. Antennae with first two segments red-brown, first small, second swollen, third segment dark red-brown swollen above and ending in two points; see figure for details.

Thorax dark red-brown. Wings hyaline, veins light tan, faint posteriorly; halter stem red-brown at base, cream below the knob which is red-brown and shining, very round. Legs uniform red-brown throughout.

Abdomen second segment red, segments three through six broadly banded with white (four bands), ninth tergum red-brown. The terminalia were lost on dissection so cannot be illustrated.

Length: Female body $2.5 \mathrm{~mm}$., wing $2 \mathrm{~mm}$.; male body $1.25 \mathrm{~mm}$, wing $1.1 \mathrm{~mm}$.

Type-locality: Mossel Bay, Cape Prov., [Republic of] South Africa, January 1922 (R. E. Turner).

Holotype: Female (BMNH).

Allotype: Male, same data.

\section{Genus Neopseudatrichia, new genus}

Type-species Neopseudatrichia kewi, new species. The genus Neopseudatrichia is closely related to Pseudatrichia which it resembles except for the male and female terminalia. The male ninth tergum short, not concealing the tenth segment, no comb of sternal hairs as in Pseudatrichia, aedeagus consists of a short median penis flanked by two short parameres, eighth stermum of female prolonged on the midline, ninth tergum with a tuft of stiff spines. This genus is limited to the Australian region.

Key to the Species of Neopseudatrichia

1. Females . . . . . . . . . . . . . . . . 2

Nales .

$313-16.50-69-20$ 
2. Wing hyaline, halter knob black, stalk of vein $\mathrm{R} 5+\mathrm{M} 1+2$ extending to wing tip on the line of $\mathrm{M} 1+2$. . . . . N. mariaensis (G. H. Hardy)

Wing hyaline, dusted brown granular, halter knob brown, elongate, granular, stalk of vein $\mathrm{R} 5+\mathrm{M} 1+2$ more nearly on a line with $\mathrm{R} 5$ to tip of wing .............. . . . . kewi, new species

3. Wing brown granular . . . . . . . . . . . . . . . 4

Wing hyaline, halter knob black, stalk of vein $\mathrm{R} 5+\mathrm{M} 1+2$ extending to tip of wing on the line of $\mathrm{M} 1+2$. . . . . . N. mariaensis (G. H. Hardy)

4. Halter knob red-brown, egg-shaped, stalk of vein $\mathrm{R} 5+\mathrm{M} 1+2$, extending to tip of wing on the line of vein R5, legs red-brown . . N. canei, new species Halter knob brown, granular, elongate pointed, vein $\mathrm{R} 5+\mathrm{M} 1+2$ extending to tip of wing, not on a direct line with vein R5, femora black-brown, remainder lighter . . . . . . . . . N. kewi, new species

199. Neopseudatrichia canei, new species

Figure 193

Pseudatrichia mariaensis Paramonov (not Hardy), 1955, p. 639.

MALE.-Head black-brown, longer than high; eyes black-brown, darker below, occupying most of head from the side view; frons shining, two fine rows of setae converging toward the midline from antennal bases to middle of frontal area; eyes separated by width of the median ocellus; ocellar tubercle prominent, black-brown, granular; ocelli black; antennae with first two segments black-brown, first twice as long as second, third segment missing; see figure.

Thorax dorsum black-brown, shining, with sparse white hairs; humeral and supra-alar calli red-brown; scutellum red-brown, shining; pleural areas red-brown, polished. Wings hyaline, with brown granulosis, veins brown; halter stem brown, knob red-brown, bluntly rounded, egg-shaped. Legs red-brown.

Abdomen segments black-brown with narrow white bands posteriorly; ninth tergum black-brown, shorter than tall, tenth segment much longer; aedeagus with two blunt lobes; see figure for details.

Female.-Unknown.

Length: Male body $4.2 \mathrm{~mm}$., wing $2.4 \mathrm{~mm}$.

Type-locality: Mt. Lofty (2334 ft.), South Australia; 15 January 1952 (H. M. Cane).

Holotype: Male (CSIRO).

200. Neopseudatrichia kewi, new species

FIGURE 194

Male.-Head black-brown, longer than high; eyes black, divided into larger upper and smaller lower facets, from side view area behind the eye extensive, back of head and back of ocellar tubercle silvery pilose above; postgena shining; frons with a slight median bulge bordered by two vittae which converge from above the antennal bases 

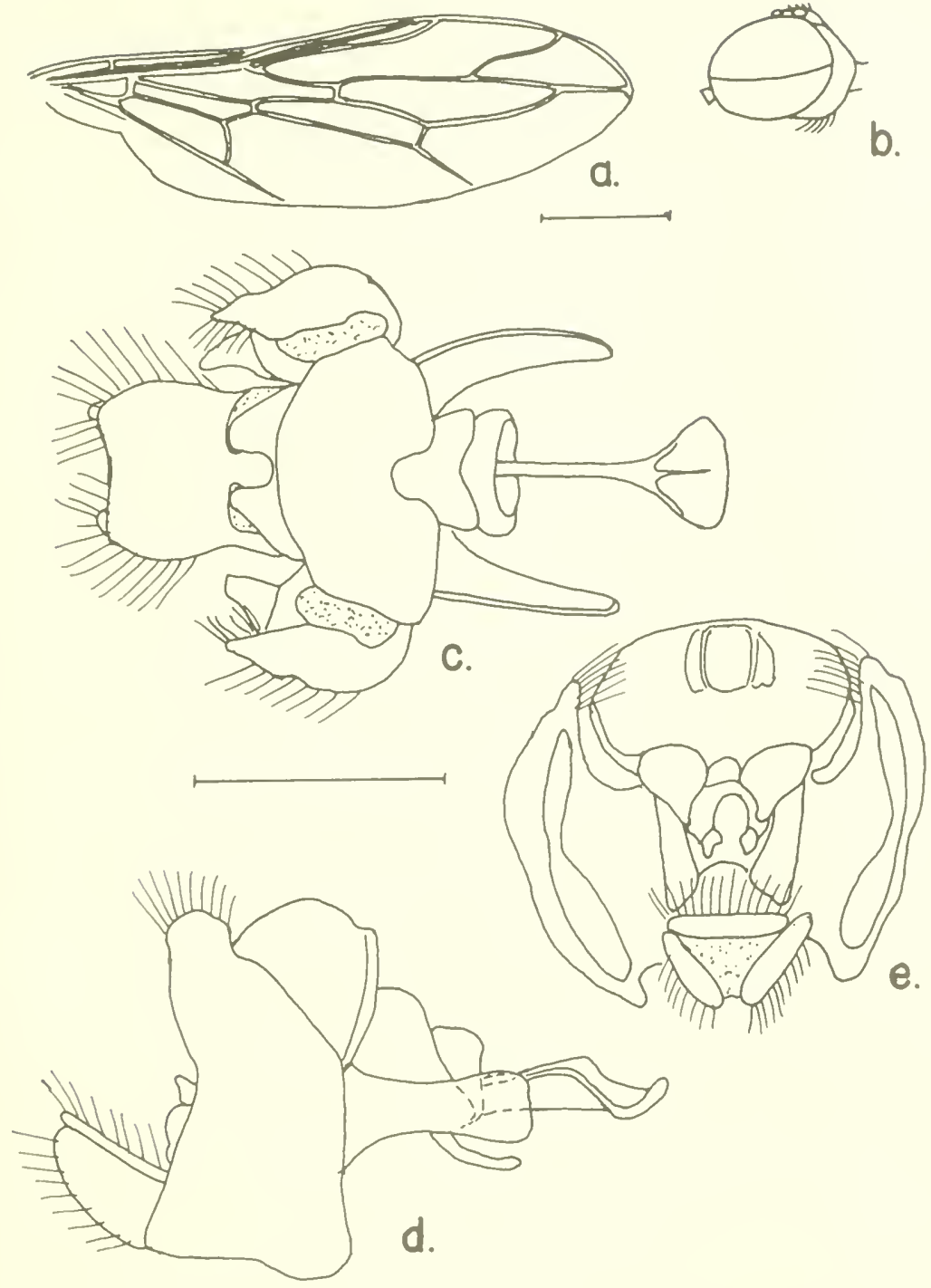

Frgure 193.-Neopseudatrichia canei, new species, male: $a$, wing; $b$, lateral aspect of head. antennae lost; $c-\ell$, ventral, lateral and posterior aspects of terminalia.

to the midpart of the frons, area laterad of vittae sparsely covered with brownish hair. Mouthparts well developed, filling the oral cavity, oral opening surrounded by silvery pile; ocellar tubercle slightly raised, subshining, with a few anteriorly directed hairs, ocelli clear; antennae black, granular, third segment oval, twice as long as 1 and 2 combined; see figure. 

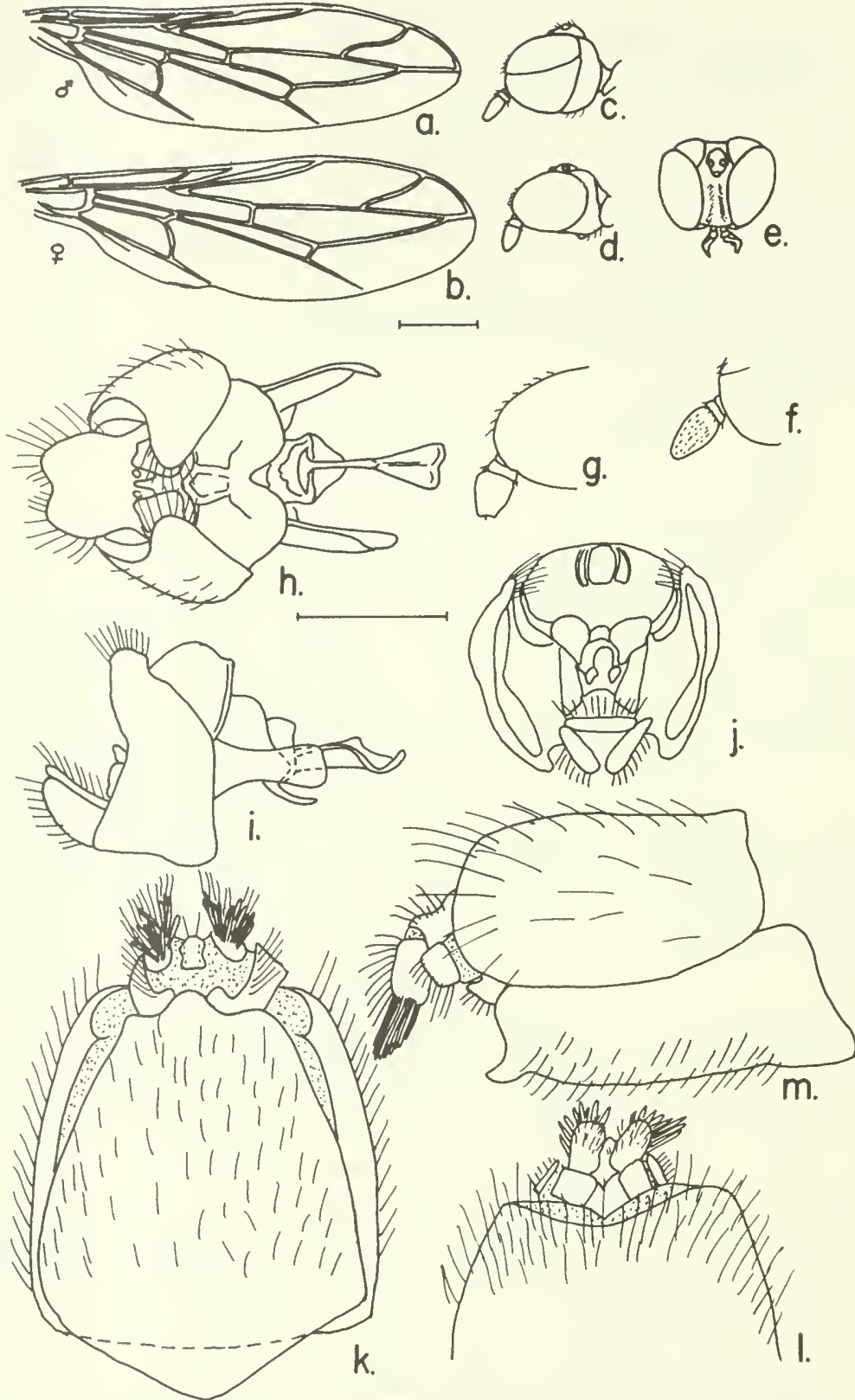

FigURE 194.-Neopseudatrichia kewi, new species, male, female: $a$, male wing; $b$, female wing; $c, \mathrm{~d}$, lateral aspects of male and female heads; $e$, dorsal aspect of female head; $f, g$, enlarged details of male and female antennae; $h-j$, ventral, lateral and posterior aspects of male terminalia; $k$, ventral aspect of female 8 th sternum and 9th segment; $l$, dorsal aspect of female 8th and Sth segments; $m$, lateral aspect of female 8 th and 9 th segments. 
Thorax dorsum black, shining, punctured with bases of sparse short whitish hairs; humeral and supra-alar calli red-brown; pleural areas blackish, shining. Wing hyaline, granular, veins red-brown; halter stem brown, pollinose, knob brown, granular, elongate, pointed. Legs with femora black-brown, remainder lighter.

Abdomen second segment surface wrinkled, with blue-black metallic sheen, remaining segments black, surface wrinkled, with metallic sheen, posterior margins white. Ninth tergum black-brown, shorter than high; tenth segment extending well beyond; aedeagus flanked by two short parameres; see figure for details.

Fenale.-Head black, elongate, flattened; eyes black; frons shining, slightly broader than the ocellar tubercle, thinly covered with short hairs; back of head silvery pilose above including the back of the ocellar tubercle; postgenae shining; oral opening surrounded by silvery pile; ocellar tubercle shining, with a few anteriorly directed hairs, ocelli red-brown. Antennae black, granular; third segment twice as long as first two combined; see figure for details.

Thorax dorsum black, shining, punctured with the bases of short golden hairs, humeral and supra-alar calli red-brown; scutellum black, polished; pleural areas black, shining. Wing hyaline, brown granular, veins brown; halter stem brown, pollinose, knob brown, granular, elongate, pointed. Legs black, tibiae and tarsi with golden hairs on ventral surfaces.

Abdomen black, rough, with metallic reflection, white posterior membrane between segments. Eighth segment black, very hairy; sternum spoonlike on midline, ninth tergum with much ventrally directed hair.

Length: Male body $4.7 \mathrm{~mm}$., wing $3 \mathrm{~mm}$.; female body $5 \mathrm{~mm}$., wing $3.2 \mathrm{~mm}$.

Type-locality: Lees Spring, A.C.T., Australia; emerged 22 November 1960 (I. F. B. Common and M. S. Upton) reared from bark of Eucalyptus.

Holotype: Male (CSIRO).

Allotype: Female Kew, New Sonth Wales; 12 October 1962 (D. H. Colless) (CSIRO).

\section{Neopseudatrichia mariaensis (G. H. Hardy), new combination}

Figure 195 (after Hardy)

Pseudatrichia mariaensis G. H. Hardy, 1933, p. 419.

The type and allotype of this species have been lost. The species is probably restricted to the Island of 'Tasmania.

Length: Male, female body $5 \mathrm{~mm}$., wing ?. 

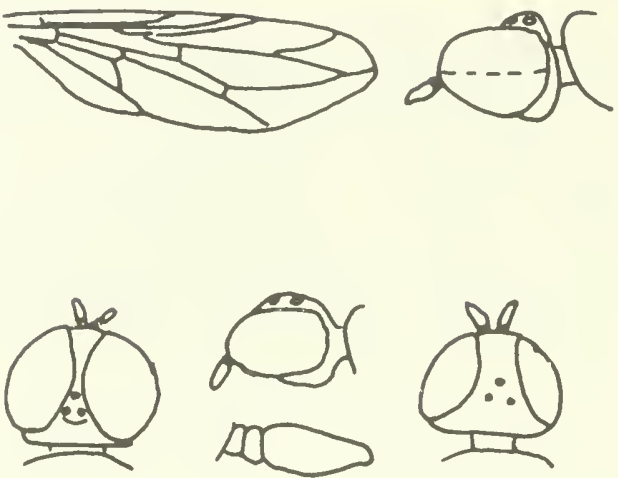

FIGURE 195.- Neopseudatrichia mariaensis (G.H. Hardy), male, female: Wing, lateral and dorsal aspects of male and female heads, and enlarged detail of antenna (after Hardy).

Type-locality: Maria Island, Tasmania; 29 December 1915 (G. H. Hardy) pair in copula, sweeping along or near the shore.

Types: lost.

\section{Genus Scenopinula Paramonov}

Scenopinula Paramonov, 1955, p. 651.

Type-species Scenopinula pallidipennis Paramonov (original designation). The genus Scenopinula Paramonov is closely related to the genus Scenopinus but differs in the strongly swollen frons of the female and indistinct weak wing venation where vein M $1+2$ runs parallel to $\mathrm{R} 5$ but does not attain the margin of the wing. This genus is limited to the Australian region.

\section{Scenopinula pallidipennis Paramonov}

FIgURE 196

Scenopinula pallidipennis Paramonov, 1955, p. 651.

This species is figured from the type.

Length: Female body $2 \mathrm{~mm}$., wing $1.5 \mathrm{~mm}$.

Type-locality: 8 mi. s. of Lake Cobham, New South Wales; 18 November 1949 (S. J. Paramonov).

Type: (CSIRO).

\section{Genus Riekiella Paramonov}

Riekiella Paramonov, 1955, p. 652.

Type-species Riekiella bicornis Paramonov (original designation). The genus Riekiella Paramonov resembles the members of the Brevi- 

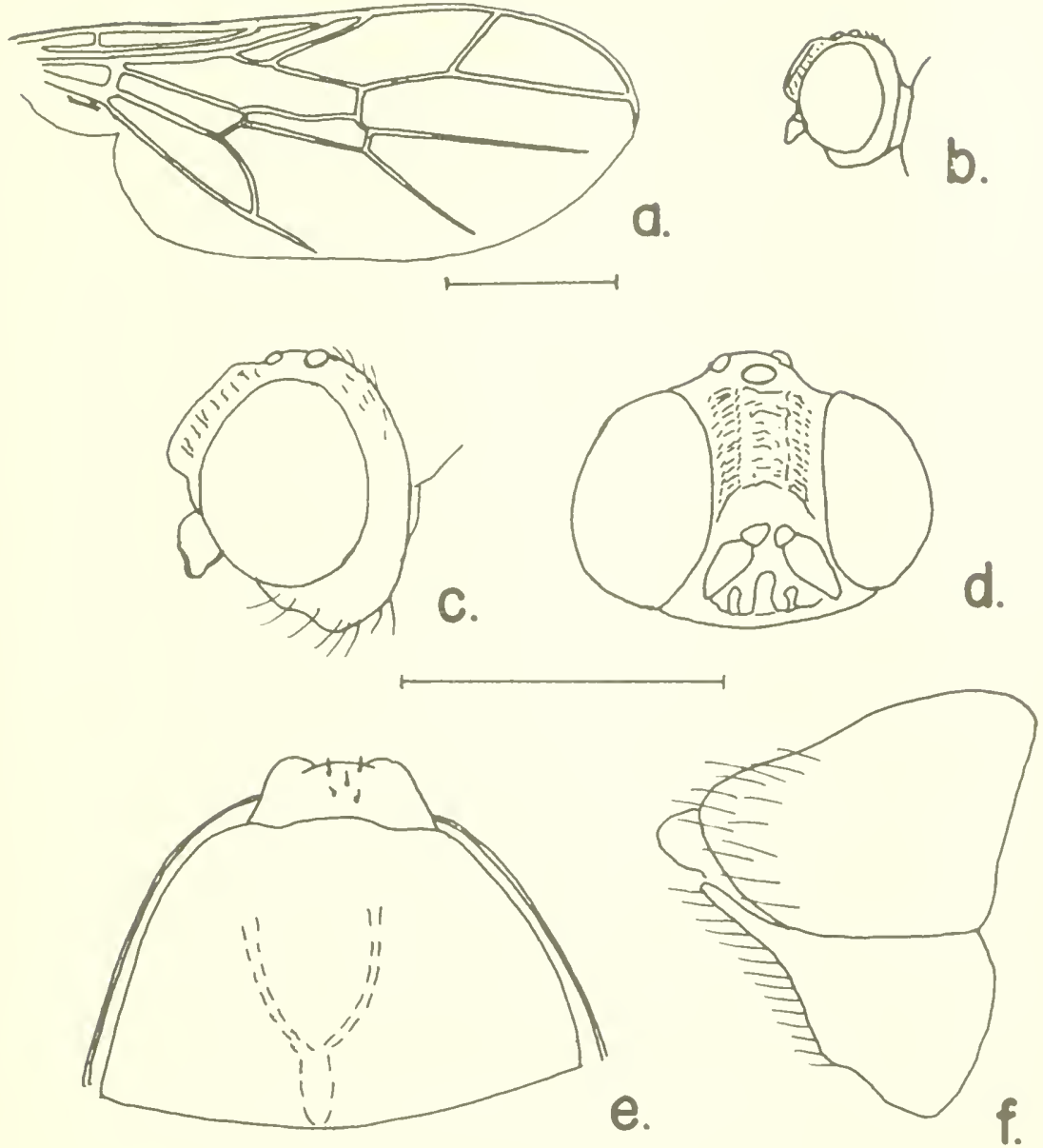

Frgere 196.-Scenopinula pallidipennis Paramonov, female: $a$, wing; $b$, lateral aspect of head; $c, d$, enlarged lateral and frontal aspects of head; $\ell$, ventral aspect of 8 th sternum; $f$, lateral aspect of 8 th and 9 th segments.

trichia complex and at present may be composed of as many as three genera. Until more specimens are a vailable for study the exact combinations are uncertain. On the basis of wing renation, the condition of the short M $1+2$ would place bicornis and complexa together while the genitalia of the male would place complexa with quadrifuda which has a closed petiolate cell. The female sternum of bicornis is quite different from that of quadrifida and dycei which have short blunt sterna, but agrees with longiventris which also has a closed cell. The members of this genus are found in the Australian region. 


\section{Key to Species of Riekiella}

1. Vein $M 1+2$ not reaching vein $R 5$ or edge of wing . . . . . . . . 2

Vein M $1+2$ ending in R5 before tip of wing. . . . . . . . . . . . . 6

2. Males . . . . . . . . . . . . . . . . . . 3

Females . . . . . . . . . . . . . . . . 4

3. Wing smoky with a scaly appearance, $\mathrm{R} 4$ branching beyond the middle of vein R5 . . . . . . . . . . . R. complexa, new species

Wing brownish, halter knob tan with a brown rib, vein $\mathrm{R} 4$ branching before the middle of vein R5, clorsal lobes of ninth segment ending in wiry hooks .. . . . . . . . . . R. uncata, new species

4. Wing brownish . . . . . . . . . . . . . . . 5

Wing hyaline, vein $R 5$ bending backward beyond the branching of vein $R 4$, halter yellow, very large . . . . . . . R. bicornis Paramonov

5. Halter knob yellow-brown, darker at base, antenna black-brown, R4 branching from $\mathrm{R} 5$ near the center of the vein, running straight to the leading edge of the wing . . . . . . . . . R. uncata, new species

Halter knob orange-brown with a tan median band, $R 4$ branching from near the basal third of R5 and curving "S"-like to the leading edge of wing . . . . . . . . . . . R. collessi, new species

\section{Males}

Females . . . . . . . . . . . . . . . . 9

7. Wing brownish .. . . . . . . . . . . . . . 8

Wing hyaline, halter knob brown with a tan ventral stripe, ninth tergum one-fourth length of body, with upper and lower seetions equal in length . . . . . . . . . R. quadrifida, new species

8. Halter knob dull yellow with a dorsal brown rib to the tip, ninth tergum one-fourth the length of the body, the dorsal portion pointed and nearly twice as long as the rounded ventral portion. . . R. taylori, new species

Halter knob tan-brown, ninth tergum short, dorsal portion pointed, ventral portion hooked, aedeagal parameres extending beyond ventral portion of ninth tergum. . . . . . . . . . R. collessi, new species

9. Wing hyaline. . . . . . . . . . . . . . . . . . 10

Wing smoky brown, granular, halter knob creamy white, vein R4 branching from near center of cell R5, ending in leading edge of wing beyond the tip of cell R5 . . . . . . . . . . . R. dycei, new species

10. Halter knob brown with a tan stripe below, antenna black, tip of cell R5 pointed, small under $4 \mathrm{~mm}$. . . . . . R quadrifida, new species

Halter knob light brown above, eream below, antenna with third segment orange at base, tip red-brown, cell R5 blunt at tip, eighth sternum pointed much longer than tergum; a large fly over $6 \mathrm{~mm}$.

R. Iongiventris, new species

\section{Riekiella bicornis Paramonov}

FIgURE 197

Riekiella bicornis Paramonov, 1955, p. 653.

The type of this species is figured for the first time. Of interest are the venation of the wing and the structure of the eighth sternum which far exceeds the dorsum and the extent of the ninth segment.

Length: Female body $3 \mathrm{~mm}$., wing $2 \mathrm{~mm}$. 

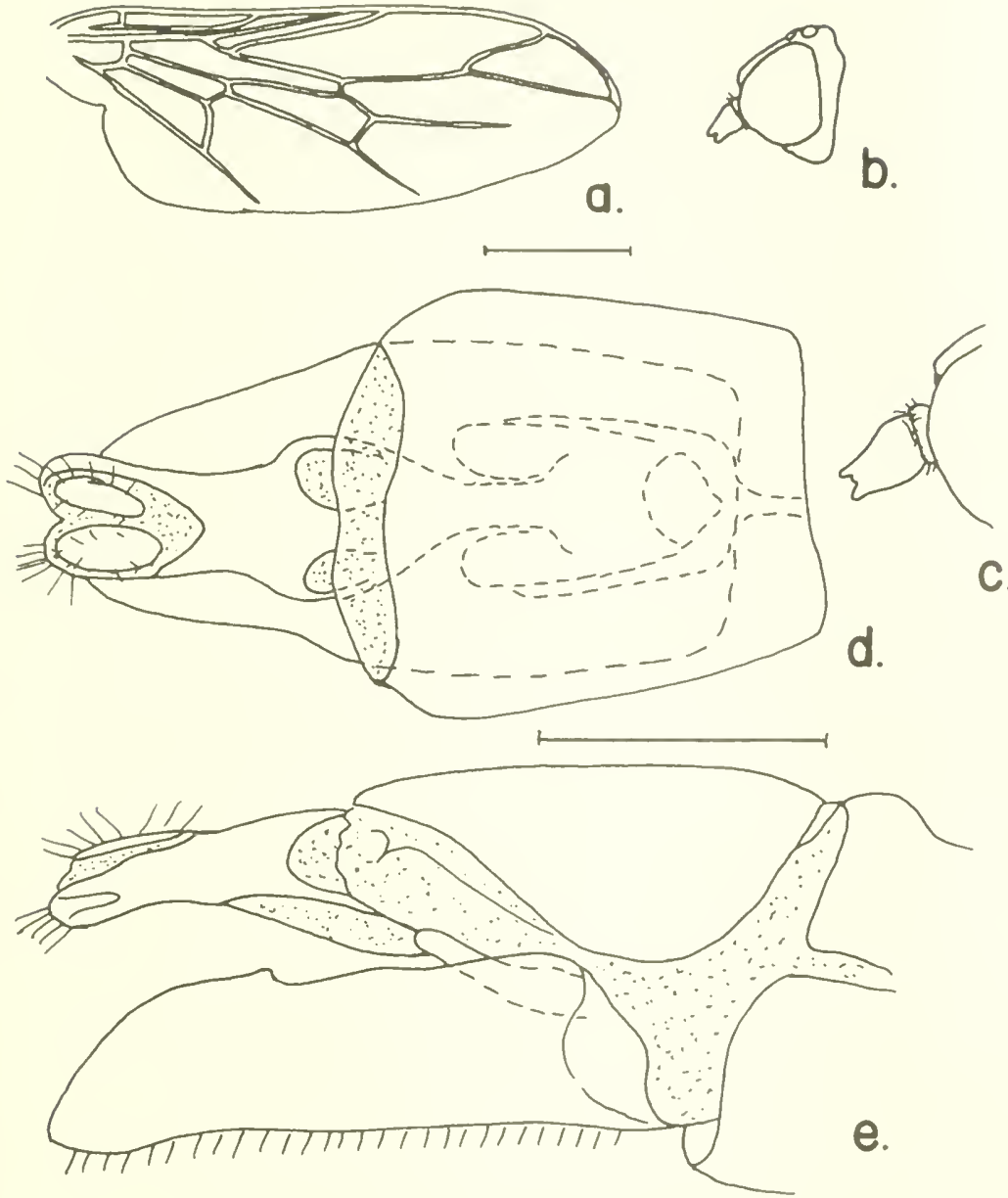

Figure 197.-Riekie!la bicornis Paramonov, female: $a$, wing; $b$, lateral aspect of head; $c$, enlarged detail of antenna; $d$, dorsal aspect of 8 th and 9 th segments; $e$, lateral aspect of 8 th and 9 th segments.

Type-locality: $10 \mathrm{mi}$. s. Bowen, Queensland; 27 September 1950 (E. F. Riek).

Type: (CSIRO).

\section{Riekiella collessi, new speeies}

Figure 198

MaLE, - Head black; eyes black, divided below the midline with coarse upper and fine lower facets; frons very narrow, triangular, with a median groove, the lower half white; ocellar tubercle black with gray 
granulosis; ocelli orange-red; mouthparts well developed, black, with a lighter tip; palpi tan; oral opening black posteriorly grading into white which joins the area on the lower frons. Antennae black, granular; first segment short; second segment twice as wide and long as first; third segment pear-shaped, not twice as long as first two combined, ending in two distinct points with a median peg.

Thorax dorsum black, covered with grayish brown pollen; humeral and supra-alar calli tan; pleura black, with gray granulosis. Wings brownish hyaline, veins brown, M $1+2$ reaching $R 5$ closing off a cell; halter stem brown, knob tan-brown; legs black-brown, granular.

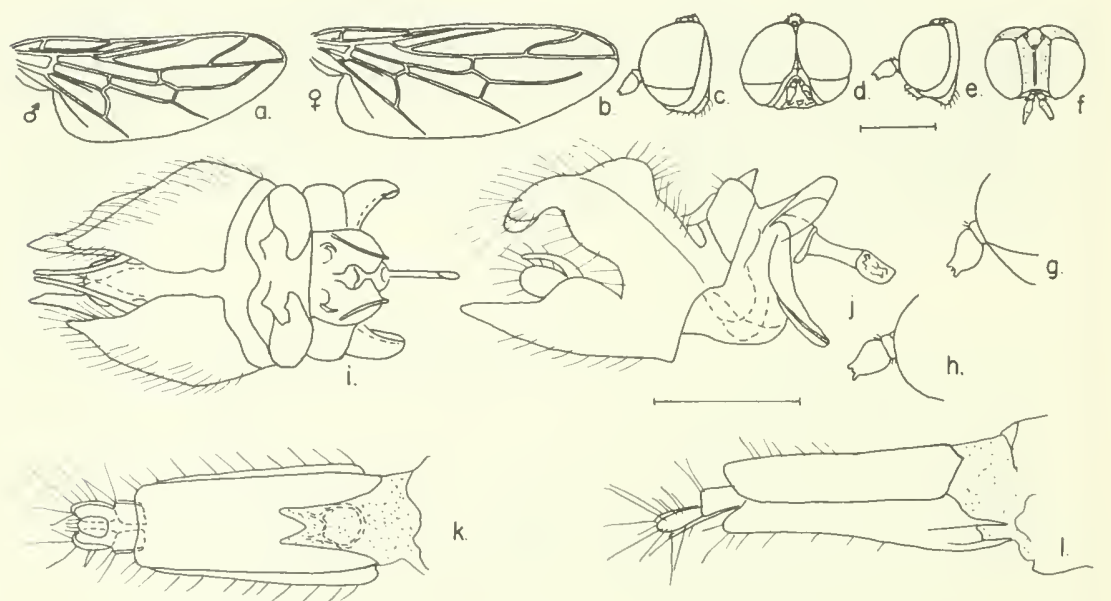

Figure 198.-Riekiella collessi, new species, male, female: $a$, male wing; $b$, female wing; $c, d$, lateral and frontal aspects of male head; $e, f$, lateral and frontal aspects of female head; $g, h$, enlarged details of male and female heads; $i, j$, ventral and lateral aspects of male terminalia; $k$, ventral aspect of female 8 th sternum and 9 th segment; $l$, lateral aspect of female 8 th and 9 th segments.

Abdomen first three segments black, with brown granulosis, remaining segments more shining, no distinct broad band of white membrane. Ninth tergum red-brown, granular, divided into four lobes; aedeagus as two stiff spines extending beyond ventral lobe; see figure for details.

Female.-Head black, eyes black; postocular ridge narrow, covered with gray pollen, with sparse stiff hairs; frons gray pollinose, with two median bands of brownish pollen on either side of a median groove, a few sparse hairs; ocellar tubercle gray pollinose with a few sparse hairs; ocelli red-orange; mouthparts brown, palpi cream-orange; oral opening with anterior two-thirds cream-orange; antennae with first two segments black with gray pollen; third segment pear-shaped, pubescent, shining bronze or black depending on the light. 
Thorax dorsum black, covered with brown and tan pollen, with evenly spaced short black hairs; humeral callus cream, supra-alar callus orange, scutellum black-brown with a tan median pollinose patch; pleura black-brown, dusted with gray pollen. Wings brown fumose, reins brown, MI $1+2$ ending before reaching R5 or edge of wing; halter stem yellow basally to brown distally, knob orangebrown above and below with a tan median band. Legs with femora red-brown, pollinose with orange knees; tibiae red-brown basally, orange-brown distally; tarsi lighter basally, darker distally.

Abdomen first three segments dark red-brown, granular; remaining segments red-brown, shining; eighth segment elongate; see figure.

Length: Male body $2.6 \mathrm{~mm}$., wing $1.8 \mathrm{~mm}$.; female body $4 \mathrm{~mm}$., wing $2.3 \mathrm{~mm}$.

Type-locality: Black Yamma State Forest, New South Wales, Australia; 11 November 1964 (D. H. Colless).

Holotypes: Male (CSIRO).

Allotype: Female, same data.

\section{Riekiella complexa, new species}

FIGURE 199

MALE.-Head black, overlain with gray scales on the back of the head; eyes black-brown above, black below, meeting on the midline; frons narrow, with a median ridge, extending half the distance to the median ocellus, ocellar tubercle black-brown with gray scales, ocelli red-brown; mouthparts black, well developed, extending to the base of the antennae, oral cavity tan. Antennae black, the third segment velvety giving off brassy sheen under light; see figure for details.

Thorax dorsum black, overlain with brown pollinose scales, sparse erect black hairs; humeral callus tan; pleural areas as on dorsum. Wings smoky, with scaly appearance; reins brown, M $1+2$ not reaching $\mathrm{R} 5$ or tip of wing; calypters large, fringed with long hairs; halteres missing on both sides. Legs black-brown, with tarsi and knees of femora red-brown.

Abdomen second segment black-brown, shining; remaining segments pollinose ventrally, shining dorsally; ninth tergum black-brown, pollinose, hairy dorsally, tan ventrally, formed into four long lobes, resembling those of $R$. quadrifula but shorter. The terminalia were lost on dissection; a rough sketch is provided; see figure.

Female.-Unknown.

Length: Male body $2.5 \mathrm{~mm}$., wing $2 \mathrm{~mm}$.

Type-locality: Canberra, Australian Capital Territory, Australia; 3 December 1962 (E. F. Rick).

Holotype: Male (CSIRO). 

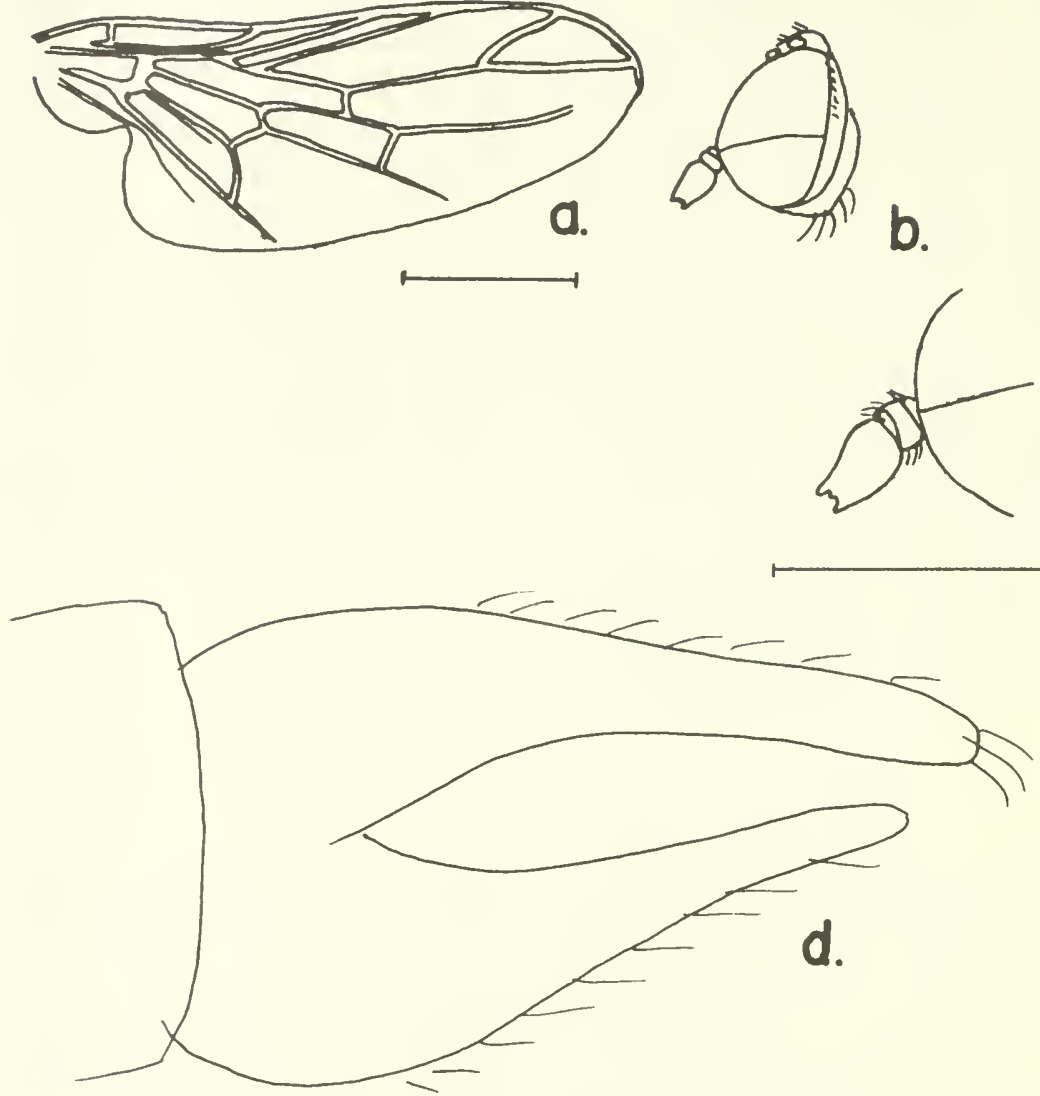

Figure 199.-Riekiella complexa, new species, male: $a$, wing; $b$, lateral aspect of head; $c$, enlarged detail of antenna; $d$, rough sketch of terminalia before loss on dissection.

\section{Riekiella dycei, new species}

Figure 200

This and the following species are placed in this genus despite the variance in the wing venation, pending the study of additional specimens, particularly pairs.

Female.-Head higher than long, pinkish brown; eyes brown; frons broad, with a median groove extending from the antennae to the median ocellus; ocellar triangle darker, set off from post-ocular ridges by grooves from the corner of the eye to the lateral ocellus; genal areas below and behind the eyes yellow-brown, unmarked; mouthparts well developed; antennal segments dark brown, the first and second short, third broad at the base truncated distally with two points. 
Thorax gray pollinose with darker setal pits. Wings smoky, granular, veins dark brown; halter stem brown, knob creamy white. Iegs dark brown basally, pollinose; femora with pale brown knees, remainder of legs light brown.

Abdomen elongate, dark brown, eighth segment elongate; see figure for details.

MaLe.-Unknown.

Length: Female body $3.25 \mathrm{~mm}$., wings $2.25 \mathrm{~mm}$.

Type-locality: 12 mi. s. Gravesend, New South Wales, Australia; 30 September 1952 (A. Dyce) attracted to rabbit.

Holotype: Female (CSIRO).
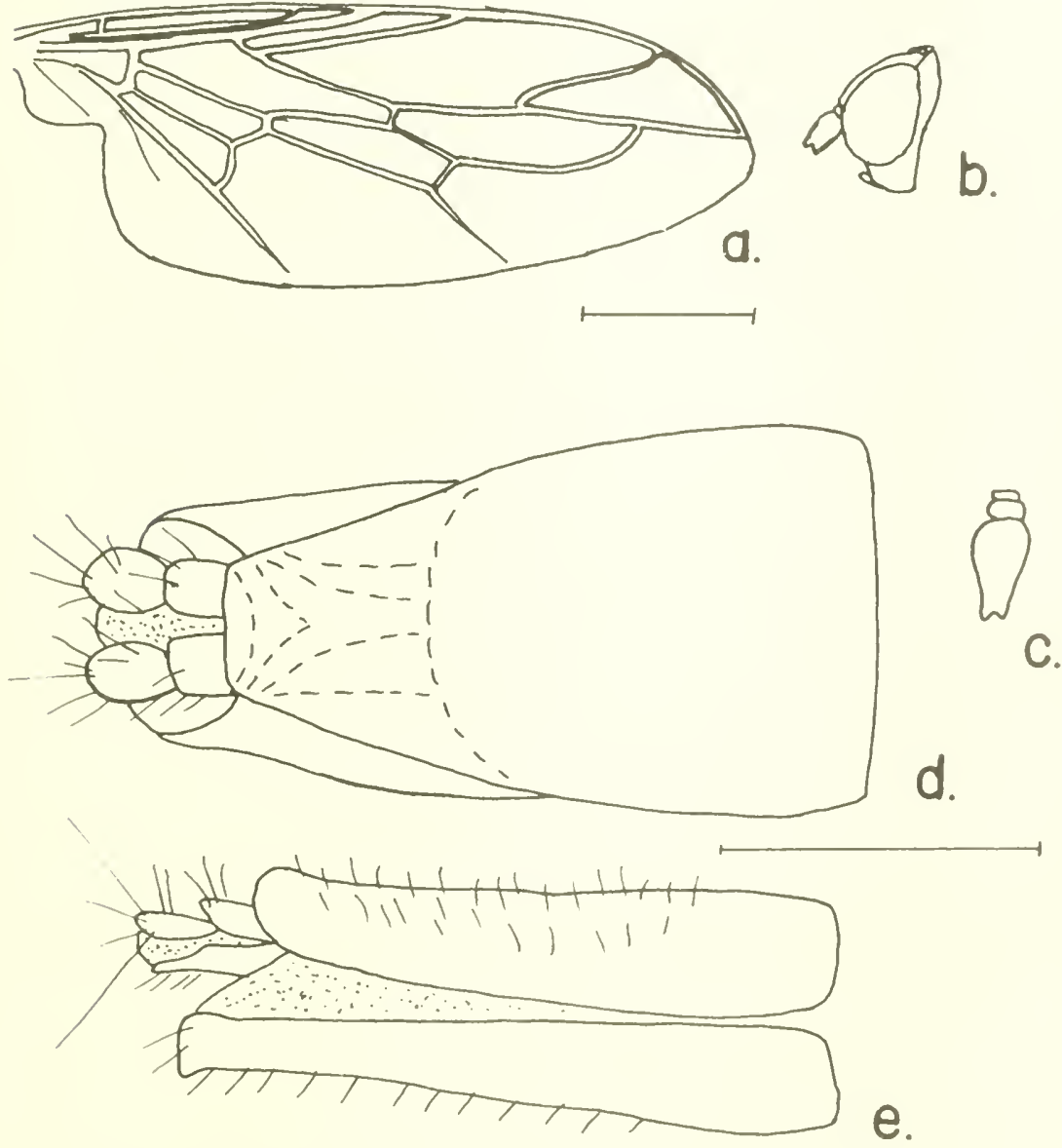

FIgURE 200.- Rickiella dycei, new species, female: $a$, wing; $b$, lateral aspect of head; $c$, enlarged detail of antenna; $d$, dorsal aspect of 8 th and 9 th segments; $e$, lateral aspect of 8 th and 9 th segments. 


\section{Riekiella longiventris, new species}

FIGURE 201

Female.-Head yellow-brown; eyes dark brown; postocular ridge with a raised vertical face behind the eye, to an elevated ridge; back of head black, covered with gray pollen and with short black hairs; frons broad, raised in a central band, covered with a band of short black hairs, lateral margins next to eye depressed, a bare triangle above the antenna bases; mouthparts well developed; ocellar tubercle black-brown, raised from a depressed base, with a few hairs; ocelli dark brown; frons separated from postocular area by grooves that
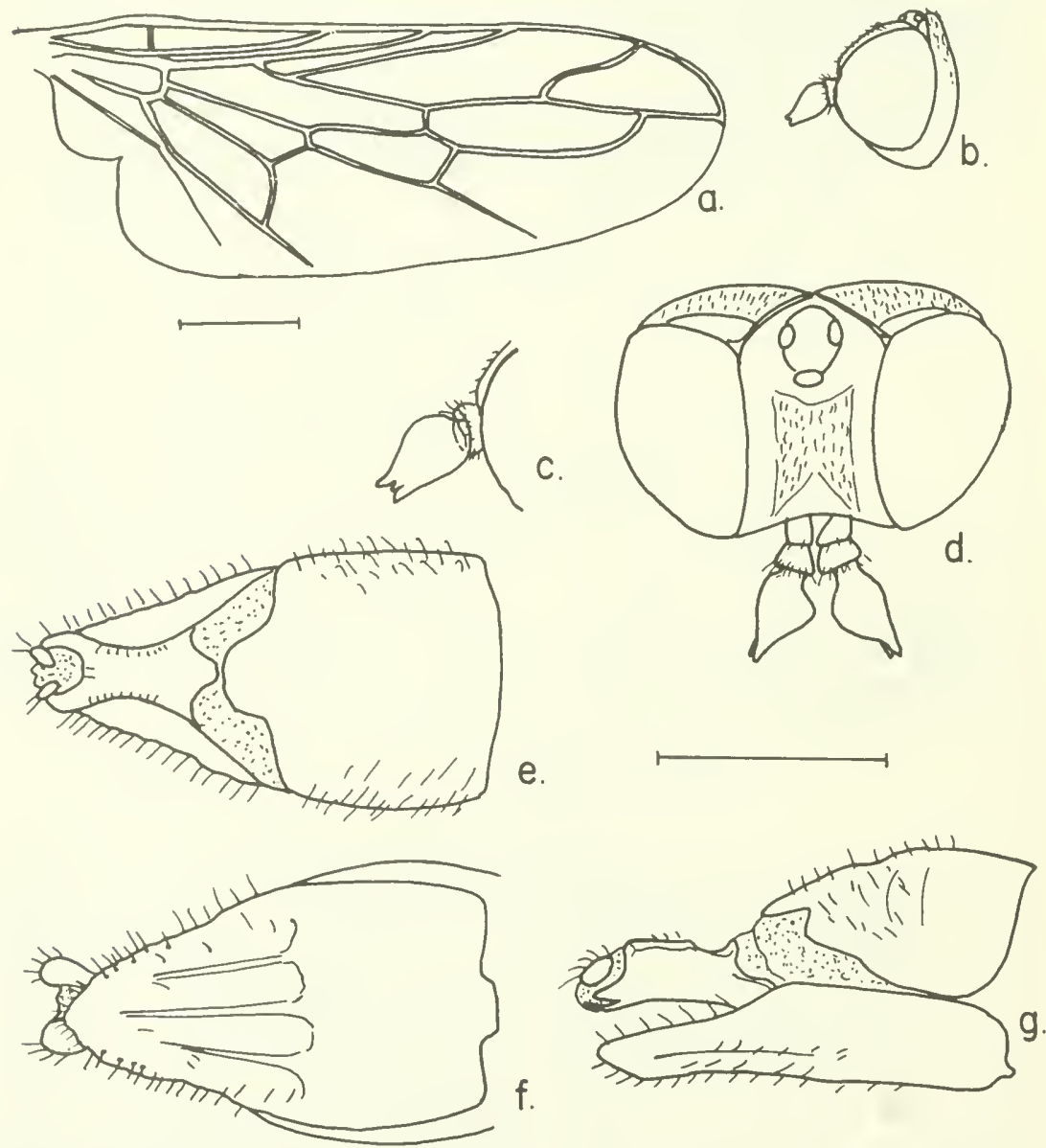

Figure 201.-Riekiella longiventris, new species, female: $a$, wing; $b$, lateral aspect of head; $c$, enlarged detail of antenna; $d$, enlarged dorsal aspect of head; $e$, dorsal aspect of 8 th $_{1}$ and 9 th segments; $f$, ventral aspect of 8 th and 9 th segments; $g$, lateral aspect of 8 th and 9 th segments. 
extend from the upper corner of the eye behind the ocellar tubercle to the midline at the back of the head. Antemnae with the first two segments black-brown, subequal; the second with a fringe of hairs; the third segment pear-shaped, orange basally darkening distally to black-brown with a two-pointed tip.

Thorax dorsum black, covered with dark brown pollinose scales, sparse short black hair; humeral callus tan; scutellum black; pleural areas black-brown, pollinose, very little membrane or light color. Wings hyaline, veins light brown; halter stem light brown, knob light brown, creamy below. Legs with femora black-brown, pollinose; remainder of legs light brown.

Abdomen very long, dark brown, grading to yellow-brown posteriorly; eighth segment with dorsum shining mahogany brown, sternum yellow-brown, keeled in posterior half, twice as long as tergum. Ninth segment long, much like R. bicornis; see figure for details.

Male.-Unknown.

Length: Female body $6 \mathrm{~mm}$., wing $2.9 \mathrm{~mm}$.

Type-locality: Applecross. West Australia; 25 February 1941 (K. R. Norris).

Holotype: Female (CSIRO).

208. Riekiella quadrifida, new species

FigURE 202

Male.-Head black, eyes red-brown above, black below; frons small, granular, extending only one-third the distance from the antennae to the median ocellus; ocellar triangle prominent, granular, ocelli dark; oral cavity tan to cream, with a black roof; monthparts tan, short, palpi short. Antennae black, granular, third segment twice is long as first two eombined, pear-shaped, ending in two points with a median peg; see figure for details.

Thorax dorsum black, with red-brown granular pollen; humeral and supra-alar ealli tan; scutellum black, subshining; pleura black, granular. Wing hyaline, veins tan, cell R5 petiolnte; halter stem brown, knob brown, with a tan band below. Legs with femora black-brown, gramular; tibiae tan; tarsi tan, darkening distally.

Abdomen black-brown, granular dorsally, shining below; ninth segment black-brown, four-lobed, elongate, being one-quarter the length of the entire body; see figure for details.

Female.-Head black-brown, eyes black; postocular flange continuous with dorsal portion of frons; back of head gramular; frons broad, shining, over twice as wide as ocellar triangle, with a groove extending from median ocellus toward the antennae where it becomes an elevated swelling with sparse hairs; oral cavity with tan sides and a 


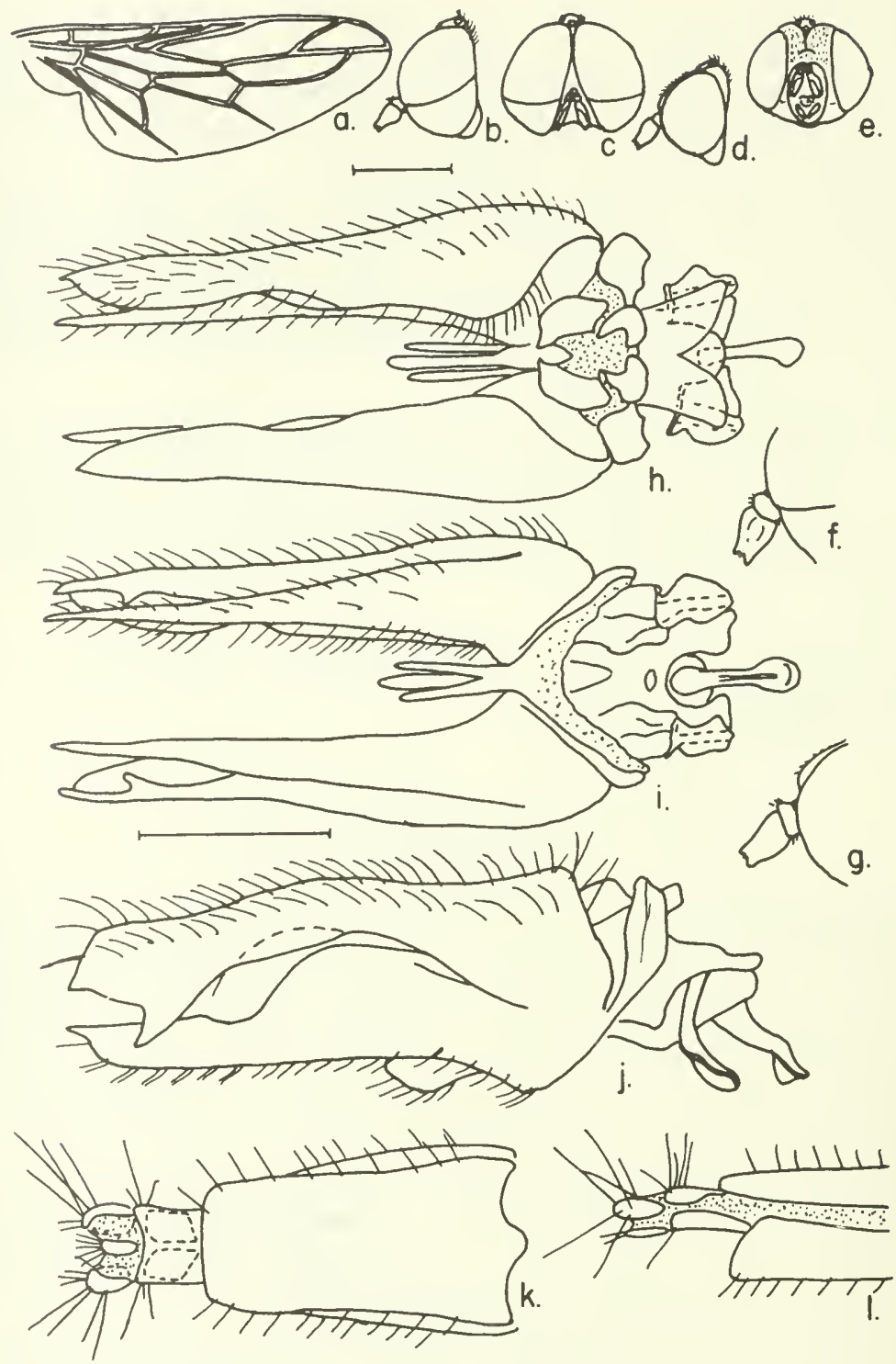

FigURE 202.-Riekiella quadrifida, new species, male, female: $a$, wing; $b, c$, lateral and anterior aspects of male liead; $d, e$, lateral and anterior aspects of female head; $f$, g, enlarged details of male and female antennae; $h-j$, ventral, dorsal, and lateral aspects of male terminalia; $k$, ventral aspect of female 8 th sternum and 9 th segment; $l$, lateral aspect of female 8 th and 9 th segments.

black roof; mouthparts brown, short; palpi tan, short. Antennae black, granular, as in male. 
Thorax as in male.

Abdomen black-brown, granular dorsally, shining below; eighth segment elongate, tergum and sternum subequal; ninth segment structures elongate; sec figure.

Length: Male body $3 \mathrm{~mm}$., wing $1.9 \mathrm{~mm}$.; female body $3.5 \mathrm{~mm}$., wing $2.2 \mathrm{~mm}$.

Type-locality: N. Rosewood, Queensland; 29 December 1961 (R. Lindsay) brigalow scrub.

Holotype: Male (CSIRO).

Allotype: Female, same data (CSIRO).

Paratypes: $10^{7}, 1$, same data (CSIRO).

\section{Riekiella taylori, new species}

Figure 203

MaLE.-Head black-brown, eyes red-brown with metallic glints, darker below; no postocular flange; frons narrow, triangular, with a median groove, lower frons granular; ocellar tubercle black-brown dusted with gray pollen, a few anteriorly directed hairs from back; ocelli orange. Antennae with first segment black-brown, small; second segment black-brown, granular; third segment missing.

Thorax dorsum black-brown, heavily dusted with gray pollen, margin of tergum behind humeral callus with stiff hairs; humeral callus cream with 8-10 stiff tan hairs, scutellum black with brown pollen; pleural areas black-brown granular. Wings brownish hyaline, veins yellow-brown, squamae noticeable; halter stem brown, knob dull yellow with a dorsal brown rib to tip. Legs dark red-brown, granular, femoral knees orange.

Abdomen black-brown, pubescent, giving a silvery-white appearance in certain light, intersegmental membrane tan; terminalia black-brown at base, tips and lower arms orange-brown, hairy, onequarter length of body; see figure for details of shape.

Female.-Unknown.

Length: Male body $3.2 \mathrm{~mm}$., wing $2.2 \mathrm{~mm}$.

Type-locality: $20 \mathrm{mi}$. w. Mildura, Victoria, Australia; 22 October 1958 (K. L. Taylor).

Holotype: Male (CSIRO).

210. Riekiella uncata, new species

Figure 204

Male.-Head black; eyes black, with reddish glints, divided on midline into larger upper and smaller lower facets; frons narrow, triangular, a dark median streak of pubescence on lower frons bordered $31.3-16.50-69-21$ 

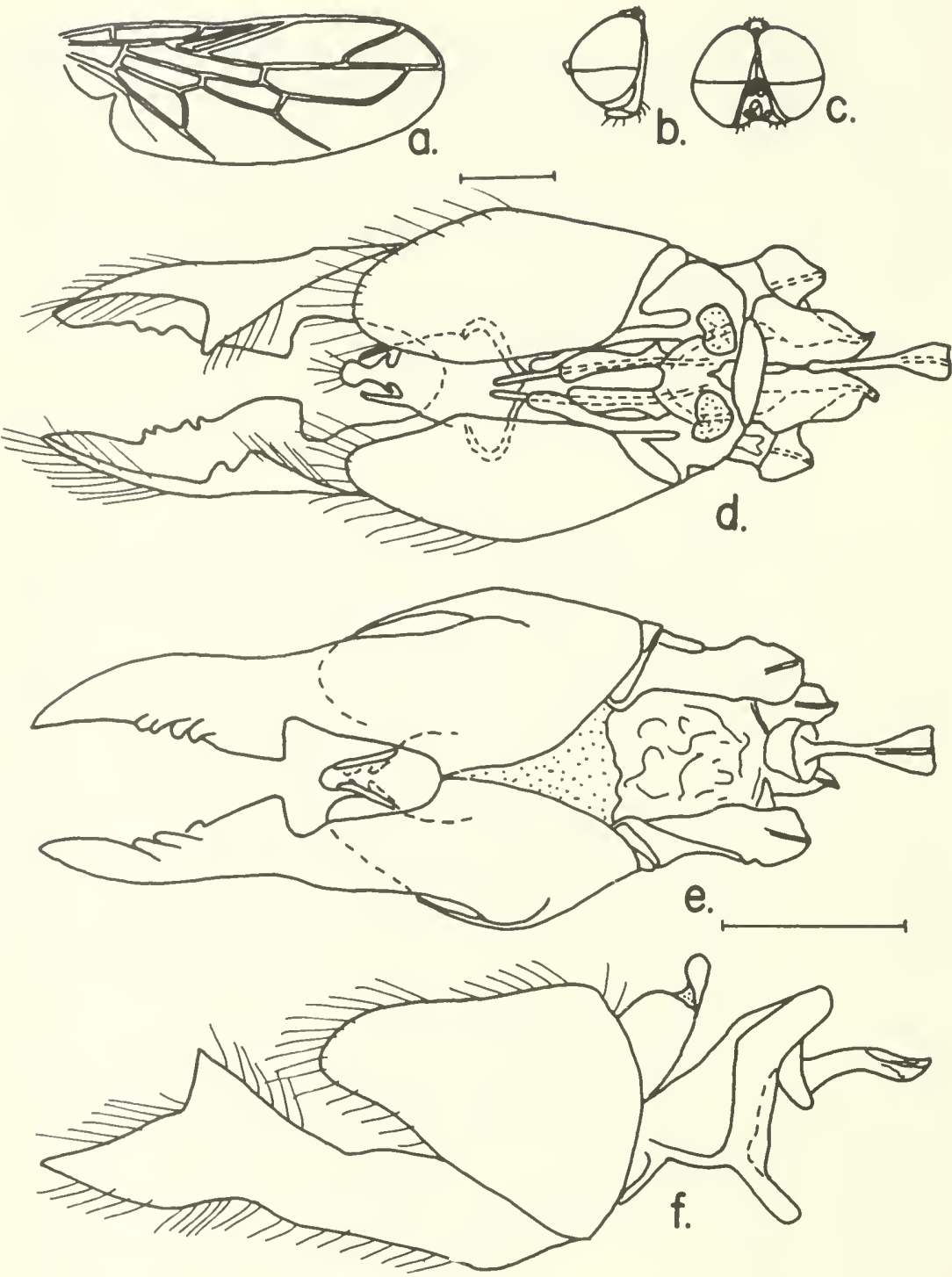

FIGURE 203.-Riekiella taylori, new species, male: $a$, wing; $b$, $c$, lateral and frontal aspects of head; $d-f$, ventral, dorsal and lateral aspects of terminalia.

by tan pubescence laterally, upper half shining, continuing as a narrow band between the eyes; ocellar tubercle black, covered with brown pubescence, a few scattered black hairs on back margin; ocelli redbrown; mouthparts black-brown, two-thirds the length of the oral opening, palpi brown, half as long as mouthparts; back of head gray 
pubescent; antennae black, pubescent, third segment pear-shaped, with a bronzy sheen.

Thorax dorsum ground black, surface covered with brown and tan pollen, a thin scattering of short posteriorly directed bristles; humeral and supra-alar calli cream; pleura with black-brown pollen. Wings brown fumose, veins brown, M $1+2$ fading before reaching $\mathrm{R} 5$; halter stem orange-brown, knob tan, with a brown rib. Legs with

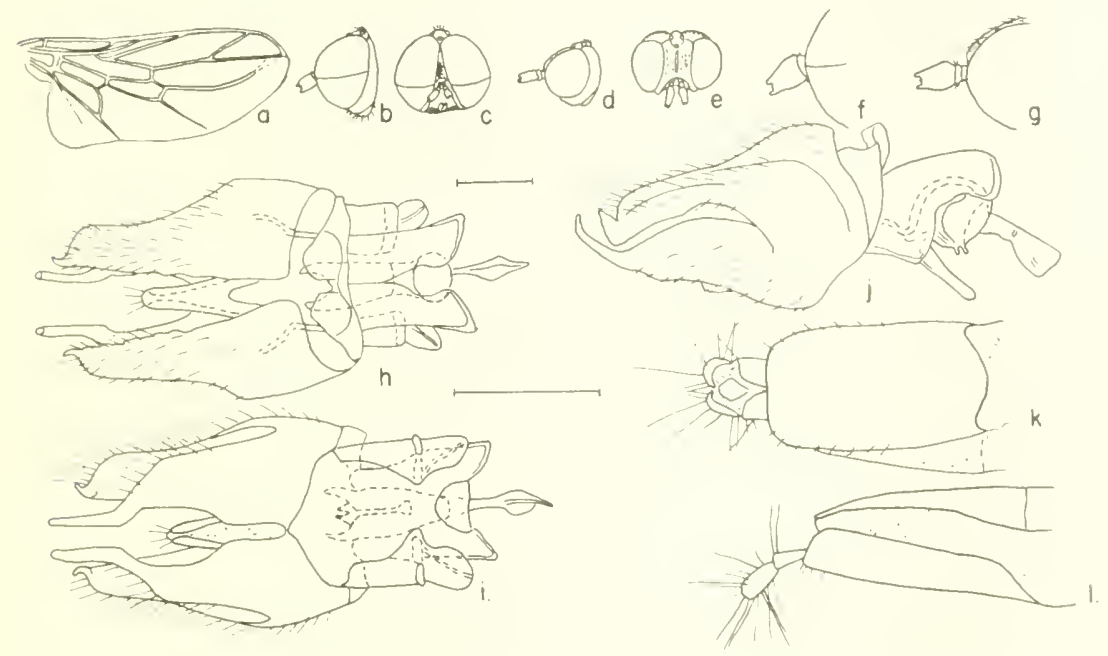

FIgURE 204.-Riekiella uncata, new species, male, female: $a$, wing, upper dashed line indicates line of vein on male wing, lower female; $b, c$, lateral and frontal aspects of male head; $d, e$, lateral and frontal aspects of female head; $f, g$, enlarged details of male and female heads; $h-j$, ventral, dorsal and lateral aspects of male terminalia; $k$, ventral aspect of female 8 th sternum and 9 th segment; $l$, lateral aspect of female 8 th and 9 th segments.

coxae and femora black, pollinose; tibiae orange-brown, tarsi brown.

Abdomen black-brown with brown pollen, ninth tergum blackbrown to orange-brown, pollinose, hairy, tergum ends in a pair of rounded hooks.

Female.-Head black-brown, eyes red-brown with red metallic glints; postocular ridge narrow, with a band of hairs, granular; frons with dark brown granulosis, with tan margins next to eyes, a median groove from median ocellus, sunken for half the length of the frons, continuing over the swollen lower half to antennal base, a few scattered short hairs; back of head covered with dark brown pollen; mouthparts brown, two-thirds the length of oral opening, palpi shorter, pale orange, anterior half of oral opening light orange; ocellar tubercle dark brown, granular; ocelli red-brown; antennae black-brown, first 
segment granular; second granular, with a few hairs; third segment pear-shaped pubescent giving off bronze glints.

Thorax dorsum dark brown, granulose, with tan bands, with scattered short, stiff, posteriorly directed bristles; humeral and supraalar calli yellow-brown; scutellum black-brown, granular; pleura black-brown, granular. Wings brown fumose, veins brown, $\mathrm{M} 1+2$ not reaching $\mathrm{R} 5$; halter stem orange-brown basally darkening to brown distally, knob yellow brown, darker at base. Legs with femora red-brown, granular; tibiae yellow-brown; tarsi with first segment yellow-brown, remainder red-brown.

Abdomen first three segments black-brown, granular, remaining segments black-brown shining, eighth segment elongate; see figure for details.

Length: Male body $2.2 \mathrm{~mm}$., wing $1.7 \mathrm{~mm}$.; female body $3.3 \mathrm{~mm}$., wing $2 \mathrm{~mm}$.

Type-locality: Parkes, New South Wales, Australia; 12 November 1964 (D. H. Colless).

Holotype: Male (CSIRO).

Allotype: Female, same data.

Paratypes: $10^{7}, 19$, Parkes, New South Wales, same data as type; $1 \sigma^{7}, 1$ o, Eugowra, New South Wales, 15 November 1964 (D. H. Colless) (CSIRO).

\section{Genus Stenomphrale Kröber}

Stenomphrale Kröber, 1937, p. 220.

Type-species Pseudomphrale teutankhameni Kröber. The genus Stenomphrale Kröber closely resembles the genus Pseudatrichia; the male genitalia, however, lack the ventral brush of hairs and the tergites are longer than those of Neopseudatrichia; the female terminalia are very different from those of Pseudatrichia, having a brush of hairs on the ninth tergum which is larger than those of Neopseudatrichia. This genus is found in the circum-Mediterranean area of the Palaearctic region.

\section{Stenomphrale flaroscutellata (Kröber)}

Figure 205 (after Kröber)

Pseudomphrale flavoscutellata Kröber, 1929, p. 80.

Stenomphrale flavoscutellata (Kröber), 1937, pp. 213, 220.

The only figures available for this species are those of Kröber accompanying the original description and are among the least adequate of the many figures he published. All attempts to locate the types of this species have failed. The material supposedly is in the 

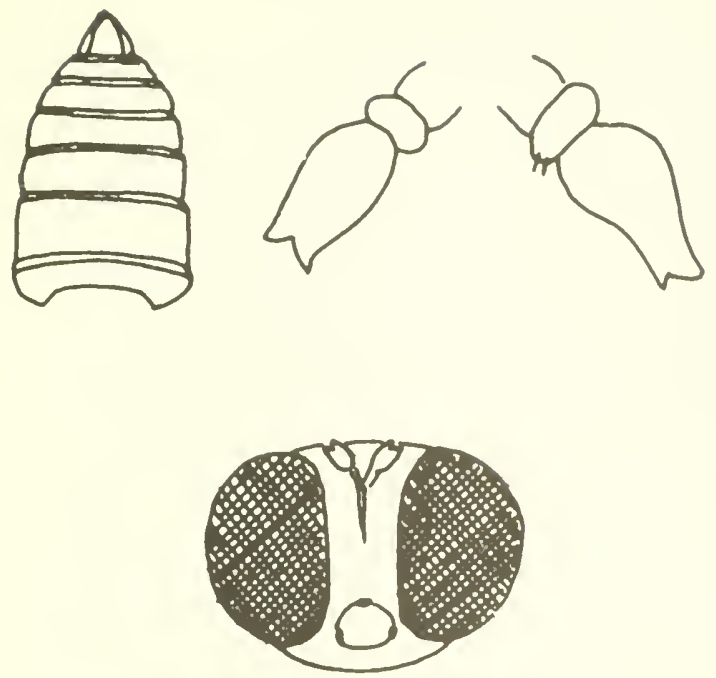

Figure 205.-Stenomphrale flavoscutellata (Kröber), male, female: Anterodorsal aspect of head, detail of antennae and dorsal aspect of abdomen (after Kröber).

collections of the Royal Entomological Society of Egypt but the curators of that collection were unable to locate it.

Length: Male body 3.5-3.6 mm., wing 2.1-2.4 mm.; female body $4 \mathrm{~mm}$., wing $3 \mathrm{~mm}$.

Type-locality: Burg (Mariout), Egypt; 10 May 1927.

Type: (SEE) lost?

\section{Stenomphrale teutankhameni (Kröber)}

Figure 206

Pseudomphrale teutankhameni Kröber, 1923, p. 72.

Stenomphrale teutankhameni (Kröber), 1937, pp. 213, 220.

Kröber attributes the authorship of this species to Collin. However, inasmuch as Kröber made complete original descriptions of both the male and female, and no reference is found in the literature to a description or even a reference to this species by Collin, I feel that this species should be attributed to Kröber. This species appears closely related to the Australian generi Neopseulatrichia and Paratrichia in the form of the male ninth and tenth terga; it differs, however, in the large mouthparts and the renation of the wing. The female eighth and ninth segments are quite different.

Length: Male body 3.5-3.7 mm., wing $2.4 \mathrm{~mm}$.; female body $2.5-$ $3.5 \mathrm{~mm}$., wing $2 \mathrm{~mm}$.

Type-locality: Mariout, Egypt; 16 March 1922. 


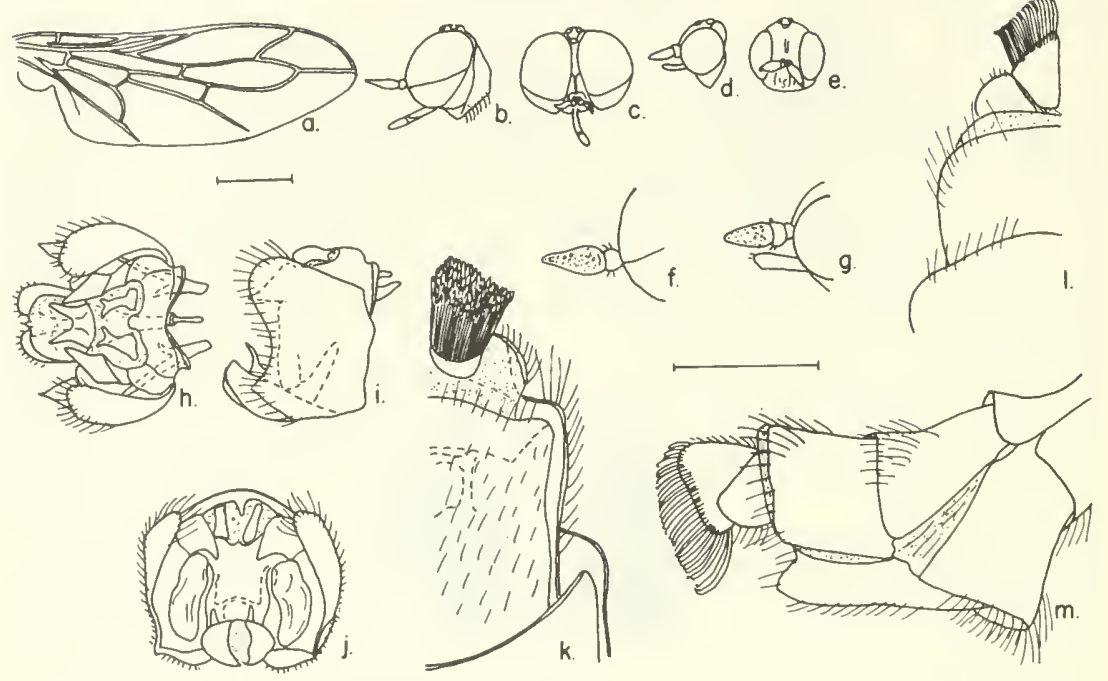

FigURE 206.-Stenomphrale teutankhameni (Kröber), male, female: $a$, wing; $b, c$, lateral and frontal aspects of male head; $d, e$, lateral and frontal aspects of female head; $f, g$, enlarged details of male and female antennae; $h-j$, ventral, lateral and posterior aspects of male terminalia; $k$, ventral aspect of right half of female 8 th and 9 th segments; $l$, dorsal aspect of left half of female 8 th and 9 th segments; $m$, lateral aspect of female 6 th, 7 th, 8 th and 9 th segments.

Types: (SEE).

Allotype: Female, same data as type.

Paratypes: $10^{\top}$, same data as type; 1 \%, Mariout, 5 April 1921 (SEE).

\section{Genus Paratrichia, new genus}

Type-species Paratrichia lobosa, new species. The genus Paratrichia resembles the genus Pseudatrichia in wing venation; the head is higher than long, the antennae short and forked at the tip. The male genitalia have a pair of flaplike processes on the inside walls of the ninth tergite which character separates it from other genera. The female is unknown. Members of this genus are found in the Australian region.

\section{Paratrichia lobosa, new species}

Figure 207

MALE.-Head dark brown; eyes brown above, darker below; frons narrowing to a point halfway to the median ocellus; ocellar tubercle brown, ocelli clear; mouthparts well developed, filling half the oral cavity, which is tan. Antennae brown, third segment oval, with a bilobed tip. 


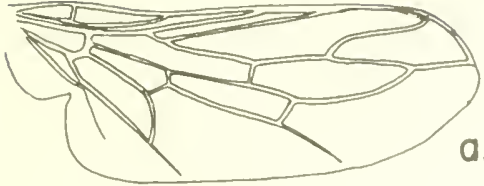

a.

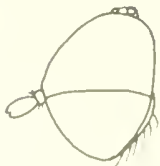

b.

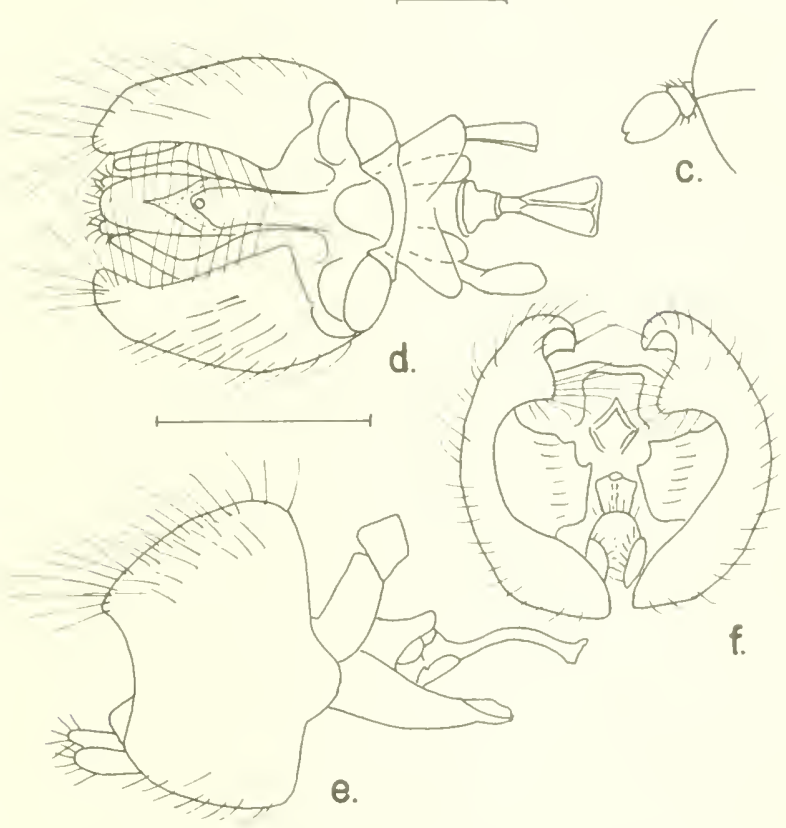

Figure 207.-Paratrichia lobosa, new species, male: $a$, wing; $b$, lateral aspect of head; $c$, cnlarged detail of antenna; $d-f$, ventral, lateral and posterior aspects of terminalia (notc flaps on either side of tergum).

Thorax dorsum dark brown, covered thinly with long hairs which show white, a dusting of brown on the integument; humeral callus with a small tan spot; scutellum solid dark brown, with erect white hairs; pleura dark brown. Wings hyaline, veins brown, cell R5 closed petiolate; halter stem light brown, knob chocolate brown. Legs dark brown with tan knees.

Abdomen chocolate-brown, subshining. Ninth tergum small, blunt, chocolate-brown, with sclerotized flaplike processes on inner face, aedeagus short without visible parameres; see figure for details.

Female.-Unknown.

Length: Male body $3.3 \mathrm{~mm}$., wing $2.2 \mathrm{~mm}$.

Type-locality: Black Mt., Australian Capital Territory, Australia; 30 November 1920 (A. 'Tonnoir).

Holotype: Male (CSIRO). 


\section{Paratrichia westralica (Paramonov), new combination}

Figure 208

Pseudomphrale westralica Paramonov, 1955, p. 641.

This species, though not agreeing in all respects with $P$. lobosa, is placed with it for the present on the basis of similarity in the place of branching of vein $\mathrm{R} 4$ from the middle of the cell and the presence of sclerotized flaps on the inner surface of the ninth tergum.

Length: Male body $2 \mathrm{~mm}$., wing $2.2 \mathrm{~mm}$.

Type-locality: Zanthers, W. Australia; 21 August 1926.

Type: (CSIRO).
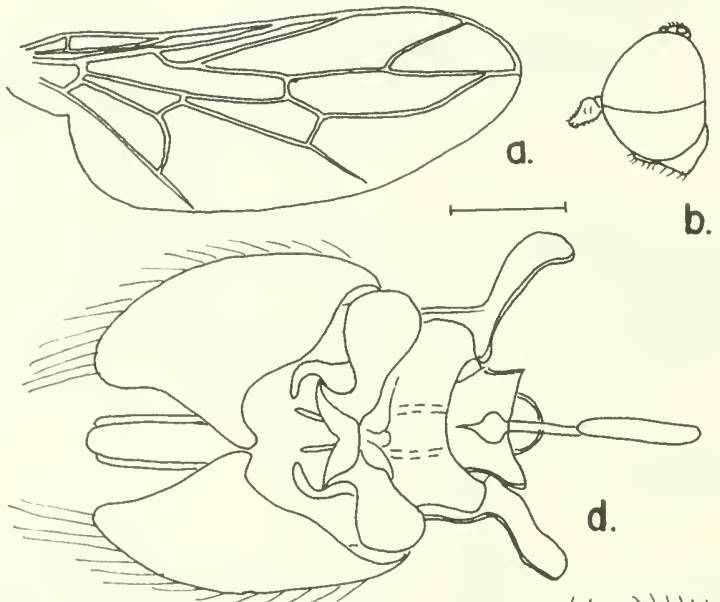

b.

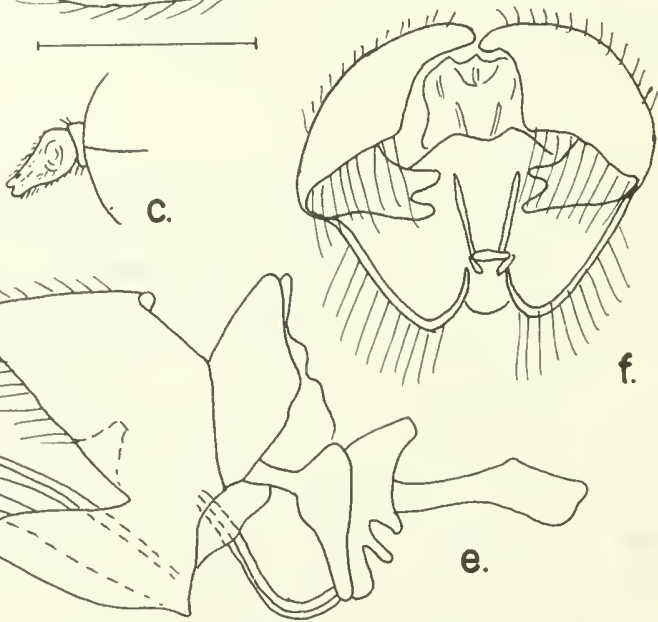

FIGURE 208.- Paratrichia westralica (Paramonov), male: $a$, wing; $b$, lateral aspect of head; $c$, enlarged detail of antenna; $d-f$, ventral, lateral and posterior aspects of terminalia (note flaps on inside of tergum). 


\section{Literature Cited}

Adsus, C. F.

1904. Notes on and descriptions of North American Diptera. Kans. Univ. Sei. Bull., vol. 2 (=whole ser., 12):433-45.5. (= Kans. Univ. Bull., vol. $4[6]$.)

Agissiz, L.

1S46. Nomenclatoris Zoologiei. Index Universalis . . . 393 pp. Solodure [Solothurn], Switzerland.

BECKER, T.

1902. Aegyptische Dipteren. Berlin Zool. MIus. Mitt. vol. 2, (h. 2, art. 1) pp. 1-66, 1 plate.

1907. Die Ergebnisse meiner dipterologischen Frühjahrsreise nach Algier und Tunis, 1906 (Conel.). Z. system. Hym. Dipt., vol. 7, pp. 33-61, 97-12S, 225-256, 369-407, 454, 12 figures.

1913. Persisehe Dipteren von den Expeditionen des Herrn N. Zarudny 1898 und 1901. (Akad. Nauk, S.S.S.R.) Imp. Akad. Nauk. St. Petersburg, Zool. MIus. Ezheg. (Acad. Imp. des Sei. de St. Pétersbourg, Zool. Mus. Ann.), vol. 17, pp. 503-654, 3 plates.

BEzzi, M.

1598. Contribuzioni alla fauna ditterologica italiana. Soc. Ent. Ital. Bull., vol. 30, pp. 19-50.

1922. On the South American species of the Dipterous genus Chiromyza Wied. (Diptera). Ann. Ent. Soe. Amer., vol. 15, pp. 117-124.

1925. Une Nouvelle Espèce du Genre Pseudomphrale de l'Afrique du Sud. Eneyclopédie Entomol., sér. B, Diptera. Vol. 2, pp. 95-95.

Cole, F. R.

1923. Expedition of the California Academy of Seiences to the Gulf of California in 1921. Diptera from the islands and adjacent shores of the Gulf of California. II. General report. Proc. California Acad. Sci., ser. 4, vol. 12, pp. 2S9-314, 38 figures, pp. 457-4\$1, 16 figures.

Coquillett, D. W.

1900. New Scenopinidae from the United States. Ent. News, vol. 11, pp. $500-501$.

1902. New Diptera from North America. U.S. Nat. Mus. Proe. (1903) vol. 25 , pp. 83-126.

Cresson, E. T., Jr.

1907. The North American species of the dipterous family Scenopinidae. Trans. Amer. Ent. Soc., vol. 33, pp. 109-114, 1 plate.

D.ILLA TORRE, K. W. voN

1S78. Beitrage zur Phyto-\& Zoostatik des Egerlandes. Jelıresb. 11aturh. Ver. Lotos, vol. 27 (1877), pp. 7-208. Prague.

De Geer, C.

1776. Mémoires pour servir à l'histoire des Insectes. Vol. 6, 523 pp., 30 plates. Stockholm. 
Edwards, F. W.

1932. Scenopinidae, Mydaidae. Diptera of Patagonia and South Chile, Enderlein, G. part 5, fasc. 3, pp. 258-260.

1913. Dipterologische Studien III. Ủber Lagarinus nov. gen., eine isoliert stehende Fliegengattung. Zool. Anz., vol. 42, pp. 250-253.

1914. Dipterologische Studien X. Zur Kenntnis der Stratiomyiiden mit 3 zästiger Media und ihre Gruppierung. B. Formen, bei denen der 1. Cubitalast mit der Discoidalzelle eine Strecke verschmolzen ist (Familien: Hermetiinae, Clitellariinae). Zool. Anz., vol. 44, pp. $1-25$.

1934. Dipterologica. I. Ges. Naturf. Freunde, Berlin. Sitzb. (1933), pp.

ENGEL, E. O. 416-429.

1932. Familie: Omphralidae, pp. 123-126. In Dahl, F., ed., Die Tierweldt Fabricius, J. C. Deutschlands. Vol. 26, Teil 5, 204 p. Jena.

1781. Species insectorum exhibentes eorum differentias specificas, synonyma, auctorum, loca natalia, metamorphosin. Vol. 2, 517 pp. Hamburg and Kiel.

1794. Entomologia systematica emendata et aucta. Vol. 4, 472 pp. Copenhagen.

Fallen, C. F.

1817. Scenopinii et Conopsariea Sveciae. 14 pp. Lund.

FREY, R.

1937. Die Dipterenfauna der Kanarischen Inseln und ihre Probleme. Comment. biol. Finska Vetensk. Soc., vol. 6, 237 pp., 10 plates.

1945. Tierogeographische Studien über die Dipterenfauna der Azoren. I. Verzeichnis der bisher von den Azoren bekannten Dipteren. Comment. biol. Finska Vetensk. Soc., vol. 8, 114 pp., 4 plates.

Grimshaw, P. H.

1901. Part I: Diptera. pp. 1-77, plates 1-3. In Sharp, D., ed., Fauna HALId AY, A. H. Hawaiiensis. Vol. 3, 704 pp., 19 plates. Cambridge, England.

1851. Über die Dipteren der in London befindlichen Linnéischen Sammlung. Stettin ent. Zeitung, vol. 12, pp. 131-145.

HARDY, D. E.

1944a. A Revision of the North American Omphralidae (Scenopinidae). Kansas Ent. Soc. J., vol. 17, pp. 31-51, 1 plate.

1944b. A new Pseudatrichia from Brazil (Omphralidae-Scenopinidae). Kansas Ent. Soc. J., vol. 17, pp. 104-105, 1 figure.

1958. Diptera: Omphralidae (Scenopinidae). In Insects of Micronesia, vol. 13, pp. 11-13, 1 figure.

1960. Diptera: Nematocera-Brachycera (except Dolichopodidae). In Zimmerman, E. C., ed., Insects of Hawaii, Honolulu. Vol. 10, 368

HARDY, G. H. pp., 120 figures.

1921. Revision of the Chiromyzini. Proc. Linn. Soc., New South Wales (1920), vol. 45, pp. 532-542, 2 plates.

1933. Miscellaneous Notes on Australian Diptera, I. Proc. Linn. Soc., New South Wales, vol. 58, pp. 408-420, 4 figures.

1942. Miscellaneous Notes on Australian Diptera, IX: Superfamily Asiloidea. Proc. Linn. Soc., New South Wales, vol. 67, pp. 197-204. 
International Commission on Zoological Nomenclature

1963b. Opinion 678. The suppression under the Plenary Powers of the pamphlet published by Meigen, 1800. Int. Comm. Zool. Nomenel., Bull. Zool. Nomencl., vol. 20, pp. 339-342.

JAMES, M. T.

1938. The dipterous families Nemestrinidae, Cyrtidae and Scenopinidae in Colorado. Kansas Ent. Soe. J., vol. 11, pp. 21-23.

1955. Two new Diptera from the Pacific Coast States. Kansas Ent. Soc. J., vol. 28 , pp. 47-48, 1 figure.

KEntÉsz, K.

1899. Verzeichniss einiger, von L. Biró in Neu-Guinea und am Malayischen Arehipel. Gesammelten Dipteren. Természetn. Fuz., vol. 22, pp. 173-195.

KRöвER, O.

1912. H. Sauter's Formosa-Ausbeute. Thereviden, Omphraliden (Dipt.). Suppl. Ent., vol. 1, pp. 24-26.

1913. Die Omphraliden. Eine monographisehe Studie. Ann. Mus. Nat. Hung., vol. 11, pp. 174-210, 4 plates.

1914a. Diptera Fam. Omphralidae. Fase. 161, pp. 1-16, 4 plates. In Wytsman P., ed., Genera insectorum (q.v.). Bruxelles.

1914b. Beiträge zur Kenntnis der Thereviden und Omphraliden. Jahrb. Hamburg. wiss. Anst. (1913), vol. 31 Beih. 2, pp. 29-74, 3 figures, (=Zool. Mus. Hamberg Mitt., vol. 31).

1923. Aegyptische Dipteren aus den Familien der Conopidae, Omphralidae, und Therevidae. Bull. Soc. Roy. Ent. d'Egypte, vol. 7, pp. 57116,26 figures.

1925. Omphralidae (Scenopinidae). In Lindner, E., ed., Die Fliegen der palaeartischen Region. Vol. 4 , pt. 3 , seet. 2 , fam. 27, pp. 1-8, 2 plates.

1928a. Neue und wenig bekannte Dipteren aus den Familien Omphralidae, Conopidae und Therevidae. Konowia, vol. 7, pp. 1-23, 17 figures.

1928b. Neue Dipteren des Deutschen Entomolog. Museums in Dahlem. Ent. Mitt., vol. 17, pp. 31-41.

1929. Neue Dipteren aus Aegypten aus den Familien Tabanidae, Therevidae, Omphralidae u. Conopidae. Bull. Soc. Roy. Ent. d'Egypte, in.s., vol. 13, pp. 73-84.

1937. Ein Beitrag zur Kenntnis der Omphraliden (Scenopiniden), Diptera. Stettin ent. Zeitung, vol. 98, pp. 211-231, 2 figures.

1939. Beitrag zur Kenntnis der Therevidae und Omphralidae. Ann. Mag. Nat. Hist., ser. 11, vol. 3, pl). 395-400, 5 figures.

LAMB, C. G.

1922. The Perey Sladen Trust Expedition to the Indian Oeean in 1905. No. VIII.-Diptera: Asilidae, Scenopinidae, Dolichopodidae, Pipunculidae, Syrphidae. Trans. Linn. Soe. London, vol. 18, pp. $361-416,4$ plates.

L.itreille, P. A.

1802. Histoire naturelle, générale et particulière, des Crustacés et des Insectes, Tome troisième [vol. 3], (vol. 95), 468 pp. In Sonnini, C. S., ed., Histoire naturelle par Buffon (৭. v.). Paris, "An X."

LINDNER, E.

1955. Ostafrikanische Omphralidae, Therevidae und Conopidae (Dipt.) Jahrb. Ver. vaterl. Naturk. Württenberg, vol. 110, pp. 19-23, 3 figures. 
1962. Afrikanische Rhagionidae, Therevidae und Omphralidae (Dipt.). Linnaeus, C. Stuttgarter Beitr. Nat., no. 83, 3 pp., 1 figure.

1758. Systema naturae per regna tria naturae. 10th ed., vol. 1, $824 \mathrm{pp}$. Stockholm.

LIOY, P.

1864. I ditteri distribuiti secundo un nuova metodo di classificazione naturale. Atti Ist. Veneto Sci., ser. 3, vol. 9, pp. 499-518, 569-604, 719-771, 879-910, 989-1027, 1087-1126, 1311-1352.

LoEw, H.

1845. Ueber die systemat. Stellung von Scenopinus, und Beschreibung einer neuen Art. Stettin Ent. Zeit., vol. 6, pp. 312-315.

1857. Die bis jetzt bekanntgewordenen Arten der Gattung Scenopinus. Verhandl. Zool.-Bot. Ver. Wien, 7 (Abhandl.) pp. 87-90.

1866. Diptera Americae septentrionalis indigena. Centuria septima. Berlin. ent. Z., vol. 10, pp. 1-54.

1869. Diptera Americae septentrionalis indigena. Centuria octava. Berlin. ent. Z., vol. 13, pp. 1-52.

1873. Beschreibung europäischer Dipteren. Systematische Beschreibung der bekannten europäischen zweifügeligen Insecten, von Johann Wilhelm Meigen. Vol. 3, Zehnter Theil oder vierter Supplementband, $320 \mathrm{pp}$. Halle.

1874. Diptera nova a Hug. Theod. Christopho Collecta. Ztschr. f. die Gesam. Naturw., vol. 43, pp. 413-420.

Macquart, J.

1835. Histoire naturelle des Insectes. Diptères, Tome deuxième. Diptera, vol. 2, 703 pp., 12 plates. In Roret, N. C., ed., Collection des suites à Buffon (q. v.). Paris.

1843. Diptères exotiques nouveaux ou peu connus. Vol. 2, part 3, pp. 5-304, 36 plates. Paris.

Meigen, J. W.

1800. Nouvelle classification des mouches à deux ailes (Dipterea L.) d'après un plan tout nouveau. $40 \mathrm{pp}$. Paris. This publication has recently been suppressed by the International Commission on Zoological Nomenclature (International Commission on Zoological Nomenclature, 1963b).

1803. Versuch einer neuen Gattungseintheilung der europäischen zweiflügeligen Insekten. Mag. Insektenkunde, vol. 2, pp. 259-281.

1824. Systematische Beschreibung der bekannten europäischen zweiflügeligen Insekten. Vol. 4, 428 pp., 9 plates. Hamm.

1838. Systematische Beschreibung der bekannten europäischen zweiflügeligen Insekten. Vol. 7, 434 pp., 8 plates. Hamm.

Meijere, J. C. H. de

1924. Studien über Südostasiatische Dipteren, XV. Tijdschr. Ent., vol. 67, pp. 1-64.

Osten Sacken, C. R.

1877. Western Diptera: Descriptions of new genera and species of Diptera from the region west of the Mississippi and especially from California. Bull. U.S. Geol. Geog. Survey Ter., vol. 3, pp. 189-354.

Panzer, G. F. W.

1809. Faunae insectorum germanicae initiae oder Deutschlands Insecten. H. 98, p. 20, plate 20 . 
PARAMONor, S. J.

1955. A Review of Australian Scenopinidae (Diptera). Australian Journ. Zool., vol. 3, pp. 634-653, 2 figures.

RoNidini, C.

1548. Esame di varie specie d'insetti ditteri brasiliani. Studi Ent. (Turin), vol. 1 , pp. 63-112.

Rossi, P.

1794. Mantissa Insectorum, exhibens species nuper in Etruria collectas, adjectis fauna Etruseae illustrationibus a c emendationibus. Pisa, Polloni, 1792-1794. 4. 2 vol., 148 pp., 154 pp., 8 eolored plates.

SAY, T.

1823. Descriptions of dipterous insects of the United States. J. Acad. Nat. Sei. Phila., vol. 3, pp. 9-54, 73-104.

1829. Deseriptions of North Ameriean dipterous inseets. J. Acad. Nat. Sei. Phila., vol. 6, pp. 149-178.

Schellexberg, J. R.

1S03. Genres des mouches Diptères représentés en XLII planches projettées et dessinées et expliquées par deux amateurs de l'entomologie. 95 pp., 42 plates. Zurich.

SCHINER, I. R.

1S62. Die Fliegen (Diptera) In Redtenbacher, L. and Schiner, I. R., Fauna Austriaca (q. v.). Vol. 1, 674 pp., 2 plates.

Schrank, F. yon $P$.

1803. Fauna Boica. Durchgedachte Geschichte der in Baiern einheimischen und zahmen Thiere. Tol. 3, $272 \mathrm{pp}$.

SCOPOLI, J. A.

1763. Entomologia earniolica exhibens insecta carnioliae indigene et distributa in ordenes, genera, species varietates methodo Linnaeana. $421 \mathrm{pp}$. Vienna.

SÉGY, E.

1920. Note sur quelques Omphrale (Dipt. Omphralidae) et descriptions d'espèces nouvelles. Bull. Soe. Ent. de France, pp. 317-319.

1930. Contribution à l'étude des diptères du Maroc. Mém. Sci. Nat. Maroe, vol. 24, 206 pp. 115 figures.

1931. Contribution à l'étude de la Faume du Mlozambique. Toyage de M. P. Lesne 1928-1929. Bull. Mus. d'Hist. Nat., Paris, vol. 3, pp. 113-121, 1 figure.

1932. Spedizione seientifica all'oasi di Cufra (MIarzo-Luglio 1931) Insectes Diptères. Ann. Miss. Stor. Nat., (ienova, vol. 5.5, pp. 490-511, 3 figures.

1933. Mission Saharienne Augiéras-Draper 1927-192S. Insectes Diptères. Bull. Mus. d'IIist. Nat., Paris, sér. 2, vol. i, pp. 122-127, 9 figures.

1934. Diptères d'Afrique. Encyelopédie Entomol., sér. B, Diptera. Vol. 7 , pp. 63-s0, 12 figures.

1938. Mission seientifique de l'Omo. Diptera I, Nematocera et Brachycera. Mém. Mus. Ilist. Nat., Paris Mémoires, n.s., vol. \&, pp. 319-380, i): figures.

1948. Diptères nouveaux ou peu connus d'extrême-orient. Mus. Heude Notes. Fint. Chin., vol. 12, pp. 153-172, 10 figures.

Senior-Winte, R. A.

1922/24. New Ceylon 1)iptera. Spolia Zeylan., vol. 13, pp. 193-253, 12 plates. 


\section{Speiser, P.}

1920. Zur Kenntnis der Diptera Orthorrhapha Brachycera. Zool. Jahresb., vol. 43, pp. 195-220, 7 figures.

STrobl, G.

1904. Neue Beiträge zur Dipterenfauna der Balkanhalbinsel. Wiss. Mitt. Bosn. Herz., vol. 9, pp. 519-581.

Trojan, P.

1956. Notes on the taxonomy of some European species of the genus Omphrale Meigen (Diptera, Omphralidae). Annls. Zool. Warsz., vol. 16 , pp. 147-156.

VAN DUZEe, M. C.

1926. A new species of Scenopinidae from California (Diptera). Pan-Pacific Ent., vol. 2, p. 164.

Villeneuve, J.

1913. Diptères nouveaux ou intéressants. Feuille des Jeunes Nat.; vol. 43, pp. 111-113.

WALKER, F.

1851. In Walker, F., Stainton, H. T. and Wilkinson, S. J., Insecta Britannica (q. v.). Vol. 1, 314 pp., 10 plates. London.

Zetterstedt, J. W.

1844. Diptera Scandinaviae. Disposita et descripta. Vol. 3, pp. 895-1280. Lund.

1859. Diptera Scandinaviae. Disposita et descripta. Vol. 13, pp. 49436190. Lund. 


\section{Index}

(Names of new species and genera in italics; page numbers of principal aecounts in italics)

addacifons, Brevitrichia, 10, 169, 170 beameri, Omphrale, 117

(fig.)

adventicius, scenopints, 9, 113 (fig.)

aethiopicus, Omphrale, 48

aethiopieus, scenopinus, 8, 48, 49 (fig.)

africanı, Pseudomphrale, 219

alalacteus, Scenopinus, 9,114 (fig.)

albicincta, Musca, 49

albicinetus, Scenopinus, S, 49, 50 (fig.)

Albicinctus group, seenopinus, 2, 8, 15,

45 (key), 57, 76, 83, 92

albicomus, Scenopinus, $7,1 \%, 18$ (fig.)

albidipennis, Scenopinus, 147, $14 \mathrm{~S}$

albifasciata, Omphralosoma, 115

albifaciatus, Seenopinus, 2, 8, 115, 116

(fig.)

albipilosa, Belosta, 12, 274, 275, 276

(fig.)

albocineta, Pseudatrichia, 11, 225 (fig.)

angustifrons, Omphrale, 51

angustifrons, Scenopinus, 8, 51 (fig.)

antennata, Omphrale, 19

antennata, Paromphrale, 19

antennatus, Scenopinus, $2,7,19$ (fig.)

anthrax, Scenopinus, 8, 51, 52 (fig.)

aquelonius, Scenopinus, $7,20,21$ (fig.)

arnaudi, 10, $1 \% 1$ (fig.)

Arehiscenopinus, 2, 15

aspinosa, Brevitrichia, 10, 172, 173 (fig.)

atombomba, Pseudatrichia, 21, 225, 226

(fig.)

atra, Scenopinus. 36

Astoma, 15

Atrichia, 14, 221

fasciata, 26

longurio, 221, 25.5

balteatus, Scenopinus, $8,53,57$ (fig.)

bakeri, Pseudatrichia, 11, 227, 229 (fig.)

barbcri, Scenopinus, 9, 115, 116 (fig.)

barnesi, Pseudatrichia, 11, 229 (fig.)

beameri, Brevitrichia, 10, 174, 175) (fig.)

beameri, Scenopinus, 9, 11\%, 119 (fig.)

beameri var. fusea, Omphrale, 117

beameri var. fusca, scenopinus, 9, 11\%, 119 (fig.)

Belosta, 5, 12, 2\%'t (key)

albipilosa, 12, 274, 275, 276 (fig.)

flariceps, $27 \overline{5}, 278$

pilosa, 12, 275, 277 (fig.)

telfordi, 12, 278, 279 (fig.)

termitophaga, 12, 278, 250 (fig.)

viticolapennis, 12, 281, 282 (fig.)

biacristerna, Pseudatrichia, 11, 230, 231 (fig.)

bicornis, Riekiella, 13, 306, 307 (fig.)

biroi, Scenopinus, $8,53,54$ (fig.)

boharti, Brevitrichia, 10, $1 \% 4,176$ (fig.)

bolgarti, Seenopinus, $8,55,56$ (fig.)

bouvieri, Omphrale, 57

bouvieri, Scenopinus, $8,5 \%$, 58 (fig.)

brevicornis, Scenopinus, 9, 60, 94 (fig.) 95 (fig.)

Brevicomis group, seenopinus, 9, 15, 93 (key)

brevilerminus, s'cenopinus, 7, 22, 23 (fig.)

Brevitrichia 10, 165 (key), 1\$9, 2\$1, 2\$6, 304

addacifons, 10, 169, 170 (fig.)

arnaudi, 10, $1 \tau 1$ (fig.)

aspinosa, 10, 1\%2, 173 (fig.)

beameri, 10, 174, 175 (fig.)

boharti, 10, $1 \%$, 176 (fig.)

castanea, 10, 17\%, 178 (fig.)

coquilletti, 10, 1\%\%, 179 (fig.), 189

davisi, 10, 180, 181 (fig.)

dicksoni, 10, 182, 1\$3 (fig.)

(lowncyi, 10, 184, 18.5 (fig.)

flocki, 10, 186, 187 (fig.)

griffini, 10, 186, 185 (fig.)

griseola, 10, 189, 190 (fig.), 212

halli, 10, 192, 193 (fig.)

helenae, 10, 194, 19.) (fig.) 
Brevitrichia-Continued hodgdeni, 10, 194, 196 (fig.) insulana, 10, 196, 197 (fig.) kerni, 11, 196, 198 (fig.) melanderi, 11, 199, 200 (fig.) minuta, 11, 201 (fig.) oculiverida, 11, 202, 203 (fig.) ordwayi, 11, 204, 205 (fig.) pruinosa, 11, 206 (fig.) schlingeri, 11, 207, 208 (fig.) scitulaesca, 11, 209, 210 (fig.) timberlakei, 11, 210, 211 (fig.) yucatani, 11, 212, 213 (fig.) brunneus, Scenopinus, 8, 5\%, 59 (fig.) bryanti, Pseudatrichia, 11, 231, 232 (fig.)

bryanti, Scenopinus, 9, 118, 119 (fig.) bulbapennis, Scenopinus, 8, 60, 61 (fig.) bulbosa, Metatrichia, 11, 214, 215, 216 (fig.), 219

bulbosus, Scenopinus, 215

bupennis, Pseudatrichia, 11, 232, 233 (fig.)

buscki, Scenopinus, 9, 119, 120 (fig.)

butleri, Scenopinus, 9, 121, 122 (fig.)

caenofrons, Omphrale, 150

Caenoneura, 6, 10, 162

nigra, 10, 163 (fig.)

robusta, 10, 162 (fig.)

cajoni, Pseudatrichia, 11, 234, 235 (fig.) canarius, Scenopinus, 8, 60, 62 (fig.), 94 canei, Neopseudatriacia, 10, 300,301 (fig.)

castanea, Brevitrichia, 10, 17\%, 178 (fig.) cavifrons, Omphrale, 24

cavifrons, Scenopinus, 7, 24, (fig.)

Cerocatus, 1

chico, Scenopinus, 9, 122, 123 (fig.)

chilensis, Pseudatrichia, 286

chilensis, Heteromphrale, 12, 286, 288 (fig.)

chinchona, Seguyella, 12, 294, 295 (fig.) civiculus, Scenopinus, 28

clausa, Pseudomphrale, 10, 164

clausus, Scenopinus, 164

cloudcrofti, Pseudatrichia, 11, 236, 237 (fig.)

cochisei, Scenopinus, 9, 124, (fig.), 139 cockerelli, Pseudatrichia, 11, 236, 238 (fig.)

collessi, Riekiella, 13, 307, 308 (fig.) |complexa, Riekiella, 13, 305, 309, 310 (fig.)

Cona, 14

concava, Pseudatrichia, 11, 239, 240 (fig.)

convexa, Pseudatrichia, 11, 241, 242 (fig.)

cooki, Scenopinus, 9, 125, 126 (fig.)

coquilletti, Brevitrichia, 10, 17\%, 179

(fig.), 189

crenata, Omphrale, 164

crenata, Pseudomphrale, 10, 164

cretatus, Scenopinus, 7, 127 (fig.)

curticornis, Omphrale, 128

curticornis, Scenopinus, 9, 128, 129

(fig.)

curtipilosus, Scenopinus, 8, 63, 64 (fig.)

cyanops, Heteromphrale, 12, 286, 287

(fig.)

darwini, Scenopinus, 8, 64, 65 (fig.)

davisi, Brevitrichia, 10, 180, 181 (fig.)

dicksoni. Brevitrichia, 10, 182, 183 (fig.)

domesticus, Scenopinus, 26

downeyi, Brevitrichia, 10, 184, 185 (fig.)

dubiosa, Omphrale, 164

dubiosa, Pseudomphrale, 10, 164

dycei, Riekiella, 13, 305, 310, 311 (fig.)

eaithales, Pseudatrichia, 11, 241, 243 (fig.)

electus, Scenopinus, 9, 117, 180 (fig.)

effatouni, Scenopinus, 7, 24, 25 (fig.)

evansi, Scenopinus, 8, 66, 67 (fig.)

evergreeni, Pseudatrichia, 51, 244, 245 (fig.)

fasciata, Atrichia, 26

fasciata, Scenopinus, 36

femoratus, Scenopinus, 9, 131

Fenestralis group, Scenopinus, 2, 7, 13, 15, 16 (key), 39

fenestralis, Musca, 15, 26, 36

fenestralis, Scenopinus, 1, 5, 7, 20, 22, $24,26,27$ (fig.) $28,33,36,39,41$

fijianus, Omphrale, 131

fijianus, Scenopinus, 9, 131 (fig.)

flandersi, Scenopinus, 9, 182 (fig.)

flaviceps, Pseudatrichia, 275, 278

flavipes, Omphrale, 68

flavipes, Scenopinus, 8,68 (fig.)

flavoscutellata, Pseudomphrale, 318 
flavoscutellata, Stenomphrale, 13, 818, insulana, Brevitrichia, 10, 196, 197

319 (fig.)

flocki, Brevitrichia, 10, 186, 187 (fig.) fragosifrons, Scenopinus, S, 68, 69 (fig.)

fraterna, Omphrale, 96

fraternus, scenopinus, 9,96 (fig.), 97

(fig.), 106

fryeri, Scenopinus, 9, 9\%, 98 (fig.), 99, 100,106

fureinervis, Scenopinus, 26

fuscinervis, Scenopinus, 26

galaetica, Omphrale, 294, 296

galactica, Sceguyella, 12, 294, 296, 297

(fig.)

garretti, Pseudatrichia, 11, 244, 246

(fig.)

glabrifrons, Paromphrale, 28

glabrifrons, Scenopinus, 2, 5, 7, 28, 29

(fig.), 36, 44, 70, 76

glabrifrons var. surcoufi, Scenopinus, 28

gossypius, Scenopinus, 9, 198, 134 (fig.), 136

graeilipennis, Pseudatriehia, 11, 247,

248 (fig.)

graminieola, Seenopinus, 26

griffini, Brevitriehia, 10, 186, 188 (fig.)

griscola, Brevitrichia, 10, 189, 190 (fig.),

212

griseola, Pseudatrichia, 165, 174, 177, 180,189

grisea, Omphrale, 28

griseus, seenopinus, $7,28,30$ (fig.)

gromieri, Seenopinus, 8, 70, 71 (fig.)

hagae, Scenopinus, 9, 135, 136 (fig.)

halli, Brevitriehia, 10, 192, 193 (fig.)

halteralis, secnopinus, 9, 97, 98 (fig.)

halterata, Seenopinus, 28

helenae, Brevitrichia, 10, 194, $19 j$ (fig.) helenae, Pseudatrichia, 194

Heteromphrale, 12, 286

ehilensis, 12, 286, 288 (fig.)

eyanops, 12, 286, 287 (fig.)

hodgdeni, Brevitrichia, 10, 194, 196 (fig.)

howdeni, Pseudatriehia, 11, 247, 249 (fig.)

howdeni, Seenopinus, 9, 187, 138 (fig.) Hypseleura, 14

inquelinus, seenopinus, $8,72,73$ (fig.) (fig.)

insulana, Pseudatriehia, 196

jamesi, Pseudatrichia, 11, 250, 251 (fig.)

japonicus, Omphrale, 31

japonieus, Scenopinus, 7,31 (fig.)

kalbergi, Scenopinus, 8, 72,74 (fig.)

keiseri, Scenopinus, 8, $\gamma_{4}, 75$ (fig.)

kerni, Brevitriehia, 11, 196, 198 (fig.)

kewi, Neopseudatrichia, 12, 299, 300, 302 (fig.)

kuiterti, Omphrale, 139

laevifrons, Scenopinus, 28

Lagarinus, 1

leechi, Pseudatrichia, 11, 250, 252 (fig.)

Lepidomphrale, 2, 14

lesinensis, Seenopinus, $7,31,32$ (fig.)

limpidipennis, Scenopinus, 8,76

lincinus, Scenopinus, 9, 99, 100 (fig.), 106

lobosa, Paratrichia, 13, 320, 321 (fig.)

longirostris, Omphrale, 16.)

longirostris, Pseudomphrale, 10, 164

longiventris, Omphrale, 100

longiventris, Pseudatrichia, 11, 253, 254 (fig.), 265

longiventris, Riekiella, 13, 305, 312 (fig.)

longiventris, seenopinus, 9, 97, 99, 100, 101 (fig.), 106

longurio, Atrichia, 221, 25.5

longurio, Pseudatrichia, 11, 221, 255 (fig.)

lophrysoma, Metatrichia, 11, 215, 217 (fig.)

lophysoma, Pseudomphrale, 215

Lucidomphrale, 2, 15, 76

lueidus, Seenopinus, 2, 8, 76, 77 (fig.)

madagaseariensis, seenopinus, $8,76,77$ (fig.)

magdalenai, Secnopinus, 9, 140, 141

(fig.)

magnicornis, Omphrale, 142

magnicornis, Scenopinus, 9, 1. 4 (fig.)

mariaensis, Neopseudatrichia, 12, 303, 30.4 (fig.)

mariaensis, Pseudatriehia, 300, 303

mateni, Prepsendatrichia, 12, 286, 289, 290 (fig.) 
melanderi, Brevitrichia, 11, 199, 200|nitidulus, Scenopinus, 9, 96, 99, 103, (fig.)

melanderi, Pseudatrichia, 11, 256, 257 (fig.)

Metatrichia, 11, 214 (key), 221

africana, 219,221

bulbosa, 11, 214, 215, 216 (fig.) 219

lophrysoma, 11, 215, 217 (fig.)

robusta, 11, 215, 218 (fig.), 219

stevensoni, 11, 219, 220 (fig.)

waterhousei, 11, 221, 222 (fig.)

microgaster, Omphrale, 33

microgaster, Scenopinus, 7, 33, 34 (fig.)

minuscula, Omphrale, 100

minusculus, Scenopinus, 9, 100, 102 (fig.)

minuta, Brevitrichia, 11, 201 (fig.)

minutus, Scenopints, 11, 78, 79 (fig.)

mirabilis, Scenopinus, 10, 121, 125,143

(fig.), 152, 156, 161, 168

monodi, Omphrale, 80

monodi, Scenopinus, 8,80 (fig.)

morlani, Pseudatrichia, 11, 258, 259

(fig.)

Musca

albicincta, 49

fenestralis, $15,26,36$

rugosa, 36

saltitans, 26

senilis, 26

spoliata, 26

"tarda," 26

Nemotelus

niger, 36

tarsata, 36

Neopseudatrichia, 12, 299 (key), 318, 319 canei, 12, 300, 301 (fig.)

kewi, 12, 299, 300, 302 (fig.)

mariaensis, 12, 300, 303, 304 (fig.)

nevius, Scenopinus, 2, 8, 81 (fig.)

nidorcaupulus, Scenopinus, 7, 33, 35 (fig.)

niger, Nemotelus, 36

niger, Scenopinus, 2, 7, 15, 36, 37 (fig.), 85, 113

nigra, Caenoneura, 10, 163 (fig.)

nigripes, Scenopinus, 36

nitidifrons, Omphrale, 101

nitidifrons, Scenopinus, 9, 101, 107 (fig.)

104 (fig.), 106

nordeni, Pseudatrichia, 11, 260, 261

(fig.)

norrisi, Scenopinus, 8, 82 (fig.)

nubilipes, Omphrale, 157

nubilipes, Scenopinus, 10, 143, 144

(fig.), 156

nubilipes, Omphrale, 157

oculivirida, Brevitrichia, 11, 202, 203 (fig.)

oldenbergi, Omphrale, 83

oldenbergi, Scenopinus, 8, 83 (fig.)

Omphrale, 1, 14

aethiopicus, 48

angustifrons, 51

antennata, 19

beameri, 117

beameri var. fusca, 117

bouvieri, 57

brunnea, 57

caenofrons, 150

cavifrons, 24

crenata, 164

curticornis, 128

dubiosa, 164

fijianus, 131

flavipes, 68

fraterna, 96

galactica, 294, 296

grisea, 28

japonicus, 31

kuiterti, 139

longirostris, 165

longiventris, 100

magnicornis, 142

microgaster, 33

minuscula, 100

monodi, 80

nitidif rons, 101

nubilipes, 157

oldenbergi, 83

papuana, 85

patrizi, 87

physadius, 36

pilosa, 103

sinensis, 41

tarsalis, 107

valga, 155

velutina, 157

whittakeri, 161 
Omphralosoma, 2, 15, 92, 115

albifasciata, $11 i i$

squamosa, 92

opaculus, scenopinus, $7,36,38$ (fig.)

opacus, scenopinus, $8,83,84$ (fig.)

orbita, scenopinuts, 28

ordwayi, Brevitrichia, 11, 204, 20j (fig.)

palaestimensis, Pseudomphrale, 10, 165 , 166 (fig.)

pallidipennis, scenopintula, 12, 804, 30.5 (fig.)

pallipes, scenopinus, 26

palmulapalpus, Scenopinus, 8, 85, 86 (fig.)

papuana, Omphrale, 8.j

papuanus, scenopinus, $8,85,86$ (fig.)

parallelus, scenopinus, 9, 103, 105 (fig.)

Paratrichia, 13, 319, 320

lobosa, 53, 320, 321 (fig.)

westralica, 13, 322 (fig.)

Paromphrale, 2, 15

antennata, 19

glabrifrons, 28

parva, Pscudatrichia, 11, 260, 262 (fig.)

partipennis, Pseudatrichia, 11, 260, 263

(fig.)

bryanti, 11, 231, 232 (fig.)

bupennis, 11, 232, 233 (fig.)

cajoni, 11, 234, 235 (fig.)

chilensis, 286

cloudcrofti, 11, 236, 237 (fig.)

cockerelli, 11, 236, 238 (fig.)

concava, 11, 239, 240 (fig.)

convexa, 11, 241, 242 (fig.)

eaithales, 11, 241, 243 (fig.)

evergrceni, 11, 244, 245 (fig.)

flaviceps, 275,278

garretti, 15, 244, 246 (fig.)

gracilipennis, 11, 247, 248 (fig.)

griseola, 165, 174, 177, 180, 189

helenae, 194

howdeni, 11, 247, 249 (fig.)

insulana, 196

jamcsi, 11, 250, 25.5 (fig.)

leechi, 11, 250, 252 (fig.)

longiventris, 11, 258, 254 (fig.), 265, 266

longurio, 11, 221, 255 (fig.)

mariaensis, 2.77, 300, 303

melanderi, 11, 256, 257 (fig.)

patrizi, Omphrale, 87 patrizi, Scenopinus, $8,8 \%, 8 \&$ (fig.) pecki, Scenopintu, 10, 145,146 (fig.) perkinsi, Scenopinus, $8,26,88,89$ (fig.) peromysci, Pseudatrichis, 12, 264 (fig.) phaidimos, Scenopinus, $8,70,8 S, 89$ (fig.)

physadius, Omphrale, 36 plysadius, scenopinus, $7,36,40$ (fig.) pilosa, Belosta, 12, 275, 277 (fig.)

pilosa, Omphrale, 103

pilosia, Pscudatrichis, 27.5

pilosus, Seenopinus, 9, 103, 10.j (fig.)

Prepseudatrichia, 6, 12, 286, 289 (kev)

mateui, 12, 286, 289, 290 (fig.)

stenogaster, 12, 291, 292 (fig.)

violacea, 12, 291, 293 (fig.)

Propebrevitrichia, 12, 281, $283(\mathrm{kcy}), 286$

stuckenbergi, 12, 283 (fig.)

turneri, 12, 281, 254, 285 (fig.)

pruinosa, Brevitrichia, 11, 206 (fig.)

Pscudatrichia 5, 11, 221, 223 (key), 274, $286,291,299,318,320$

albocincta, 11, 225 (fig.)

atombomba, 11, 225, 226 (fig.)

bakeri, 11, 227, 225 (fig.)

barnesi, 11, 229 (fig.)

biacristerna, 11, 230, 231 (fig.)

morlani, 11, 25s, 259 (fig.)

nordeni, 11, 260, 261 (fig.)

parva, 11, 260, 262 (fig.)

parvipennis, 11, 260, 263 (fig.)

peromysci, 12, 264 (fig.)

pilosa, 275

punctulata, 12, 253, 265, 266 (fig.)

sabroski, 12, 266, 267 (fig.)

saccharcupa, 12, 268, 269 (fig.)

toupeta, 12, 270, 271 (fig.)

truncata, 12, 270, 272 (fig.)

unicolor, 12, 225, 236, 258, 273 (fig.)

Pseudomphrale 6, 10, 16\%, 221

africana, 219

elatusa, 10, 164

crenata, 10,164

dubiosal 10, 16 :

flavoscutellata, 318

longirostris, 10, 165

lophrysoma, 21.5

palaestinensis, 10, 165, 166 (fig.)

stevensoni, 219

teutankhameni, 318, 319

waterlousei, 221

westralica, 322 
punctulata, Pseudatrichia, 12, 253, 265, 266 (fig.)

pygmaeus, Scenopinus, 10, 128, 147 (fig.), 148

quadrifida, Riekiella, 13, 305, 309, 313, 314 (fig.)

ramaleyi, Scenopinus, 143

reduncus, Scenopinus, 9, 106 (fig.)

Riekiella, 13, 304, 306 (key)

bicornis, 13, 304, 305, 306, 307 (fig.), 313

collessi, 13, 307, 308 (fig.)

complexa, 13, 305, 309, 310 (fig.)

dycei, 13, 305, 310, 311 (fig.)

longiventris, 13, 305, 312 (fig.)

quadrifida, 13, 305, 309, 313, 314 (fig.)

taylori, 13, 315,316 (fig.)

uncata, 13, 315, 317 (fig.)

robusta, Caenoneura, 10, 162, (fig.)

robusta, Metatrichia, 11, 215, 218 (fig.), 219

rossi, Scenopinus, 10, 148, 149 (fig.)

sabroskyi, Pseudatrichia, 12, 266, 267 (fig.)

saccharcupa, Pseudatrichia, 12, 268, 269

(fig.)

saini, Scenopinus, 8, 39, 42 (fig.)

saltitans, Musca, 26

Scaenopius, 15

Scenopinula, 12, 304

pallidipennis, 12, 304, 305 (fig.)

Scenopinidae, 1, 5 (fig.), 6, 7, 13 (key)

Scenopinus, 2, 7, 14, 76, 92, 99, 286, 289 ,

291, 294, 304

bulbosus, 215

clausus, 164

stenogaster, 291

Scenopinus, Albicinctus group, 2, 8, 15,

45 (key), 55, 57, 76, 83, 92

aethiopicus, 8, 48, 49 (fig.)

albicinctus, 8, 49, 50 (fig.)

angustifrons, 8,51 (fig.)

anthrax, 8, 51, 52 (fig.)

balteatus, 8, 58, 54 (fig.), 57, 66

biroi, $8,59,55$ (fig.)

bolgarti, 8, 55, 56 (fig.)

bouvieri, $8,57,58$ (fig.)

brevicornis, 60

brunneus, $8,57,59$ (fig.)

bulbapennis, 8, 60, 61, (fig.)
Scenopinus-Continued

canarius, 8, 60, 62 (fig.), 94

curtipilosus, 8, 63, 64 (fig.)

darwini, 8, 64, 65 (fig.)

evansi, 8, 66, 67 (fig.)

flavipes, 8, 68 (fig.)

fragosifrons, 8, 68, 69 (fig.)

gromieri, 8, 70, 71 (fig.)

inquelinus, 8, 72, 73 (fig.)

katbergi, 8, 72, 74 (fig.)

keiseri, 8, 74, 75 (fig.)

limpidipennis, $8, \gamma 6$

lucidus, $2,8,76,77$ (fig.)

madagascariensis, $8,76,78$ (fig.)

minulus, 8, 78, 79 (fig.)

monodi, 8,80 (fig.)

niger, 85

niveus, $2,8,81$ (fig.)

norrisi, 8,82 (fig.)

oldenbergi, 8,83 (fig.)

opacus, $8,83,84$ (fig.)

palmulapalpus, $8,85,86$ (fig.)

papuanus, $8,85,87$ (fig.), 113

patrizi, $8,87,88$ (fig.)

perkinsi, $8,88,89$ (fig.)

phaidimos, $8,70,88,89$ (fig.)

spurrelli, 8, 90, 91 (fig.)

squamosus, 2, 8, 92, (fig.)

zelleri, 49

zeylanicus, 85,86

Scenopinus, Brevicornis group, 9, 15, 93 (key)

brevicornis, 9, 60, 94 (fig.), 95 (fig.)

fraternus, 9,96 (fig.), 97 (fig.), 99, 106

fryeri, 9, 97, 98 (fig.), 99, 100, 106

halteralis, 9, 98, 99 (fig.)

lincinus, 9, 99, 100 (fig.), 106

longiventris, 9, 97, 100, 101 (fig.), 106

minusculus, 9, 100, 102 (fig.)

nitidifrons, 9, 101, 107

nitidulus, 9, 99, 103, 104 (fig.), 106

parallelus, 9, 103, 105 (fig.)

pilosus, 9, 103, 105 (fig.)

reduncus, 9, 99, 106 (fig.)

tarsalis, 9, 101, 107 (fig.)

turneri, 9, 107, 108 (fig.)

unifasciatus, 9, 108, 109 (fig.)

Scenopinus, Fenestralis group, 2, 7, 15,16 (key), 39

albicomus, 7, 17, 18 (fig.)

antennatus, 7,19 (fig.)

aquelonius, 7, 20, 21 (fig.) 
Scenopinus-Continued

atra, 36

breviterminus, $7,22,23$ (fig.)

cavifrons, 7,24 (fig.)

civiculus, $2 \mathrm{~s}$

domesticus, 26

efflatouni, $7,24,25$ (fig.)

fasciata, 26,36

fenestralis, 1, $5,7,15,20,22,24$, 26,27 (fig.), 28, 33, 39, 41

furcinervis, 26

glabrifrons, 2, 5, 7, 15, 28, 29 (fig.), $36,44,70,76$

glabrif rons var. surcoufi, 28

graminicola, 26

griscus, $7,28,30$ (fig.)

halterata, 28

japonieus, 7,81 , (fig.)

leavifrons, 28

lesinensis, $7,81,32$ (fig.)

microgaster, 7, 83, 34 (fig.)

nidorcaupulus, 7, 38, 35 (fig.)

niger, 2, 7, 15, 36, 37 (fig.), 85, 113

nigripes, 36

opaculus, $7,36,38$ (fig.)

orbita, 28

pallipes, 26

perkinsi, 26

physadius, 7, 86, 40 (fig.)

rufitarsis, 26

rugosa, 36

saini, 8, 39, 42 (fig.)

saltitans, 26

schroederi, 8, 39, 43 (fig.)

scutellatus, 26

scutellatus var. nigroseutellatus, 26

senilis, 26

sinensis, 8, 41, 43 (fig.)

spoliata, 26

sulcicollis, 26

"tarda," 26

tarsata, 26

undulafrons, $8,41,44$ (fig.)

varipes, 8 , 4t

vitripennis, $8,28,44,45$ (fig.)

Scenopinus, Velutinus group, 2, 9, 16, 110 (key), 115

adventicius, 9, 113 (fig.)

alalcteus, 9, 114 (fig.)

albidipennis, 147,148

albifasciatus, 2, 9, 115, 116 (fig.)

barberi, $9,11 \%, 116$ (fig.)
Scenopinus-Continued

beameri, 9, 117, 118 (fig.)

beameri var. fuscus, $9,117,118$ (fig.)

bryanti, 9, 118, 119 (fig.)

buscki, 9, 119, 120 (fig.)

butleri, 9, 121, 122 (fig.)

caenof rons, 150

chico, 9, 122, 123 (fig.)

cochisei, 9, 124 (fig.), 139

cooki, 9, 125, 126 (fig.)

crelatus, 9, 12\%, (fig.)

curticornis, 9, 128, 129 (fig.)

clectus, 9, 117, 130 (fig.)

femoratus, 9, 131

fijianus, 9, 131 (fig.)

flandersi, 9, 132 (fig.)

gossypius, 9, 133, 134 (fig.), 136

hagai, 9, 185, 136 (fig.)

howdeni, 9, 13\%, 138 (fig.)

kuiterti, 9, 139 (fig.)

magdalenai, 9, 140, 141 (fig.)

magnicornis, 9, 1.42 (fig.)

mirabilis, $10,121,125,143$ (fig.), 152,

$156,158,161$

nubilipes, 10, 143, 144 (fig.), 156, 157

pecki, 10, 145, 146 (fig.)

pygmacus, 10, 12S, 142, 1.47 (fig.)

ramaleyi, 143

rossi, 10, 148, 149 (fig.)

schulzi, 10, 150, 151 (fig.)

seftoni, 10, 152 (fig.)

serratus, 10, 153, 154 (fig.)

valgus, 10,155 (fig.)

randuzeci, 10, 156, 157 (fig.)

velutinus, 10, 134, 142, 157, 158 (fig.)

weemsi, 10, 158, 159 (fig.)

uerneri, 10, 160 (fig.)

whittakeri, 10, 161 (fig.)

Scenopoeus, 14

schlingeri, Brevitrichia, 11, 20\%, 208 (fig.)

schroederi, Scenopinus, s, 39, 43 (fig.)

schulzi, secuopinus, 10, 150, 151 (fig.)

scitulaesca, Brevitrichia, 11, 209, 210 (fig.)

sentellatus, sicenopinus, 26

scutellatus var. nigroscullatus, sicenopinus, 26

seftoni, Scenopinus, 10,152 (fig.)

Seguyella, 12, 294 (key)

chinchona, 12, 29\%, 29.) (fig.)

galactica, 12, 294, 296, 297 (fig.) 
Seguyella-Continued turneri, 12, 296, 298 (fig.)

senilis, Musca, 26

serratus, Scenopinus, 10, 158, 154 (fig.)

sinensis, Omphrale, 41

sinensis, Scenopinus, 8, 41, 43 (fig.)

spoliata, Musca, 26

spurrelli, Scenopinus, 8, 90, 91 (fig.)

squamosa, Omphralosoma, 92

squamosus, Scenopinus, 2, 8, 92 (fig.), 97

stenogaster, Prepseudatrichia, 12, 291,

292 (fig.)

stenogaster, Scenopinus, 291

Stenomphrale, 3, 13, 318

flavoscutellata, 13, 318, 319 (fig.)

teutankhameni, $13,318,319,320$ (fig.)

stevensoni, Metatrichia, 11, 219, 220 (fig.)

stevensoni, Pseudomphrale, 219

stuckenbergi, Propebrevitrichia, 12, 283 (fig.)

sulcicollis, Scenopinus, 26

"tarda," Musca, 26

tarsalis, Omphrale, 107

tarsalis, Scenopinus, 9, 101, 107 (fig.)

tarsata, Nemotelus, 36

taylori, Riekiella, 13, 315, 316 (fig.)

telfordi, Belosta, 12, 278, 279 (fig.)

teutankhameni, Pseudomphrale, 318, 319

teutankhameni, Stenomphrale, 13, 318, 319, 320 (fig.)

timberlakei, Brevitrichia, 11, 210, 211 (fig.)

toupeta, Pseudatrichia, 12, 270, 271 (fig.) turneri, Propebrevitrichia, 12, 281, 284, 285 (fig.)

turneri, Scenopinus, 9, 107, 108 (fig.) turneri, Seguyella, 12, 296, 298 (fig.)

truncata, Pseudatrichia, 12, 270, 272 (fig.)

uncata, Riekiella, 13, 315, 317 (fig.)

undulafrons, Scenopinus, 8, 41, 44 (fig.)

unicolor, Pseudatrichia, 12, 225, 236, 258, 273 (fig.)

unifaciatus, Scenopinus, 9, 108, 109 (fig.)

valga, Omphrale, 155

valgus, Scenopinus, 10, 155 (fig.)

vanduzeei, Scenopinus, 10, 156, 157 (fig.)

varipes, Scenopinus, 8,44

Velutinus group, Scenopinus, 2, 9. 16, 110 (key), 115

velutina, Omphrale, 157

velutinus, Scenopinus, 10, 142, 157, 158 (fig.)

violacea, Prepseudatrichia, 12, 291, 293 (fig.)

viticolapennis, Belosta, 12, 281, 282 (fig.)

vitripennis, Scenopinus, 8, 28, 44, 45 (fig.)

waterhousei, Metatrichia, 11, 221, 222

(fig.)

waterhousei, Pseudomphrale, 221

weemsi, Scenopinus, 10, 158, 159 (fig.)

werneri, Scenopinus, 10, 160 (fig.)

westralica, Paratrichia, 13, 322 (fig.)

westralica, Pseudomphrale, 322

whittakeri, Omphrale, 161

whittakeri, Scenopinus, 10, 161 (fig.)

yucatani, Brevitrichia, 11, 212, 213 (fig.)

zelleri, Scenopinus, 49

zeylanicus, Scenopinus, 85,86 





